\title{
MONOGRAPH
}

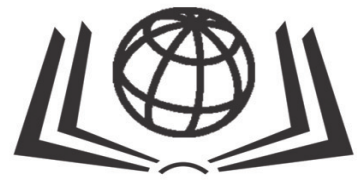

INTERNATIONAL

SCIENCE GROUP

\section{THEORETICAL ASPECTS OF MODERN ENGINEERING}

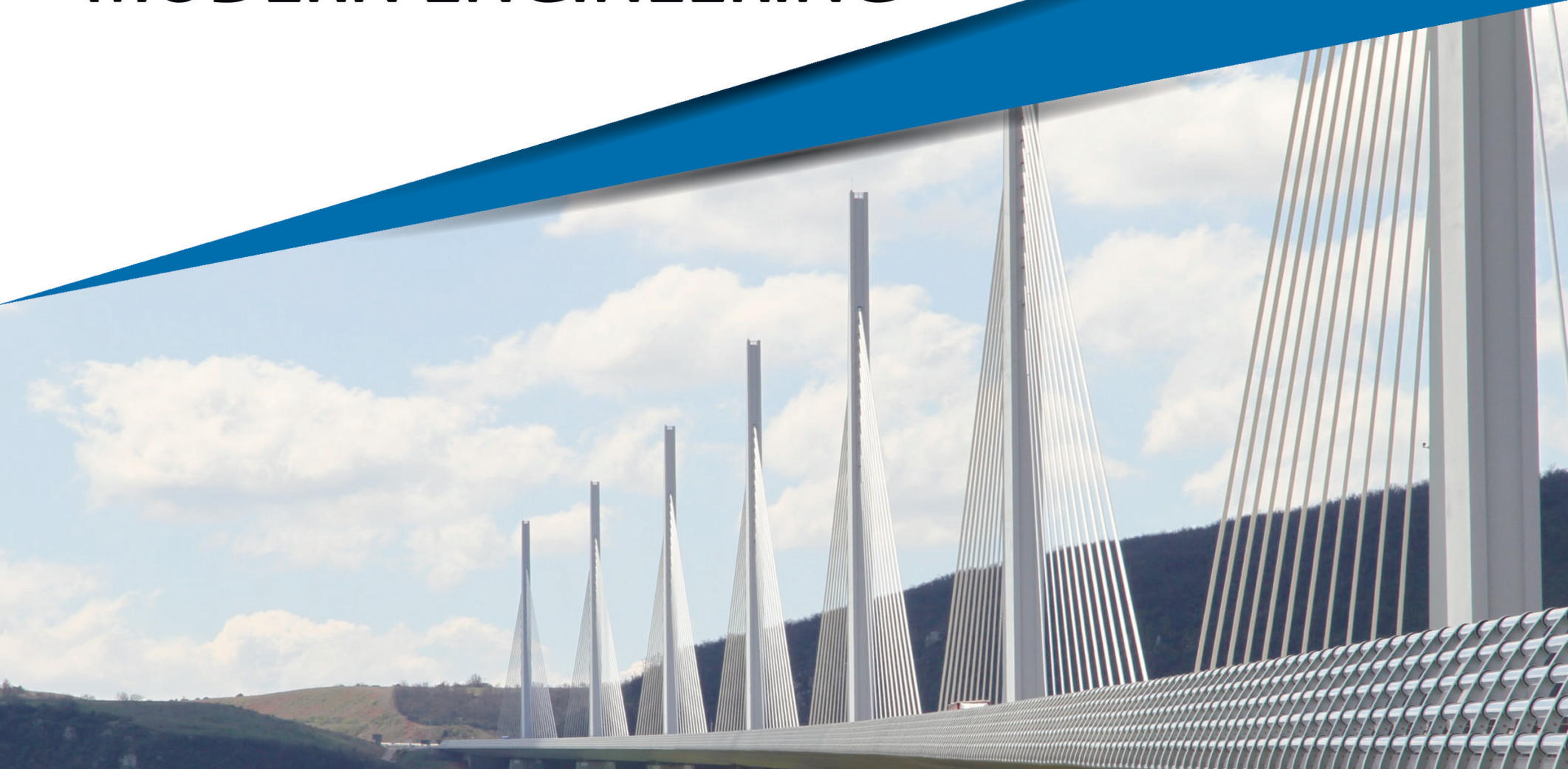


ISBN - 978-1-64945-862-9

DOI- 10.46299/isg.2020.MONO.TECH.III

Theoretical aspects of modern

\section{engineexing}

Gollective monograph

Boston 2020 
Library of Congress Cataloging-in-Publication Data

ISBN - 978-1-64945-862-9

DOI- 10.46299/isg.2020.MONO.TECH.III

Authors - Hnes L., Kunytskyi S., Medvid S., Khovanskyy S., Sotnyk M., Sapoznikov S., Boiko V., Shkliar S., Vasylkova I., Usachova O., Vovk L., Matsiyevska O., Zhdanov О., Дудка О.М., Попова O.A., Смірнова O.B., Bereziuk O., Lemeshev M., Cherepakha A., Senyk I., Butenko O., Khomenko V., Chernysh O., Шматок Ю., Чикида Т., Глоба Н., Ліснича Т., Кириллов С., Воуkо N., Dmytrenko T., Derkach T., Dmytrenko A., Kulykovska N., Terentyev O., Gorbatyuk I., Rusan I., Borodavka Y., Balina O., Tkachenko S., Stepanov D., Stepanova N., Гулевський B., Постол Ю., Стручаєв М., Попрядухін В., Борохов I., Сафронов О., Mandrichenko O., Demydenko T., Dorozhko V., Pshenychna Y., Topchii O., Verchenko M., Honcharenko T., Sotnyk M., Marynych T., Drozdenko A., Leontiev P., Telizhenko O., Левченко Л.О., Ходаковський О.В., Козачук А., Pryadko N., Arkhypov O., Bakun V., Sukhov V., Kozei Y., Marynoshenko O., Chasov D., Ventsel Y., Shchukin O., Orel O., Yevtushenko A., Voronova Y., Бондарева O.M., Kopayev A., Zadnieprianniy D., Kovalenko T., Matiko H., Serdiuk V., Sotnyk M., Telizhenko O., Sotnyk I., Kurbatova T., Koplyk I., Moroz L.B., A.V. Uhrynovskyi, Osinnij V., Makeiev S., Havrilov D., Volovyk A., Koval L., Yarovyi D., Piltyay S., Bulashenko A., Sokol G., Gerasymov D., Shuhailo A., Gordiienko S., Pluznikova A., Kalinichenko Y., Alexandrovskaya N., Stenhach O., Kunda N., Sharai S., Oliskevych M., Roi M., Silenko V., Tretynychenko A., Tretynychenko Y., Sokulskyi O., Hilevska K., Vasiltsova N., Lebid V., Kopiak N., Петрик А., Козлов В., Головатюк М., Шапенко С.M., Лебідь B.B.,Serediuk D., Pelikan Y., Bas O..

\section{Published by Primedia eLaunch https://primediaelaunch.com/}

Text Copyright (C) 2020 by the International Science Group(isg-konf.com) and authors. Illustrations (C) 2020 by the International Science Group and authors.

Cover design: International Science Group(isg-konf.com). (C)

Cover art: International Science Group(isg-konf.com). (C)

All rights reserved. Printed in the United States of America. No part of this publication may be reproduced, distributed, or transmitted, in any form or by any means, or stored in a data base or retrieval system, without the prior written permission of the publisher. The content and reliability of the articles are the responsibility of the authors. When using and borrowing materials reference to the publication is required.

Collection of scientific articles published is the scientific and practical publication, which contains scientific articles of students, graduate students, Candidates and Doctors of Sciences, research workers and practitioners from Europe and Ukraine. The articles contain the study, reflecting the processes and changes in the structure of modern science.

The recommended citation for this publication is:

Theoretical aspects of modern engineering: collective monograph / Hnes L., - etc. International Science Group. - Boston : Primedia eLaunch, 2020. 356 p. Available at : DOI- 10.46299/isg.2020.MONO.TECH.III 
TABLE OF CONTENTS

\begin{tabular}{|c|c|c|}
\hline 1 & $\mathrm{AR}$ & 9 \\
\hline 1.1 & 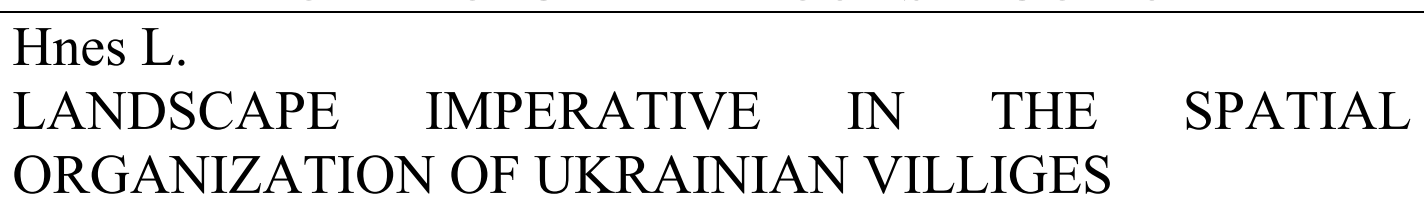 & 9 \\
\hline 1.2 & $\begin{array}{l}\text { Kunytskyi S. } \\
\text { THE DESIGN OF THE FILTER FOR WATER TREATMENT } \\
\text { FROM UNDERGROUND HORIZONS }\end{array}$ & 16 \\
\hline 1.3 & $\begin{array}{l}\text { Medvid S., Khovanskyy S., Sotnyk M., Sapoznikov S., } \\
\text { Boiko V. } \\
\text { METHODS FOR ASSESSING THE THERMAL CAPACITY } \\
\text { OF BUILDINGS }\end{array}$ & 21 \\
\hline 1.4 & $\begin{array}{l}\text { Shkliar S., Vasylkova I. } \\
\text { ARCHITECTURE OF CHILDREN'S PRESCHOOL } \\
\text { INSTITUTIONS IN THE CONTEXT OF MODERN TRENDS } \\
\text { IN THE EDUCATIONAL PROCESS }\end{array}$ & 33 \\
\hline 1.5 & $\begin{array}{l}\text { ЙНІ ЗАСОБИ ПРОЕКТУВАННЯ ПАРКІВ } \\
\text { ЛЕНД» }\end{array}$ & 38 \\
\hline 1.6 & $\begin{array}{l}\text { Vovk L., Matsiyevska O., Zhdanov O. } \\
\text { PRACTICAL EXPERIENCE OF USING MICROALGAE } \\
\text { CHLORELLA VULGARIS IN WASTEWATER } \\
\text { TREATMENT PROCESSES }\end{array}$ & 43 \\
\hline 1.7 & $\begin{array}{llr}\text { Дудка О.М., Попова О.А. } & & \\
\text { ОСОБЛИВОСТІ } & \text { ФОРМУВАННЯ } & \text { АРХІТЕКТУРИ } \\
\text { СУЧАСНИХ } & \text { БІЗНЕС-ЦЕНТРІВ } & \text { У } \\
\text { СЕРЕДОВИЩЕКОМУ } & & \end{array}$ & 4 \\
\hline 1.8 & $\begin{array}{l}\text { Смірнова О.В. } \\
\text { СУЧАСНІ } \quad \text { ТЕНДЕНЦІї } \\
\text { ЕКООРІСНТОВАНИХ БУДІВЕЛЬ І СПОРУД }\end{array}$ & 53 \\
\hline 2. & $\mathrm{GY}$ & 5 \\
\hline 2.1 & $\begin{array}{l}\text { Bereziuk O., Lemeshev M., Cherepakha A. } \\
\text { UKRAINIAN PROSPECTS FOR LANDFILL } \\
\text { PRODUCTION AT LANDFILLS }\end{array}$ & 8 \\
\hline
\end{tabular}




\begin{tabular}{|c|c|c|}
\hline 2.2 & $\begin{array}{l}\text { Senyk I., Butenko O., Khomenko V., Chernysh O., } \\
\text { Barsukov V. } \\
\text { THIN COMPOSITE FILMS BASED ON CARBON- } \\
\text { GRAPHITE MATERIALS FOR PROTECTION AGAINST } \\
\text { ELECTROMAGNETIC RADIATION }\end{array}$ & 65 \\
\hline 2.3 & $\begin{array}{l}\text { Шматок Ю., Чикида Т., Глоба Н., Ліснича Т., Кириллов С. } \\
\text { ЕФЕКТИВНІСТЬ ЦИКЛУВАННЯ НАНОРОЗМІРНОГО } \\
\text { ТІО2 В НАТРІЄВИХ ДЖЕРЕЛАХ СТРУМУ }\end{array}$ & 71 \\
\hline 3. & COMPUTER SCIENCE & 78 \\
\hline 3.1 & $\begin{array}{l}\text { Boyko N. } \\
\text { SOFTWARE APPROACH TO CREATING A LAYOUT } \\
\text { WITH DYNAMIC INTERFACES }\end{array}$ & 77 \\
\hline 3.2 & $\begin{array}{l}\text { Dmytrenko T., Derkach T., Dmytrenko A. } \\
\text { DEVELOPMENT OF THE INFORMATION SYSTEM } \\
\text { «DEPARTMENT PORTAL» }\end{array}$ & 82 \\
\hline 3.3 & $\begin{array}{l}\text { Kulykovska N. } \\
\text { ANALYSIS OF MODERN DISTRIBUTED COMPUTER } \\
\text { SYSTEMS }\end{array}$ & 87 \\
\hline 3.4 & $\begin{array}{l}\text { Terentyev O., Gorbatyuk I., Rusan I., Borodavka Y., Balina O. } \\
\text { BUILDING A SYSTEM OF DIAGNOSIS TECHNICAL } \\
\text { CONDITION OF BUILDINGS ON THE EXAMPLE OF } \\
\text { FLOOR BEAMS USING METHODS OF FUZZY SETS }\end{array}$ & 91 \\
\hline 4. & ELECTRICAL ENGINEERING & 101 \\
\hline 4.1 & $\begin{array}{l}\text { Tkachenko S., Stepanov D., Stepanova N. } \\
\text { PROSPECTS FOR BIOGAS TECHNOLOGIES } \\
\text { VINNYTSIA REGION OF UKRAINE }\end{array}$ & 101 \\
\hline 4.2 & $\begin{array}{l}\text { Гулевський В., Постол Ю., Стручаєв М., Попрядухін В., } \\
\text { Борохов І. } \\
\text { OСНОВНІ ПРИНЦИПИ } \\
\text { АВТОНОМНОГО } \\
\text { КОМПЛЕКСУ }\end{array}$ & 106 \\
\hline 4.3 & $\begin{array}{l}\text { Сафронов О. } \\
\text { ВПЛИВ ПРИЄДНАННЯ } \\
\text { ЕЛЕКТРОСТАНЦЙ } \\
\text { ЕЛЕКТРИЧНИХ МЕРЕЖ }\end{array}$ & 115 \\
\hline
\end{tabular}




\begin{tabular}{|c|c|c|}
\hline 5. & ENGINEERING GRAPHICS & 120 \\
\hline 5.1 & $\begin{array}{l}\text { Mandrichenko O., Demydenko T. } \\
\text { ENGINEERING GRAPHICS - THE BASIS FOR FORMING } \\
\text { THE THEORETICAL BASE OF ENGINEERING } \\
\text { THINKING }\end{array}$ & 120 \\
\hline 6. & FOOD TECHNOLOGY & 125 \\
\hline 6.1 & $\begin{array}{l}\text { Dorozhko V., Pshenychna Y. } \\
\text { RESEARCH OF TECHNOLOGICAL PROPERTIES AND } \\
\text { EXPERIMENTAL SUBSTANTIATION OF CREATION OF } \\
\text { TECHNOLOGIES OF MEAT PRODUCTS FROM OSTRICH } \\
\text { MEAT }\end{array}$ & 125 \\
\hline 6.2 & $\begin{array}{l}\text { Topchii O., Verchenko M., Honcharenko T. } \\
\text { USE OF OILSEED POLYFUNCTIONAL SUPPLEMENTS } \\
\text { IN THE MANUFACTURE OF MEAT PRODUCTS }\end{array}$ & 130 \\
\hline 7. & $\begin{array}{l}\text { INFORMATICS, COMPUTER ENGINEERING AND } \\
\text { AUTOMATION }\end{array}$ & 139 \\
\hline 7.1 & $\begin{array}{l}\text { Sotnyk M., Marynych T., Drozdenko } \\
\text { Telizhenko O., Leontiev P., } \\
\text { MONITORING AND FORECASTING } \\
\text { ELECTRICITY CONTEMS FOR } \\
\text { INSTITUTIONS }\end{array}$ & 139 \\
\hline 7.2 & $\begin{array}{l}\text { Левченко Л.О., Ходаковський О.В., Козачук А. } \\
\text { ПРОБЛЕМАТИКА СТВОРЕННЯ ЗАХИСНОГО ЕКРАНУ } \\
\text { НА ОСНОВІ ЗАЛІЗОРУДНОГО ПИЛУ ІЗ ЗАДАНИМИ } \\
\text { ВЛАСТИВОСТЯМИ }\end{array}$ & 159 \\
\hline 8. & INNOVATIVE TECHNOLOGIES & 163 \\
\hline 8.1 & $\begin{array}{l}\text { Pryadko N. } \\
\text { INNOVATIVE FINE GRINDING TECHNOLOGY WITH } \\
\text { ACOUSTIC PROCESS CONTROL }\end{array}$ & 163 \\
\hline 9. & $\begin{array}{l}\text { MECHANICAL ENGINEERING AND MECHANICAL } \\
\text { ENGINEERING }\end{array}$ & 169 \\
\hline 9.1 & $\begin{array}{l}\text { Arkhypov O., Bakun } \text { V., Sukhov V., Kozei Y., } \\
\text { Marynoshenko O. } \\
\text { VIBRO PROTECTIVE SYSTEMS OF QUASE ZERO } \\
\text { RIGIDITY }\end{array}$ & 169 \\
\hline 9.2 & $\begin{array}{l}\text { Chasov D. } \\
\text { ANALYSIS OF EXISTING METHODS OF GRINDING } \\
\text { WASTE FROM MECHANICAL INDUSTRIES }\end{array}$ & 179 \\
\hline
\end{tabular}




\begin{tabular}{|c|c|c|}
\hline 9.3 & $\begin{array}{l}\text { Ventsel Y., Shchukin O., Orel O., Yevtushenko A., } \\
\text { Voronova Y. } \\
\text { RAISING OF DURABILITY OF AUTO GRADER KNIVES } \\
\text { CUTTING ELEMENTS }\end{array}$ & 184 \\
\hline 9.4 & $\begin{array}{l}\text { Бондарева О.М. } \\
\text { БЕЗВІДХОДНІ СПОСОБИ } \\
\text { ДЕТАЛЕЙ ТИПУ КІЛЬЦЯ }\end{array}$ & 192 \\
\hline 10. & METALLURGY AND ENERGY & 199 \\
\hline 10.1 & $\begin{array}{l}\text { Kopayev A., Zadnieprianniy D. } \\
\text { TECHNOLOGY, STRUCTURE AND MAGNETIC } \\
\text { PROPERTIES OF THE NI-AL FERRITE NANOPOWDERS }\end{array}$ & 199 \\
\hline 10.2 & $\begin{array}{l}\text { Kovalenko T., Matiko H., Serdiuk V. } \\
\text { FEATURES OF OPERATION OF STEAM GENERATOR } \\
\text { PGV-1000 OF NUCLEAR POWER PLANTS OF UKRAINE }\end{array}$ & 205 \\
\hline 10.3 & $\begin{array}{l}\text { Sotnyk M., Telizhenko O., Sotnyk I., Kurbatova T., Koplyk I. } \\
\text { SUBSTANTIATION OF THE LAYOUT SCHEME AND } \\
\text { THE VALUE OF THE INSTALLED ELECTRIC POWER OF } \\
\text { THE SOLAR POWER PLANT IN THE EDUCATIONAL } \\
\text { INSTITUTION }\end{array}$ & 211 \\
\hline 11. & MINING AND SURVEYING & 232 \\
\hline 11.1 & $\begin{array}{l}\text { Moroz L.B., A.V. Uhrynovskyi } \\
\text { ДОСЛІДЖЕННЯ ЗАСТОСУВАННЯ } \\
\text { МЕТОДІВ ПІДВИЩЕННЯ } \\
\text { ЗАВЕТОВННИХ } \\
\text { ЗАВРШАЛЬНІЙ СТАДІЇ } \\
\text { РОДОВИЩ }\end{array}$ & 233 \\
\hline 11.2 & $\begin{array}{l}\text { Osinnij V., Makeiev S. } \\
\text { MINIMIZATION OF RISKS DURING THE RAISES } \\
\text { ADVANCE }\end{array}$ & 241 \\
\hline 12. & RADIO ENGINEERING & 245 \\
\hline 12.1 & $\begin{array}{l}\text { Havrilov D., Volovyk A., Koval L., Yarovyi D. } \\
\text { FREQUENCY METER BASED ON MICROCONTROLLER } \\
\text { FOR BIOMEDICAL MEASUREMENT SYSTEMS }\end{array}$ & 246 \\
\hline 12.2 & 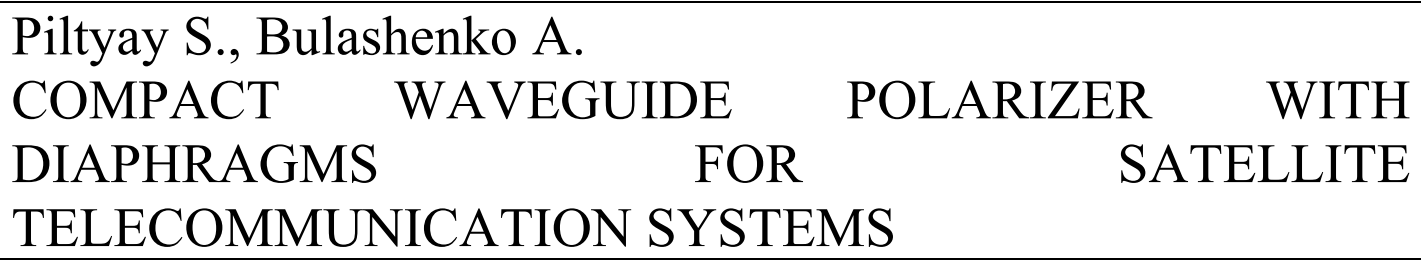 & 251 \\
\hline 13. & TELECOMMUNICATIC & 254 \\
\hline
\end{tabular}




\begin{tabular}{|c|c|c|}
\hline 13.1 & $\begin{array}{l}\text { Sokol G., Gerasymov D., Shuhailo A. } \\
\text { ANALYSIS OF RECURSIVE ESTIMATION PROCEDURE }\end{array}$ & 255 \\
\hline 14. & TRANSPORT & 259 \\
\hline 14.1 & $\begin{array}{l}\text { Gordiienko S., Pluznikova A. } \\
\text { EFFICIENCY OF THE IMPACT OF SPEED LIMITS ON } \\
\text { ROAD TRAFFIC SAFETY IN UKRAINE }\end{array}$ & 260 \\
\hline 14.2 & $\begin{array}{l}\text { Kalinichenko Y., Alexandrovskaya N., Stenhach O. } \\
\text { ENSURE RELIABILITY AND SAFETY OF VESSELS } \\
\text { DURING COLLISION AVOIDANCE ACTIONS }\end{array}$ & 266 \\
\hline 14.3 & $\begin{array}{l}\text { Kunda N. } \\
\text { DIGITAL TOOLS IN PRACTICE TIR }\end{array}$ & 270 \\
\hline 14.4 & $\begin{array}{l}\text { Sharai S., Oliskevych M., Roi M. } \\
\text { ANALYSIS OF TECHNOLOGICAL AND ECONOMICAL } \\
\text { PRECONDITIONS OF INTERCITY CARRIERS BUSINESS } \\
\text { INTERACTION }\end{array}$ & 276 \\
\hline 14.5 & $\begin{array}{l}\text { Silenko V., Tretynychenko A., Tretynychenko Y. } \\
\text { THE CHOOSING OF CARGO DELIVERY RATIONAL } \\
\text { METHODS FOR INTERNATIONAL TRANSPORTATION } \\
\text { CUSTOMERS }\end{array}$ & 289 \\
\hline 14.6 & 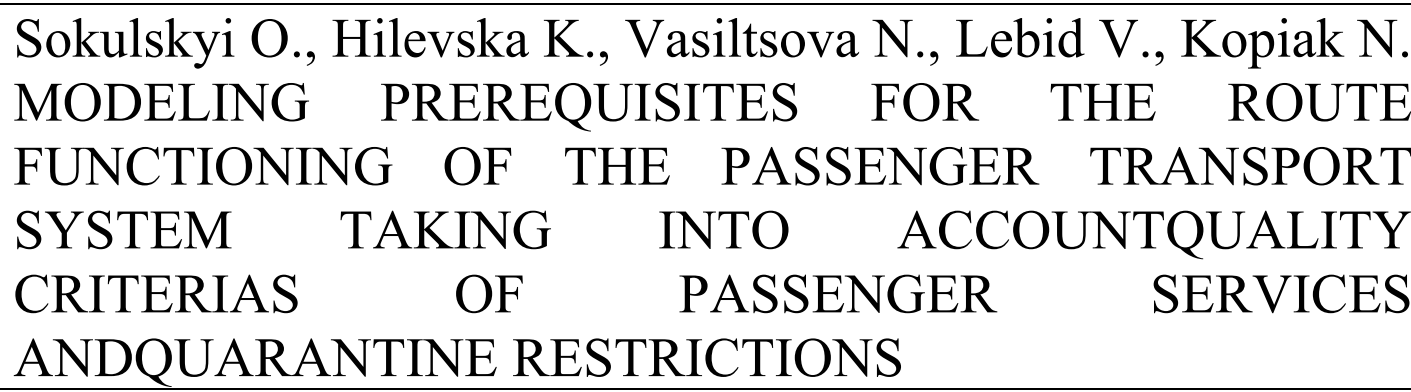 & 294 \\
\hline 14.7 & $\begin{array}{l}\text { Петрик А., КозЛов В., Головатюк М. } \\
\text { ВПРОВАДЖЕННЯ ІНТЕГРОВАНОГО УПРАВЛІННЯ } \\
\text { ТРАНСКОРДОННИМ } \\
\text { СТРУКТУРУ ТРАНСПОРТНИХ СИСТЕМ }\end{array}$ & 299 \\
\hline 14.8 & $\begin{array}{l}\text { Шапенко С.М., Лебідь В.В. } \\
\text { АНАЛІЗ НАПРУЖЕНОСТІ } \quad \text { РОБОТИ } \\
\text { АВТОБУСІВ В МІСТАХ }\end{array}$ & 305 \\
\hline 15 & $\begin{array}{l}\text { METROLOGY, STANDARDIZATION AND } \\
\text { CONFORMITY ASSESSMENT }\end{array}$ & 311 \\
\hline 15.1 & $\begin{array}{l}\text { Serediuk D., Pelikan Y., Bas O. } \\
\text { INTERNATIONAL COMPARISONS GAS VOLUME AND } \\
\text { VOLUME FLOW RATE STANDARDS }\end{array}$ & 311 \\
\hline
\end{tabular}


THEORETICAL ASPECTS OF MODERN ENGINEERING

REFERENCES

320 


\section{SECTION 1. ARCHITECTURE AND CONSTRUCTION}

\subsection{Landscape imperative in the spatial organization of Ukrainian villiges}

Сучасна наукова література досить вільно оперує терміном «ландшафт», при цьому словникові роз'яснення подають різні, але схожі за своєю суттю тлумачення цього слова. Перше трактується як - «загальний вигляд місцевості, пейзаж, малюнок; друге - малюнок, картина із зображенням переважно сільської місцевості; третє - географічний термін - частина земної поверхні з певним сполученням рельєфу, клімату, грунтів, рослинного i тваринного світу». (Великий тлумачний словник сучасної української мови, 2005, с. 605).

Існує інше трактування ландшафту, яке охоплює ще й сучасне буття людини - «ландшафт - це обличчя поверхні землі, яке є синтезом природних елементів і діяльності людини». (С. Мигаль, Методологічні концепції ландшафтного дизайну та їх еволюція в сучасних умовах - 2013, с. 355).

Сучасний ландшафт у більшій мірі базується на таксономічних принципах природної, соціальної, господарської, культурної складової. При цьому сутність терміну містить у собі єдність історичної території з її господарським укладом, де взаємозв'язок природного ландшафту із антропогенним розглядається в діалектичній взаємодії - людини і природи, в якій обидва учасника своєю діяльністю залежать один від одного.

Історично українське село формувалося протягом століть під впливом власних етнокультурних традицій та соціально-побутових взаємовпливів інших народів, що яскраво відобразилось на образі українського села. Безумовно, цей процес тривалий та багатовекторний. Та саме упродовж останніх десятиліть, сучасне українське село активно долучається до цінностей європейської культури, а разом із цим поступово втрачає свою самобутність.

Культура народу є основним чинником етногенезу, у якому різні суспільноекономічні формації тривалий час побутували на теренах України, безпосередньо впливали на життєву активність народу. Ці впливи проявилися в 
усіх сферах життєдіяльності суспільства - економіці, побуті, культурі тощо. Особливо наочно це проявилося в архітектурі, яка акумулювала у собі всі прояви суспільного життя, насамперед в архітектурно-просторовій організації сільських територій, починаючи від вибору місця під заселення i закінчуючи опорядженням середовища та інтер'єрів споруд. 3 одного боку, архітектура села, яка формує середовище, враховуючи при цьому реальні потреби і можливості, використання ресурсів, зв'язок $з$ природним оточенням, а 3 іншого - виробничофункціональне буття 3 його архітектурними ансамблями. Власне тому архітектура, у силу свого специфічного положення між мистецтвом та інженерією, опинилася в епіцентрі дихотомії. Ці два підходи у розвитку архітектури села найяскравіше відобразилися в усіх аспектах її оцінки.

Дослідженнями наукової спадщини архітектури українського села та збереженості національних традицій завдячуємо працям багатьох вітчизняних учених - дослідників, зокрема А. Байгеру, Х. Вовку, В. Войтовичу, О. Воропаю, 3. Гудченко, А. Данилюку, В. Кармазін-Каковському, В. Ніколаєнку, Л. Прибєзі, В. Самойловичу, Р. Сілецькому, В. Січинському, Ю. Хохолу та іншим. Відомими є праці з розпланування територій сільських поселень М. Габреля, М. Дьоміна, Є. Клюшниченка, А. Кондухова, Г. Лоїка, та ін. Однак теоретичні і прикладні дослідження урбаністичних традицій українського села в контексті сучасних реалій потребують подальших досліджень. Власне такий науково-дослідницький вектор у цій тематиці, у сукупності з актуальними сучасними викликами, визначив мету дослідження, а саме: виявлення впливу природно-ландшафтних чинників на формування розпланувальної структури українського села.

Відомо, що народна архітектура враховувала природні умови, рельєф, клімат, які впливали на господарсько-культурне освоєння земель, творчість народу, земельні відносини, побут населення, окремі функції виробництва у веденні домашнього господарства, тощо. Протягом століть, 3 економічних позицій, функціонально-утилітарних i естетичних вимог сепарувались найдосконаліші форми будівель та споруд. У такій самій залежності розвивали планування сіл та забудову сільських садиб, в якій формувалися зв’язки 3 
навколишнім просторовим оточенням, 3 природним ландшафтом. Народні майстри прагнули розташовувати житлові будинки неподалік річок. Таке розпланування має свою функціональну доцільність - вода життєво необхідна, окрім цього є велика потреба для ведення сільському господарства. Також наявність водойм сприяло створенню комфортного мікроклімату та формувало естетичний вигляд поселення. Поряд із цим, у багатьох випадках, за збільшення кількості населення в умовах малоземелля, під створення поселень намагалися використовувати неродючі i малопридатні, для сільськогосподарського обробітку землі. У результаті цього сформувалися найрізноманітніші форми групового розселення та типи поселень за обсягом, функцією та планувальною структурою. Центром такої групи часто було село, яке завдяки зручному розташуванню поступово наповнювалося значною соціально-культурною інфраструктурою і з давніх часів прив'язувало до себе багатьма життєвими зв’язками сусідні села, завдяки чому іноді отримувало статус містечка із центром - ринковою площею (Г. Лоїк, 2003, с. 348-359). Як правило на вибір форми геометрії ринкової площі впливали ландшафт, рельєф території, наявність існуючих сформованих шляхів, оборонна стратегія розвитку поселення, досвід інженерів проектувальників, землемірів. Такі площі існують і до цього часу. Для прикладу у селах (колись містечках) Білий Камінь, Львівської області, Глиняни, Комарно, Щирець та інших численних поселеннях. Зокрема одним із таких прикладів слугує село Наварія Пустомитівського району Львівської області. Село Наварія розташоване всього в 4,5 км до початку територіальної межі Львова. Відомо, що на початку XVI-XVIII ст. село було містечком Руського воєводства, якому 1578 року було надано Магдебурзьке право і привілеї 3 дозволом на проведення торгівлі, що мало великий вплив на розвиток самого містечка i навколишніх сіл (http://pustomyty-miskarada.gov.ua/selonavariya/istoriya-sela). Відповідно до цього сформувалася його планувальна структура 3 ринковою площею в центрі села, історично-сформованою центральною вулицею, яка з’єднує Наварію із Львовом в одному напрямку і 3 містом Пустомитами і Щирцем - у другому. Архітектурно-розпланувальна 
структура села групувалася довкола ринкової площі, яка розпланована на вищій точці рельєфу місцевості і вздовж головної артерії- центральної вулиці. Головна комунікаційна артерія пронизує середину ринкової забудови, яка $\epsilon$ композиційною домінантою у розпланувальній композиції поселення iз численним набором громадських споруд. Вигідне розташування Ринкової площі на узвишші рельєфу сприяє панорамному огляду місцевості, поєднуючи із довколишніми ландшафтами.

Свого часу містечко розвивалось як торговельно - рільниче. Рільнича справа у містечку була достатньо розвинена, оскільки виходячи 3 функціональної програми містечок - господарських осередків, кожний поселенець отримував від власника містечка, окрім міської парцелі, ще й городню ділянку та ріллю. Рільничі угіддя розташовувалися за межами містечка. Позаміська частина охоплювала також угіддя для спільного використання - пасовища, ліс, водоймища, луки (Топилко C, 2003). Інші, у минулому колишні містечка, в яких виражена сильніша реміснича функція (Білий Камінь, Калуш, Магерів, Немирів, Сасів, Станіславчик, Янів) мають компактну планувальну структуру. Для них характерні проста геометрична форма плану, регулярна мережа вулиць 3 ринковою площею посередині, розвинена краща збереженість будівельної субстанції, менш деформована планувальна структура. Наприклад село Нове Місто у Старосамбірському районі Львівської області у XIX ст. було центром усієї округи. Iз XIV ст. розвивалося як ремісничо-торговельне містечко, яке було наділене магдебурзьким правом. Відповідно до цього сформувалася його планувальна структура з ринковою площею й мережею вулиць, які забезпечують зв’язок із зовнішнім середовищем, різними об'єктами господарського, культурно-побутового і духовного обслуговування. Розміщення цих об'єктів у містечку функціонально і візуально було пов'язане з навколишнім середовищем, його ландшафтом та іншими осадниками наближених поселень. Аналогічно цьому можна навести численні приклади, коли певні історичні, виробничогосподарські, земельні відносини і завжди природні чинники вплинули на формування містобудівних структур (Г. Лоїк, 2003, с.348-359). Так, 
архітектурно-планувальна структура села Нова Скварява у Жовківському районі Львівської області історично формувалася під впливом життєвих потреб його мешканців і ландшафтно - природного чинника. У сформованій структурі села чітко простежується неповторний просторовий ансамбль поєднання архітектури 3 природою. Злиття простору лісового масиву окреслює протяжна головна вулиця села, вздовж якої групується садибна забудова, яка переростає у забудову громадської функції. Завершує ансамбль вулиці споруда церкви, яка домінує у цьому ландшафті й візуально об'єднує весь виднокрай усього села.

Багато сіл, що сформувалися історично у лінійно-вуличну та квартальномістобудівну структури, виникли не за певними надуманими геометричними композиціями (окремі 3 яких, як нам відомо, були штучно надумані i впроваджені у планувальні рішення сіл), а як такі, що підпорядковувалися ландшафту, гідрографії, рельєфу, функціональним особливостям, ущільненням забудови тощо. Цьому факту можна навести численні приклади таких рішень, коли виробничо-господарські історичні, природні чинники тісно переплітаються між собою і впливають на формування містобудівних структур, зокрема село Надичі Гребінці Жовківського р-ну Львівської області (мал.1).

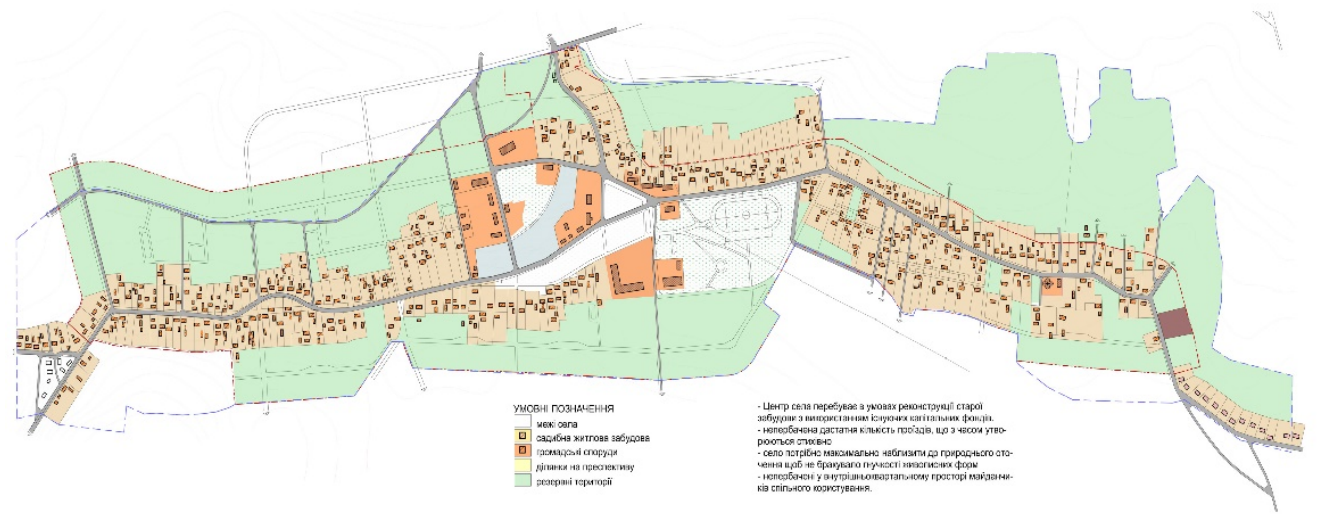

Малюнок 1. Генплан, с. Надичі Гребіниі Жовківського р-ну

Львівської області (креслення автора)

Іншим типом містобудівної структури слугують села, що сформувалися на базі окремих «поодиноких садиб». Спершу планування таких сіл видається безсистемними, але насправді вони відображають послідовну еволюцію 
розвитку - від окремих груп з «поодинокими-садибами» до створення єдиної цілісної композиції поселення. Прикладом є село Брахівка Буського району Львівської області, що сформувалось як поселення лісорубів, яких ще називали брахарами (мал. 2). Саме цьому сприяла наявність протяжних лісів довкола села (https://uk.wikipedia.org/wiki/). В основу планувального вирішення цього села покладено досить характерну містобудівну структуру, сформовану як окремі розкидані одна від одної «поодинокі-садиби», схожі на хутірське розселення над річкою Покровою. Природно так склалося, що в цьому разі річка слугує своєрідною композиційною віссю. Але з часом ці колишні «поодинокі садиби» функціонально об'єдналися дорогами, стежками, окремими будівлями різного призначення, i поступово перетворилися в єдину систему вулиць, проїздів $\mathrm{i}$ глухих кутів (мал. 2).

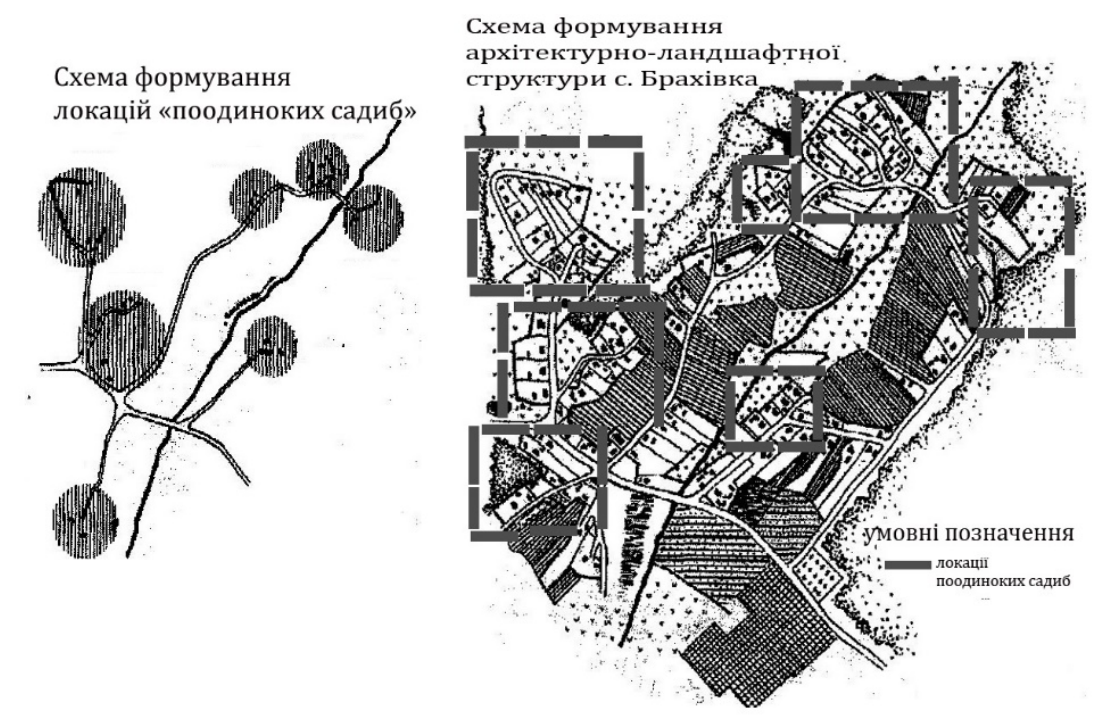

Малюнок 2. Схема формування архітектурно-ландшафтної структури с. Брахівки. а) локації поодиноких садиб; б) схема генплану з виділеними колишніми локаціями «поодиноких садиб»(Г. Лоӥк, 2003. с.353, доопраџьовано автором статті)

У селі, вздовж дороги, яка пронизує поселення і єднає його з сусідніми, сформовано громадський центр, у складі якого є церква, школа, народний дім, 
ФАП, магазини. Отож, сформувався архітектурно-функціональний, багатоплановий простір, який доповнюється і об'єднується природноландшафтним оточенням, створюючи при цьому досить гармонійне середовище.

Висновки. У наш час, в Україні досить активно оновлюються, генплани сіл. Цей процес цілком логічний і закономірний, оскільки змінилися соціальнополітичні реалії життя людей і країни загалом. Але сьогодні, ще з радянських часів, залишилася структура законодавчої бази проектування, яка не враховує регіональних відмінностей територій, конкретних населених пунктів, міст (об'єктів): історичних, природних, екологічних, трудових тощо. Отож, дещо усувається питання особистої відповідальності суб'єктів проектної діяльності.

Найголовніше, що можна констатувати, це те, що не відбувається гуманізації сфери проектування (Вадимов В, 2003), де у проектній продукції, на жаль, ще не з'являються враховані фахівцями унікальність і неповторність кожного природного комплексу, його історична спадщина тощо. Отже, пропонуючи нові розпланувальні вирішення генпланів сіл, фахівцям не варто забувати про історичну складову у розпланувальних рішеннях проектної продукції, адже в минулому і в сьогоденні ринкові площі, майдани у поселеннях завжди займали домінуючу роль, як у розташуванні їх у поселенні, так i безпосередньо у громадському житті мешканців. Себто, від проектантів вимагається детально аналізувати ситуації територій, враховувати індивідуальні особливості кожного конкретного випаду і місця, для подальшого розпланування поселень. 


\subsection{The design of the filter for water treatment from underground horizons}

Groundwater often contains high iron content (for drinking water, the standard content is $0.2 \mathrm{mg} / \mathrm{dm} 3$ [8]). Excessive amount of iron in drinking water from underground sources has a negative effect on human health, causes odor, turbidity, water color, leads to overgrowth of water pipes $[9,10]$.

Water is deironed by reagent, non-reagent, cation exchange and biochemical methods. The first two methods involve the oxidation of ferrous iron by oxidants chlorine and oxygen. The method of cation exchange is the exchange of iron cations for sodium and hydrogen cations due to special filter loads. The biochemical method involves the settlement on a suitable carrier of special iron bacteria with subsequent filtration on special filters [11].

The filtration purification mechanism is the most important characteristic of the filter's ability to retain water impurities.

One of the best ways to iron groundwater is to install a polystyrene foam filter. Styrofoam filters are containers in which the retaining grid in the submerged state holds a floating polystyrene backfill.

The filtration rate of water in the filter is determined:

$$
v_{f}=\frac{3,6 \cdot q_{s}}{f_{c}}
$$

де $q_{s}$ - consumption of source water, $\mathrm{dm} 3 / \mathrm{s}$;

$f_{c}$ - area of the filter column, $\mathrm{m} 2$.

The intensity of washing is determined by:

$$
\omega=\frac{q_{f}}{f_{c}},
$$

де $q_{f}$ - flushing water consumption, $\mathrm{dm} 3 / \mathrm{s}$.

Pressure loss $\left(h_{f . b .}\right)$ in the filter backfill during the filter cycle:

$$
h_{f . b .}=P_{1}-P_{2},
$$

when $P_{1}, P_{2}$ - respectively, the readings of piezometers №1 and №2. 
Determination of the concentration of soluble oxygen is carried out by the method of Winkler, according to which the oxygen concentration in water, $\mathrm{mgO} 2 / 1$, is determined:

$$
O_{2}=\frac{8 \cdot V_{t} \cdot n \cdot 1000}{V_{1}-V_{2}}
$$

де $V_{t}$ - volume of sodium thiosulfate used for titration, $\mathrm{ml}$;

$n$ - normality of sodium thiosulfate solution, $n=0,05$;

$V_{1}$ - oxygen cup volume, $\mathrm{ml}$;

$V_{2}$ - volume of reagents introduced into the water for oxygen precipitation, $\mathrm{ml}$.

Experimental studies of the deironing process were conducted in the laboratory of the Department of Water Supply, Sewerage and Drilling at the installation for deironing water.
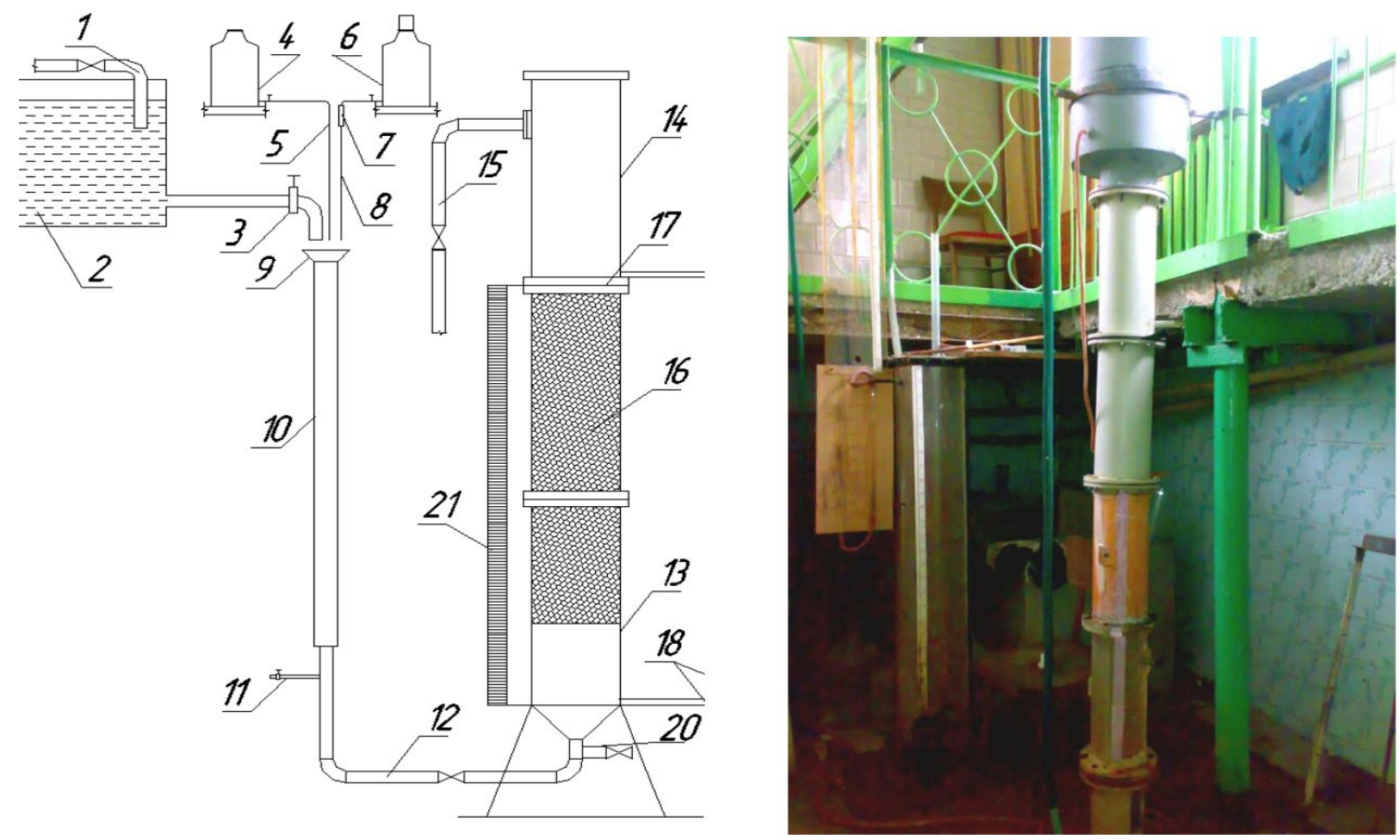

Figure 1. Experimental installation for the study of hydraulic properties of expanded polystyrene

The laboratory installation works as follows: tap water through the pipeline 1 is fed into the tank of constant level 2, from which flows through the pipeline 3 into the mixing funnel 9 . On the pipeline 3 there is a valve to control the filtration rate on the 
installation. Also in the mixing funnel 9 is fed through the pipeline 5 a solution of lime milk from the tank 4 and a solution of iron sulfate from the tank 6 , which is dispensed through the dispenser 7 through the pipe 8. The mixing funnel 9 is a device that provides uniform mixing of water and solutions of sulfuric acid. . The solution of uniform consistency after the funnel 9 enters the regulator of the filtration rate 10. In the regulator of the filtration rate (air separators) is a disk-shaped element that provides aeration of water and additional oxygen saturation. Aerated water through the pipeline 12 is fed to the lower part of the filter column 13. The source water passes through the expanded polystyrene backfill 16 , held by the grid 17 in the tank to collect the filtrate 14.

Through the discharge line 15, the removal of iron-free water after purification. Two piezometric tubes 18 , connected under the layer of expanded polystyrene backfill and above the retaining lattice 17, are used to control the level of calcination of the expanded polystyrene backfill. In the lower part of the column is arranged flushing pipe 20 , when opening the valve on which the regeneration of the backfill by its expansion and friction of the grains against each other. To control the amount of backfill expansion during flushing, a rail 21 with a scale is attached.

At filtration speeds less than $4 \mathrm{~m} / \mathrm{h}$ there is a slight change in pressure loss during filtration, and at speeds of 8 and $9 \mathrm{~m} / \mathrm{h}$ the quality of the filtrate did not meet regulatory requirements, so the studies adopted a range of filtration speeds in the range of 4-7 m / h.

Studies of pressure loss changes were performed for the speed range from 4 to 7 $\mathrm{m} / \mathrm{h}$ at iron concentrations in the source water $-1 \ldots 2 \mathrm{mg} / \mathrm{dm} 3$.

The functional dependence of the effect of water purification has the form of changing the pressure loss with complete flushing of the filter backfill $H=f\left(C_{s}, V_{f}, T_{f}\right)$

The regression equation for determining the pressure loss in the filtering expanded polystyrene backfill when it is completely washed will look like:

$$
\begin{aligned}
& H=0.034+1.572 C_{s}+0.852 V_{f}-0.019 T_{f}-0.133 C_{s} \cdot V_{f}+0.087 V_{f} \cdot T_{f} \\
& C_{s} \text { - concentration of iron in water at the inlet of the filter, } \mathrm{mg} / 1 ;
\end{aligned}
$$


$V_{f}-$ water velocity at the inlet to the filter, $\mathrm{m} / \mathrm{h}$;

$T_{f}$ - filtration duration, $\mathrm{h}$.

The dependence of the change in pressure loss in the filter backfill on the duration of filtration in the filter backfill in the range of filtration rates $4-7 \mathrm{~m} / \mathrm{h}$ at an iron concentration in the source water over $2.0 \mathrm{mg} / \mathrm{dm} 3$ with complete flushing of the backfill is shown in Figure 2.

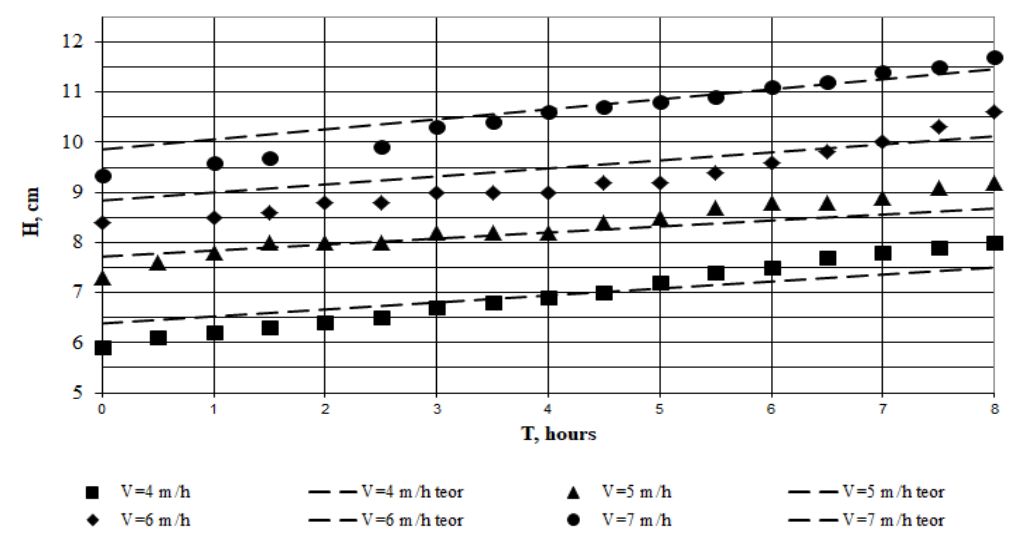

Figure 2. The dependence of the change in pressure loss on the duration of filtration at a speed of 4-7 m/ h and the concentration of iron in water $2.0 \mathrm{mg} / \mathrm{dm} 3$.

For a filter cycle lasting $8 \mathrm{~h}$, the pressure loss in the filter backfill with its complete washing at the concentration of iron in the source water $C_{s}=2.0 \mathrm{mg} / \mathrm{dm} 3$ for a speed of $4 \mathrm{~m} / \mathrm{h}$ increased from 6.0 to $7.8 \mathrm{~cm}$ and was for the filter cycle $-1.8 \mathrm{~cm}$, for $5 \mathrm{~m} /$ $\mathrm{h}$ - from 7.3 to $9.2 \mathrm{~cm}$ and was $1.9 \mathrm{~cm}$, for a speed of $6 \mathrm{~m} / \mathrm{h}$ increased from 8.4 to $10.6 \mathrm{~cm}$ and amounted to $2.2 \mathrm{~cm}$, for $7 \mathrm{~m} / \mathrm{h}$ - from 9.3 to $11.7 \mathrm{~cm}$ and for the entire filter cycle was respectively $2.4 \mathrm{~cm}$.

The head loss and iron content in the filtrate were removed at the initial time and after 0.5 hours. For the filter cycle, 17 values were removed and a confidence interval with a probability of $5 \%$ was constructed. At the end of each filter cycle, the expanded polystyrene backfill was completely washed for 2.5-3.0 minutes.

The dependence of the filtrate quality on the filtration duration in the speed range 4-7 m/ h and the iron concentration in the source water of $2.0 \mathrm{mg} / \mathrm{dm} 3$ with complete backfill flushing is shown in Figure 3. 


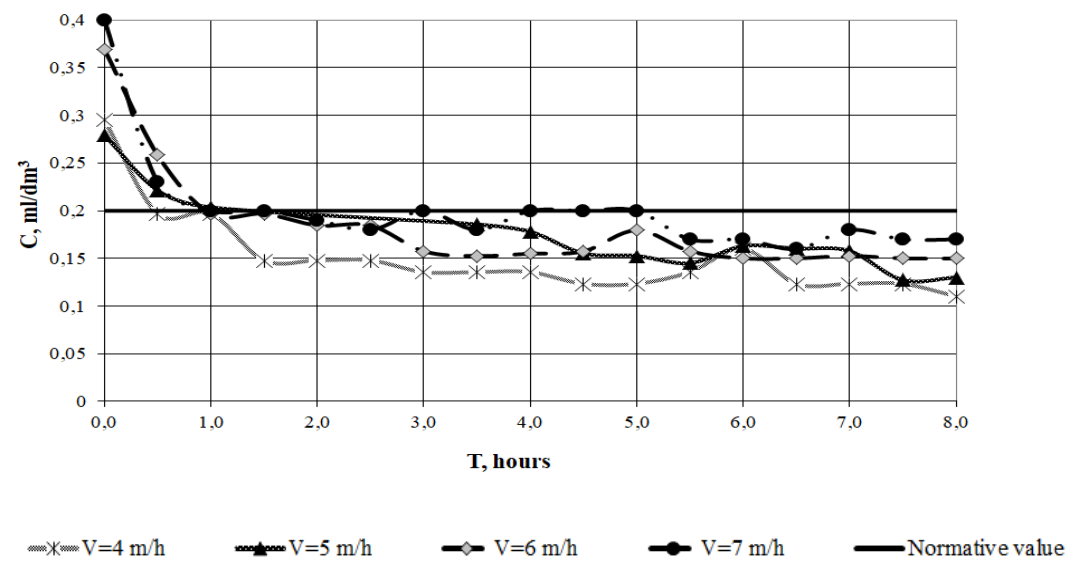

Figure 3. The dependence of the quality of the filtrate on the duration of filtration at a rate of $4-7 \mathrm{~m} / \mathrm{h} \mathrm{dm} 3$ concentration of iron in water $2.0 \mathrm{mg} / \mathrm{dm} 3$

The studies were performed when the $\mathrm{pH}$ value in the source water was 7.45-7.6. In the filtrate, the hydrogen index was $\mathrm{pH}=7.45-7.75$.

At an iron concentration in the source water of $2.0 \mathrm{mg} / \mathrm{dm} 3$, the compliance of normative values for filtration rates of $4-7 \mathrm{~m} / \mathrm{h}$ was observed. For the range of filtration rates of $4-7 \mathrm{~m} / \mathrm{h}$ at the 8 th hour of the filter cycle, the quality of the filtrate is in the range of $0.17-0.11 \mathrm{mg} / \mathrm{dm} 3$. The effect of iron removal was $90-91 \%$. After the filter cycle, the filter backfill was washed. The washing intensity was 16-17 dm2 / $\mathrm{s} * \mathrm{~m} 2$, the duration was $120-140 \mathrm{~s}$. 


\subsection{Methods for assessing the thermal capacity of buildings}

Питання ефективного використання паливно-енергетичних ресурсів (ПЕР) останнім часом стає дедалі актуальнішим для забезпечення енергетичної незалежності України. За даними [12], щороку наша держава імпортує близько $50 \%$ ПЕР від загального обсягу їх споживання, що в свою чергу зумовлює вагому залежність від країн-експортерів. При цьому, прогнозовані значення потенціалу енергозбереження для України сягають 42-48 \% від сумарного обсягу споживаних ПЕР.

Будівлі навчальних закладів, житловий фонд України являється одним із основних споживачів енергоресурсів в Україні. Оскільки, вік більшої частини житлового фонду України перевищує 50 років, то, більше ніж 60\% будинків потребують модернізації та/або капітального ремонту [12]. Окрім цього, майже 90\% будівель нині не відповідають сучасним вимогам енергоефективності [13], «із загального обсягу споживаної енергії, що становить близько 43 \% вироблюваної теплової енергії, 90 \% витрачається на опалення» [14]. Особливо актуальною ця проблема постає при проєктуванні та впровадженні новітніх систем опалення 3 використанням альтернативних джерел енергії: сонячної енергії (сонячні електростанції та колектори); низькопотенційної теплової енергії навколишнього середовища (теплові насоси), які в основі свого технологічного процесу використовують електроенергію. При проєктуванні завжди першим постає запитання: « Якої максимальної теплової потужності є приєднане теплове навантаження споживачів? Чи $€$ воно достатньо обгрунтованим?» 2017 року Верховна Рада України прийняла законопроект №4941 «Про енергетичну ефективність будівель» [15]. Відповідно до його положень вводиться обов'язкова енергетична сертифікація та визначення класів енергоефективності будівель. Зокрема, об’єкти будівництва, що знаходяться на стадії проектування та вже побудовані будівлі повинні будуть пройти сертифікацію енергетичної ефективності 3 метою визначення фактичних іï 
показників та проведення оцінки відповідності зазначених показників встановленим мінімальним вимогам до енергетичної ефективності будівель.

Задля грамотного вирішення поставленого завдання необхідно використовувати відповідні методики розрахунку теплової потужності будівель. У зв'язку з великою їх різноманітністю, важливим є визначення однієї найбільш достовірної, коректної та простої у реалізації.

Метою даної роботи є оцінка існуючих нормативних документів у сфері енергозбереження для розрахунку теплової потужності будівель. Задля цього застосовано розрахункові методи визначення теплової потужності будівлі відповідно до методик: [16], [17], [18], [19], [20] та [21] та порівняльний аналіз значень, що були отримані у результаті розрахунків з дійсними показниками для заданого об'єкту.

Класифікація методів оцінки теплової потужності будівлі

Існуючі методи визначення теплової потужності будівель $є$ досить розгалуженими та мають певні особливості, що обумовлені конструктивним виконанням і призначенням цих обчислень. При проведенні розрахунків реальний об'єкт доцільно розглядати у вигляді моделі, тим самим враховуючи чи нехтуючи певними факторами.

Відповідно до інформації, що наведена у [22], моделлю називають «об’єктзамінник, створений з метою відтворення за певних умов суттєвих властивостей об’єкта-оригіналу». Основною задачею моделювання є створення такого опису заданого об'єкта, що зміг би у повній мірі відобразити оригінал, відповідно до заданої мети моделювання [22]. При виборі розрахункової моделі необхідно визначитися з основними критеріями (див. рисунок 1). 

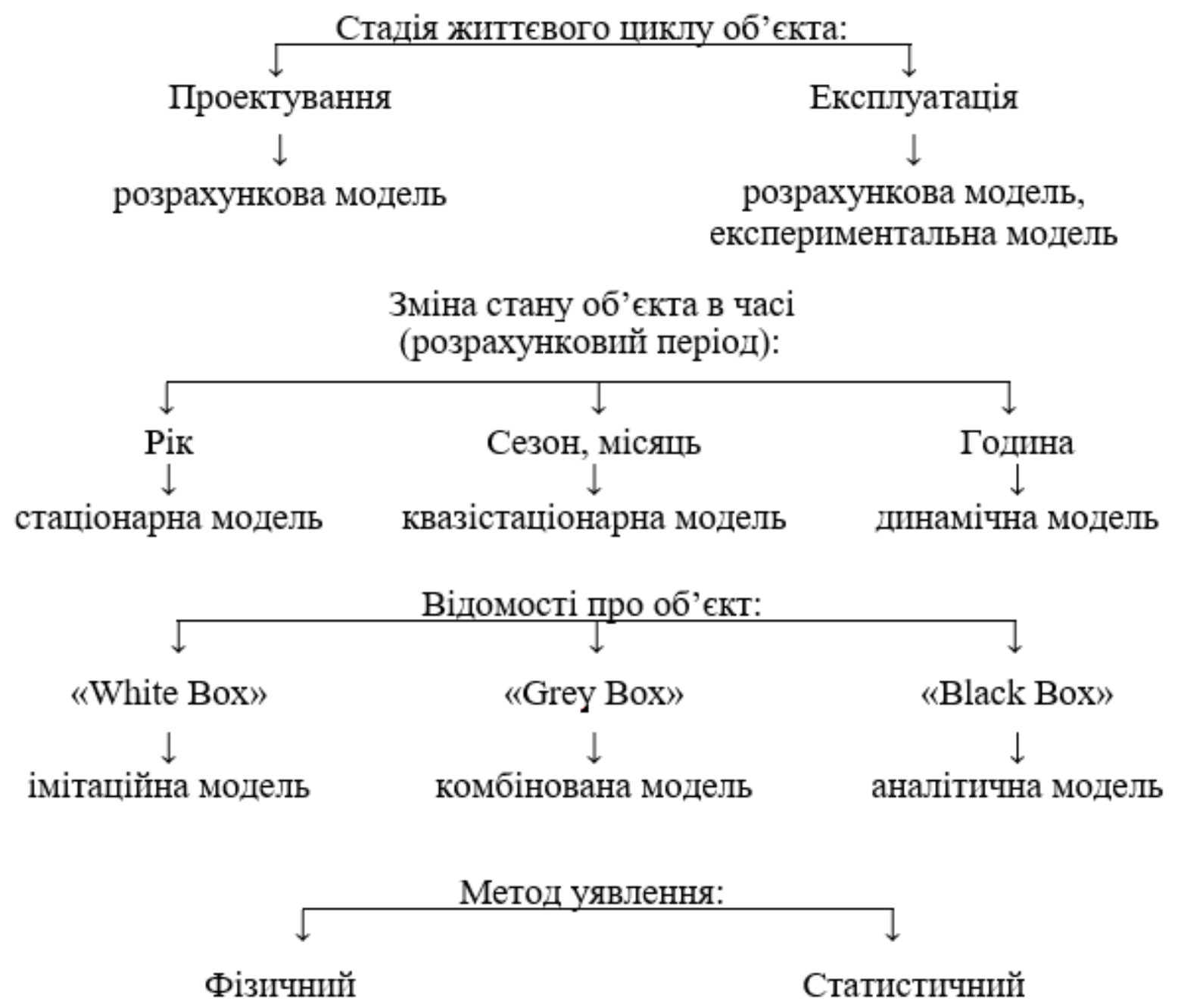

Рисунок 1. Класифікація методів оцінки теплової потужності будівлі

Розглянемо більш детально кожну з приведених моделей.

1) Залежно від стадії життєвого циклу змінюються і методики обрахунку теплової потужності. На етапі проектування іiі визначають для прогнозування енергопотреби будівлі та передбачення обсягів споживання енергії - для цього використовують розрахункові моделі. На стадії експлуатації, теплову потужність будівлі знаходять, переважно, з метою подальшої модернізації систем для зменшення обсягів енергоспоживання - для цього користуються розрахунковими та експериментальними моделями. Розрахункові моделі базуються на основі проектних та статистичних відомостей, тому в порівнянні 3 
експериментальними, що базуються на даних, отриманих у ході експерименту, можуть давати більшу похибку, але вимагають менших затрат часу та праці на їх реалізацію.

2) Залежно від поставленої мети, розрахунок теплової потужності можна проводити за допомогою стаціонарних, квазістаціонарних чи динамічних моделей. Найбільшого поширення на території України здобули стаціонарні методи розрахунку. Дану методику, переважно, використовують для отримання орієнтовних значень енергоспоживання існуючих будівель, оскільки розрахунки ведуться, здебільшого, за нормативними та статистичними даними. Розрахунковий період даного методу складає один рік та не враховує інерційних особливостей будівлі. Дана модель базується на основі таких нормативних документів, як [16] та [20]. Квазістаціонарні методики використовують при розрахунках для більш тривалого інтервалу часу (зазвичай один місяць чи цілий сезон) та враховують динамічні зміни стану будівлі за рахунок емпіричних коефіцієнтів використання теплонадходжень та тепловтрат. Дана методика розкрита у [17] та [18]. Динамічні методики для моделювання енергоспоживання в Україні використовуються найрідше, i, здебільшого, для розрахунку погодозалежних систем. Цей метод дозволяє проводити розрахунки для короткотривалих часових інтервалів (одна година) та враховує обсяг тепла, що акумулюється в, або вивільняється від масиву будинку. Приведений спосіб розрахунку базується на стандарті [17].

Найбільшу точність результатів передбачає динамічний метод розрахунку, але для його обчислення необхідна значна кількість вхідних даних та тривалий час на їх обробку. Для підвищення точності отриманих результатів за стаціонарним методом необхідне своєчасне оновлення і поповнення вхідних даних.

3) Залежно від відомостей про взаємозв'язок між параметрами системи розглядаються три типи моделей: метод чорного ящику ("black-box"), білого ящику ("white-box") та cipi моделі ("grey-box"), в основі яких лежать аналітичий, імітаційний та комбінований способи моделювання, відповідно. Автор [22], 
пояснює це так: «... для аналітичних моделей (analytical models) властиво те, що процеси функціонування об'єкта подаються у вигляді аналітичних математичних залежностей: алгебраїчних, диференціальних, інтегральних рівнянь або їх систем, логічних умов. Імітаційне моделювання (simulation) передбачає подання моделі у вигляді алгоритму та комп'ютерної програми, яка дозволяє відтворити поведінку об'єкта. Імітаційні моделі розглядаються як експерименти, що проводяться на комп'ютерах з математичними моделями, які імітують поведінку реальних об'єктів. При цьому імітуються елементарні явища, що складають процес, зі збереженням їх логічної структури та послідовності у часі, що дозволяє отримати відомості про стан системи у певний момент часу та оцінити характеристики системи. Імітаційні моделі дозволяють вирішувати більш складні задачі, ніж аналітичні. Інколи застосовується комбіноване (аналітико-імітаційне) моделювання, яке полягає в тому, що об'єкт диференціюється на окремі підсистеми. Для тих підсистем, для яких це можливо, використовуються аналітичні моделі, а для інших розробляються імітаційні моделі...».

4) Залежно від методів аналізу будівель виділяють два види моделей: фізичні та статистичні. Фізичні моделі використовують для опису систем, що підлягають поясненню з фізичної точки зору. Для формування таких моделей вхідними даними є параметри реальних процесів. Якщо цих закономірностей невідомо, то розрахунки проводять на основі статистичних даних , модель являє собою абстрактну схему відношень між параметрами, що характеризують властивості дійсного процесу [23].

При виборі відповідної методики для розрахунку теплової потужності будівель необхідно враховувати мету проведення розрахунків та їх призначення, а також конструктивні особливості об'єкту та його теплофізичні характеристики.

2. Опис існуючих методів визначення теплової потужності будівлі

Для моделювання теплового стану будівель використовують методики, що базуються на нормативних актах, доповнень до них та різноманітних програмних 
продуктів. Найбільшого поширення серед існуючих методик здобули [16], [17], [18], [19], [20] та [21].

КТМ-204 Україна 244-94 [16] призначений для планування потреб в теплоті та паливі на опалення, вентиляцію та гарячого водопостачання (ГВП) житлових та громадських споруд, а також на господарсько-побутові потреби. Витрати теплоти на потреби опалення визначаються як величина для покриття тепловтрат крізь будинкові огородження, що викликані інфільтрацією. Розрахунки базуються на основі укрупнених питомих опалювальних характеристиках та статистичних даних, залежно від призначення будівлі, року забудови та від іiі габаритних розмірів. Дана методика $\epsilon$ прикладом стаціонарного методу розрахунку енергопотреби на опалення будівель, що експлуатуються. Аналогом [16] є Міжгалузеві норми [24].

Згідно зі стандартом [20] теплову потужність будівлі визначається як різниця між тепловтратами та теплонадходженнями. На відміну від попередніх методик, що базуються на розрахункові за укрупненими показниками, використовується метод розрахунку на основі градусо-діб опалювального сезону. Також дана методика дозволяє враховувати найбільшу кількість факторів впливу серед інших стаціонарних методик розрахунку, тим самим вона $\epsilon$ найбільш коректною серед найбільш розповсюджених на території України. Її використовують для розроблення та складання енергетичного паспорта будівель різного призначення з параметрами мікроклімату, що нормуються, під час проектування нового будівництва, реконструкції, капітального ремонту (термомодернізації) та проведення енергетичного обстеження будівель.

Відповідно до стандарту СС в Україні був створений його повний аналог ДСТУ Б EN ISO 13790 [17]. Даний стандарт надає два основних види методик розрахунку: квазістаціонарний та динамічний методи. У динамічних методах миттєвий надлишок тепла протягом опалювального періоду має ефект, при якому внутрішня температура перевищує задану, в результаті чого видалення надлишку тепла відбувається через додаткову трансмісію, вентиляцію та акумуляцію, якщо відсутнє механічне охолодження. Даний метод моделює 
теплопередачу трансмісією, тепловий потік за рахунок вентиляції, акумулювання тепла та внутрішні і сонячні теплові надходження до зони будівлі. У квазістаціонарних методах динамічні ефекти прийняті до уваги через впровадження кореляційних коефіцієнтів. Для опалення коефіцієнт використання внутрішніх та сонячних теплових надходжень береться до уваги як факт, що тільки частина внутрішніх та сонячних теплових надходжень використана для зменшення енергопотреби для опалення. Залишок призводить до небажаного зростання внутрішньої температури понад задане значення. ДСТУ Б EN ISO 13790 [17] охоплює три різні типи методу: повністю визначений місячний квазістаціонарний розрахунковий метод (сезонний метод), повністю визначений спрощений динамічний погодинний розрахунковий метод, методики розрахунку для детальних (погодинних) динамічних методів моделювання, який розглядає модель - п'ять опорів, одна ємність (5R1C). Даний метод не набув широкого вжитку в України і потребує проведення аналізу, накопичення баз даних та досвіду використання.

Спираючись на квазістаціонарний метод розрахунку стандарту [17] було створено ДСТУ Б А.2.2-12:2015 [18]. Цей стандарт встановлює розрахунковий метод оцінки річного енергоспоживання при опаленні, охолодженні, вентиляції, освітленні та гарячому водопостачанні будівель житлового та громадського призначення, що проектуються або експлуатуються. Для режиму опалення цей стандарт визначає квазістаціонарний метод, за яким тепловий баланс розраховують для періоду в один місяць, що дозволяє взяти до уваги динамічні ефекти за емпірично визначеним коефіцієнтом використання надходжень та/або втрат. За цим стандартом, будівля розподіляється на окремі теплові зони. Енергетичний (тепловий) баланс рівня зони будівлі включає наступні складові: трансмісійну теплопередачу між кондиціонованим об'ємом та зовнішнім навколишнім середовищем; вентиляційну теплопередачу (від природної вентиляції або системи механічної вентиляції); внутрішні теплонадходження (включаючи від'ємні надходження від тепловідводу), від людей, устаткування, освітлення та теплота, що виділена або поглинута 3 систем опалення, 
охолодження, ГВП, вентиляції тощо; сонячні теплонадходження; акумульовану теплоту в будівлі або вивільнений запас теплоти з масиву будівлі; енергопотребу для опалення: якщо зона опалюється, та енергопотребу для охолодження: якщо зона охолоджується [18].

\section{3. Авторські методики}

У зв’язку $з$ частою відсутністю нормативних значень показників, їх невідповідністю реальним умовам чи застарілістю, набули поширення авторські методики визначення розрахункового значення теплової потужності будівлі.

«Авторськими» мають право називатися всі існуючі методи розрахунку, за основу яких взяті нормативні документи чи поняття про фізичні явища та зазнали певних змін, удосконалень чи доповнень.

Одним з таких методів є розрахунок за [21]. Дана методика є, певним чином, удосконаленням тієї, що наведена у КТМ-204 Україна 244-94 [16] і отримала назву - «Метод збільшених показників». Замість використання нормативних значень питомих опалювальних характеристик, даний метод пропонує залежність для їх розрахунку. Його використовують, здебільшого, як оціночний, 3 причини неможливості в такий спосіб визначити основні чинники, що впливають на порушення вимог до тепловологісного балансу будівлі.

Методика, яку наведено у [19], розроблено викладачами Сумського державного університету. Вона $\epsilon$ узагальненням існуючих нормативних документів та спеціалізованої літератури, які розкривають питання визначення теплових балансів та систем опалення, кондиціонування i вентиляції для будівель різного призначення, що знаходяться у експлуатації, так званий «комбінований метод». Саме завдяки цьому, даний спосіб дозволяє врахувати найбільшу кількість необхідних параметрів та визначити основні чинники негативного впливу на тепловологісний стан будинку.

4 Програмні продукти

Існуючі методики розрахунку теплової потужності будівель $є$ досить громіздкими та вимагають певних затрат часу на їх оброблення. У зв’язку зі стрімким розвитком технологій великого поширення здобули різноманітні 
програмні продукти для визначення теплової потужності будівель, що у свою чергу дозволило зменшити затрати часу на оброблення результатів та підвищити точність отриманих результатів. Найбільш відомими серед них є: SolidWorks Flow Simulation, ANSYS, EnergyPlus та ENSI EAB Software.

SolidWorks має стандартний зрозумілий графічний інтерфейс і ефективно взаємодіє з такими Windows-додатками, як Excel, Word та ін. Комплекс завдань, пов'язаних 3 питаннями гідродинаміки і теплообміну, в SolidWorks Flow Simulation вирішується за допомогою системи диференціальних рівнянь руху, нерозривності, енергії, теплопровідності стінок каналу. Саме це робить цей програмний продукт зрозумілим для користувача. Але серед недоліків даного продукту можна виділити обмеженість бібліотечних елементів. [25, 26].

Моделі, що розроблені на базі програмного комплексу ANSYS CFX дозволяють оцінити параметри його теплового стану об'єкту, а саме: отримати розподіл температурних полів, полів швидкостей руху повітря; визначити значення теплових потоків на поверхнях конструкцій; встановити наявність застійних зон та зон вихроутворення в процесі прогрівання приміщення 3 урахуванням реального розташування технологічного обладнання [27].

Програмний продукт EnergyPlus застосовується для моделювання енергоспоживання будівель та оцінки теплових балансів і враховує такі аспекти, як: характеристики огороджувальних конструкцій; параметри роботи систем опалення, вентиляція та кондиціонування; додаткові теплонадходження; електропостачання; освітлення та обладнання; альтернативні джерела тощо. Програма має широку базу шаблонів типових інженерних систем, а методики розрахунків здійснюються відповідно до європейських стандартів. Недоліком даного програмного продукту $\epsilon$ відсутність графічного інтерфейсу, що ускладнює роботу з нею, але існує можливість внесення даних через сторонні програми (наприклад Google Sketch Up, DesignBuilder та ін.). Результати розрахунків виводяться у файлі HTML та структуровані в табличних формах. Наявність моделі енергоспоживання будівлі в програмі EnergyPlus дозволяє в перспективі прийняти оптимізаційні рішення шляхом дослідження зміни 
енергетичних характеристик будівлі при зміні технічних характеристик обладнання, огороджувальних конструкцій, режимів роботи інженерних систем тощо. У EnergyPlus використано методики DOE2, до яких наближені європейські стандарти, що робить ії привабливою для застосування $[13,28]$.

Програма ENSI EAB Software призначена для проведення енергоаудитів та розрахунку показників енергоефективності новобудов та існуючих будівель. Квазістаціонарний розрахунок енергоспоживання проводиться за наступними статтями: опалення, вентиляція, гаряче водопостачання, охолодження; вентилятори та насоси; освітлення та інше обладнання 3 урахуванням ефективності систем розподілу та генерації систем. Інтерфейс програми передбачає введення користувачем попередньо розрахованих теплофізичних параметрів оболонки будівлі. Моделювання та складання балансу відбувається по фактичному рівню споживання, базовому рівню та по споживанню після заходів 3 енергоефективності. Важливою особливістю $\epsilon$ урахування взаємовпливу заходів з енергоефективності та інженерних систем. У програмі не передбачено можливості виводити повноцінний звіт про енергетичне обстеження будівлі та автоматизувати процес визначення теплотехнічних показників, проте ENSI EAB дозволяє отримати: показники потенціалу економії енергії кожного заходу; фактичне, базове розрахункове енергоспоживання після впровадження заходів; залежність енергоспоживання від зовнішньої температури (ЕТ-крива). [29].

Використання програмних продуктів для проектування, моделювання та розрахунку енергетичних систем дозволяє підвищити точність отриманих результатів та зменшити час на обробку даних. Але основним недоліком і досі зостається відносна складність інтерфейсу та обмежена база даних.

5. Аналіз отриманих результатів i порівняння розрахункових значень теплової потужності будівель

Найбільшого поширення в Україні здобули методики, що покладені в основу таких нормативних документів та доповнень до них: КТМ-204 Україна 244-94 [12], ДСТУ Б EN ISO 13790 [13], ДСТУ Б А.2.2-12:2015 [14], ДСТУ-Н Б 
А.2.2.5:2007 [15] та так звані авторські методики «комбінований метод» [16] та «Метод збільшених показників» [17]. Усі вони різняться за способами задання вихідних даних, способами обчислення і залежать від мети проведення розрахунку [18].

Для проведення якісного аналізу запропонованих методів розрахунку теплової потужності будівель та отримання якісної їх оцінки, доцільним є не лише вивчення особливостей кожного 3 стандартів, але й порівняння розрахункових значень отриманих опалювальних характеристик із фактичними даними щодо обсягів споживання теплової енергії на потреби опалення. Розрахунки за даними стандартами проводилися на основі одного реального об’єкту у м. Суми. Розбіжність у результатах розрахункових та фактичних даних $\epsilon$ досить значною. Так, найближчими до дійсних значень $є$ значення, що отримані за методиками [12], [13], [14] (див. рис. 2).

Результати проведеного аналізу, показали, що жодна 3 приведених методик не відображає, у повній мірі, реальної поведінки системи опалення обстежуваного закладу. Для цього є ряд пояснень:

- моральна застарілість існуючих нормативних документів та не адаптованість міжнародних стандартів до національних;

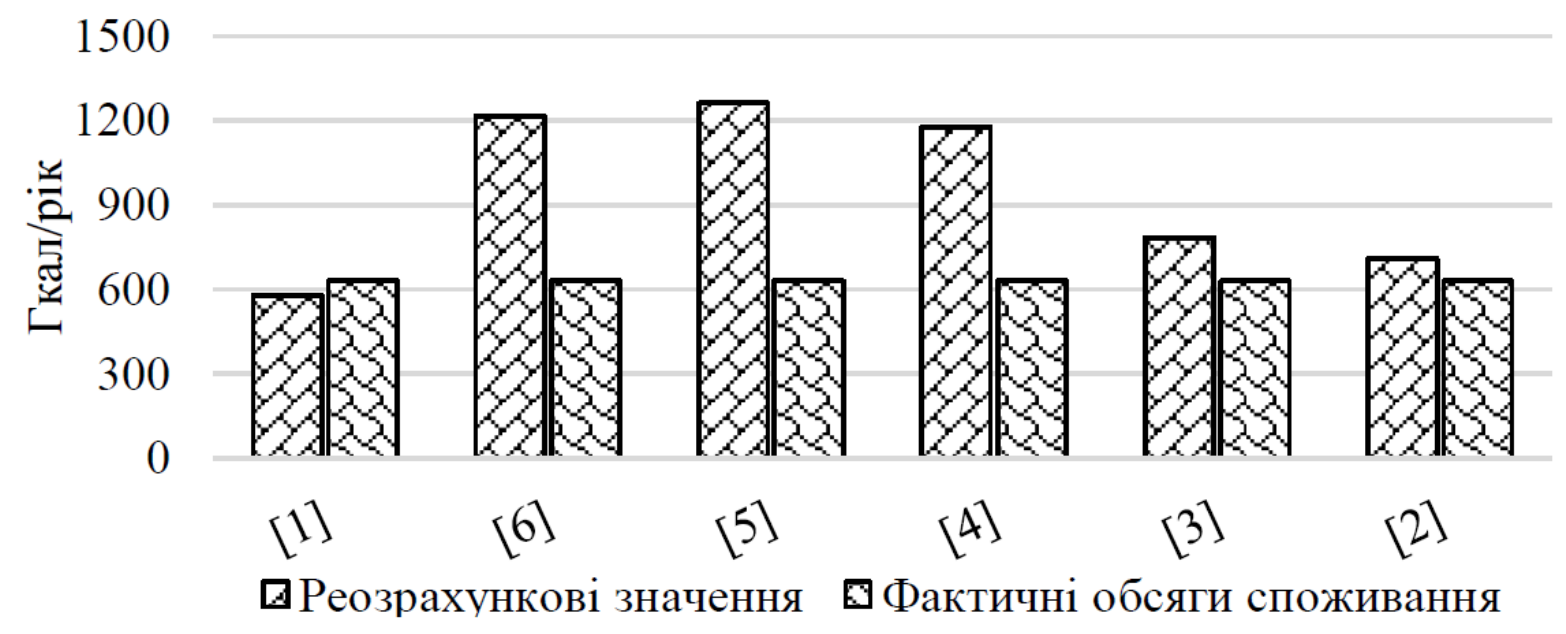

Рисунок 2. Порівняння розрахункових значень теплової потужності будівель: [12] КТМ-204 Україна 244-94, [13] ДСТУ Б EN ISO 13790, [14] ДСТУ 
Б А.2.2-12:2015, [15] ДСТУ-Н Б А.2.2.5:2007, [16] авторські методики «комбінований метод», [17] «Метод збільшених показників»

- для погодинних розрахунків практично повна відсутність нормативної бази для їх проведення;

- певна невідповідність зовнішніх умов та температурних графіків, за якими працюють надавачі послуг із забезпечення тепловою енергією;

- невизначеність порядку та умов функціонування закладу.

Отже, при виборі методики для аналізу теплового стану об'єкту слід керуватися такими критеріями: мета проведення розрахунку, наявність вихідних даних та бажана точність результатів.

\section{Висновки}

Встановлено, що для розрахунку теплової потужності та енергопортеби для будинків використовують різноманітні методики, які базуються на певних нормативних документах чи доповненнях до них. Усі вони різняться за способами задання вихідних даних, способами обчислення і залежать від мети проведення.

Для підвищення ефективності проведення енергетичних обстежень та досягнення бажаного рівня енергоефективності, необхідно підібрати таку універсальну методику обчислення, що буде забезпечувати найбільшу точність отриманих результатів та дозволить проаналізувати якнайкраще стан роботи обстежуваних систем.

3 цією метою, є сенс проведення критичного аналізу існуючих методів обрахунку. Він дозволяє не тільки виокремити найкращий спосіб, але виявляє основні недоліки найпоширеніших методик та дозволяє запропонувати корективи до них.

Матеріали підготовлено в процесі виконання держбюджетної теми $0118 U 003583$ (договір № 53.17.01-01.18/20.3П). 


\subsection{Architecture of children's preschool institutions in the context of modern trends in the educational process}

В останні роки у вітчизняній шкільній і дошкільній освіті відбувається зміна пріоритетів навчального процесу, яка, 3 огляду на іiі тісний зв’язок із функціональними процесами у навчальних закладах, може суттєво вплинути на їхнє архітектурне рішення.

По-перше, згідно із багатьма державними і регіональними програмами, освітній процес має бути інклюзивним, тобто передбачати умови доступності для дітей з обмеженими можливостями та особливими потребами [30, 31$]$.

По-друге, освітня діяльність все більше спрямовується не на безпосереднє отримання дитиною певного контенту знань, а на оволодіння умінням отримати необхідні знання і застосувати їх на практиці. Така методика має водночас багато позитивних і негативних аспектів, але їхній аналіз належить більшою мірою до сфери педагогічної, а не архітектурної науки. Беззаперечним при цьому є лише той факт, що збільшення «самостійності» спонукає дитину до творчого креативного мислення, для розвитку якого необхідні сприятливі умови, у тому числі й відповідним чином організоване архітектурне середовище.

Отже, підчас розробки проектів нових і реконструкції існуючих закладів освіти, перед архітектором постає досить складна задача: формування доступного (безбар'єрного) середовища, здатного забезпечувати вимоги інклюзивного навчального процесу і розвивати розумові та творчі здібності дітей. Особливо це стосується архітектурного середовища для найменших, тобто закладів дошкільної освіти.

Інклюзивний навчальний процес - це система освітніх послуг, гарантованих державою, що базується на принципах недискримінації, врахування багатоманітності людини, ефективного залучення та включення до освітнього процесу всіх його учасників. Іншими словами, діти 3 особливими освітніми потребами повинні мати доступ до навчання у звичайних освітніх установах. В 
свою чергу, школи, дитячі садки та інші заклади освіти зобов’язані створити умови навчання, що забезпечують потреби дитини.

Основою інклюзії $є$ «залучення» - активна участь дітей у щоденних видах діяльності, передбачених тими чи іншими програмами. Це поняття тісно пов’язане з навчанням і взаємодією між дитиною і середовищем.

Інклюзивне освітнє середовище передбачає, що внутрішній i зовнішній простори закладу дошкільної освіти не мають містити жодних небезпечних предметів, які можуть зашкодити дитині підчас гри, дослідження, пізнання [30].

Розрізняють три взаємопов’язані компоненти освітнього середовища дитячих дошкільних закладів: фізичне середовище, соціальне середовище та структурне середовище. До сфери архітектурної діяльності з цього переліку належить організація фізичного (предметно-просторового) середовища.

У даному контексті фізичне середовище - це сукупність усіх елементів предметно-просторового оточення (архітектурно-конструктивних, інженернотехнічних, навчально-методичних тощо), з якими контактує дитина в процесі освітньої і розважальної діяльності. Головною вимогою до організації фізичного середовища дитячих дошкільних закладів $є$ його відповідність фізичним i розумовим здібностям дітей [32].

Для забезпечення відповідних вимог до фізичного (предметнопросторового) середовища закладів дошкільної освіти воно має проектуватися: ергономічним; - універсальним; - розвивальним.

Ергономічність предметно-просторового середовища передбачає:

- наявність меблів та обладнання, які відповідають віку дітей;

- архітектурні конструкції, меблі та обладнання, здатні до трансформації [33].

Універсальність дитячих закладів забезпечує ціла низка складових:

- архітектурно-планувальні рішення, які задовольняють умови вільного пересування у предметно-просторовому середовищі дітей 3 обмеженими можливостями чи особливими потребами, а також догляд за ними (відповідність геометричних параметрів приміщень потребам дітей-інвалідів: відсутність 
порогів і перепадів висот підлоги, місце для розвороту інвалідного візка, збільшена ширина дверей тощо);

- включення до складу будівлі інженерно-технічних засобів, призначених для забезпечення умов доступності (пандуси, підйомники, системи зв’язку, спеціалізоване сантехнічне обладнання);

- застосування засобів візуальної комунікації (загального спектру та спеціалізованих піктограм, інформаційних табло, тактильних елементів тощо).

Розвивальне фізичне (предметно-просторове) середовище закладів дошкільної освіти і початкової школи забезпечується синтезом архітектурнокомпозиційних та навчально-педагогічних складових.

Архітектурно-композиційна складова:

- організація і дизайн групової кімнати, що охоплює центри ігрової та навчальної діяльності;

- активне застосування кольору, фактури і текстури;

- можливість моделювання конфігурації i параметрів оточуючого предметно-просторового середовища самими дітьми - застосування мобільних блоків чи меблів-трансформерів [34].

Навчально-педагогічна складова:

- наявність навчальних матеріалів та іграшок, які відповідають віку, інтересам та фізичним і розумовим здібностям дітей;

- застосування медіатехнологій та інтрерактивних засобів активізації навчального процесу.

Дотримання усіх вище згаданих умов дозволить формувати інклюзивне освітнє середовище дитячих дошкільних закладів.

Друга важлива тенденція формування архітектурного середовища закладів дошкільної освіти - включення до їх структури комунікативного простору.

У цьому контексті слід враховувати те, що одними із важливих засобів отримання інформації та набуття певних навичок дітьми дошкільного i молодшого шкільного віку є спілкування та гра. Тому обов’язковим, а може навіть і головним, функціонально-планувальним елементом дитячого садка i 
молодшої школи має бути комунікативний простір. Поняття «комунікативний простір» останнім часом активно вживається у різних сферах людської діяльності і, здебільшого, пов'язується із соціалізацією, інформаційним полем, візуальними комунікаціями тощо. Проте у випадку формування архітектурного середовища для дітей комунікативний простір отримує дещо інші значення, структуру і завдання.

Дитячий комунікативний простір - це приміщення в структурі групового осередку чи спільне на кілька груп (класів молодшої школи), призначене для активних ігор та освітньо-пізнавальної діяльності із застосуванням інтерактивних засобів активізації навчального процесу.

Отже, дитячий комунікативний простір відповідає розвивальній функції фізичного (предметно-просторового) середовища закладу дошкільної освіти.

При проектуванні комунікативного простору для дітей доцільно застосовувати такі архітектурно-дизайнерські прийоми формування предметнопросторового середовища:

- поліфункціональність простору (можливість послідовного використання приміщення для навчання, гри, спілкування, проведення масових заходів);

- трансформативність простору в цілому i його окремих складових елементів (мобільні перегородки для об'єднання / розділення комунікативного простору між двома суміжними груповими осередками, меблі-трансформери);

- архітектура як складова ігрової і пізнавальної діяльності (використання огороджувальних конструкцій та їхніх елементів - ніш, отворів, сходів тощо для гри та спілкування);

- перетворення системи горизонтальних і вертикальних комунікацій (за винятком шляхів евакуації) на комунікативний простір загального використання;

- матеріальність середовища як активний елемент пізнавальної діяльності (поверхні з різною текстурою, ігрові блоки різних геометричних форм та ваги);

- переважання плавних криволінійних обрисів у формотворенні предметнопросторового середовища; 
- активне використання кольору та системи освітлення для моделювання предметно-просторового середовища;

- виділення «зон творчості та психокорекції» (поверхні стін чи підлоги, де діти можуть вільно малювати, або частини приміщення, де діти можуть моделювати простір на власний розсуд) [33, 34].

Комплексне рішення питань відповідності архітектурного середовища закладів дошкільної освіти вимогам інклюзивного освітнього процесу та включення до їх структури комунікативних просторів дозволить формувати ці об'єкти на якісно новому рівні, з урахуванням провідних тенденцій світової педагогічної науки. 


\section{5 Композиційні засоби проектування парків типу «АКВАЛЕНД»}

Викладається системний підхід до проектування парків типу «АКВАЛЕНД» на основі гармонізації з навколишньою природою , техногенним і соціальним середовищем.

Проектування мережі водно-оздоровчих і розважальних комплексів у містах України має на меті створення нової системи « центр активного відпочинку людин - навколишнє середовище» і нових функцій, зв'язків у навколишнім середовищі, а мистецтво проектування в остаточному підсумку зводиться до можливого повного обліку всіх тих факторів і впливів, які виникнуть у результаті будівництва й експлуатації.

Поліпшення комфортності міського середовища зв'язано, насамперед, 3 поліпшенням iї екологічних i естетичних характеристик. Експлуатаційні характеристики вимагають створення більше комфортних і різноманітних умов для організації відпочинку населення в міському середовищі. Ніж повніше вибір рекреаційної діяльності, тим вище соціальний, а посередковано й економічний ефект - багатогранний розвиток особистості, фізичне здоров'я, зміцнення сімейних і соціальних зв'язків.

На жаль, в Україні приділяється недостатня увага до формування рекреаційного середовища в містах у зв'язку з новими соціально-економічними умовами. Фактично не раз розробляються інвестиційні програми по формуванню рекреаційних об'єктів у міському середовищі. Недостатня увага цій проблемі приділяється й у наукови розробках (2-4).

Успішне функціонально-планувальне зонування, що є складової нової природно-технічної системи «центр активного відпочинку- людин- навколишнє середовище забезпечується, якщо система гармонійно входить в існуючі природні, техногенну й соціальну середовища. 3 обліком цього можна сформулювати наступна вимога до проекту парків типу “АКВАЛЕНД”: у проекті повинне бути забезпечене функціонування природно - технічної системи “центр активного відпочинку- людин навколишнє середовище”; враховані соціальна 
значимість, економічна ефективність, эстетическое досконалість, екологічна прийнятність і технічна безпека .

Тип парку “АКВАЛЕНД” ,зведений з урахуванням зазначених вимог, дозволяє створити цілісну й гармонічну композицію. Парк такого типу являє собою структуру об'єднуючі композиційні елементи парків типу “ДИСНЕЙЛЕНД” і “АКВАПАРК” (Рис. 1).

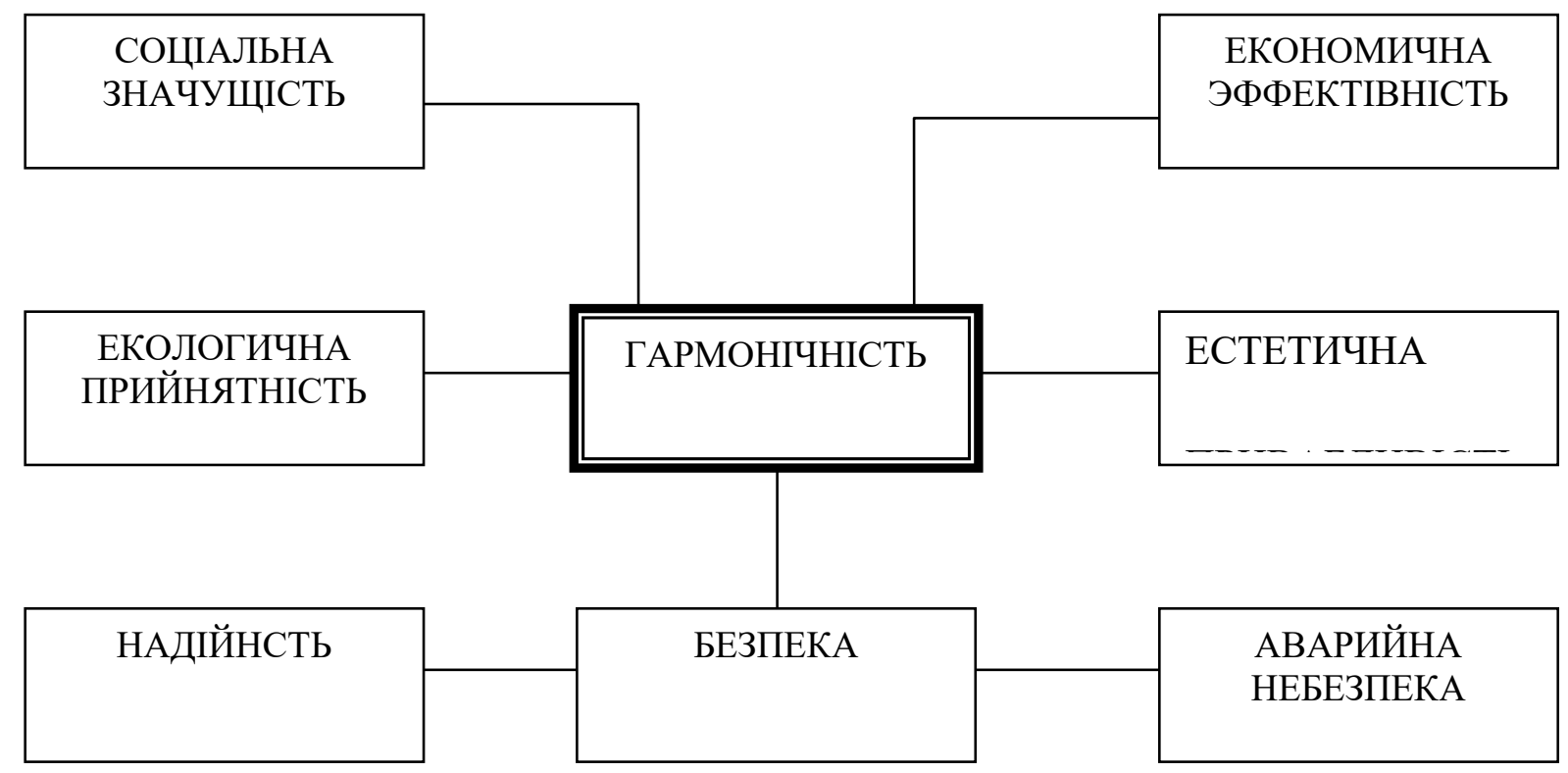

Рис. 1. Структура гармонійності системи «людина - об'єкт - середовище».

Гармонійність - інтегральна властивість системи « центр активного відпочинку -людин -навколишнє середовище», що забезпечує соціальну значимість економічну ефективність, эстетическое досконалість, екологічну прийнятність і технічну безпеку.

Соціальна значимість - властивість системи бути востребовательной суспільством і необхідної для його ефективного розвитку. Прикладами споруджень високої соціальної значимості є рекреаційні комплекси для дітей і молоді типу “ДИСНЕЙЛЕНД”, “АКВАПАРКИ”. Оцінками соціальної значимості таких споруджень є, наприклад: кількість відвідувачів , розмаїтість атракціонів, культурно- розважальних зон (кафе, ресторан) . 
Економічна ефективність означає відповідність економічним принципам розвитку суспільства. Оцінками економічної ефективності центра відпочинку є: вартість будівництва такого типу спорудження , строк його окупності , питомі капіталовкладення, собівартість продукції (кіловат -години електроенергії, одного кубічного метра води)і ін.

Екологічна прийнятність - властивість системи, що характеризує екологічні наслідки впровадження спорудження в навколишнє природне й соціальне середовище й прийняття його цим середовищем . Екологічна прийнятність характеризується сукупністю позитивних і негативних впливів експлуатованого спорудження на геологічне середовище й гідросферу, атмосферу й біосферу, у тому числі й на людину.

Естетична привабливість - властивість системи відповідати ідеалам прекрасного й гармонічного, що $є$ необхідною умовою для нормального функціонування центра активного відпочинку й підтримки його соціальної значимості. Раціональність і досконалість форм ігрового встаткування, водних розваг, різноманітних атракціонів, їх эстетическая виразність, колірна гармонійність із природним ландшафтом , захоплюючі пригоди в парку світового рівня.

Технічна безпека - властивість системи виконувати необхідні функції в заданих режимах і умовах експлуатації й технічного обслуговування, а також підтримувати нормативний рівень попереджень аварій шляхом контролю стану атракціонів, ігрового встаткування. Під зоною впливу мається на увазі та частина навколишнього середовища , що впливає на спорудження.

Технічна безпека такого типу спорудження складається з експлуатаційної надійності й аварійної небезпеки.

Експлуатаційна надійність - властивість спорудження зберігати в часі й установлених межах значення всіх параметрів, а також підтримувати нормативний рівень попередження аварій. Експлуатаційна надійність атракціонів і гідротехнічних споруджень забезпечується не тільки надійністю 
але й системою експлуатації ( працівники служби безпеки, які покажуть як користуватися ігровим устаткуванням ), у процесі тривалої експлуатації.

Будь-яке саме надійне спорудження потенційно небезпечно й на ньому може відбутися аварія. Мірою цієї небезпеки є аварійна небезпека як властивість системи “центр активного відпочинку - людин- навколишнє середовище” зберігати у встановлених межах значення параметрів, що характеризують можливість виникнення аварій об'єкта по різних сценаріях і їхнього наслідку.

Труднощі проектування складних своєрідних центрів активного відпочинку для дітей і дорослих полягає в необхідності обліку великого числа науковотехнічних, соціальних, екологічних, економічних і ін. факторів,а проектування як специфічний вид творчої діяльності людини вимагає сполучення науки, техніки й мистецтва. Визначено, що формування простору рекреаційного середовища для дітей повинне відрізнятися індивідуальністю 3 переваженням природних елементів середовища і володіти яскравим художнім образом.

Найкращім вирішенням даного завдання є створення системи рекреаційних тематичних модулів, об’єднаних в рекреаційні комплекси або центри дозвілля для дітей та інші типи рекреаційного середовища. Рекреаційний тематичний модуль є відособленим простором площею від 900 до 2500кв. м, сформованим 3 використанням усіх засобів ландшафтного дизайну - рослин, геопластики, водних пристроїв, малих архітектурних форм, декоративного покриття, призначених для однієї або двох вікових груп дітей, які володіють яскравим художнім образом і різноманітністю рекреаційної діяльності. Залежно від займаної площі тематичні модулі диференціюються на такі типи: малі - 900 кв.м.; середні - 1200кв.м.; великі - 2500кв.м. Рекреаційний тематичний модуль може включати 1-2 тематичних зони і 2-3 аттарактивних елементи середовища.

Просторове середовище тематичних модулів включає плошинні підстави поверхня землі, елементи рельєфу, водні пристрої і об’єми - рослинні угрупування, рекреаційне обладнання,малі архітектурні форми, скульптуру, візуальні комунікації. Взаємозв'язок простору, площини і об’єму визначається об’ємно - просторовою композицією. 
При вирішенні композиційних завдань у формуванні тематичних модулів враховуються геометричний вид форми, величина, масса, фактура, колір, освітленність, положення у просторі. Рекреаційні модулі можуть бути відкритого й закритого типу. Найбільшого поширення повинні набути модулі відкритого типу. Вони можуть бути призначені для декількох видів рекреаційної діяльності дітей. Для виявлення їх художнього образу слід створювати модулі 3 тематичною стилістикою. Вона повинна бути достатньо різноманітною $\mathrm{i}$ впливати на характер їх просторової організації.

Розроблені варіанти композиційних структур рекреаційного середовища 3 тематичними модулями з лінійною, трикутною, компактною, розосередженою формою плану. Розроблені експериментальні проекти рекреаційних комплексів і дитячих центрів, які перш за все слід розміщувати в зоні впливу дитячих залізниць. Запропонована модель розміщення об’єктів відпочинку для дітей в міському середовищі, (на прикладі м.Харкова). 


\subsection{Practical experience of using microalgae chlorella vulgaris in wastewater treatment processes}

Стічні води від населених пунктів містять значну кількість органічних i біогенних речовин. Більшість каналізаційних очисних споруд в Україні не забезпечує видалення біогенних елементів зі стічних вод. Недостатньо очищенні стічні води, що надходять у поверхневі водойми, призводять до їх евтрофікації, деградації водних екосистем, погіршення якості води та потенційної небезпеки для здоров'я людини.

Очищення стічних вод 3 використанням мікроводоростей $\epsilon$ новим екологічно чистим біотехнологічним методом. Стічні води забезпечують мікроводорості необхідними поживними речовинами, зокрема вуглецем, азотом та фосфором, які асимілюються у цінній біомасі [39-41].

Порівняно 3 іншими методами очищення стічних вод від біогенних елементів застосування мікроводоростей має значні переваги. А саме: ефективне та одночасне видалення азоту та фосфору, відсутність необхідності в реагентному господарстві, утворення кисню. Під час життєдіяльності мікроводорості поглинають вуглекислий газ. Тому інтеграція процесів очищення стічних вод та біофіксації вуглекислого газу - ще одна перевага мікроводоростей, особливо у промислово розвинених регіонах [42].

Аналіз досліджень свідчить, що використання мікроводоростей виду Chlorella vulgaris дає змогу досягнути ефекту очищення побутових стічних вод від сполук азоту та фосфору на понад 95 \% [43]. Доведена висока ефективність використання Chlorella vulgaris для видалення біогенних елементів із виробничих стічних як в аеробних, так і в анаеробних умовах [44 ]. Доведена ефективність використання Chlorella vulgaris для очищення фільтратів сміттєзвалищ з високими концентраціями амонійного азоту та ХСК [45].

Завдяки фотосинтезу мікроводорості виділяють кисень, який використовується активним мулом для розкладання органічних речовин у процесах біологічного очищення стічних вод. Це дає змогу зменшити енерговитрати на традиційну аерацію стічних вод [44]. 
Застосування мікроводоростей $є$ способом утилізації цінних домішок стічних вод. Зібрану біомасу використовують як корм для тварин, біодобриво, а також для отримання біологічно активних речовин у фармацевтичній та косметичній промисловості $[39,40]$. Мікроводорості отримали величезну увагу з боку світового наукового співтовариства, ставши сировиною для виробництва біодизелю, вигіднішою порівняно з іншими джерелами біопалива $[41,42]$.

Стічні води є багатокомпонентною системою, склад якої постійно змінюється. Разом зі значними кліматичними змінам, які останнім часом спостерігаються у світі, це відображається й на роботі каналізаційних очисних споруд. Серед існуючих досліджень очищення стічних вод за допомогою мікроводоростей бракує інформації за основними параметрами процесу. Зокрема, щодо впливу на цей процес температури стічних вод. Тому дослідження ефективності застосування мікроводоростей виду Chlorella vulgaris у процесах очищення стічних вод на діючих очисних спорудах населених пунктів $\epsilon$ надзвичайно актуальними.

Метою дослідження є аналіз роботи каналізаційних очисних споруд міста в західній області України, визначення ефективності застосування мікроводоростей виду Chlorella vulgaris у процесах очищення стічних вод, а також експериментальне дослідження зміни ефекту очищення стічних вод (iз застосуванням Chlorella vulgaris) залежно від їх температури за показниками БСК 5 та ХСК.

Під час досліджень обстежено стан та проаналізовано роботу каналізаційних очисних споруд міста 3 населенням близько 20 тис. мешканців, розташованого в західній області України. Продуктивність очисних споруд 3400 м³/добу. Системою каналізаційних колекторів стічні води від міста транспортуються до приймального резервуару головної каналізаційної насосної станції. 3 приймального резервуара насос зануреного типу перекачує стічні води в приймальну камеру очисних споруд. Рух стічних вод по спорудах самопливний. Зворотні води скидаються у р. Случ, що є водним об'єктом рибогосподарського призначення. Існуючі очисні споруди побудовані в 70-х 
роках минулого століття. Результати їх обстеження свідчать, що споруди вичерпали свій ресурс і нині знаходяться у незадовільному стані.

Значення БСК5 та ХСК у стічних водах, що надходять на очисні споруди становили відповідно 314,85 та 440,75 мгО ${ }_{2} /$ дм³ $^{3}$ З Значення вказаних показників у зворотних водах до застосування Chlorella vulgaris становили відповідно 18,80 та $119,98 \mathrm{M \Gamma O}_{2} /$ дм$^{3}$, що перевищує нормативні значення. Отже, у р. Случ скидаються недостатньо очищені стічні води.

Експериментальні дослідження, проведені у весняно-літній період 2019 р., полягали у додаванні до вихідних стічних вод концентрату живого штаму мікроводостей виду Chlorella vulgaris у кількості 24 л.

Ефект очищення, за вказаними показниками (П) визначали за формулою

$$
E=100 \cdot\left(\Pi_{b x}-\Pi_{b u x}\right) / \Pi_{b x}
$$

де $\Pi_{6 x}, \Pi_{\text {sux }}$ - значення показників якості стічної води на вході та на виході очисних споруд, відповідно. Зміну ефекту очищення стічних вод за показниками БСК 5 та ХСК залежно від температури води наведено на рисунку.

У межах діапазону температури досліджуваних стічних вод від $10,5{ }^{\circ} \mathrm{C}$ до $20{ }^{\circ} \mathrm{C}$ ефект їх очищення змінювався: за БСК 5 - від 92,77 \% до 95,67 \%; а за ХСК - від 73,25\% до 83,73\%. За допомогою комп’ютерних програм проведено лінійну апроксимацію отриманих результатів:

$$
\begin{aligned}
& E_{Б C K}=0,031 t+93,886 ; \\
& E_{X C K}=0,254 t+74,932,
\end{aligned}
$$

де $E_{5 C K}, E_{X C K}$ - ефективність очищення стічних вод за показниками відповідно БСК 5 та ХСК, \%; $\mathrm{t}$ - температура стічних вод, ${ }^{\circ} \mathrm{C}$. 
a)

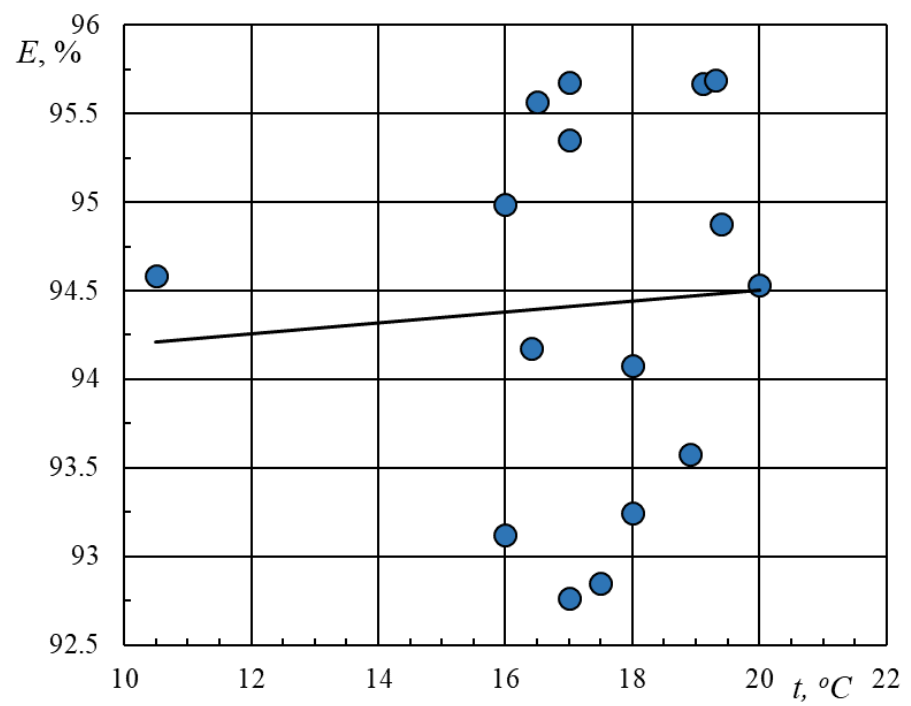

б)

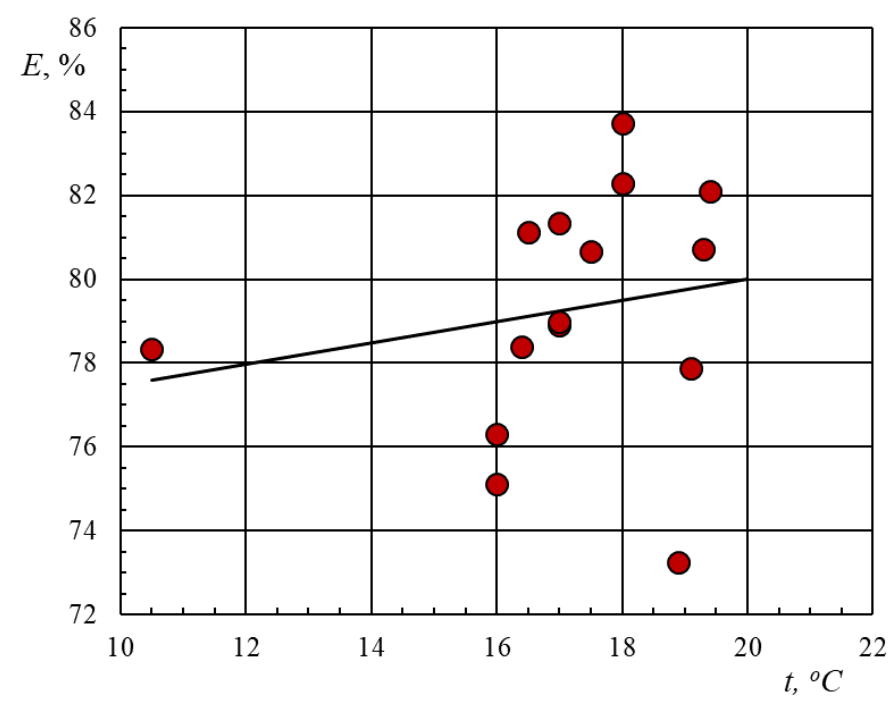

Рисунок. Зміна ефекту очищення стічних вод за БСК 5 (а) та ХСК(б) залежно від температури води

Результати обстеження та аналізу роботи діючої каналізаційної очисної станції міста свідчать про недостатній ступінь очищення стічних вод. Експериментально доведено ефективність застосування мікроводоростей виду Chlorella vulgaris у процесі очищення стічних вод. Отримано математичні залежності ефекту очищення стічних вод (із застосуванням Chlorella vulgaris) від їх температури за показниками БСК 5 та ХСК. Представлені на рисунку залежності описуються лінійною функцією, яка характеризує загальну поведінку отриманих даних. 


\section{7 Особливості формування архітектури сучасних бізнес-центрів у міському середовище}

В нашому сучасному житті особливого значення набуває питання розвитку новітніх ділових відносин. Надзвичайно актуальним стає питання про формування нових типів об'єктів багатопрофільної ділової спрямованості - a саме сучасні бізнес-центри в структурі великих міст. Еволюція ділових контактів, як однієї з основ комунікативності і діалогу культур, диктує необхідність появи дійсно нового, відповідного комунікаційного простору в сучасних архітектурних об'єктах ділового спрямування. Тому сьогодні поліфункціональний діловий комплекс чи крупний бізнес-центр формується в новітніх якостях універсальності, трансформованості і багатопрофільності, що $€$ характерним для всіх типів ділових відносин, і $є$ найбільш затребуваним типом громадської будівлі.

Актуальність даного дослідження пов'язана 3 широким розмахом будівництва ділових центрів, у всіх найбільших містах світу, включно 3 великими містами України, де постійно виникає проблема реагування на соціально-економічні зміни. Також, актуальність розвитку архітектури таких об'єктів обумовлена багатьма факторами до яких слід віднести природнокліматичні, соціально-економічні, містобудівні, екологічні та інші специфічні характеристики, що впливають на розвиток формування сучасного міського середовища та формують новітні умови для розвитку новітньої ділової діяльності. Важливо підкреслити, що сьогодні такі великі ділові комплекси $є$ місцем проведення різноманітних ділових зустрічей, бізнес-переговорів, професійним місцем укладення угод, контрактів та проведенням конференцій, симпозіумів, бізнес-тренінгів тощо. Більш того, саме комунікативні ділові заходи формують основний функціональний процес таких архітектурних об'єктів, а інші супутні функції є допоміжними саме для досягнення необхідного бізнесефекту. Важливо, також, відмітити, що нові методи включають новітні технологічні системи проектування ділових комплексів за їх основними функціональними, типологічними та планувальними ознаками; нові принципи i 
прийоми проектування таких об’єктів та інноваційні концептуальні моделі архітектурно-просторової організації крупних бізнес-центрів.

При всьому різноманітті реальних умов і потреб формування архітектури бізнес-центрів головна типологічна відмінність таких об’єктів знаходиться в унікальності власної соціально-технологічної структури, в індивідуальному виявленні ключових (національних та регіональних) соціальних питань та інтересів населення, в спеціалізації і особливостях проектування провідних функціонально-просторових блоків. До найбільш актуальних соціальних програм, що надає змогу інтегрувати нескінченне різноманіття різних сторін суспільного ділового життя і інтересів різних соціальних груп населення, слід віднести: - самоврядування, демократизацію всіх сфер суспільного життя; культуру виробництва, побуту і дозвілля; - екологічні умови регіону; - здоров'я нації та розвиток суспільства; - господарську грамотність та підприємництво.

Виділення цих програм дозволяє, з одного боку, оперувати обмеженим набором провідних функціонально-просторових блоків, відповідних актуальним соціальним програмам і здатних повноцінно існувати, з іншого боку, ці програми дозволяють в рамках кожного блок-центру всього ділового простору вирішувати як ключові, так і пов'язані з ними соціально-економічні питання в самих різних бізнес-комбінаціях.

В ході аналізу теоретичного досвіду формування ділових об’єктів сучасного міста визначено, що адміністративно-ділова діяльність як міська функціонально сформована традиція сповнена сенсу тільки в тому випадку, коли вона пов'язана 3 певним місцем і забарвлена характером цього місця.

Багатофункціональний діловий комплекс або великий міський бізнес-центр - це концепт-ідея, принцип формування, але не завжди певна форма, його внутрішній простір, як частина міського середовища, має вирішуватися за принципом багатофункціональності самого міського простору.

При формуванні внутрішнього простору і фізично і метафорично надаються властивості двох основних якостей міста: якість шляху клієнтів (ділова активна вулиця) і якість місця (діловий осередок, офісні приміщення, банківський зал). 
Ця двоїстість відображає природу ділового центру, як будь-якого великого суспільного будинку, - воно частково належить міському рівню, але в той же час і рівню будинку, так як забезпечує людині певний комфорт ділових стосунків.

Сучасний етап розвитку ділових відносин призводить до нових принципів проектування офісних просторів, що характеризується незрівнянно вищим професійним і загальнокультурних рівнем.

Перший з них пов'язаний з системою реальних просторових розмірів, які осягає людина, потрапляючи в центральний простір - критий бізнес-центр.

Другий - історичний: від культурно-історичних образів до сучасної індустріальної естетики.

Третій принцип заснований на ряді елементів екстер'єру в інтер'єрі.

Типи таких багатофункціональних ділових будівель і офісних комплексів формуються під впливом наступних тенденцій:

- безперервне розширення виробництва товарів споживання та розвиток великої ділової індустрії;

- укрупнення торгових підприємств та ділова активність великих корпорацій та бізнес-структур;

- розвиток нових технічних i організаційних форм офісного та адміністративно-ділового обслуговування населення;

- скорочення витрат споживання та економічність;

- скорочення часу обслуговування та оптимізація ділових відносин.

В ході детального аналізу практичного досвіду формування архітектури сучасних бізнес-центрів було виявлено, що за складом та змістом ділових заходів всі розглянуті комплекси можна розділити на групи: - комплекси, де ділові заходи представлені переговорами і консультаціями (1-а група); - комплекси, де ділові заходи представлені переговорами, консультаціями, семінарами та майстер-класами, культурними та розважальними заходами (2-а група); комплекси, програми яких включають всі види ділових заходів: переговори, консультації, семінари, майстер-класи, церемоніальні і рекламно-розважальні заходи, круглі столи та конференції (3-тя група); окремо слід виділити такі 
заходи (шоу, дефіле, огляди, покази й таке інше), що проводяться за індивідуальним сценарієм та має специфіку їх проведення. Ділові переговори, офісні консультації, професійні майстер-класи, фахові семінари, «круглі столи» та окремі тематичні конференції відрізняються від інших ділових заходів спрямованістю на професійні обговорення та досягнення економічного ефекту, також, і кількістю учасників

Важливо відмітити, що сьогодні активно будуються численні торгові центри, урядові міністерства, посольства, офісні будівлі і торгово-розважальні та житлові, що активно формують сучасне міське середовище. Так, наприклад, Будапештський центр міста - найбільший центральний діловий район (CBD) i найбільший фінансовий центр в Угорщині і Центральної Свропи. У Канаді «центральний діловий район» не використовується в якості офіційного терміну StatsCan. Замість цього терміни «центр міста» або «в центрі» використані, більшменш синонімічно. Найбільше місто країни, Торонто, офіційно має цілих чотири ділових райони, які є центральним. В Оттаві «центральний діловий район» це 31 міський квартал, що містить офісні центри, ділові комплекси, банки та інші громадські установи.

Торговельна палата в Україні розробила стандартну класифікацію офісних приміщень і на карту Києва були нанесені кордони Центрального ділового району. Експерти ринку офісної нерухомості запропонували розширити центральний діловий район Києва та по-новому класифікувати українські бізнесцентри та ділові комплекси як місця для проведення різноманітних ділових заходів, симпозіумів, семінарів та конференцій, а також приміщення для воркшопів таких художніх практик, як театр, музика, образотворче та скульптурне мистецтво.

У сучасних великих компаніях та світових корпораціях, орієнтованих на стійкість, успіх майбутнього бізнесу залежить, також, від важливих питань збереження екології та розвитку енергоефективності, більш того, ці питання включаються в загальну ідеологічну стратегію цих компаній. 
Реалізацію концепції енергоефективності забезпечують архітектурнопланувальні особливості формування ділових комплексів (форма, оболонка i внутрішня структура будівель), інженерно-технічні й конструктивні рішення (регенерація ресурсів, економія енергії) та оздоблювальні матеріали.

В структурі великого міста ділові комплекси та бізнес-центри знаходяться в центрі громадського управління малим та середнім бізнесом. Тут важливо визначити весь комплекс морфологічних, функціональних, естетичних i копозіційних елементів формування архітектури ділових комплексів. Такі великі багатофункціональні ділові центри є великими громадськими комплексами 3 інтеграцією різних супутніх функцій громадського обслуговування, що відображає сучасні тенденції ділового і культурного життя суспільства. А сучасні бізнес-центри сьогодні $є$ провідними фаховими організаціями, що спеціалізується на підтримці малого та середнього бізнесу на початкових етапах його становлення.

Архітектурна композиція великих бізнес-центрів і ділових комплексів має ряд інших характерних особливостей, пов'язаних з обслуговуванням трьох категорій відвідувачів: пішоходів, пасажирів громадського транспорту i власників індивідуальних автомобілів. Звідси наближення ділових центрів до транспортних дорог і зупинок і разом з тим створення в них пішохідних зон, що в цілому відповідає сучасній містобудівній концепції - «будівля серед простору», що прийшла на зміну старій - «простір серед будівель».

Таких багатофункціональних ділових комплексів стає все більше, і вони мають тенденцію розвиватись та трансформуватись на різних етапах формування архітектури міського середовища. Найбільш розвинені держави мають організовані ділові райони або регіони, бо це є одною з основоположних критеріїв розвиненості ділового аспекту країни.

Сьогодні великі міста розвиваються таким чином аби задовільнити всі потреби його мешканців, та зробити їх життя максимально комфортним. Найкрупніші міста, столиці провідних країн світу є розвиненими, оскільки вони приваблюють найбільшу кількість різноманітних життєдіяльних процесів. 
Центральний діловий район (з англ. CBD - central business district) - це комерційний та діловий центр міста. У великих містах часто синонімом $є$ "фінансовий район". Географічно діловий район часто збігається з "центром міста", але ці поняття є різними: у багатьох містах центральний діловий район розташований далеко від торгового, культурного центру міста.

Важливо відмітити, що багатофункціональні ділові комплекси орієнтовані на активну взаємодію із зовнішнім міським середовищем, їх основна суспільна роль - створення центрів соціальної активності, сприяють соціальних комунікацій та культурному збагаченню міської життя, тому торгова складова (товари масового споживання) громадської частини не повинна домінувати. Набір елементів громадської частини і їх взаємне співвідношення визначаються виходячи з комплексного аналізу соціально-містобудівного контексту.

Таким чином, цінності активного сучасного суспільства роблять пріоритетним розробку саморегулюючих ділових комунікаційних структур. В даному контексті одним 3 найбільш перспективних напрямків розвитку функціонально-просторової організації ділових бізнес-структур стає модель саморегульованої системи з гнучкою функціональної програмою, яка дозволяє динамічне коригування співвідношення суспільної і ділової функцій і володіє потенціалом для відповідності вимогам майбутнього. 


\section{8 Сучасні тенденції формування екооріснтованих будівель і споруд}

У третьому тисячолітті багато екоорієнтованих будівель і споруд формуються як в міському середовищі, так і за його межами в структурі природного ландшафту. Особливості вигляду природного ландшафту, що відноситься до різних природних зон, визначаються специфікою і поєднанням форм рельєфу, водних поверхонь і рослинності.

Найбільш виразними ділянками для розміщення екоорієнтованих будівель і споруд $є$ кромки схилів, заплавних терас і берегів водойм, а так само акцентні форми рельєфу - пагорби, скелі, урвища, акваторії моря, річок, озер, ставків, рослинність (гаї, групи дерев, заплавні луки). Виявлення таких акцентних елементів і включення в їх структуру екоорієнтованих будівель сприяє створенню ділянок 3 яскравим індивідуальним виглядом [49]. Залежно від ландшафту елементи екоорієнтованих будівель і споруд мають не однакове значення - від домінуючого над великими територіями до підлеглого, 3 обмеженими зв'язками з оточенням. 3 урахуванням специфіки конкретного типу ландшафту створюється інтегрована система інтер'єрних i екстер'єрних просторів екоорієнтованих будівель і споруд. Дослідження сучасного досвіду проектування визначило різні прийоми включення екоорієнтованих будівель і споруд в структуру природного ландшафту:

а) домінування будівлі в природному ландшафті засобами особливостей форми, маси, кольору, фактури тощо;

б) нейтральне співвідношення будівлі і природного ландшафту;

в) органічне включення архітектурного об'єму будівлі в структуру рельєфу із підпорядкуванням природному ландшафту.

У XXI столітті все більшого поширення набуває прийом формування екоорієнтованих будівель 3 використанням рельєфу. Це обумовлено появою нових технологій, застосуванням нетрадиційних конструктивних рішень тепло зберігаючих будівель, а також потребою більш органічного поєднання об'єму будівлі і навколишнього ландшафту шляхом його інтеграції в природне 
середовище 3 використанням засобів геопластики. Сучасна техніка дозволяє створити практично будь-який рельєф. В якості основних засобів формування геопластики рельєфу використовують укоси, підпірні стінки, сходи, пандуси, земляні насипи, пагорби.

Слід зазначити, що при вирішенні об'ємно-просторової і планувальної структури екоорієнтованих будівель, архітектори активно використовують різні проміжні рекреаційні простори: релаксаційно-оздоровчі приміщення, що формують різні релакс-простори (сприяють оздоровленню, відновленню i емоційному розвантаженню людського організму), рекреаційні приміщення для об'єднання або розмежування функціональних зон, забезпечення резерву розвитку. Основні приміщення - балкон, веранда, лоджії, зимовий сад. Тераси, сади на дахах, дворики патіо влаштовуються з метою розширення обмеженого простору будівлі і організації панорамних видів на ландшафтні та архітектурні композиції (водойми, пагорби, МАФ) [50].

Перспективні тенденції формування об'ємно-просторової структури екоорієнтованих будівель спрямовані на створення і розвиток їх багатопланового простору за допомогою наступних прийомів композиційного об'єднання:

- виявлення домінуючого простору (центральне розташування, збільшення висоти, пристрій світлових ліхтарів, акцентування основного елемента);

- посилення візуальної осі простору (в вертикальному і горизонтальному рівні - світлом, кольором, приєднанням відкритих і засклених просторів);

- наявність загальних межуючих елементів простору (нерухомі i трансформовані екрануючі конструкції, гнучкі огорожі, вертикальне озеленення для функціонального і зорового об'єднання, ізоляції приміщень);

- наявність проникаючих структурних елементів простору (приміщення або функціональна зона як структурний елемент, здатні вільно «перетікати» в інші для створення багатофункціонального простору);

- гармонізація в оформленні інтер'єрного та екстер'єрного простору (відображення зовнішнього вигляду будівлі в його інтер'єрі - використання єдиного стилю і матеріалів, колірного і світлового рішення, декору). 
Використання даних прийомів дає можливість комплексно поєднувати в об'ємно-планувальній структурі екоорієнтованих будівель сучасність, комфорт, індивідуальність для функціонального і естетичного збагачення, а також інтеграції інтер'єрних і екстер'єрних просторів [51].

Формування архітектурно-ландшафтного середовища екоорієнтованих будівель повинно здійснюватися з використанням регулярної, ландшафтної та змішаної планувальної структури і з використанням природних (рослинність, геопластика, водні пристрої) і антропогенних (МАФ, скульптура, декоративне покриття) засобів ландшафтного дизайну.

Розміщення екоорієнтованих будівель в урбанізованому або природному середовищу визначає два протилежні підходи до організації будівлі i ландшафту. Якісна їх відмінність визначається кількісним співвідношенням параметрів форми будівлі, що створює кордони, і навколишнього простору:

- урбанізоване середовище - незначні (0,1-0,3 га) або середні (0,4-0,6 га) кількісні показники ландшафтного середовища біля будівлі;

- природне середовище - високі (1-3 га і більше) кількісні показники ландшафтного середовища біля будівлі.

В урбанізованому середовищі з позиції економіки необхідне створення максимально заповненою масою компактної форми будівлі 3 мінімальною площею забудови, яка забезпечує зв'язок з природним середовищем шляхом створення веранд, терас, озеленених стін і поверхонь. 3 цієї точки зору найбільш доцільні такі компактні форми, як куб, сфера, півсфера.

Компактний симетричний об'єм кубообразної форми - це характерне рішення традиційної будівлі. Яскраво виражена вісь симетрії, центральне розташування головного входу і двухсвітлового холу роблять планувальну схему будівлі досить жорсткою. У симетричних композиціях будівлі принцип дзеркальності всього об'єму щодо центральної осі часто піддається центричній організації інтер'єру головного простору. У компактний об’єм можуть активно впроваджуватися відкриті простори (лоджії і тераси, веранди, балкони, малі сади на пласкій покрівлі). Вони забезпечують зв'язок архітектурних об'ємів 3 
природним середовищем i дозволяють пом'якшити деяку жорсткість їх симетричною схеми.

Компактний асиметричний обсяг дозволяє більш гнучко розміщувати планувальні елементи будівлі. Це може бути не тільки куб, а й пластина, іноді піднята над рівнем землі.

Протяжний об’єм витягнутий уздовж однієї, як правило, вуличної осі. Він дозволяє розкрити весь простір, зорово збільшивши його глибину. Довжина стає домінуючою і визначає форму, планувальну структуру і функцію приміщень. Такий обсяг дозволяє розділити їх в плані на кілька окремих, але пов'язаних між собою просторів.

У природному середовищу слід створювати вільні форми, виражені мінімальною кількістю маси будівлі 3 умовою значного переважання ландшафтного середовища. У порівнянні 3 компактними об’ємами екоорієнтованих будівель в міському середовищі таким будівлям притаманні більш складні просторові зв'язки між їх композиційними елементами.

При перетині об’ємів (павільйонне геометричне планування) створюються вищі приміщення. Вони організовуються на перетині об’ємів і можуть мати подвійну висоту. На даху таких домінуючих об’ємів доцільно робити озеленені рекреаційні простори з оглядовими майданчиками. Екстер'єрні простори повинні вирішуватися шляхом інтегрованого об'єднання об'єму будівлі і ландшафту. Слід зазначити, що лінійні об’єми екоорієнтованих будівель є особливо виразними в поєднанні з криволінійними.

Екоорієнтовані будівлі вільної конфігурації - прийом, характерний скоріше для більш м'якого клімату, коли великий периметр зовнішніх стін не є недоліком. Складні криволінійні об’єми характеризуються наявністю динамічно і візуально активних викривлених стін. Увігнуті частини викривленого об’єму концентрують простір в центрі, а опуклі частини виокремлюють його зсередини. Важливим акцентом при роботі 3 криволінійним об'ємом будівлі вільної конфігурації $\epsilon$ наявність активного інтегрованого зв'язку 3 природним оточенням. Він досягається шляхом створення вбудованих або прибудованих 
зимових садів; організації одного або системи внутрішніх двориків; включення терас, лоджій, соляріїв; залучення в будівлі природних ландшафтів як різних рекреаційних просторів, експлуатованих садів на дахах, вертикального озеленення та ін.

Таким чином, екоорієнтовані будівлі можуть мати різноманітну форму об’єму «оболонки» - куб, паралелепіпед, сфера, півсфера, вільне поєднання різноманітних об'ємів і ін. Вони можуть проектуватися такими, що стоять окремо (у природному середовищі) або в структурі забудованих міських територій, мати один або кілька рівнів. Функціональна організація таких екоорієнтованих будівель повинна знайти своє відображення при формуванні екстер'єрного простору поряд 3 будівлею. Організація грамотної прямої залежності між рішенням об'ємно-планувальної структури будівлі і ландшафтним оформленням прилеглої до неї ділянки дозволить максимально зберегти природні елементи середовища і забезпечити контакт людини 3 природою. 


\section{SECTION 2. CHEMICAL TECHNOLOGY}

\subsection{Ukrainian prospects for landfill gas production at landfills}

Increasing the level of fuel and energy independence is one of the priority goals of the state energy policy of Ukraine. At the same time, there are some negative trends that are observed in the system of traditional energy, which for a number of reasons are related to the problem of providing hydrocarbon fuel and energy resources of the state. This created the preconditions for the need to develop certain segments of alternative energy.

In this situation, the issue of extraction and use of renewable energy sources, one of which is landfill gas (LG), is extremely important for Ukraine. The energy obtained from $L G$ is renewable because it comes from an organic renewable substrate, which attaches even greater importance to gas production in biogas plants.

Consumption of the benefits of civilization is constantly growing, and with it the amount of waste. Colourful packaging, disposable products and much more that is made for general use, invariably turns into scrap. No matter how much you manage to compact the garbage can - you still have to take out the garbage. This means that there is an urgent need to invent new ways of recycling waste.

Municipal solid waste (MSW), which in contrast to solid industrial waste [52-57], is a mixture of organic substances of different origins, is a high-calorie fuel that is not inferior in energy to traditional brown coal [58]. Receiving energy from garbage simultaneously solves the problem of solid waste disposal.

Fuel derived from conventional solid waste is: 1) gaseous (LG, which contains methane); 2) solid; 3) liquid.

At present, waste processing plants are being set up in different countries, equipped with special storage facilities equipped for the proper storage of solid waste in order to obtain LG from them. However, low-calorie gaseous fuels are difficult to transport, and therefore they are usually used directly at the place of extraction for the production of electricity and heat. 
Solid fuel from solid waste [59] is a high-calorie fraction consisting of household waste. This type of fuel is widely used as a cheap substitute for combustible minerals and can replace resources such as brown coal, coal, petroleum products, wood.

Liquid fuel is a synthetic diesel fuel that can be used in internal combustion engines. It differs favorably from diesel fuel obtained from oil refining, because it does not contain sulfur, which clogs the engines, which in turn has a negative impact on their durability.

One of the main ways to remove solid waste around the world is to bury it in the surface geological environment. Under these conditions, the waste is subjected to intensive biochemical decomposition with the formation of LG [60-65]. The main components of LG include not only greenhouse gases (methane and carbon dioxide), but also such toxic compounds as carbon monoxide, nitrogen oxides, hydrogen sulfide, sulfur dioxide $[66,67]$. Physico-chemical properties of landfill gas are given in table. 1.

In the process of thermal exposure and ignition of waste, carcinogenic compounds are released - benzene, benzopyrene. Emissions of landfill gases entering the environment have negative effects of both local and global geoecological nature.

As a result of anaerobic (in the complete absence of oxygen) decomposition of the organic fraction of solid waste from the total amount of methane that enters the atmosphere annually, $40 \ldots 70 \%$ is formed as a result of anthropogenic activity, and $20 \%$ of them are landfills. It is estimated that about $200 \mathrm{~m}^{3}$ of $\mathrm{LG}$ is formed from one ton of solid waste. Thus the first 15 ... 20 years at decomposition of one ton of MSW up to $7,5 \mathrm{~m}^{3}$ of LG a year are allocated. In the future, the intensity of LG secretion decreases sharply.

Depending on the methane content, LG has a specific heat of combustion in the range from 15 to $25 \mathrm{MJ} / \mathrm{m}^{3}\left(3600 \ldots 4800 \mathrm{kcal} / \mathrm{m}^{3}\right)$, which corresponds to $1 / 2$ of the heat of combustion of natural gas. The average heat of combustion of LNG is 4200 $\mathrm{kcal} / \mathrm{m}^{3}$. The heat of combustion of $1 \mathrm{~m}^{3}$ of LG is equivalent to: $0.8 \mathrm{~m}^{3}$ of natural gas, $0.7 \mathrm{~kg}$ of fuel oil or $1.5 \mathrm{~kg}$ of firewood. 
THEORETICAL ASPECTS OF MODERN ENGINEERING

Table 1.

Physico-chemical properties of landfill gas [66, 67]

\begin{tabular}{|c|c|c|c|}
\hline Characteristic & $\begin{array}{l}\text { Quantitative } \\
\text { indicator }\end{array}$ & Characteristic & $\begin{array}{l}\text { Quantitative } \\
\text { indicator }\end{array}$ \\
\hline $\begin{array}{l}\text { Chemical composition, \%: } \\
\text { - methane } \mathrm{CH}_{4}\end{array}$ & $55.1 \ldots 72.6$ & $\begin{array}{l}\text { Volumetric heat of } \\
\text { combustion, } \mathrm{MJ} / \mathrm{m}^{3}\end{array}$ & $18 \ldots .23$ \\
\hline $\begin{array}{l}\text { - carbon dioxide } \mathrm{CO}_{2} \\
-\mathrm{H}_{2} \mathrm{O} \text { water }\left(\text { at } 40^{\circ} \mathrm{C}\right)\end{array}$ & $\begin{array}{c}10.1 \ldots .22 .2 \\
5.12\end{array}$ & $\begin{array}{l}\text { Energy consumption, } \\
\mathrm{kWh} / \mathrm{m}^{3}\end{array}$ & 6.5 \\
\hline $\begin{array}{l}\text { - hydrocarbons } \\
\text { - nitrogen dioxide } \\
\text { - ammonia } \mathrm{NH}_{3}\end{array}$ & $\begin{array}{c}0.09 \ldots 1.2 \\
0.6 \ldots 0.71 \\
0.33 \ldots 0.35\end{array}$ & $\begin{array}{l}\text { Explosive concentration in } \\
\text { air,\% }\end{array}$ & $6 \ldots 12$ \\
\hline $\begin{array}{l}\text { - toluene } \\
\text { - propane }\end{array}$ & $\begin{array}{c}0.08 \ldots 0.1 \\
0.06 \ldots 0.08\end{array}$ & Ignition temperature, ${ }^{\circ} \mathrm{C}$ & $650 \ldots 750$ \\
\hline $\begin{array}{l}\text { - sulfur dioxide } \\
\text { - chloroethane }\end{array}$ & $\begin{array}{l}0.04 \ldots 0.06 \\
0.04 \ldots 0.06\end{array}$ & Critical pressure, $\mathrm{MPa}$ & 7.5 \\
\hline $\begin{array}{l}\text { - dichloroethane } \\
\text { - total chlorine }\end{array}$ & $\begin{array}{l}0.04 \ldots 0.06 \\
0.01 \ldots 0.06\end{array}$ & Critical temperature, ${ }^{\circ} \mathrm{C}$ & -2.5 \\
\hline $\begin{array}{l}\text { - ichlorodifluoromethane } \\
\text { - dean }\end{array}$ & $\begin{array}{l}0.02 \ldots 0.03 \\
0.02 \ldots 0.03\end{array}$ & Normal density, $\mathrm{kg} / \mathrm{m}^{3}$ & 1.2 \\
\hline - isopropylbenzene & 0.01 & Density relative to air & 0.83 \\
\hline
\end{tabular}

Statistics on the extraction and potential of LG in different countries are given in table. 2 [68]. In fig. 1 shows the prevalence of LG extraction methods in different countries. As can be seen from Fig. 1, the most common method of LG utilization is electricity generation.

LG is one of the causes of the outbreak of solid waste in landfills and dumps. When the content in the air is $5 \ldots 15$ methane and $12 \%$ oxygen, an explosive mixture is formed. The concentration of methane and other components of LG can be controlled using a gas analyzer, which is considered in detail and described in $[69,70]$. 
Table 2.

Statistics on the extraction and potential of LG in different countries [68]

\begin{tabular}{|c|c|c|c|c|c|}
\hline Country & 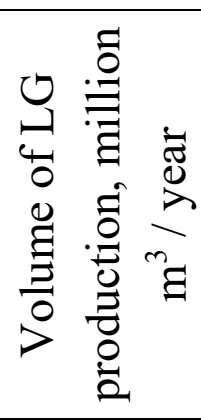 & 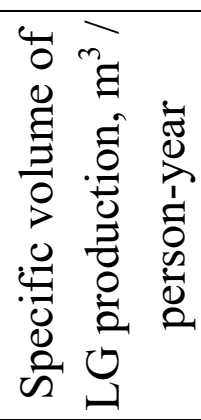 & 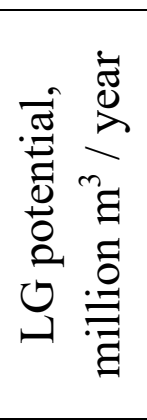 & 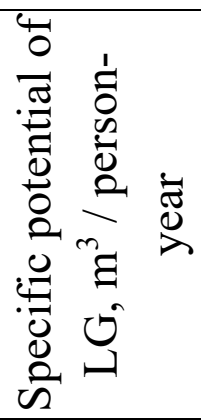 & 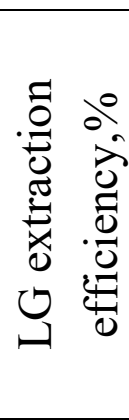 \\
\hline USA & 500 & 1.723 & 13000 & 44.79 & 3.85 \\
\hline Germany & 400 & 4.872 & 2050 & 24.97 & 19.51 \\
\hline UK & 200 & 3.317 & 2520 & 41.80 & 7.94 \\
\hline Netherlands & 50 & 3.058 & 560 & 34.25 & 8.93 \\
\hline France & 40 & 0.637 & 874 & 13.91 & 4.58 \\
\hline Italy & 35 & 0.583 & 1040 & 17.31 & 3.37 \\
\hline Denmark & 5 & 0.917 & 105 & 19.27 & 4.76 \\
\hline
\end{tabular}

LG also has a negative effect on vegetation, suppressing vegetation in areas adjacent to MSW (the mechanism of action is associated with the saturation of LG in the pore space of the soil and the displacement of oxygen from it).

LG is one of the gases that create a "greenhouse effect" and affect climate change in the Earth as a whole. The United Nations Framework Convention on Climate Change [71] obliges member states to minimize emissions of greenhouse gases such as methane and carbon dioxide (emissions of $1 \mathrm{~m}^{3}$ of methane are detrimental to climate change equivalent to emissions into the atmosphere about $25 \mathrm{~m}^{3}$ of carbon dioxide). In this regard, the reduction of GHG emissions into the atmosphere not only improves the environmental situation around landfills, but also contributes to Ukraine's fulfillment of its international obligations. 


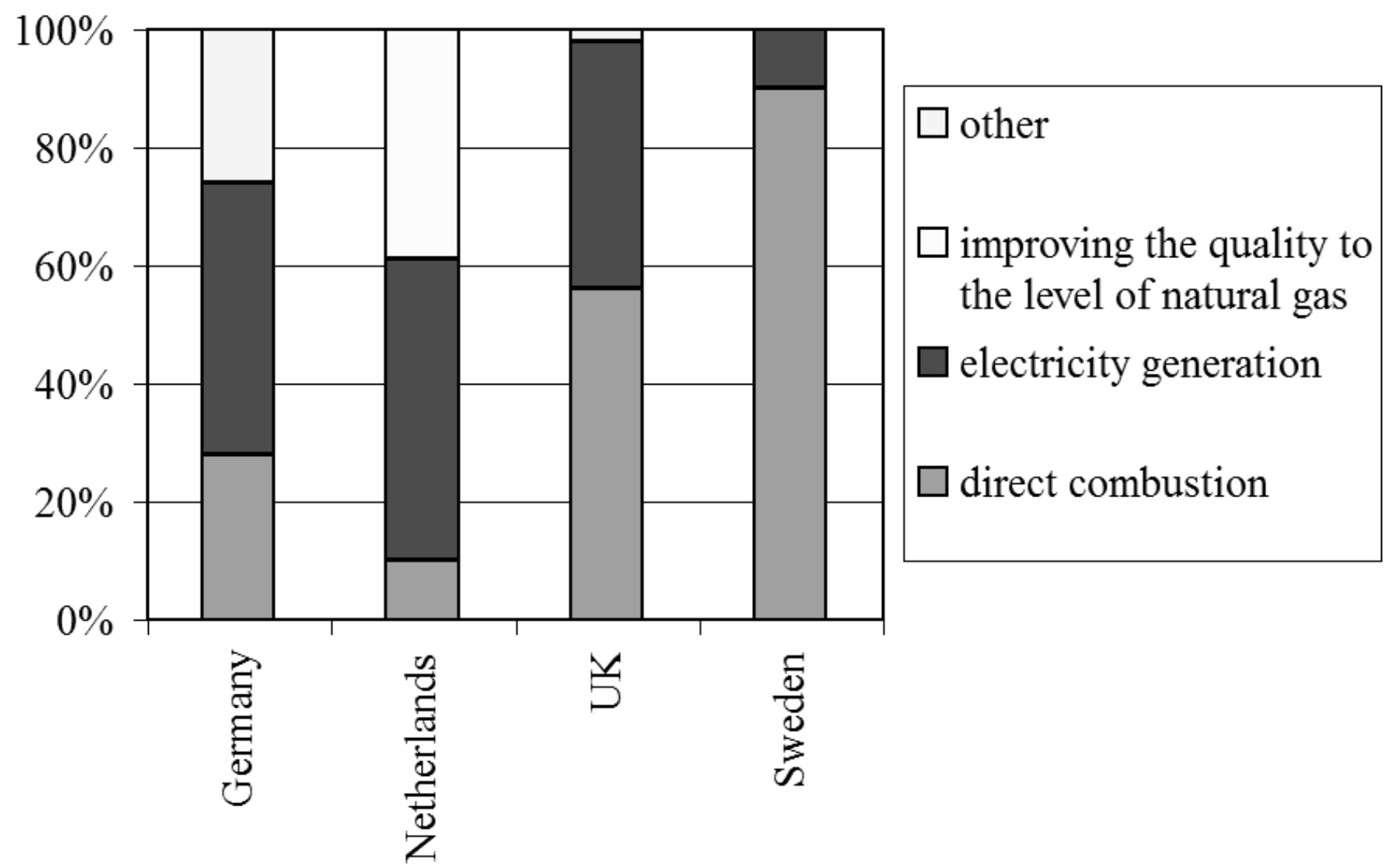

Figure 1. Prevalence of methods of LG extraction in different countries

The need to reduce environmental pollution and save energy makes it more rational to use traditional energy resources, look for other, preferably inexpensive and renewable energy sources, which recently increasingly include solid waste generated in large quantities, and usually do not find application and pollute the environment, are renewable secondary energy resources. Currently, two main areas of energy utilization of solid waste, their incineration and disposal with the production of GHG are intensively developing.

Solid waste incineration requires expensive treatment systems, so landfill is more common worldwide [72]. The main advantage of burial technology is simplicity, relatively low capital and operating costs, and relative safety.

For the energy of developed countries, the use of LGs is not crucial, but this source should not be neglected for both environmental and economic reasons, as evidenced by the experience of many countries. The EU has adopted a directive requiring the collection and disposal of LG from all landfills where biodegradable solid waste has been disposed of in order to minimize harmful effects on the environment and human 
health. LG generated in landfills since the early 80 's is intensively mined in many countries. Today, the total amount of LG used is approximately 1.2 billion $\mathrm{m}^{3}$ / year, which is equivalent to 429 thousand tons of methane, or $1 \%$ of its global emissions.

Currently, about 60 types of biogas technologies are used or developed in the world. The average service life of one well is 15 years, the estimated payback period of the project is from 4 to 5 years.

Let us consider in more detail the process of LG formation and its features. LG occurs due to the decomposition of organic matter by bacteria [73-75]. Different groups of bacteria decompose organic substrates, consisting mainly of water, protein, fat, carbohydrates and minerals into their primary components - carbon dioxide, minerals and water. As a product of metabolism, a mixture of gases is formed, which is called LG. Combustible methane $\left(\mathrm{CH}_{4}\right)$ is from $5 \%$ to $85 \%$ and is the main component of $\mathrm{LG}$, and therefore the main energy-intensive component.

This natural decomposition process is possible only under anaerobic conditions in special biogas plants. The energy released due to the anaerobic process is not lost and due to the activity of methane bacteria it is converted into methane molecules.

The essence of the process of obtaining LG is the decomposition of biomass under the influence of three types of bacteria: hydrolysis, acid-forming, methane-forming.

The formation of $L G$ can be divided into four phases:

1. Hydrolysis phase, during which as a result of bacterial activity, stable substances (proteins, fats and carbohydrates) decompose into simple components (amino acids, glucose, fatty acids).

2. Acid-forming phase. The components obtained during the hydrolysis phase are decomposed by acid-forming bacteria into other organic substances (acetic, propionic acids, alcohols and aldehydes) and inorganic substances $\mathrm{H}_{2}, \mathrm{CO}_{2}, \mathrm{~N}_{2}, \mathrm{H}_{2} \mathrm{~S}$. This process occurs until the development of bacteria is slowed down by the formed acids.

3. Acetogenic phase, during which acetic acid is produced from the formed acids under the influence of acetogenic bacteria. 
4. Methanogenesis, as a result of which acetic acid decomposes into methane, carbon dioxide and water. Hydrogen and carbon dioxide are converted to methane and water.

All the described reactions take place simultaneously, and methane-forming bacteria make much higher demands on the conditions of their existence than acidforming ones.

All this complex of transformations is carried out by a large number of microorganisms - up to several hundred species. Of these, hydrolytic, fermentation, syntrophic and methane groups are predominant. The qualitative and quantitative composition of microorganisms strongly depends on the composition of fermenting organic substances and the conditions created in the environment.

The composition of LG depends on the content of hydrogen sulfide and other gases, the parameters of the process.

The energy consumption of LG directly depends on the concentration of methane in it, which is a colorless, non-toxic gas that is lighter than air and odorless. Methane combustion produces carbon dioxide and water vapor. With a methane content of more than $60 \%$, LG is considered a very valuable fuel [76].

Thus, the technology of solid waste processing at landfills has the greatest prospects for obtaining and further use of landfill gas because it can be achieved: improving the environmental condition, additional energy benefits, increasing fuel and energy potential and energy independence of Ukraine. 


\subsection{Thin composite films based on carbon-graphite materials for protection against electromagnetic radiation}

\section{Introduction}

Progress trends of the electronic equipment market dictate the technology development needs to design new effective technical solutions for shielding the electromagnetic field. Now, all manufacturers follow the way of minimizing and optimizing the dimensions of the equipment. This, therefore, poses a task for world scientists to create efficient and easy to work with shielding material.

In the general case, shielding means protection of devices from influence of external fields and radiation localization of any means, that interfering with manifestation of these radiations in environment. In any case, the shielding efficiency is the degree of attenuation of the field components (electric, magnetic), which is defined as the ratio of the current values of field strength in a given point in space in the absence and presence of the screen.

The most common materials used for protection against electromagnetic radiation are metals in the form of grids or plates, which generally successfully cope with the task. The main disadvantage of them is the increase in the cost and structural complexity, because it is necessary to take into account significant mass and dimensional changes when designing equipment, ensure "continuity" of the screen, adapt to structural features of devices, provide additional protection (corrosion, grounding), etc.

Despite of the variety of conditions that must be met for high-quality shielding, the main factors remains the radio physical properties of materials and design features.

Therefore, the search for alternative materials is the most important, among them special attention deserve carbon and graphite materials. They have a number of advantages, such as electrical conductivity, low bulk density, variability in particle size and shape, ease of processing, and others. 


\section{Materials and methods}

The experimental samples contained of carbon and graphite additives of various shapes and origins. During the research the following carbon graphite materials were compared: thermoexpanded graphite ABG 1010 (Superior Graphite Co. Chicago, Illinois, USA), graphitized carbon black "PUREBLACK®" (Superior Graphite Co. Chicago, Illinois, USA); technical carbon black PowCarbon 3200F (YongFeng Chemicals Co., Ltd); experimental sample of fine grade graphite "Drill - 200 mesh" (Focus Graphite Inc., Ottawa, Canada), domestic colloidal graphitic product brand C1 (Zavallivsky graphite, Ukraine) and American rod-shaped graphite brand DBX-010.

Composite mix were prepared by loading the ingredients (carbon and graphite materials, polymer solution) in a mechanical stirrer and subjecting to long-term stirring. The content of conductive filler was $40-60 \%$. The process of mixing is one of the most important stages, because its result plays an important role in the further processing of the composite and the quality of the finished product. The main task in this stage is deagglomeration of powder materials (polymer and fillers) to distribute them evenly in the system and prevent their negative impact on the physical and mechanical, electrodynamic properties of the films. The finished mixture was applied by "doctor blade method" on the base and dried at a temperature of $50-60{ }^{\circ} \mathrm{C}$ during 90 minutes.

Formed films were characterized by uniform thickness, porosity and smooth surface.

\section{Results and discussion}

Through comparing the measured values of the modules of the reflection coefficient and the transmission coefficient was calculated the electromagnetic losses during the passage of an electromagnetic wave through a sample of composite material, which was embedded in the waveguide. Studies on the ability to attenuate electromagnetic radiation were performed in the frequency range from 17 to $27 \mathrm{GHz}$.

Electromagnetic properties of composites with dispersed conductive fillers depend not only on the concentration parameters, but also on the morphology and 
nature of the all components, layer thickness, porosity, surface roughness, etc. It is important to note that for diamagnetic materials, which include carbon-containing structures, absorption of electromagnetic waves is caused only by dielectric losses.

The produced samples had a flat shape and a thickness of 150-300 $\mu \mathrm{m}$.

Figure 1 shows the results of electromagnetic attenuation of samples based on black carbons.

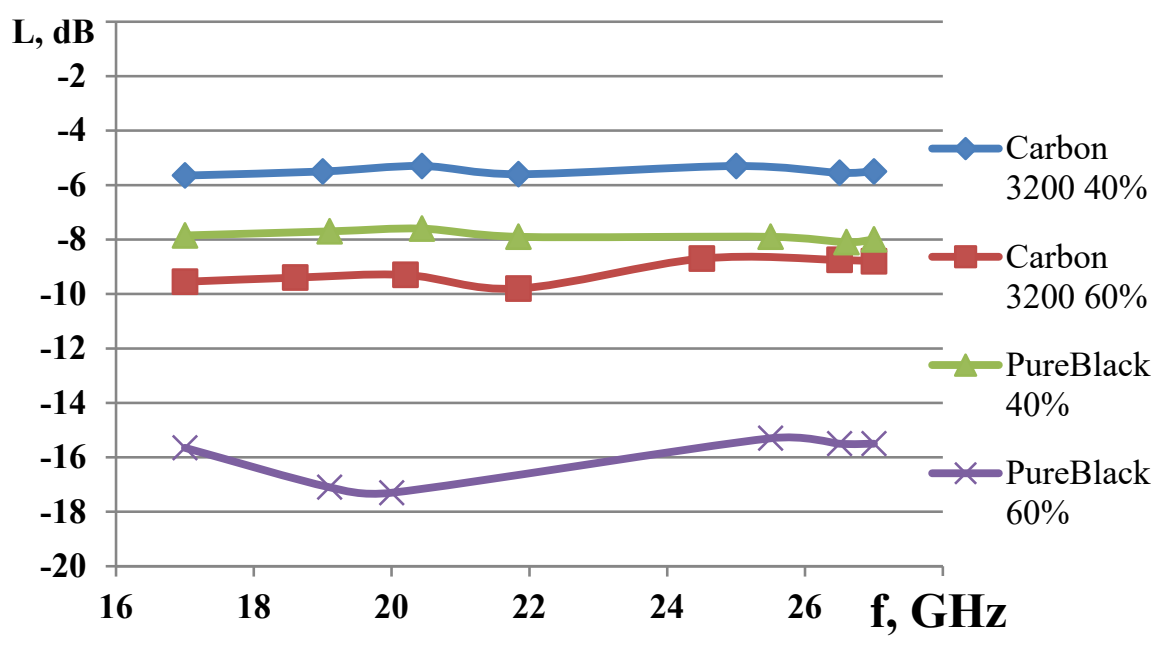

Figure 1. The level of signal attenuation introduced by samples of technical (Carbon 3200F) and graphitized (PUREBLACK $®)$ carbon black of different concentrations.

It is obvious that the graphitized carbon black has better electromagnetic losses over technical carbon black with the same content, which is explained by its better electrical conductivity.

A feature of graphitized carbon black is its structure [77], where graphitized plates are "built up" around the "carbon core". Its increase the level of electrical conductivity and create a multifaceted structure that promotes multiple reflections of the electromagnetic wave in the material. These features make graphitized carbon black the leader among this class of materials. 


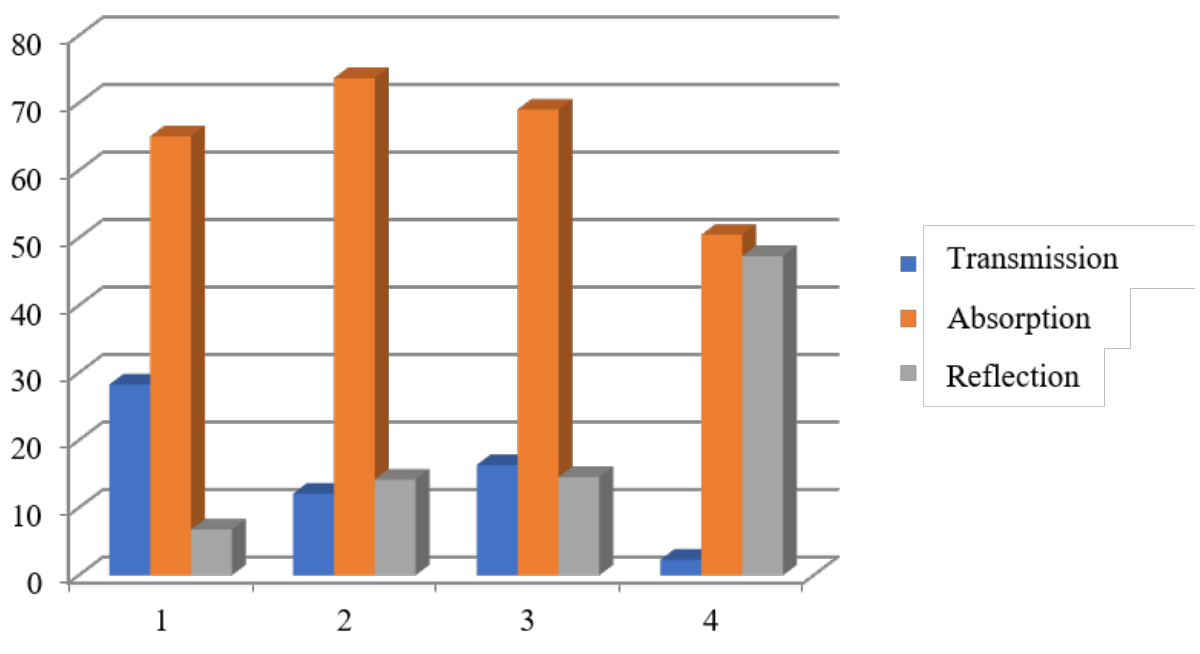

Figure 2. Diagram of the partitioning of electromagnetic losses in the carbon black composites, where 1 and 2 - composites with a content of Carbon $320040 \%$ and $60 \%$, respectively, 3,4 - composites with a content of Carbon Black $40 \%$ and $60 \%$, respectively.

During development of protective materials, and especially during protection of information, one of the main conditions is to ensure minimal leakage of electromagnetic waves [78]. Although technical carbon black with increasing concentration retains the maximum rate of absorption (scattering) of EMR in the thickness of the sample, its ability to "transmit" radiation is too much high (12-28\%) for quality protection. Graphitized carbon black at a content of $60 \%$ transmits only $2 \%$ of EMR, and the attenuation of the signal is due to almost equivalent mechanisms of absorption (scattering) and reflection with a slight advantage of the first.

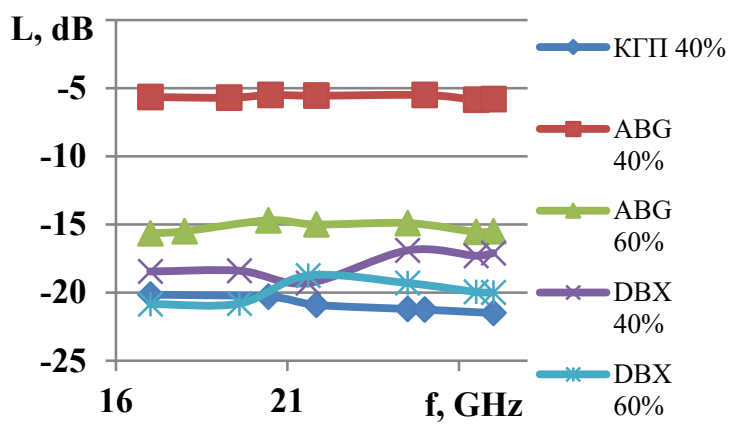

(a)

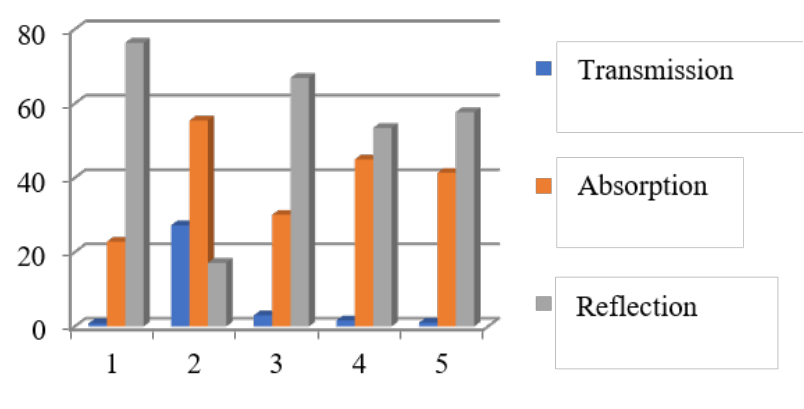

(b) 
Figure 3. Comparison of electromagnetic losses introduced by graphite materials (a), and their partitioning (b); materials and their concentration: 1 - KGP 40\%, 2 - ABG 1010 40\%, 3 - ABG 1010 60\%, 4 - DBX-010 40\%, DBX-010 60\%.

Figures 3 (a), (b) show the results of signal attenuation and the partitioning of losses caused by graphite materials. Thermoexpanded graphite ABG 1010 showed the worst results, grew only to the level of $-15 \mathrm{~dB}$ at a concentration of $60 \%$. The mechanism by which the losses were achieved changed from absorption / scattering (Fig. 3b sample №2) to reflection (Fig. 3b sample №3). Increasing the concentration of the rod-shape graphite DBX-010 did not contribute to radical changes in the attenuated signals and the partioning of electromagnetic losses, which is very well confirmed in the presented graphs (Fig. 3a, 3b). The most effective shielding -20... $22 \mathrm{~dB}$, mainly due to reflection, was demonstrated by a colloidal graphitic product, with a coefficient of transmission of $0.8 \%$.

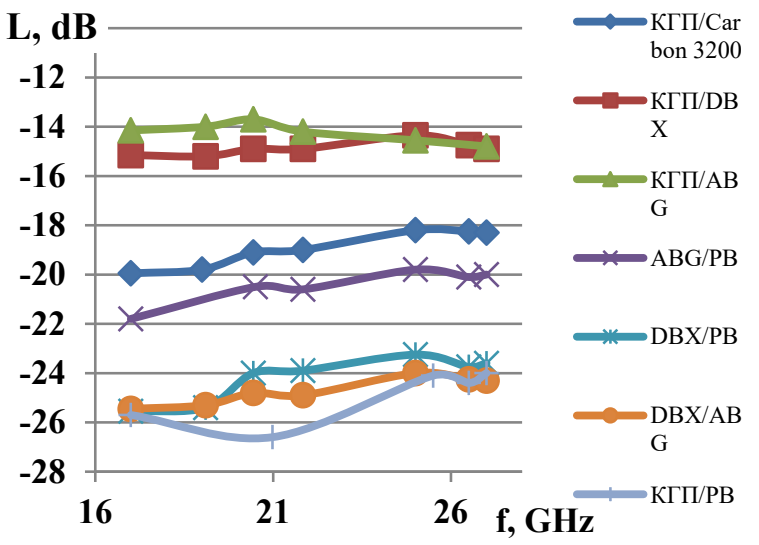

(a)

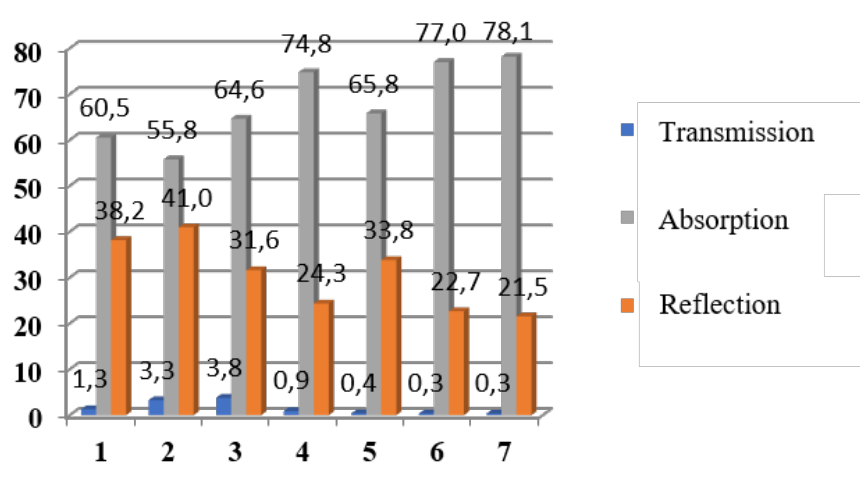

(b)

Figure 4. The attenuation level of the signal (a) made by composite samples and the partitioning diagram of electromagnetic losses (b) containing carbon and graphite materials, where are: 1 - KGP/Carbon 3200, 2 -KGP/DBX, 3 - KGP/ABG, 4 ABG/PB, 5 - DBX/PB, 6 - DBX/ABG, 7 - KGP/PB.

An interesting task was to verify the existence of a synergistic effect [79] when combining carbon and graphitic materials on the example of the ability to shield 
electromagnetic radiation. Taking into account the results of previos research of individual components (Fig. 1, 3), it was decided to prepare a series of samples containing graphitized carbon black, because it showed the best properties (Fig. 1) and various graphite materials.

The data shown in Figure 4, it is seen that in all composites the synergistic effect is positive, for example, previously a composite with a content of $40 \%$ of graphitized carbon black caused losses of $-8 \mathrm{~dB}$, and a sample with a content of $40 \%$ of colloidal graphite preparation caused losses of $-20 \mathrm{~dB}$. But, the composite, which contains a colloidal graphite preparation and graphitized carbon black in a ratio of $3: 1$, demonstrates the best shielding properties with a maximum loss peak of $-27 \mathrm{~dB}$ at a frequency of $20.9 \mathrm{GHz}$, which corresponds to a signal reduction of almost 1000 times. Some interest attract composites DBX / PB and DBX / ABG, they caused losses from -23 to $-26 \mathrm{~dB}$.

That's why, carbon materials prove to be quite promising materials in the field of EMR shielding.

Conclusions:

- In the paper were investigated and compared the electromagnetic properties of a number of carbon and graphite materials.

- Transmission, reflection and absorption coefficients of manufactured composite samples, not exceeding $300 \mu \mathrm{m}$, in the frequency range 17-27 GHz were quantified.

- A positive synergistic effect with combining carbon and graphite materials was proved and demonstrated by researcher team.

- Such composite materials can be successfully used as screens and as absorbent coatings by changing the composition, concentration and types of carbon and graphite materials in the composite. 


\section{4 Ефективність циклування нанорозмірного ТiO2 в натрісвих джерелах струму}

Діоксид титану $\mathrm{TiO}_{2}$ відноситься до електродних матеріалів, що активно досліджуються в літій- i натрій-іонних джерелах струму, а також в суперконденсаторах [80-82]. Серед існуючих структурних модифікацій (рутил, анатаз, брукіт) $\mathrm{TiO}_{2}$ зі структурою анатазу вважається найбільш перспективним завдяки високій практичній питомій ємності та здатності до зворотного циклування [80, 81].

Під час одержання $\mathrm{TiO}_{2}$ велика увага приділяється модифікуванню його структурних та поверхневих властивостей, а також отриманню нанорозмірних зразків. Зменшення розмірів частинок $\mathrm{TiO}_{2}$ до нанорівня сприяє підвищенню питомої ємності та покращенню циклічних та швидкісних характеристик $\mathrm{TiO}_{2}$ електродів в процесі зарядження-розрядження [83-88].

В літературних джерелах розглядається декілька можливих механізмів зарядження-розрядження за участю $\mathrm{TiO}_{2}$ та катіону $\mathrm{Na}^{+}$, a саме: зворотна інтеркаляція/деінтеркаляція іонів натрію з мінімальними змінами в параметрах кристалічної гратки [89, 90]; утворення при першому натріюванні невпорядкованої шаруватої фази $\mathrm{Na}_{x} \mathrm{TiO}_{2} 3$ подальшим оборотнім фазовим переходом між аморфним $\mathrm{TiO}_{2}$ та $\mathrm{Na}_{x} \mathrm{TiO}_{2}$ при циклуванні [91]; незворотна аморфізація і подальша оборотна реакція перетворення $\mathrm{TiO}_{2}$ в металічний титан та $\mathrm{Na}_{2} \mathrm{O}$ або $\mathrm{Na}_{2} \mathrm{CO}_{3}[87,92]$. Реалізація одного із представлених механізмів визначає як термодинамічні, так і кінетичні характеристики $\mathrm{TiO}_{2}$ в натрій-іонних джерелах струму та залежить як від поверхневих і розмірних властивостей $\mathrm{TiO}_{2}$, так і від складу електроліту [93].

Мета роботи полягала у встановленні впливу питомої поверхні $\mathrm{TiO}_{2}$ та складу електроліту на електрохімічні характеристики $\mathrm{TiO}_{2}$ в джерелах струму 3 натрієвим анодом.

Для цього були використані зразки $\mathrm{TiO}_{2}$, синтезовані методом лужного гідролізу відповідно до методики, запропонованої у роботі [94]. Аналіз поверхневих, структурних та електрохімічних характеристик отриманих зразків 
в літієвих джерелах струму представлений у роботі [95]. Для досліджень електрохімічних характеристик $\mathrm{TiO}_{2}$ у натрієвій системі були використані зразки, характеристики яких наведені у таблиці 1.

Таблиця 1.

Розміри кристалітів та властивості поверхні зразків $\mathrm{TiO}_{2}$

\begin{tabular}{|c|c|c|c|c|}
\hline Зразок & $d_{(101)}, \mathrm{HM}$ & $S_{\text {пит }}, \mathrm{M}^{2} / \Gamma$ & $V_{\text {пор }}, \mathrm{cm}^{3} / \Gamma$ & $R_{\text {пор }}, \mathrm{HM}$ \\
\hline $350^{\circ} \mathrm{C}-4$ год & 7,0 & 174 & 0,264 & 2,2 \\
\hline $470^{\circ} \mathrm{C}-6$ год & 9,8 & 80 & 0,152 & 2,75 \\
\hline
\end{tabular}

Електрохімічні дослідження проводили в дискових елементах габариту 2016. Робочий електрод складався 3 досліджуваного $\mathrm{TiO}_{2}$, електропровідної домішки Super P (Timcal, Швейцарія) та сполучника полівінілідендифториду (ПВДФ) Solef 6020 (Solvay, Бельгія), взятих у процентному масовому співвідношенні 85:10:5. Маса $\mathrm{TiO}_{2}$ становила 4,5-6,5 мг/см². Гальваностатичні дослідження проводили на установці Neware Battery Testing System (Китай). Циклування вели в діапазонах напруг 0,4-2,4 В та 0,2-2,4 В відносно $\mathrm{Na} / \mathrm{Na}^{+}$.

Відповідно до літературних джерел $[90,93]$ процеси взаємодії іонів натрію $3 \mathrm{TiO}_{2}$ залежать від його структурних та поверхневих характеристик, діапазону напруги розряду та складу електроліту. В натрієвих джерелах струму $\mathrm{TiO}_{2}$ зазвичай циклують в інтервалі напруги 0,1-2,7 В [86-88].

Вплив складу електроліту на питому ємність $\mathrm{TiO}_{2}$ в комірках з натрієвим анодом було визначено за даними, отриманими на першому та другому циклах розряду-заряду (таблиця 2). Представлені результати свідчать про значний вплив електроліту на здатність $\mathrm{TiO}_{2}$ до циклування. Найбільш ефективним як за питомою ємністю, так і кулонівською ефективністю (КЕ), є електроліт $1 \mathrm{M} \mathrm{NaBF}_{4}$ TG. B інших електролітах, не дивлячись на відносно високу питому ємність розряду на першому циклі, питома ємність на другому циклі була вкрай низькою. Низьку зворотну ємність $\mathrm{TiO}_{2}$ в електроліті $1 \mathrm{M} \mathrm{NaClO}_{4}$ EC:DMC:FEC автори [93] пояснюють впливом процесу розкладу електроліту та формування твердоелектролітної плівки (ТЕП) на поверхні електроду. 
Таблиця 2

Вплив складу електроліту на питому ємність та кулонівську ефективність $\mathrm{TiO}_{2}$

\begin{tabular}{|c|c|c|c|c|c|c|}
\hline \multirow{2}{*}{$\begin{array}{c}\text { Склад } \\
\text { електроліту }\end{array}$} & \multicolumn{4}{|c|}{ 1-й цикл } & \multicolumn{2}{|c|}{ 2-й цикл } \\
\hline & $\begin{array}{c}\text { Qрозр., } \\
\text { мАгод/г }\end{array}$ & $\begin{array}{c}x \text { в } \\
\mathrm{Na}_{x} \mathrm{TiO}_{2}\end{array}$ & $\begin{array}{c}\mathrm{Q}_{\text {зар. }}, \\
\text { мАгод/Г }\end{array}$ & KE, \% & $\begin{array}{c}\text { Qрозр., } \\
\text { мАгод/г }\end{array}$ & $\begin{array}{c}x \text { в } \\
\mathrm{Na}_{x} \mathrm{TiO}_{2}\end{array}$ \\
\hline $\begin{array}{l}{ }^{1} \mathrm{EC}:{ }^{2} \mathrm{DMC}:{ }^{3} \mathrm{FEC} \\
(4: 5: 1) 1 \mathrm{M} \mathrm{NaClO}\end{array}$ & 200 & 0,6 & 23,1 & 11,55 & 36,1 & 0,1 \\
\hline${ }^{4} \mathrm{DG} 1 \mathrm{M} \mathrm{NaClO} 4$ & 58,7 & 0,18 & 16,13 & 27,48 & 17,9 & 0,05 \\
\hline $\begin{array}{l}{ }^{5} \mathrm{PC}:{ }^{6} \mathrm{TG}(3: 7) \\
1 \mathrm{M} \mathrm{NaClO} 4\end{array}$ & 103,14 & 0,31 & 31,87 & 30,89 & 25,5 & 0,07 \\
\hline $\mathrm{TG} 1 \mathrm{M} \mathrm{NaBF}_{4}$ & 161,7 & 0,48 & 92,6 & 57,27 & 102,5 & 0,3 \\
\hline $\begin{array}{l}{ }^{7} \text { AND:DG (1:1) } \\
1 \mathrm{M} \mathrm{NaClO}_{4}\end{array}$ & 100,6 & 0,3 & 13,8 & 13,72 & 2,1 & 0,006 \\
\hline $\mathrm{DG} 1 \mathrm{M} \mathrm{NaBF}_{4}$ & 35,7 & 0,1 & 5,93 & 16,6 & 5,6 & 0,02 \\
\hline $\begin{array}{l}\text { PC:TG (3:7) } \\
1 \mathrm{M} \mathrm{NaBF} 4\end{array}$ & 126,52 & 0,38 & 38,9 & 30,75 & 39,8 & 0,12 \\
\hline
\end{tabular}

${ }^{1} \mathrm{EC}$ - етиленкарбонат, ${ }^{2} \mathrm{DMC}$ - диметилкарбонат, ${ }^{3} \mathrm{FEC}$ - фторетиленкарбонат, ${ }^{4} \mathrm{DG}$ - диглім, ${ }^{5} \mathrm{PC}-$ пропіленкарбонат, ${ }^{6} \mathrm{TG}$ - тетраглім, ${ }^{7} \mathrm{ADN}$ - адипонітрил. Співвідношення розчинників подані в об'ємнім частинах.

Типові заряд-розрядні криві, отримані на першому циклі та зміна питомої ємності від номера циклу при циклуванні в інтервалі напруг 0,4-2,4 В, показані на рис. 1. Подані криві суттєво відрізняються від аналогічних залежностей, характерних для анатазу в джерелах струму з літієвим анодом [95]. Для них характерна відсутність чіткого плато розрядної та зарядної напруги. Окрім того, достатньо низька напруга розряду призводить до ускладнення основного процесу побічними реакціями, пов'язаними 3 розкладанням електроліту. Саме тому отримана на першому циклі кулонівська ефективність не перевищувала 43\% за значень питомої ємності розряду 91 і 73 мАгод/г для зразків 350-4 та 470-6 відповідно. У сполуці $\mathrm{Na}_{x} \mathrm{TiO}_{2}$ це відповідає значенням $x \sim 0,12$ для зразка 350-4 ( 40 мАгод/г) i 0,09 для зразка 470-6 ( 30 мАгод/г). Більш висока питома ємність, отримана для зразка $\mathrm{TiO}_{2} 350-4$, зберігається і при подальшому циклуванні (рис. 1Б). Відповідно до результатів [93], у разі розряду $\mathrm{TiO}_{2}$ до напруги 0,5 $\mathrm{B}$, тетрагональна структура, притаманна $\mathrm{TiO}_{2}$ зі структурою анатазу, зберігається, $\mathrm{i}$ 
питома ємність зумовлюється формуванням ТЕП та поглинанням катіонів натрію поверхневим шаром частинок $\mathrm{TiO}_{2}$. Тому можна припустити, що в інтервалі напруги розряду до 0,4 В величина питомої ємності буде в основному залежати від питомої поверхні $\mathrm{TiO}_{2}$, що може пояснювати отримані відмінності.
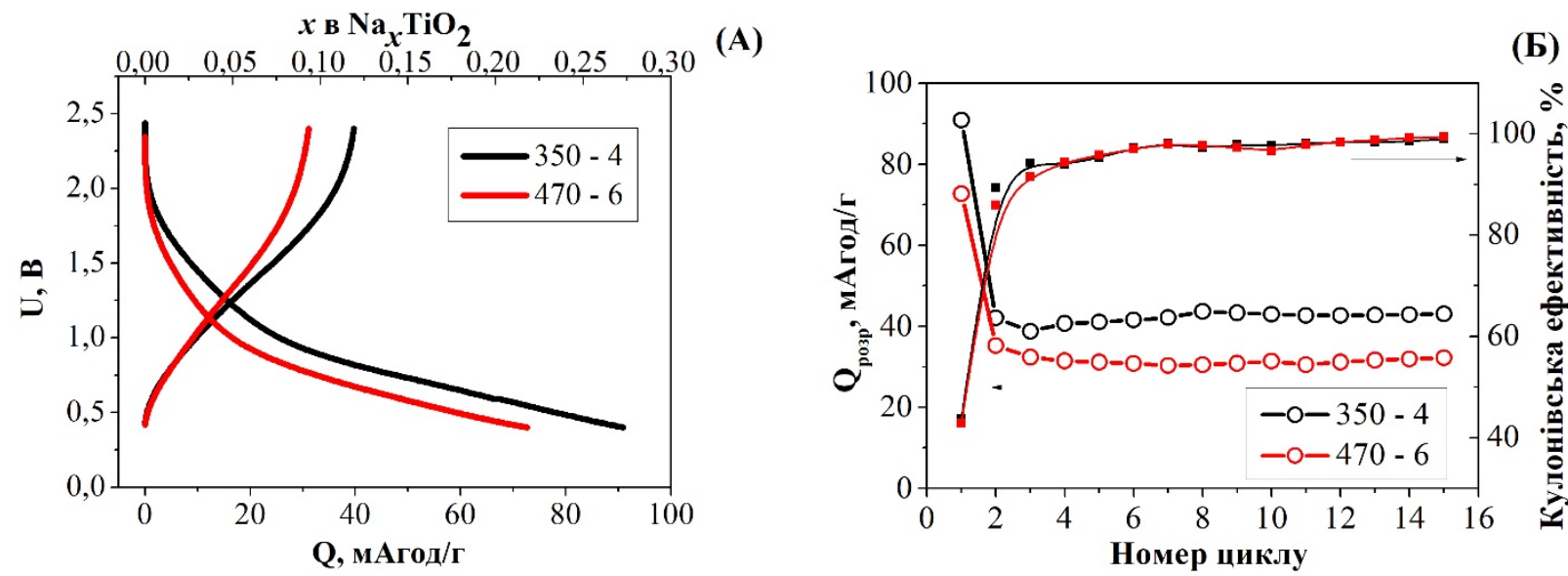

Рисунок 1. Розряд-зарядні криві першого циклу (А) та залежності питомої ємності від номера циклу (Б), отримані за циклування $\mathrm{TiO}_{2}$ в інтервалі напруги 0,4-2,4 В густиною струму 8 мА/г. Електроліт: $1 \mathrm{M} \mathrm{NaBF} 4 \mathrm{TG}$.

Криві розрядження-зарядження та криві диференційної ємності, отримані на п’ятому циклі при циклуванні в інтервалі напруг 0,2-2,4 В, показані на рис. 2. Відповідно до [93], розряд до напруги 0,25 В може бути пов'язаний не тільки 3 отриманням $\mathrm{Na}_{x} \mathrm{TiO}_{2}$, а й $з$ одночасною аморфізацією $\mathrm{TiO}_{2}$ частинок. Ступінь аморфізації залежить від складу ТЕП, що формується на поверхні електродів, властивості якої суттєво залежать від складу електроліту.

Наведені на рис. 3 результати показують, що поверхневі властивості $\mathrm{TiO}_{2}$ на перших циклах здатні впливати на величину питомої ємності, але не впливають на динаміку іï зміни за умов циклування, яка для обох зразків є подібною. Виходячи з отриманих залежностей, питома ємність, яка реалізується в інтервалі напруги 0,2-2,4 В, суттєво змінюється від номера циклу. На першому циклі розряду вона складає 172 та 161 мАгод/г відповідно для зразків 350-26 і 470-6, але через низьку кулонівську ефективність першого циклу на другому циклі спостерігається значне іï зниження. На наступних 4-5 циклах питома ємність 
збільшується від 105 мАгод/г до 164 мАгод/г для зразка 350-26 та зі 102 до 209 мАгод/г для зразка 470-6. Збільшення питомої ємності на перших циклах в роботах $[86,96]$ пояснюється низькою адсорбцією іонів натрію, яка пов'язана як 3 особливостями поверхневих властивостей $\mathrm{TiO}_{2}$, так $\mathrm{i} \quad 3$ питомою електропровідністю електроліту. Після досягнення максимальної питомої ємності спостерігається поступове ії зниження. Аналіз отриманих результатів показав, що однією із причин такого зниження є збільшення внутрішнього опору комірок який становить $~ 500$ Ом на перших 5 циклах, але зростає до більш ніж 2000 Ом на 20 циклі.
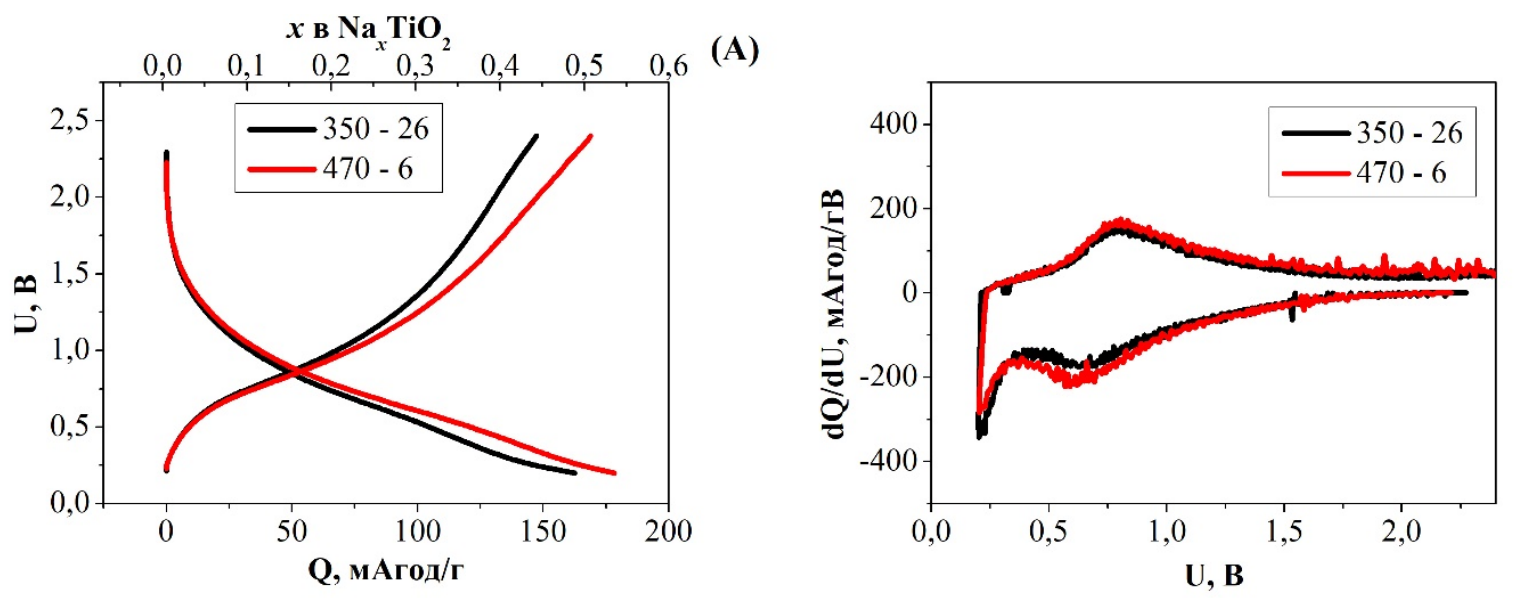

Рисунок 2. Розряд-зарядні криві (А) і криві диференційної ємності (Б) для 6-го циклу зразка 350-26 та 5-го циклу зразка 470-6 за циклування в інтервалі напруги 0,2-2,4 В густиною струму 8 мА/г. Електроліт - $1 \mathrm{M} \mathrm{NaBF}_{4} \mathrm{TG}$.
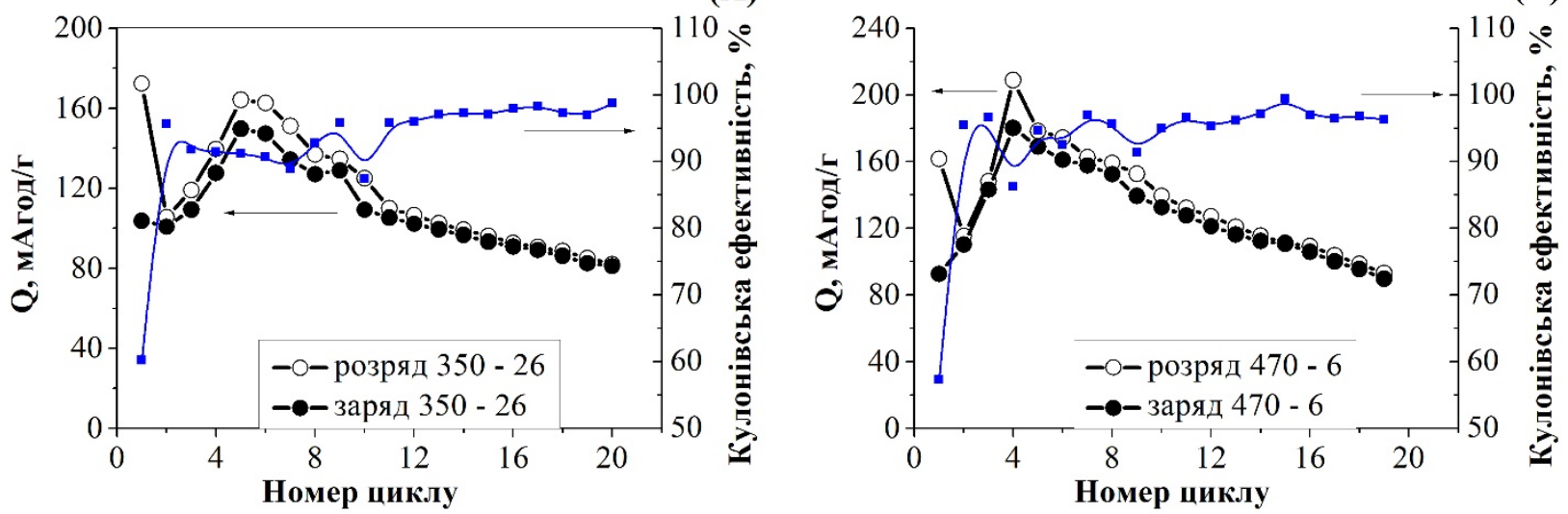

Рисунок 3. Залежність питомої ємності та кулонівської ефективності від номера циклу для зразка 350-26 (А) і 470-6 (Б) за циклування в інтервалі напруги 0,2-2,4 В густиною струму 8 мА/г. Електроліт - $1 \mathrm{M} \mathrm{NaBF}_{4} \mathrm{TG}$. 
Таким чином, у роботі були досліджені питомі характеристики зразків $\mathrm{TiO}_{2}$ в електрохімічній системі з натрієвим анодом. Показано, що питома ємність $\mathrm{TiO}_{2}$ електродів, іiі стабільність при циклуванні та кулонівська ефективність процесу розрядження-зарядження суттєво залежать від складу електроліту, що обумовлено розкладанням електроліту за низької напруги розряду. Характер отриманих гальваностатичних залежностей дозволяє припустити, що процес зарядження-розрядження відбувається без значних фазових перетворень. 


\section{SECTION 3. COMPUTER SCIENCE}

\subsection{Software approach to creating a layout with dynamic interfaces}

In the android application, user interface (UI) is everything that the user can see and interact with. Android provides many pre-built UI components, such as structured layout objects and interface controls that allow you to create a graphical user interface for the program. Android also provides other UI modules for special interfaces such as dialogs, alerts and menus $[97,100]$.

The half-dynamic layout inflation solves the problem of displaying data in most cases. However, there can be difficult situations when you need to create layout elements (widgets) during the program runtime. Any static (XML) layouts can't solve this problem.

Usually, when creating a layout for the Android application, an XML file is created. These layouts are called static because you can not add / remove any of the widgets in XML at a runtime. But this is possible in dynamic layouts, because all UI elements are created through the code without using the XML files [98].

Why do we need dynamic layouts?

Let's say we get some data from our server, and we want to create $n$ the number of fields / buttons / options in the layout. We can not do this using only XML . But we can use Java / Kotlin to replicate the layout that would normally be created gy using an XML file.

It can be used to create LinearLayout, ConstrainLayout, in which it is possible to add TextView, EditText, RadioButtons, Checkbox, or any other widget in the future [99].

What is the advantage of using dynamic layouts?

Suppose you want to display some layout elements that have been grouped together (all items have the same ViewType).

There are some ways to show them in a layout:

1. Add static widgets in XML (if we know their exact number).

2. Using RecyclerView to boot elements in the layout. 


\section{Create Dynamic Software Widgets.}

But what if the exact number of elements is unknown, and the layout requires different types of UI elements (for example, 3 TextViews, 2 CheckBoxes, etc.)?

Possible solutions to this problem are [100]:

1. Adding static XML elements to the interface will not work because their exact number is not known.

2. Using the Recycler View might work, but the same types of widgets should be grouped together in the list. In this case, there is not enough flexibility.

3. However, it is in this case dynamic layouts will fit. They are flexible and they can add several different types of screen types to our layout in any order.

User interface in android apps is usually built using XML markup language. But there are some apps that are written fully without XML by creating views dynamically, Telegram app is one of these apps.

Several tests were conducted to compare the speed of these two methods for layout creation in our application and in the telegram.

During the tests Telegram app performed approximately 6-7 times faster than our application with almost the same ui elements.

Some pre-conditions before the tests:

1. For both methods, only one MainActivity with a NoActionBar style will be created.

2. Both methods (XML and Dynamic UI) will have one Parental FrameLayout.

3. There will be 5 tests, each of which will add some TextView to the parent layout.

4. Both methods will be tested on one device: Xiaomi Mi A1 (Android 8.0)

5. MainActivity has enabled hardware acceleration.

6. In each test, the application will open 5 times to get the most accurate information about start-up time.

So that the application always starts from a cold start, we wait some time after each test(about few minutes) To record the exact time in milliseconds, we use Android Studio Activity Manager logs. 
Xiaomi Mi A1 Android 8.0.0, A.PI 26 com.kayumov.abduaziz.addviewtest (21851)

06-04 08:08:51.279 2411-246B/? I/ActtwityManage 06-04 08:11:13.508 2411-2468/? I/ActivityManager: Displayed com.kayumov,abduaziz.addviewtest/.MainActivity: +1m45s416ms 06-04 08:11:52.796 563-563/? E/H/Composer: presentAndGetReleaseFences: failed for display 0: NotValidated (7)

06-04 08:12:17.285 2411-2468/? I/ActivityManager: Displayed com.kayumov, abduaziz.addviewtest/. MainActivity: +20s76ms

06-04 08:13:16.887 2411-2468/? I/ActivityManager: Displayed com.kayumov.abduaziz.addviewtest/.MainActivity: +23s150ms

TEST №1. Application is opened 5 times in both methods. One parent FrameLayout and 100 TextViews are dynamically created and by using XML (Tabl. $1)$.

Table 1. TEST №1 for the application

\begin{tabular}{|c|c|c|}
\hline App Opening & XML (ms) & Dynamic (ms) \\
\hline 1 & 676 & 648 \\
\hline 2 & 670 & 570 \\
\hline 3 & 659 & 566 \\
\hline 4 & 660 & 568 \\
\hline 5 & 658 & 558 \\
\hline
\end{tabular}

TEST №2. One parent FrameLayout and 500 TextViews are dynamically created and by using XML (Tabl. 2).

Table 2. TEST №2 for the application

\begin{tabular}{|c|c|c|}
\hline App Opening & XML (ms) & Dynamic (ms) \\
\hline 1 & 1,307 & 1,202 \\
\hline 2 & 1,235 & 1,087 \\
\hline 3 & 1,234 & 1,102 \\
\hline 4 & 1,253 & 1,080 \\
\hline 5 & 1,249 & 1,098 \\
\hline
\end{tabular}

TEST №3. One parent FrameLayout and 2500 TextViews are dynamically created and by using XML (Tabl. 3).

Table 3. TEST №3 for the application

\begin{tabular}{|c|c|c|}
\hline App Opening & XML (ms) & Dynamic (ms) \\
\hline 1 & 2,400 & 1,832 \\
\hline 2 & 2,290 & 1,748 \\
\hline 3 & 2,284 & 1,762 \\
\hline 4 & 2,247 & 1,749 \\
\hline 5 & 2,258 & 1,748 \\
\hline
\end{tabular}


TEST №4. One parent FrameLayout and 15,000 TextViews are dynamically created and by using XML. The preview of the XML version in Android Studio is no longer working. We had to edit the layout file in a text editor (Tabl. 4).

Table 4. TEST №3 for the application

\begin{tabular}{|c|c|c|}
\hline App Opening & XML (ms) & Dynamic (ms) \\
\hline 1 & 12,325 & 5,478 \\
\hline 2 & 12,349 & 5,403 \\
\hline 3 & 13,467 & 5,389 \\
\hline 4 & 12,220 & 5,405 \\
\hline 5 & 11,993 & 5,399 \\
\hline
\end{tabular}

TEST №5. One parent FrameLayout and 60,000 TextViews are created dynamically and using XML. The program was opened 3 times for each method (Tabl. $5)$.

Table 4. TEST №3 for the application

\begin{tabular}{|c|c|c|}
\hline App Opening & XML (ms) & Dynamic (ms) \\
\hline 1 & $1 \mathrm{~m} 52 \mathrm{~s} 169 \mathrm{~ms}$ & $20 \mathrm{~s} 76 \mathrm{~ms}$ \\
\hline 2 & $1 \mathrm{~m} 45 \mathrm{~s} 416 \mathrm{~ms}$ & $23 \mathrm{~s} 150 \mathrm{~ms}$ \\
\hline 3 & $1 \mathrm{~m} 46 \mathrm{~s} 888 \mathrm{~ms}$ & $22 \mathrm{~s} 515 \mathrm{~ms}$ \\
\hline
\end{tabular}

From the above tables (Tabl. 1-5) can be seen that dynamic views creation works only in cases where there are a huge amount of ui-elements in android apps (Fig. 1):
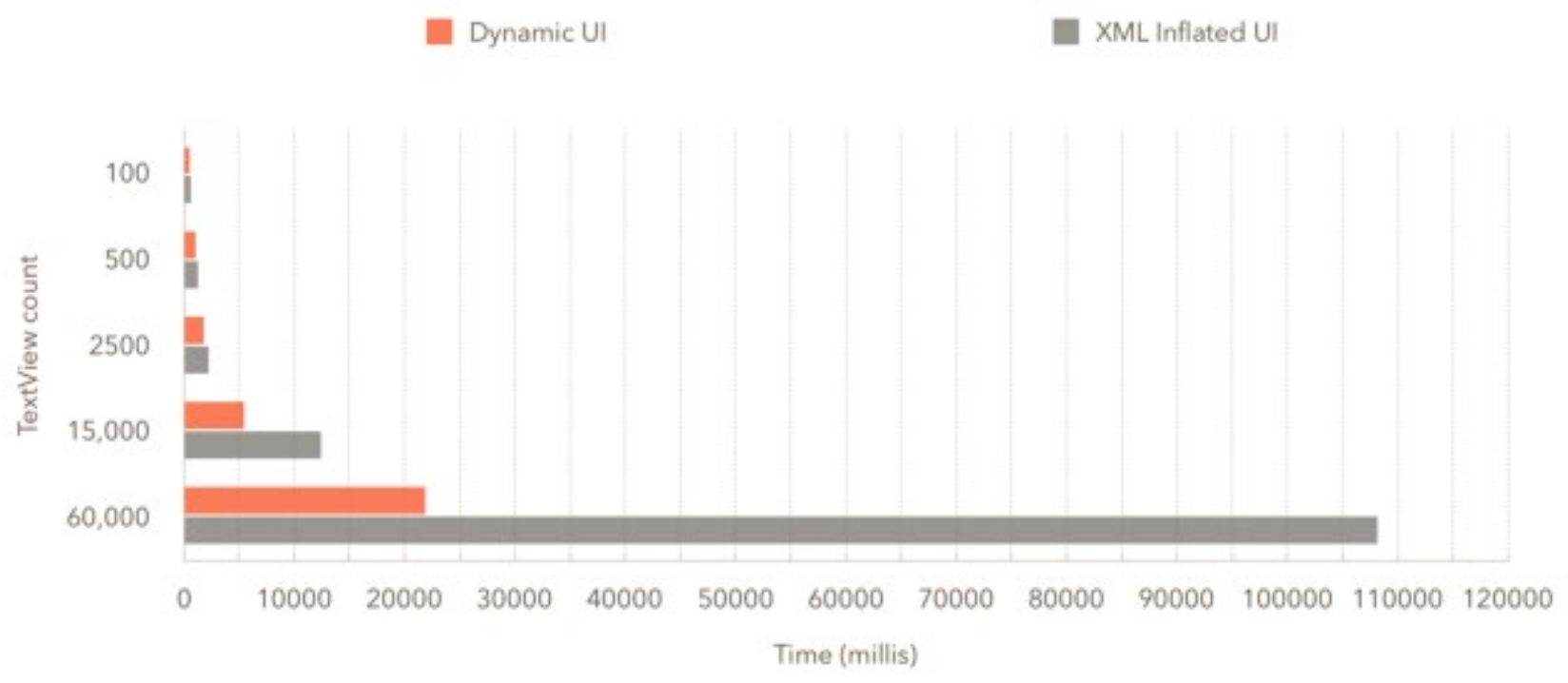

Fig. 1. Example for the Application opening 5 times in both methods 
It is clear from the chart (Fig. 1) that building UI dynamically is not working faster in general than inflating UIs from XML.

So, building UI dynamically will work faster than XML inflation only when there is a huge amount of elements in app. Usually we have about 20-30 elements for the layout, so there is almost no such cases in practice. We can conclude that XML based layouts aren't worse than dynamically created in a whole.

There is a number of key advantages in using XML resource files for UI creation against the dynamic approach.

One of them is the possibility of using a graphical layout tool that automatically generates XML resource files. Another advantage is that after the app is created the changes to the user interface can be done only by changing XML file without the need of recompiling the code.

In addition, even when writing XML-layouts by hand, you can get instant feedback about the look of the user interface of your app by simply switching between the XML editor and the Graphic Layout tool in the Eclipse environment, which is very comfortable unlike the program approach, where the developer in order to check the look of the interface needs to repeat the cycle compiling and testing app.

The most important advantage of a program approach to creating layouts is to work with dynamic user interfaces. XML resource files are useful in determining static layouts, in other words, layouts that won't change much from the one activity call to another that is. Kotlin code is ideal for creating user interfaces dynamically in program runtime. This is especially useful in situations where the user interface layouts may appear differently each time the activity is launched. Also, dynamic layout creation will work best when there is a huge number of UI elements in app, but in practice, there are almost no such cases. 


\subsection{Development of the information system «Department portal»}

Впервые разработана прикладная программная система управления контентом с расширенным инструментарием информационно-учебных Webпорталов, которая содержит программные средства контроля разработки и публикации запланированных результатов обучения, контроля оценки уровня знаний студентов, контроля над научно-методической работой преподавателей подразделения. Система позволит оптимизировать процедуру проведения обучения, расширить возможности для анализа результатов, обеспечить прозрачность и объективность в процедуре обучения и квалификационного оценивания студентов.

В работе был проанализирован опыт практических решений проектирования ИСУ университетов, которые успешно внедряют информационные системы для автоматизации процессов управления. Особое внимание было уделено анализу опыта; выполнение проектов EC TEMPUS INURE и INARM, практики внедрения информационных систем в европейских университетах [101, 104-108].

Разработка информационных систем для дистанционного обучения обеспечивает в первую очередь экономическую эффективность образования для широкой аудитории [109].

Система дистанционного обучения, которая является одним из модулей информационной системы «Портал кафедры» имеет сложную конструкцию обеспечения взаимодействия студентов и преподавателей [111]. Эта система известна как Community of Inquiry (CoI) [110].

Могут использоваться различные методы сбора информации. Важно, чтобы студенты и сотрудники участвовали в предоставлении и анализе информации, а также планировании дальнейшей деятельности [102].

Информационная система позволит оптимизировать процедуру проведения обучения, расширить возможности для анализа результатов, обеспечить прозрачность и объективность в процедуре обучения и квалификационного 
оценивания студентов, что, в итоге, будет способствовать повышению уровня доверия граждан к высшей школе, а также автоматизировать представления отчетности по методической и научной деятельности профессорскопреподавательского состава кафедры.

Элементы проектирования определяют принципиальные моменты, связанные с процессом разработки и внедрением информационной системы. Система была разделена на ряд подпроцессов.

Контроль разработки и публикации запланированных результатов обучения, а также контроль над разработкой учебного плана, составлением и содержанием образовательных программ предполагают вынесения на обсуждение преподавательским составом, проекта учебных планов. По результатам данного обсуждения возможно внесение корректив.

Контроль уровня преподавания предполагает, что руководство подразделения (кафедры) должно иметь механизмы и критерии оценки компетентности преподавателей. Мониторинг успешности и достижений студентов предполагает наличие развитой системы мониторинга и анализа.

Контроль информирования о качестве описывается как требование к регулярной публикации современной, непредвзятой и объективной, количественной и качественной информации по реализованным программам.

В АИС структура соответствует хорошо известной в менеджменте пирамиде управления по вертикальному разделению труда [103].

Объектом автоматизации является информационная система, обеспечивающая работу кафедры высшего учебного заведения.

Исходя из анализа предметной области и нормативной документации, в структуре АИС можно выделить четыре основных взаимосвязанных модуля.

1. Модуль планирования учебного процесса предназначен для автоматизации таких процессов.

2. Модуль методического обеспечения подразделения предназначен для ведения анализа деятельности подразделения, формирование автоматического отчета. 
3. Модуль научной деятельности научно-педагогического состава подразделения предназначен для автоматизации процессов формирования рейтинговых показателей и создание отчетной информации.

4. Модуль дистанционного обеспечения предназначен для работы преподавателей со студентами в дистанционном режиме.

Описанные модули связаны между собой информационными потоками. Для демонстрации распределения ролей пользователей и их возможностей на сайте были построены диаграммы в среде Rational Rose. Концептуальная модель системы выражается в виде диаграмм вариантов использования (Use-case duagram).

Информационная система «Веб-портал кафедры» реализована на языке РНР 5.x, СУБД MySQL, веб-сервер Apache, Unix - подобная операционная система. Количество пользователей изменяется в пределах от 300 до 3000 (зависит от количества дисциплин, преподаваемых на кафедре и контингента студентов). Основная нагрузка на сервер будет создавать подсистема дистанционного образования Веб-портала кафедры. Пик нагрузки на сервер будет происходить во время проведения сессий. Поэтому для определения аппаратной конфигурации были определены пиковые нагрузки на информационную систему. Также такие параметры, как количество вычислительных ядер (процессоров), объем оперативной памяти, необходимую пропускную способность сетевого канала.

Результатом исследования стала автоматизированная информационная система управления кафедрой высшего учебного заведения.

Модуль дистанционного обеспечения разработанной информационной системы предусматривает подготовку учебных курсов на основе образовательных потребностей авторизованных пользователей, организацию доступа к материалам курса, организацию общения участников учебного процесса, прохождение студентами точек контроля и завершения курса экзаменом. 
На момент выполнения отчетных мероприятий в рамках научной и методической работы связано с некоторыми организационными трудностями (опрос преподавателей и студентов, заполнение вручную названий конференций и тезисов докладов).

Предложенные нами решения позволят оптимизировать систему оповещения, упростить организацию отчетности, в социальном плане позволяет привлечь внимание к научной деятельности.

Особенностью созданной системы является возможность создания в автоматизированном режиме отчетности по научной, научно-методической и учебной работе преподавателей. Информационная система позволяет проводить анализ деятельности преподавательского состава кафедры, дает рекомендации по повышению выполнения плановых показателей научной деятельности кафедр и научных подразделений университета.

В системе предоставлена возможность автоматического сбора информации для определения h-индекса и количества цитирований научно-педагогических работников, аспирантов и докторантов по номеру ID ORCID базы Google Scholar Citations.

Большинство информационных систем работы кафедр не дают возможность создавать отчетность о деятельности подразделения.

Представленная система позволяет авторизованным пользователям вносить информацию о своей деятельности самостоятельно. В системе предусмотрена возможность проверки внесенных данных.

Подсистема «Планирование учебного процесса» управления учебным процессом в разработанной информационной системе включает в себя следующие подпроцессы:

- управление контингентом студентов;

- формирование учебных планов (curriculum) и графиков учебного процесса;

- формирование рабочих учебных программ (syllabus)

- формирование индивидуальных учебных планов студентов;

- расчет и распределение учебной нагрузки; 
- формирование расписания учебного процесса;

- ведение электронного журнала и др.

Созданная информационная система подразделения. позволяет оптимизировать процедуру проведения обучения, расширить возможности для анализа результатов, обеспечить прозрачность и объективность в процедуре обучения и квалификационного оценивания студентов, что, в итоге, способствует повышению уровня доверия граждан к высшей школы. 


\subsection{Analysis of modern distributed computer systems}

Networked information technologies are included in many areas of production. The rapid development of this area has led to a variety of construction of distributed computer systems for various purposes. Distributed systems can be classified and typified according to various criteria: by the number of elements in the system, by the level of organization, by the type of resources, etc. [112].

In modern society, there is a need to improve the quality and speed of processing, first of all, "big data" [113] and, secondly, data in distributed systems [114]. In this regard, the importance of distributed systems focused on efficient data management [115] as a means of solving this problem is growing. One of the main tasks of any distributed system is to analyze the properties of the obtained data, which, for a number of reasons, cannot be estimated at a single node. Creation of efficient and adaptive distributed systems can significantly speed up data processing speed.

Distributed systems consist of autonomous computers that work together, presenting in the form of a single connected system [116]. Their important advantage is that they simplify the integration of various applications running on different computers into a single system. Another advantage is that when properly designed, distributed systems scale well. Their size is limited only by the size of the underlying network. The price to pay for these benefits is often very complex software, performance degradation, and especially security issues. However, interest in building and implementing distributed systems is ubiquitous.

The technologies for building modern distributed systems include serviceoriented architecture, grid and cloud computing [117]. Let's highlight the main requirements for them: transparency, system openness, security, scalability, reliability, efficiency, cross-platform.

Distributed system transparency. Transparency, in the general case, lies in the fact that distributed systems should be perceived by users of the system as a homogeneous object, and not as a set of autonomous objects that interact with each other [118]. Location transparency. In distributed systems, location transparency means that the 
user does not need to know where the resources they need are located. Access transparency. In distributed systems, the principle of transparency of access plays the most important role. Transparency in this case is about ensuring that access differences are hidden and the data is provided. Access concurrency transparency. Different users of distributed systems must be able to access shared data in parallel. In this case, it is necessary to ensure the parallel sharing of system resources, and, accordingly, to ensure the concealment of the fact of resource sharing. Replication transparency. In order to ensure the safety of data, especially on distributed file systems, it is necessary to ensure data replication.

System openness. The application of the principle of openness to distributed systems became possible due to the development of data transmission lines, an increase in processor performance, as well as the general development of information technologies. The openness of distributed systems is understood as the ability to interact with other open systems. The openness of the system can be achieved using: programming languages, hardware platforms, software.

Safety. A special place in modern distributed systems is their security. The security of distributed computer systems is, in general, a combination of three factors: ensuring the confidentiality of data and resources; ensuring confidentiality of access to resources for multiple users; ensuring the integrity of resources and data.

Scalability of distributed systems is one of the top priorities in the design of distributed systems. Distributed systems made it possible to avoid the main drawback of centralized systems - the limited increase in the computing power of the system.

One of the trends in the development of distributed systems at the present time is a significant variety of used types of computing devices. At the same time, the heterogeneity of the system and the need for interaction of dissimilar components increase, in connection with which the developers of control programs face the problem of software portability between different types of computers.

Let us give a comparative analysis of the technologies for the design of modern distributed systems according to the above characteristics (Table 1). 
Table 1.1

Comparative analysis of distributed computer systems

\begin{tabular}{|c|c|c|c|}
\hline \multirow{2}{*}{ Characteristic } & \multicolumn{3}{|c|}{ Distributed computer systems } \\
\hline & SOA & Grid & Cloud \\
\hline \multicolumn{4}{|c|}{ Transparency: } \\
\hline Location & + & + & + \\
\hline Data access & + & + & + \\
\hline Parallelism & + & + & + \\
\hline Data replication & - & + & + \\
\hline \multicolumn{4}{|c|}{ Openness: } \\
\hline Interoperability & - & - & + \\
\hline Permanent nodes & + & + & + \\
\hline Adaptability & - & + & - \\
\hline Availability & + & + & + \\
\hline Standardization & + & $+/-$ & - \\
\hline Communication between nodes & + & + & + \\
\hline \multicolumn{4}{|c|}{ Safety: } \\
\hline Confidentiality & $+/-$ & $+/-$ & $+/-$ \\
\hline Access security & - & + & + \\
\hline Resource itegrity & - & + & - \\
\hline Scalability & + & + & + \\
\hline Cross-platform & - & + & - \\
\hline Heterogeneity & + & + & + \\
\hline Flexibility & - & + & - \\
\hline Data semantics & - & + & - \\
\hline
\end{tabular}

Common problems of the considered systems are:

- insufficient elaboration and lack of formal descriptive means for checking the semantics of interaction between business processes and verification of transmitted data;

- currently insufficiently developed general model of safety in heterogeneous systems;

- insufficient means to describe complex distributed services (first of all, when implementing cross-platform composite services);

- insufficient elaboration of means for inclusion in the system of legacy systems and batch applications (implemented by the so-called adapters of XML applications); 
- high load on the network data transmission medium (both hardware and software) during the interaction of the components (the exchange is carried out in the "unpacked" XML format).

These problems are quite common in developing technologies, and they are and will be solved by well-known common means: increased standardization, unification, the development of new descriptive means, the use of data transportation means of increased productivity, etc.)

To this general list are added quite new problems associated with the rapid pace of Internet adoption and the growth of accumulated information about objects:

- insufficient reliability of message delivery in complex heterogeneous networks and the consequent need to implement asynchronous interactions between components and event-driven interactions;

- the general problem of incompleteness of information about the object as a whole;

- system administration problems;

- problems of limited PC scalability;

- software portability problems.

It should be understood that this list is generalized, i.e. for each specific distributed system, problems may arise that are not described in this work. But these problems are the most common in practice and deserve special attention when designing a distributed system. The last two problems are well studied, and in the software market for distributed systems there are many developed software tools that provide both statistics collection and software updates. Methods of presenting information for its automatic processing, increasing the efficiency of systems by increasing the significance of data, i.e. their semantics and search for the necessary resources. Due to the specifics of a distributed system, as well as the heterogeneity of the equipment and architecture of the distributed system, there is no single design method that would provide a solution to these problems. 


\subsection{Building a system of diagnosis technical condition of buildings on the example of floor beams using methods of fuzzy sets}

The urgency of the work lies in the effectiveness of the proposed models and methods of diagnosis and prediction of technical condition of buildings sold analytical apparatus of fuzzy sets, which makes it possible to create an information platform to collect real, accurate and minimally unprofitable media as a powerful tool for accurate and reliable diagnosis of temporal phases of buildings within the life cycle $[119,120]$.

The main purpose of development is to build a system of diagnosis technical condition of buildings on the example of floor beams using the methods of the theory of not clear sets.

Formulated states $S_{1}, S_{2}, S_{3}, S_{4}, S_{5}$ types of diagnoses are considered to be recognized. In the diagnosis parameters are set - nine diagnostic features of their discharges, in the form of ranges change [121]:

$k_{1}$ - damaged concrete, reducing its protective properties against fittings ( 1 or $0)$;

$k_{2}-$ longitudinal cracks in the protective layer of concrete reinforcing rods along, corrosion products along the reinforcing rods ( 1 or 0$)$;

$k_{3}$ - the presence and width of opening of normal cracks $(0-1 \mathrm{~mm})$;

$k_{4}$ - availability inclined cracks ( 1 or 0$)$;

$k_{5}$ - strength concrete $(0-31 \%)$;

$k_{6}-$ reinforcement corrosion $(0-21 \%)$;

$k_{7}-$ deflection $(0-31 \%)$;

$k_{8}$ - strength test conditions for normal sections ( 1 or 0$)$;

$k_{9}$ - strength test conditional on inclined sections ( 1 or 0 ).

The task of diagnosis is to put each combination of parameter values in line one solution: $S_{i}(i=\overline{1,5})$.

Parameters $k_{1}-k_{9}$ regarded as linguistic variables. For further analysis should be divided into groups that are linguistic variables: 
$k_{1}, k_{2}, k_{4}$ - group of options identified during the examination visually;

$k_{3}, k_{5}, k_{6}, k_{7}-$ a group of parameters are determined by the results of instrumental measurements;

$k_{8}, k_{9}$ - group parameters determined by the results of test calculations.

Also introduced linguistic variable $\mathrm{S}$, which is measured by a range of conditions, diagnoses $S_{1}-S_{5}$. Structure model of diagnostics of considered beams shown in a tree inference that meets the following equation:

$$
\begin{aligned}
& s=f_{s}(x, y, z) ; \quad x=f_{x}\left(k_{1}, k_{2}, k_{4}\right) ; \\
& y=f_{y}\left(k_{3}, k_{5}, k_{6}, k_{7}\right) ; \quad z=f_{z}\left(k_{8}, k_{9}\right) .
\end{aligned}
$$

For evaluation of linguistic variables $k_{1}-k_{9}$, and $x, y$ and $z$ there are introduced a single scale qualitative terms:

$L-$ low;

$B A$ - below average;

$A$ - average;

$A A$ - above average;

$H$ - high.

Each of these terms is fuzzy sets, given by protecting supplies. Using qualitative terms imposed intervals and analyzing the changes in the numerical values of probability of realization signs $p=\left(k_{i j} / S_{i}\right)$ in diagnostic matrix (Table 1,2), equation (1) are given in tables 3-6 [122]. 
Table 1.

Diagnostic matrix for beams overlap in general

\begin{tabular}{|c|c|c|c|c|c|c|c|c|c|}
\hline № & $\begin{array}{l}\text { Diagnostic } \\
\text { signs }\end{array}$ & $k_{j s}$ & $\begin{array}{l}\text { Attribute } \\
\text { discharge } \\
\mathrm{s}\end{array}$ & $p\left(k_{i j}\right)$ & $\begin{array}{c}\text { Comp. } \\
\boldsymbol{S}_{\mathbf{1}} \\
P\left(S_{1}\right)\end{array}$ & $\begin{array}{c}\text { Comp. } \\
\boldsymbol{S}_{\mathbf{2}}\end{array}$ & $\begin{array}{c}\text { Comp. } \\
\boldsymbol{S}_{\mathbf{3}} \\
P\left(\boldsymbol{S}_{2}\right)\end{array}$ & $\begin{array}{c}\text { Comp. } \\
\boldsymbol{S}_{\mathbf{4}} \\
P\left(S_{4}\right)\end{array}$ & $\begin{array}{c}\text { Comp. } \\
\boldsymbol{S}_{\mathbf{5}} \\
P\left(\boldsymbol{S}_{5}\right)\end{array}$ \\
\hline \multirow[b]{3}{*}{1} & \multirow{3}{*}{$\begin{array}{l}\text { Damage to } \\
\text { concrete, } \\
\text { reducing its } \\
\text { properties in } \\
\text { relation to } \\
\text { reinforcement }\end{array}$} & $l_{2}$ & wec & $a_{1}$ & 4.) & ) & $\left(I_{1} / C_{1}\right.$ & t & $g_{1} / C_{\lambda}$ \\
\hline & & & yes & & & & & & 5) \\
\hline & & $k_{12}$ & no & $p\left(k_{12}\right)$ & $p\left(k_{12} / S_{1}\right)$ & $p\left(k_{12} / S_{2}\right)$ & $p\left(k_{12} / S_{3}\right)$ & $p\left(k_{12} / S_{4}\right)$ & $p\left(k_{12} / S_{5}\right)$ \\
\hline \multirow[b]{2}{*}{2} & \multirow{2}{*}{$\begin{array}{l}\text { Longitudinal } \\
\text { cover cracks } \\
\text { along the } \\
\text { reinforcing } \\
\text { bars }\end{array}$} & $k_{21}$ & yes & $p\left(k_{21}\right)$ & $p\left(k_{21} / S_{1}\right)$ & $p\left(k_{21} / S_{2}\right)$ & $p\left(k_{21} / S_{3}\right)$ & $p\left(k_{21} / S_{4}\right)$ & $p\left(k_{21} / S_{5}\right)$ \\
\hline & & $k_{22}$ & no & $p\left(k_{22}\right)$ & $p\left(k_{22} / S_{1}\right)$ & $p\left(k_{22} / S_{2}\right)$ & $p\left(k_{22} / S_{3}\right)$ & $p\left(k_{22} / S_{4}\right)$ & $p\left(k_{22} / S_{5}\right)$ \\
\hline \multirow{3}{*}{3} & \multirow{3}{*}{$\begin{array}{l}\text { Normal cracks } \\
\text { (opening } \\
\text { width) }\end{array}$} & $k_{31}$ & $<0,4 \mathrm{~mm}$ & $p\left(k_{31}\right)$ & $p\left(k_{31} / S_{1}\right)$ & $p\left(k_{31} / S_{2}\right)$ & $p\left(k_{31} / S_{3}\right)$ & $p\left(k_{31} / S_{4}\right)$ & $p\left(k_{31} / S_{5}\right)$ \\
\hline & & $k_{32}$ & to $1,0 \mathrm{~mm}$ & $p\left(k_{32}\right)$ & $p\left(k_{32} / S_{1}\right)$ & $p\left(k_{32} / S_{2}\right)$ & $p\left(k_{32} / S_{3}\right)$ & $p\left(k_{32} / S_{4}\right)$ & $p\left(k_{32} / S_{5}\right)$ \\
\hline & & $k_{33}$ & $\geq 1,0 \mathrm{~mm}$ & $p\left(k_{33}\right)$ & $p\left(k_{33} / S_{1}\right)$ & $p\left(k_{33} / S_{2}\right)$ & $p\left(k_{33} / S_{3}\right)$ & $p\left(k_{33} / S_{4}\right)$ & $p\left(k_{33} / S_{5}\right)$ \\
\hline \multirow{2}{*}{4} & \multirow{2}{*}{$\begin{array}{l}\text { Oblique } \\
\text { cracks } \\
\text { (presence) }\end{array}$} & $k_{41}$ & yes & $p\left(k_{41}\right)$ & $p\left(k_{41} / S_{1}\right)$ & $p\left(k_{41} / S_{2}\right)$ & $p\left(k_{41} / S_{3}\right)$ & $p\left(k_{41} / S_{4}\right)$ & $p\left(k_{41} / S_{5}\right)$ \\
\hline & & $k_{42}$ & no & $p\left(k_{42}\right)$ & $p\left(k_{42} / S_{1}\right)$ & $p\left(k_{42} / S_{2}\right)$ & $p\left(k_{42} / S_{3}\right)$ & $p\left(k_{42} / S_{4}\right)$ & $p\left(k_{42} / S_{5}\right)$ \\
\hline \multirow{3}{*}{5} & \multirow{3}{*}{$\begin{array}{l}\text { Concrete } \\
\text { strength }\end{array}$} & $k_{51}$ & designed & $p\left(k_{51}\right)$ & $p\left(k_{51} / S_{1}\right)$ & $p\left(k_{51} / S_{2}\right)$ & $p\left(k_{51} / S_{3}\right)$ & $p\left(k_{51} / S_{4}\right)$ & $p\left(k_{51} / S_{5}\right)$ \\
\hline & & $k_{52}$ & $\leq 30 \%$ & $p\left(k_{52}\right)$ & $p\left(k_{52} / S_{1}\right)$ & $p\left(k_{52} / S_{2}\right)$ & $p\left(k_{52} / S_{3}\right)$ & $p\left(k_{52} / S_{4}\right)$ & $p\left(k_{52} / S_{5}\right)$ \\
\hline & & $k_{53}$ & $>30 \%$ & $p\left(k_{53}\right)$ & $p\left(k_{53} / S_{1}\right)$ & $p\left(k_{53} / S_{2}\right)$ & $p\left(k_{53} / S_{3}\right)$ & $p\left(k_{53} / S_{4}\right)$ & $p\left(k_{53} / S_{5}\right)$ \\
\hline \multirow{3}{*}{6} & \multirow{3}{*}{$\begin{array}{l}\text { Reinforcemen } \\
t \text { corrosion }\end{array}$} & $k_{61}$ & $<5 \%$ & $p\left(k_{61}\right)$ & $p\left(k_{61} / S_{1}\right)$ & $p\left(k_{61} / S_{2}\right)$ & $p\left(k_{61} / S_{3}\right)$ & $p\left(k_{61} / S_{4}\right)$ & $p\left(k_{61} / S_{5}\right)$ \\
\hline & & $k_{62}$ & $5-20$ & $p\left(k_{62}\right)$ & $p\left(k_{62} / S_{1}\right)$ & $p\left(k_{62} / S_{2}\right)$ & $p\left(k_{62} / S_{3}\right)$ & $p\left(k_{62} / S_{4}\right)$ & $p\left(k_{62} / S_{5}\right)$ \\
\hline & & $k_{63}$ & $>20 \%$ & $p\left(k_{63}\right)$ & $p\left(k_{63} / S_{1}\right)$ & $p\left(k_{63} / S_{2}\right)$ & $p\left(k_{63} / S_{3}\right)$ & $p\left(k_{63} / S_{4}\right)$ & $p\left(k_{63} / S_{5}\right)$ \\
\hline \multirow{3}{*}{7} & \multirow[t]{3}{*}{ Deflection } & $k_{71}$ & $\begin{array}{l}\text { admissibl } \\
\mathrm{e}\end{array}$ & $p(k 71)$ & $p\left(k_{71} / S_{1}\right)$ & $p\left(k 71 / S_{2}\right)$ & $p\left(k 71 / S_{3}\right)$ & $p\left(k_{71} / S_{4}\right)$ & $p\left(k_{\left.71 / S_{5}\right)}\right.$ \\
\hline & & $k_{72}$ & $\leq 30 \%$ & $p\left(k_{72}\right)$ & $p\left(k_{72} / S_{1}\right)$ & $p\left(k_{72} / S_{2}\right)$ & $p\left(k_{72} / S_{3}\right)$ & $p\left(k_{72} / S_{4}\right)$ & $p\left(k_{72} / S_{5}\right)$ \\
\hline & & $k_{73}$ & $>30 \%$ & $p\left(k_{73}\right)$ & $p\left(k_{73} / S_{1}\right)$ & $p\left(k_{73} / S_{2}\right)$ & $p\left(k_{73} / S_{3}\right)$ & $p\left(k_{73} / S_{4}\right)$ & $p\left(k_{73} / S_{5}\right)$ \\
\hline \multirow[b]{2}{*}{8} & \multirow{2}{*}{$\begin{array}{l}\text { Strength } \\
\text { conditions for } \\
\text { normal } \\
\text { sections } \\
\end{array}$} & $k_{81}$ & yes & $p\left(k_{81}\right)$ & $p\left(k_{81} / S_{1}\right)$ & $p\left(k_{81} / S_{2}\right)$ & $p\left(k_{81} / S_{3}\right)$ & $p\left(k_{81} / S_{4}\right)$ & $p\left(k_{81} / S_{5}\right)$ \\
\hline & & $k_{82}$ & no & $p\left(k_{82}\right)$ & $p\left(k_{82} / S_{1}\right)$ & $p\left(k_{82} / S_{2}\right)$ & $p\left(k_{82} / S_{3}\right)$ & $p\left(k_{82} / S_{4}\right)$ & $p\left(k_{82} / S_{5}\right)$ \\
\hline \multirow[b]{2}{*}{9} & \multirow{2}{*}{$\begin{array}{l}\text { Strength } \\
\text { conditions for } \\
\text { inclined } \\
\text { sections }\end{array}$} & $k_{91}$ & yes & $p\left(k_{91}\right)$ & $p\left(k_{91} / S_{1}\right)$ & $p\left(k_{91} / S_{2}\right)$ & $p\left(k_{91} / S_{3}\right)$ & $p\left(k_{91} / S_{4}\right)$ & $p\left(k_{91} / S_{5}\right)$ \\
\hline & & $k_{92}$ & no & $p\left(k_{92}\right)$ & $p\left(k_{92} / S_{1}\right)$ & $p\left(k_{92} / S_{2}\right)$ & $p\left(k_{92} / S_{3}\right)$ & $p\left(k_{92} / S_{4}\right)$ & $p\left(k_{92} / S_{5}\right)$ \\
\hline
\end{tabular}


Table 2.

Diagnostic matrix for beams overlap with numerical values and probabilities of the

signs

\begin{tabular}{|c|c|c|c|c|c|c|c|c|c|}
\hline \multirow[t]{3}{*}{ № } & \multirow[t]{3}{*}{ Diagnostic signs } & \multirow[t]{3}{*}{$k_{j s}$} & \multirow[t]{3}{*}{$\begin{array}{l}\text { Attribute } \\
\text { discharges }\end{array}$} & \multirow[t]{3}{*}{$p\left(k_{i j}\right)$} & $\begin{array}{l}\text { Comp. } \\
S_{1}\end{array}$ & $\begin{array}{l}\text { Comp. } \\
\boldsymbol{S}_{\mathbf{2}}\end{array}$ & $\begin{array}{l}\text { Comp. } \\
\boldsymbol{S}_{\mathbf{3}}\end{array}$ & $\begin{array}{l}\text { Comp. } \\
\boldsymbol{S}_{\mathbf{4}}\end{array}$ & $\begin{array}{l}\text { Comp. } \\
\boldsymbol{S}_{\mathbf{5}}\end{array}$ \\
\hline & & & & & $P\left(S_{1}\right)$ & $P\left(S_{2}\right)$ & $P\left(S_{3}\right)$ & $P\left(S_{4}\right)$ & $P\left(S_{5}\right)$ \\
\hline & & & & & 0,18 & 0,29 & $\mathbf{0 , 3 5}$ & 0,13 & 0,05 \\
\hline \multirow[b]{2}{*}{1} & \multirow{2}{*}{$\begin{array}{l}\text { Damage to } \\
\text { concrete, reducing } \\
\text { its properties in } \\
\text { relation to } \\
\text { reinforcement } \\
\end{array}$} & $k_{11}$ & yes & $p\left(k_{11}\right)$ & 0,14 & 0,29 & 0,4 & 0,56 & 0,76 \\
\hline & & $k_{12}$ & no & $p\left(k_{12}\right)$ & 0,86 & 0,71 & 0,6 & 0,44 & 0,24 \\
\hline \multirow{2}{*}{2} & \multirow{2}{*}{$\begin{array}{l}\text { Longitudinal cover } \\
\text { cracks along the } \\
\text { reinforcing bars }\end{array}$} & $k_{21}$ & yes & $p\left(k_{21}\right)$ & 0,05 & 0,27 & 0,38 & 0,59 & 0,88 \\
\hline & & $k_{22}$ & no & $p\left(k_{22}\right)$ & 0,95 & 0,73 & 0,62 & 0,41 & 0,12 \\
\hline \multirow{3}{*}{3} & \multirow{3}{*}{$\begin{array}{l}\text { Normal cracks } \\
\text { (opening width) }\end{array}$} & $k_{31}$ & $<0,4 \mathrm{~mm}$ & $p\left(k_{31}\right)$ & 0.92 & 0,78 & 0,67 & 0,54 & 0,22 \\
\hline & & $k_{32}$ & to $1,0 \mathrm{~mm}$ & $p\left(k_{32}\right)$ & 0,07 & 0,21 & 0,28 & 0,34 & 0,48 \\
\hline & & $k_{33}$ & $\geq 1,0 \mathrm{~mm}$ & $p\left(k_{33}\right)$ & 0,01 & 0,01 & 0,05 & 0,12 & 0,3 \\
\hline \multirow{2}{*}{4} & \multirow{2}{*}{$\begin{array}{l}\text { Oblique cracks } \\
\text { (presence) }\end{array}$} & $k_{41}$ & yes & $p\left(k_{41}\right)$ & 0,03 & 0,05 & 0,28 & 0,3 & 0,35 \\
\hline & & $k_{42}$ & no & $p\left(k_{42}\right)$ & 0,97 & 0,95 & 0,72 & 0,7 & 0,65 \\
\hline \multirow{3}{*}{5} & \multirow[t]{3}{*}{ Concrete strength } & $k_{51}$ & designed & $p\left(k_{51}\right)$ & 0,79 & 0,49 & 0,33 & 0,28 & 0,2 \\
\hline & & $k_{52}$ & $\leq 30 \%$ & $p\left(k_{52}\right)$ & 0,17 & 0,33 & 0,36 & 0,39 & 0,42 \\
\hline & & $k_{53}$ & $>30 \%$ & $p\left(k_{53}\right)$ & 0,04 & 0,18 & 0,31 & 0,33 & 0,38 \\
\hline \multirow{3}{*}{6} & \multirow{3}{*}{$\begin{array}{l}\text { Reinforcement } \\
\text { corrosion }\end{array}$} & $k_{61}$ & $<5 \%$ & $p\left(k_{61}\right)$ & 0,73 & 0,52 & 0,33 & 0,26 & 0,13 \\
\hline & & $k_{62}$ & $5-20$ & $p\left(k_{62}\right)$ & 0,23 & 0,28 & 0,34 & 0,39 & 0,4 \\
\hline & & $k_{63}$ & $>20 \%$ & $p\left(k_{63}\right)$ & 0,04 & 0,2 & 0,33 & 0,35 & 0,47 \\
\hline \multirow{3}{*}{7} & \multirow[t]{3}{*}{ Deflection } & $k_{71}$ & admissible & $p\left(k_{71}\right)$ & 0,93 & 0,82 & 0,59 & 0,35 & 0,11 \\
\hline & & $k_{72}$ & $\leq 30 \%$ & $p(k 72)$ & 0,05 & 0,11 & 0,28 & 0,39 & 0,43 \\
\hline & & $k_{73}$ & $>30 \%$ & $p\left(k_{73}\right)$ & 0,02 & 0,07 & 0,13 & 0,26 & 0,46 \\
\hline \multirow{2}{*}{8} & \multirow{2}{*}{\begin{tabular}{|l} 
Strength \\
conditions for \\
normal sections
\end{tabular}} & $k_{81}$ & yes & $p\left(k_{81}\right)$ & 0,93 & 0,75 & 0,53 & 0,29 & 0,09 \\
\hline & & $k_{82}$ & no & $p\left(k_{82}\right)$ & 0,07 & 0,25 & 0,47 & 0,71 & 0,91 \\
\hline \multirow[b]{2}{*}{9} & \multirow{2}{*}{$\begin{array}{l}\text { Strength } \\
\text { conditions for } \\
\text { inclined sections }\end{array}$} & $k_{91}$ & yes & $p\left(k_{91}\right)$ & 0,94 & 0,83 & 0,75 & 0,55 & 0,33 \\
\hline & & $k_{92}$ & no & $p\left(k_{92}\right)$ & 0,06 & 0,17 & 0,25 & 0,45 & 0,67 \\
\hline
\end{tabular}

Table 3 .

Knowledge of the interrelation $\boldsymbol{S}$

\begin{tabular}{|c|c|c|c|c|c|c|c|c|c|c|c|c|c|c|c|}
\hline$S$ & \multicolumn{3}{|c|}{$S_{1}$} & \multicolumn{3}{c|}{$S_{2}$} & \multicolumn{3}{c|}{$S_{3}$} & \multicolumn{3}{c|}{$S_{4}$} & \multicolumn{3}{c|}{$S_{5}$} \\
\hline$X$ & $L$ & $H$ & $H$ & $B A$ & $A$ & $A A$ & $B A$ & $B A$ & $A$ & $B A$ & $A$ & $A$ & $B A$ & $B A$ & $A A$ \\
\hline$Y$ & $L$ & $L$ & $H$ & $L$ & $B A$ & $A$ & $L$ & $B A$ & $B A$ & $B A$ & $B A$ & $A$ & $L$ & $B A$ & $A$ \\
\hline$Z$ & $L$ & $A$ & $H$ & $B A$ & $A$ & $A A$ & $A$ & $A$ & $A A$ & $B A$ & $A$ & $A A$ & $B A$ & $A$ & $H$ \\
\hline
\end{tabular}


Table 4.

Knowledge of the interrelation $\boldsymbol{X}$

\begin{tabular}{|c|c|c|c|c|c|c|c|c|c|c|c|c|c|c|c|}
\hline$X$ & \multicolumn{3}{|c|}{$L$} & \multicolumn{3}{c|}{$B A$} & \multicolumn{3}{c|}{$A$} & \multicolumn{3}{c|}{$A A$} & \multicolumn{3}{c|}{$H$} \\
\hline$k_{1}$ & $B A$ & $A$ & $A A$ & $A$ & $B A$ & $A$ & $L$ & $A A$ & $A A$ & $B A$ & $A$ & $A A$ & $B A$ & $B A$ & $A$ \\
\hline$k_{2}$ & $L$ & $B A$ & $A A$ & $B A$ & $A$ & $A$ & $L$ & $H$ & $H$ & $B A$ & $A$ & $A A$ & $B A$ & $B A$ & $A$ \\
\hline$k_{4}$ & $B A$ & $B A$ & $A$ & $B A$ & $A$ & $A$ & $L$ & $H$ & $H$ & $L$ & $B A$ & $A A$ & $B A$ & $A$ & $A A$ \\
\hline
\end{tabular}

Table 5 .

Knowledge of the interrelation $\boldsymbol{Y}$

\begin{tabular}{|c|c|c|c|c|c|c|c|c|c|c|c|c|c|c|c|}
\hline$Y$ & \multicolumn{3}{|c|}{$L$} & \multicolumn{3}{c|}{$B A$} & \multicolumn{3}{c|}{$A$} & \multicolumn{3}{c|}{$A A$} & \multicolumn{3}{c|}{$H$} \\
\hline$k_{3}$ & $B A$ & $B A$ & $A$ & $L$ & $B A$ & $A$ & $L$ & $L$ & $H$ & $L$ & $B A$ & $A A$ & $L$ & $B A$ & $A$ \\
\hline$k_{5}$ & $L$ & $B A$ & $B A$ & $B A$ & $B A$ & $B A$ & $L$ & $L$ & $A A$ & $L$ & $B A$ & $A$ & $B A$ & $B A$ & $B A$ \\
\hline$k_{6}$ & $L$ & $B A$ & $A$ & $B A$ & $B A$ & $B A$ & $L$ & $B A$ & $A A$ & $B A$ & $B A$ & $A$ & $B A$ & $B A$ & $B A$ \\
\hline$k_{7}$ & $L$ & $B A$ & $B A$ & $L$ & $B A$ & $B A$ & $L$ & $L$ & $H$ & $L$ & $L$ & $A A$ & $L$ & $B A$ & $A$ \\
\hline
\end{tabular}

Table 6.

Knowledge of the interrelation $\boldsymbol{Z}$

\begin{tabular}{|c|c|c|c|c|c|c|c|c|c|c|c|c|c|c|c|}
\hline $\boldsymbol{Z}$ & \multicolumn{3}{|c|}{$\boldsymbol{L}$} & \multicolumn{3}{c|}{$\boldsymbol{B A}$} & \multicolumn{3}{c|}{$\boldsymbol{A}$} & \multicolumn{3}{c|}{$\boldsymbol{A A}$} & \multicolumn{3}{c|}{$H$} \\
\hline$k_{8}$ & $L$ & $A$ & $H$ & $B A$ & $A$ & $A A$ & $L$ & $A$ & $H$ & $B A$ & $A$ & $A A$ & $A$ & $A$ & $A$ \\
\hline$k 9$ & $B A$ & $A$ & $A A$ & $A$ & $A$ & $A$ & $L$ & $A$ & $H$ & $L$ & $B A$ & $A A$ & $B A$ & $A$ & $A A$ \\
\hline
\end{tabular}

Using Table 3-6 and logical operations $•(A N D-\min )$ and V (OR - max), we can write the system of fuzzy logic equations linking the membership function diagnoses and linguistic input variables [123]:

$$
\begin{aligned}
& \left.\mu^{S_{1}}(s)=\left[\mu^{L}(x) \cdot \mu^{L}(y) \cdot \mu^{L}(z)\right] \vee\left\lfloor\mu^{H}(x) \cdot \mu^{L}(y) \cdot \mu^{A}(z)\right] \vee \mid \mu^{H}(x) \cdot \mu^{A A}(y) \cdot \mu^{H}(z)\right] ; \\
& \mu^{S_{2}}(s)=\left[\mu^{B A}(x) \cdot \mu^{L}(y) \cdot \mu^{B A}(z)\right] \vee\left[\mu^{A}(x) \cdot \mu^{B A}(y) \cdot \mu^{A}(z)\right] \vee\left[\mu^{A A}(x) \cdot \mu^{A}(y) \cdot \mu^{A A}(z)\right] ; \\
& \mu^{S_{3}}(s)=\left[\mu^{B A}(x) \cdot \mu^{B A}(y) \cdot \mu^{A}(z)\right] \vee\left[\mu^{B A}(x) \cdot \mu^{B A}(y) \cdot \mu^{A}(z)\right] \vee\left[\mu^{A}(x) \cdot \mu^{A}(y) \cdot \mu^{A A}(z)\right] ; \\
& \mu^{S_{4}}(s)=\left[\mu^{B A}(x) \cdot \mu^{B A}(y) \cdot \mu^{B A}(z)\right] \vee\left[\mu^{A}(x) \cdot \mu^{B A}(y) \cdot \mu^{A}(z)\right] \vee\left[\mu^{A}(x) \cdot \mu^{B A}(y) \cdot \mu^{A A}(z)\right] ; \\
& \mu^{S_{5}}(s)=\left[\mu^{B A}(x) \cdot \mu^{L}(y) \cdot \mu^{B A}(z)\right] \vee\left[\mu^{B A}(x) \cdot \mu^{B A}(y) \cdot \mu^{A}(z)\right] \vee\left[\mu^{A A}(x) \cdot \mu^{B A}(y) \cdot \mu^{H}(z)\right] ;
\end{aligned}
$$




$$
\begin{aligned}
& \mu^{L}(x)=\left\lfloor\mu^{B A}\left(k_{1}\right) \cdot \mu^{L}\left(k_{2}\right) \cdot \mu^{B A}\left(k_{4}\right)\right\rfloor \vee\left\lfloor\mu^{A}\left(k_{1}\right) \cdot \mu^{B A}\left(k_{2}\right) \cdot \mu^{A}\left(k_{4}\right)\right\rfloor \vee \\
& \vee\left[\mu^{A A}\left(k_{1}\right) \cdot \mu^{A A}\left(k_{2}\right) \cdot \mu^{A}\left(k_{4}\right)\right] \text {; } \\
& \mu^{B A}(x)=\left[\mu^{B A}\left(k_{1}\right) \cdot \mu^{B A}\left(k_{2}\right) \cdot \mu^{B A}\left(k_{4}\right)\right] \vee\left[\mu^{B A}\left(k_{1}\right) \cdot \mu^{A}\left(k_{2}\right) \cdot \mu^{A}\left(k_{4}\right)\right] \vee \\
& \vee\left[\mu^{A}\left(k_{1}\right) \cdot \mu^{A}\left(k_{2}\right) \cdot \mu^{A}\left(k_{4}\right)\right] \text {; } \\
& \mu^{A}(x)=\left[\mu^{L}\left(k_{1}\right) \cdot \mu^{L}\left(k_{2}\right) \cdot \mu^{L}\left(k_{4}\right)\right] \vee\left[\mu^{A A}\left(k_{1}\right) \cdot \mu^{H}\left(k_{2}\right) \cdot \mu^{H}\left(k_{4}\right)\right] \vee \\
& \vee\left[\mu^{A A}\left(k_{1}\right) \cdot \mu^{H}\left(k_{2}\right) \cdot \mu^{H}\left(k_{4}\right)\right] \text {; } \\
& \mu^{A A}(x)=\left[\mu^{B A}\left(k_{1}\right) \cdot \mu^{B A}\left(k_{2}\right) \cdot \mu^{L}\left(k_{4}\right)\right] \vee\left[\mu^{A}\left(k_{1}\right) \cdot \mu^{A}\left(k_{2}\right) \cdot \mu^{B A}\left(k_{4}\right)\right] \vee \\
& \vee\left[\mu^{A A}\left(k_{1}\right) \cdot \mu^{A A}\left(k_{2}\right) \cdot \mu^{A A}\left(k_{4}\right)\right] \text {; } \\
& \mu^{H}(x)=\left[\mu^{B A}\left(k_{1}\right) \cdot \mu^{B A}\left(k_{2}\right) \cdot \mu^{B A}\left(k_{4}\right)\right] \vee\left[\mu^{B A}\left(k_{1}\right) \cdot \mu^{B A}\left(k_{2}\right) \cdot \mu^{A}\left(k_{4}\right)\right] \vee \\
& \vee\left[\mu^{A}\left(k_{1}\right) \cdot \mu^{A}\left(k_{2}\right) \cdot \mu^{A A}\left(k_{4}\right)\right] \\
& \mu^{L}(y)=\left\lfloor\mu^{B A}\left(k_{3}\right) \cdot \mu^{L}\left(k_{5}\right) \cdot \mu^{L}\left(k_{6}\right) \cdot \mu^{L}\left(k_{7}\right)\right\rfloor \vee\left\lfloor\mu^{B A}\left(k_{3}\right) \cdot \mu^{B A}\left(k_{5}\right) \cdot \mu^{B A}\left(k_{6}\right) \cdot \mu^{B A}\left(k_{7}\right)\right\rfloor \vee \\
& \vee\left[\mu^{A}\left(k_{3}\right) \cdot \mu^{B A}\left(k_{5}\right) \cdot \mu^{A}\left(k_{6}\right) \cdot \mu^{B A}\left(k_{7}\right)\right] \\
& \mu^{B A}(y)=\left[\mu^{L}\left(k_{3}\right) \cdot \mu^{B A}\left(k_{5}\right) \cdot \mu^{B A}\left(k_{6}\right) \cdot \mu^{L}\left(k_{7}\right)\right] \vee\left[\mu^{B A}\left(k_{3}\right) \cdot \mu^{B A}\left(k_{5}\right) \cdot \mu^{B A}\left(k_{6}\right) \cdot \mu^{B A}\left(k_{7}\right)\right] \vee \\
& \vee\left[\mu^{A}\left(k_{3}\right) \cdot \mu^{B A}\left(k_{5}\right) \cdot \mu^{B A}\left(k_{6}\right) \cdot \mu^{B A}\left(k_{7}\right)\right] \\
& \mu^{A}(y)=\left[\mu^{L}\left(k_{3}\right) \cdot \mu^{L}\left(k_{5}\right) \cdot \mu^{L}\left(k_{6}\right) \cdot \mu^{L}\left(k_{7}\right)\right] \vee\left[\mu^{L}\left(k_{3}\right) \cdot \mu^{L}\left(k_{5}\right) \cdot \mu^{B A}\left(k_{6}\right) \cdot \mu^{L}\left(k_{7}\right)\right] \vee \\
& \vee\left[\mu^{H}\left(k_{3}\right) \cdot \mu^{A A}\left(k_{5}\right) \cdot \mu^{A A}\left(k_{6}\right) \cdot \mu^{H}\left(k_{7}\right)\right] \text {; } \\
& \mu^{A A}(y)=\left[\mu^{L}\left(k_{3}\right) \cdot \mu^{L}\left(k_{5}\right) \cdot \mu^{B A}\left(k_{6}\right) \cdot \mu^{L}\left(k_{7}\right)\right] \vee\left[\mu^{B A}\left(k_{3}\right) \cdot \mu^{B A}\left(k_{5}\right) \cdot \mu^{B A}\left(k_{6}\right) \cdot \mu^{L}\left(k_{7}\right)\right] \vee \\
& \vee\left[\mu^{A A}\left(k_{3}\right) \cdot \mu^{A}\left(k_{5}\right) \cdot \mu^{A}\left(k_{6}\right) \cdot \mu^{A A}\left(k_{7}\right)\right] \\
& \mu^{H}(y)=\left[\mu^{L}\left(k_{3}\right) \cdot \mu^{B A}\left(k_{5}\right) \cdot \mu^{B A}\left(k_{6}\right) \cdot \mu^{L}\left(k_{7}\right)\right] \vee\left[\mu^{B A}\left(k_{3}\right) \cdot \mu^{B A}\left(k_{5}\right) \cdot \mu^{B A}\left(k_{6}\right) \cdot \mu^{B A}\left(k_{7}\right)\right] \vee \\
& \vee\left[\mu^{A}\left(k_{3}\right) \cdot \mu^{B A}\left(k_{5}\right) \cdot \mu^{B A}\left(k_{6}\right) \cdot \mu^{A}\left(k_{7}\right)\right] \\
& \mu^{L}(z)=\left\lfloor\mu^{L}\left(k_{8}\right) \cdot \mu^{B A}\left(k_{9}\right)\right\rfloor \vee\left\lfloor\mu^{A}\left(k_{8}\right) \cdot \mu^{A}\left(k_{9}\right)\right\rfloor \vee\left\lfloor\mu^{H}\left(k_{8}\right) \cdot \mu^{A A}\left(k_{9}\right)\right] \text {; } \\
& \mu^{B A}(z)=\left[\mu^{B A}\left(k_{8}\right) \cdot \mu^{A}\left(k_{9}\right)\right] \vee\left[\mu^{A}\left(k_{8}\right) \cdot \mu^{A}\left(k_{9}\right)\right] \vee\left[\mu^{A A}\left(k_{8}\right) \cdot \mu^{A}\left(k_{9}\right)\right] \text {; } \\
& \mu^{A}(z)=\left[\mu^{L}\left(k_{8}\right) \cdot \mu^{L}\left(k_{9}\right)\right] \vee\left[\mu^{A}\left(k_{8}\right) \cdot \mu^{A}\left(k_{9}\right)\right] \vee\left[\mu^{H}\left(k_{8}\right) \cdot \mu^{H}\left(k_{9}\right)\right] \text {; } \\
& \mu^{A A}(z)=\left[\mu^{B A}\left(k_{8}\right) \cdot \mu^{L}\left(k_{9}\right)\right] \vee\left[\mu^{A}\left(k_{8}\right) \cdot \mu^{B A}\left(k_{9}\right)\right] \vee\left[\mu^{A A}\left(k_{8}\right) \cdot \mu^{A A}\left(k_{9}\right)\right] \text {; } \\
& \mu^{H}(z)=\left[\mu^{A}\left(k_{8}\right) \cdot \mu^{B A}\left(k_{9}\right)\right] \vee\left[\mu^{A}\left(k_{8}\right) \cdot \mu^{A}\left(k_{9}\right)\right] \vee\left[\mu^{A}\left(k_{8}\right) \cdot \mu^{A A}\left(k_{9}\right)\right] \text {. }
\end{aligned}
$$

The total number of fuzzy logic equations is 20 . In general, each input variable $k_{1}-k_{9}$ has its own membership function, fuzzy terms $(L, B A, A, A A, H)$ used in these twenty equations (2-5). However, to facilitate further construction modeling within the fuzzy knowledge base for all variables $k_{1}-k_{9}$ is only one form of membership 
function. To do this, each variable spacing reduced to one universal interval $(0,4)$, carried out using the following ratios [124]:

$$
\mu^{j}\left(k_{i}\right)=\widetilde{\mu}^{j}(u) ; \quad u=4 \frac{k_{i}-\underline{k_{i}}}{\overline{k_{i}}-\underline{k_{i}}}, j=L, B A, A, A A, H,
$$

where $\left(k_{i}\right)$ - change interval variable $k_{i}, i=1,9$.

The final analytical model of membership function is:

$$
\tilde{\mu}^{j}(u)=\frac{1}{1+\left(\frac{u-b}{c}\right)^{2}} .
$$

Option b for terms $L, B A, A, A A, H$ is set to $0,1,2,3,4$, respectively. Option c terms with all the same and equal to 0.923 . The choice of these relationships (6) and options $b$ and $c$ in that form due to the fact that they are proven approximation membership functions obtained by pairwise comparisons.

Further, the fuzzy logic equations (2-5) with functions of fuzzy terms (7) allow us to decide on the specific diagnosis of the following algorithm [125].

1. Fixed values for the condition of the subject element is implementationdefined attributes in the form of quantitative values that fall within the boundaries of these ranges of change

$$
K^{*}=\left(k_{1}^{*}, k_{2}^{*}, k_{3}^{*}, \ldots, k_{9}^{*}\right) \text {. }
$$

2. Using relations (7) and options $b$ and $c$, determine the value of membership functions for fixed values of the parameters $k_{i}^{*}$.

3. Using the logic equations (2-5) values calculated at a fixed membership functions of the state vector $K^{*}$ for all diagnoses $S_{1}, S_{2}, S_{3}, S_{4}, S_{5}$. It is important to note that logical operations AND $(\Lambda)$ and OR $(V)$ of the membership functions are replaced by operations min and max:

$\mu(a) \wedge \mu(b)=\min [\mu(a), \mu(b)] ; \mu(a) \wedge \mu(b)=\max [\mu(a), \mu(b)]$.

4. Finally, the final decision for which

$$
\mu^{S_{j}^{*}}\left(k_{1}^{*}, k_{2}^{*}, \ldots, k_{9}^{*}\right)=\max \left[\mu^{S_{j}}\left(k_{1}^{*}, k_{2}^{*}, \ldots, k_{9}^{*}\right)\right] \quad j=1,9 .
$$


An example of the proposed algorithm can be reduced by building a state vector $K^{*}$ in the form that corresponds to the implementation of signs of an observed beams. In this case, follow the same conditions diagnosis [126]:

1) damage to the outer surface is that $k_{1}=1,0 \mathrm{~mm}$;

2) longitudinal cracks in the protective layer is that $k_{2}=1,0 \mathrm{~mm}$;

3) normal cracks in the tension zone opening to $0.4 \mathrm{~mm}$ is accepted that $k_{3}=0,2$ $\mathrm{mm}$;

4) inclined crack is that $k_{4}=1,0$;

5) concrete strength was $10 \%$ below the design, i.e. $k_{5}=10 \%$;

6) there is exposure fittings, $5 \%$ of which section affected by corrosion, that is $k 6_{1}=5 \%$;

7) deflection does not exceed normative; i.e. $k_{7}=0$;

8) Conditions strength calculation of normal intersections satisfied, that $k_{8}=1,0$

9) Conditions strength calculation on inclined sections satisfied, that $k_{9}=1,0$.

Using the model (8) and the accepted value parameters $b$ and $c$, calculate the value of membership functions in points $k_{i}^{*}(i=1,9)$ for all fuzzy terms. The results are shown in Table 7.

Table 7.

The value of membership functions

\begin{tabular}{|l|c|c|c|c|c|c|c|}
\hline № & $k_{i}^{*}$ & $u_{i}^{*}$ & $\mu^{L}\left(k_{i}^{*}\right)$ & $\mu^{B A}\left(k_{i}^{*}\right)$ & $\mu^{A}\left(k_{i}^{*}\right)$ & $\mu^{A A}\left(k_{i}^{*}\right)$ & $\mu^{H}\left(k_{i}^{*}\right)$ \\
\hline 1 & 1,0 & 4,0 & 0,0506 & 0,086 & 0,176 & 0,460 & 1,0 \\
\hline 2 & 1,0 & 4,0 & 0,0506 & 0,086 & 0,176 & 0,460 & 1,0 \\
\hline 3 & 0,2 & 2,0 & 0,176 & 0,460 & 1,0 & 0,460 & 0,176 \\
\hline 4 & 1,0 & 4,0 & 0,0506 & 0,086 & 0,176 & 0,460 & 1,0 \\
\hline 5 & 10,0 & 1,29 & 0,339 & 0,910 & 0,628 & 0,226 & 0,104 \\
\hline 6 & 5,0 & 0,95 & 0,485 & 0,997 & 0,437 & 0,169 & 0,084 \\
\hline
\end{tabular}




\begin{tabular}{|l|c|c|c|c|c|c|c|}
\hline 7 & 0,0 & 0,0 & 1,0 & 0,460 & 0,176 & 0,086 & 0,0506 \\
\hline 8 & 1,0 & 4,0 & 0,0506 & 0,460 & 0,176 & 0,460 & 1,0 \\
\hline 9 & 1,0 & 4,0 & 0,0506 & 0,460 & 0,176 & 0,460 & 1,0 \\
\hline
\end{tabular}

These values obtained are presented in equation (3): $\mu^{L}(x)=[0,086 \cdot 0,0506 \cdot 0,086] \vee[0,176 \cdot 0,086 \cdot 0,176] \vee[0,460 \cdot 0,460 \cdot 0,176]=0,176$

Similarly:

$\mu^{B A}(x)=0,176 ; \quad \mu^{A}(x)=0,460 ; \quad \mu^{A A}(x)=0,460 ; \quad \mu^{H}(x)=0,176$.

According to equation (4):

$$
\begin{aligned}
\mu^{L}(y)= & {[0,460 \cdot 0,339 \cdot 0,785 \cdot 1,0] \vee[0,460 \cdot 0,910 \cdot 0,997 \cdot 0,460] \vee } \\
& \vee[1,0 \cdot 0,9100 \cdot 0,437 \cdot 0,460]=0,460 .
\end{aligned}
$$

Similarly:

$$
\mu^{B A}(y)=0,460 ; \quad \mu^{A}(y)=0,176 ; \quad \mu^{A A}(y)=0,460 ; \quad \mu^{H}(y)=0,176 .
$$

According to equation (5):

$$
\mu^{L}(z)=[0,0506 \cdot 0,086] \vee[0,176 \cdot 0,176] \vee[1,0 \cdot 0,460]=0,460 .
$$

Similarly:

$$
\mu^{B A}(z)=0,176 ; \quad \mu^{A}(z)=0,176 ; \quad \mu^{A A}(z)=0,460 ; \quad \mu^{H}(z)=0,460 .
$$

Finally, according to equation (2):

$$
\mu^{S_{1}}(s)=[0,176 \cdot 0,176 \cdot 0,460] \vee[0,176 \cdot 0,460 \cdot 0,176] \vee[0,176 \cdot 0,460 \cdot 0,460]=0,176
$$

\section{Similarly:}

$$
\mu^{S_{2}}(s)=0,176 ; \quad \mu^{S_{3}}(s)=0,460 ; \quad \mu^{S_{4}}(s)=0,176 ; \quad \mu^{S_{5}}(s)=0,176 .
$$

Based on the results of fuzzy sets of the data is formulated as follows: since the most important decision membership functions corresponding to $S_{3}$, then the state is taken as unsuitable technical condition (category III) element floor beams.

Thus, considered approach promotes certainty in recognizing states of buildings with limited and inaccurate input. Together with probabilistic approaches and methods 
of information theory of fuzzy sets considered approach adds confidence to the expert in justifying the necessary decisions on the extent and depth of engineering interventions in order to bring it in normal technical condition $[127,128]$. 


\section{SECTION 4. ELECTRICAL ENGINEERING}

\subsection{Prospects for biogas technologies in Vinnytsia region of Ukraine}

Due to the depletion of traditional fuels and the increase in industrial potential and, consequently, the consumption of energy resources on the planet, the problems of energy efficiency and the introduction of renewable energy sources come to the fore. In addition, the problem of increasing the amount of organic waste from agriculture, food and processing industries, etc. is acute.

Biogas technologies allow to comprehensively solve the problems of organic waste disposal and production of environmentally friendly energy for the needs of the national economy [129].

Biogas technologies have recently been intensively implemented in Ukraine, including through the introduction of a "green tariff" for electricity from renewable sources. Such systems have a number of advantages that confirm their relevance and effectiveness. On the one hand, it is a rational way of processing waste from agriculture, food and processing industries, on the other hand, obtaining energy from biomass is a technology of renewable energy [130]. Biogas technologies are especially important for the decentralization of energy supply, as they allow to diversify the energy supply of private, municipal and state enterprises, farms, etc. The introduction of digestate obtained after anaerobic fermentation of waste provides a confirmed increase in yield. Both liquid livestock waste and solid organic crop waste are subject to anaerobic processing.

Vinnytsia region ranks first in terms of agricultural production and processing. The volume of sold agricultural products is more than $8.4 \%$ in the economy of Ukraine. The growth rate of agricultural production reaches $10 \ldots 12 \%$ annually. More than 200,000 people work in agriculture. At the same time, more than 2 million hectares of land are used, including 1.725 million hectares of arable land.

The leading place in the industrial potential of the region is occupied by the food industry (over 64\%). There are 6 sugar factories in Vinnytsia region with a production of over 3 million tons of sugar per year [131]. Vinnytsia region ranks 5th in Ukraine in 
terms of man-made impact on the environment, with Ladyzhyn TPP accounting for the bulk of emissions, producing electricity by burning a comprehensive energy resource - coal. At the same time, the region consumes more than 750 million $\mathrm{m}^{3}$ of natural gas, with the lion's share of consumption per capita $(60 \%)$.

According to statistics, from 1998 to 2020 there were significant changes in the number of farm animals in Vinnytsia region. Thus, the number of cows decreased by $17 \%$, other cattle - by $56 \%$, pigs - by $32 \%$. Instead, the number of goats and sheep increased by $67 \%$, and the number of poultry - by 31.9 times. Such changes allow us to estimate the increase in the biogas potential of Vinnytsia region by 4.4 times.

To calculate the energy potential of biogas in Vinnytsia region, statistical data on the number of animals as of May 1, 2020 were taken into account [132]. The volume of waste generation at distilleries and sugar factories corresponds to 2019 statistics. The estimated annual amount of livestock waste, sugar and alcohol industry is about 13 million tons. The potential output of biogas from such wastes in the process of monofermentation, calculated on the basis of specific indicators [133], is 939 million cubic meters per year.

The distribution of the biogas potential of the region by sources of organic waste is shown in Fig. 1.

As can be seen from Fig. 1, 49.4\% of the total annual biogas potential of Vinnytsia region can be produced only from poultry waste, and 36.5\% - from waste from sugar factories. As the number of sheep and goats in Vinnytsia region is the lowest among all farm animals, the share in the total annual potential of biogas is only $0.29 \%$.

In our opinion, currently the most effective method of utilization of produced biogas is its combustion in cogeneration plants with the production of commercial electricity and heat. Calculations have shown that the annual potential for electricity generation from biogas is 2.083 million MWh. In addition, it is possible to produce 11.8 million GJ of heat per year. 


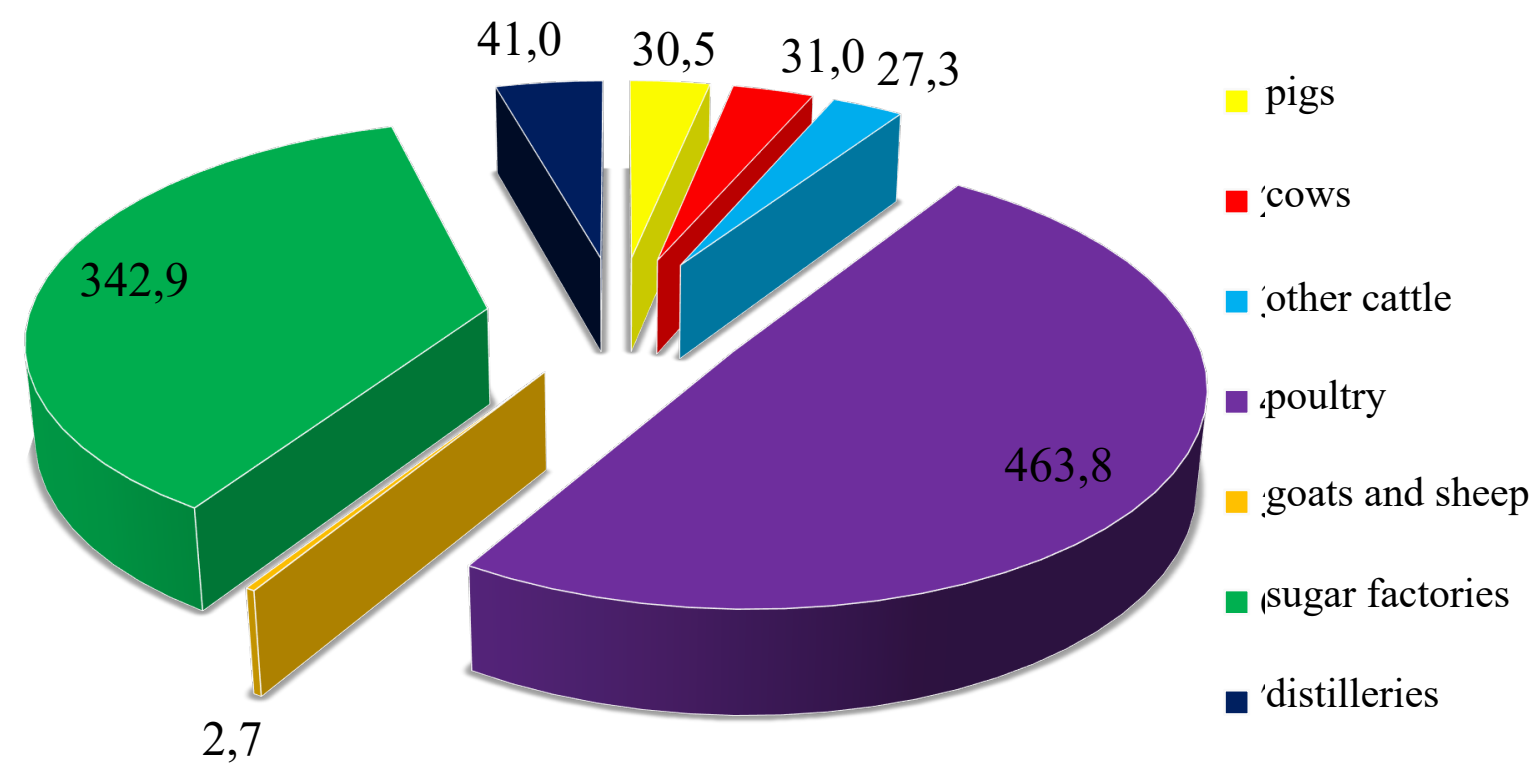

Fig. 1. Biogas production potential in Vinnytsia region by sources of organic waste, million cubic meters

According to statistics for the Vinnytsia region, such an energy effect is sufficient to cover all energy needs of Vinnytsia region by major economic activities.

The economically feasible potential of biogas, calculated according to the recommendations of the Bioenergy Association of Ukraine [134], was also assessed. It amounted to 545 million cubic meters per year, which is $58 \%$ of the total potential.

At present, no methodology has been developed for relatively accurate estimation of biogas yield from various organic wastes and waste mixtures. Features of fattening and waste collection technologies do not allow to fully use the results of research by authors from other countries.

Livestock waste is characterized by relative continuity and simplified collection, but their biochemical features do not allow to obtain high values of biogas yield. The world is actively using technologies for the joint fermentation of various types of organic waste. There are known results on the fermentation of cattle waste with grass, fruit and vegetable residues, corn silage, etc. Statistics show that in Germany up to 9\% of agricultural arable land is used to grow corn for silage, followed by its joint fermentation with livestock waste in biogas plants. According to the authors' research 
[135], due to the addition of plant residues to wastewater, it was possible to increase the biogas yield by 2.7 times compared to mono-fermentation of wastewater.

In [136], an increase in methane yield by $18 \ldots 35 \%$ was recorded as a result of adding corn, grass, vegetable, and cereal wastes to livestock wastes in comparison with mono-fermentation of livestock effluents.

At present, there are significant prospects in improving the technology of harvesting and processing of vegetable waste of vegetable tops, straw, cereals and oilseeds, corn and sunflower residues. Instead, biogas technologies for their processing will not only provide better fertilizer than during composting processes, but also provide the company with diversification of energy supply.

The authors [134] indicated that taking into account corn silage as a raw material for biogas technology will triple the energy potential of this energy-efficient environmentally friendly technology.

The effects of biogas technology are described in detail in [129]. The complex effect of cofermentation at the first stage of project development can be assessed on the basis of the energy effect from the produced biogas and expert data on the ratio of energy, economic and environmental effects.

The energy effect from the produced biogas can be determined by different methods: technical and economic, thermodynamic, thermoeconomic, etc. Its value also depends on the choice of biogas utilization technology.

Technologies for obtaining hydrogen and biomethane from biogas in the future will provide the highest values of the energy effect. Due to the "green tariff" for electricity, the most efficient at present is the combustion of biogas in cogeneration plants with heat and electricity, which allows to implement decentralization and diversification of energy supply, to compensate for peak loads of the central power system. For dairy companies, we can offer a three-generation system with the release of heat, electricity and cold.

Thus, the state of agriculture of Vinnytsia region, volumes of energy consumption and volumes of harmful emissions into the environment are analyzed. An increase in 
the raw material base for biogas technology was revealed due to a 31.9-fold increase in the number of poultry in the Vinnytsia region.

Using statistical data, the amount of livestock waste, sugar and alcohol industry of Vinnytsia region was calculated, which amounted to 13 million tons per year. Anaerobic bioconversion of this amount of organic waste will allow to obtain about 939 million cubic meters of biogas per year.

To analyze the energy effect of biogas, the option of its utilization in cogeneration units was chosen. Thus, it is potentially possible to obtain 2.083 million $\mathrm{MWh}$ of electricity and an additional 11.8 million GJ of heat. That is, the energy potential of biogas from organic livestock waste, sugar and alcohol industry is sufficient to cover the energy needs of Vinnytsia region for the main types of economic activity.

Using the recommendations of the Bioenergy Association of Ukraine, the economically feasible potential of biogas in Vinnytsia region was assessed. It amounted to 545 million cubic meters per year or $58 \%$ of the total capacity.

Biochemical features of livestock waste do not allow to obtain a high yield of biogas. The addition of plant residues, fruit and vegetable waste, silage, grass, etc. provides an increase in biogas yield and increase the efficiency of biogas technology in general. Co-fermentation allows not only to more efficiently dispose of crop waste, but also to increase the energy effect of biogas technology.

It is proposed to determine the complex effect of a biogas plant based on its energy effect, which depends on the method of biogas utilization. At the moment, in our opinion, the most efficient is the production of electricity from biogas. And in the future, the production of biomethane and hydrogen should come to the fore. 


\section{2 Основні принципи просктування автономного енергогенеруючого комплексу}

Загальновідомо, що зростання виробництва i споживання енергії нерозривно пов'язане з прогресом суспільства, яке протягом усієї своєї історії, а особливо у сучасних умовах, постійно веде боротьбу за збільшення свого енергетичного багатства.

Сьогодні велика увага приділяється питанням економного використання енергоресурсів через різке збільшення витрат на їх видобування і виробництво, а також високу вартість нафти та газу на світовому ринку.

Дослідження вчених свідчать про те, що в сучасних умовах економія $1 \mathrm{~T}$ умовного палива вимагає, як правило, менших витрат, ніж приріст видобування еквівалентної його кількості. Енергозберігаючий шлях розвитку економіки передбачає:

- значне зниження в розрахунку на одиницю продукції витрат палива, електроенергії і теплоти на кінцевій стадії їх споживання;

- докорінне вдосконалення видобутку, виробництва, перетворення, транспортування i зберігання енергоресурсів, що зумовлює підвищення коефіцієнту їх використання;

- удосконалення структури енергобалансу в напрямку заміщення в ньому дефіцитних і дорогих енергоресурсів дешевшими і доступнішими, а також нетрадиційними джерелами енергії.

Традиційні джерела енергії є звичними для використання (рис.1). Їх кількість обмежена. Такі джерела характеризуються високим рівнем екологічного забруднення, тож в багатьох країнах світу використання таких джерел зменшують на користь відновлювальних або нетрадиційних джерел (рис.1).

У сучасній Україні основи використання альтернативних джерел енергії закладені в загальнодержавних програмах економічного розвитку [137, 148], основними засадами яких $є$ : 
- $\quad$ нарощування обсягів виробництва та споживання енергії, виробленої 3 альтернативних джерел, з метою економного витрачання традиційних паливноенергетичних ресурсів та зменшення залежності України від їх імпорту;

- реструктуризація виробництва 3 метою створення умов для збільшення споживання частки енергії, виробленої із альтернативних джерел;

- $\quad$ д додержання екологічної безпеки за рахунок зменшення негативного впливу на стан довкілля при створенні та експлуатації об'єктів альтернативної енергетики, а також при передачі, транспортуванні, постачанні, зберіганні та споживанні енергії, виробленої з альтернативних джерел;

- $\quad$ додержання безпеки для здоров'я людини на об'єктах альтернативної енергетики на всіх етапах виробництва, сортуванні, постачанні та споживанні енергії, виробленої з альтернативних джерел;

- $\quad$ науково-технічне забезпечення розвитку альтернативної енергетики, упровадження науково-технічних досягнень у даній сфері, підготовка відповідних фахівців у вищих та середніх навчальних закладах;

- залучення вітчизняних та іноземних інвестицій i підтримка підприємництва, у тому числі шляхом розробки і здійснення загальнодержавних і місцевих програм розвитку альтернативної енергетики. 


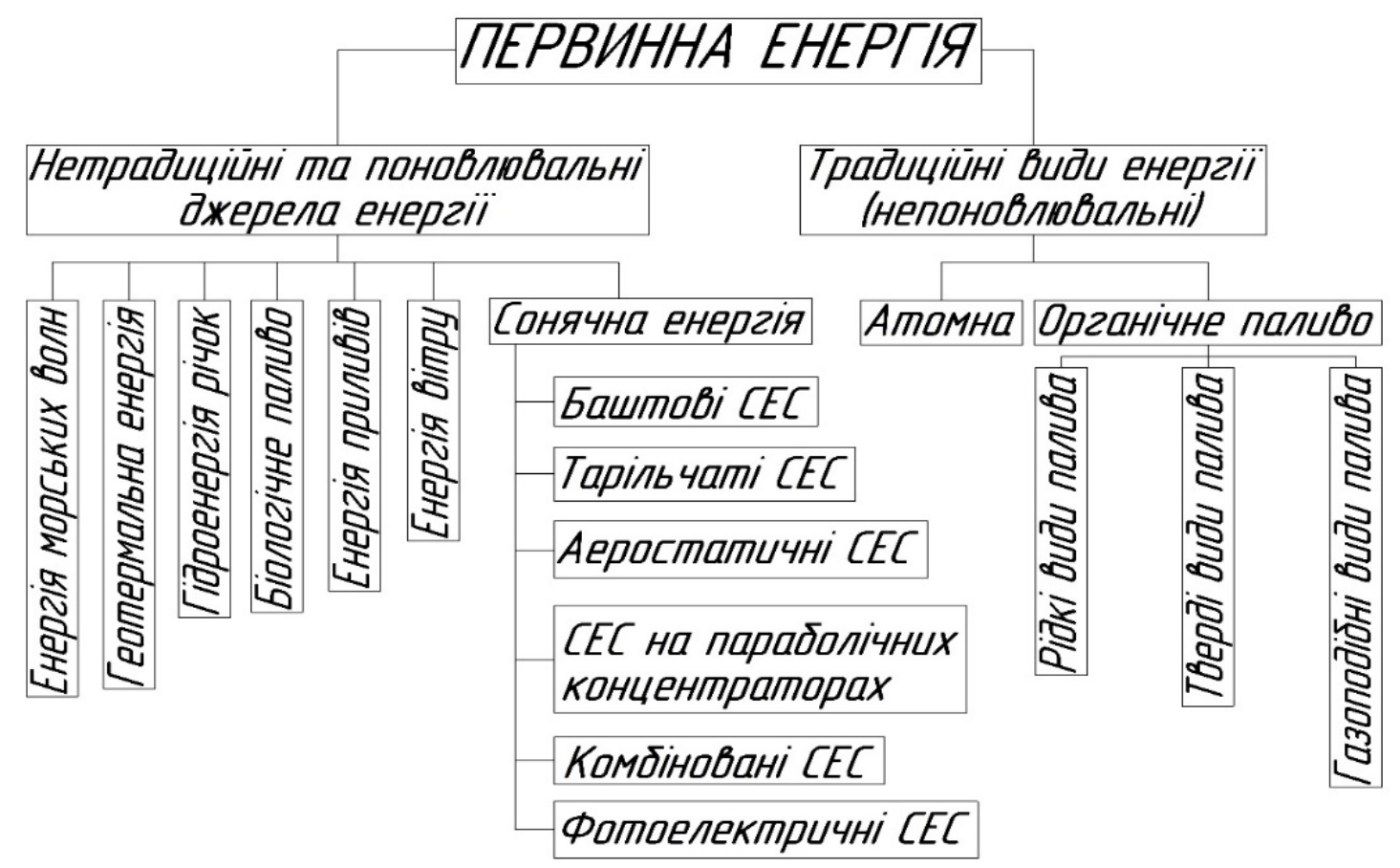

Рисунок 1. Види та типи джерел електричної енергії

Економічне забезпечення діяльності у сфері альтернативних джерел енергії включає [137]:

- створення сприятливих економічних умов для спорудження об'єктів альтернативної енергетики;

- визначення джерел i напрямів фінансування заходів у сфері альтернативних джерел енергії;

- застосування економічних важелів і стимулів 3 метою розширення використання альтернативних джерел енергії.

Найбільш перспективною галуззю альтернативної енергетики є сонячна енергія. Потенціал сонячної енергії в Україні є достатньо високим для широкого впровадження геліосистем як теплоенергетичного, так i фотоелектроенергетичного обладнання практично на всій території [147].

Всі сонячні електростанції (CEC) поділяють на кілька типів: ті що використовують фотоелектричні модулі (фотоефект) [146] (рис.1) та ті що 
перетворюють сонячну енергію на теплову, яка приводить у дію тепловий двигун (сонячно теплові).

Агровольтаїка - це нещодавно розроблена системна технологія, що дозволяє одночасно використовувати землі для виробництва сільськогосподарської продукції і розміщення сонячних електростанцій [138].

Сучасне сільське виробництво є багатогранним. У рослинництві та тваринництві застосовується багато різних технологій. При цьому такий економічний фактор, як собівартість продукцї в сучасних умовах відсутності дефіциту товарів сільськогосподарського призначення, виступає на перший план поряд із якістю та екологічністю продукції в умовах жорсткої конкуренції виробників. Фактор зниження собівартості продукції за рахунок використання нетрадиційних джерел енергії інколи набуває головного [148].

Поєднання сонячної енергетики і сільського господарства не тільки вирішує проблему нестачі землі для встановлення сонячних панелей, але й підвищує врожайність деяких сільськогосподарських культур.

У випадку, коли господарство має пряме підключення до електромережі, то використання сонячної електростанції дозволить суттєво зекономити на платежах за використанні електроенергії, а інколи і реалізовувати згідно умов зеленого тарифу.

Отож, як висновок, монтування фотомодулів на фермерських угіддях - це раціональне рішення, яке дозволяє зекономити місце при монтуванні, а також забезпечити затінення рослин і повноцінне функціонування станції [147].

Сонячна електростанція може бути джерелом освітлення житлових приміщень біля сільськогосподарських угідь, а також для великомасштабного освітлення сховищ, комор, чи будівель для утримання великої рогатої худоби, свиней та овець. Також типовим виглядає застосування зовнішнього та охоронного освітлення, а також освітлення у теплицях. Крім цього, сонячне тепло може використовуватися для нагрівання води. Ефект нагрівання досягається шляхом використання спеціальних колекторів. Завдяки 
правильному плануванню та проєктуванню, сонячні нагрівачі повітря/простору можуть бути в загальній системі, щоб підігріти вхідне свіже повітря $[139,140]$.

Тож для створення автономного джерела живлення найбільше підходять саме фотоелектричні модулі для перетворення сонячної енергії. Це зменшить вкладення на обслуговування станції, наддасть можливість швидкої та безперешкодної модернізації системи.

При проєктуванні автономного енергогенеруючого комплексу необхідно враховувати можливості місцевості. Потенціал сонячної енергії визначається за показником сумарної сонячної радіації [141]:

$$
\sum S=\sum D_{p}+\sum I_{n} \cdot \sin \gamma
$$

де $\Sigma S$ - сумарна сонячна радіація,

$\Sigma D_{p}$ - розсіяна радіація,

$\Sigma I_{n}-$ пряма радіація,

$\gamma$ - висота Сонця над обрієм.

Тобто, важлива не кількість сонячних променів, які потрапляють на батарею, а загалом кількість сонячних днів регіону. Під цим розуміють кількісні характеристики потоків прямої та розсіяної сонячної інсоляції та можливість їхнього використання для роботи різних типів сонячних установок.

Для визначення потенціалу сонячної енергії часто використовуються показники тривалості сонячного опромінення. Вивченням сонячної активності в усіх регіонах нашої планети займається Національне управління з аеронавтики $\mathrm{i}$ дослідженню космічного простору (NASA). Цілодобово супутники стежать за діяльністю сонця і заносять отриману інформацію в таблиці [141]. У розрахунках враховуються дані останніх 25 років. Знаючи значення інсоляції можемо розрахувати приблизне виробництво електроенергії в даному регіоні в конкретний місяць або в середньому в рік. Між тим отримані результати розраховані для ідеальних умов: повна відсутність хмарності і падіння сонячних променів на поверхню під прямим кутом (перпендикулярно). Якби прозорість 
атмосфери протягом доби не змінювалась, зміна кількість сонячної енергії була б симетрична відносно істинного полудня. Від нуля в момент сходу сонця вона збільшується до свого максимуму, а після полудня спадає до нуля. Але прозорість атмосфери може змінюватись дуже швидко протягом дня (табл.1).

Таблиця 1.

Коефіцієнт прозорості атмосфери

\begin{tabular}{|l|c|}
\hline \multicolumn{1}{|c|}{ Стан атмосфери } & Коефіцієнт прозорості \\
\hline Повітря абсолютно прозоре & 0,99 \\
\hline Виключно висока прозорість & 0,97 \\
\hline Повітря дуже прозоре & 0,96 \\
\hline Добра прозорість & 0,92 \\
\hline Середня прозорість & 0,81 \\
\hline Повітря трохи мутне & 0,66 \\
\hline Імла & 0,36 \\
\hline Сильна імла & 0,12 \\
\hline Легкий туман & 0,015 \\
\hline Туман & Від $2 \cdot 10^{-4}$ до $8 \cdot 10^{-10}$ \\
\hline Густий туман & Від $10^{-19}$ до $10^{-34}$ \\
\hline
\end{tabular}

Хмари та туман в значній кількості поглинають і розсіюють сонячну радіацію. Для характеристики режиму хмарності використовують ймовірність похмурого та ясного неба. При цьому приймається небо похмурим, якщо кількість хмар перевищує 8 балів, і ясним, якщо кількість хмар не перевищує 2 балів.

Можна виділити два підходи до обліку впливу хмарності на радіацію, що надходить на похилу поверхню. Перший з них заснований на обліку загальної хмарності, другий - на обліку візуальних оцінок хмарності [142].

Вплив загальної хмарності на сумарну радіацію що падає на похилу поверхню, $\Sigma S_{x м}$ можна оцінити [142] 


$$
\sum S_{x M}=\left(\sum I_{n}+\sum D_{n}+R\right)(1-(a+b k) k)
$$

де $\Sigma I_{n}$ - пряме сонячне випромінювання, падаюче на похилу поверхню, Вт / м²; $\Sigma D_{n}$ - розсіяне сонячне випромінювання, що надходить на похилу поверхню, $\mathrm{BT} / \mathrm{M}^{2}$;

$R$ - відбита від земної поверхні радіація, Вт / м².

$a$ - коефіцієнт, що залежить від середовища і від широти місцевості;

$b$ - коефіцієнт, який можна вважати постійним і рівним 0,38 ;

$k$ - коефіцієнт хмарності

Тож $є$ необхідність визначення коефіцієнту, який враховує реальні погодні умови відношенням інсоляції в реальних умовах хмарності до інсоляції при безхмарному небі.

Для вирішення цього завдання за даними метеорологічних станцій та супутникових знімків опромінення земної поверхні побудовані графічні залежності сонячної активності (рис. 2) та сонячної інсоляції (рис. 3) Мелітопольського району.
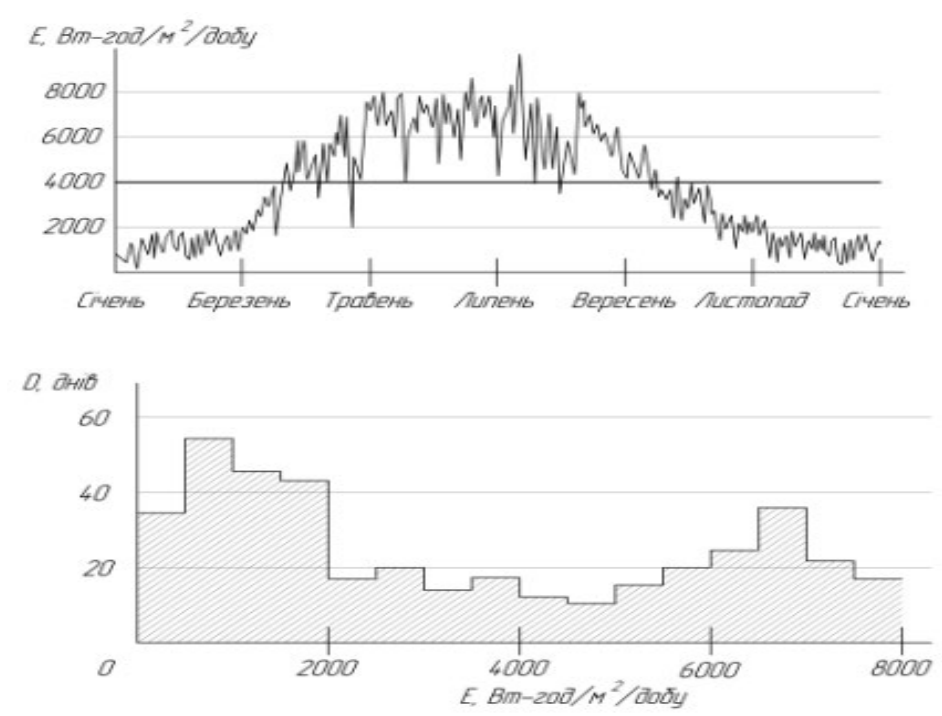

Рисунок 2. Графічні залежності сонячної активності Мелітопольського району

Для визначення сонячної активності в реальних умовах було розроблено методику, яка визначала кількість активних сонячних днів протягом 
календарного року. Точкою відліку було взято 31 грудня 2018 року. Спостереження проводилось 3 рази на добу. Визначався час сходу сонця, астрономічного полудня, та заходу сонця [143] в визначений час на відкритій місцевості визначалась хмарність, наявність або відсутність туману, імли, смогу, диму.
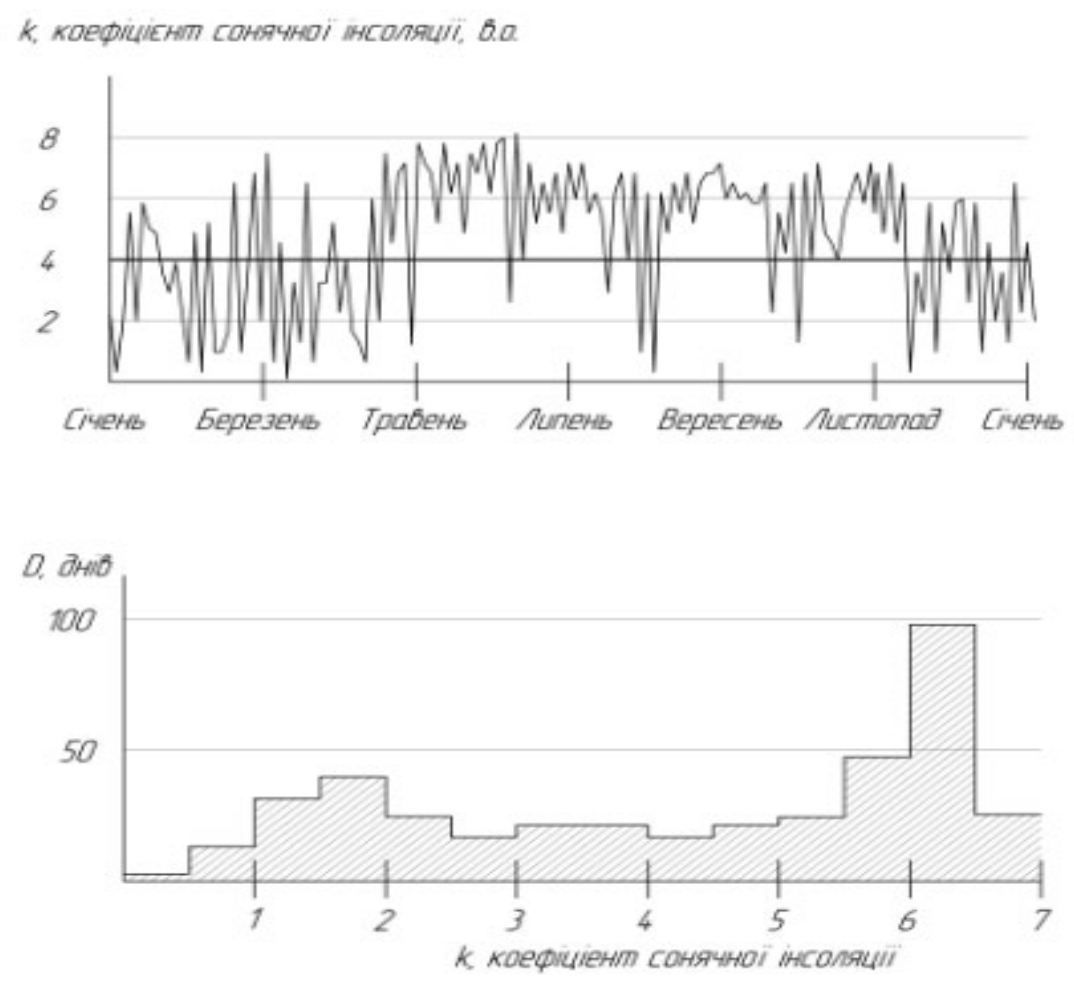

Рисунок 3. Графічні залежності сонячної інсоляції Мелітопольського району

На основі отриманих даних побудовані графічні залежності (рис. 4)

Залежність кількості опадів, сонячних та похмурих днів

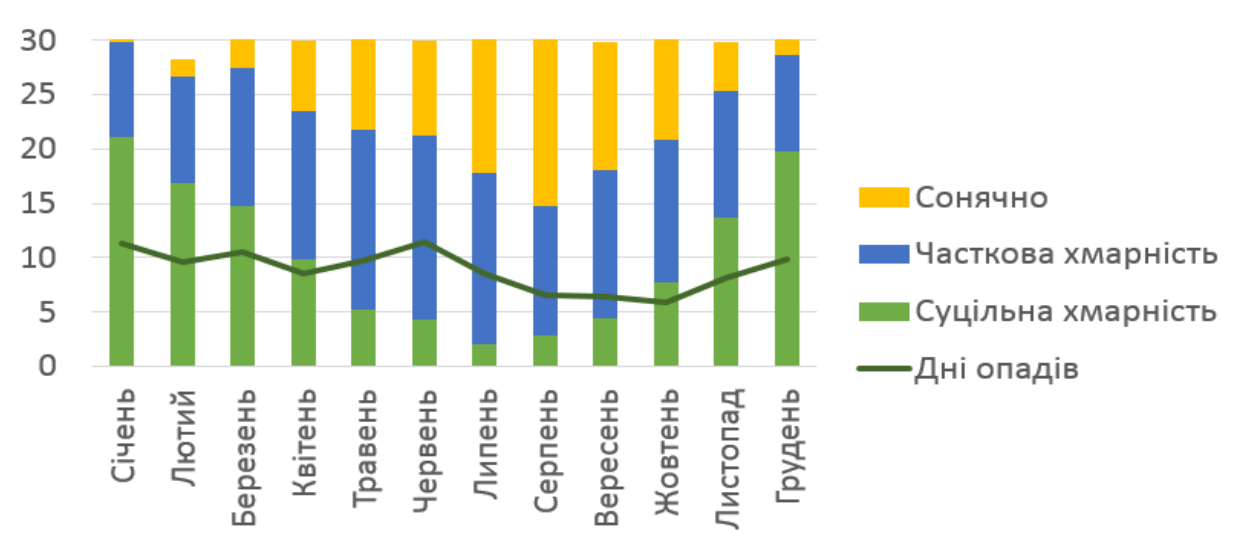


Рисунок 4. Графічні залежності сонячної активності в реальних умовах Мелітопольського району

Визначення коефіцієнту хмарності можливо за формулою

$$
k_{n}=\frac{N_{1}+N_{2}}{N_{1}+N_{2}+N_{3}},
$$

де $N_{1}$ - кількість сонячних днів;

$N_{2}$ - кількість днів с частковою хмарністю;

$N_{3}$ - кількість днів з суцільною хмарністю.

Отримані за результатами розрахунків оцінки сонячної радіації дозволяють забезпечити прогнозування можливих об'ємів енергії інсоляції при проєктуванні сонячних електростанцій та перейти до розрахунку потужності сонячних батарей автономної сонячної електростанції $[144,145]$. 


\section{3 Вплив присднання сонячних електростанцій до розподільних електричних мереж}

В наш час перед споживачами стоїть вибір: орієнтуватися на централізовані джерела або використовувати автономну енергетику. В Україні впроваджується розподілена генерація на основі активного використання альтернативних джерел енергії: води, сонця, вітру. Станом на 1 січня 2020 року в Україні встановлена потужність об'єктів відновлювальної енергетики, яким встановлено зелений тариф, становила 4038 МВт.

Розподілені джерела енергії поділяються за рівнем впливу неконтрольованих факторів навколишнього природного середовища та первинними енергоносіями на:

- відновлювальні джерела 3 слабо-керованим генеруванням використовують відновлювані ресурси, але генерування значно відрізняється залежно від часу доби та погодних умов( вітрові електростанції (BEC), сонячні електростанції (СЕС));

- відновлювальні джерела 3 керованим генеруванням - використовують відновлювані ресурси, мають стабільне генерування протягом встановленого проміжку часу (малі ГЕС), геотермальні, біогазові установки).

Впровадження альтернативних джерел в електроенергетичних системах, крім зниження шкідливого впливу на навколишнє середовище і вирішення проблем, що пов'язані з забруднення відходами під час виробітку електричної енергії, знизить використання природних ресурсів та розвантажить системоутворюючі і розподільні ЛЕП. Однак відновлювальні джерела енергії мають ряд недоліків. В першу чергу, велику роль відіграє нестабільне генерування ВДЕ через залежність від погодних умов. Отже виникає необхідність вдосконалення систем релейного захисту та автоматики 3 метою узгодження електропостачання від ВДЕ та живильних підстанцій електроенергетичної системи. Вплив ВДЕ на режими РЕМ суттєво залежить від значення сумарного розосередженого генерування в ній, від одиничної 
встановленої потужності ВДЕ та їх типу, а також від їх місця під’єднання в електричній мережі.

Зіставлення графіків електроспоживання i генерування такими відновлюваними джерелами, як СЕС та ВЕС, дозволяє говорити про низьку їх стабільність для забезпечення балансу потужності в електричній мереж, що відображено на мал.1 та мал.2.

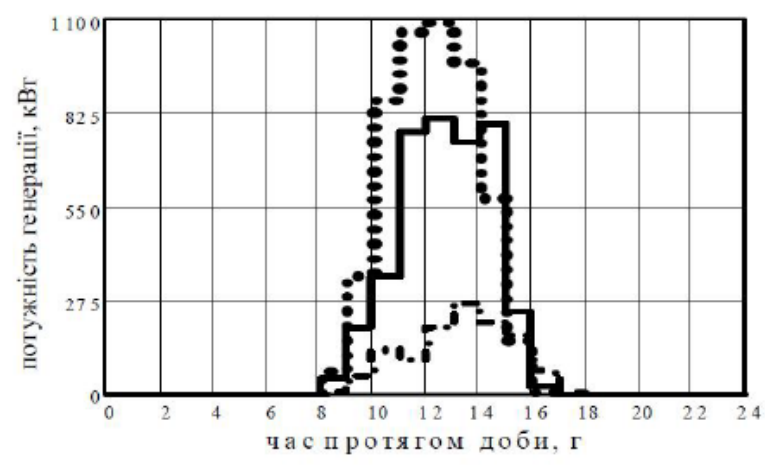

Малюнок 1. Сезонна зміна добового графіка роботи СЕС

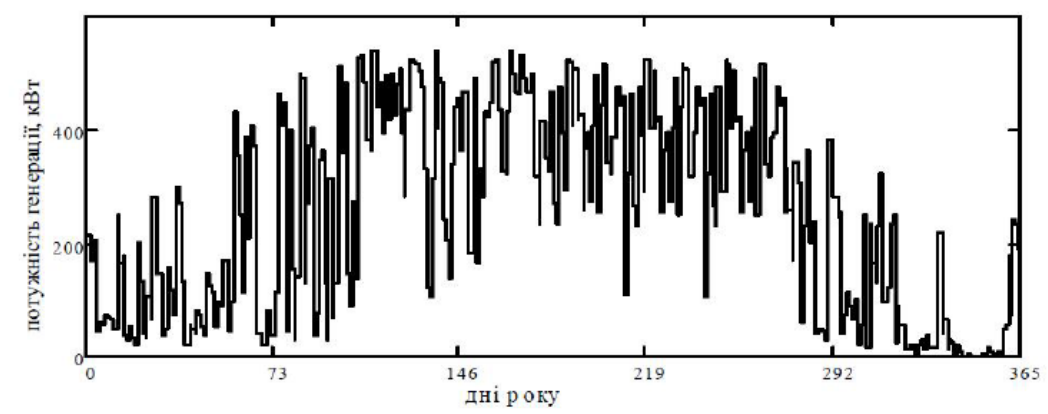

Малюнок 2. Характер зміни середніх значень середніх значень генерації CEC, визначених за добовими графіками, протягом року

В задачі забезпечення балансу потужності СЕС та ВЕС можна віднести до умовно регульованих джерел, тобто джерел з теоретичною можливістю зміни генерування в межах природних можливостей. Зазвичай практично таку можливість не використовують, оскільки в такому разі їхня економічна ефективність різко знижується.

На сьогодні втрати електричної енергії в мережах енергопостачальних компаній України складають 11,5-12,1% від іï відпуску в електричну мережу, що 
більш ніж в США (6,5 \%), Англії (8,6 \%), Франції (4,5 \%). Визнано, що розподільні мережі $\epsilon$ найбільш проблемним i затратним фактором електропостачання територій. Важливим напрямком впливу на втрати електроенергії у розподільних мережах є ВДЕ. Очевидно, що на значення втрат в ЕМ впливають як параметри ВДЕ, так і схеми їх приєднання, а також обсяг та графік споживання суміжних навантажень. На мал.3 наведено можливі схеми приєднання ВДЕ в РЕМ, які суттєво відрізняються впливом на потоки потужності і, відповідно, на втрати потужності і електроенергії в мережі.

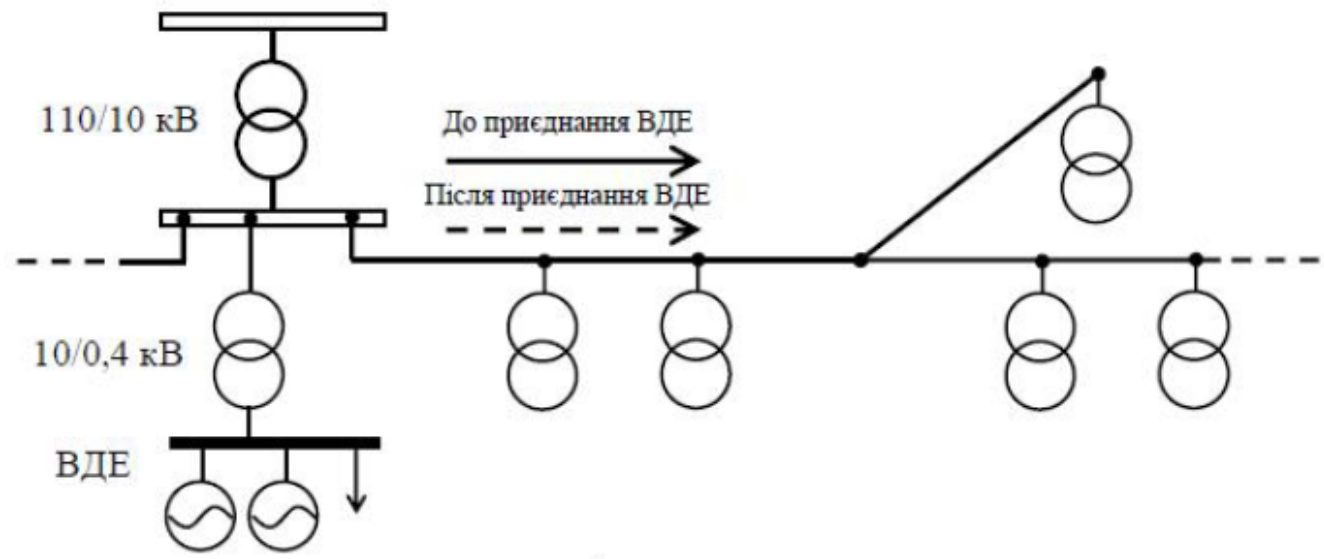

a)

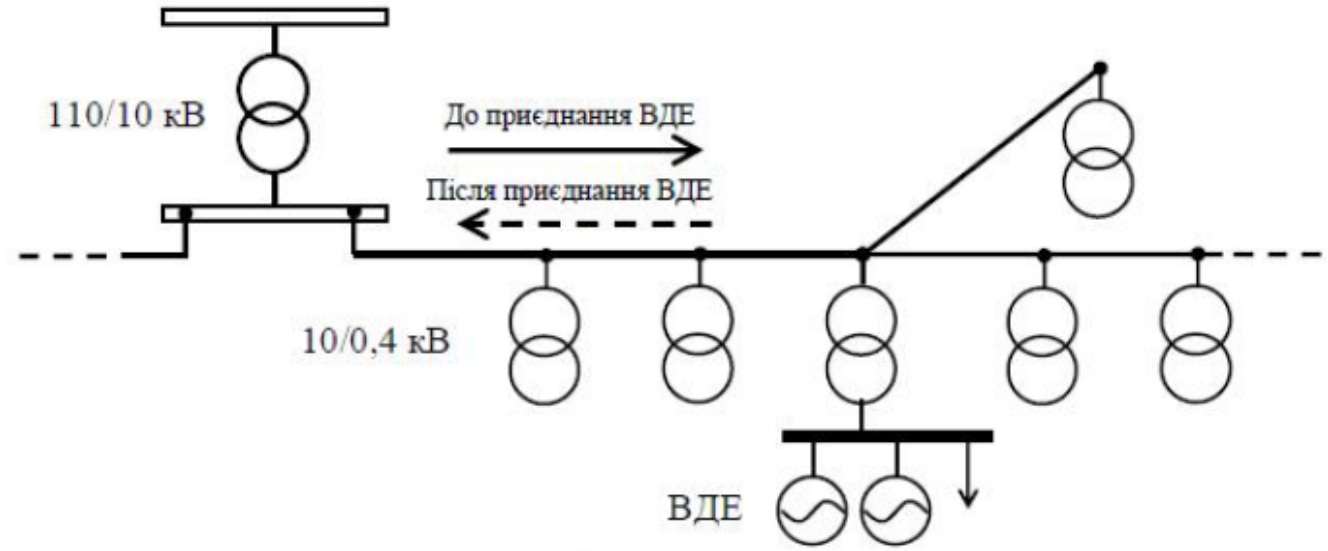

б)

Малюнок 3. Варіанти приєднання ВДЕ в електричній мережі

На мал.3а ВДЕ приєднані до шин підстанції. В цьому випадку трансформатор розвантажується на потужність, яка виробляється ВДЕ, і в результаті зменшуються навантажувальні втрати в трансформаторі. В лініях електропередачі втрати не змінюються. У варіанті, показаному на рис. 1.3б, розвантажуються як трансформатор підстанції, так і частина ЛЕП, що забезпечує 
додаткове зменшення втрат потужності. Оскільки зменшується потік потужності, то зменшуються також втрати напруги, що сприяє покращенню рівнів напруги на шинах підстанцій. Виходячи з типових схем приєднання ВДЕ до розподільних мереж, за певних потужностей генерування вони частково компенсують потоки потужності, що зумовлені навантаженням споживачів, i надходження електроенергії 3 боку системи зменшується. Разом 3 цим зменшуються втрати електроенергії в розподільних мережах.

Для порівняння переваг і недоліків встановлення ВДЕ в розподільну електричну мережу: виконаємо дослідження на прикладі РЕМ 150/35/10 АТ “Херсонобленерго”, карта-схема якої наведена на мал. 1.4.

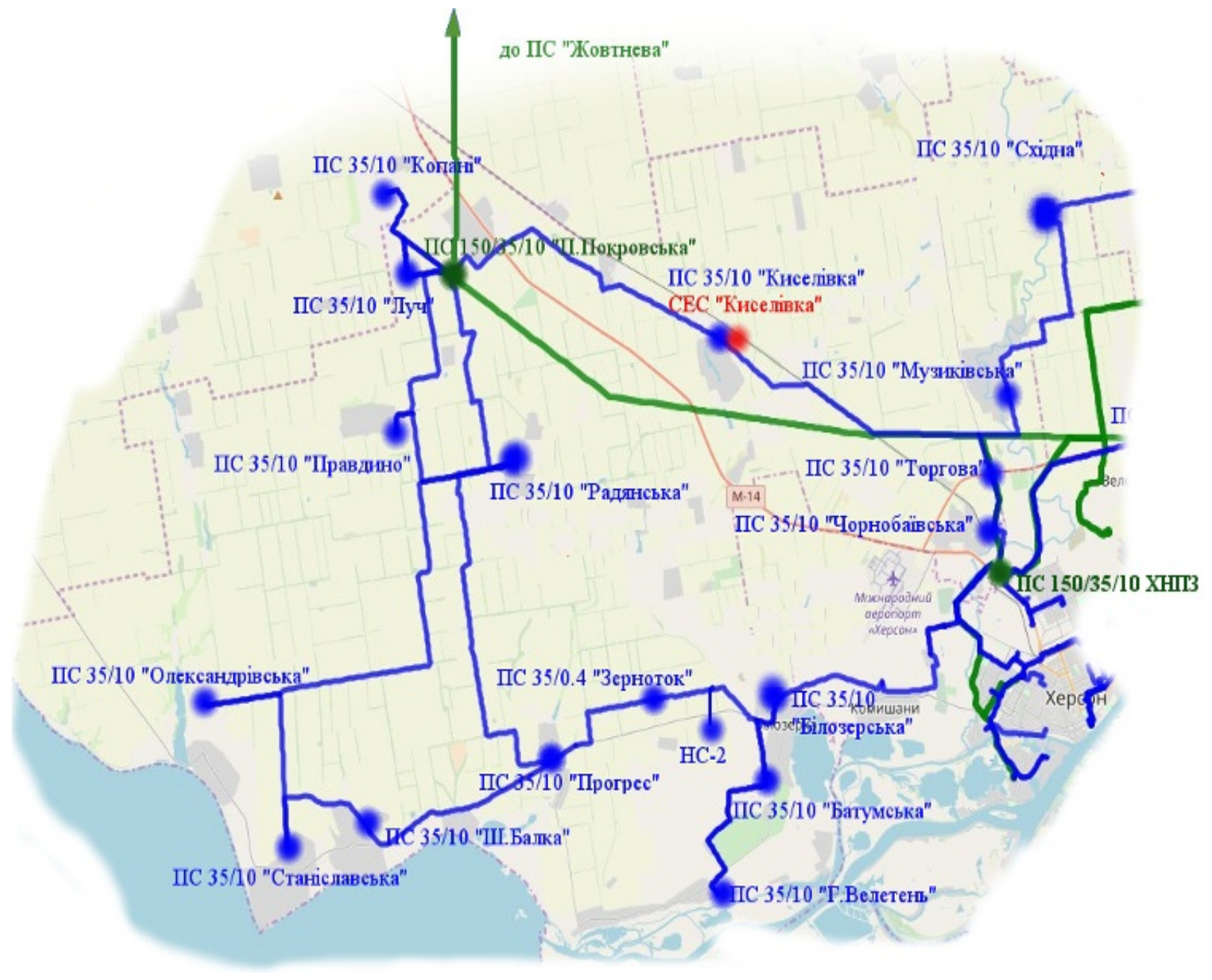

Малюнок 4. Схема мережі 150/35/10

Встановимо до мережі СЕС з постійним виробленням потужності 10 MBТ, зі схемою приєднання “а)”, та порівняємо режими роботи до та після 
встановлення, за показником сумарних втрат потужності. Результати порівняння наведені в табл.1.

Таблиця 1. Сумарні втрати в мережі до та після встановлення СЕС

\begin{tabular}{|c|c|}
\hline Режим роботи & $\Delta \mathrm{S} \Sigma(\mathrm{MBT})$ \\
\hline До СЕС & 0.87 \\
\hline Після СЕС & 0.632 \\
\hline
\end{tabular}

При цьому струмове навантаження по всім ділянкам електричної мережі знаходиться в межах допустимого значення.

Аналізуючи вищезазначену інформацію можна сказати, що при підключенні CEC, з будь-якої з наведених схем, можна знизити сумарні втрати потужності в мережі, але вироблення нею потужності буде дуже сильно залежати від погодних умов.

При встановлення СЕС, за однією з схем, в оптимальному місці приєднання до мережі, дослідження показало, що: не дивлячись на зазначені вище недоліки, при вироблені постійної активної потужності в 10 МВт, забезпечує покращення параметрів електричної енергії, в якості: підвищення рівня напруги у віддалених ділянках мережі та зниження втрат активної потужності в мережі майже на 35\%. 


\section{SECTION 5. ENGINEERING GRAPHICS}

\subsection{Engineering graphics - the basis for forming the theoretical base of engineering thinking}

Найважливішим завданням освіти є розвиток в учнів здатності самостійно аналізувати і мислити. що дозволить їм грамотно використовувати отримані і осмислені знання у практичній діяльності. Особливо важливий навик висловлювати свої технічні думки і ідеї за допомогою креслень, що досягається при вивченні базового курсу «Інженерної та комп'ютерної графіки».

Інженерна комп'ютерна графіка займає одне з головних місць в сучасній освіті і є необхідною дисципліною в процесі технічного навчання. Графічна підготовка формує теоретичну і практичну базу інженерної освіти, так як є основою діяльності фахівців.

На практиці кожен інженер зустрічається з таким чи іншим різновидом конструкторської документації, тому знання теорії зображень та стандартів $\epsilon$ необхідністю для фахівця. Вивчення методів проектування і побудови, на їх основі, графічних зображень, правил виконання креслень відповідно до діючих стандартів дозволять студентам стати грамотними в області читання креслень та уяви справжньої форми і розміру реальних тривимірних об'єктів. Вивчаючи нарисну геометрію студенти пізнають основи проектування $\mathrm{i}$ вчаться представляти подумки форму об'єктів і їх взаємне розташування в просторі, що розвиває просторове мислення. 
Інженерна графіка вчить представляти об'єкти тривимірного простору в двовимірному вигляді (на папері або на екрані комп'ютера) або по зображенню на площині уявити реальний тривимірний об'єкт з точки зору його геометричних властивостей. Грамотне прочитання кресленика має велике значення для процесу моделювання, а отже, двовимірне моделювання нерозривно пов'язане 3 тривимірним. Обидва відображають способи представлення об'єктів з метою їх проектування, аналізу і візуалізації.

Сьогодні іде активнє впровадження нових інформаційних технологій в різні галузі промисловості і особливо важливою стає система навчання, що забезпечує висококваліфіковану загальноінженерну графічну підготовку у вузі. Використання сучасних комп'ютерних графічних засобів можливо лише на основі законів і правил інженерної графіки [151].

Комп'ютерні технології дають можливість зв'язати теорію з практикою, автоматизувати деякі види механічної, рутинної роботи на заняттях з нарисної геометрії та інженерної графіки.

Студентам необхідно, в першу чергу, навчитися читати кресленики деталей, виконувати графічні роботи, кресленики і схеми за допомогою креслярських інструментів та без них. Тобто важливо вміти встановлювати асоціативні зв'язки між візуальними образними даними i їх проекціями, зрозуміти сенс i призначення проекцій. Для полегшення сприйняття на заняттях 3 інженерної графіки можна використовувати комп'ютерні технології, наприклад, для демонстрації можливих варіантів вирішення при варіюванні вихідних даних. 
У той же час $є$ необхідність включення в курси нарисної геометрії та інженерної графіки питань, що забезпечують комп'ютерну графіку, таких як основи теорії кривих і плоских обводів. При розгляді в курсі способів утворення поверхонь, слід звернути увагу на інженерні методи проектування технічних поверхонь, тобто на кінематичний спосіб їх утворення. Меню графічних систем автоматизованого проектування містить різні способи завдання досить великого набору кривих ліній; побудови обводів, заданих масивом точок і дотичних, способів побудови поверхонь і природно, що користувач, повинен знати області їх застосування, переваги і недоліки [152].

При побудові необхідних видів, розрізів, перерізів і виносних елементів використовуються завдання нарисної геометрії: побудова зображень поверхонь, лінії перетину поверхонь, перетворення комплексного креслення, які здійснюються в автоматизованому режимі в 3D-моделюванні. Для компонування зображень використовуються геометричні перетворення: способи перенесення, повороту, масштабування. Важливим принципом графічної підготовки є розумне поєднання традиційних і комп'ютерних технологій [153].

В результаті засвоєння курсу інженерної графіки студенти отримують навички прочитання креслень, зображення на них деталей i складальних креслень, а також знання стандартів Єдиної системи конструкторської документації (ЕСКД). Це стає особливо актуально в роботі з новими технічними засобами, при розробці і проектуванні сучасних пристроїв i технології їх виготовлення. Графічна грамотність $є$ найважливішою складовою багажу знань 
хорошого фахівця, адже мова графіки - це міжнародна мова спілкування. «Інженерна графіка» - перша дисципліна інженерного циклу 3 якою знайомляться студенти.

Системність теоретичних знань в області інженерної графіки та застосування їх на практиці сприяє розвитку технічного мислення. Важливо розвивати логічне, образне, просторове мислення і уяву, формувати систему знань, в тому числі професійних, розвивати практичне мислення за рахунок рішення різної складності завдань.

Можливості комп'ютерних технологій повинні не тільки зв'язати теорію 3 практикою, автоматизувати деякі види механічної, рутинної роботи на заняттях 3 нарисної геометрії та інженерної графіки, а й сприяти пізнавальної і творчої активності учнів. Комп'ютерні технології навчання повинні органічно вписатися в традиційні методи придбання знань по "Інженерної графіку" 3 метою підвищення ефективності процесу навчання.

Для успішного виконання своєї професійної діяльності інженер повинен володіти відповідним рівнем політехнічної і графічної підготовки, яка має на увазі розвиток технічного інтелекту, просторового мислення, творчої уяви, вміння i навичок в галузі графіки, вміння користуватися прикладними програмами автоматизованого проектування, наявність активного, творчого ставлення до процесу навчання, до професійної підготовки до майбутньої професії. 


\section{THEORETICAL ASPECTS OF MODERN ENGINEERING}

Включення 3D-технологій в навчальний процес дозволить підвищити інтерес до графічної діяльності, більш ефективно, в короткі терміни сформувати геометро-графічні вміння [154]. 


\section{SECTION 6. FOOD TECHNOLOGY}

\subsection{Research of technological properties and experimental substantiation of creation of technologies of meat products from ostrich meat}

Важливим завданням сучасної харчової промисловості та ресторанного бізнесу є створення технологій м'ясних виробів високої харчової та біологічної цінності, проте зі зниженим вмістом холестерину. Одним із шляхів вирішення цього завдання $\epsilon$ застосування в технологіях м'ясних виробів нових, альтернативних видів сировини, зокрема м'яса страуса.

Експериментальні дослідження проводилися у лабораторії кафедри інноваційних харчових і ресторанних технологій Харківського торговельноекономічного інституту Київського національного торговельно-економічного університету, а також у лабораторії кафедри фізики Харківського державного університету харчування та торгівлі.

Функціонально-технологічні властивості м'ясної сировини визначали за умов дослідження масової частки зв'язаної вологи до маси м'яса за методом пресування, масової частки зв'язаної вологи до загальної вологи, також за методом пресування. Втрату маси при термічній обробці визначали як різницю маси сирого зразка до маси термічно обробленого. Органолептична оцінка проведена з використанням бального методу [155].

У роботі використовували зразки м'яса страуса, яловичини, свинини, курятини в однакових пропорціях. Всього було проаналізовано 4 зразки:1- м'ясо страуса, 2 - курятина, 3 - свинина, 4- яловичина.

Дані показники вказують на вихід продукту, втрату маси при зберіганні, а також на стійкість до гнильної мікрофлори. Результати досліджень представлено на рисунку 1.1. 


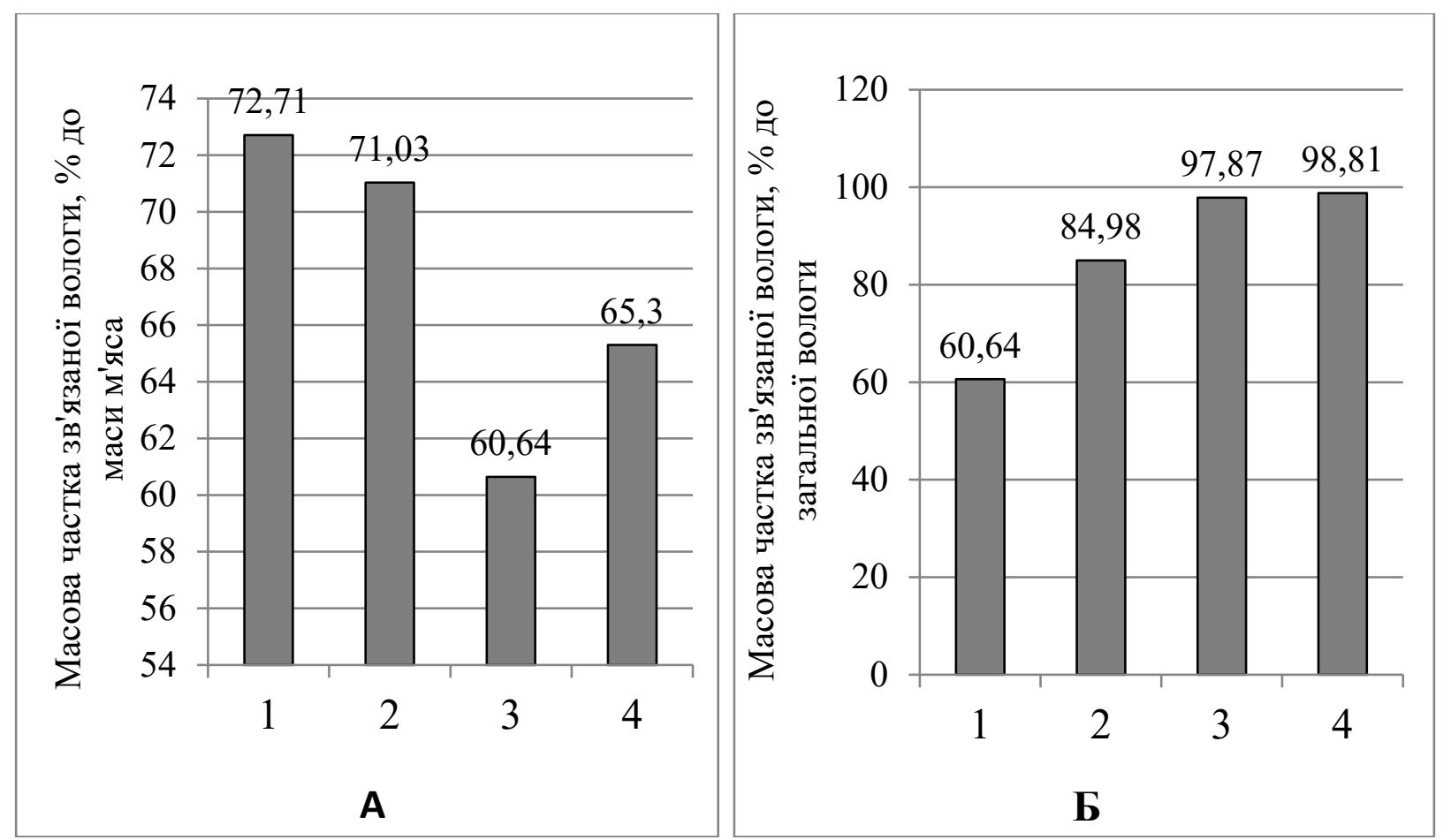

Рисунок 1.1 - Масова частка зв’язаної вологи до маси м'яса (а) та до загальної вологи (б), \%: 1 - страуса; 2 - курятини; 3 - свинини; 4 - яловичини

Аналіз даних, представлених на рисунку 2.1 показує, що найбільше значення масової частки зв'язаної вологи до маси м'яса спостерігали в зразку м’яса страуса. У порівнянні м’яса страуса та яловичини масова частка зв'язаної вологи до маси м’яса на 7,41\% вище (страусятина).

Порівнюючи результати слід зазначити, що масова частка зв’язаної вологи до загальної вологи за методом пресування у яловичині на 38,17\% вища, ніж у м’ясі страуса.

Підвищена вологозв'язувальна здатність усіх досліджуваних зразків порівняно з контрольним гіпотетично може забезпечити кращі органолептичні характеристики готових виробів, зокрема ніжність і соковитість, що потребує дослідження.

Завдяки високій вологозв’язувальній здатності та низькій масовій частці зв’язаної вологи за методом пресування його доцільно використовувати для виробництва других гарячих страв. Теплова обробка найбільш оптимальна для м’яса страуса, порівняно з свининою, курятиною, яловичиною, оскільки воно виділяє найменше вологи. Для приготування других гарячих страв - це важливий 
критерій. Приготовані страви будуть соковитими та корисними у харчуванні людей.

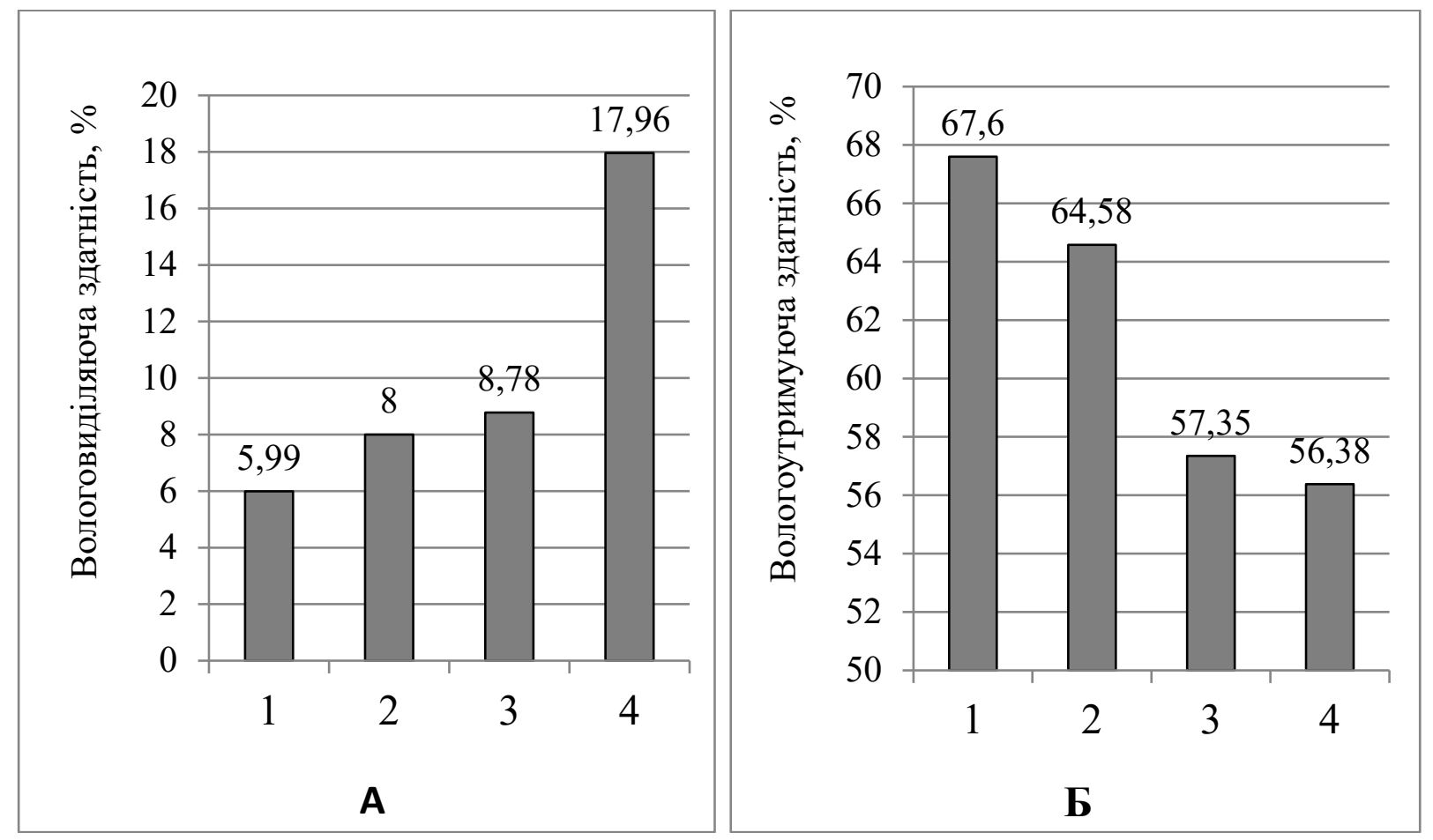

Рисунок 1.2 - Вологовиділяюча (а) та вологоутримуюча (б) здатність м'яса, \%:

1 - страуса; 2 - курятини; 3 - свинини; 4 - яловичини

Підтвердженням вищезазначеного $€$ показники вологовиділяючої здатності та вологоутримуюючої здатності (рис.1.2.). Так, у порівнянні 3 яловичиною, м'ясо страуса має на $11 \%$ вищу вологозв'язувальну та вологоутримуючу здатність, що може бути пов'язано із більшим вмістом білка в м'ясі страуса та меншим вмістом жиру. Вологоутримуюча здатність: 67,60\% м'ясо страуса; $56,38 \%$ - яловичина.

Здатність жирів утворювати емульсію залежить від природи жиру, температури його плавлення, ступеня подрібнення і наявності емульгаторів. Свинячий жир емульгується краще яловичого, оскільки легше подрібнюється і плавиться при більш низьких температурах. Температура середовища відіграє роль важливого емульгуючого фактора при утворенні водножирових дисперсійних систем [156]. 


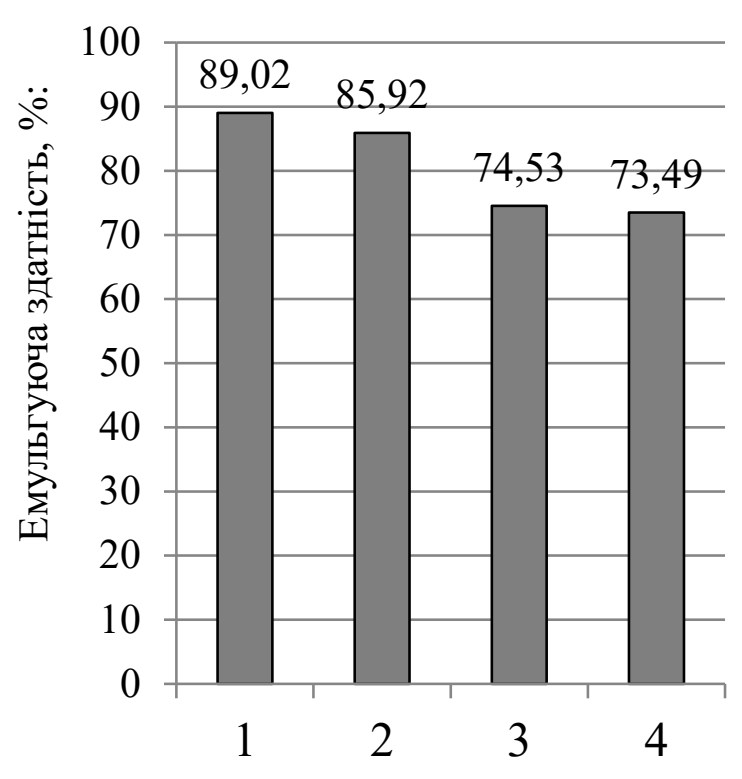

A

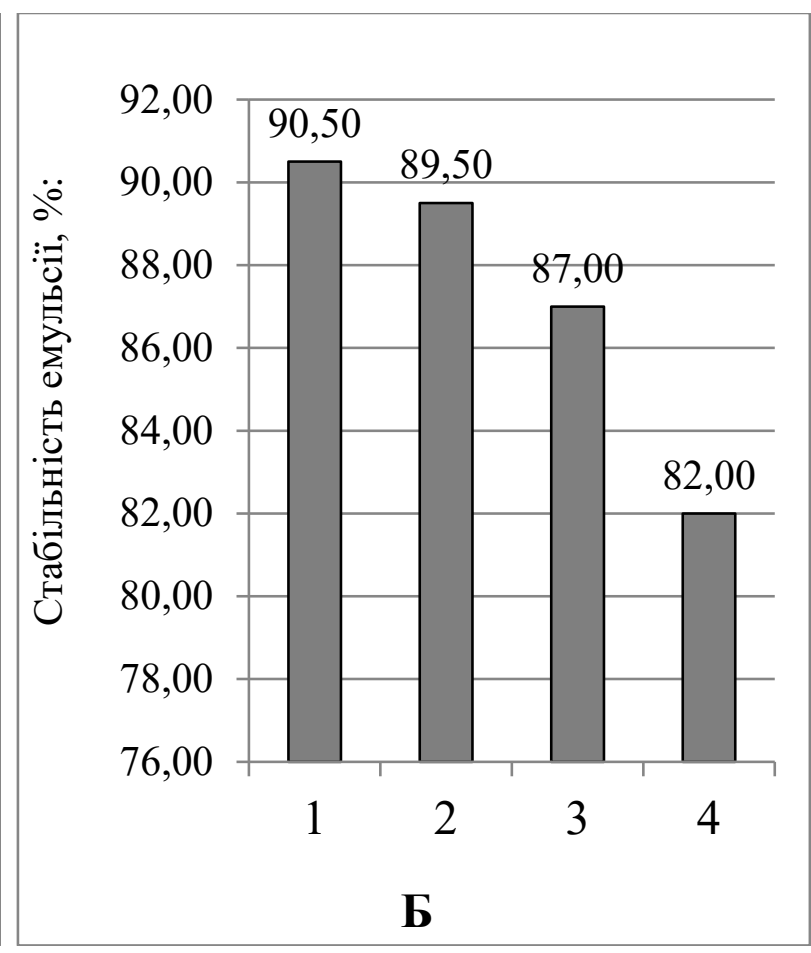

Б

Рисунок 1.3 - Емульгуюча здатність (а), стабільність емульсії(б), \%:

1 - м'яса страуса; 2 - курятини; 3 - свинини; 4 - яловичини

Під час розроблення технологій м'ясних страв важливо знати емульгуючі властивості м'ясної сировини (рисунок 1.3.). Виявлено, що м'ясо страуса має на 19 і 21\% кращу емульгуючу здатність, а самі емульсії характеризуються більшою стабільністю. Слід зазначити, що чим кращою $є$ емульгуюча здатність, тим меншою може бути температура під час термічної обробки м'яса. Відповідно, невеликий час приготування при однаковій температурі. А це, у свою чергу, веде до менших витрат енергії. Час приготування їжі визначає час очікування другої гарячої страви клієнтом.

Дані експериментального дослідження (рис.1.4) свідчать про те, що приготування других гарячих страв з м'ясом страуса мають найнижчі показники втрати маси під час теплової обробки (варіння, смаження). 


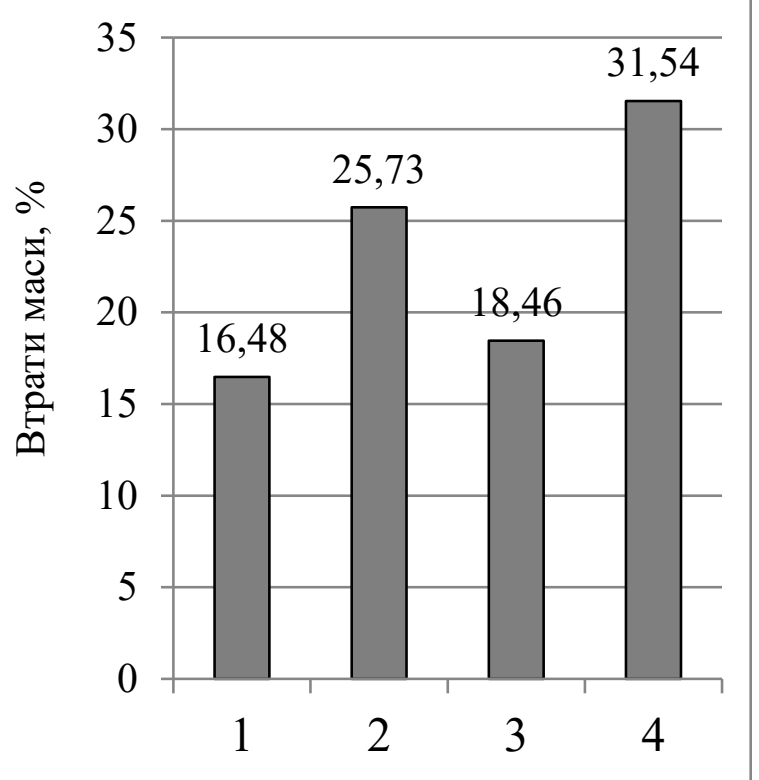

A

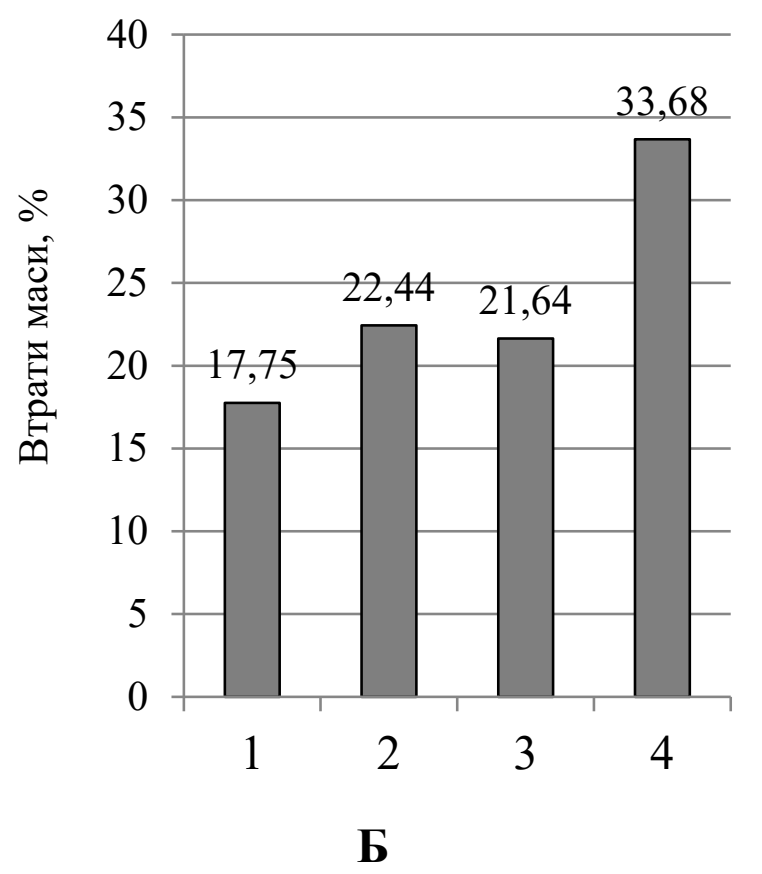

Б

Рисунок 1.4 - Втрати маси м'ясом під час варіння(а) та смаження(б),\%:

1 - страуса; 2 - курятини; 3 - свинини; 4 - яловичини

До недоліків страусятини як м'ясної сировини слід віднести підвищену порівняно з курятиною та свининою адгезію, що може ускладнювати процес перероблення цього виду м'яса у промислових масштабах [157]. У той же час адгезія для м'яса страуса на 10,5\% менша, ніж яловичини, що дозволяє обробляти м'ясо страуса на такому ж устаткуванні, що і яловичину.

Адгезія, із реологічних характеристик $є$ найважливішою. У технології виробництва м'ясних фаршів адгезія виявляється в момент формування м'ясних січених напівфабрикатів на котлетоформувальних апаратах. Із вищезазначеного можна зробити висновок про доцільність поєднання різних видів сировини у рецептурі других гарячих страв із м'яса страуса. 


\subsection{Use of oilseed polyfunctional supplements in the manufacture of meat products}

The ecological deterioration observed in the recent years in our country and globally results in higher morbidity rates. Besides, today, there is a tendency to a more hurried lifestyle, which tells on an average Ukrainian's dietary regimen and quality of nutrition. So, it seems necessary to modernise today's meat production technologies by improving their quality, expanding the range of products, and using raw materials more effectively.

A promising direction of research that allows implementing all the above is enriching meat with vitamins, minerals, and other substances that people generally lack for a balanced diet. To this end, appropriate functional ingredients should be purposefully selected. Particularly noteworthy are oilseeds due to their high nutritional value and specific functional and technological properties [158-160].

A thorough analysis of reference materials and research papers presenting the results of experimental studies has shown that a promising raw material to enrich traditional meat products (in particular, pâtés and chopped semi-finished products) is the seeds of pumpkins, sunflowers, sesame, and flax, which are unique in their chemical composition and pharmacological properties.

Meat is a high-value protein-containing edible raw material. However, there are cases when it needs enriching with vitamins, minerals, and other substances the lack of which makes a diet unbalanced. The problem is of theoretical and practical interest, and a great number of domestic and foreign studies prove it is still important. The results of the studies allow concluding that meat products with a well-balanced fatty acid, vitamin, and mineral content can be obtained by introducing raw material of plant origin (primarily oils and flours) into their formulation [161-162].

Thus, pumpkin seeds are a source of valuable bioactive agents. They have been proved to contain a lot of proteins (35\%), fats (40-55\%), essential oils, phytosterol cucurbitol, cucurbitin (0.5\%), phytin, organic acids (salicylic, malic), vitamins (carotene, carotenoids, ascorbic acid, and Group B vitamins - B1, B2, PP) - up to $0.2 \%[163-165]$. 
Laboratory studies show that ripe sunflower seeds contain the following substances: vitamin A, Group B vitamins (B1, B2, B5, B6, PP, B9), vitamins E, D; $\beta$ carotene and carotenoids; choline; mineral substances (selenium, manganese, magnesium, calcium, sodium, potassium, phosphorus, iron, zinc, copper); starch; mono and disaccharides; fatty acids; amino acids; phytosterols; dietary fibre; essential and fatty oils. These seeds provide the body with more than $100 \%$ of vitamins $\mathrm{E}$ it needs, and with $70 \%$ of Group B vitamins. The nutritional and caloric value of $100 \mathrm{~g}$ of the product is: proteins - about $20.2 \mathrm{~g}$; fats - about $53.5 \mathrm{~g}$; carbohydrates - about $10.6 \mathrm{~g}$; food energy - about $605 \mathrm{kcal}$ [166].

The percentage of the main nutrients in ripe sesame seeds: soluble carbohydrates - 16-20\%, proteins - 19-27\%, sesame oil - 53-65\%, ash - 5\%, phytosterols, sitosterols, phytin, amino acids, tocopherols, choline.

The percentage of the main nutrients in ripe flax-seeds (Linum usitatissimum): proteic substances - 18-33\%, mucilage - 5-12\%, carbohydrates - 12-26\%, nitrogen-free extractives $-22 \%$, fatty oils $-30-50 \%$, fatty acid triglycerides: linolenic $-30-45 \%$, linoleic $-25-59 \%$, oleic $-18-20 \%$, glyceride stearic $-8-9 \%$, palmitic, arachidic, myristic, and $\alpha$-tocopherol. The seeds contain phytosterols, enzymes, vitamins C, A, F. In flax seed coats, high-molecular compounds were found, which, when hydrolysed, release linocinamarin. Its action is similar to that of pilocarpine and carbachol, so flax seeds stimulate gastrointestinal activity [167].

Thus, there are unsystematised data on how some supplements of plant origin (among them oilseed-based ones) effect on meat raw material and finished meat products. However, we can find no information as for the systemic approach to developing oilseed-based complex supplements to be used in the forcemeat products technology. So, it should be studied and scientifically reasoned whether it is practical to combine different oilseeds when making a dietary supplement to be added to forcemeat products.

The purpose of the study is giving scientific reasons and creating a multifunctional dietary supplement, which is a mixture of different oilseed varieties, to be further used in the technology of meat pâtés and chopped semi-finished products. 
The objects of the study were products of the brand Sto pudiv (Kharkov, Ukraine), namely: flax-seeds (country of origin - Ukraine, nutritional value of $100 \mathrm{~g}$ of the product: proteins $-21.8 \mathrm{~g}$, fats $-39.5 \mathrm{~g}$, carbohydrates $-27.8 \mathrm{~g}$ ), sunflower kernels (country of origin - Ukraine, nutritional value of $100 \mathrm{~g}$ of the product: proteins $20.8 \mathrm{~g}$, fats $-51.4 \mathrm{~g}$, carbohydrates $-20.1 \mathrm{~g}$ ), sesame seeds (country of origin - India, nutritional value of $100 \mathrm{~g}$ of the product: proteins - $20.0 \mathrm{~g}$, fats $-40.0 \mathrm{~g}$, carbohydrates $-28.1 \mathrm{~g}$ ), pumpkin seeds (country of origin - Ukraine, nutritional value of $100 \mathrm{~g}$ of the product: proteins $-24.0 \mathrm{~g}$, fats $-33.1 \mathrm{~g}$, carbohydrates $-4.7 \mathrm{~g}$ ).

Model forcemeat systems were prepared by mincing the meat raw material (50\% of beef and $50 \%$ of chicken) in a laboratory mincer (the hole plate diameter $8 \mathrm{~mm}$ ).

At the first stage of the research, an analysis of scientific literature allowed selecting four oilseed varieties, namely sesame, flax, sunflower, and pumpkin seeds, as they were promising raw materials for bioactive supplements to meat products due to their valuable chemical composition and functional properties.

In meat products manufacturing technology, plant raw material can be preprocessed in different ways, and the most common preparatory operation is grinding, or crushing [164]. So, to improve the functional and technological characteristics of the samples, they were ground into particles as big as 800 to $350 \mu \mathrm{m}$, and the changes in the properties depending on the fineness of grinding were determined. In a similar way, model meat systems were studied, with the crushed seeds content $10 \%$ of the weight of the forcemeat. It has been determined that the more finely the seeds are ground, the higher is the water-binding capacity of meat systems. The highest waterbinding capacity was observed in the samples where seeds had been added ground into $350 \mu \mathrm{m}$ particles (Fig. 1). 


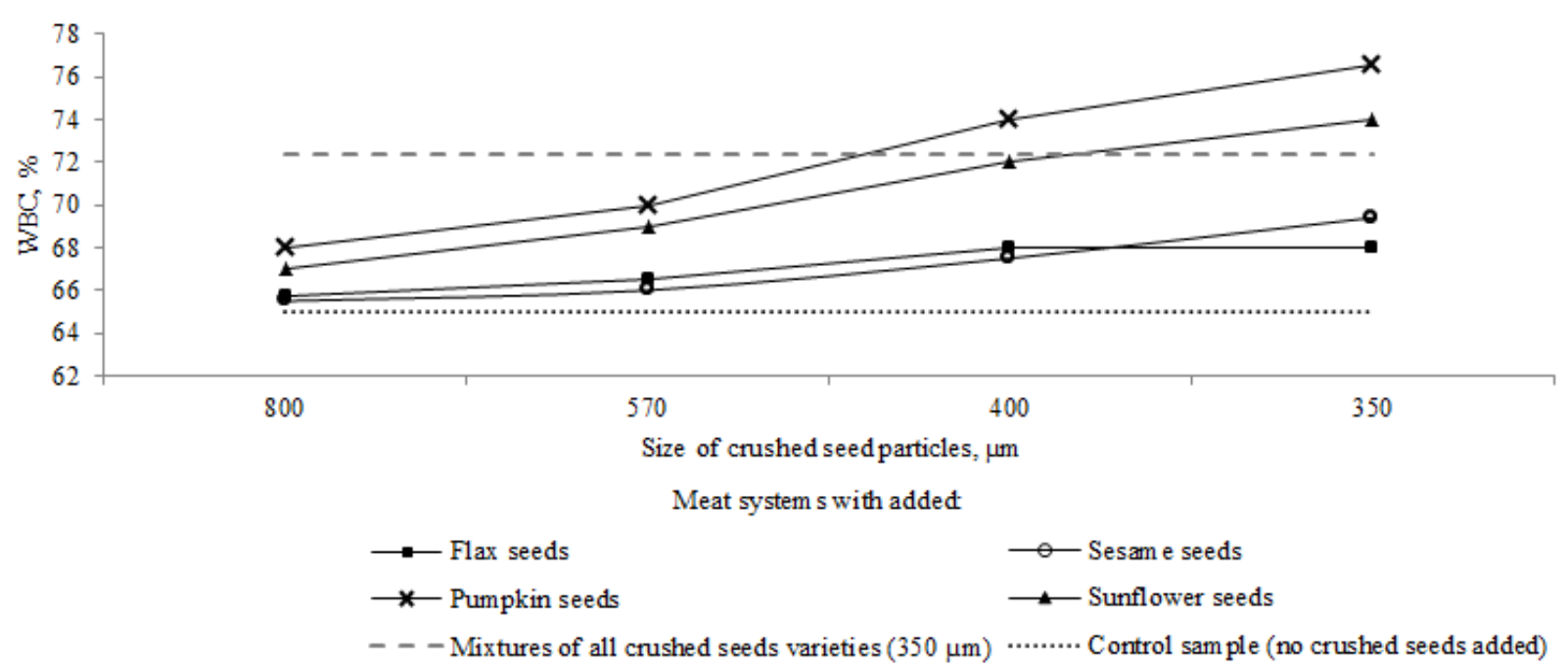

Fig. 1. Changes in the water binding capacity of meat systems containing seeds of different crops, depending on the size of the vegetable component particles

The results can be explained by fibre microcrystallisation that takes place while grains are finely crushed. During this process, there is an increase in fibre's waterabsorbing capacity and in its ability to form stable colloidal gel.

It has also been established that seeds crushed into $350 \mu \mathrm{m}$ particles, when added to meat systems, increase their fat holding capacity (Fig. 2).

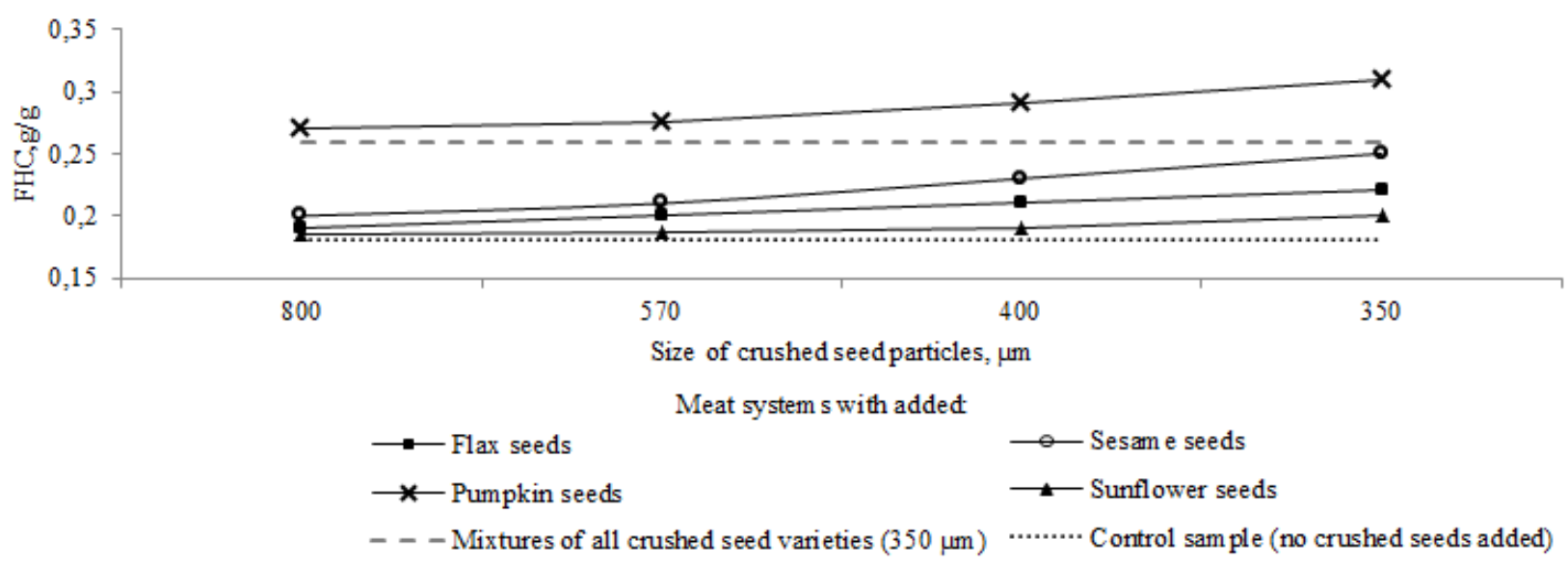

Fig. 2. Changes in the fat holding capacity of meat systems containing seeds of different oil crops, depending on the size of the vegetable component particles

This is important for the technology, as this parameter is responsible for the product's delicate and smooth texture, prevents fat separation, and reduces the weight loss during heat treatment. 
Besides, it has been observed that the output of the finished product increases by 3-5\%. This parameter is the highest for the samples with crushed pumpkin seeds added. The increased output reduces the loss of valuable water-soluble dietary and bioactive substances while water is lost during heat treatment.

As a most important parameter that allows evaluating whether a supplement can be used is its sensory properties depending on its individual compositional features, the content of certain components has been determined, primarily, by sensory evaluation. To this end, sesame, flax, sunflower, and pumpkin seeds, ground as fine as into $350 \mu \mathrm{m}$ particles were mixed together in different proportions. The content of certain components varied 10 to $50 \%$ (Table 1 ).

Table 1 - Selection of the components of the oil crops composite mixture

\begin{tabular}{|c|c|c|c|}
\hline \multicolumn{4}{|c|}{ Variant combination of the components of the oil crops composite mixture } \\
\hline \multicolumn{2}{|c|}{ Variant 1} & \multicolumn{2}{|c|}{ Variant 2} \\
\hline Seed variety & Percentage when added & Seed variety & Percentage when added \\
\hline sesame & $10 \%$ & sesame & $30 \%$ \\
\hline flax & $30 \%$ & flax & $10 \%$ \\
\hline sunflower & $30 \%$ & sunflower & $30 \%$ \\
\hline pumpkin & $30 \%$ & pumpkin & $30 \%$ \\
\hline \multicolumn{2}{|c|}{ Variant 3} & \multicolumn{2}{|c|}{ Variant 4} \\
\hline sesame & $30 \%$ & sesame & $30 \%$ \\
\hline flax & $30 \%$ & flax & $30 \%$ \\
\hline sunflower & $10 \%$ & sunflower & $30 \%$ \\
\hline pumpkin & $30 \%$ & pumpkin & $10 \%$ \\
\hline \multicolumn{2}{|c|}{ Variant 5} & \multicolumn{2}{|c|}{ Variant 6} \\
\hline sesame & $25 \%$ & sesame & $20 \%$ \\
\hline flax & $25 \%$ & flax & $20 \%$ \\
\hline sunflower & $25 \%$ & sunflower & $10 \%$ \\
\hline pumpkin & $25 \%$ & pumpkin & $50 \%$ \\
\hline
\end{tabular}

The qualitative characteristics of the experimental supplement are given in Tables 2 and 3. 
Table 2 - Physico-chemical and functional and technological characteristics of the experimental supplement

\begin{tabular}{|l|c|l|c|}
\hline \multicolumn{2}{|c|}{ Physico-chemical characteristics } & \multicolumn{2}{c|}{ Functional and technological characteristics } \\
\hline $\begin{array}{l}\text { Mass fraction of moisture, } \\
\%\end{array}$ & 8.30 & Water holding capacity, g water/g product & 2.8 \\
\hline Mass fraction of protein, \% & 21.40 & Fat holding capacity, g fat/g product & 0.8 \\
\hline Mass fraction of fat, \% & 44.70 & Emulsifying efficiency, \% & 89 \\
\hline $\begin{array}{l}\text { Mass fraction of } \\
\text { carbohydrates, \% }\end{array}$ & 22.50 & Critical gelation concentration, \% & 45 \\
\hline in particular, fibre, $\%$ & 2.10 & Hydromodulus at $20^{\circ} \mathrm{C}$ & $1: 3$ \\
\hline Mass fraction of ash, \% & 1.00 & $\mathrm{pH}$ & 5.8 \\
\hline
\end{tabular}

Table 3 - Sensory characteristics of the experimental supplement

\begin{tabular}{|l|l|}
\hline \multicolumn{1}{|c|}{ Parameter } & \multicolumn{1}{c|}{ Description } \\
\hline Appearance & Friable loose-textured powder \\
\hline Colour & Light creamy, with brown flax inclusions \\
\hline Odour & No off-odours, no mouldy or stale smell \\
\hline Taste & Taste of raw seeds, with a specific tinge of flavour \\
\hline
\end{tabular}

The studies evidence that the gustatory and aromatic features of the whole supplement and of its individual components are quite pronounced. Nevertheless, at a certain concentration, they do not affect the sensory characteristics of finished products.

The biological value of any functional supplement is as important. It is known that oilseed proteins are high in various essential amino acids. Table 4 presents the amino acid composition of the supplement under analysis.

It has been established that the supplement can be a source of high quality protein (21-22\%). A considerable carbohydrate content, where starch and fibre prevail, results in the complex supplement's water and fat binding capacity. Besides, it has a positive effect on its emulsifying efficiency and gel-forming capability. 
THEORETICAL ASPECTS OF MODERN ENGINEERING

Table 4 - Amino acid composition of the supplement (per $100 \mathrm{~g}$ protein)

\begin{tabular}{|l|c|l|c|}
\hline \multicolumn{2}{|c|}{ Essential amino acids, g } & \multicolumn{2}{c|}{ Non-essential amino acids, g } \\
\hline Lysine & 5.40 & Alanine & 4.37 \\
\hline Valine & 5.26 & Arginine & 11.59 \\
\hline Methionine + cystine & 1.93 & Aspartic acid & 9.26 \\
\hline Isoleucine & 4.26 & Histidine & 2.54 \\
\hline Threonine & 3.94 & Glycine & 6.4 \\
\hline Leucine & 6.90 & Glutamic acid & 19.17 \\
\hline Phenylalanine + tyrosine & 4.00 & Oxyproline & 0.00 \\
\hline Tryptophan & 1.60 & Proline & 4.30 \\
\hline Total & 33.29 & Serine & 4.56 \\
\hline & & Total: & 62.19 \\
\hline Total amino acids & & 95.48 \\
\hline
\end{tabular}

However, the presence of all essential amino acids in the composition of protein is not enough to make it nutritionally valuable. That is why, to determine the biological value of the supplement, the amino acid score has been calculated - the percentage of each amino acid compared to its content in protein taken as standard (ideal protein). The amino acid score calculated for the experimental supplement is shown as a chart (Fig. 3).

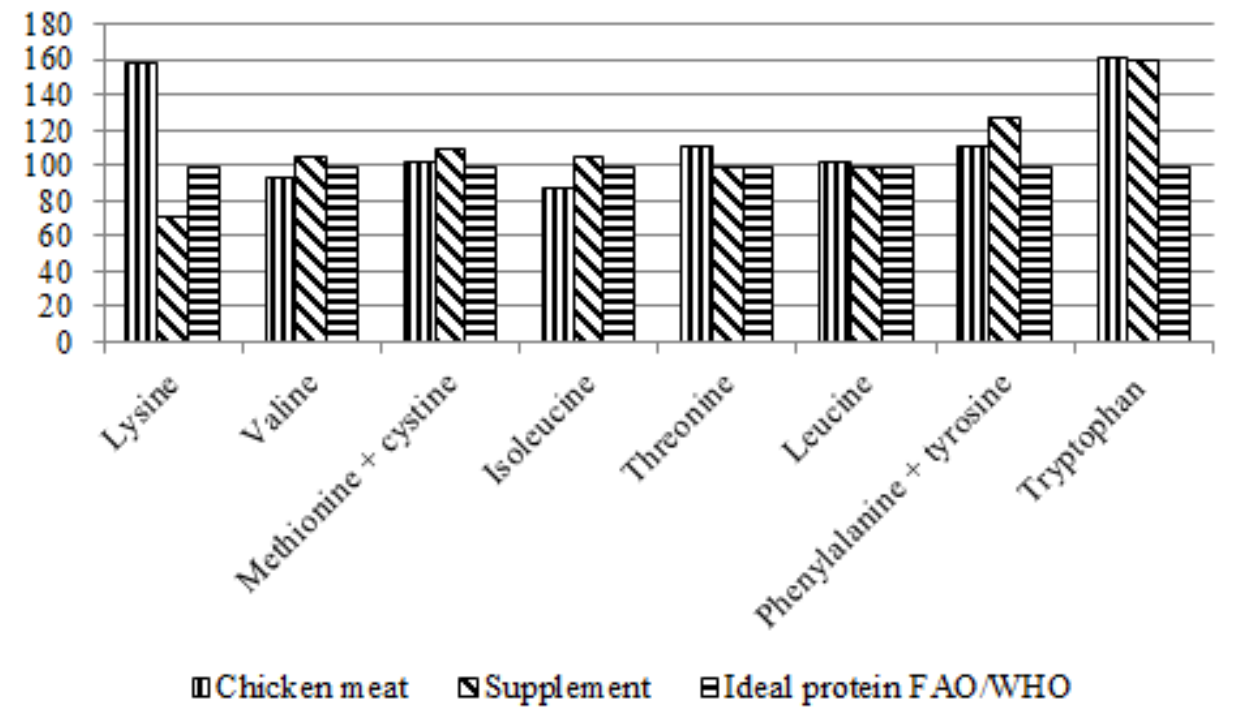

Fig. 3. Amino acid score (\%) of the supplement, of chicken meat (category 1), and of 'ideal protein' 
In the experimental supplement, the limiting amino acid is lysine, which is typical of proteins contained in seeds. This disadvantage can be cancelled out by combining the supplement with proteins of animal origin (in particular, with chicken meat) or with animal fat. As the amino acid compositions of vegetable and animal proteins complement each other, it can make the protein well-balanced, and the biological value of the composite product can become adequate for the body's needs.

When using structure-forming dietary supplements, one should know their hydromodulus (proportion of water), as gel-formation is only possible at a certain concentration of proteins and polysaccharides. To determine the optimum hydromodulus for the experimental supplement, a series of experiments has been carried out, with different mass fractions of moisture at $20^{\circ} \mathrm{C}$. The results of the experiments have shown that one part of the supplement can strongly bind 3-3.5 parts of water. That is why, the recommended hydromodulus is $1: 3$. Besides, the experiments made it possible to determine the optimum resting time of gel and the dependence of its viscosity on the temperature. The results are presented as a graph in Fig. 4.

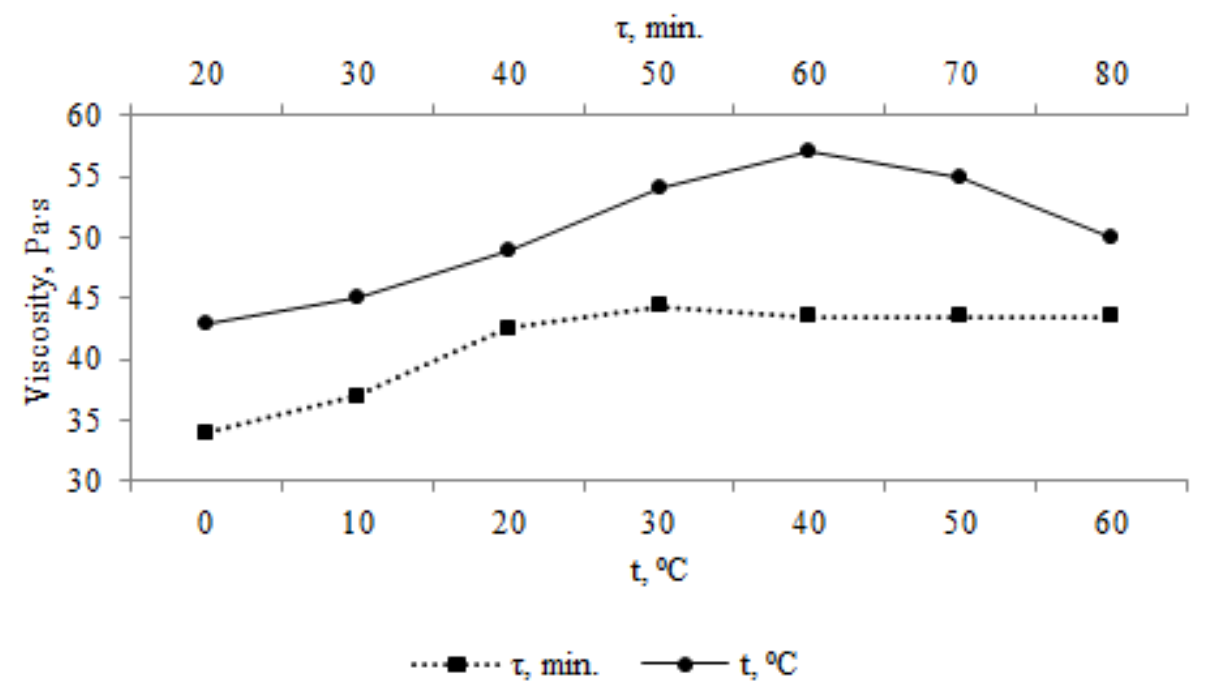

Fig. 4. Dependence of gel viscosity on the temperature and resting time

The study has shown that gel's optimum resting time is 30 minutes. Within this interval, gel stabilises, and during the further resting time, it gets no stronger. As seen in Fig. 4, when gel is heated to $60^{\circ} \mathrm{C}$, its viscosity increases, and if the temperature rises, this parameter decreases, which can be explained by protein denaturation. 
Today, the manufacture of meat products is rather empirical: recipes are based on sensory data, and the technology is traditional in its structure, in the set and sequence of operations using traditional equipment. The optimum amount of the mixture in the formulations of pâtés and chopped semi-finished products has been determined by sensory evaluation of model forcemeat systems. The content of the supplement varied 5 to $25 \%$.

To evaluate the quality of a product, sensory analysis has an advantage as it allows determining quite quickly whether a product is safe to consume. The parameters like colour, taste, odour, consistency give a general idea of the product and help make the right choice of the main ingredients and their ratio. The research results make it possible to conclude that the supplement's percentage in the formulations of chopped semi-finished products should not be more than $20 \%$, and in those of meat pâtés, not more than $15 \%$, as a higher percentage of the supplement results in worse sensory characteristics.

Based on an analysis of research papers and reference materials, the properties of different oilseed varieties have been studied. Four oilseed varieties have been selected as the most promising to be used in meat product technologies, namely, sesame, flax, sunflower, and pumpkin seeds. A model of the seed mixture composition has been created. It has been established that the equal ratio of the seed varieties in the composition of the complex supplement is the optimum. On analysing the functional and technological properties of the four varieties of the seed raw material, it has been established that the oilseed crops can be modified by mechanodestruction. It has been shown that crushing seeds effects positively on such parameters as water binding and fat holding capacities, as well as on forcemeat output. Experimentally, it has been determined that the optimum hydromodulus for the supplement developed is $1: 3$, with the gel resting time 30 minutes at $60^{\circ} \mathrm{C}$.

The model samples of meat pâtés and chopped semi-finished products have been organoleptically evaluated. The evaluation results have made it possible to recommend including $15-20 \%$ of the oilseed mixture into the composition of these meat products. 


\section{SECTION 7. INFORMATICS, COMPUTER ENGINEERING AND AUTOMATION}

\subsection{Monitoring and forecasting systems for electricity consumption in educational institutions}

Підвищення ефективності використання первинних енергетичних ресурсів та енергії є однією з актуальних проблем. Зменшення обсягів використання теплової, електричної енергії можливе за рахунок техніко-технологічного удосконалення основних та допоміжних процесів. Іншим, не менш важливим фактором, є розробка та впровадження організаційно-технічних заходів, які стосуються режимів функціонування підприємств та організацій, узгодження між собою режимів електро- та теплоспоживання, регулювання електроспоживання. Вирішення проблеми підвищення енергоефективності технологічних процесів - це, перш за все, скорочення витрат електричної енергії. За існуючих технологій генерації електричної енергї в Україні на теплових та атомних електростанціях, скорочення споживання електричної та теплової енергії пов’язане зі скороченням генерації електроенергії, a, отже, i зі зменшенням викидів у атмосферу парникових газів та інших забруднюючих речовин. Будь-який технологічний процес (якщо навіть у ньому не утворюються шкідливі для довкілля відходи), у якому використовується електроенергія завжди має негативний «екологічний слід», тому проблема ефективного та економного використання електричної енергії є загальнодержавною у будь-якій країні. Однією з основних умов досягнення успіху у діяльності щодо підвищення енергоефективності технологічних процесів має бути можливість отримання поточної інформації про реальне енергоспоживання об'єктом (підприємством, установою, повним циклом окремого технологічного процесу, обладнанням тощо). Для цього, згідно чинного законодавства [168], енергоресурси, які використовують енергоспоживаючі пристрої (агрегати), мають бути обраховані 3 використанням приладів обліку (лічильників). Здебільшого такі лічильники побудовані за різним принципом дії, але їх об’єднує одна особливість: вони 
фізично фіксують обсяги енергоресурсів наростаючим підсумком, тобто фіксують проходження через вузол обліку (лічильник) енергоресурсу у кількості, яка визначається наперед заданими одиницями виміру. Тобто, інформація щодо спожитих обсягів енергоресурсу накопичується, архівується (у тому чи іншому вигляді) у, практично, автоматичному режимі без участі людини. При цьому проблематичним є організація процесу зчитування такої інформації у визначені моменти часу. Здебільшого це виконує людина з занесенням результатів на паперові або електронні носії інформації, формуючи відповідні бази даних про споживання енергоресурсу за певні проміжки часу. Робота кропітка, має значну трудомісткість, не завжди виконується персоналом у точно визначені моменти часу, що вносить певні невідповідності у результати документального оформлення результатів фіксації обсягів енергоспоживання. За чинними нормами та правилами зняття показань лічильників та оформлення результатів комерційної взаємодії між споживачем та постачальником проводиться через певний проміжок часу, який визначається умовами договору між контрагентами. За цих умов організація неперервного контролю поточного енергоспоживання у споживача постачальником практично не можлива, бо лічильник зазвичай знаходиться у споживача, або у віддалених від персоналу постачальника місцях. Така ситуація практично унеможливлює контроль дотримання споживачем умов використання потужності споживання енергоресурсу без застосування додаткових засобів обмеження ï граничних значень, обумовлених режимами енергоспоживання або максимальними величинами, які визначаються умовами договору. Крім того проблемною $є$ організація формування добових «профілів» енергоспоживання для контролю ефективності використання енергоресурсів протягом доби. Звісно, зазначені проблеми є стримуючим фактором підвищення енергоефективності споживання енергоресурсів, «вирівнювання» добових графіків енергоспоживання, визначення поточних величин питомого використання електроенергії та інших енергоносіїв через велику трудомісткість та низьку оперативність їх отримання. 
Подальшим кроком щодо усунення зазначених недоліків, усунення «людського фактору» у процесі отримання даних щодо споживання електроенергії є запровадження АСКОЕ (автоматизованих систем комерційного обліку електроенергії). Впровадження таких систем дає змогу автоматизувати процес обліку спожитих енергоресурсів (електроенергії) протягом визначених періодів часу з можливістю виконання відповідного протоколу, виключивши «людський фактор».

Система розрахована на можливість використання ï інформаційних потоків для визначення обсягів споживання електроенергії при формуванні протоколів для комерційних розрахунків між споживачем та постачальником. Це накладає свої обмеження на обладнання та формування каналів зв'язку системи. Вони мають бути веріфіковані з метрологічної точки зору, мати захист щодо спотворення результатів вимірювань при їх передачі інформаційними каналами, а також захищені від не санкціонованого стороннього втручання. Виходячи 3 економічної доцільності постачальники електроенергії зацікавлені та наполягають на впровадженні таких систем у господарствах споживачів, струмоприймачі яких споживають значні обсяги електроенергії, а також мають декілька пунктів обліку споживання. Первинним елементом системи є лічильник електричної енергії, який функціонально такий же як і звичайний електронний лічильник. Однак, додатково він повинен мати так званий цифровий вихід для організації інформаційних потоків від лічильника через проміжні пристрої, які можуть формувати проміжні бази даних, до центрального сервера. Центральний сервер формує протоколи системи, за якими надається інформація щодо обсягів споживання електроенергії за певні визначені проміжки часу. Така інформація отримується від електричного лічильника i $\epsilon$ інтегральною щодо всіх струмоприймачів, які споживають електроенергію, що надходить через нього. Дійти до обрахунку споживання кожним окремим споживачем $є$ проблематичним з економічної точки зору і потребує значних капітальних вкладень. Однак, інформаційні потоки системи АСКОЕ можна використовувати для моніторингу фактичного електроспоживання у минулі періоди часу. 
Зважаючи на метрологічні та безпекові аспекти зазвичай цією інформацією користуються більше «візуально», без автоматичного інтегрування iï баз даних в інші системи. Позитивним результатом впровадження є виключення з процесів АСКОЕ «людського фактору», а також можливість отримання інформації для формування профілів добового споживання струмоприймачами електроенергії за минулі періоди часу з метою проведення детального техніко-економічного аналізу функціонування споживачів. Середні витрати на впровадження однієї точки обліку системи АСКОЕ наразі оцінюються у 30 тис. грн. Вони включають вартість обладнання, вартість програмного забезпечення, вартість налагоджувальних робіт [169].

Описані інформаційні можливості систем АСКОЕ в основному фіксують обсяги енергоспоживання у минулих періодах, дають можливість, 3 використанням інших інформаційних технологій, визначати профілі добового електроспоживання. Однак, вони не можуть дати вичерпну відповідь на питання: «На скільки доцільними та виправданими 3 технічної та організаційної точки зору були витрати електроенергії у той чи інший період часу?» Для відповіді на це запитання мають формуватися інформаційні масиви автоматизованих систем моніторингу електроспоживання. У їх побудові використовується принцип контролю, за яким визначається фактичне електроспоживання у певні періоди часу, розраховуються питомі чи інші величини показників споживання струмоприймачами та порівнюються 3 розрахунковими контрольними показниками електроспоживання, які визначаються з урахуванням умов та режимів функціонування струмоприймачів. Оцінювання коректності обсягів споживання електроенергії (ефективності функціонування систем енергозабезпечення об'єктів) визначається співставленням зазначених фактичних та розрахункових контрольних показників. У разі їх не відповідності протокол системи має сигналізувати персоналу про необхідність внесення коректив у режими функціонування таких систем для їх повернення до розрахункових у майбутні або поточний періоди. У більшості випадків за таких умов ми можемо отримати відповідь на питання: «Виграли чи програли у минулі 
періоди?» без можливості корегування 3 урахуванням зміни умов функціонування струмоприймачів у майбутньому (нехай і короткотерміновому).

Реалізація визначених функцій системою моніторингу може відбуватися 3 використанням баз даних, які можуть формуватися: 3 використанням інформаційних масивів АСКОЕ, 3 використанням власних баз даних щодо фактичного електроспоживання струмоприймачами, які можуть створюватися у автоматичному режимі апаратними засобами самої системи.

Як вже зазначалося, використання баз даних АСКОЕ в автоматичному режимі є проблематичним. Тобто, перенесення інформації з АСКОЕ до баз системи моніторингу здебільшого відбувається у майже «ручному» режимі. Формування власної інформаційної бази системи моніторингу щодо фактичного споживання електроенергії має використовувати власний комплекс обладнання, включаючи первинні датчики зняття показань, накопичувачі та передавачі інформації з використанням окремих або існуючих інформаційних мереж, обладнання центрального сервера. При цьому слід звернути увагу на те, що такі системи формально не мають статусу функції комерційного обліку споживання електроенергії і їx інформацію не можна використовувати при оформленні протоколів взаємних комерційних розрахунків між постачальником та споживачем. Однак, це не означає, що точність фіксації показань системою не відповідає точності АСКОЕ. Крім того, як вже зазначалося, чинне законодавство та нормативна база не вимагає оснащення АСКОЕ невеликих споживачів, якими у більшості випадків є заклади освіти. Тобто, впровадження у них систем моніторингу споживання електроенергії не є дублюванням АСКОЕ i, 3 економічної точки зору, у більшості випадків є виправданим.

Врахування змінних зовнішніх та внутрішніх факторів, які впливають на функціонування струмоприймачів та їх електроспоживання при визначенні планових обсягів електроспоживання у минулих, поточних та майбутніх періодах можливе у інформаційних системах моніторингу та короткострокового прогнозування обсягів споживання електричної енергії, які доцільно застосовувати у закладах освіти. У навчальних закладах на профіль споживання 
електроенергії значною мірою впливають розклад занять (на яких у навчальному процесі використовуються гаджети, що споживають електроенергію), змінні кліматичні (погодні) умови, які впливають на освітленість робочих місць, обсяги виконання допоміжних процесів, а також споживання електроенергії у процесах не пов’язаних з навчальним. Тобто, необхідно створити математичну модель електроспоживання.

Фундаментальні науково-методичні підходи до створення моделей процесу електроспоживання, організації на основі даних вимірювань 3 використанням сучасних методів декомпозиції запропоновані в роботі [170]. Зокрема автором запропоновано варіант апаратно-програмного комплексу для моніторингу штатного режиму процесу електроспоживання організації.

На окрему увагу заслуговують роботи в яких розглядаються питання планування та управління використанням електричної енергії в бюджетних установах i, зокрема, у навчальних закладах $[171,172,173]$. Зокрема, в роботі [172] на основі використання реальних статистичних даних одержані регресійні моделі електроспоживання у будівлях вищого навчального закладу (гуртожитках). В роботі [173] доведено ефективність використання методів, заснованих на деревах регресії, при короткотерміновому прогнозуванні навантаження. При цьому автори пропонують враховувати крім зовнішніх факторів (температура навколишнього середовища) також і внутрішні, календарні змінні (розклад занять, час проведення занять та ін.).

Останнім часом на українському ринку послуг, пов’язаних iз енергоефективністю та енергоощадністю, з’явився ряд програмних продуктів від різних розробників, основною функцією яких $є$ програмно-апаратна підтрика моніторингу споживання енергоресурсів. Достатньо грунтовний аналіз таких програмних продуктів здійснено експертами Асоціації «Енергоефективні міста України» в рамках реалізації одного 3 компонентів Ініціативи «Розумний енергетичний менеджмент в ОТГ», що впроваджується за дорученням Програми «U-LEAD з Свропою» компанією «Deutsche Gesellschaft fur Internationale 
Zusammenarbeit (GIZ) GmbH» [174]. Ці програмні продукти є, як правило, багатофунціональними та такими, що дозволяють організувати систему моніторингу та управління електроспоживанням складних промислових систем, населених пунктів, групи будинків та ін.

Для реалізації системи прогнозування та моніторингу споживання електроенергії на рівні окремих об’єктів (наприклад закладів освіти, медичних закладів та ін.) виникає необхідність у розробці простого апаратно-технічного та програмного забезпечення яке б забезпечувало, при цьому, необхідний рівень виконання всіх функцій, притаманних складним програмним продуктам.

Необхідною передумовою для розробки таких програмних продуктів є уточнення методики обрахунку величин нормального енергоспоживання, яка б враховувала короткотермінові зміни технологічного процесу та зовнішні змінні умови його виконання. Моделювання електроспоживання повинно спиратися на вихідні дані, які коректно характеризують процеси енергоспоживання. Їх визначення $\epsilon$ складною задачею i без диференціації загальних показників електроспоживання цього зробити майже не можливо. Застосування методик формування «спектру» електроспоживання, які поєднують розрахункові, статистичні методи моделювання мають підвищити точність визначення складових електроспоживання окремими системами та точність прогнозування. Результати проведених досліджень показують можливість створення «спектру» енергоспоживання (диференціацію електроспоживання за окремими групами струмоприймачів) 3 використанням результатів проведення енергетичного аудиту навчального закладу. Графічну інтерпретацію усередненого добового «спектру» електроспоживання навчального закладу представлено на рис. 1 [175]. За структурою споживання струмоприймачі можна розділити за системами в яких вони використовуються:

- системи штучного освітлення приміщень де проводяться основні та допоміжні технологічні процеси; 
- системи виконання основного технологічного процесу та допоміжних процесів (навчального процесу та допоміжних до нього);

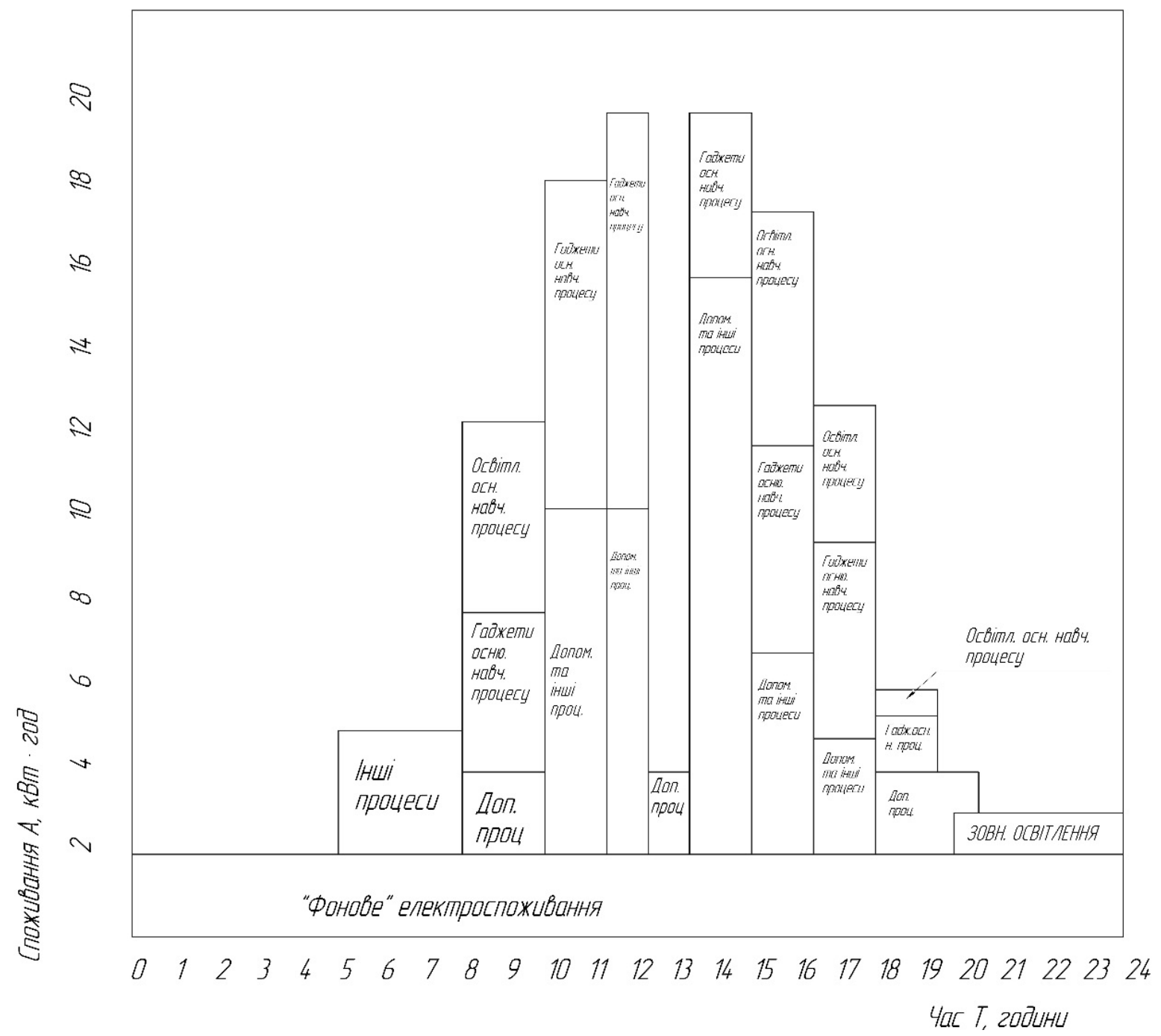

Рисунок 1. Графічна інтерпретація усередненого добового «спектру» електроспоживання навчального закладу.

- системи енергозабезпечення будівель та процесів, а також їх підтримки;

- системи забезпечення адміністративної діяльності та побутових потреб.

За цією градацією характер споживання електроенергії струмоприймачами пропонується визначати, виходячи 3 аналізу режимів їх функціонування, враховуючи структуру елементів «спектру». Автоматизацію процесу розрахунку лімітних показників прогнозованого електроспоживання пропонується виконувати з використанням можливостей комп'ютерної техніки та створенням алгоритмів і програм у існуючих пакетах. Об’єднання та візуалізацію результатів 
поточного контролю обсягів електроспоживання та відповідного прогнозу, оцінювання їх не відповідності пропонується виконувати 3 використанням математичних методів моделювання, що дає можливість створення автоматизованих комплексів короткотермінового прогнозування та моніторингу їх електроспоживання.

Протягом доби спостерігається «фонове» електроспоживання, тобто у будівлі функціонують струмоприймачі систем безперебійної підтримки функціонування процесів, які виконуються у будівлі, а також систем енергетичної та функціональної підтримки самої будівлі. При аналізі електроспоживання його можна виділити 3 загального обсягу електроспоживання як константу. Врахування впливу кліматичних факторів на обсяги та характер споживання електричної енергії можливе шляхом аналізу напрацьованого за певний час масиву статистичних даних метеорологічних спостережень, поточної та прогнозної інформації щодо погодних умов місцевості (території) розташування закладу. Характер споживання електроенергії струмоприймачами пропонується визначати, виходячи з аналізу режимів їх функціонування. Накопичення статистичних даних щодо складових «спектру» електроспоживання у подальшому дозволяє при прогнозуванні обсягів споживання застосовувати i iнші способи моделювання процесів енергоспоживання.

Повертаючись до систем штучного освітлення, зазначимо, що їх використання має забезпечувати необхідний санітарно-гігієнічний рівень освітленості робочих місць та інших приміщень. Обсяги споживання ними електричної енергії мають визначатися фактичною $P_{\text {осв.факт. }}$ (або установленою $P_{\text {осв.усm. }}$, яко їх величини співпадають) електричною потужністю та періодом проведення технологічного процесу $t_{\text {осв. }}$ протягом якого освітленість нижче

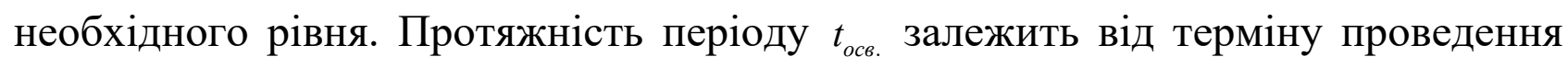
технологічного процесу, графіку функціонування закладу, кліматичних умов. Вплив кліматичних умов можна враховувати 3 використанням кліматичного 


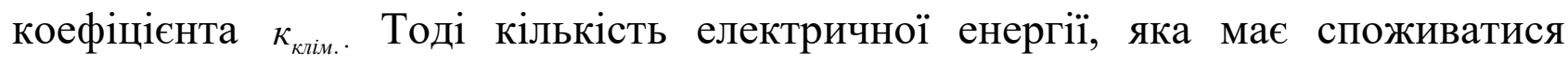
струмоприймачами систем штучного освітлення $A_{\text {осв. }}$ може бути розрахована за виразом:

$$
A_{\text {осв. }}=P_{\text {осв.факт. }} \cdot t_{\text {осв. }} \cdot \kappa_{\text {клім. }}
$$

Аналогічно, за формулою (1) можна розрахувати обсяги споживання електроенергії системами освітлення будь-якого приміщення.

Розрахунок обсягів споживання електричної енергії власне у навчальному процесі має виконуватися 3 урахуванням встановленої потужності струмоприймачів $P_{\text {навч. }}$, які задіяні у навчальних технологіях та періоду часу $t_{\text {навч. }}$ протягом якого вони використовуються на визначеному занятті та у визначеній аудиторії. $t_{\text {навч. }}$ залежить від виду занять (лекційні, практичні та інші), а також від дисципліни та ऑii тематики. Для спрощення алгоритму автоматизованого розрахунку прогнозованих обсягів електроспоживання доцільно оперувати відносною величиною $\kappa_{3}$ часу використання струмоприймачів $t_{\text {навч. }}$ до загального (календарного ) часу проведення заняття $t_{\text {календ. }}$ яка розраховується як коефіцієнт завантаження (використання) за виразом $\kappa_{3}=t_{\text {навч. }} / t_{\text {калоенд. }}$

Тоді розрахунковий обсяг споживання електричної енергії струмоприймачем протягом заняття $A_{\text {навч. }}$ визначиться за виразом:

$$
A_{\text {навч. }}=P_{\text {навч. }} \cdot t_{\text {календ. }} \cdot \kappa_{3} .
$$

Аналогічно формулі (2) мають бути розраховані інші складові «спектру» електроспоживання. Сумарні обсяги прогнозованого електроспоживання мають розраховуватися як сума визначених складових. Вони мають формуватися за періодами доби, які відповідають розкладу проведення занять та тривалості робочого дня допоміжних підрозділів, формуючи профілі електроспоживання будівлею. Дані можуть бути сформованими у вигляді таблиць та графіків 
прогнозного споживання на наступну добу. Алгоритм системи дозволяє вносити корективи у результати прогнозного розрахунку по закінченню поточного періоду, якщо в ньому виникли суттєві зміни вихідних даних, пов'язаних зі зміною розкладу занять, чи зміною метеорологічних умов. Структурна схема інформаційних блоків алгоритму розрахунку прогнозних обсягів споживання електроенергії у навчальному процесі представлено на рис. 2 [175]. За цією схемою інформаційні потоки формуються за декількома базами даних, джерелами яких є константи, що корегуються періодично в залежності від зміни параметрів будівлі або навчальних приміщень (постійна база даних), змінні величини, які залежать від розкладу занять (змінна база даних) та змінні величини, які характеризують вплив на електроспоживання поточних кліматичних (погодних) змін (інформаційний метеопортал). Окрім цих інформаційних потоків сервер системи потребує поточної інформації щодо реального електроспоживання. Їх джерелом може бути інформаційна база АСКОЕ. Однак, як вже зазначалося у більшості випадків іiі використання $\epsilon$ проблематичним.

Система моніторингу електроспоживання складається 3 програмноалгоритмічної і апаратної частин. В свою чергу програмно-алгоритмічна частина поділяється на дві складові: алгоритми прогнозу споживання електроенергії і алгоритми аналізу результатів. Більш детальний опис складу системи i структурної схеми процесу моніторингу ілюструє рис. 3. 


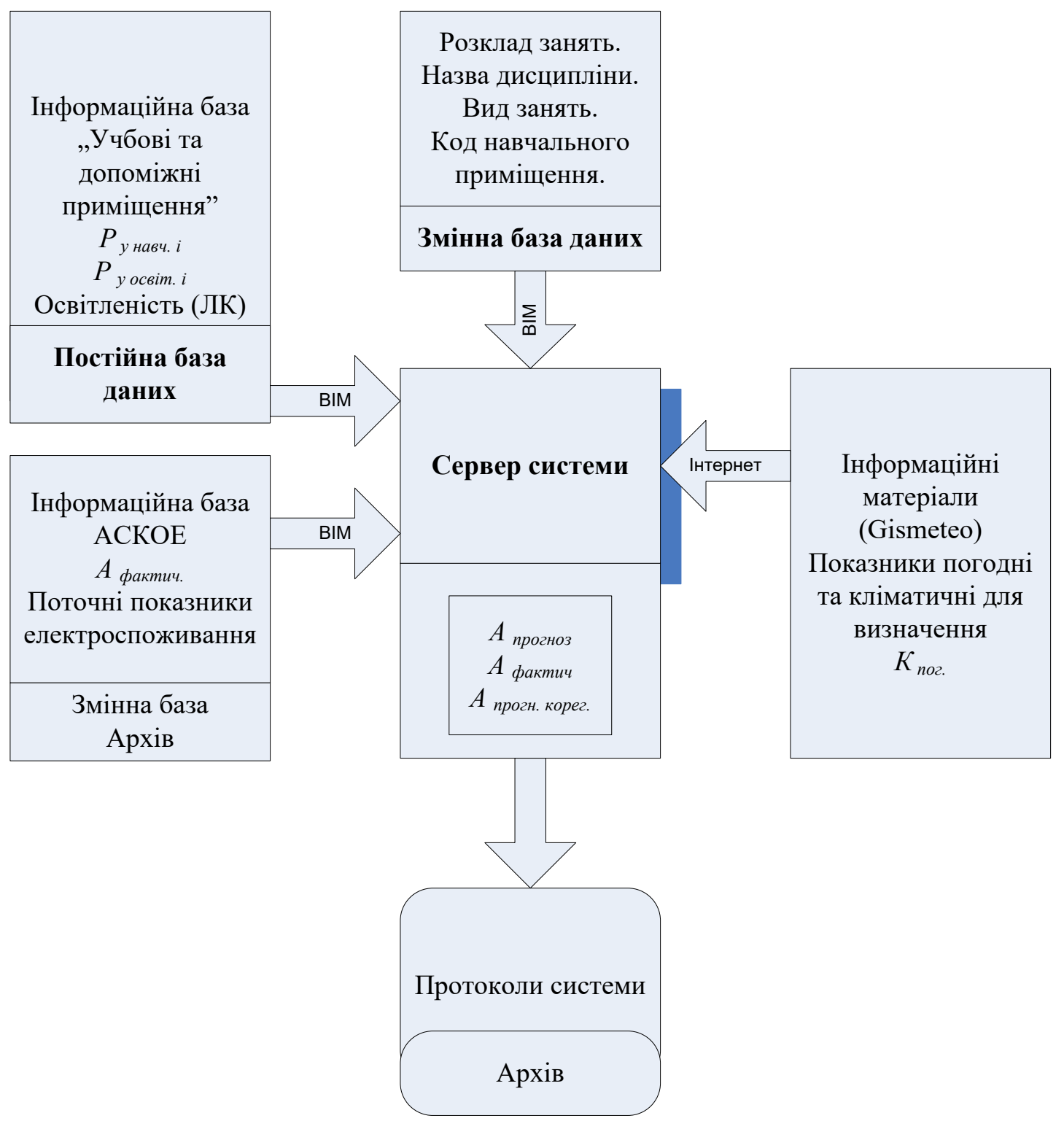

Рисунок 2. Структурна схема інформаційних блоків алгоритму розрахунку прогнозних обсягів споживання електроенергії у навчальному процесі.

Модуль розрахунку споживання електричної енергії базується на моделях короткострокового і довгострокового прогнозування споживання електричної енергії об’єктом. Витрата електроенергії завжди обумовлена двома тенденціями: електроенергія яка необхідна для виконання технологічного процесу (роботи об’єкта за призначенням) та електроенергія, яка витрачається на компенсацію впливу зовнішніх факторів. Для розрахунку планового прогнозу електроспоживання в системі моніторингу повинні бути введені характеристики всіх струмоприймачів, які є в наявності на об'єкті. Під характеристиками розуміють: потужність струмоприймача та місце його підключення. 


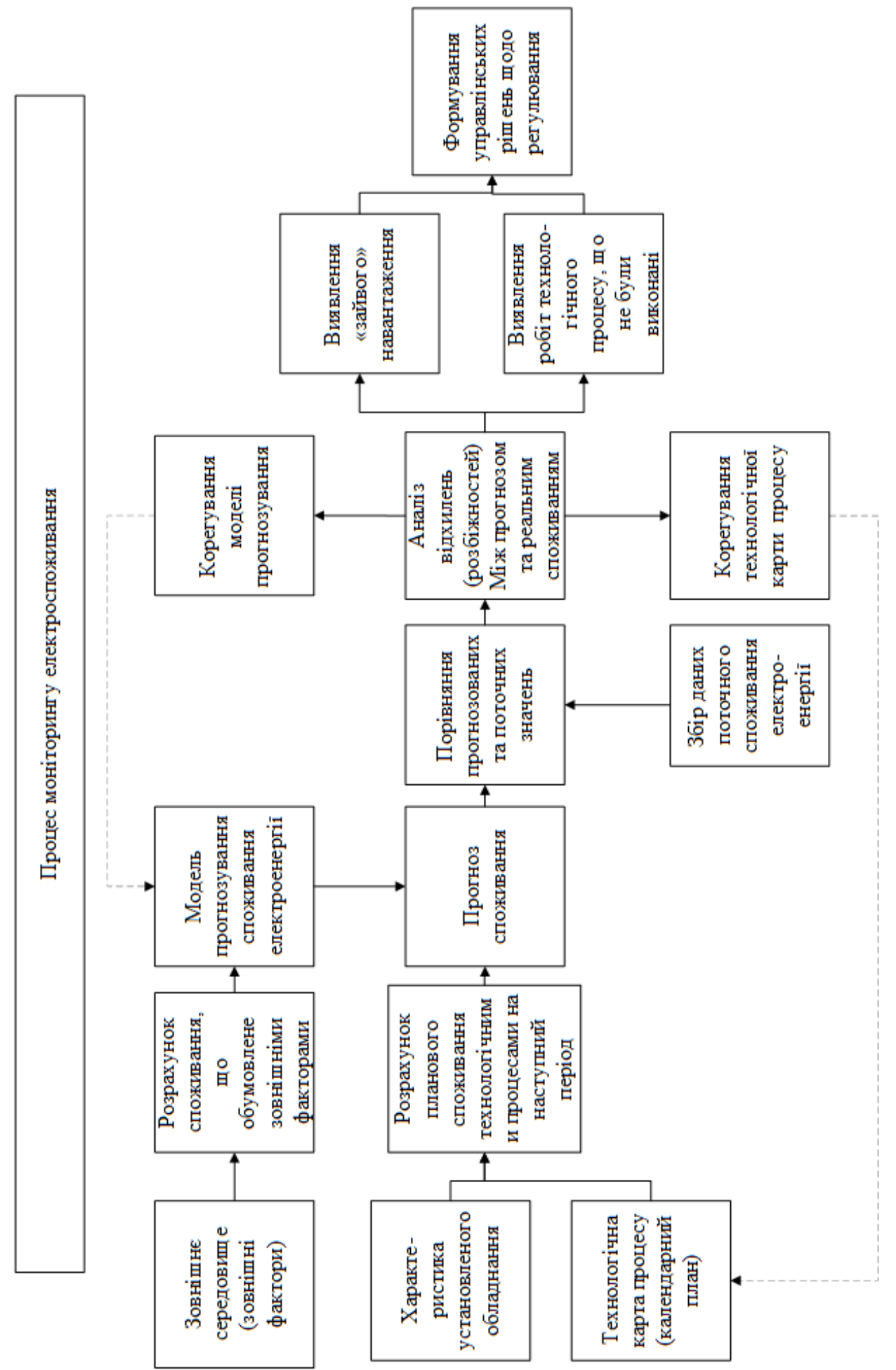

Рисунок 3. Структурна схема процесу моніторингу електроспоживання. 
Також для визначення планового електроспоживання потрібно мати карту технологічного процесу (розкладу занять). Карта являє собою послідовність операцій, що будуть виконуватись у період, на який складається прогноз.

Крім цього, повинні бути в наявності дані про те яке обладнання буде задіяне для виконання цих операцій і час, впродовж якого, воно буде працювати. Якщо об'єкт це заклад освіти, то у якості карти технологічного процесу виступає розклад занять з зазначенням у ньому виду заняття, місця та часу його проведення, а також, бажано, теми заняття. Маючи інформацію щодо потужності струмоприймачів та послідовності технологічного процесу проводиться розрахунок щодо кількості спожитої електричної енергії на період планування.

Частина електроенергії, що витрачається об'єктом споживання, обумовлена зовнішніми факторами, які не можуть бути враховані детерміністичною складовою тому, що значення цих факторів може бути випадковим, а також спостерігається взаємний вплив цих факторів один на одного. До таких факторів, перш за все, слід віднести природні явища: хмарність, температура повітря, напрям на швидкість вітру, тощо, які у сукупності не можна детерміністично врахувати при розрахунку споживання електроенергії. Також, у таку групу факторів слід віднести і період доби (день, ніч, сутінки). Маючи ретроспективні дані попереднього споживання, та дані по значенню покажчиків факторів за попередній час, проводиться «навчання» моделей короткострокового та довгострокового споживання електричної енергії. Для успішної роботи модулю прогнозування споживання електроенергії необхідно мати: 1) ретроспективні дані споживання електроенергії на яких проводиться «навчання» моделей; 2) прогнози значень зовнішніх факторів (наприклад, прогноз погоди) для успішного створення прогнозу споживання; 3) дані споживання за минулий період прогнозу, що постійно оновлюються. Це стосується застосування як розрахункового методу, так і створення математичних моделей. 
За умови використання математичних моделей для прогнозування обсягів споживання електроенергії основні етапи моделювання та прогнозування включають:

1. Збір даних для моделі (дивись рис. 4):

- дані електроспоживання з лічильників та датчиків.

- дані щодо запланованого споживання 3 наперед визначеним навантаженням.

- дані зміни погоди та календарні ефекти.

- показники енергоефективності за об’єктом.

2. Виділення фіксованої та випадкової компонент часових рядів електроспоживання.

3. Обробка та трансформація даних, робота з аномаліями.

4. Моделювання за класичними підходами аналізу часових рядів (моделі векторної авторегресії та ковзного середнього ARIMA, моделі експоненційного згладжування, векторні моделі авторегресії VAR та коінтеграційні моделі корекції похибки VEC для пошуку довгострокових та короткострокових зв'язків). Перевагою класичних підходів $є$ їх простота, легкість інтерпретації та можливість використання для невеликих вибірок. Ідеальні для пояснення причинно-наслідкових зв'язків та прогнозування одночасно.

5. Моделювання за ансамблевими підходами машинного навчання (нейронні мережі, моделі градієнтного бустінгу, випадкових лісів тощо). Зазначені методи покращують точність прогнозу ітераційно за рахунок навчання на ансамблі простих моделей. Недоліком використання є складність інтерпретації та необхідність забезпечення великої кількості даних спостережень для якісного навчання. При малих виібрках прогнозні якості суттєво погіршуються.

6. Підбір оптимальних моделей з точки зору статистичної адекватності та прогнозної якості. Оцінка узагальненого середнього значення прогнозу для обраних моделей. Декомпозиція прогнозу відносно наперед визначеного фіксованого споживання та залишкового споживання. 
7. Аналіз причинно-наслідкових зв'язків та формулювання рішень для підвищення енергоефективності та енергозбереження.

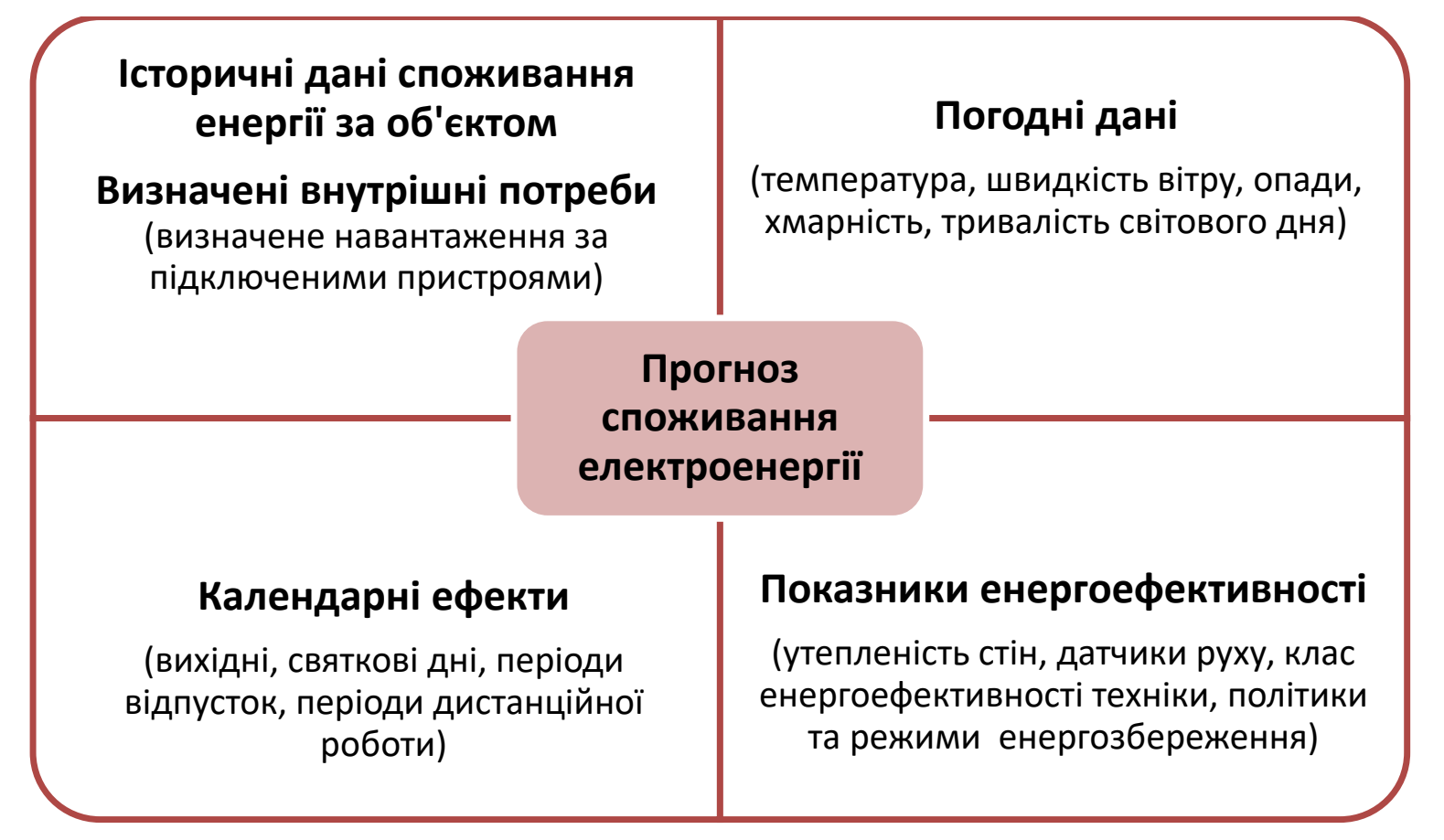

Рисунок 4. Збір даних для моделі прогнозування електроспоживання.

Для вирішення задачі моніторингу необхідно мати пристрої збору даних поточного споживання. Для моніторингу поточного електроспоживання пропонується у системі моніторингу та короткотермінового прогнозування застосовувати окрему систему. Ця система побудована 3 використанням струмових датчиків, мультиплексора, мікроконтролера опитування датчиків, мікроконтролера зв'язку з сервером. Ї̈ї організовано як безконтактну з мережею електропостачання. Структурну схему пристрою для моніторингу поточного електроспоживання представлено на рис. 5. Слід зазначити, що пристрій дозволяє отримувати інформацію 316 датчиків одночасно і концентрувати ії для подальшої передачі одним мультиплексором. Система слугує для опитування датчиків струму, перетворення значення струму в електричну потужність за визначений період часу. Вона являє собою пристрій, який включає наступні комплектуючі: датчики струму, мультиплексори, мікроконтролери опитування 
датчиків, мікроконтролер зв'язку з сервером. Датчик струму використовується індуктивний для безконтакного зняття значень сили струму. Датчик передає аналоговий сигнал на контролер через мультиплексор. Мультиплексор виконує перемикання між 16-ма датчикам на канал АЦП мікроконтролера.

Мікроконтролер виконує опитування датчиків за допомогою АЦП, перетворює отриманий сигнал в значення сили струму в Амперах. В залежності від константного значення напруги відбувається обрахунок потужності за певний проміжок часу. Значення потужності в контролері нарощується i передається на контролер зв'язку з сервером по інтерфейсу UART, кожні 30 секунд і при умові, що контролер зв'язку з сервером отримав підтвердження, що сервер прийняв повідомлення. Якщо підтвердження від сервера не прийшло, значення потужності далі буде накопичуватись.

Мікроконтролер зв'язку з сервером отримує повідомлення з інформацією про «накопичену» величину електричної потужності від контролера опитування датчиків, формує пакет для відправки по MQTT протоколу на віддалений веб сервер, підтримує зв'язок з Wi-fi роутером для передачі інформації, при втраті 3’єднання кожні 30 секунд «намагається» його відновити.

Система може бути сконфігурована для вимірювання від 1 до 16 каналів сили струму для одного пристрою. Також передавати інформацію можна за допомогою бездротового GSM або Ethernet з'єднання.

Результати проведених досліджень та вимірювань показують, що при значеннях напруги на вимірюваній лінії 210-230 В похибка вимірювань складає до 5\%. При напрузі на вимірюваній лінії 220 В похибка вимірювань складає менше $1 \%$, що є прийнятним для інформаційних систем [176, 177]. 


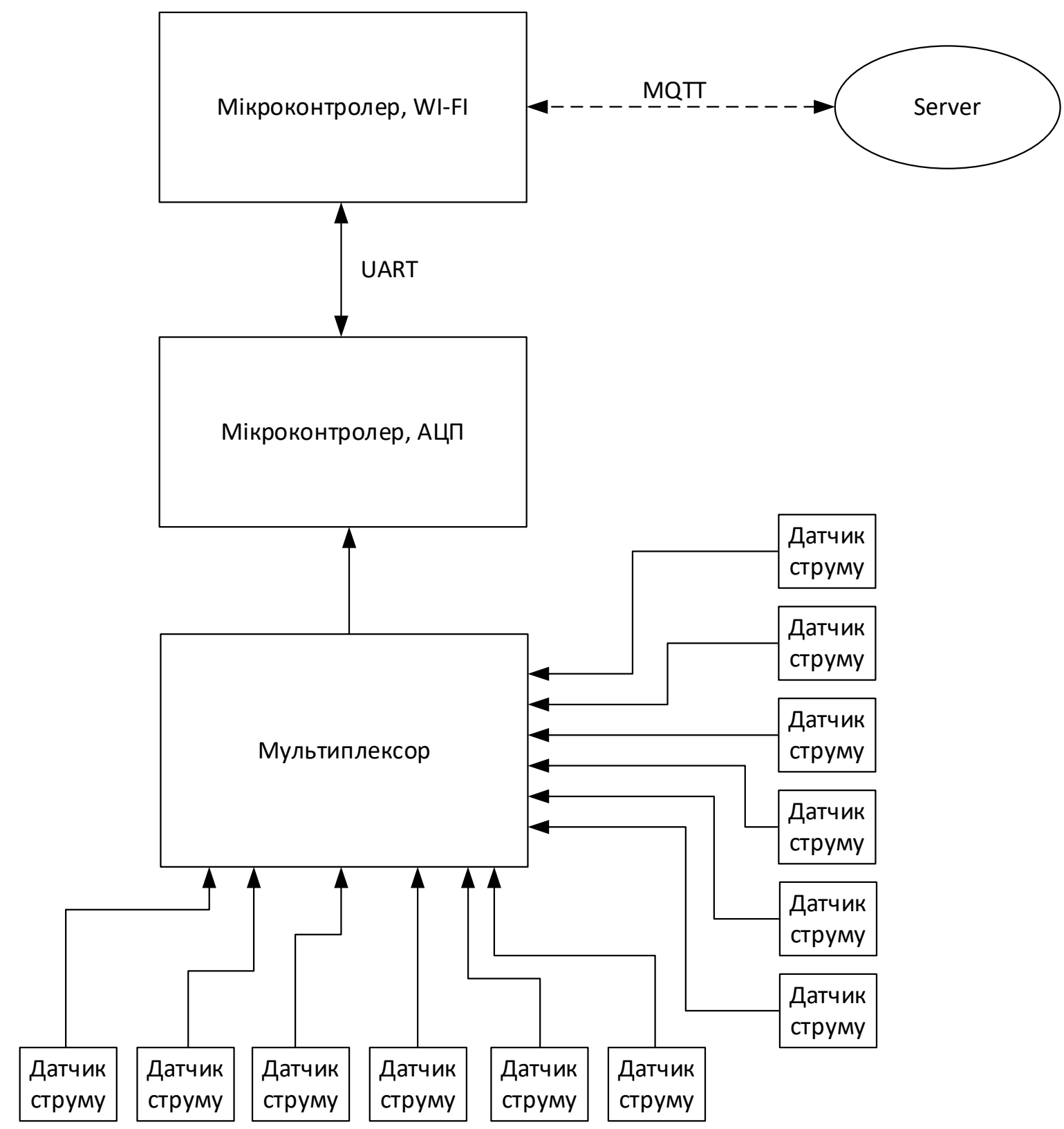

Рисунок 5. Структурна схема пристрою для моніторингу поточного електроспоживання.

Стосовно витрат на впровадження такої системи варто зауважити, що сумарна розрахункова вартість впровадження (включаючи витрати на прилади, комплектуючі, монтажні та пусконалагоджувальні роботи, а також вартість ліцензії) становить близько 11,55 тис. грн. (за умови можливості підключення 16 точок вимірювання). Тоді питома вартість підключення однієї точки вимірювання має становити близько 0,72 тис. грн. Порівняння середніх вартісних показників впровадження однієї точки АCКОЕ та запропонованої інформаційної системи моніторингу і короткострокового прогнозування обсягів 
споживання електроенергії закладами освіти KODROS СумДУ, яку створено за наведеними принципами та алгоритмами, показує доцільність впровадження такої системи. Результати стендових випробувань елементів системи, іiі дослідна експлуатація показує, що за рахунок впровадження нормативних показників електроспоживання та їх дотримання за інформаційної підтримки вказаною системою можливо зменшити обсяги споживання електроенергії навчальним закладом у межах 7 - $8 \%$.

Проведений аналіз показав, що обсяг фактичного електроспоживання у одному iз навчальних корпусів Сумського державного університету в середньому становить 1318,2 кВт*год. на тиждень. В табл. 1 наведені укрупнені розрахунки техніко-економічних показників вузла моніторингу електроспоживання.

Таблиця 1.

Техніко-економічні показники вузла моніторингу електроспоживання.

\begin{tabular}{|c|l|l|c|}
\hline № & \multicolumn{1}{|c|}{ Показник } & \multicolumn{1}{|c|}{ Розмірність } & Значення \\
\hline 1 & $\begin{array}{l}\text { Вартість обладнання (прилади та } \\
\text { комплектуючі) }\end{array}$ & тис. грн. \\
\hline 2 & Монтажні та пусконалагоджувальні роботи & $\begin{array}{l}25 \% \text { від п. } 1, \text { тис. } \\
\text { грн. }\end{array}$ & 1,75 \\
\hline 3 & Витрати на програмне забезпечення & $\begin{array}{l}\text { Частина від } \\
\text { загальних на } \\
\text { один вузол } \\
\text { вимірювання, } \\
\text { тис. грн. }\end{array}$ & 1,3 \\
\hline 4 & Вартість ліцензії & тис. грн. & \\
\hline 5 & Всього витрат на один вузол вимірювання & тис. грн. & 1,5 \\
\hline 6 & Кількість точок вимірювання & шт. & 11,55 \\
\hline 7 & Всього витрат на одну точку вимірювання & тис. грн. & 0,72 \\
\hline 8 & Середнє тижневе споживання електроенергії & кВт*год. & 1318,2 \\
\hline 9 & Кількість навчальних тижнів & & 32 \\
\hline 10 & Тариф & Грн/кВт*гд. & 2,6 \\
\hline 11 & Річні витрати на електроенергію & грн. & 42182,4 \\
\hline 12 & Розрахункова економія витрат на & $\begin{array}{l}8 \% \text { від п. } 11 . \\
\text { грн. } \\
\text { електроенергію }\end{array}$ & 3374,6 \\
\hline 13 & Простий термін окупності & 3,4 \\
\hline
\end{tabular}


Необхідно зазначити, що наведені в таблиці 1 розрахунки є попередніми. Практично, при вирішенні задач загального моніторингу електроспоживання, прилад, з шістнадцятьма точками контролю, може забезпечувати збір і обробку даних в двох-трьох суміжних корпусах у залежності від існуючої схеми електроживлення. Тоді простий термін окупності одного вузла вимірювання складатиме $1,2 \ldots 1,4$ роки. Система моніторингу окрім функції «визначення слабких місць» електроспоживання, може слугувати інструментом контролю додержання технологічних, санітарно-гігієнічних та інших нормативів (в тому числі забезпечення навчального процесу) функціонування будівель (корпусів, лабораторій та ін.) навчального закладу.

Порівняння поточних значень і тих, що отримані за допомогою модулю прогнозу надає змогу проаналізувати відхилення пронозу та реально спожитої електроенергії. Якщо похибка прогнозу не перевищує допустиме значення, автоматично робиться висновок щодо належного функціонування систему моніторингу та правильного виконання всієї технологічної карти процесу. Якщо спостерігається суттєва розбіжність між прогнозними та реальними даними, тоді проводяться наступні заходи:

1. Корегування моделі прогнозу електроспоживання та, при необхідності, iї повторне «навчання»;

2. Виявлення навантаження, яке не було занесено до переліку встановленого, а потім або корегування переліку встановленого обладнання (та технологічної карти процесу, за необхідності), або виявлення причин чому додаткове обладнання було задіяне у виробничому процесі;

3. Виявлення робіт технологічного процесу, які не були виконані.

За результатами пунктів 2) та 3) мають формуватися управлінські рішення щодо посилення виробничої дисципліни, або зміни послідовності технологічних операцій, або корегування карти технологічного процесу. 


\section{2 Проблематика створення захисного екрану на основі залізорудного пилу із заданими властивостями}

Дослідження та прикладні розробки у галузі електромагнітної безпеки довели, що найбільш ефективним засобом поліпшення електромагнітної обстановки є екранування. Захист працюючих у виробничому середовищі від негативного впливу електромагнітних полів та підвищення нормативного рівню електромагнітної сумісності технічних засобів забезпечують сучасні екрануючі матеріали різного класу. На жаль, у деяких випадках, в умовах щільного розміщення приладів, в перенавантаженому магнітному середовищі, спостерігається нестабільна робота чутливих електричних та електронних приладів.

Розробленню та дослідженню захисних властивостей матеріалів для екранування електромагнітних полів приділяється багато уваги. Це можна пояснити підвищенням електромагнітного навантаження на виробниче середовище (обладнання, персонал) та довкілля. Зокрема, спостерігається тенденція збільшення амплітуд та розширення частотного спектра електромагнітних полів [178]. У таких умовах традиційні металеві магнітні екрани мають суттєві недоліки - відсутність керованості захисними властивостями, великі коефіцієнти відбиття електромагнітних хвиль та у багатьох випадках надлишковість коефіцієнтів екранування. У сучасних умовах, поряд із захистом людей та електронного обладнання від впливу електромагнітних полів, необхідним $\epsilon$ забезпечення безперебійного функціонування засобів бездротового зв'язку [179]. Небажаним також $є$ екранування природного геомагнітного поля. Тому найбільш перспективними засобами захисту $\epsilon$ композиційні матеріали. Їх перевагами $€$ керованість коефіцієнтами екранування за рахунок зміни концентрацій екрануючої субстанції у матеріалі основи (тканини або полімеру) та товщини матеріалу. Але головною проблемою $є$ складність технології виготовлення композитів та їх висока вартість, що є проблемою для практичного застосування таких матеріалів 
для облицювання поверхонь великих площ та серійного вироблення 3 них спеціального захисного одягу.

Для вироблення металополімерного матеріалу у якості полімера обрано стандартний харчовий латекс (latex) NRL виробництва «Vytex» (USA). Цей матеріал виробляється у рідкому стані, широко використовується й має малу вартість. У якості екрануючої субстанції використовувався залізорудний концентрат, отриманий методом флотації (flotation) на Полтавському гірничозбагачувальному комбінаті (Україна). Склад концентрату - Fe - 72-73 \%, $\mathrm{FeO}, \mathrm{Fe}_{3} \mathrm{O}_{4}-8-20$ \%. Середня дисперсність 150-200 мкм.

Вимірювання ефективності матеріалів (коефіцієнтів екранування) електромагнітного поля наднизьких частот виконувалися за допомогою каліброваного аналізатора електромагнітного спектра Spectran NF 5035 (Німеччина) згідно інструкції з експлуатації. Максимальна основна похибка вимірювань не перевищувала 1 \%. Для визначення коефіцієнтів екранування електромагнітних полів ультрависокої частоти використовувався калібрований вимірювач щільності потоку енергії П3-31 (Російська Федерація) згідно інструкції 3 експлуатації. Максимальна основна похибка вимірювань не перевищувала 2,7 дБ. Вимірювання коефіцієнтів екранування здійснювалося для геометрично замкнених екранів, які повністю огортали вимірювальні антени. Фонові рівні напруженості електричного поля промислової частоти під час вимірювань не перевищували 10 В/м, магнітного поля - 0,1 A/м. Фонова щільність потоку енергії, у діапазоні частот 0,3-30 ГГц, не перевищувала 0,265 $\mathrm{M \kappa BT} / \mathrm{cm}^{2}$.

У якості екрануючої субстанції для виготовлення засобів колективного захисту - матеріалів для облицювання поверхонь великих площ застосовується більш дешевий матеріал - залізорудний концентрат. Як зазначалося, головною задачею підвищення якості матеріалу є рівномірність розподілу екрануючих частинок у об’ємі носія - рідкого латексу.

На першому етапі сухий концентрат залізної руди додавався у латекс (у даному випадку - 20 \% за вагою) та механічно перемішувався. Після цього суміш 
піддавалася ультразвуковій обробці.

Дослідження захисних властивостей отриманих матеріалів (визначення коефіцієнтів екранування) виконувалося для електромагнітних полів наднизьких частот (промислова частота, iii гармоніки та інтергармоніки) та електромагнітного поля ультрависокої частоти 2,45 ГГц.

Рівні електромагнітних полів наднизької частоти, враховуючи їх квазістаціонарність, визначаються окремо за магнітною та електричною складовими поля (малюнок 2)[180].

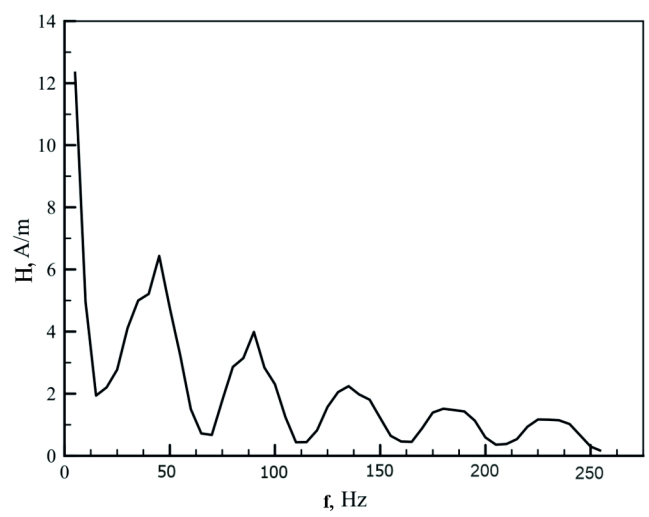

$a$

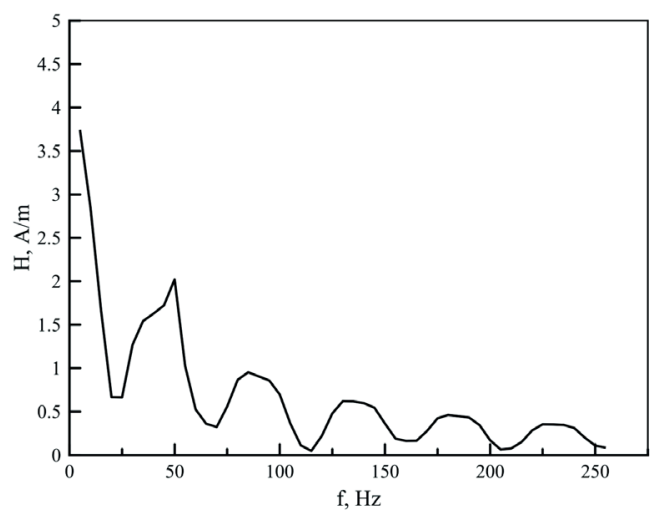

$\sigma$

Малюнок 2 - Екранування магнітного поля наднизької частоти захисними матеріалами: $a$ - вихідний спектр магнітного поля; $\sigma$ - спектр магнітного поля, екранованого металополімерним матеріалом

Результати вимірювань змін електричної складової електромагнітного поля наднизької частоти наведено на малюнку 3.

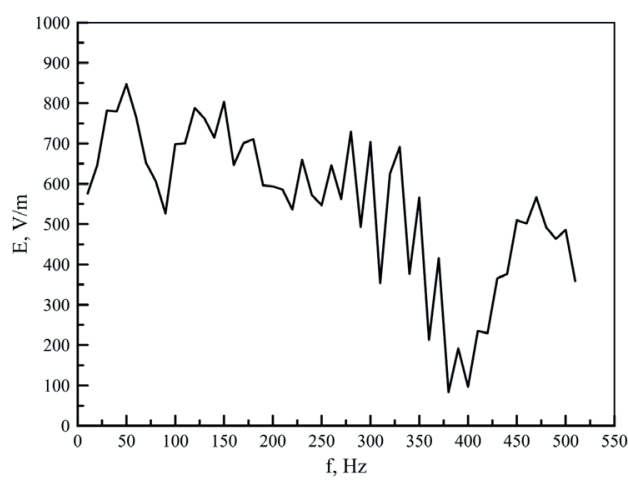

$a$

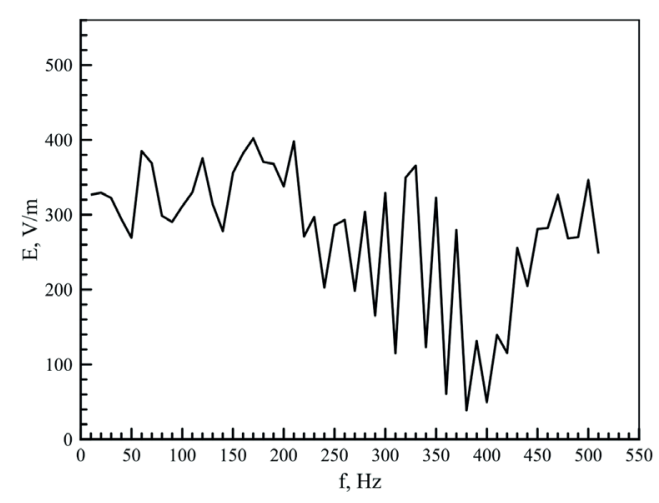

$\sigma$ 
Малюнок 3 - Екранування електричного поля наднизької частоти захисними матеріалами: $a$ - вихідний спектр електричного поля; $\sigma$ - спектр електричного поля, екранованого металополімерним матеріалом

Цей результат очікуваний через те, що екрануюча субстанція має малу провідність, що знижує коефіцієнти екранування електричного поля. Але магнітне поле вважається більш критичним щодо впливу на біологічні об'єкти. До того ж екранування електричного поля у виробничих умовах, на відміну від магнітного, не складає труднощів через можливість застосування будь-якого суцільного металевого матеріалу [181].

Розроблений матеріал для екранування низькочастотних та високочастотних електромагнітних полів складається з пінолатексу та доданого до нього у необхідній (розрахованій) кількості залізорудного пилу, який $є$ екрануючою субстанцією. Для розрахунку потрібної товщини необхідні значення $\sigma$ та $\mu_{a}$. Оскільки матеріал є інноваційним, ці відомості відсутні у довідковій літературі, тому на попередньому етапі було досліджено залежність $\sigma$ від концентрації металевої субстанції, а також залежність від неї відносної магнітної проникності $\varepsilon$ [182]. Значення за $\mu_{a}$ розраховувалося зі значення $\varepsilon$, виходячи $з$ відомих співвідношень електродинаміки суцільних середовищ. Наведений підхід допомагає регулювати коефіцієнт екранування електромагнітного поля промислової частоти у межах $2-6$, електромагнітного поля ультрависокої частоти - 2,5 - 12. При цьому можливе однозначне розв'язання як прямої, так і зворотної задачі: для потрібного коефіцієнта екранування визначається товщина захисної поверхні та ії фізико-хімічний склад або для можливої товщини екрана у конкретних умовах розраховується склад матеріалу та коефіцієнти екранування. Враховуючи достатню складність технології виготовлення композитних метало-полімерних матеріалів, автоматизація процесу ї проектування та алгоритмізація розроблення та впровадження організаційно-технічних заходів з електромагнітної безпеки дає змогу скоротити час виконання робіт, підвищити їх ефективність та знизити матеріальні витрати. 


\section{SECTION 8. INNOVATIVE TECHNOLOGIES}

\subsection{Innovative fine grinding technology with acoustic process control}

Introduction. Grinding processes are used to prepare mineral raw materials for processing in the mining, metallurgical, chemical industries, powder metallurgy, production of building materials, glass, plastics, ceramics, solid fuels and other types of fine materials. Products are mainly ground in energy-intensive ball, jet and planetary mills. Grinding costs are significant, and the quality of the resulting products does not always reach the required level [183].

At dressing factories, $45-65 \%$ of the total energy consumption is spent on grinding ores. About $4 \%$ of the world energy costs are spent on grinding operations for various technical products. At fine and ultrafine grinding, energy costs increase in direct proportion to the size of the product. For example, to obtain in a ball mill one ton of material with a particle size of less than 100 microns, it is required $25 \mathrm{~kW} \cdot \mathrm{h}$, to obtain the same material sized less than 50 microns, $50 \mathrm{~kW} \cdot \mathrm{h}$ are required, 25 microns - $100 \mathrm{~kW} \cdot \mathrm{h}, 12$ microns $-200 \mathrm{~kW} \cdot \mathrm{h}, 1$ micron $-1400 \mathrm{~kW} \cdot \mathrm{h}$

The development of industry requires the fine (less than 20 microns) and ultrafine (less than 7 microns) product production. Fulfillment of such requirements leads to a further increase in energy consumption per unit of production. Therefore, the reducing energy consumption during fine mineral grinding and improving of equipment and grinding technology remains the relevant question. This process is hindered by the lack of a theoretical justification for the choice of optimal grinding modes, methods for on-line product dispersion control that does not allow reducing the process energy consumption. At the Institute of Technical Mechanics of NASU and SSAU, an innovative technology of jet grinding with acoustic process monitoring has been proposed [184-186].

The purpose of the work is to substantiate the possibility of optimizing the jet grinding technology of bulk materials based on acoustic process monitoring.

To study the process of destruction and, in particular, grinding, it is possible applying a method using the effect of acoustic emission during the material destruction. 
Acoustic emission is a physical phenomenon associated with the elastic wave radiation from a solid body when it is loaded [185]. The energy consumption for grinding is connected with the occurrence and development of cracks in the fracture process of a loaded solid. Dispersion completes this developing process. Due to the fact that a certain part of the energy released during destruction is converted into acoustic energy, modern techniques and acoustic hardware tools for technical diagnostics of micro- and macrodestruction are applicable to identify dispersion effects based on information about the formation of acoustic activity areas [187].

Research results. In this work, it is proposed to reduce the energy consumption of fine grinding by using acoustic monitoring of two mill working zones: the grinding chamber and the pipeline at the gas suspension outlet from the classifier to the ready product collector. According to the adopted technique, acoustic information (spectra of the amplitude-frequency characteristics of acoustic signals) was obtained using a piezoelectric sensor connected to a brass waveguide installed in the study area. The acoustic signal (AS) sensor is connected to an analog-to-digital converter and a computer [184]. Studies have shown that at various stages of the jet grinding technology, including the material feeding, changing the solid phase content in the jets and the particle size, there are changes in the AS activity (quantity) and amplitude distributions. The use of acoustic monitoring of the grinding zone makes it possible to establish the total signal activity $\dot{N}_{\Sigma}$ in the grinding zone and signal count (quantity) with conventionally minimum $\left(A_{\min } \cong 2-5 \mathrm{mV}\right.$ ), exceeding the noise signal amplitude of the energy carrier jet without supplying a solid phase ("idle jet"), maximum $A_{\max }$, that is the greatest amplitude value characterizing at least $1 \%$ of the total signal number, and the average amplitude values $\boldsymbol{A}$. Figure 1 shows the acoustic signal recordings of the studied areas under different classification modes and, accordingly, with different product dispersion. 


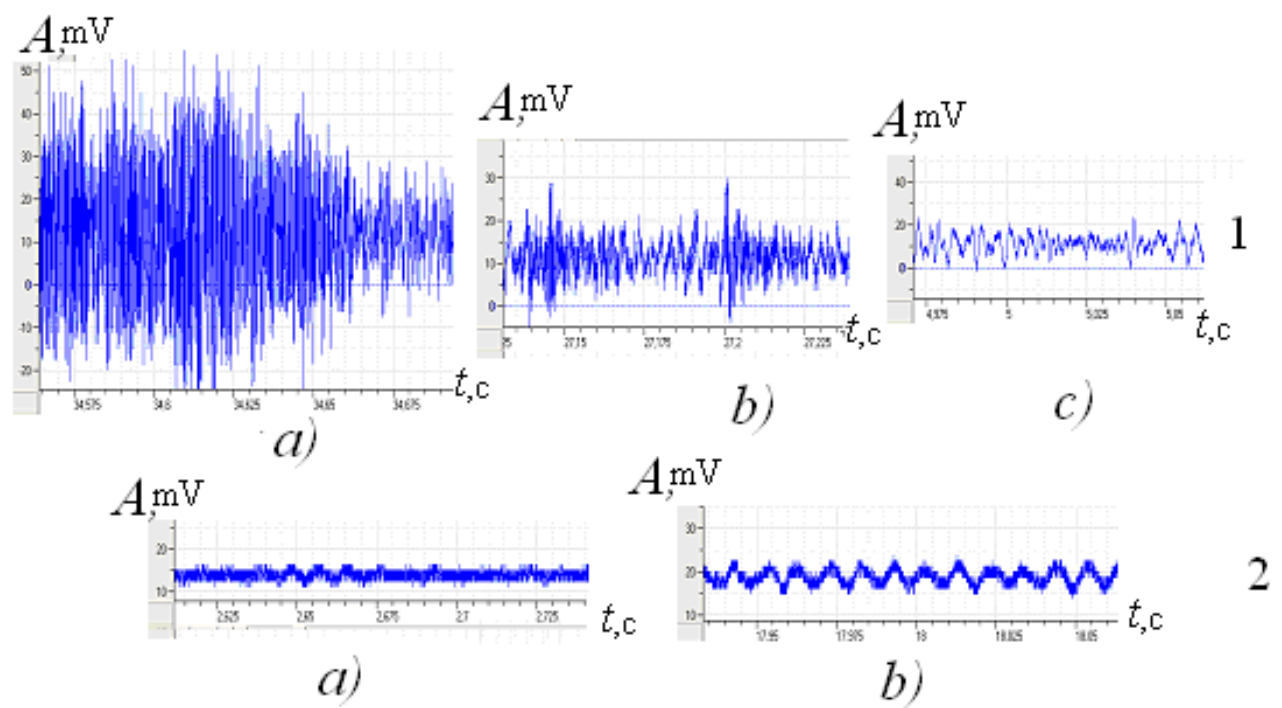

Figure 1. AS records of the grinding (1) and transportation (2) product zones in different modes of the classifier operation:

a) $n=80 \mathrm{~min}^{-1}$, b) $n=107 \mathrm{~min}^{-1}$, c) $n=170 \mathrm{~min}^{-1}$.

The analysis of the AS characteristics of the mill working zones made it possible to establish their dependence on changes in the mill productivity and the specific surface of the crushed product. This fact became the basis of the technique for increasing the technology efficiency. To optimize the process, three criteria have been established - the efficiency $K e$, the circulation $K c$ and the optimality Ka.

The jet grinding efficiency is estimated [188] by the conditional coefficient $\mathrm{Ke}$ $=Q / \lg \dot{N}(\mathrm{~g} / \mathrm{imp})$, which characterizes the ratio of the mill productivity $Q$ to the corresponding logarithm of acoustic activity in the grinding zone. A linear relationship has been established between the $\mathrm{Ke}$ coefficient and the mill productivity for various heterogeneous material processing (chamotte, limestone, slag, brown and gas coal). It has been experimentally shown that the optimal acoustic activity level of the grinding zone with a process efficiency of $K e \geq 0.4 \mathrm{~g} / \mathrm{imp}$ is in the range $\dot{N}=10^{3.5}-10^{5.3}$, while obtaining a product with increased dispersion is accompanied by an increase in acoustic activity $\dot{N}$ (fig. 2 d).

An important technological parameter of the jet mill operation is also the material circulation rate in the system, i.e. the value of the circulating mill load [189]. The ratio $K c \approx N / N_{\text {load }}$ of the AS number at a specific moment $t$ of the grinding process 
with $N$ number of AS and at the initial moment $N_{\text {load }}$ of the material loading ( $t_{1}$ in fig 2) characterizes the value of the acoustic circulation coefficient. Under conditions of optimal mill operation ( $t_{e f}$ in fig. 2 ) with maximum productivity, this coefficient is close to unity; under conditions of overfilling of the jets with material $\left(t_{3}\right)$, it is in the range of $K_{c}=2-4$, and with their excessive jet unloading $\left(\mathrm{t}_{6}\right)$ it becomes less than 1 (see Fig. $2 \mathrm{e})$.

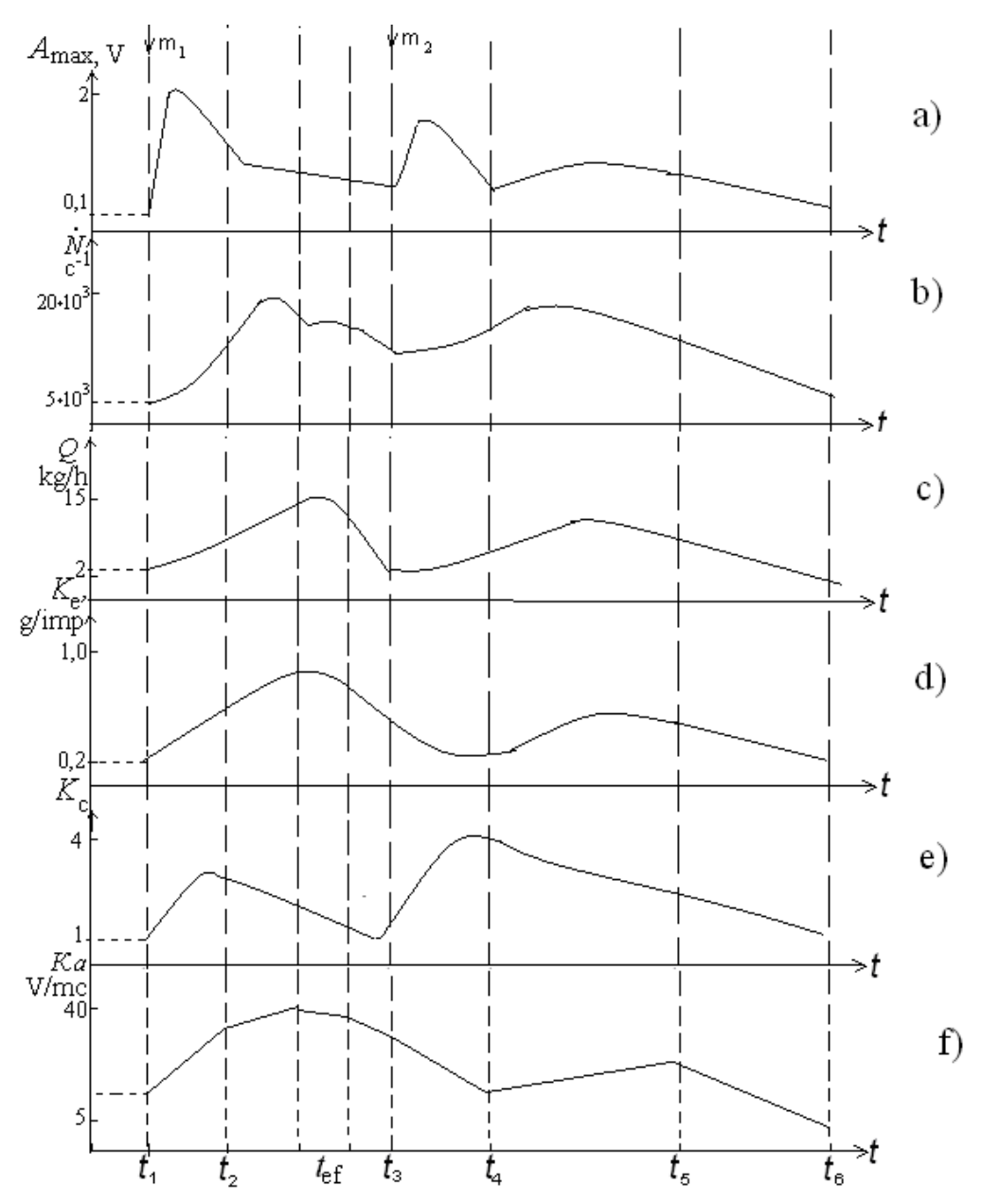

Figure 2. The circuit of basic interrelations of acoustic and technological jet grinding parameters of slag, chamotte and quartz sand grinding

Next important jet grinding factor is frequency of the effective particle impacts characterized with acoustic activity. In this connection for an estimation of optimum mill operation an acoustic criterion $K a$ is offered. Its value is characterized by product of maximal amplitude $A_{\max }$ on the general amount $\dot{N}_{\Sigma}$ of acoustic activity or particular one $\dot{N}_{\text {Aiào }}: K_{a}\left(\dot{N}_{\Sigma}\right)=A_{\text {ião }} \cdot \dot{N}_{\Sigma} ; K_{a}\left(\dot{N}_{\dot{A} \max }\right)=A_{\text {ião }} \cdot \dot{N}_{A \max }$. Processing of experimental data has 
shown that it is more preferable to use the first formula because of wider change range of criterion in various grinding modes. From physical positions of destruction the offered criterion characterizes acoustic effect of kinetic energy transformation of the particles accelerated by jets in acoustic energy of crack formation at particle destructions by impacts. Thus, the size of criterion is theoretically proportional particle destruction tension during jet grinding.

The analysis of the acoustic monitoring data of various material jet grinding has allowed designating $\mathrm{Ka}$ change borders (allowable and inadmissible ones from positions of process optimality) for single operating grinding cycle (one portion loading, grinding, jet unloading). The admissibility border of the criterion should correspond to transition of an optimum grinding mode to not optimum one. Optimum size $\mathrm{Ka}$ lies in a range (1935) $10^{3} \mathrm{~V} / \mathrm{c}$, allowable one is $K a^{a l w}=(6-17) \cdot 10^{3} \mathrm{~V} / \mathrm{c}$ and inadmissible one is $K a^{\text {inad }}=(0,4-$ 6) $\cdot 10^{3} \mathrm{~V} / \mathrm{c}$. Research has shown, that the recommended level of values $\mathrm{Ka}$ depends from observed ready product dispersity: for $S_{s p}=0,6-0,7 \mathrm{~m}^{2} / \mathrm{g}$ (sand, chamotte, slag) there is $K a=(23-35) \cdot 10^{3} \mathrm{~V} / \mathrm{c}$, whereas for $S_{s p} 0,98 \mathrm{~m}^{2} / \mathrm{g}$ (coal) there is $K a=(12-15) \cdot 10^{3} \mathrm{~V} / \mathrm{c}$.

The acoustic criterion value of grinding process optimality depends on physics mechanical properties of a crushed material, in particular, its density and particle size. So, increase of material density results in appreciable decline of grinding productivity. Accordingly the optimality criterion value decreases at grinding materials of higher density. For example, grinding of zircon and quartz sand: for zircon $K a=16,1 * 10^{3} \mathrm{~V} / \mathrm{c}$, for quartz sand $3 \mathrm{Ka}=35,5^{*} 10^{3} \mathrm{~V} / \mathrm{c}$. The criterion kinetics is kept identical for various loose materials. For a loading mode it increases typically, and for mill unloading the criterion value reduction is compared with its value for an optimum operating conditions of grinding process (fig. $4 \mathrm{f}$ ).

Thus jet grinding process control should be founded on the information given by acoustic monitoring about a jet loading conditions. Then on the basis of the received information analysis it's needed to provide duly material portion feeding for achievement of grinding process maximum efficiency [190].

The conclusion. The idea of an optimization consists in constant monitoring 
values of acoustic signal amplitude and activity of a grinding and qualifier zone, their processing and comparison of the established criteria with their control values. At a significant deviation of criteria there can be carried out additional material loading or classification mode changes. Testing this optimization for laboratory and industrial jet grinding has shown satisfactory result concurrence that has proved the revealed grinding optimization principles for innovative technology. 


\section{SECTION 9. MECHANICAL ENGINEERING AND MECHANICAL ENGINEERING}

\subsection{Vibro protective systems of quase zero rigidity}

Сучасні транспортні засоби, виробництва, опірні конструкції працюють в умовах постійних вібраційних і ударних навантажень. Актуальність захисту складних технічних систем від вібрацій постійно зростає внаслідок збільшення швидкостей руху, навантажень, зростання технологічної складності конструкції, росту вимог до точності приладів і механізмів. Також враховується екологічний аспект в плані збільшення ресурсу роботи обладнання. Для забезпечення працездатності технічних систем і заданого ресурсу використовуються різні підходи і методи. Вибір способу захисту залежить від характеристик збурюючого навантаження, об’єкта, що потребує захисту та технічної культури проектанта.

На цей час розроблені численні конструкції віброзахисних систем як широкого застосування так і орієнтованих на конкретний об'єкт, що підлягає захисту. За способом реагування на зовнішній вплив віброзахисні системи поділяють на пасивні та активні. Ідея пасивних систем віброзахисту полягає у використанні власних стабільних параметрів конструкції, без залучення додаткового джерела енергії, тобто, для прикладу, використання пружніх елементів, ресор тощо. Їх важливою перевагою $є$ простота конструкцій та мінімальна або повністю відсутня енергозатратність, що суттєво зменшує саму вартість виготовлення механізму. Використання енергії відбувається тільки для живлення приладу, що захищається від вібрації. До недоліків таких систем можна віднести те, що віброзахист впевнено ведеться на частотах більше ніж 20 Гц.

Поява активних віброзахисних систем була обумовлена незадовільними результатами роботи класичних пасивних за умови широкополосного спектра частот збурюючого навантаження, особливо за наявності ударних навантажень. 
Але їх розвиток має значний опір внаслідок великої складності і дороговизни. Власне через підведення додаткового живлення до системи захисту їх називають активними. Окрім цього, активність системи пов'язана зі примусовим переміщенням конструкцій відносно основи, яка вібрує. Це відбувається на основі показників датчиків, що вбудовані в саму віброзахисну конструкцію.

Особливі складності виникають як для активних так і для пасивних систем в низькочастотному діапазоні частот збурюючого навантаження. Але ці проблеми у активних і пасивних систем принципово різні. Для активних систем в низькочастотному діапазоні коливань важко реалізувати значні за амплітудою переміщення у протифазі збуренню внаслідок інертності значних за масою механічних систем. В пасивних лінійних системах віброізоляції ступінь віброзахисту належить від різниці між власною частотою коливань захисної системи та нижньою частотою збурення. Але зменшення власної частоти вимагає суттєвого збільшення габаритів і маси самої віброзахисної системи. В результаті маса останньої стає співставною з масою об'єкта що підлягає захисту. Для транспорту, особливо в авіації це неприпустимо. Для стаціонарних об’єктів, особливо при частотах менше 10 Гц габарити захисних систем на основі пружних елементів вимушені мати значні габарити, а пневматичні потребують уважного обслуговування, частина з них чутлива до агресивного середовища. Складність задачі і різноманітність технічних об’єктів дозволяють зробити прогноз щодо неможливості створити універсальну віброзахисну систему в близькому майбутньому.

Мета статті є ознайомлення з принципом роботи віброзахисної системи 3 корекцією жорсткості (ВСКЖ) і опис конструкції віброізолятора побудованого за цими принципами.

Детально теорія віброзахисних систем з корекцією жорсткості розглянута в роботі колектива авторів на чолі з П.М. Алабужевим [191]. Хоча на цей час ВСКЖ не набули широкого поширення, що напевно, можна пояснити браком інформації про переваги таких систем. Промислове застосування їх починалось 3 захисту від ударів рук операторів при клепальних операціях. 3 часом сфера 
використання розширилася. За конструкцією вони поділяються на три типа (рисунок 1): А, В, С.

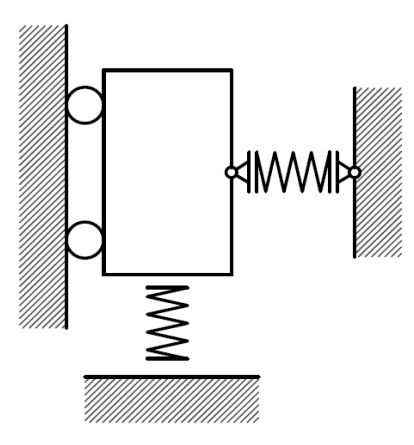

1

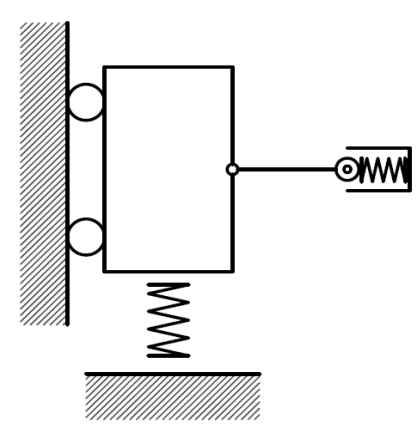

2

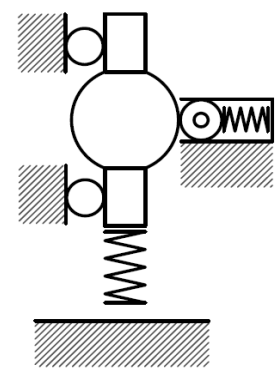

3

Рис. 1. Приклади конструкцій ВСКЖ: 1 - mun $A, 2$ - mun $B, 3$ - mun $C$.

Конструкції віброзахистних систем 3 квазінульовою жорсткістю можуть варіюватись залежно від постановленої задачі. Вони належать до пасивних систем віброзахисту. Дані системи не потребують додаткових енергетичних затрат та не є затратними з матеріальної сторони, що $є$ великим плюсом при виробництві.

На рисунку 2 показаний ВСКЖ типу А, що складається 3 наступних елементів: 1 - основний несучий, пружній елемент певної сталої жорсткості (зазвичай використовується пружина), 2 - пружній елемент коректора, 3 - об’єкт, що захищається від вібрацій. Для забезпечення рухомості використовуються коліщатка 4 або аналогічний технологічний елемент.

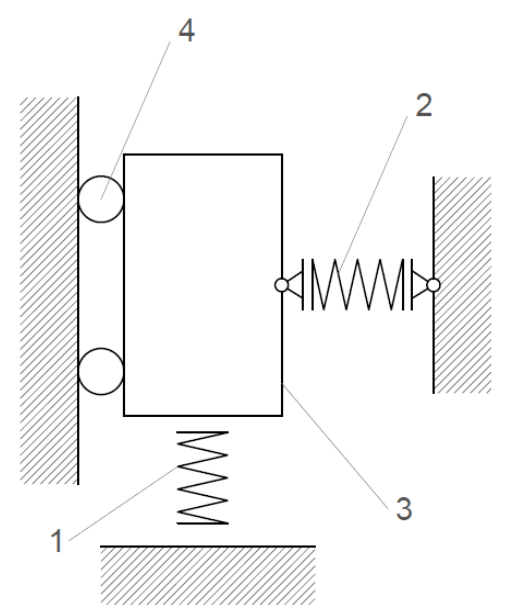


Рис. 2. Конструкція ВСКЖ типу А.

1 - перший несучий пружній елемент, 2 - другий несучий пружній елемент, 3 об'єкт, щзо ізолюється від вібрацій, 4 - коліщатка.

Даний тип вважається найпростіший 3 точки зору технологічності та виробництва. Дана конструкція дає можливість підбору несучих пружних елементів різної жорсткості, в результаті чого відбувається коригування загальної жорсткості на будь-якому інтервалі переміщень. Це означає, що конструкція має гарні віброзахисні властивості при різних величинах коливань, за умови підбору необхідної жорсткості несучих елементів.

На рисунку 3 та 4 показані ВСКЖ типів В та С відповідно. Дані властивості наведених систем повністю співпадають, проте суттєвою відмінністю є сама конструкція.

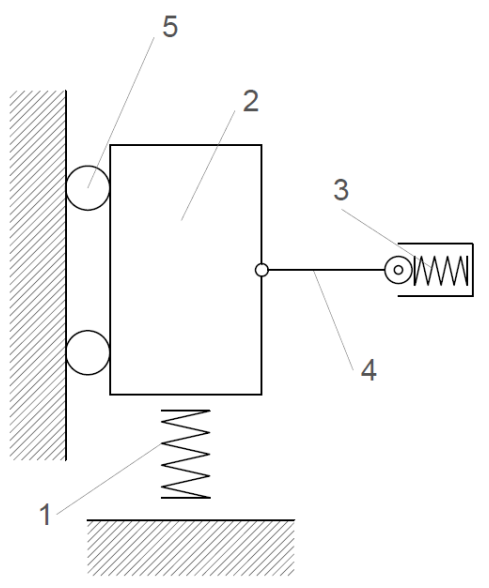

Рис.3. Конструкція ВСКЖ типу В.

1 - основний пружній елемент, 2 - об'єкт, щзо ізолюється від вібраиій, 3 пружній елемент коректора, 4 - стержень, 5 - коліщатка. 


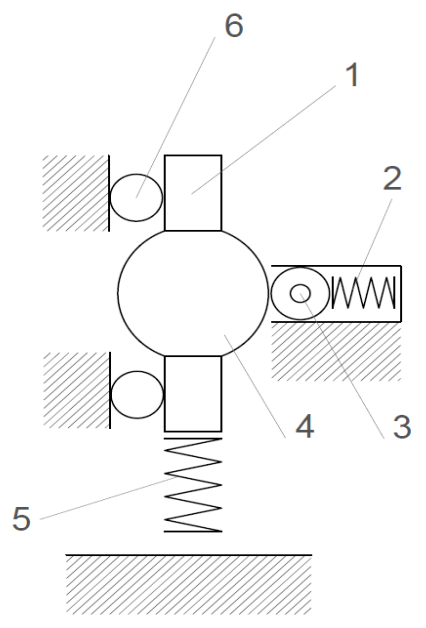

Рис. 4. Конструкція ВСКЖ типу С.

1 - основний пружній елемент, 2 - об'єкт, щэо ізолюється від вібрацій, 3 пружній елемент, коректора, 4-стержень, 5 -коліматка.

Виклад основного матеріалу. Розглянемо механічну систему що містить об’єкт захисту масою $\mathrm{m}$, основний (несучий) пружний елемент жорсткості $c_{1} \mathrm{i}$ пружні елементи коректора жорсткості $c_{2}$ (рис. 5).

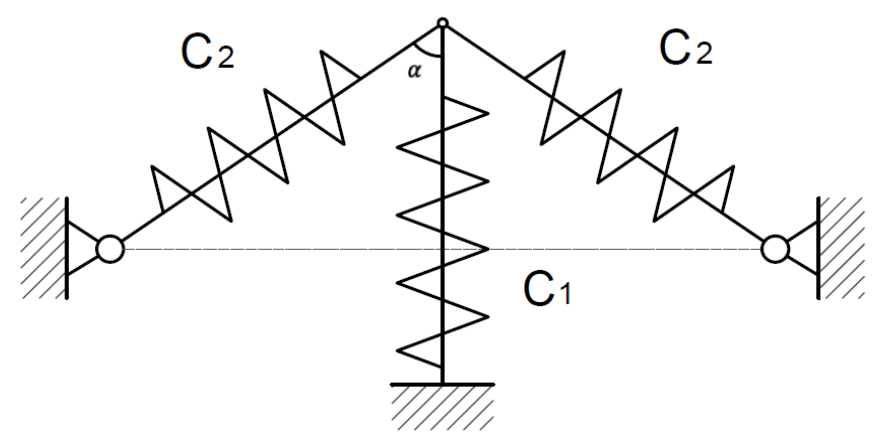

Рис. 5. Розрахункова схема ВСКЖ

Представлена система може коливатись лише вздовж вертикальної осі х. В положенні статичної рівноваги масу захищаємого об’єкта сприймає лише основний пружній елемент, пружні елементи коректора розташовані горизонтально і лінія їх дії складає з лінією дії основного пружного елемента кут 
$90^{0}$. Це положення вважаємо вихідним, а координата х в цьому разі дорівнює нулю.

Для того, щоб відхилити масу з положення рівноваги, необхідно докласти деяку силу F, яка за величиною дорівнює реакції пружин. Скориставшись принципом можливих переміщень, можна записати:

$$
\left(F-m g-F_{1}\right) \delta x-2 F_{2} \times \delta L,
$$

де $F_{1}$ і $F_{2}$ - реакції вертикальної(основної) і горизонтальної пружин (коректуючих) відповідно.

Значення сил $\mathrm{F}_{1}$ i $\mathrm{F}_{2}$ визначимо за формулами:

$$
\begin{gathered}
F_{1}=c_{1}(x-\Delta b) \\
F_{2}=c_{2}\left(L-\delta_{0}\right)
\end{gathered}
$$

де $L$ - довжина пружини коректора в довільному стані;

$$
\begin{aligned}
& L_{01}=b+\Delta b \\
& L_{02}=a+\delta_{0}
\end{aligned}
$$

- відповідно довжини пружин у недеформованому стані.

Враховуючи залежність:

$$
L=\sqrt{x^{2}+a^{2}}
$$

і з врахуванням рівняння 2, з рівняння 1 знаходимо вираз для реакції системи:

$$
F=c_{1} x+c_{2} x\left[1-\frac{\left(a+\delta_{0}\right)}{\sqrt{x^{2}+a^{2}}}\right]
$$

Тут враховано умову статичної рівноваги. Визначимо область параметрів, в яких пружні реакції оптимальні. Продиференціюємо рівняння 3 і знайдемо жорсткість системи, віднесену до жорсткості вертикальної пружини:

$$
c_{c}=1+2 c_{2 c}\left[1-\frac{1+a_{c}}{\left(1+x_{c}^{2}\right)^{3 / 2}}\right]
$$

де $c_{2 c}=\frac{c_{2}}{c_{1}} ; x_{c}=\frac{x}{a} ; \quad a_{c}=\frac{\delta_{0}}{a}$

В положенні статичної рівноваги маємо:

$$
c_{c}=1-2 c_{2 c} a_{c}
$$

Умова нульової жорсткості у відхиленому положенні має вигляд: 


$$
2 c_{2 c} a_{c}=1
$$

Найбільше переміщення, на якому жорсткість менше або дорівнює деякому наперед заданому значенню с' визначається з рівняння 4:

$$
s_{1}=\sqrt{\left\{\left[\left(1+2 c_{2 c} /\left(1+2 c_{2 c}-c^{\prime}\right]^{2 / 3}-1\right\}\right.\right.}
$$

Останнє рівняння показує, що віброізолятор забезпечує будь-яку малу жорсткість.

Важливим є те, що несуча здатність ВСКЖ залежить лише від жорсткості основного пружного елемента:

$$
F_{\text {нес. }}=m g=c_{1} \Delta b
$$

Отже за такої умови усувається основний недолік лінійних систем, який полягає в необхідності значних габаритів пружних елементів за низьких власних частот коливань.

Типова характеристика жорсткості ВСКЖ типу С наведена на рис. 6.

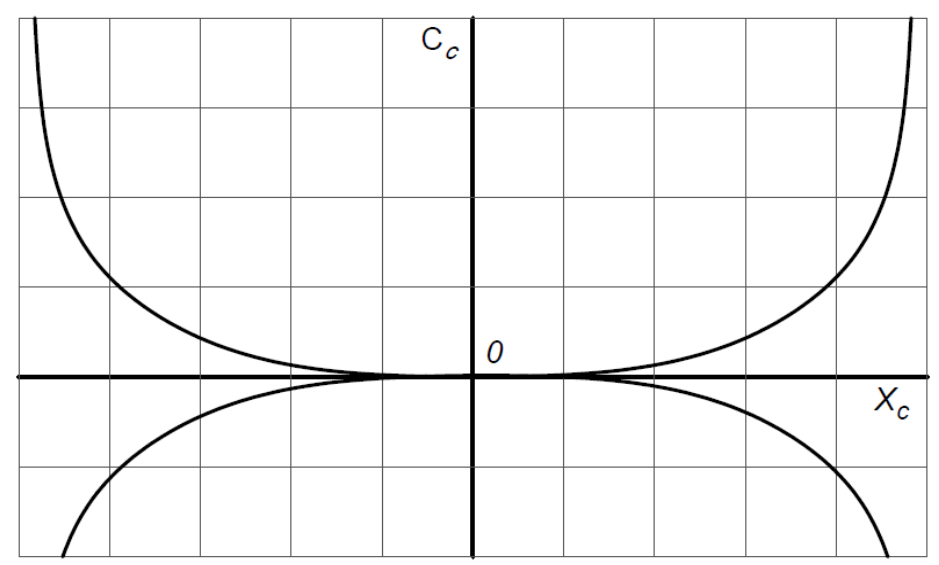

Рис. 6. Характеристика жорсткості ВСКЖ типу С

На рис. 7 наведено схему ВСКЖ, що використовувалися як опори віброзахисних платформ установлених на судах [192]. Захист забезпечувався від вертикально спрямованих низькочастотних коливань, нижня границя спектру яких дорівнювала 5 Гц. Для опір платформ використовувалися 6 однотипних ВСКЖ, кріплення велось до штока 3, елемент корпусу показано заштрихованим. 


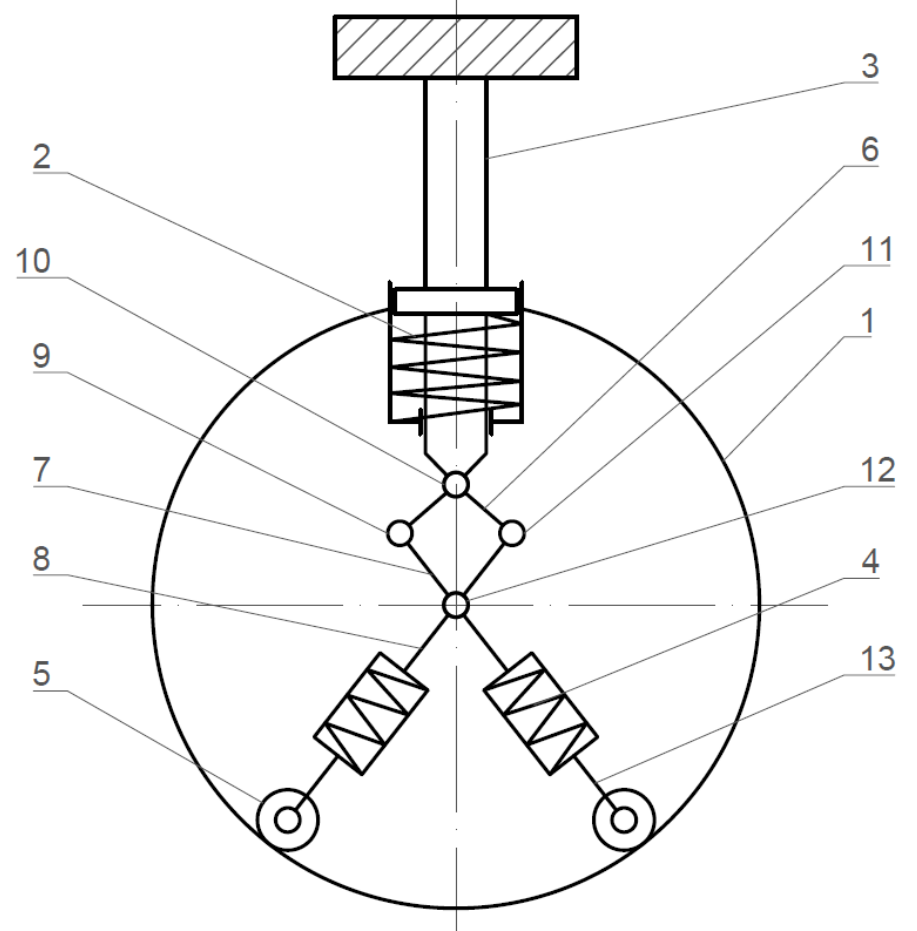

Рис. 7. Схема кулачкового ВСКЖ: 1 - профільований корпус; 2 - основний пружний елемент; 3 - шток; 4 - пружні елементи коректора; 5 - кулачки; 6,

7, 8-важелі; 9, 10, 11, 12 - шарніри; 13 - поршень зі штоком кулачка

Працює ВСКЖ наступним чином. Виходячи з загальних принципів систем 3 корекцією жорсткості статичне навантаження сприймає основний пружний елемент 2. В стані статичної рівноваги кулачки 5 розташовуються горизонтально, пружні елементи коректора 4 попередньо стиснуті, лінія дії пружних сил з їх боку перпендикулярна вертикальній осі ізолятора.

При прикладанні збурюючого навантаження відбувається, наприклад, переміщення об'єкта захисту, а отже і штока 3 вверх. Важелі 6 і 7 з'єднані шарнірами утворюють рухомий ромб. Отже котки 5 з важелем 8 провертаються і опускаються вниз обкочуючи направляючий корпус. Пружня сила коректорів в такому положенні спрямована під деяким кутом до корпуса i може бути розкладена на вертикальну і горизонтальну складову. Напрямок дії сил основного пружного елемента і вертикальних складових пружних елементів коректорів спрямовані в протилежних напрямках. Горизонтальні складові, що діють в шарнірах ромбу однакові за величиною і протилежні за напрямком. Дотримуючись раніше наведених умов при проектуванні можна досягти значень 
жорсткості близької до нуля в заданому діапазоні частот. При переміщенні в протилежному напрямку дія сил в пружних елементах змінюється на протилежний. Приклад конструкції ВСКЖ побудованої за приведеною вище схемою наведено на рисунку 8.
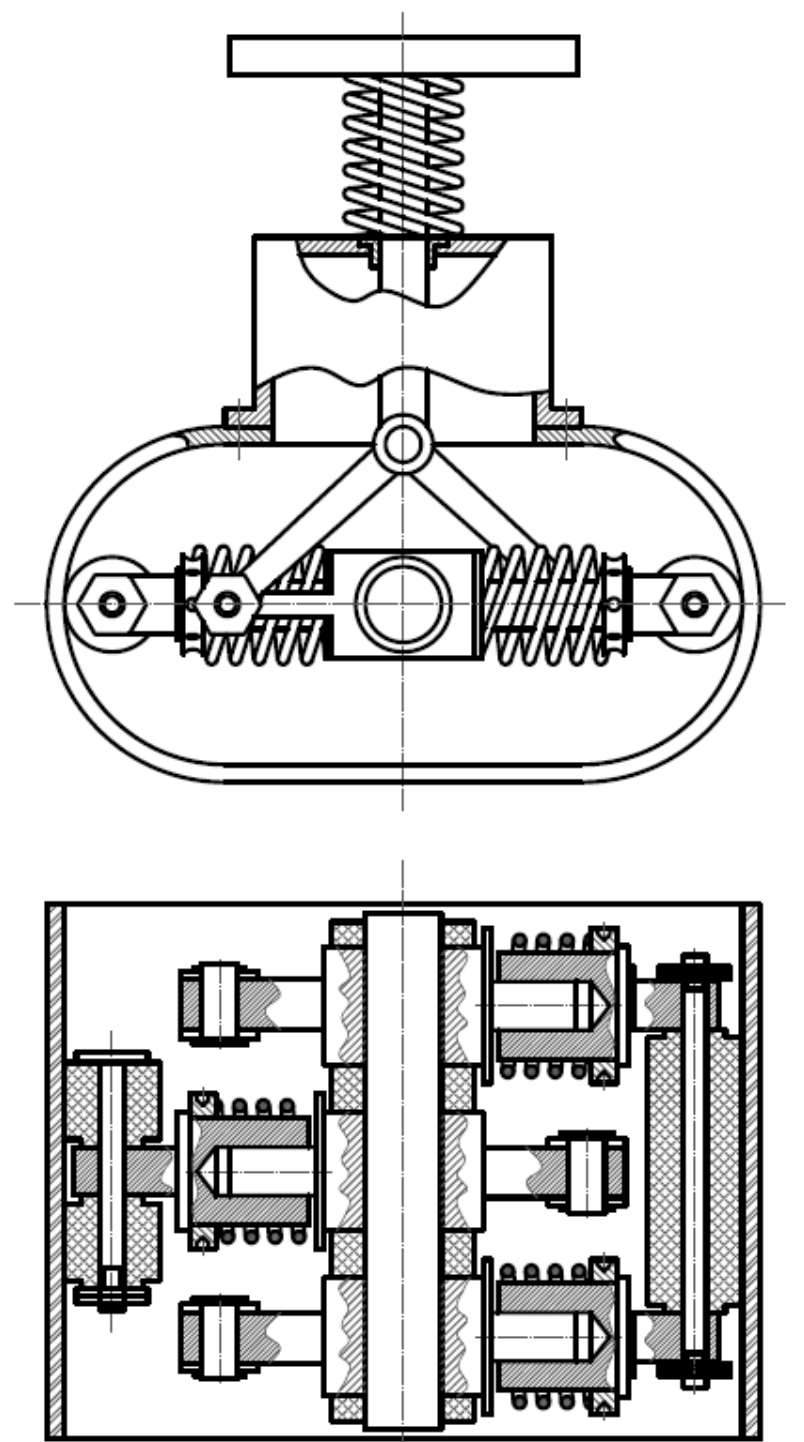

Рис. 8. Конструкція кулачкового ВСКЖ

Як відомо [193], в пасивних віброзахисних системах власна частота віброзахисної системи має бути, як мінімум, в (2) $)^{1 / 2}$ менше нижньої границі спектра збурюючих частот. В даному випадку ВСКЖ мала власну частоту 2,5-3 Гц. Подальше зниження можливе, але в реальних системах завжди є тертя, 
значення якого важко передбачити теоретично. Тому жорсткість системи має забезпечувати гарантоване повернення системи в стан первинної рівноваги. За занадто низьких власних частот і відносно великих сил тертя після припинення дії вібрації можлива зупинка в положенні близькому до граничних відхилень. Отже, в цьому випадку при повторному навантаженні можливі удари об обмежувачі. Тому необхідно забезпечувати певну додатню жорсткість системи, отже в теоретичному плані реальна система не має бути оптимальною 3 точки зору квазінульової жорсткості [194].

Описана конструкція ВСКЖ може бути рекомендована для використання в сейсмічно небезпечних районах, на річкових і морських судах в системах віброзахисту і стаціонарних універсальних низькочастотних віброзахисних системах. 


\subsection{Analysis of existing methods of grinding waste from mechanical industries}

During the mechanical processing of materials, waste is generated, which is 15$25 \%$ of the weight of the workpieces. Given the significant indicator for the regeneration of raw materials, the processing process is appropriate. However, before the recycling stage, there is an important and capacious transport process, for which the material must also be prepared, because the machining waste (chips and sludge) has a low bulk density. Transportation of bulk cargo is not economically feasible. Along with the financial part of the issue, there is an open issue of ecological content: unprepared chips have on their surface the remnants of lubricating and cooling fluids, which without disposal carry a bacterial threat to the environment. If we assume that 1 cubic meter DM removal of metal is consumed when turning approximately $0.5 \mathrm{kWh}$ of energy and the volume of steel chips 8 times greater than the initial volume of metal removed from the original workpiece, then on a modern machine with a capacity of 30 $\mathrm{kW}$ per hour is formed more than 0.2 cubic meters shavings. This chip, especially if it has a drain type according to the classification of IA Time, clutters not only the workplace of the machine, but also the area adjacent to the machine, complicating the normal operation of equipment and maintenance of the machine. There are many ways to prepare chips for transportation by grinding, which can be combined into two methods - during cutting (kinematic) and during transportation (non-kinematic).

The first method includes methods where the process of grinding chips is achieved by a special tool geometry, which is assigned in relation to the modes of cutting and processing materials, special devices (chip circles and chippers), pre-treatment of the surface, finding certain processing modes.

Chip crushing in the cutting process (kinematic method) is caused by the following prerequisites:

-increase in cutting speed;

-increasing the volume of mechanical engineering products and automation of machining processes;

-trauma from metal shavings. 
A specific feature of chip grinding on the machine is that the machine-building plants are equipped with a variety of metal-cutting equipment, a wide range of machined materials, a variety of cutting modes. Currently, a large number of methods of chip grinding process of blade processing, which can be divided into the following types:

- curling from an independent installation;

- with the contact of the curler and the cutter of the support surface;

- periodic stop of supply of the cutter;

- use of self-oscillations (change of elastic system machine - device - tool - part and selection of cutting modes).

The second method includes all methods associated with changing the kinematics of the cutting process, based on changes in feed. Obtaining crushed chips by the kinematic method is associated with a change in the design of the machine.

The most difficult to perform are the requirements for cutters for universal machines of serial and individual production, due to changes in parts, materials and cutting modes.

The main requirements for them are as follows: the cutter must stably form a favorable shape of the chips, with the widest possible fluctuations of the workpiece material and cutting modes; the cutter should not be bulky; preferably mechanical mounting of the cutter plates; possibility to perform a number of operations, transitions with the help of one cutter; the cutter must have normal stability; the design of the cutter should be simple and allow high-quality, economical sharpening.

Currently, many designs of cutters that adjust the shape of the chips to a more favorable, but they have a limited scope and do not have the properties of universality.

There are three types of the most characteristic designs of such cutters: cutters with a constant shape (without adjusting elements); cutters with overhead adjustable chippers; cutters with unground multifaceted plates.

Cutters with a constant shape have a number of limitations in their application and only partially meet the requirements for them for serial and linear-flow production. 
The main types of cutters for linear-flow production with constant cutting conditions include:

- cutters with fine powder;

- cutters with long regrind plates;

- cutters with overhead curlers, have a simplified design.

The disadvantages of such designs of cutters - the sensitivity of the shape of the chips to changes in cutting conditions (depth of cut, hardness of the material of the workpiece) and deviations in sharpening).

For automatic lines, four types of cutters are used, which can meet the requirements. These include:

- cutters with overhead curlers;

- cutters with holes (grooves);

- cup-shaped cutters;

- cutters with multifaceted non-grinding carbide inserts.

The disadvantages of these cutters are:

- the need for mounting plates and insufficiently stable nature of the chips, which changes with fluctuations in allowance, hardness of the material and with blunt cutters;

- the need in each case to carefully choose the geometry of sharpening the cutter;

- increasing the vertical and radial component of the cutting force in cup cutters;

- sensitivity of cutters to constantly changing cutting conditions and to instability of sharpening of cutters.

Thus, in terms of production non-kinematic method of grinding chips does not always provide reliable grinding in the processing of plastic and hardened materials, to grind chips by this method is almost impossible.

Due to these reasons, the kinematic method of chip chipping has recently become widespread.

The kinematic method of grinding chips into elements due to the periodic exit of the cutter from the cutting zone provides reliable grinding of chips regardless of the workpiece, cutting mode and tool geometry. There are two ways to use this method: 
- cutting with periodic switching off of giving of the cutter at continuous rotation of a detail;

- cutting by introducing additional oscillating motion of the cutter.

The first method is called discrete, and the second, which implements the sinusoidal law of oscillating motion, is called the vibrational method.

However, they are not widespread, as they have a number of disadvantages:

- do not provide constancy of glow of shaving;

- reduce productivity in comparison with continuous cutting;

- reduce the rigidity of the system machine -device - tool - part;

- difficult to install, unreliable, not versatile in operation;

- Does not provide the necessary roughness and shape of the processed surface;

- the required safety and convenience during operation is not provided;

- associated with sources of variable design of machines.

Free from the disadvantages of the kinematic method of grinding chips is relaxation, which consists in the fact that the cutting tool receives a total movement in the feed direction, consisting of a uniform motion with the feed described by the law of relaxation oscillations, which significantly distinguishes this method from vibration, in which this movement described by the law of harmonic oscillations.

However, this method has a number of significant disadvantages:

- apply for a certain range of cutting speeds;

- not used for finishing turning;

- requires certain changes in the existing designs of metal-cutting equipment.

After analyzing the existing methods of grinding chips on a lathe and after inspecting the mechanical shops of large plants, we can draw the following conclusions:

- the problem of chip grinding in the cutting process is not widely used and is currently unresolved;

- there is no universal, effective and optimal way to process any workpiece on any machine; 
- for the final grinding of chips it is necessary to create special equipment that will ensure the grinding of chips during transportation by conveyor from the machine to the packing and processing area. 


\subsection{Raising of durability of auto grader knives cutting elements}

Ensuring sufficiently high durability of cutting elements (CE) used in motor graders and other earthmoving machines (EM) is considered to be one of the compulsory conditions determining the reliable operation of earthmoving machines (EM) and the highest efficiency of their operation. This is due to the fact that the decrease in the durability of (EM) occurs due to the excessive abrasive wear of their (CE) [197, 198]. In connection with this, there is a search for new, as well as improvement of the existing methods for reducing abrasive wear of $\mathrm{CE}$ materials used for their manufacture. It is possible to reduce the abrasive wear of CE by several methods (by hard surfacing with various alloys, volumetric hardening, surface strengthening, etc.). However, these methods have a number of shortcomings, since they worsen the stress-free state of the material after the application of a particular technology and, as a consequence, lead to insufficient resistance to abrasive wear during operation of $\mathrm{CE}$ in the operating environment (dredging soil).

The solution of the problem can be expected by using an ion-plasma coating (IPC) $\mathrm{TiN}-\mathrm{Cr}_{2} \mathrm{~N}$ on the surface of the CE [199]. However, at present there is no information in the literary sources about the use of such coating for the CE of EM. In case of a positive result of such a solution to the problem, it becomes possible to increase the service life of the EM in difficult operating conditions, to cut downtime on repair, as well as the cost of restoring or replacing worn-out electronic devices with new ones.

To assess the efficiency and obtain quantitative specifications confirming the positive effect of IPC application in real operating conditions, the corresponding tests of DZ-180 motor grader were carried out (Fig. 1). 


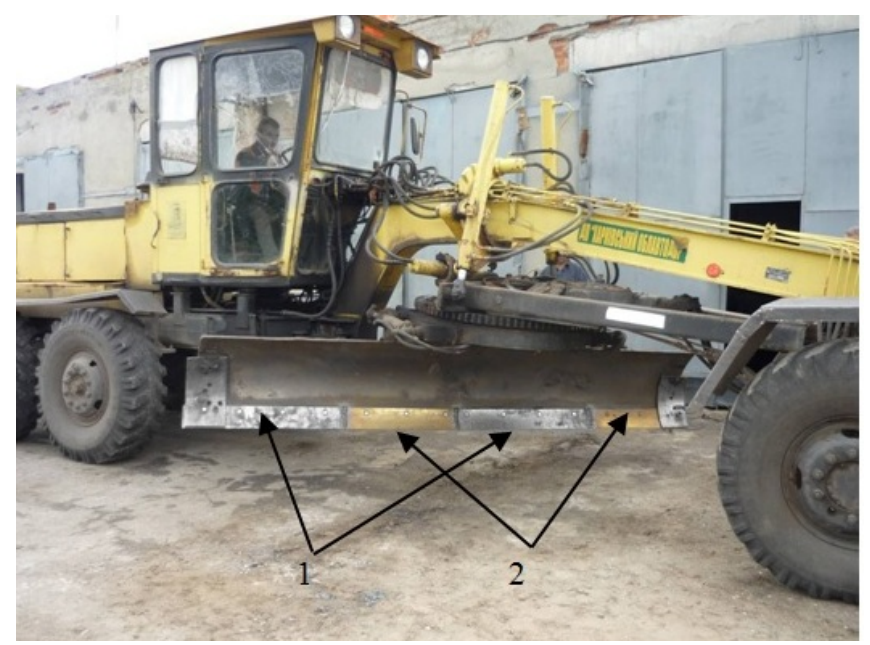

Figure 1. General view of the auto grader DZ-180 with cutting knives hardened by high frequency currents (HFC) (1) and HFC $+\mathrm{TiN}^{-\mathrm{Cr}_{2} \mathrm{~N}}$ (2)

Operational tests of auto grader DZ-180 were carried out in two stages. At the first stage of testing, the grader blade was installed at the angle of $90^{\circ}$, at which loading on the knives was maximum [200], and therefore their durability was the smallest. In addition, such entrance angle ensures uniform abrasive runout of the knife along the entire length.

At the second stage of testing, the auto grader was operated in regular operation mode without any limiting, so it performed all types of work in which the blade entrance angle varied from 10 to $90^{\circ}$.

During the first stage of testing, two middle knives made of $65 \mathrm{G}$ steel after hardening with high frequency current were cut into two parts each (Fig. 2). By doing so, the smaller two parts of the knife (Fig. 2 b) were grinded to a surface of roughness $0.32 \mu \mathrm{m}$ and then subjected to IPC $\mathrm{TiN}-\mathrm{Cr}_{2} \mathrm{~N}$ under the conditions presented in Table. $1[200,201]$. The applied coating consists of a fusion of alternating five layers of $\mathrm{Cr} 2 \mathrm{~N}$ and four layers of TiN. In the process of applying multilayer coating there occurs tempering of steel $65 \mathrm{G}$, which leads to a decrease in hardness to HRC 30. After thermal treatment, the hardness of the substrate constitutes HRC 50-54. 
Table 1

Modes of $\mathrm{TiN}-\mathrm{Cr}_{2} \mathrm{~N}$ coating [201]

\begin{tabular}{|c|c|c|c|c|c|c|}
\hline $\begin{array}{c}\text { Emission } \\
\text { cathode } \\
\text { material }\end{array}$ & $\begin{array}{c}\text { Current } \\
\text { on Cr, A }\end{array}$ & $\begin{array}{c}\text { Current on } \\
\text { Ti, A }\end{array}$ & $\begin{array}{c}\text { Voltage } \\
U, \mathrm{~V}\end{array}$ & $\begin{array}{c}\text { Current } I, \\
\mathrm{~A}\end{array}$ & $\begin{array}{c}\text { Pressure } \\
P, \mathrm{~Pa}\end{array}$ & $\begin{array}{c}\text { Depositi } \\
\text { on time } \\
t, \mathrm{~min}\end{array}$ \\
\hline \multicolumn{6}{|c|}{ 1st stage: cleansing, heating and activation by chromium ions } \\
\hline chromium & 80 & - & 90 & 2 & 1,33 & 7 \\
\hline \multicolumn{7}{|c|}{ 2nd stage: spraying of coating in nitrogen atmosphere } \\
\hline $\begin{array}{c}2 \\
\text { cathodes: } \\
\text { 1st } \\
\text { chrome } \\
\text { 2nd } \\
\text { titanium }\end{array}$ & 80 & 70 & 150 & 3 & 0,67 & 25 \\
\hline
\end{tabular}

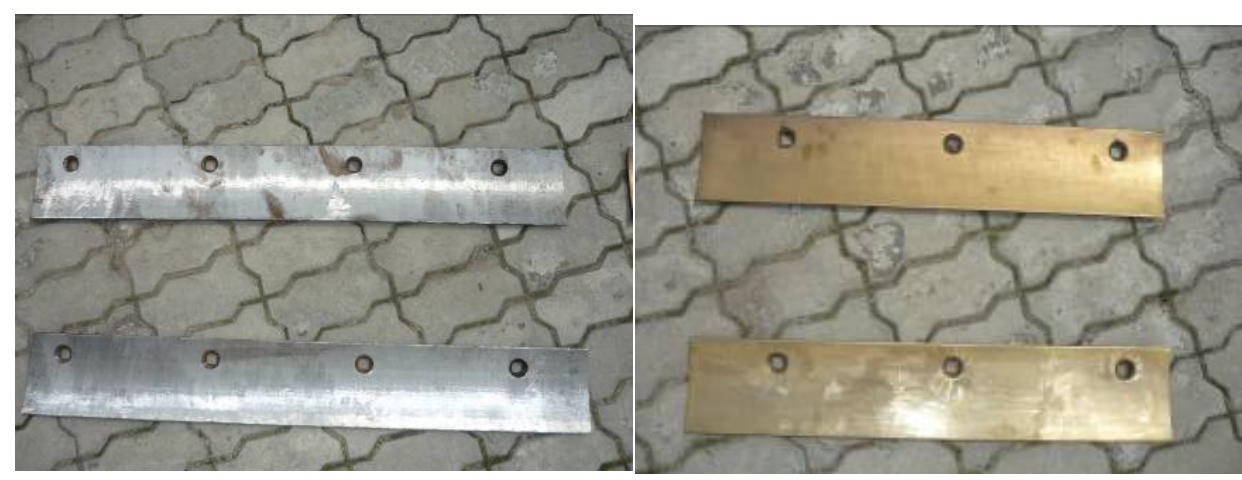

a)

b)

a) - cutting knives with HFC hardening;

b) - cutting knives with HFC and IPC TiN-Cr2N hardening

Figure 2. Auto grader cutting knives made of $65 \mathrm{G}$ steel.

Further, the cutting knives with and without coating were installed on the blade of the auto grader DZ-180 in the order shown in Fig. 1, that is, the parts of the knife without a coating (1) and with the $T i N-\mathrm{Cr}_{2} \mathrm{~N}$ IPP coating (2) were taking turn (interleaving). After that, the auto grader was subjected to operation for 150 machinehours, which under normal operating conditions provides the cutting knives greatest wear [199].

Before the performance testing of the auto grader, the blade cross-sectional thicknesses were measured using a plaster mix. For this, it was taken a mixture, 
consisting of gypsum and alabaster in a ratio of 10:1. The method to determine the thickness of the cross-section consisted in fact that motor grader cutting knives were placed in plastic molds, filled with carefully whipped plaster mixture (Fig. 3). Each cutting knife fragment was mounted on three identical plastic containers with a gypsum mixture. In this case, one container with the mixture was placed in the center of the cutting knife fragment, and the remaining two were placed along the edges. In this position, the cutting knives have been kept for 1 hour (Fig. 3). After an hour, all the fragments of the cutting knives were dismantled from the containers together with the hardened gypsum mixture. Then these containers were cut along the cross section of the cutting knife, the trace of which remained after dismantling (Fig. 3).

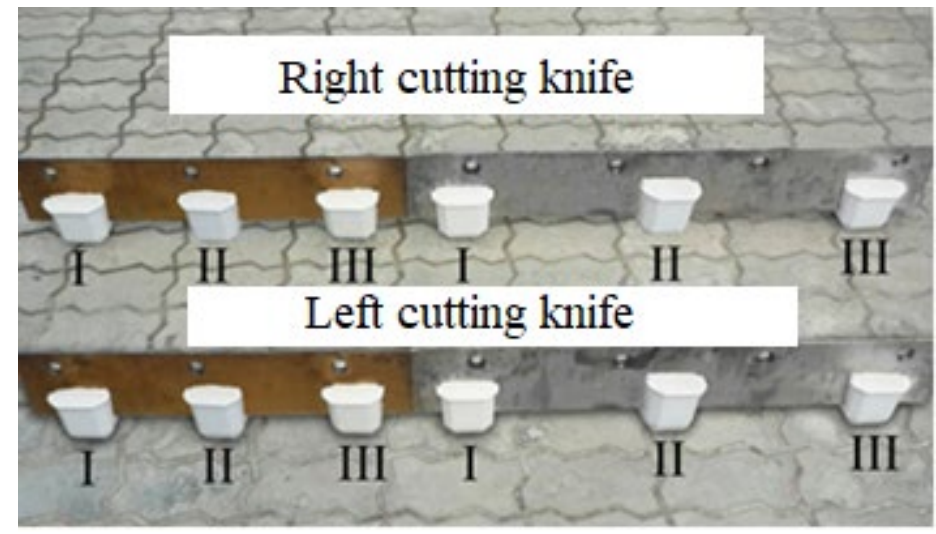

Figure 3. Plastic molds with medium cutting knives before testing on the motor grader DZ-180.

Then, the received cuts of the knife cross-section were scanned using the Canon MP280 multifunctional device. On 12 prints of the cross-section of the cutting knife, obtained as a result of scanning before and on 12 prints after the operation of the auto grader using the KOMPAS-3D V19 program, the thickness of the cross-section of the cutting knife was defined at a height of $12 \mathrm{~mm}$ from the top of the print. The choice of this height rate is due to the fact that the wear-out of the cutting knives occurs evenly over the entire surface, which is connected with the installation of the blade at an angle of $90^{\circ}$ relatively to the direction of the motor grader movement.

Each cutting knife (right and left) of the auto grader was measured six times in total. However, due to the fact that the side cutting knives overlapped the ends of the 
middle cutting knives during installation (Fig. 1), the wear-out value of the first zone of the left and third zone of the right cutting knife wasn 't taken into account, as cutting knife wear in these zones occurred only on the rear surface. In this regard, in order to obtain reliable experimental results, the wear-out values of the grader knife were taken into account only for five zones of the same cutting knives with HFC hardening and for five with $\mathrm{TiN}_{-} \mathrm{Cr}_{2} \mathrm{~N}$ coating.

The purpose of the second stage of the tests was to establish the wear-limit of the parts of the cutting knife with HFC hardening and $\mathrm{TiN}_{-} \mathrm{Cr}_{2} \mathrm{~N}$ coating under normal operating conditions.

At the second stage of the tests, the auto grader performed all the regular work (repair and maintenance of the road surface, profiling of the ground, road construction, etc.), herewith, the cutting knife installation system used was the same as in the first stage of testing the auto grader.

During the entire test period, the cutting knives were dismantled every 50 machine-hours and their thickness was determined according to the method described above. Fragments of the standard cutting knife subjected to HFC hardening were tested until their wear reached the limit value, and fragments of the cutting knife with IPC continued to operate up to the amount of wear corresponding to the limit wear of standard cutting knives.

The results of cross-sectional measurements of wearing values are presented in table. 2 , and in fig. 4 .

As it can be seen from table 2, the wear on the first zone of the left cutting knife and on the third zone of the right cutting knife have the lowest values. This is due to the fact that in the process of mounting the middle cutting knives, their outer parts are overlapped by the bits (side cutters) installed on the top i.e. only the rear surface of the cutting knife on these zones and the front surface of the bits are worn.

The least wear also occurs with TiN- $\mathrm{Cr}_{2} \mathrm{~N}$ IPC of cutting knives. For example, the wear of the second and third zones of the left cutting knife with TiN-Cr2N is 1.57 and 1.61 times less than the wear of the same zones of the left cutting knife after HFC hardening. The wear of the first and second zones of the right cutting knife with IPC, 
is 1.63 and 1.62 times less than the wear in the same zones for the right knife with HFC hardening. Comparing the wear values of the out areas (the first zone on the left and the third zone of the right cutting knife), we can conclude that the process of wear on the back surface was less intense than on the rest of the cutting knife. However, the wear of the first zone of the left cutting knife with IPC TiN-Cr2N is 1.58 times less than the wear of the third zone of the right knife. Herewith, the wear of the cutting knives after HFC hardening, averaged $2.79 \mathrm{~mm}$, and the same cutting knives, but with IPC TiN-Cr2N $-1.75 \mathrm{~mm}$, i.e. 1.59 times less than the wear of regular cutting knives. In addition, during the operational tests of the cutting knives, an intense rounding of their cutting edge was observed (Fig. 4). At the same time, after 150 machine-hours of testing of the auto grader, the latter had a shape close to cylindrical. This led to a pronounced bluntness of the cutting knife, especially in those areas that were subject only to HFC hardening .

Table 2.

Thickness and wear of the auto grader blade after operation for 150 machine-hours

\begin{tabular}{|c|c|c|c|c|c|c|c|c|c|c|c|c|}
\hline Paramete & \multicolumn{12}{|c|}{ Knife cross-section thickness, mm } \\
\hline Knife & \multicolumn{6}{|c|}{ Left knife } & \multicolumn{6}{|c|}{ Right knife } \\
\hline $\begin{array}{c}\text { Knife } \\
\text { processin } \\
\text { g method }\end{array}$ & \multicolumn{3}{|c|}{$\begin{array}{c}\text { With HFC } \\
\text { hardening +IPC } \\
\text { TiN-Cr } 2 \mathrm{~N}\end{array}$} & \multicolumn{3}{|c|}{$\begin{array}{l}\text { With HFC } \\
\text { hardening }\end{array}$} & \multicolumn{3}{|c|}{$\begin{array}{c}\text { With HFC } \\
\text { hardening + IPC } \\
\text { TiN-Cr } 2 \mathrm{~N}\end{array}$} & \multicolumn{3}{|c|}{$\begin{array}{l}\text { With HFC } \\
\text { hardening }\end{array}$} \\
\hline Zone & I & $\mathrm{I}$ & III & I & II & III & I & II & III & I & II & III \\
\hline $\begin{array}{l}\text { Before } \\
\text { testing }\end{array}$ & $\vec{m}$ & $\stackrel{\substack{0 \\
r}}{n}$ & $\frac{n}{n}$ & $\begin{array}{c}\infty \\
N \\
N\end{array}$ & 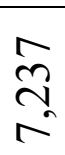 & $\underset{\sim}{\stackrel{\sim}{\sim}}$ & 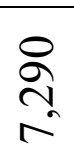 & $\vec{m}$ & 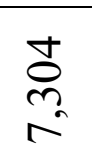 & $\underset{N}{N}$ & 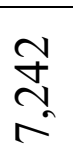 & సે \\
\hline $\begin{array}{l}\text { After } \\
\text { testing }\end{array}$ & $\begin{array}{l}n \\
n \\
n \\
0\end{array}$ & $\frac{n}{n}$ & $\begin{array}{l}n \\
n \\
n \\
n\end{array}$ & $\begin{array}{l}\hat{N} \\
\hat{\sigma} \\
\forall\end{array}$ & 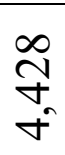 & $\stackrel{n}{\tilde{f}_{n}}$ & $\begin{array}{l}0 \\
8 \\
\text { in }\end{array}$ & $\begin{array}{l}+ \\
\infty \\
n \\
n\end{array}$ & $\begin{array}{l} \pm \\
n \\
n \\
n\end{array}$ & 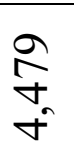 & $\underset{⿱}{\stackrel{J}{+}}$ & $\ddot{8}$ \\
\hline
\end{tabular}




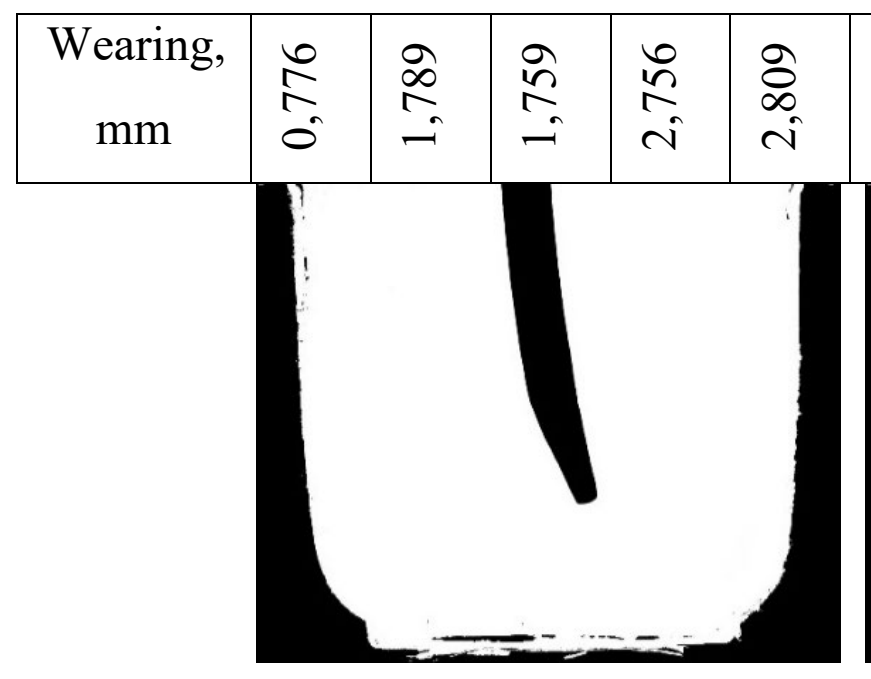

a)

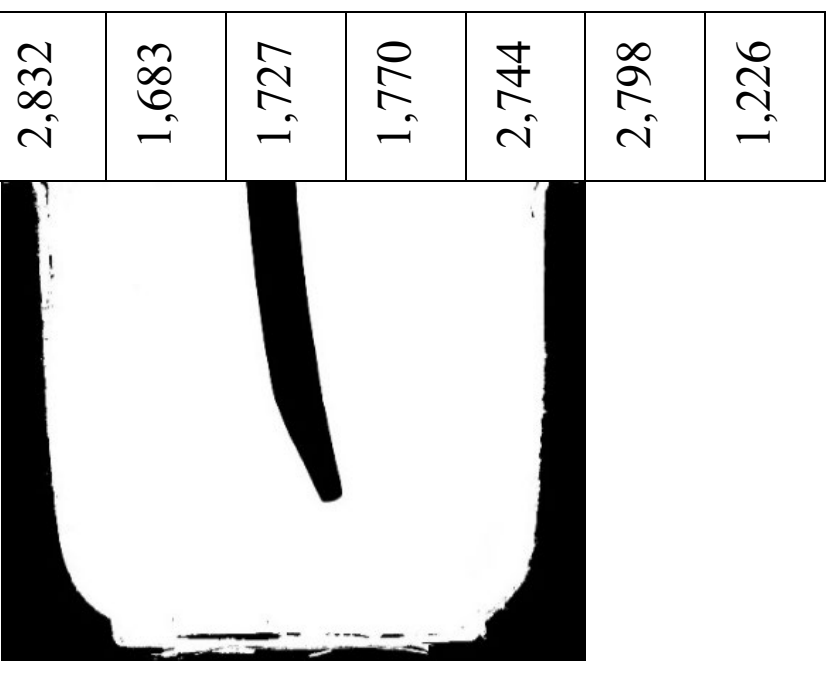

b)

Figure 4. Imprint of the auto grader cutting knife cast after testing with IPP TiN$\mathrm{Cr}_{2} \mathrm{~N}$ (a) and subjected only to HFC hardening (b).

Thus, at the location of the middle blade of auto grader at an angle of $90^{\circ}$, the wear of cutting knives with IPC TiN- $\mathrm{Cr}_{2} \mathrm{~N}$, on the average, was 1.6 times less than the wear of regular cutting knives after HFC hardening

The results of the second stage of tests during the long service life of the auto grader blades are shown in Fig. 5.

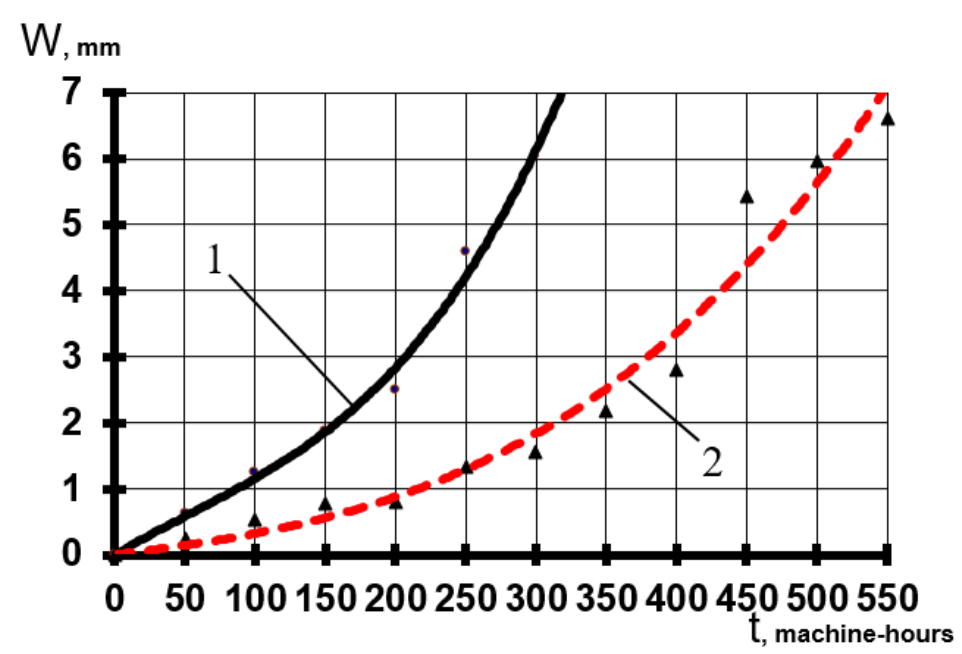

Figure 5. Dependence of wear $W$ of a cutting element with HFC hardening (1) and with IPC TiN-Cr $2 \mathrm{~N}$ hardening (2) on time t of operation. 
As it can be seen from the graphs presented in Fig. 5, the wear of standard cutting knives reached the limit value $(7 \mathrm{~mm})$ after 322 machine-hours of testing. The same amount of wear of cutting knives with IPC TiN- $\mathrm{Cr}_{2} \mathrm{~N}$ hardening reached after 550 machine-hours, which is 1.7 times more than regular cutting knives.

The operational tests of the auto grader confirmed the positive effect of applying IPC TiN-Cr $r_{2} \mathrm{~N}$ on the surface of cutting knives with thickness of $4 \mu \mathrm{m}$ and roughness of $0.32 \mu \mathrm{m}$, and the cutting knife material hardness of $50 \mathrm{HRC}$. This effect is expressed in a decrease in wear (increase in durability) of the medium auto grader cutting knives by an average of 1.6 times at the maximum loading on the blade (at the entrance angle $90^{\circ}$ ). 


\section{4 Безвідходні способи видавлювання деталей типу кільця}

У промисловості широко застосовуються деталі типу кільця різної конфігурації. Безвідходним способом виготовлення таких деталей є радіальне видавлювання з наступним відділенням багатоштучної заготовки від отриманої деталі [202]. Однак відомий спосіб на забезпечує високої якості різу (з'являються задирки у місці різу).

Розроблений спосіб комбінованого радіального видавлювання-розділення деталей типу кільця, що забезпечує отримання гладкої поверхні отвору деталі (рис. 1) [203]. Процес цього способу видавлювання-розділення можна поділити на декілька стадій: 1 - вільного радіального видавлювання; 2 - стадія радіального видавлювання 3 підпором (коли фланець торкнувся стінки порожнини матриці); 3 - стадія пробивання.

На першій стадії радіального видавлювання відносно тонких фланців 3 відношенням $h_{\phi} / R_{0}<0,5$ порожнина, у тому числі кут на периферії фланця заповнюється повністю при досягненні пуансона верхньої межі кругової порожнини матриці (верхнього торця фланця).

До кінця стадії радіального видавлювання відносно товстих фланців (переважно для фланців 3 відношенням $h_{\phi} / R_{0} \geq 0,5$ ) порожнина заповнюється практично цілком, за винятком верхнього кута на периферії фланця. Цей кут може бути заповнений наприкінці першої стадії, коли здійснюється занурення пуансона 4 у тіло фланця на висоту $h$.

Таким чином завдяки досягненню пуансона верхньої межі кругової поперечної порожнини матриці або зануренню пуансона у тіло фланця переходять від стадії видавлювання до стадії прошивання, заповнюючи повністю порожнину матриці та зміцнюючи зону зрізу, що дозволяє отримувати деталі 


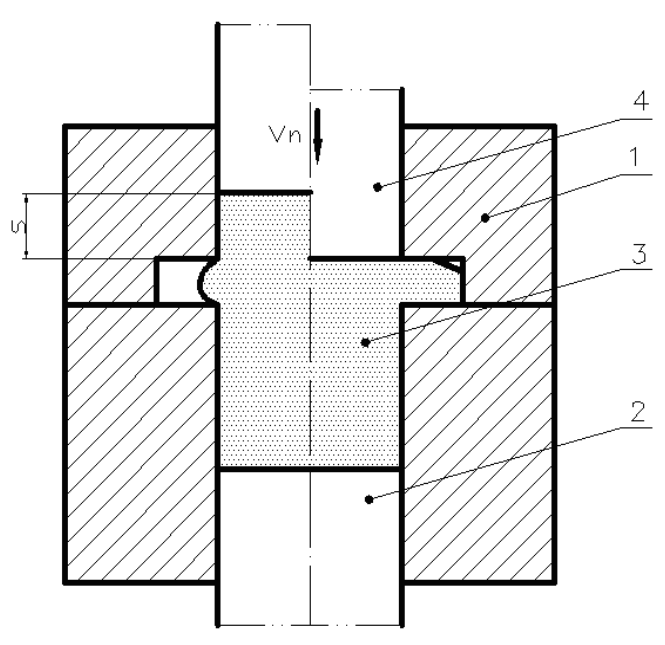

a

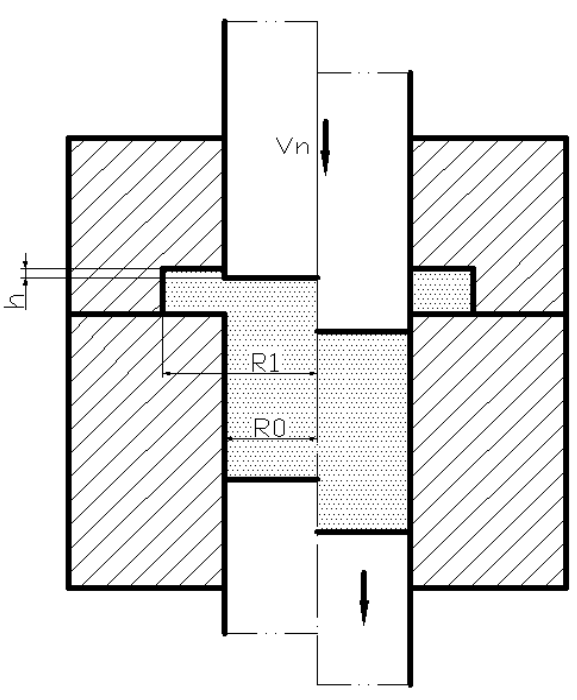

6

Рисунок 1. Схема процесу комбінованого радіального видавлюваннярозділення деталей типу кільця: а - початок стадії радіального видавлювання (зліва) та кінцю радіального видавлювання кільця із зовнішньою фаскою (справа); б занурення пуансона у тіло фланця (зліва) та пробивання отвору (справа)

типу кільце з чітко оформленою зовнішньою поверхнею та одержати якісну поверхню отвору. За рахунок впливу високого гідростатичного тиску в осередку деформації, що утворюється завдяки підпору зі сторони фланця, поверхня отвору отримується пластичним зсувом замість сколювання при пробиванні та калібрується при подальшому ході деформуючого пуансона, що значно покращує якість поверхні отвору кільця.

На наступному кроці отриману деталь видаляють 3 порожнини штампу, висувають заготівку на висоту, що дорівнює ходу пуансона на стадії радіального видавлювання $s$, відносно порожнини штампу та продовжують процес деформування. Цикл повторюють до закінчення багатоштучної заготівки (переважно для 3-5 деталей).

Також для заповнення верхнього кута на периферії фланцю та для отримання високого гідростатичного тиску (підвищення пластичності металу) в зоні зрізу було запропоновано в кінці комбінованого радіального видавлюваннярозділення виконувати підсадку фланця [204]. 
Але підсадку фланця для даного способу отримання деталей типу кільце можливо виконувати за трьома схемами деформування, коли під час підсадки: 1 пуансон знаходиться під навантаженням; 2 - коли пуансон вимкнений; 3 - коли пуансон рухається униз зі швидкістю відмінною або рівною від швидкості матриці.

Коли пуансон знаходиться під навантаженням у момент підсадки фланцю, під дією деформуючого інструменту (верхньої половини матриці) метал переміщується у зовнішній кут периферії фланцю, тим самим утворюючи чітко оформлену зовнішню поверхню. Але під час такого деформування тиск буде стрімко зростати, що знижує стійкість інструменту та потребує обладнання 3 більшим зусиллям.

Для схеми підсадки, коли пуансон вимкнений, характерно дві ступені вільності металу: 1 - коли метал переміщується у верхній кут матриці; 2 - у зону під пуансоном, рухаючи пуансон угору.

Наявність декількох ступенів вільності течії металу дозволяє знизити зусилля деформування та навантаження на інструмент (матрицю і пуансон), що збільшить строк служби штампового оснащення [205, 206].

Для схеми підсадки фланцю, коли пуансон рухається вниз, характерна можливість керувати швидкістю пуансона.

Дослідження енергосилових параметрів процесів підсадки фланців за вказаними схемами було виконано методом верхньої оцінки (рис. 3).

Встановлено, що для схеми підсадки фланця, коли пуансон під навантаженням, зі збільшенням коефіцієнту тертя від 0 до 0,5 за Зібелем приведений тиск підсадки фланця, коли пуансон знаходиться під навантаженням, збільшується на 5-55\% (рис. 4). Найбільший вплив коефіцієнту тертя спостерігається при менших співвідношеннях геометричних параметрів кільця, так при $H / s=0,5$ приведений тиск знаходиться у межах $1,87 \ldots 2,9$, а при $h / s=1,1-\bar{p}=4,4 \ldots 4,94$.

Встановлено, що для схеми підсадки фланця, коли пуансон вимкнений (є 2 ступеня вільності), зі збільшенням коефіцієнту тертя від 0 до 0,5 за Зібелем приведений тиск зростає у 1,6...8 разів. Тому для цієї схеми важливий ретельний 
підхід до вибору змащень, що забезпечать мінімальний коефіцієнт тертя.
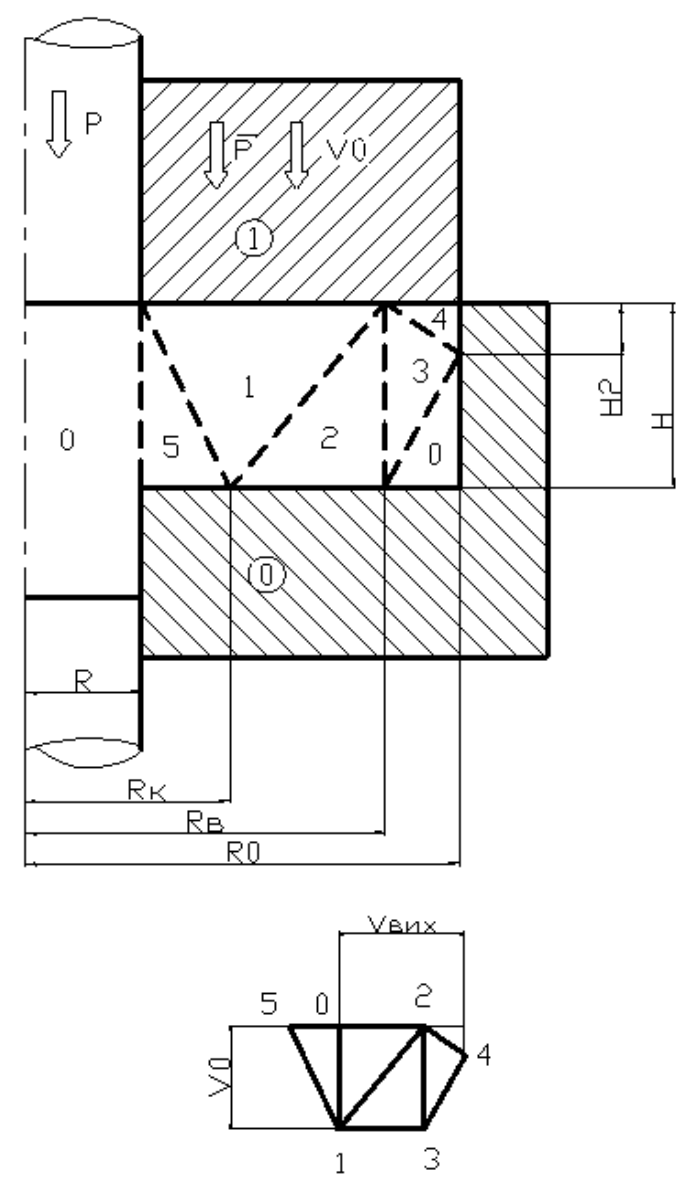

a

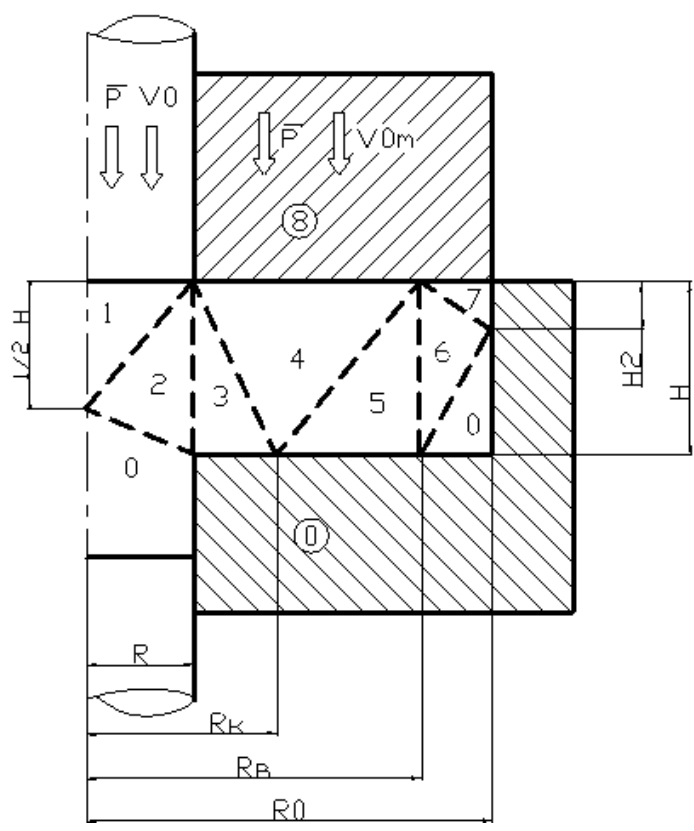

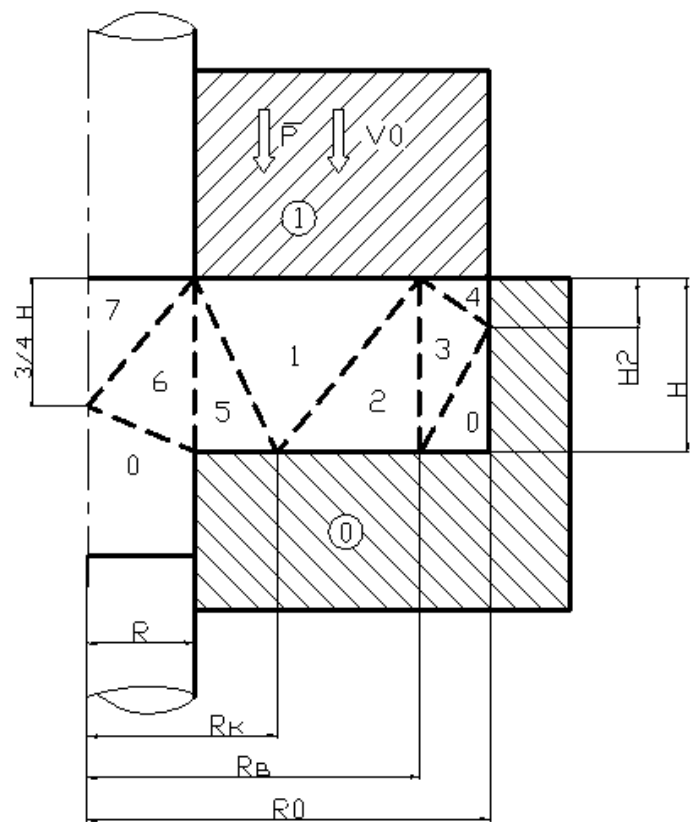

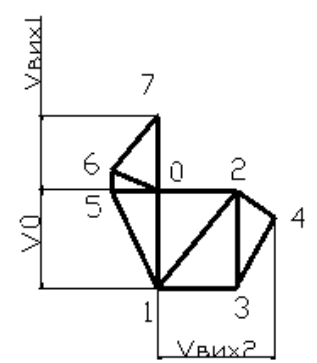

б

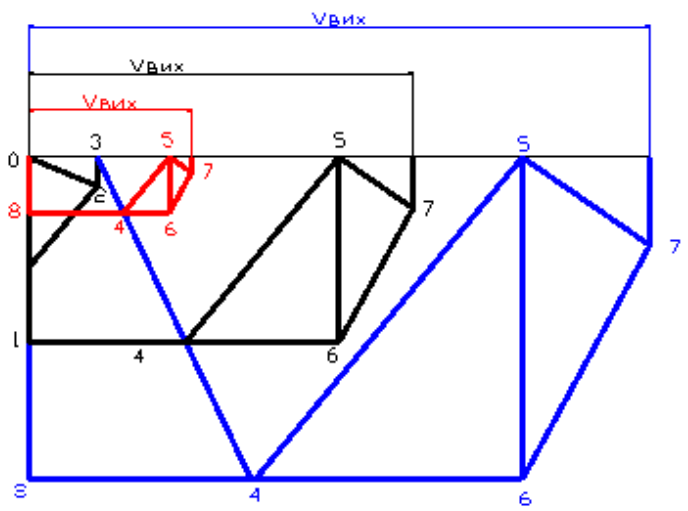

B

Рисунок 3. Розрахункові схеми та годографи швидкостей процесів підсадки фланців: а - коли пуансон під навантаженням, та годограф швидкостей; б - коли 
пуансон вимкнений; в - пуансон рухається разом з матрицею

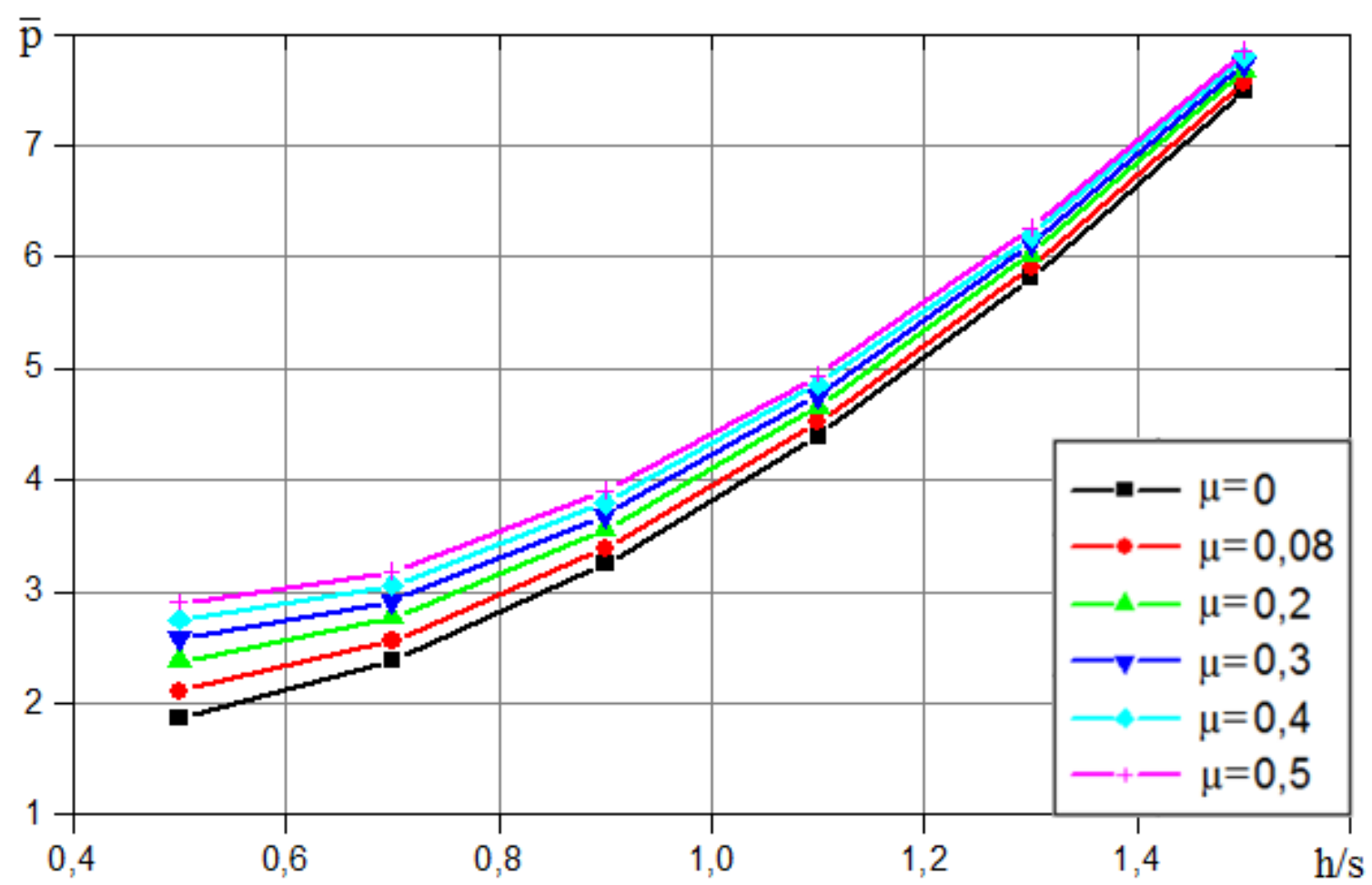

Рисунок 4. Залежність приведеного тиску від геометричних параметрів кільця $h / s$ та коефіцієнту тертя $\mu$ для процесу підсадки фланця, коли пуансон під навантаженням

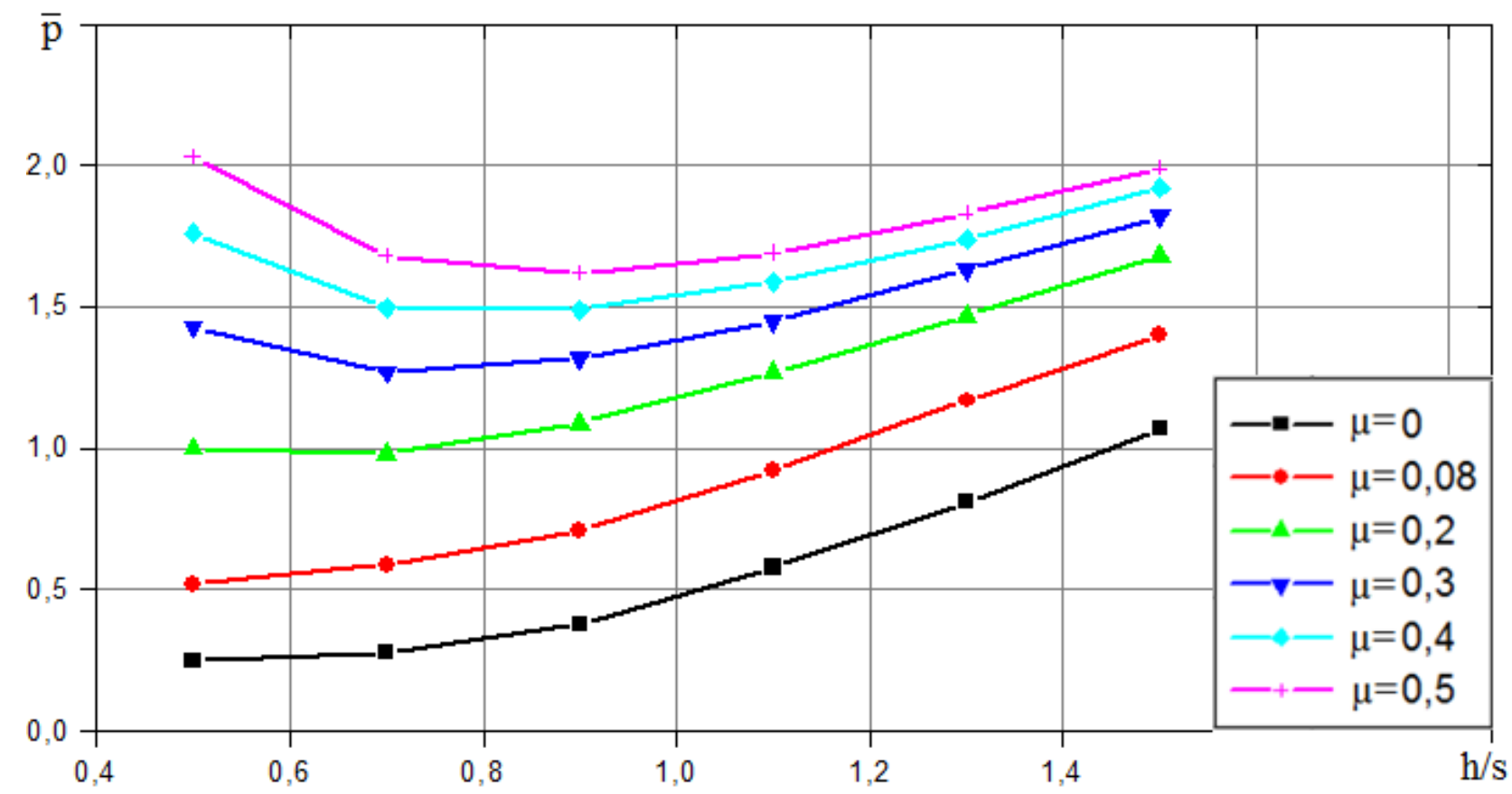

Рисунок 5. Залежність приведеного тиску від геометричних параметрів кільця 
$h / s$ та коефіцієнту тертя $\mu$ для процесу підсадки фланця, коли пуансон вимкнений

Крім того, для схеми підсадки фланця, коли пуансон вимкнений, характерне збільшення приведеного тиску до 4 разів при збільшенні геометричних параметрів деталі $h / s=0,5 \ldots 1,5$.

Для схеми підсадки фланця, коли пуансон рухається рухається разом 3 матрицею особливий інтерес представляє вплив відносної швидкості руху пуансона на приведений тиск деформування (рис. 6).

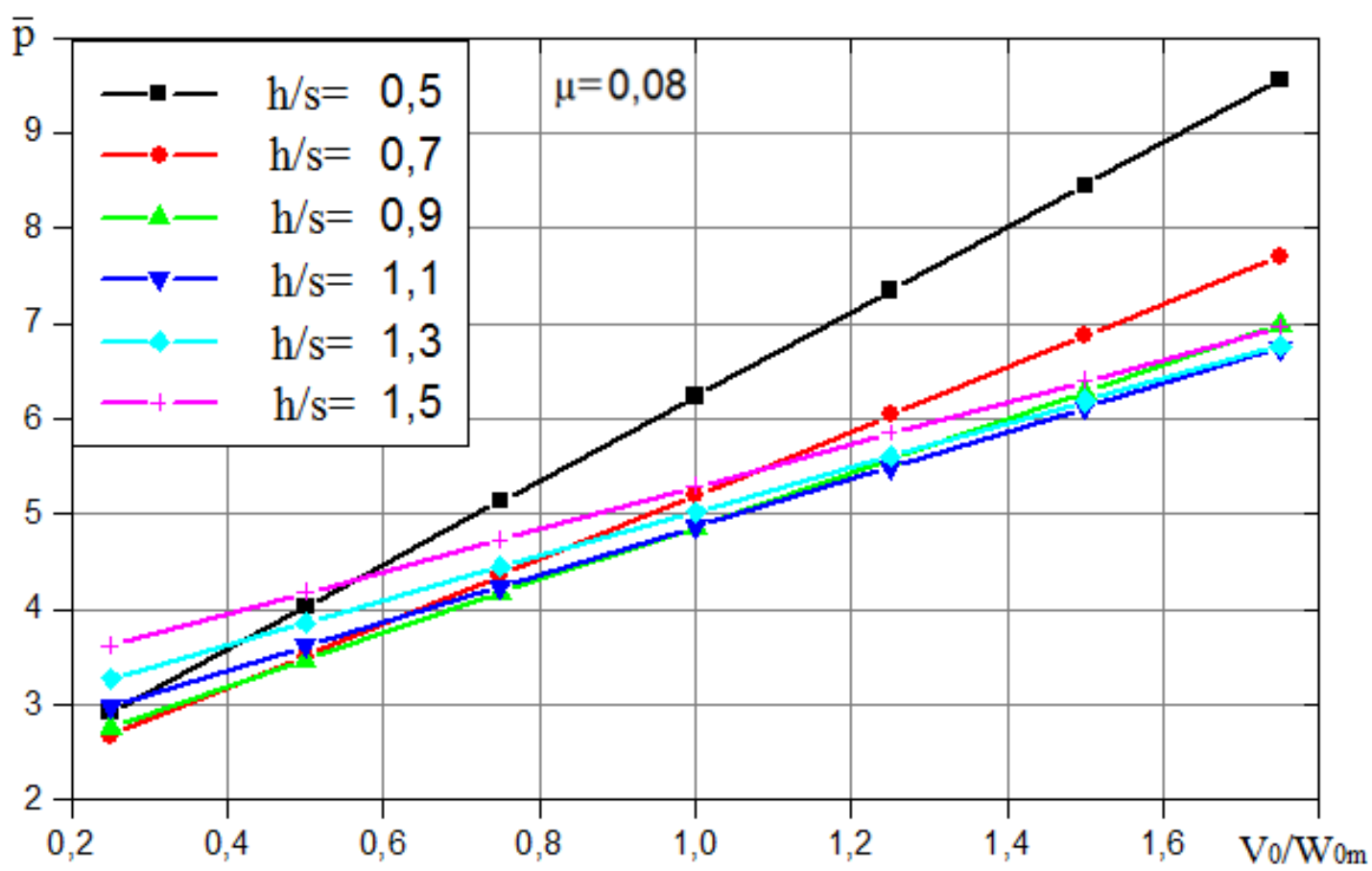

Рисунок 6. Залежність приведеного тиску від відносної швидкості пуансона при підсадці фланця при різних співвідношеннях геометричних параметрів деталі та коефіцієнті тертя $\mu=0,08$

Встановлено, що зі збільшенням відносної швидкості пуансона в інтервалі 0,25 до 1,75 приведений тиск збільшується на $1,67 \ldots 3,7$ рази. Таке збільшення приведеного тиску пояснюється тим, деформування під пуансоном відбувається швидше, ніж у процесі самого процесу підсадки, що потребує більших енергосилових витрат. Крім того, коли пуансон рухається зі швидкістю руху 
матриці $\left(V_{0} / W_{0 m}=1\right)$ приведений тиск мало залежить від геометричних параметрів деталі у діапазоні $h / s=0,7 \ldots 1.5$.

Як видно з представлених графіків, підсадка фланця, коли пуансон вимкнений $є$ найменш енерговитратною, а найбільш - процес підсадки фланцю, коли пуансон рухається разом із матрицею. Зниження приведеного тиску під час підсадки фланцю із вимкненим пуансоном дозволить збільшити строк слугування деформуючого інструменту, що значно знизить собівартість виготовлених деталей. Однак, схема підсадки фланця, коли пуансон рухається разом iз матрицею дозволить досягти максимального заповнення порожнини матриці, що спостерігається при звичайному радіальному видавлюванні.

Усі ці схеми видавлювання деталей типу кільце дозволяють регулювати течію металу під час штампування, це дозволяє отримувати деталі необхідної якості та пристосовувати процес виготовлення деталей типу кільце до обладнання, що є у наявності виробника. 


\section{SECTION 10. METALLURGY AND ENERGY}

\subsection{Technology, structure and magnetic properties of the Ni-Al ferrite nanopowders}

$\mathrm{Ni}-\mathrm{Al}$ ferrites are perspective materials, which can be effectively used in the microwave engineering [207]. That's why obtaining the optimal characteristics for microwave devices is of great importance. Microwave and other characteristics of $\mathrm{Ni}$ $\mathrm{Al}$ ferrites have already been investigated and are presented in [208,209].

Though many requirements are specific for each microwave device, some of them are common for all devices. Among these characteristics generally most important are the small polycrystals size, low conductivity and high homogeneity of chemical composition with the accurate ratio of components' concentrations. Such requirements can be achieved in Ni-Al ferrites obtained by sol-gel method which is accompanied with auto-combustion. The above mentioned properties of the Ni-Al ferrites can be used not only as components for the production of microwave devices but also as components for the production of the composite magneto-electric materials. It should be noted, that the technology of polycrystalline ferrites production suggests that their electro-magnetic parameters are formed at the stage of preparation of the half-finished product, i.e. at the ferrite powder preparation stage. Nevertheless, many features relating the sol-gel auto-combustion technology of the Ni-Al ferrites and their properties are still un-known and needs more detailed studies.

Ferrites of the $\mathrm{NiAl}_{\mathrm{x}} \mathrm{Fe}_{2-\mathrm{x}} \mathrm{O}_{4}(\mathrm{x}=0,0.07,0.15)$ composition were obtained by nanotechnology with using sol-gel method accompanied by auto-combustion. As precursors the metal nitrates with the chemical formula $\mathrm{Me}_{\mathrm{n}}\left(\mathrm{NO}_{3}\right)_{\mathrm{m}} \times \mathrm{rH}_{2} \mathrm{O}(\mathrm{Me}=\mathrm{Ni}$, $\mathrm{Fe}, \mathrm{Al}$ ) were used. The reaction of polycondensation took place in the presence of such organic electrolyte as citric acid $\left(\mathrm{C}_{6} \mathrm{H}_{8} \mathrm{O}_{7}\right)$. Neutralisation of gel up to $\mathrm{pH}=7-8$ was carried out with using ammonium hydrate. Drying and auto-combustion of xerogel were carried out in the air with the heating up to $120-130^{\circ} \mathrm{C}$ according to patent [210]. The nanopowdered samples $\mathrm{NiFe}_{2} \mathrm{O}_{4}$ (marked as $\mathrm{Z}$ ), $\mathrm{NiAl}_{0.07} \mathrm{Fe}_{1.93} \mathrm{O}_{4}$ (1NA), and $\mathrm{NiAl}_{0.15} \mathrm{Fe}_{1.85} \mathrm{O}_{4}$ (2NA) were investigated directly after auto-combustion. The last 
obtained powder (sample $\mathrm{NiAl}_{0.15} \mathrm{Fe}_{1.85} \mathrm{O}_{4}$ ) had been annealed at high temperature $\left(1000^{\circ} \mathrm{C}\right)$ in the air for obtaining the larger Ni-Al ferrite particles (marked as $\left.2 \mathrm{NA} 2\right)$.

According to $\mathrm{XRD}$ analysis $\left(\mathrm{CuK}_{\alpha} \mathrm{X}\right.$-radiation) the $\mathrm{Ni}$ - $\mathrm{Al}$ ferrites obtained by solgel method are amorphous materials and their diffractograms consist of two diffusion maxima at $2 \theta=44$ and 18 degrees (Fig. 1, curve a). The similar diffractogram was observed in the porous amorphous carbon [211]. This fact allows supposing that the formation of xerogel is a result of the polycondensation reaction, where the bridges are carbon atoms. Thus, the carbon contained reagent (citric acid) is the important component of the sol-gel technology.

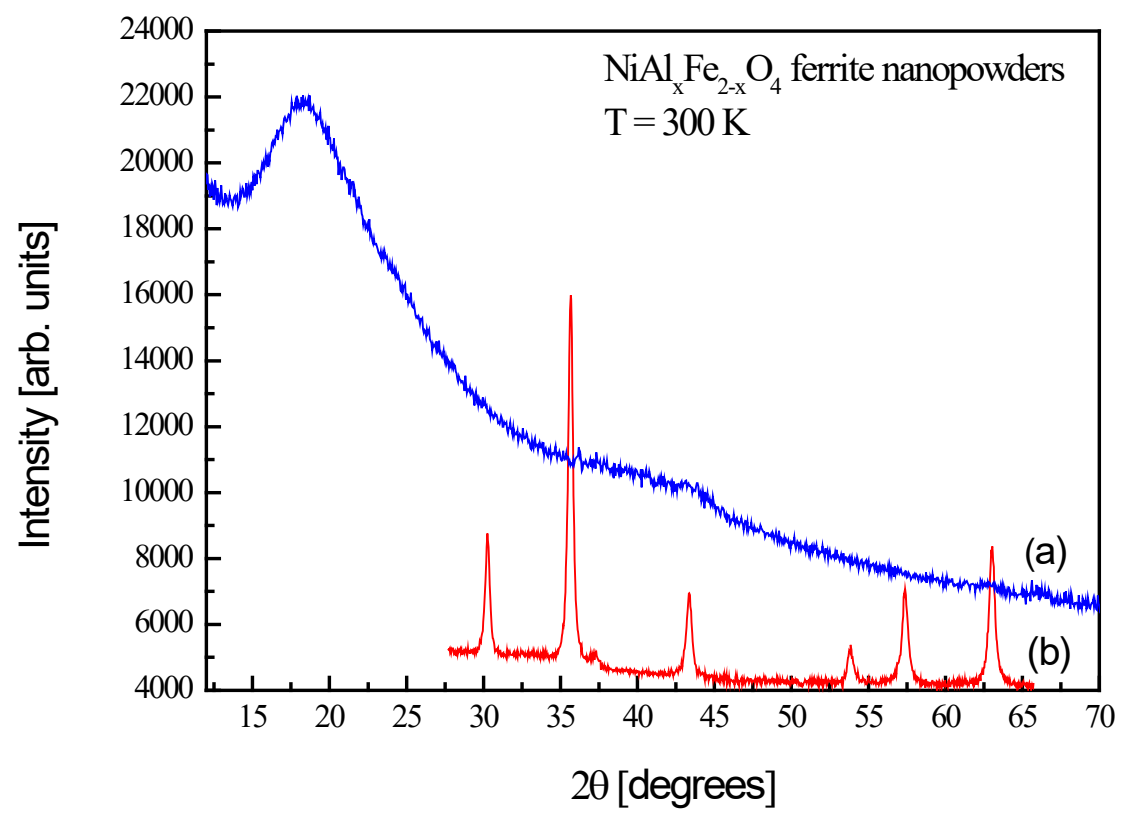

Figure 1. The X-ray diffractograms of the $\mathrm{NiAl}_{0.07} \mathrm{Fe}_{1.93} \mathrm{O}_{4}$ ferrite, obtained by sol-gel synthesis before (a) and after (b) auto-combustion process.

The auto-combustion process leads to formation the single phase of $\mathrm{Ni}-\mathrm{Al}$ ferrites with planned composition, the X-ray diffractograms of which contains strongly broadened peaks from atomic planes (Fig. 1, curve b) that is caused by small size of blocks of the coherent scattering. The average sizes of the $\mathrm{NiAl}_{\mathrm{x}} \mathrm{Fe}_{2-\mathrm{x}} \mathrm{O}_{4}$ ferrite particles with different chemical composition was calculated taking into consideration the (311) XRD line broadening with using the Sherrer formula [209] are presented in Table 1. 
The results of the SEM qualitatively prove these data, because the calculated $<\mathrm{D}>$ values practically coincide with particles size, determined from the SEM images of the same samples. As we can see from Table 1 the size of blocks of the coherent scattering lies in the $25 \div 50 \mathrm{~nm}$ range. At the increase of the $\mathrm{Al}_{2} \mathrm{O}_{3}$ impurity concentration, when it replaces the ferric oxide $\mathrm{Fe}_{2} \mathrm{O}_{3}$, the lattice parameters decreases (Table 1), which indicates the regular incorporation of the aluminium atoms into the $\mathrm{NiAl}_{\mathrm{x}} \mathrm{Fe}_{2-\mathrm{x}} \mathrm{O}_{4}$ crystal lattice with the spinel structure, because the ionic radius of the $\mathrm{Al}^{3+}$ less than the ionic radius of the $\mathrm{Fe}^{3+}$.

Table 1. The lattice parameters $(a)$, average size of ferrite particles $\langle D>$, as well as measured $\left(\chi_{n}\right)$ and calculated $\left(\chi_{n}\right.$ calc $)$ values of magnetic susceptibilities (normalized) of the $\mathrm{NiAl}_{\mathrm{x}} \mathrm{Fe}_{2-\mathrm{x}} \mathrm{O}_{4}$ ferrite particles with different chemical compositions

\begin{tabular}{|c|c|c|c|c|}
\hline Designation & $\begin{array}{c}a, \\
\mathrm{~nm}\end{array}$ & $\begin{array}{c}<D> \\
\mathrm{nm}\end{array}$ & $\begin{array}{c}\chi_{\mathrm{n}}, \\
\text { arb. units }\end{array}$ & $\begin{array}{c}\chi_{n \text { calc }} \\
\text { arb. units }\end{array}$ \\
\hline $\mathrm{Z}$ & 0.8348 & 30 & 1 & 1 \\
\hline 1NA & 0.8344 & 25 & 0.21 & 0.22 \\
\hline 2NA & 0.8337 & 35 & 0.68 & 0.67 \\
\hline 2NA2 & 0.8342 & 120 & - & - \\
\hline
\end{tabular}

The fine structure of the $\mathrm{Fe} \mathrm{K}$-edge registered at the synchrotron in the $\mathrm{NiFeO}_{4}$ (Fig. 2, curve 1) and $\mathrm{NiAl}_{0.07} \mathrm{Fe}_{1.93} \mathrm{O}_{4}$ (Fig. 2, curve 2) ferrites nanopowders reveals a tendency influx at $7.11 \mathrm{keV}$ before main peak and increasing of the intensity with increasing the number of ions in the tetrahedrally-coordinated sites. That corresponds transition of electrons from 1s- to 3d-level, because in tetrahedral coordination 3d-level is degenerated and this transition is allowed. The main slope edge in both samples practically not changed his position (Fig. 2), which according to [212], corresponds to the trivalent iron ions $\left(\mathrm{Fe}^{3+}\right)$. 


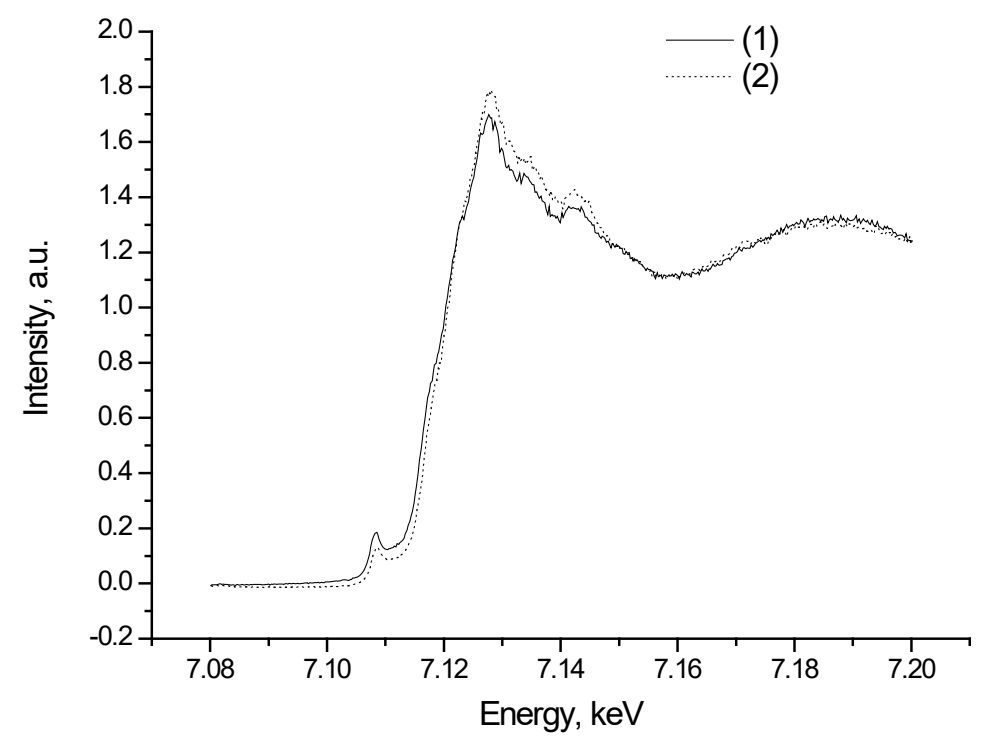

Figure 2. The XANES Fe $K$-edge of the $\mathrm{NiFeO}_{4}\left(1\right.$, sample $\mathrm{Z}$ ) and $\mathrm{NiAl}_{0.07} \mathrm{Fe}_{1.93} \mathrm{O}_{4}(2$, sample 1NA) ferrites nanopowders, after auto-combustion process.

Magnetic properties of materials are tightly connected with the parameters of the magnetic structure, which was investigated by the method of Mössbauer spectroscopy (Fig.3). It is shown, that the area and the characteristics of the paramagnetic doublet (samples 1NA and 2NA), which is observed on the background

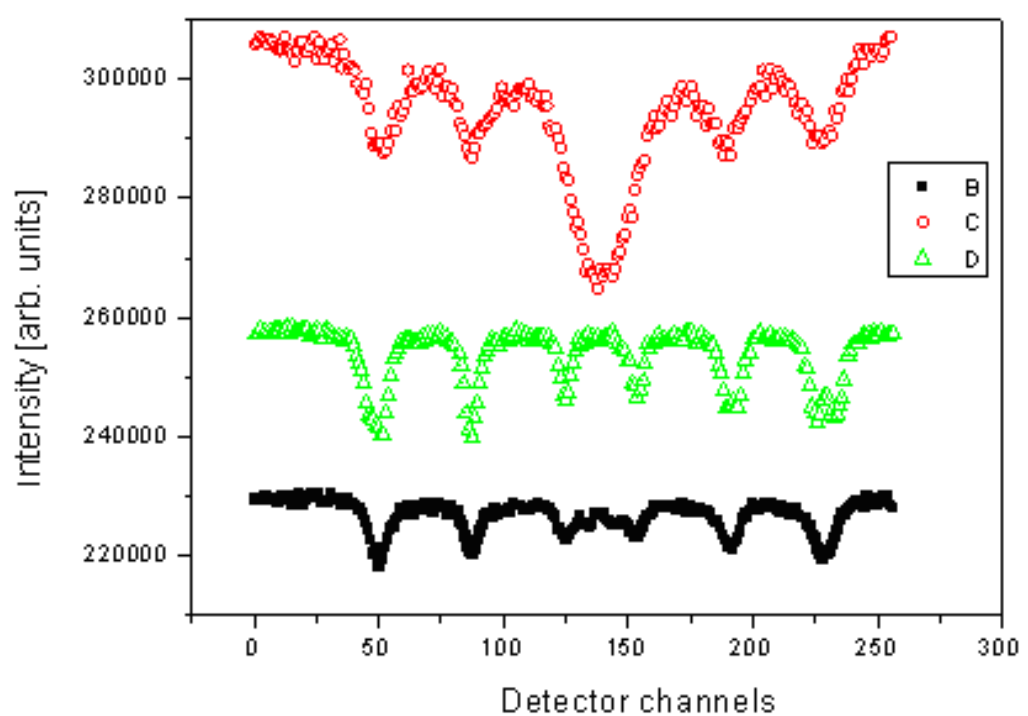

Figure 3. The Mössbauer spectra of the $\mathrm{NiAl}_{0.07} \mathrm{Fe}_{1.93} \mathrm{O}_{4}$ (marked $\mathrm{B}-1 \mathrm{NA}$ ) and $\mathrm{NiAl}_{0.15} \mathrm{Fe}_{1.85} \mathrm{O}_{4}(\mathrm{C}-2 \mathrm{NA}, \mathrm{D}-2 \mathrm{NA} 2)$ ferrite nanopowders. 
of the sextet from magnetically ordered phase are dependent on the powder preparation regimes (sample 2NA2). The spectrum of each sample has two sextets. They belong to magnetically non-equivalent positions of iron ions in the crystal lattice of spinel - to the tetrahedral (A) and octahedral (B) cavities, limited oxygen ions. The effective magnetic field $\mathrm{H}$ in the B-position $\left({ }^{\mathrm{B}} \mathrm{H}\right)$ more than in the A-position $\left({ }^{\mathrm{A}} \mathrm{H}\right)$, as observed in nickel ferrite obtained by traditional ceramic technology. According to experimental data obtained on bulk ceramic samples ${ }^{\mathrm{B}} \mathrm{H}=52.0 \pm 1 \mathrm{~T}$ [213]. Obtained in our experiments nanopowders are characterized by magnetic field ${ }^{\mathrm{B}} \mathrm{H}=49.0 \pm 0.5 \mathrm{~T}$ (sample 1NA). This obviously means that part of the Fe atoms in the nearest octahedral sites surrounded by the tetra-substituted non-magnetic $\mathrm{Al}^{3+}$ ions.

As we previously expected, in the Ni-Al ferrite nanopowders, obtained by sol-gel auto-combustion process, the Ni ions can occupy A-positions, although they tend not to the relatively slow quasi-equilibrium processes occurring in the synthesis of ferrites by ceramic technology. The rapid cooling of the nanoparticle powder in the sol-gel auto-combustion technology facilitates non-equilibrium distribution of $\mathrm{Ni}$ ions on the sublattices A and B.

As it was pointed out by Neel, clusters and small particles of magnetic, can exhibits superparamagnetic effect. The decrease of magnetic nanoclusters' size, while preserving their spontaneous magnetization, increases the probability of thermal fluctuations of nanocluster's magnetic moment.

The magnetic moments of small magnetic particles are able to rotate around the vector magnetic field strength. The magnetic susceptibility of a magnetic on the rotation mechanism is

$$
\chi_{n}=k D^{3}
$$

where D is the particle's diameter. In formula (1) the magnetic susceptibility and the diameter of nanoparticles are normalized within the experimental error range in order to get rid of the coefficients of proportionality [214].

Magnetic susceptibility, calculated with taking into account the demagnetization factor is close to the experimental values, which confirms the proposed model for reversal of 
nanopowders at low frequencies (see Table 1). Measuring the magnetic susceptibility of ferrite powders allows you to quickly test the size of magnetic nanoparticles.

Nanotechnology makes it possible to obtain ferrites in non-equilibrium conditions. Studies have shown the features of the electron-ion structure of ferrites in nonequilibrium states. 


\subsection{Features of operation of steam generator PGV-1000 of nuclear power plants of Ukraine}

Забезпечення надійної роботи парогенераторів (ПГ) $є$ одним із найважливіших завдань для атомних електричних станцій (AEC) в усьому світі. AEC України оснащені енергоблоками 3 реакторами типу BBEP, в яких теплообмін між теплоносіями першого та другого контурів здійснюється через парогенератори. У світовій атомній енергетиці використовують ПГ двох типів горизонтальні та вертикальні. Досвід експлуатації показав, що горизонтальні ПГ мають низку важливих переваг, як з точки зору надійності, так і безпеки. Тому в атомній енергетиці України застосовують ПГ горизонтального типу [215].

Основними проблемами, що виникають при експлуатації парогенератора ПГВ-1000 є конструкційна цілісність колекторів та фланцевих роз'ємів, корозійно-ерозійне зношування колекторів живильної води, тріщини в місцях швів, корозійне пошкодження теплообмінних труб (ТОТ) ПГ. Актуальними на сьогоднішній день $є$ питання, пов'язані з конструкційною цілісністю швів і корозією теплообмінних труб ПГ. Тому підвищення надійності роботи парогенераторів АЕС, збільшення міжремонтного періоду їх експлуатації, завдяки виключенню незапланованих зупинок енергоблоків 3 причини виникнення дефектів металу корпусів та теплообмінних труб $є$ особливо важливим та актуальним завданням для збільшення вироблення електроенергії на діючих енергоблоках АЕС ДП “НАЕК Енергоатом” [216].

Таким чином, об'єктом дослідження у даній роботі $є$ парогенератор ПГВ-1000, який $є$ основною складовою циркуляційних петель реакторної установки АЕС, що призначена для вироблення сухої насиченої пари. Метою роботи $\epsilon$ аналіз механізмів корозійних пошкоджень теплообмінних труб парогенератора ПГВ-1000 у різних режимах його роботи та способів їх усунення або зменшення для забезпечення стабільної роботи парогенератора, а отже i надійної роботи енергоблоку в цілому. 
На малюнку 1 зображено основні конструктивні елементи парогенератора ПГВ-1000.

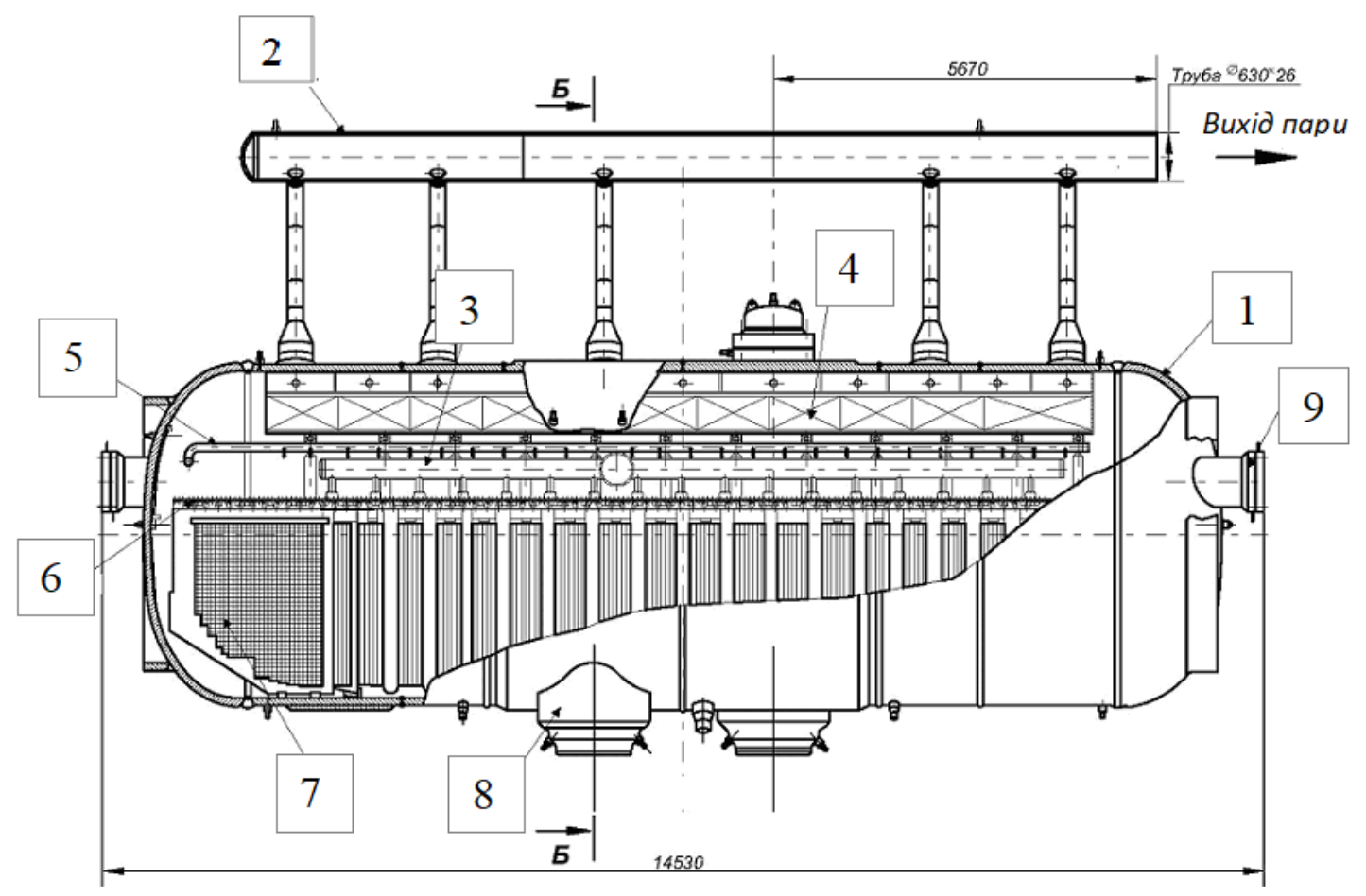

Малюнок 1. Горизонтальний парогенератор ПГВ-1000:

1 - корпус; 2 - паровий колектор; 3 - колектор основної живильної води;

4 - сепараційні пристрої; 5 - колектор аварійної живильної води;

6 - занурений дірчастий лист; 7 - теплообмінна поверхня;

8 - колектор першого контуру; 9 - люк-лаз

Парогенератор складається 3 корпусу, вхідного та вихідного колекторів, U-подібного трубного пучка поверхні теплообміну, колектора, що роздає живильну воду, вбудованого сепараційного пристрою, паровідвідної системи, системи продувок і дренажу. Корпус ПГВ-1000 являє собою горизонтальну циліндричну ємність, торці якої з двох боків закриті еліптичними днищами. Матеріал корпусу - легована конструкційна сталь 10ГН2МФА. Поверхня теплообміну парогенератора ПГВ-1000 включає в себе 11000 труб 
горизонтального пучка, які спираються на дистанціюючі гратки. Теплообмінні труби парогенератора ПГВ-1000 виконані з аустенітної сталі марки 08X18Н10Т.

Дослідженнями у роботах [217]-[219] встановлено, що під час експлуатації парогенератора виникають корозійні пошкодження, які значною мірою спричинені особливостями водно-хімічного режиму другого контуру: наявністю устаткування з різних конструкційних матеріалів (нержавіюча сталь, вуглецеві сталі, мідні сплави); великими діапазонами тиску й температур; двофазним середовищем (пара-вода); наявністю великої кількості теплообмінного устаткування з великими площами нагріву; пароутворенням у ПГ; великою вірогідністю забруднення робочого середовища домішками в конденсаторах, бойлерах тепломережі тощо. У цих умовах найуразливішим елементом устаткування виявилися теплообмінні труби парогенератора [218].

Аналіз експлуатаційних даних показує, що найбільша інтенсивність пошкодження ТОТ спостерігається, як правило, в зоні парогенератора у «гарячого» колектора. Також дуже поширені дефекти під дистанціюючими гратками в нижній частині ПГ, але вони розподілені рівномірніше по довжині трубних пучків [219].

У цілому для ПГ з активною деградацією ТОТ, характерне утворення так званих «критичних зон», де локалізуються дефекти. Це пов'язано з осадженням в цих зонах ТОТ продуктів корозії значної товщини, що призводить до забивання простору між трубами [220]. У роботі [219] наведено результати вихорострумового контролю (ВСК) теплообмінних труб ПГ та показано, що після накопичення на поверхні ТОТ значних відкладень продуктів корозії 3 питомим забрудненням 300-400 г/м² проводять, як правило, перші систематичні глушіння ТОТ.

Отже, процес корозійного ушкодження ТОТ ПГ можна розділити на декілька послідовних обов'язкових стадій з характерними для кожної стадії механізмами деградації труб:

I - зростання відкладень продуктів корозії на ТОТ до критичних значень питомої забрудненості; 
II - накопичення під відкладеннями хлоридів та інших активаторів, які при досягненні критичних концентрацій, спричиняють зародження пітингів i корозійне розтріскування за наявності окисників;

III - зародження пітингів при критичній концентрації хлоридів і окисників;

IV - зростання пітингів при транспортуванні окисників в зону реакції;

$\mathrm{V}$ - зародження корозійних тріщин при активній локальній пластичній деформації мікрооб'ємів металу ТОТ.

VI - зростання корозійних тріщин до моменту глушіння.

Кожна стадія за певних умов може протікати в режимах стаціонарної роботи ПГ, а також в нестаціонарних режимах і в режимах простою.

Відкладення, що утворюються при роботі ПГ, в основному $\epsilon$ дрібнодисперсними частинками (розміром до 10 мкм), що містять дегідратовані оксиди - продукти корозії вуглецевої сталі і мідних сплавів, які застосовують як конструкційні матеріали конденсатора турбіни, трубопроводів і устаткування конденсатно-живильного тракту $\left(\mathrm{Fe}_{2} \mathrm{O}_{3}, \mathrm{Fe}_{3} \mathrm{O}_{4}, \mathrm{CuO}_{2} \mathrm{Cu}_{2} \mathrm{O}\right.$ тощо). Крім того, у складі відкладень, зазвичай, присутні малорозчинні солі - сульфати, силікати, гідрати кальцію, магнію, які потрапляють в конденсатно-живильний тракт в результаті присмоктів охолоджувальної води через нещільності вальцювання трубок конденсатора. Нижні шари відкладень мають компактну структуру 3 низькою пористістю. У складі відкладень на ТОТ ПГ основну частину становлять оксиди заліза - більше 70 \%, оксиди міді - до 30\%, а також оксиди кальцію, магнію та кремнію - від 1 до 5 \% кожний.

Основним механізмом утворення відкладень $є$ кристалізація продуктів корозії з котельної води, що випаровується, а також осідання дрібнодисперсних домішок під дією фізичних $\mathrm{i}$ фізико-хімічних сил. Під час формування відкладень в процесі кипіння відбувається збільшення кількості безперервних ланцюжків пор (каналів), по яких усередині відкладень до поверхні ТОТ підходить вода, що випаровується, і відводиться утворена пара.

Враховуючи пористу структуру відкладень, а також їх досить високу теплопровідність $\left(\sim 1,1 \mathrm{BT} / \mathrm{M}^{2} \cdot \mathrm{K}\right)$ [220], можна вважати, що кипіння води у 
відкладеннях продуктів корозії, що утворилися, відбувається як в шарі перегрітої рідини на поверхні ТОТ, так і на поверхні відкладень, а також і в самих відкладеннях [219]. На місце води, що випарувалася, з ядра потоку до поверхні ТОТ надходять нові порції води, а разом 3 нею і розчинені в ній домішки. Оскільки розчинність домішок в парі менша, ніж у воді, видалення домішок 3 парою не компенсує їх надходження з водою, що випаровується. Таким чином, між граничним шаром і ядром потоку виникає різниця концентрацій домішок, внаслідок чого виникає процес дифузії, спрямований у бік вирівнювання концентрації. При стаціонарному режимі роботи парогенератора виникає стан рівноваги, при якому конвективне надходження домішок компенсується їх видаленням $з$ парою і дифузією.

Враховуючи, що при кипінні води в ПГ кисень практично відсутній, то в цьому випадку найбільш сильними окисниками є іони міді. У відкладеннях мідь знаходиться у вигляді оксидів $\left(\mathrm{CuO}, \mathrm{Cu}_{2} \mathrm{O}, \mathrm{CuFeO}\right)$, а також вкраплень металевої міді. У воді парогенератора мідь є присутньою у вигляді іонів $\mathrm{Cu}^{2+}, \mathrm{Cu}^{+}$або комплексних сполучень. Іони тривалентного заліза $\mathrm{Fe}^{3+}$ також можуть служити окисником в корозійних процесах. Проте, враховуючи високу ступінь гідролізу іонів $\mathrm{Fe}^{3+}$ в нейтральних середовищах і надзвичайно низьку розчинність $\mathrm{Fe}(\mathrm{OH})_{3}$ у воді (при $20{ }^{\circ} \mathrm{C} \sim 0,2$ мкг/кг), іони $\mathrm{Fe}^{3+}$ не відіграють істотної ролі в корозії ТОТ.

Одночасно, під дією утвореної різниці потенціалів, всередину пітингу переносяться негативні іони $\left(\mathrm{OH}^{-}, \mathrm{Cl}^{-}\right)$. При цьому, хлориди, які не витрачаються при корозії, накопичуються усередині пітингу.

У режимах пуску і при роботі ПГ на потужності, за наявності активної локальної пластичної деформації мікрооб'ємів металу у вершинах пітингів, може відбуватися зародження і розвиток корозійних тріщин. Як показують результати металографічного аналізу [219], на дні пітингу може зароджуватися одночасно декілька тріщин, але у міру зростання однієї з них, зростання інших тріщин загальмовується. При цьому у будь-який момент розвитку магістральна тріщина може мати декілька відгалужень. 
На основі проведеного аналізу літературних джерел та результатів експериментальних досліджень можна стверджувати, що розглянуті механізми ушкодження не $є$ неминучими і можуть бути ліквідовані або зведені до мінімуму при дотриманні наступних умов [219]:

- недопущення перевищення граничної величини питомої забрудненості ТОТ шляхом зниження надходження в ПГ продуктів корозії;

- виключення з устаткування конденсатно-живильного тракту АЕС 3 реакторною установкою ВВЕР-1000 сплавів, що містять мідь;

- обмеження доступу кисню до ТОТ на всіх стадіях життєвого циклу ПГ, дотримання умов консервації.

Таким чином, авторами детально розглянуто механізми виникнення корозійних пошкоджень теплообмінних труб парогенератора ПГВ-1000 у різних режимах його роботи. Виділено основні стадії механізму деградації ТОТ ПГ: від появи перших відкладень продуктів корозії до зародження і зростання пітингів та корозійних тріщин, що призводить до глушіння труб. Встановлено, що корозійні дефекти локалізуються переважно в нижній частині трубних пучків парогенератора. Доведено, що для забезпечення надійної роботи тонкостінні ТОТ парогенератора ПГВ-1000 ТОТ не повинні мати значних або наскрізних дефектів. Обгрунтовано способи запобігання та сповільнення виникнення корозійних пошкоджень, які забезпечать надійну та тривалу роботу парогенератора без незапланованих зупинок для його ремонту. 


\subsection{Substantiation of the layout scheme and the value of the installed electric power of the solar power plant in the educational institution}

Сталою тенденцією розвитку електроенергетики $є$ швидке розширення сфер використання сонячної генерації як для централізованого виробництва електроенергії, так і в індивідуальних системах електропостачання промислових підприємств, громадських об'єктів і домогосподарств.

В Україні існують достатньо сприятливі умови для генерації сонячної енергії. Річний, технічно досяжний, енергетичний потенціал сонячної енергії в Україні еквівалентний 6 млн. т у. п. Його використання дозволило б замінити біля 5 млрд. м³ природного газу [221].

Середньорічна кількість сумарної сонячної радіації, що потрапляє на $1 \mathrm{~m}^{2}$ поверхні, на території України знаходиться в межах від 1070 кВт·год/м² в ії північній частині до 1400 кВт·год/м² і вище на півдні України [222].

В науковій літературі широко обговорюються технніко-технологічні, метео-кліматичні, регіональні, галузеві, еколого-економічні та інщі аспекти впровадження сонячної генерації. Зокрема, в аналітичній доповіді [223] комплексно розглянуто стан, проблеми та перспективи розвитку відновлюваної енергетики в Україні та запропоновано рекомендації щодо підвищення ефективності державної політики у сфері розвитку відновлюваної енергетики як одного з пріоритетних напрямів реалізації Енергетичної стратегії України на період до 2030 року.

Слід зазначити, що національна нормативно-правова база, яка регламентує умови впровадження сонячної генерації відповідає, в основному, положенням Директиви Свропейського парламенту та Ради 2009/28/ЄС від 23 квітня 2009 року [224].

Окремої уваги заслуговують роботи в яких досліджуються питання планування та управління використанням електричної енергії в бюджетних установах i, зокрема, у навчальних закладах $[225,226]$. Зокрема, в роботі на 
основі використання реальних статистичних даних одержано регресійні моделі електроспоживання у будівлях вищого навчального закладу (гуртожитків).

В роботі [227] доведено ефективність використання методів, заснованих на деревах регресії, при короткотерміновому прогнозуванні навантаження. При цьому автори пропонують враховувати крім зовнішніх факторів (температура навколишнього середовища) також і внутрішні - календарні змінні (розклад занять, час проведення занять та ін.).

Необхідно зазначити, що на етапі передпроєктних розрахунків щодо визначення доцільності оснащення навчальних закладів локальними сонячними електростанціями необхідно визначити вичерпний перелік, кількісну та якісну інтерпретацію коректних обмежувальних умов та критеріїв, які мають бути враховані при проектуванні. Очевидно, що тільки 3 урахуванням таких обмежувальних умов може бути вирішена взаємообумовлена та взаємопов’язана системна задача «обгрунтування оптимальної схеми компонування - визначення раціональної установленої електричної потужності» сонячної електростанції у навчальному закладі.

Однією із найбільш важливих обмежувальних умов оснащення навчальних закладів локальними сонячними електростанціями та такою, що потребує спеціальних організаційно-технічних рішень $є$ нерівномірний помісячний режим електричного навантаження. В літній період, коли сонячна генерація $\epsilon$ максимальною, електричне навантаження в частині освітнього процесу та значного обсягу навантаження допоміжних процесів $є$ мінімальним. Таке сезонне розбалансування є головною передумовою вибору схеми компонування та, відповідно, визначення раціональної установленої електричної потужності сонячної електростанції у навчальному закладі. В свою чергу, схема компонування сонячної електростанції безпосередньо визначає технікотехнологічні особливості конструювання контуру управління електроспоживанням у навчальному закладі, розроблення та впровадження проектів з енергозбереження на основі принципів Enterprise Content Management (ECM). 
В низці наукових розробок пропонуються підходи до обгрунтування схем компонування та визначення раціональної установленої електричної потужності сонячних електростанцій. Зокрема, в роботі [228] виділені ключові критерії та техніко-економічні показники промислових проектів сонячних електростанцій та обгрунтовані умови максимальної стабільності та доцільності проектів сонячної генерації. Робота [229] присвячена теоретичному узагальненню i вирішенню важливої науково-практичної проблеми достовірного визначення електричного навантаження у системах електропостачання цивільних об'єктів.

В наукових роботах запропоновані та обгрунтовані процедури технікоекономічного обгрунтування будівництва сонячних електростанцій різних типів. Так, в роботах $[230,231]$ наведені вихідні дані для техніко-економічного обгрунтування та фінансового моделювання проекту будівництва сонячної електростанції, наведені шляхи оптимізації будівництва та налаштування станції.

Методичні підходи до прогнозування ефективності запровадження саме мережевих сонячних станцій на підставі моделювання динаміки розвитку технології їх виготовлення, вартості устаткування, монтажу, експлуатаційних витрат і зміни тарифів на електроенергію запропоновані в роботі [232].

Разом $з$ тим, в наведених працях не розглядаються особливості оснащення локальними сонячними електростанціями навчальних закладів. Проблему сезонного розбалансування генерації та споживання доцільно, на наш погляд, вирішувати в трьох напрямках.

Перший напрямок - організаційний. Зважаючи на особливості проведення навчального процесу у навчальних закладах, необхідно звернути увагу на літній період року (липень, серпень) у якому навчальний процес не відбувається. Споживання електричної енергії у цей період мінімальне, а от генерація електричної енергії сонячними панелями сягає майже $29 \%$ від загального річного обсягу. Разом з тим, сучасні університети (особливо класичні та технічні) мають, як правило, потужну науково-дослідну та експериментальновиробничу базу, оснащену енергоємним обладнанням. Саме такі наукові центри 
мають відносно стабільне електричне навантаження протягом року. Крім того, в таких наукових центрах проводяться дослідження 3 розробки інноваційного енергетичного обладнання, засобів контролю та управління складними енергетичними системами, розробками в галузі машинобудування та ін. В табл. 1 наведені приклади навчально-науково-виробничих центрів окремих українських університетів.

Таблиця 1.

Приклади навчально-науково-виробничих центрів українських університетів.

\begin{tabular}{|c|c|c|}
\hline № & Навчальний заклад & Навчально-науково-виробничі центри \\
\hline 1. & $\begin{array}{l}\text { Національний технічний } \\
\text { університет «Харківський } \\
\text { політехнічний університет» }\end{array}$ & $\begin{array}{l}\text { Навчально-науково-виробничий комплекс «Блискавка». } \\
\text { http://web.kpi.kharkov.ua/molnia/ru/uchebno-nauchno- } \\
\text { proizvodstvennyj-kompleks-natsionalnogo-tehnicheskogo- } \\
\text { universiteta-harkovskij-politehnicheskij-institut/ } \\
\text { Основний напрямок діяльності, - інженерна електрофізика. }\end{array}$ \\
\hline 2. & $\begin{array}{l}\text { Національний університет } \\
\text { цивільного захисту України }\end{array}$ & $\begin{array}{l}\text { Навчально-науково-виробничий центр. } \\
\text { https://nuczu.edu.ua/ukr/nauka/navchalno-naukovo-vyrobnychyi- } \\
\text { tsentr } \\
\text { До складу центу входять: науковий відділ з проблем } \\
\text { управління у сфері цивільного захисту та науковий відділу з } \\
\text { проблем державної безпеки. }\end{array}$ \\
\hline 3. & $\begin{array}{l}\text { Національний університет } \\
\text { «љвівська політехніка» }\end{array}$ & $\begin{array}{l}\text { Навчально-науково-виробничий центр «Інформаційні } \\
\text { технології та системи». } \frac{\text { https://lpnu.ua/nnvc }}{\text { Головними напрямками діяльності } є \text { наукова, науково- }} \\
\text { технічна, виробнича, інноваційна діяльність } 3 \text { впровадження } \\
\text { досягнень науково-технічного прогресу у галузі IT. }\end{array}$ \\
\hline 4. & $\begin{array}{l}\text { Східноєвропейський } \\
\text { університет }\end{array}$ & $\begin{array}{l}\text { Навчально-науково-виробничий центр. } \\
\text { http://www.suem.edu.ua/uk/educationalTechnologies/mill } \\
\text { До складу центру входять: «Навчальний готель i pecторан»; } \\
\text { «Юридична клініка»; «ІТ-компанія СУЕМ»; «Туристична } \\
\text { агенція»; «Банк СУЕМ»; «Навчально-науково-виробничий } \\
\text { центр з підготовки гідів-перекладачів»; «Школа директорів } 3 \\
\text { персоналу». Діяльність ННВЦ спрямована на підготовку та } \\
\text { перепідготовку кадрів у галузі малого та середнього бізнесу } \\
\text { у рамках підвищення кваліфікації фахівців. }\end{array}$ \\
\hline 5. & $\begin{array}{l}\text { Відкрите акціонерне товариство } \\
\text { «Український інститут по } \\
\text { проектуванню засобів та споруд } \\
\text { зв’язку»; Вінницький } \\
\text { державний технічний } \\
\text { університет; Національний } \\
\text { університет «Львівська } \\
\text { політехніка» (Інститут } \\
\text { телекомунікації, } \\
\text { радіоелектроніки і електронної } \\
\text { техніки); Національний } \\
\text { авіаційний університет; }\end{array}$ & $\begin{array}{l}\text { Навчально-науково-виробничий комплекс } \\
\text { «Інфокомунікації». } \\
\text { https://onat.edu.ua/navchalno-naukovo-vyrobnychyj-komple/ } \\
\text { Створений спільним наказом Міністерства освіти і науки } \\
\text { України та Міністерства транспорту і зв’язку України від } \\
\text { 23.07.2007 р. № 645/626 «Про створення навчально-науково- } \\
\text { виробничого комплексу «Інфокомунікації»». }\end{array}$ \\
\hline
\end{tabular}




\begin{tabular}{|c|c|c|}
\hline & $\begin{array}{l}\text { Національний технічний } \\
\text { університет «Харківський } \\
\text { політехнічний інститут»; } \\
\text { Харківський національний } \\
\text { університет радіоелектроніки } \\
\text { та ін. }\end{array}$ & \\
\hline 6. & $\begin{array}{l}\text { Одеський національний } \\
\text { університет ім. I.I. Мечникова }\end{array}$ & $\begin{array}{l}\text { Навчально-науково-виробничий центр. } \\
\text { http://info.onu.edu.ua/naukovo-doslidni-pidrozdily/navchalno- } \\
\text { naukovo-vyrobnychyi-tsentr }\end{array}$ \\
\hline 7. & $\begin{array}{l}\text { Харківський національний } \\
\text { університет радіоелектроніки }\end{array}$ & $\begin{array}{l}\text { Навчально-науково-виробничий центр аутсорсингу. } \\
\text { https:/nure.ua/branch/navchalno-naukovo-virobnichiy-tsentr- } \\
\text { autsorsingu } \\
\text { Центр забезпечуєефективне функціонування IT- } \\
\text { інфраструктури та програмного забезпечення замовників } \\
\text { шляхом підготовки і навчання кадрів. }\end{array}$ \\
\hline 8. & $\begin{array}{l}\text { Сумський державний } \\
\text { університет }\end{array}$ & $\begin{array}{l}\text { Навчально-науково-виробничий комплекс «Сучасний } \\
\text { машинобудівник». } \\
\text { https://news.sumdu.edu.ua/uk/7659-u-sumdu-stvoreno- } \\
\text { navchalno-naukovo-virobnichi-kompleks-suchasni- } \\
\text { mashinobudivnik.html }\end{array}$ \\
\hline
\end{tabular}

Саме такі центри можуть і повинні стати споживачами електричної енергії, що генерується власними сонячними електростанціями та стати своєрідними об’єктами вирівнювання загального річного балансу електроспоживання університетами.

Другий напрямок - обгрунтування та впровадження найбільш прийнятних схем компонування сонячної електростанції у навчальному закладі.

Філософію компонування сонячних електростанцій для забезпечення струмоприймачів навчальних закладів можна розглядати виходячи 3 декількох варіантів:

- варіант 1 - повне автономне забезпечення електроенергією автономних струмоприймачів або об’єктів за умови, що профіль їх електроспоживання співпадає з профілем генерації сонячної електростанції;

- варіант 2 - повне автономне забезпечення електроенергією автономних струмоприймачів або об’єктів за умови, що профіль їх електроспоживання не співпадає 3 профілем генерації сонячної електростанції, 3 можливістю накопичення «надлишкової» електроенергї у накопичувачах станції;

- варіант 3 - часткове або повне (деяких струмоприймачів) забезпечення струмоприймачів навчальних та адміністративних будівель цілодобово та у періоди проведення навчального процесу 3 використанням схеми мережевої 
станції (підключення сонячної електростанції об’єкту, будівлі до загальної мережі постачальника електроенергіï);

- варіант 4 - часткове або повне забезпечення струмоприймачів навчальних та адміністративних будівель цілодобово та у періоди проведення навчального процесу 3 використанням схеми мережевої станції (підключення сонячної електростанції об’ єкту, будівлі до загальної мережі постачальник електроенергії) 3 можливістю накопичення «надлишкової» електроенергії у накопичувачах станції.

Практичне прийняття рішення щодо варіанту компонування сонячної електростанції має грунтуватись на врахуванні такого показника як обсяг можливої сонячної генерації електроенергії станцією за певний проміжок часу 3 відповідним його співставленням 3 профілем фактичного/прогнозного електроспоживання навчального закладу в цілому або його окремого об’єктуструмоприймача. 3 метою співставлення різних варіантів компоновки зручно оперувати показником обсягу електроенергії, що може бути згенерована електростанцією, який припадає на 1 кBm їі установленої потужності $P_{\text {уст.ел.станиіi }}$, тобто питомий показник генерації електроенергї за певних кліматичних умов та за певний проміжок часу $\rho_{\text {ел.станиіi }}$.

Для зручності проведення комерційних розрахунків між постачальником та споживачем проміжок часу, для якого визначається $\rho_{\text {ел.станціi }}$, за протяжністю має відповідати загальноприйнятим розрахунковим періодам. Як правило - це календарний місяць.

За результатами проведених досліджень функціонування сонячних електричних станцій у різні періоди за умов північного регіону України, використовуючи зазначені середні обсяги щомісячної генерації електроенергії $A_{\text {ігенераиіi }}$, показник $\rho_{\text {ел.станціi }}$ для кожного місяця року $\rho_{\text {іел.станціі }}$ пропонується визначати за формулою:

$$
\rho_{\text {іел.станиіi }}=A_{\text {ігенераиіi }} / P_{\text {уст.ел.станиіi }} .
$$


Розрахункові величини $\rho_{\text {ien.cmaниї }}$ для кожного місяця року зведено у табл. 2 .

Таблиця 2.

Розрахункові величини питомого показника $\rho_{\text {ien.cmaнуії }}$ (за місяцями)

\begin{tabular}{|c|c|c|c|c|c|c|c|c|c|c|c|c|}
\hline \multirow[t]{2}{*}{ Показники } & \multicolumn{12}{|c|}{ Місяць року } \\
\hline & 1 & 2 & 3 & 4 & 5 & 6 & 7 & 8 & 9 & 10 & 11 & 12 \\
\hline $\begin{array}{l}\rho_{\text {іел.станиіі }}, \\
\kappa B m *_{\text {год} / \kappa B} \\
m\end{array}$ & $\begin{array}{l}10,6 \\
4\end{array}$ & $\begin{array}{l}12,5 \\
8\end{array}$ & $\begin{array}{l}26,5 \\
7\end{array}$ & $\begin{array}{l}139,4 \\
4\end{array}$ & $\begin{array}{l}153,2 \\
9\end{array}$ & $\begin{array}{l}161,0 \\
4\end{array}$ & $\begin{array}{l}131,2 \\
1\end{array}$ & $\begin{array}{l}152,1 \\
2\end{array}$ & $\begin{array}{l}104,7 \\
1\end{array}$ & $\begin{array}{l}59,7 \\
6\end{array}$ & $\begin{array}{l}18,8 \\
5\end{array}$ & $\begin{array}{l}7,0 \\
2\end{array}$ \\
\hline $\begin{array}{l}\text { Частка } \\
\text { обсягу } \\
\text { генерації, } \\
\text { від річної, } \\
\%\end{array}$ & 1,1 & 1,29 & 2,72 & 14,22 & 15,7 & 16,5 & 13,4 & 15,5 & 10,7 & 6,1 & 1,92 & $\begin{array}{l}0,7 \\
2\end{array}$ \\
\hline
\end{tabular}

Зазначені розрахункові величини $\rho_{\text {ien.cmaнuii }}$ практично $є$ інтегральними питомими показниками функціонування сонячної електростанції в кліматичних умовах співставних проміжків часу на протязі календарного року i характеризують (визначають) проміжок часу у годинах у якому електрична станція функціонувала б зі стовідсотковим навантаженням іiі установленої електричної потужності. Наведені розрахункові дані $\rho_{\text {ien.станиіі }} \in$ коректними за умови розташування сонячних панелей на частині шатрової поверхні покрівлі, орієнтованої на південь або південний схід з незмінним кутом нахилу близько $24^{0} \ldots 25^{0}$ до лінії горизонту та стаціонарним безповоротним закріпленням.

Зважаючи на описані відмінності та передумови, не складно провести розрахунок прогнозного обсягу генерації електроенергії сонячною електростанцією за визначений місяць року (з використанням $\rho_{\text {iел.станиіi }}$ ) будь-якої установленої потужності $P_{\text {iусm.ег.cmanціi }}$, виходячи 3 наявних умов розташування максимальної кількості сонячних панелей на конструкційних елементах будівлі. Тобто,

$$
A_{\text {іенерації }}=\rho_{\text {іел.станціi }} \cdot P_{\text {уст.ел.станції }}
$$


Як відомо, установлена електрична потужність сонячної електростанції, при інших рівних умовах, прямо пропорційно залежить від кількості встановлених панелей та їх одиничної потужності. За наведених умов та допущень установлена потужність буде залежати від конструктивних особливостей панелей (габаритних розмірів і фізичної здатності ефективно генерувати електричну енергію) та їх кількості $n$ (площі та способу розміщення на елементах конструкції будівлі).

За цими міркуваннями, використовуючи інформацію щодо конструкційних будівельних особливостей будівлі, також не складно розрахувати енергетичний потенціал розташування панелей та майбутньої сонячної електростанції, визначивши максимально можливу установлену потужність $P_{\text {yсm.ел.станиїї max }}$.

Максимальна ефективність використання установленої потужності сонячної електростанції при ії функціонуванні в кліматичних умовах північних та північно-східних регіонів України має місце в період квітень - жовтень. У інші місяці сумарний обсяг генерації становить близько 7-8 \% від річного. Цей факт має вирішальне значення при врахуванні обмежень вибору встановленої потужності сонячних панелей та вихідних умов розрахунку термінів окупності інвестицій у побудову сонячної електростанції за умови іiї експлуатації у навчальних закладах (окрім дошкільних).

Варіант 1 доцільно розглядати при функціонуванні відокремленого об’єкта навчального закладу не великої потужності не відповідальних струмоприймачів періодичної дії за умови їх функціонування у період генерації електроенергії станцією.

У цьому випадку максимальна установлена потужність сонячних панелей має вибиратися за критерієм забезпечення максимальної потужності струмоприймачів за умови хмарної погоди.

Така схема компонування станції передбачає завищену установлену потужність сонячних панелей. Як результат: не раціональне використання площ 
їх розміщення; завищені капітальні витрати на закупівлю обладнання, можлива надлишкова генерація електроенергії у години найвищої сонячної активності за певних погодних умов. Зазначена схема використовується вкрай мало.

Варіант 2 доцільно розглядати при функціонуванні відокремленого об’єкта навчального закладу не великої потужності періодичної дії не відповідальних струмоприймачів за умови економічної недоцільності або технічної неможливості приєднання їх до електричних мереж постачальника (як приклад, це можуть бути освітлювальні прилади зовнішнього освітлення території і т. i.).

У цьому випадку основними вихідними критеріями вибору величини установленої потужності сонячної електростанції мають бути електрична потужність струмоприймачів, графік їх функціонування, обсяги добового споживання електроенергії. За таких умов потужність електричної станції повинна розраховуватися 3 урахуванням також технічних параметрів накопичувача електричної енергії (ступінь допустимого розрядження, можливі обсяги накопичення електроенергії, вольт-амперна характеристика накопичувача у режимі джерела електроенергії, втрати електроенергії у системі при іï функціонуванні у режимі накопичення і джерела та інше).

Установлена електрична потужність електростанції повинна забезпечувати приєднану електричну потужність струмоприймачів за умови іiі функціонування у режимі генерації, мати «надлишок» потужності, достатній для додаткового генерування та накопичення обсягу електроенергії протягом добового періоду генерації з метою подальшого ії споживання. Тобто за цих умов мають виконуватися умови:

$$
A_{\text {еенерраиіїобове }}=A_{\text {спохсив.поточ. }}+A_{\text {накопич.добове }}+A_{\text {втрат }},
$$

або 


$$
A_{\text {генерраиіїобове }}=P_{\text {спожив.поточ. }} t_{\text {генерації }}+P_{\text {спожив.поточ. }} t_{\text {спожии. }}+A_{\text {втрат }}
$$

де: $A_{\text {генераиїобове }}$-кількість електроенергії (кВт*год), що має бути згенерована для забезпечення добового функціонування струмоприймачів об'єкту; $A_{\text {спожив.поточне }}-$ кількість електроенергії (кВт*год), яку мають споживати струмоприймачі у період доби $t_{\text {генераиї }}$, коли сонячна електростанція працює у режимі генерації; $A_{\text {накопи.добове }}$ - кількість електроенергії (кВт*год), яка має бути накопичена у накопичувачах станції для ㄲï споживання струмоприймачами у період доби $t_{\text {спожив. }}$ за відсутності сонячної генерації; $A_{\text {вмрат }}$ - кількість електроенергії (кВт*год), яка може бути втрачена у елементах сонячної електростанції при їі функціонуванні протягом доби; $P_{\text {спожив.помоне }}-$ установлена електрична потужність струмоприймачів об’єкту, приєднаних до сонячної електростанції.

Якщо визначено $A_{\text {генериїдовове }}$, то у цьому разі електричну потужність генерації $P_{\text {генераиіi }}$ можна розрахувати як:

$$
P_{\text {генерраиії }}=A_{\text {генераиіїобове }} / t_{\text {генераиіі }} \text {. }
$$

Вираз (5) справедливий за умови, якщо $P_{\text {генераиі }}=$ const протягом всього періоду $t_{\text {генераиі }}$. Однак, відомо, що протягом доби та календарного року величини $P_{\text {генерачіi }}$ та $t_{\text {генераиіi }} \epsilon$ змінними і тому визначення $P_{\text {генераиіi }} \epsilon$ проблематичним без урахування цієї обставини. Якщо ж звернутися до наших попередніх міркувань щодо визначення обсягу електроенергії, який може бути згенеровано електростанцією, що припадає на 1 кBm іï установленої потужності $P_{\text {уст.ел.станиіі }}$, тобто питомий показник генерації електроенергї за певних кліматичних умов та за певний проміжок часу $\rho_{\text {ел.станиіi }}$, то використавши формулу (1) $P_{\text {генераціi }}$ або $P_{\text {іуст.ел.станиіi }}$ розрахується як: 


$$
P_{\text {уст.ел.станціi }}=A_{\text {генерації }} / \rho_{\text {ел.станціі }}
$$

де $A_{\text {генерації }}=A_{\text {генераиііообове }} \cdot k-$ місячне споживання електроенергії струмоприймачами, приєднаними до сонячної електростанції; $k$ - кількість днів у поточному місяці.

Зазначений розрахунок є коректним, якщо прийняти допущення, що $P_{\text {спожив.поточне }} \epsilon$ незмінним протягом доби та місяця, або є максимальним. Реально обсяги генерації електроенергії у різні місяці змінюється і можлива ситуація коли вони будуть недостатніми, або надлишковими. Виходячи $3 \rho_{\text {ел.станиіi }}$, діапазон річної зміни обсягів генерації за однієї і тієї ж встановленої електричної потужності станції може варіюватися у межах 1600\%. Зазвичай приймається $P_{\text {уст.ел.станиіi }}$, яке відповідає мінімальному значенню $\rho_{\text {ел.станиіі }}$, якщо необхідно забезпечити живлення струмоприймачів протягом року за варіантом 2 побудови сонячної електричної станції.

Однак, наслідками такої методики визначення установленої потужності електростанції можуть бути значні капітальні витрати на обладнання і технікоекономічні показники функціонування станції будуть не найкращі по відношенню до варіантів 3 та 4. Крім того, прийняття величини установленої потужності за умовами мінімальної генерації призводить до «надлишкової» генерації у літні місяці. В цей період сумарне електричне навантаження струмоприймачів і обсяги добового електроспоживання можуть становити близько 10..15 \% від максимального фактичного, або розрахункового. У цей період (близько 2-х літніх місяців) може гостро стояти питання генерації «зайвої» електроенергії, або додаткового її використання.

Застосування такого варіанту комплектування та функціонування сонячної електростанції $\epsilon$ привабливим за умови змінного сезонного профілю навантаження струмоприймачів: його мінімальні значення взимку, максимальні - влітку. Тобто, для прийняття рішення щодо запровадження сонячної електростанції за варіантом 2 попередньо необхідно провести аналіз профілю 
електроспоживання, сформувати його «спектр», визначити важливість споживачів з точки зору безперервності їх функціонування та першочерговості енергозабезпечення i за цими ознаками формувати мінімально можливу установлену електричну потужність електростанції та визначати потужності накопичувачів електроенергіï за умови додаткового приєднання струмоприймачів у періоди максимальної генерації.

Варіант 3. Основною технічною відмінністю (конструктивною особливістю) сонячної електростанції за цим варіантом від комплектування за варіантами 1 і 2 є підключення іï до мережі постачальника електроенергії i залежність іï функціонування від якості та безперервної наявності електроенергії постачальника (загальної мережі).

Зазначений варіант компонування станції не передбачає спеціального окремого накопичувача електричної енергії. У якості такого акумулятора виступає загальна мережа електропостачання. Тобто, електрична станція включається у мережу споживача, який споживає згенеровану станцією електроенергію, надлишок генерації «перетікає» до мереж постачальника. У разі дефіциту генерації, або ii відсутності живлення струмоприймачів буде відбуватися частково (або повністю) від електростанції та загальної мережі постачальника, або повністю від мережі постачальника. За цих обставин необхідно звернути увагу на дві проблеми: коректність обліку «перетікання» обсягів електроенергії між мережами споживача та постачальника, а також якість електричної енергії, що генерується сонячною електричною станцією. Перша проблема має вирішуватися з використанням у вузлах обліку споживання спеціальних лічильників електричної енергії, які фіксують обсяги «перетікання» електроенергії між споживачем та постачальником i враховуються автоматизованими системами комерційного обліку електроенергії. Друга проблема має вирішення суто технічними засобами щодо автоматизації фазування та синхронізації електричної станції 3 мережею, регулювання генерації гармонік і стабілізації напруги та інше. Ці проблеми вирішуються 3 
використанням засобів, якими комплектуються сучасні сонячні електричні станції.

Виходячи з цього, додатковим обладнанням, a, отже, i додатковими капітальними витратами на комплектацію станції $є$ вузол обліку та інші комутаційні засоби. Ще одним вагомим фактором, який суттєво може впливати на формування вартісних та економічних показників функціонування сонячної електростанції, є додаткові витрати на приєднання до електромережі та забезпечення передачі електроенергії, які залежать від обсягу додаткової електричної потужності споживача та способу (виду) іiі приєднання до мереж постачальника. У деяких випадках він може стати одним зі стримуючих при визначенні величини установленої електричної потужності сонячної електростанції. Наразі сума зазначеної оплати та порядок іiі розрахунку регламентується постановою НКРЕКП України від 18.12.2018 № 1965.

Виходячи з техніко-економічних та організаційних міркувань максимальна установлена електрична потужність при комплектуванні та функціонуванні сонячної електростанції за варіантом 3 може бути максимально можливою.

У разі відповідності обсягу генерації електроенергії станцією обсягу споживання струмоприймачами будівлі (закладу) за розрахунковий період часу матимемо практично нульове споживання електроенергії 3 мережі постачальника, тобто повне їі заміщення. При цьому вартість електроенергії, яка враховується при розрахунках економічної ефективності функціонування станції має відповідати тарифу закупівлі електроенергії споживачем у постачальника.

Якщо обсяги генерації електроенергії станцією будуть більші від обсягів їі споживання струмоприймачами закладу (будівлі), ми матимемо повне заміщення електроенергії, яка надходить від постачальника, а також додаткове «перетікання» «надлишково» згенерованого станцією обсягу електроенергії до мереж постачальника. У цьому випадку вартість електроенергії, яка враховується при розрахунках економічної ефективності функціонування станції, має бути прийнято: 
- за тарифом (ціною) постачальника на обсяг спожитої електроенергії струмоприймачами будівлі (закладу);

- за тарифом (ціною) узгодженим між споживачем та постачальником (або законодавчо урегульованою ціною) на обсяг перетікання згенерованої електроенергії сонячною електростанцією споживача до мереж постачальника, за умови чинного законодавства, це можуть бути «зелені» тарифи.

Як вже зазначалося, за варіантом 3 суттєвих технічних обмежень та передумов щодо визначення максимальної установленої електричної потужності сонячної електростанції $P_{\text {усп.ел.станиії }}$ не існує, за виключенням однієї обставини. Вона стосується технічної можливості розташування максимальної кількості сонячних панелей на конструкційних елементах будівлі (покрівлі, стінах). Основними критеріями тут має бути орієнтація зазначених елементів на південь, південний схід, південний захід, а також кут нахилу покрівлі до горизонту. Тобто, $P_{\text {уст.ллстаниї }}$ за цим варіантом, в основному, залежить від кількості установлених сонячних панелей та їх одиничної електричної потужності. На фактичну ж електричну потужність генерації також будуть впливати кути розташування сонячних панелей на зовнішніх елементах будівель та їх миттєве розташування відносно Сонця.

Варіант 4. Він є аналогічним варіанту 3. Основною технічною відмінністю (конструктивною особливістю) сонячної електростанції за цим варіантом від комплектування за варіантом 3 є наявність додаткових накопичувачів електроенергії та інвертора, що дає переваги перед варіантом 33 точки зору безперебійності електрозабезпечення (так звані «гібридні» сонячні станції).

Відомо, що мережева сонячна станція працює за наявності напруги у мережах постачальника. У разі iї відсутності на шинах споживача сонячна електростанція не функціонує. Сонячні панелі можуть мати можливість генерації електроенергії, але за конструктивними особливостями станції скористатися нею не можливо. Особливо не приємна ситуація у цьому випадку може виникнути у 
навчальних закладах медичного спрямування, де для надання медичних послуг електропостачання має бути неперервним.

Для усунення цієї проблеми застосовують резервні станції, у яких приводом служать дизельні двигуни. Електрична потужність таких станцій визначається за величиною електричної броні, тобто електричною потужністю струмоприймачів, періодом їх функціонування, обсягом споживання ними електричної енергії для забезпечення проведення чи закінчення медичних заходів. Для підтримання у робочому стані таких станції необхідно залучати додатково кваліфікований обслуговуючий персонал, підтримувати у належному стані паливне господарство, комутаційні пристрої та інше. Використання у мережевих сонячних станціях додаткових пристроїв накопичення енергії спрощує вирішення цієї проблеми. Накопичувачі повинні мати ємність достатню для виконання функції енергетичного підтримання медичних або інших заходів у обсягах визначеного бронювання. Наразі на ринку України присутні та пропонуються продавцями накопичувачі електричної енергії, що базуються на літій - іонних та кислотних акумуляторних батареях різної ємності. При виборі потужності та моделі накопичувачів необхідно звертати у першу чергу увагу на їх технічні параметри. Електрична потужність та ємність накопичувача має визначатися з урахуванням декількох умов:

- корисної електричної ємності накопичувача, тобто треба мати на увазі, що рівень розряджання акумуляторних батарей здебільшого не повинен перевищувати 50.. 75\%;

- потужність накопичувача та його ємність повинна розраховуватися виходячи $з$ переліку та сумарної установленої потужності струмоприймачів, які мають функціонувати у періоди відсутності мережевої електроенергії та їх протяжності, а також особливостей функціонування деяких струмоприймачів у момент їх включення (підвищення струму споживання у $3 \ldots 4$ рази від номінального при пусках); 
- за існуючої практики та вимог нормативних документів регламентовані перерви у електропостачанні мають бути для навчальних закладів у межах 1 доби (II та III категорії надійності електропостачання згідно ДБН В.2,5 - 23:2010).

Необхідно також звернути увагу на обмежену кількість струмоприймачів, які можуть функціонувати одночасно в системі, їх сумарну потужність обмежують можливості гібридного інвертора.

Узагальнена інформація про основні варіанти комплектування та критерії і особливості застосування сонячних електростанцій зведено у табл. 3.

Таблиця 3.

Основні варіанти комплектування сонячних електростанцій, які доцільно розташовувати на об’єктах навчальних закладів.

\begin{tabular}{|c|c|c|c|}
\hline $\begin{array}{l}\text { Варіанти } \\
\text { комплектації та } \\
\text { архітектури станції }\end{array}$ & Умови застосування & $\begin{array}{l}\text { Критерії вибору } \\
\text { установленої } \\
\text { електричної } \\
\text { потужності }\end{array}$ & $\begin{array}{l}\text { Особливості } \\
\text { застосування }\end{array}$ \\
\hline $\begin{array}{l}\text { Варіант1. } \\
\text { Комплект сонячних } \\
\text { панелей, інвертор, } \\
\text { допоміжна захисна та } \\
\text { з'єднувальна група } \\
\text { обладнання }\end{array}$ & $\begin{array}{l}\text { Доцільно за умови } \\
\text { функціонування } \\
\text { відокремленого об’єкта } \\
\text { навчального закладу не } \\
\text { великої потужності не } \\
\text { відповідальних } \\
\text { струмоприймачів } \\
\text { періодичної дії за умови їх } \\
\text { функціонування у період } \\
\text { генерації електроенергії } \\
\text { станцією. }\end{array}$ & $\begin{array}{l}\text { Максимальна } \\
\text { установлена } \\
\text { потужність } \\
\text { сонячних панелей } \\
\text { має вибиратися за } \\
\text { критерієм } \\
\text { забезпечення } \\
\text { максимальної } \\
\text { потужності } \\
\text { струмоприймачів за } \\
\text { умови хмарної } \\
\text { погоди. }\end{array}$ & $\begin{array}{l}\text { Повне автономне } \\
\text { забезпечення } \\
\text { електроенергією } \\
\text { автономних } \\
\text { струмоприймачів або } \\
\text { об'єктів за умови, що } \\
\text { профіль їх } \\
\text { електроспоживання } \\
\text { співпадає з профілем } \\
\text { генерації сонячної } \\
\text { електростанції; }\end{array}$ \\
\hline $\begin{array}{l}\text { Варіант 2. Комплект } \\
\text { сонячних панелей, } \\
\text { інвертор, допоміжна } \\
\text { захисна та } \\
\text { з'єднувальна група } \\
\text { обладнання, } \\
\text { накопичувачі енергії }\end{array}$ & $\begin{array}{l}\text { Доцільно при } \\
\text { функціонуванні } \\
\text { відокремленого об’єкта } \\
\text { навчального закладу не } \\
\text { великої потужності } \\
\text { періодичної дії не } \\
\text { відповідальних } \\
\text { струмоприймачів за умови } \\
\text { економічної недоцільності } \\
\text { або технічної неможливості } \\
\text { приєднання їх до } \\
\text { електричних мереж } \\
\text { постачальника }\end{array}$ & $\begin{array}{l}\text { Вихідними } \\
\text { критеріями вибору } \\
\text { величини } \\
\text { максимальної } \\
\text { установленої } \\
\text { потужності сонячної } \\
\text { електростанції } \\
\text { мають бути } \\
\text { електрична } \\
\text { потужність } \\
\text { струмоприймачів, } \\
\text { графік їх } \\
\text { функціонування, } \\
\text { обсяги добового } \\
\text { споживання } \\
\text { електроенергіі. За } \\
\text { таких умов } \\
\text { потужність }\end{array}$ & $\begin{array}{l}\text { Повне автономне } \\
\text { забезпечення } \\
\text { електроенергією } \\
\text { автономних } \\
\text { струмоприймачів або } \\
\text { об'єктів за умови, що } \\
\text { профіль їх } \\
\text { електроспоживання не } \\
\text { співпадає з профілем } \\
\text { генерації сонячної } \\
\text { електростанції; }\end{array}$ \\
\hline
\end{tabular}




\begin{tabular}{|c|c|c|c|}
\hline & & $\begin{array}{l}\text { електричної станції } \\
\text { повинна } \\
\text { розраховуватися } 3 \\
\text { урахуванням також } \\
\text { технічних } \\
\text { параметрів } \\
\text { накопичувача } \\
\text { електричної енергії }\end{array}$ & \\
\hline $\begin{array}{l}\text { Варіант 3. Комплект } \\
\text { сонячних панелей, } \\
\text { мережевий інвертор, } \\
\text { допоміжна захисна та } \\
\text { з'єднувальна група } \\
\text { обладнання з } \\
\text { мережею змінної } \\
\text { напруги та постійної } \\
\text { напруги сонячних } \\
\text { панелей. }\end{array}$ & $\begin{array}{l}\text { Мережева сонячна } \\
\text { електростанція. Доцільне } \\
\text { часткове або повне (деяких } \\
\text { струмоприймачів) } \\
\text { забезпечення } \\
\text { струмоприймачів } \\
\text { навчальних та } \\
\text { адміністративних будівель } \\
\text { цілодобово та у періоди } \\
\text { проведення навчального } \\
\text { процесу з використанням } \\
\text { схеми мережевої станції } \\
\text { (підключення сонячної } \\
\text { електростанції об’єкту, } \\
\text { будівлі до загальної мережі } \\
\text { постачальника } \\
\text { електроенергії). }\end{array}$ & $\begin{array}{l}\text { Максимальна } \\
\text { установлена } \\
\text { електрична } \\
\text { потужність може } \\
\text { бути максимально } \\
\text { можливою. } \\
\text { Суттєвих технічних } \\
\text { обмежень та } \\
\text { передумов щодо } \\
\text { визначення } \\
\text { максимальної } \\
\text { установленої } \\
\text { електричної } \\
\text { потужності сонячної } \\
\text { електростанції не } \\
\text { існує, за } \\
\text { виключенням } \\
\text { технічної } \\
\text { можливості } \\
\text { розташування } \\
\text { максимальної } \\
\text { кількості сонячних } \\
\text { панелей на } \\
\text { конструкційних } \\
\text { елементах будівлі } \\
\text { (покрівлі, стінах). }\end{array}$ & $\begin{array}{l}\text { Часткове або повне } \\
\text { (деяких } \\
\text { струмоприймачів) } \\
\text { забезпечення } \\
\text { струмоприймачів } \\
\text { навчальних та } \\
\text { адміністративних } \\
\text { будівель цілодобово } \\
\text { та у періоди } \\
\text { проведення } \\
\text { навчального процесу з } \\
\text { використанням схеми } \\
\text { мережевої станції } \\
\text { (підключення } \\
\text { сонячної } \\
\text { електростанції } \\
\text { об’єкту, будівлі до } \\
\text { загальної мережі } \\
\text { постачальника } \\
\text { електроенергії). } \\
\text { Залежність } \\
\text { функціонування від } \\
\text { якості та } \\
\text { безперервної } \\
\text { наявності } \\
\text { електроенергії } \\
\text { постачальника } \\
\text { (загальної мережі). }\end{array}$ \\
\hline $\begin{array}{l}\text { Варіант 4. Комплект } \\
\text { сонячних панелей, } \\
\text { мережевий інвертор, } \\
\text { допоміжна захисна та } \\
\text { з'єднувальна група } \\
\text { обладнання з } \\
\text { мережею змінної } \\
\text { напруги та постійної } \\
\text { напруги сонячних } \\
\text { панелей, додатковий } \\
\text { інвертор, } \\
\text { накопичувачі } \\
\text { електроенергії. }\end{array}$ & $\begin{array}{l}\text { Мережева сонячна } \\
\text { електростанція. Доцільне } \\
\text { часткове або повне (деяких } \\
\text { струмоприймачів) } \\
\text { забезпечення } \\
\text { струмоприймачів } \\
\text { навчальних та } \\
\text { адміністративних будівель } \\
\text { цілодобово та у періоди } \\
\text { проведення навчального } \\
\text { процесу з використанням } \\
\text { схеми мережевої станції } \\
\text { (підключення сонячної } \\
\text { електростанції об’єкту, } \\
\text { будівлі до загальної мережі } \\
\text { постачальника } \\
\text { електроенергії). Може } \\
\text { слугувати як резервне } \\
\text { джерело електроенергії. }\end{array}$ & $\begin{array}{l}\text { Максимальна } \\
\text { установлена } \\
\text { електрична } \\
\text { потужність може } \\
\text { бути максимально } \\
\text { можливою. } \\
\text { Суттєвих технічних } \\
\text { обмежень та } \\
\text { передумов щодо } \\
\text { визначення } \\
\text { максимальної } \\
\text { установленої } \\
\text { електричної } \\
\text { потужності сонячної } \\
\text { електростанції не } \\
\text { існує, за } \\
\text { виключенням } \\
\text { технічної } \\
\text { можливості }\end{array}$ & $\begin{array}{l}\text { Часткове або повне } \\
\text { (деяких } \\
\text { струмоприймачів) } \\
\text { забезпечення } \\
\text { струмоприймачів } \\
\text { навчальних та } \\
\text { адміністративних } \\
\text { будівель цілодобово } \\
\text { та у періоди } \\
\text { проведення } \\
\text { навчального процесу з } \\
\text { використанням схеми } \\
\text { мережевої станції } \\
\text { (підключення } \\
\text { сонячної } \\
\text { електростанції } \\
\text { об’єкту, будівлі до } \\
\text { загальної мережі } \\
\text { постачальника }\end{array}$ \\
\hline
\end{tabular}




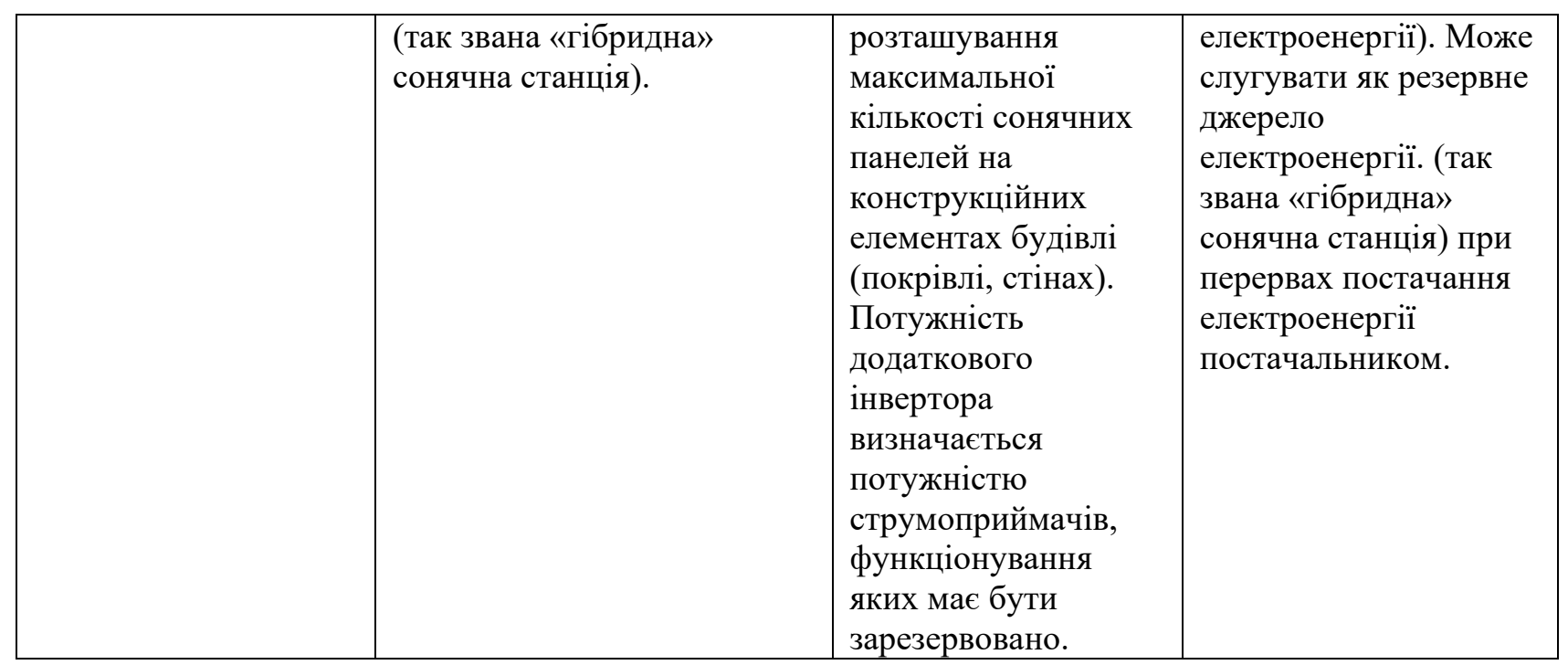

Третій напрямок - економічне обгрунтування вибору сонячної електростанції в координатах «потужність/обсяги споживання - термін окупності».

Для порівняльного аналізу нами були узагальнені техніко-економічні характеристики сонячної електростанції (варіант комплектації 3), загальною встановленою електричною потужністю 30 кВт, що розташовується на покрівлі шатрового даху навчального корпусу (табл. 4-6).

Таблиця 4.

Технічні характеристики

\begin{tabular}{|l|c|}
\hline Загальна встановлена потужність фотоелектричної установки, кВт & 30 \\
\hline Розмір земельної ділянки, яку займає генеруючий об'єкт, га & 0 (210 м² покрівлі) \\
\hline & $26920-32900$ \\
Прогнозоване річне виробництво електроенергії, кВт·год/рік & $\left.2991 *^{*}\right)$ \\
\hline Тривалість будівництва генеруючого об'єкта, років & 0,1 \\
\hline Тривалість життєвого циклу генеруючого об'єкта, років & 25 \\
\hline
\end{tabular}

Таблиця 5.

Капіталовкладення

\begin{tabular}{|l|c|c|}
\hline Кошторис загальних інвестиційних витрат & $\begin{array}{c}\text { Мінімальне та } \\
\text { максимальне } \\
\text { значення, грн (3 } \\
\text { ПДВ) }\end{array}$ & $\begin{array}{c}\text { Середнє } \\
\text { значення, } \\
\text { грн }\end{array}$ \\
\hline $\begin{array}{l}\text { Техніко-економічне обгрунтування та розроблення } \\
\text { проекту, у т. ч витрати на геодезію, геологію, отримання } \\
\text { дозвільних документів (ліцензія, землевідведення тощо) }\end{array}$ & $22500-27500$ & 25000 \\
\hline $\begin{array}{l}\text { Облаштування майданчику/під’їзна дорога/будівельні та } \\
\text { монтажні роботи }\end{array}$ & $21600-32400$ & 27000 \\
\hline Витрати на придбання фотоелектричних модулів & $240000-293700$ & 267000 \\
\hline
\end{tabular}




\begin{tabular}{|c|c|c|}
\hline $\begin{array}{l}\text { Витрати на інше обладнання та комплектуючі: інвертори, } \\
\text { металеві конструкції тощо }\end{array}$ & $50400-61600$ & 56000 \\
\hline $\begin{array}{l}\text { Додаткове облаштування вузла обліку перетікання } \\
\text { електроенергії }\end{array}$ & $15300-18700$ & 17000 \\
\hline $\begin{array}{l}\text { Витрати на приєднання до електромережі та забезпечення } \\
\text { передачі електроенергії (при середній відстані } 60 \text { метрів } \\
\text { та приєднанні потужності } 30 \text { кВт). Необхідність цих } \\
\text { витрат виникає при умові повної оплати за приєднання* }\end{array}$ & $\begin{array}{l}\text { За розрахунком у } \\
\text { відповідності до } \\
\text { фактичних умов } \\
\text { електрозабезпечен } \\
\text { ня об'єкта } \\
\end{array}$ & 97600 \\
\hline Всього & $447400-531500$ & 489600 \\
\hline
\end{tabular}

Таблиця 6. Експлуатаційні витрати та витрати на технічне обслуговування

\begin{tabular}{|l|c|c|}
\hline $\begin{array}{l}\text { Експлуатаційні витрати та витрати на технічне } \\
\text { обслуговування }\end{array}$ & $\begin{array}{c}\text { Мінімальне та } \\
\text { максимальне } \\
\text { значення, грн/рік }\end{array}$ & $\begin{array}{c}\text { Середнє } \\
\text { значення, } \\
\text { грн/рік }\end{array}$ \\
\hline $\begin{array}{l}\text { Необхідна кількість персоналу (чол.) } \\
\text { Витрати на оплату праці }\end{array}$ & 0 & 0 \\
\hline $\begin{array}{l}\text { Витрати на технічне обслуговування і витратні матеріали } \\
\text { включаючи оплату праці) сторонніми організаціями }\end{array}$ & $10800-13200$ & 12000 \\
\hline Оренда земельної ділянки (0 га) & 0 & 0 \\
\hline $\begin{array}{l}\text { Інші витрати (державна служба охорони, страхування } \\
\text { тощо) }\end{array}$ & 0 & 0 \\
\hline Всього & $10800-13200$ & 12000 \\
\hline
\end{tabular}

Техніко-економічні характеристики сонячної електростанції (варіант комплектації 4), загальною встановленою електричною потужністю 30 кВт, встановленою електричною потужністю накопичувача 15 кВт, що розташовується на покрівлі шатрового даху навчального корпусу (табл. 7-9).

Таблиця 7. Технічні характеристики

\begin{tabular}{|l|c|}
\hline Загальна встановлена потужність фотоелектричної установки, кВт & 30 \\
\hline Розмір земельної ділянки, яку займає генеруючий об'єкт, га & $0\left(210\right.$ м $^{2}$ покрівлі) \\
\hline & $26920-32900$ \\
Прогнозоване річне виробництво електроенергії, кВт·год/рік & $\begin{array}{c}\text { середнє значення } \\
\left.29910^{*}\right)\end{array}$ \\
\hline Тривалість будівництва генеруючого об’єкта, років & 0,1 \\
\hline Тривалість життєвого циклу генеруючого об’єкта, років & 25 \\
\hline
\end{tabular}

*) середнє значення 
Таблиця 8.

Капіталовкладення.

\begin{tabular}{|c|c|c|}
\hline Кошторис загальних інвестиційних витрат & $\begin{array}{l}\text { Мінімальне та } \\
\text { максимальне } \\
\text { значення, грн (3 } \\
\text { ПДВ) } \\
\end{array}$ & $\begin{array}{l}\text { Середнє } \\
\text { значення, } \\
\text { грн }\end{array}$ \\
\hline $\begin{array}{l}\text { Техніко-економічне обгрунтування та розроблення } \\
\text { проекту, у т. ч витрати на геодезію, геологію, отримання } \\
\text { дозвільних документів (ліцензія, землевідведення тощо) }\end{array}$ & $22500-27500$ & 25000 \\
\hline $\begin{array}{l}\text { Облаштування майданчику/під’їзна дорога/будівельні та } \\
\text { монтажні роботи }\end{array}$ & $21600-32400$ & 27000 \\
\hline Витрати на придбання фотоелектричних модулів & $240000-293700$ & 267000 \\
\hline $\begin{array}{l}\text { Витрати на інше обладнання та комплектуючі: інвертори, } \\
\text { металеві конструкції тощо }\end{array}$ & $50400-61600$ & 56000 \\
\hline $\begin{array}{l}\text { Додаткове облаштування вузла обліку перетікання } \\
\text { електроенергії }\end{array}$ & $15300-18700$ & 17000 \\
\hline $\begin{array}{l}\text { Витрати на придбання обладнання електричних } \\
\text { накопичувачів (15 кВт електричної потужності) та } \\
\text { додаткового інвертора }\end{array}$ & $220000-248000$ & 234000 \\
\hline $\begin{array}{l}\text { Витрати на приєднання до електромережі та забезпечення } \\
\text { передачі електроенергії (при середній відстані } 40 \text { метрів } \\
\text { та приєднанні потужності } 30 \text { кВт). Необхідність цих } \\
\text { витрат виникає при умові повної оплати за приєднання* }\end{array}$ & $\begin{array}{l}\text { За розрахунком у } \\
\text { відповідності до } \\
\text { фактичних умов } \\
\text { електрозабезпечен } \\
\text { ня об'єкта }\end{array}$ & 97600 \\
\hline Всього & $667400-779500$ & 723600 \\
\hline
\end{tabular}

Таблиця 9.

Експлуатаційні витрати та витрати на технічне обслуговування.

\begin{tabular}{|l|c|c|}
\hline $\begin{array}{l}\text { Експлуатаційні витрати та витрати на технічне } \\
\text { обслуговування }\end{array}$ & $\begin{array}{c}\text { Мінімальне та } \\
\text { максимальне } \\
\text { значення, грн/piк }\end{array}$ & $\begin{array}{c}\text { Середнє } \\
\text { значення, } \\
\text { грн/piк }\end{array}$ \\
\hline $\begin{array}{l}\text { Необхідна кількість персоналу 1 (чол.) } \\
\text { Витрати на оплату праці }\end{array}$ & 0 & 0 \\
\hline $\begin{array}{l}\text { Витрати на технічне обслуговування і витратні матеріали } \\
\text { включаючи оплату праці) сторонніми організаціями }\end{array}$ & $10800-13200$ & 12000 \\
\hline Оренда земельної ділянки (0 га) & 0 & 0 \\
\hline $\begin{array}{l}\text { Інші витрати (державна служба охорони, страхування } \\
\text { тощо) }\end{array}$ & 0 & 0 \\
\hline Всього & $10800-13200$ & 12000 \\
\hline
\end{tabular}

За обома варіантами прийнято: коефіцієнт зниження генерації електроенергії - 0,8\% щорічно; витрати на виведення генеруючого об'єкта 3 експлуатації - орієнтовно близько 30000 грн; витрати на оплату праці персоналу мають бути у межах існуючого штатного розкладу навчального закладу. У 
обов’язки штатного персоналу повинен входити періодичний огляд функціонування станції та перезавантаження апарату грозового захисту (1 раз на місяць); витрати на приєднання та забезпечення передачі мають бути скореговані у залежності від існуючої дозволеної потужності споживання струмоприймачами об'єкту.

У разі перевищення фактичної дозволеної потужності 30 кВт, згідно нормативних документів плата за цим пунктом не повинна стягуватися. Плата за різницю між 30 кВт та наразі дозволеною розраховується у відповідності до постанови НКРЕКП від 18.12.2018 № 1965 (нестандартне приєднання «під кЛЮч»).

На основі методичних підходів, запропонованих нами в роботі [233] та 3 урахуванням техніко-економічних показників (табл. 4-9) було проведено дослідження залежності строку окупності сонячної електростанції від місячного електроспоживання (рис. 1).

Функціональна залежність (рис. 1) досить точно може бути описана рівнянням:

$$
t=1254,5 P^{-0.6152}, R^{2}=0,9459
$$

де: $t$ - термін окупності, років; $P$ - місячне електроспоживання, кВт *год/місяць. 


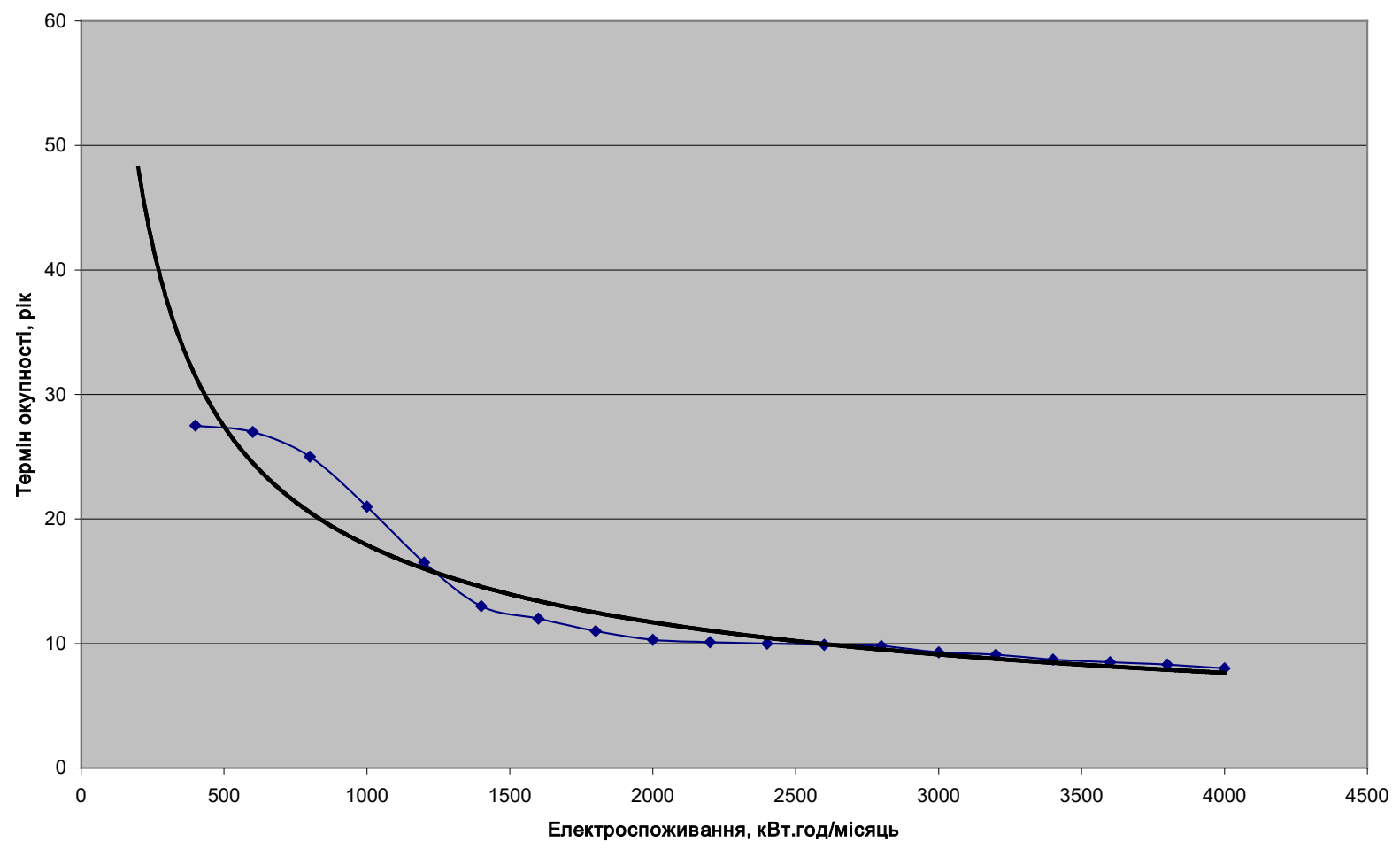

Рисунок 1. Залежності строку окупності сонячної електростанції від місячного електроспоживання (за умови однозонного тарифу).

Очевидно, що прийнятний термін окупності (10 років) сонячних електростанцій має місце при місячному електроспоживанні в межах $2400-2600$ кВт *год і більше. Цей показник є додатковим критерієм при обгрунтуванні як схеми компонування сонячної електростанції у навчальному закладі так і іiі раціональної установленої електричної потужності. 


\section{SECTION 11. MINING AND SURVEYING}

\section{1 Дослідження застосування третинних методів підвищення нафтовилучення на завершальній стадії розробки нафтових родовищ}

Значна кількість нафтових родовищ України, в тому числі Передкарпаття, вступила в період спадного видобутку нафти і завершальну стадію розробки. Тому виникає проблема дорозробки їх з метою додаткового вилучення нафти. На завершальній стадії розробки в основному використовуються гідродинамічні та фізико-хімічні методи підвищення нафтовилучення [234,235].

Прогнозування кінцевого коефіцієнта нафтовилучення після впровадження методу діяння на пласт здійснюється в лабораторних умовах. Ці дослідження $є$ довготривалими і коштовними. На теперішній час широко використовують гідродинамічне моделювання процесів нафтовидобування. Застосування комп'ютерного програмного забезпечення Petrel та Eclipse від компанії Schlumberger дає змогу більш точніше підібрати метод підвищення нафтовилучення для Струтинського нафтового родовища та оцінити ефективність від його впровадження. Отже, дослідження, розроблення i впровадження у нафтовій промисловості технологій застосування поверхневоактивних систем для збільшення нафтовилучення і поточних відборів нафти на завершальній стадії розробки родовищ $є$ актуальним завданням сьогодення [236, 237].

На завершальній стадії розробки в основному використовуються гідродинамічні та фізико-хімічні методи збільшення нафтовилучення. Гідродинамічні методи не в повній мірі забезпечують вилучення мікрозащемленої нафти 3 обводнених пластів. Тому застосування гідродинамічних методів підвищення нафтовилучення з виснажених обводнених родовищ є обмеженим [238, 239].

Серед третинних методів підвищення нафтовилучення на увагу заслуговують фізико-хімічні методи. Проте застосування фізико-хімічних методів вимагає вирішення ряду питань і вивчення процесів на дослідних 
ділянках. Питання застосування фізико-хімічних методів, для збільшення нафтовилучення та інтенсифікації нафтовидобування містить низку суперечливих аспектів. 3 одного боку, - це необхідність і можливість збільшення коефіцієнта нафтовилучення виснажених і обводнених родовищ, що спонукає до глибокого вивчення проблеми, а, 3 іншого, - наявність ряду несприятливих факторів (питання екології, постачання та якості хімреагентів, наявності необхідного обладнання), що значною мірою ускладнює вирішення питання застосування поверхнево-активних систем для видобування нафти 3 виснажених обводнених родовищ. Використано програмне забезпечення від компанії Petroleum Solutions Ltd під назвою EORgui, яке має графічний інтерфейс i дозволяє зробити підбір методу EOR для нафтового покладу більш швидким i точним. Дана програма розроблена на основі публікації в Society of Petroleum Engineers в 1996 році, яка називається „EOR Screening Criteria Revisited” [240]. Для того, щоб побачити, який з методів підвищення нафтовилучення найкраще підходить для даного родовища потрібні дані властивостей його нафти, а також гірських порід, в яких вона знаходиться. Для Струтинського нафтового родовища характеристика гірських порід і властивості нафти наступні: густина

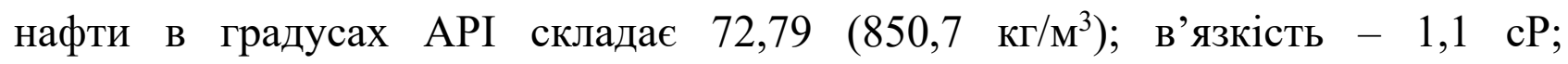
нафтонасиченість становить 77\%; тип породи - пісковик; глибина залягання покладу близько 1600 метрів (5100 футів); температура - $63{ }^{\circ} \mathrm{C}\left(145,4{ }^{\circ} \mathrm{F}\right)$; проникність на основі гідродинамічних досліджень становить $2,14 \times 10^{-3}$ мкм $^{2}$ $(2,16 \mathrm{mD})$.

На малюнку 1 у вигляді кола показано, що найбільш оптимальним методом EOR для Струтинського нафтового родовища є запомповування розчинів ASP. Даний метод полягає в запомповуванні в поклад суміші з трьох агентів: лугу, поверхнево-активних речовин і полімеру (alkaline/surfactant/polymer - ASP). Лужний агент, який входить в склад розчину, допомагає захистити розчин ASP від двовалентних йонів, зменшує адсорбцію поверхнево-активних речовин в породі та реагує з органічними кислотами, присутніми в нафті, створюючи природні поверхнево-активні речовини. В якості лужного агенту 
використовується гідроксид натрію, силікат натрію, фосфат натрію, гідроксид амонію та ін. [241].

Для побудови геологічної моделі нижньоменілітових відкладів Струтинського нафтового родовища використовувалось програмне забезпечення Petrel від компанії Schlumberger. Об'єктом для побудови моделі був Струтинський блок нижньоменілітових відкладів, який є основним об'єктом розробки. Дані для виконання статичної моделі отримали на підставі геологічних і геофізичних досліджень, сейсміки, а також лабораторних досліджень керну.

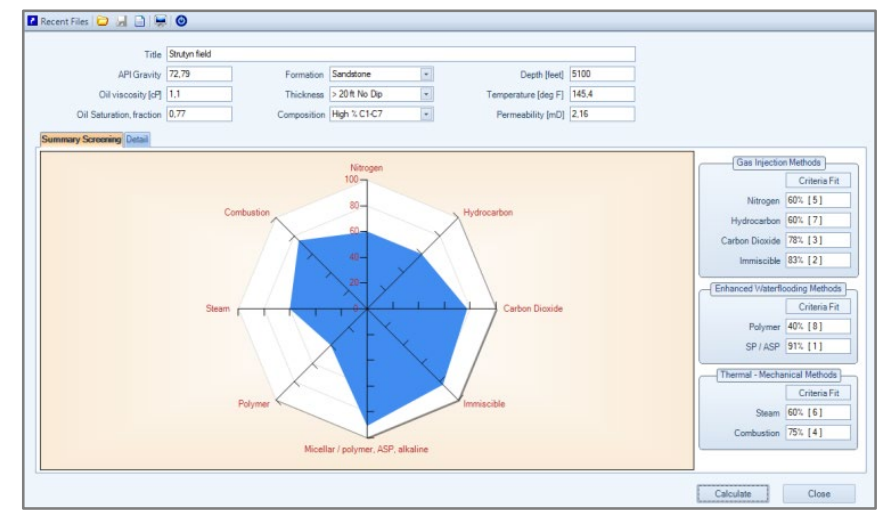

Малюнок 1 - Результати підбору методу EOR для Струтинського нафтового родовища в програмі EORgui

Процес побудови геологічної моделі розпочинається зі структурного моделювання, де можна спроектувати поверхню покрівлі та підошви горизонту, а також розломів [241]

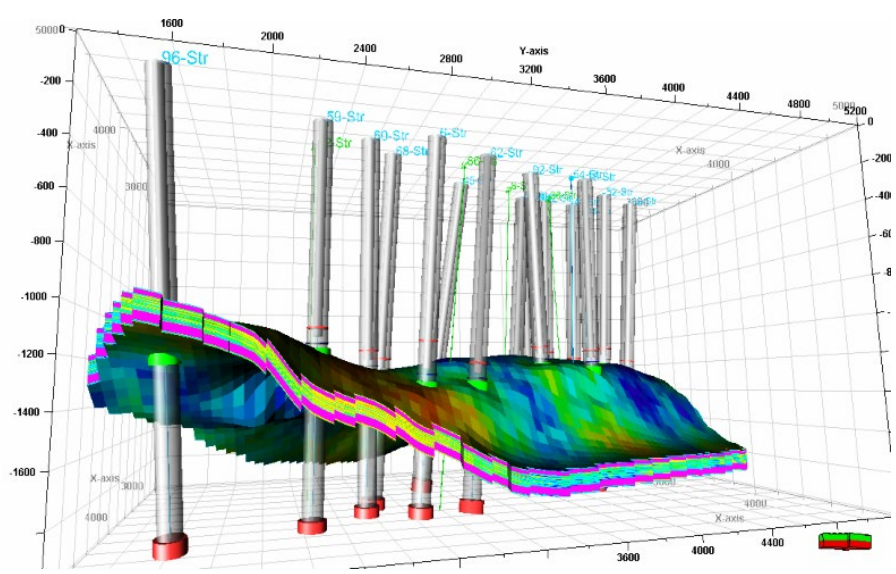

Малюнок 2 - Геологічна модель Струтинського родовища у 3D вигляді Для побудови поверхні горизонту, тобто покрівлі Струтинського блоку нижньоменілітових відкладів використано структурну карту даного родовища. 
Інтерпретація горизонту була проведена на основі ізоліній з різною глибиною, через які, власне, побудовано структурну карту. За допомогою функції калькулятора в даній програмі, при відомій з проекту розробки кількості та товщині відповідних пластів побудувано поверхню підошви для даного блоку (малюнок 2).

Як модель флюїду для гідродинамічного моделювання використана модель типу blackoil зі всіма фазами, тобто газ, нафта і вода. Дані для створення такої моделі було взято з проекту розробки Струтинського нафтового родовища. До них належать: мінімальний пластовий тиск, який становить 18,1 МПа, максимальний пластовий тиск $-27,8 \mathrm{MПа,} \mathrm{пластова} \mathrm{температура}-63^{\circ} \mathrm{C}$, густина

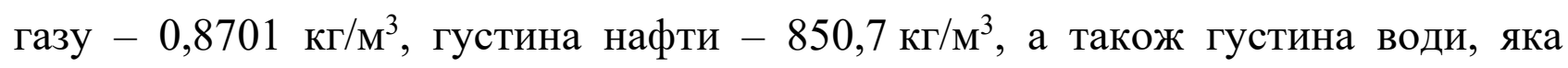
становить 1019 кг/м³. Після створення моделі blackoil результати властивостей PVT моделі флюїду представлені на малюнку 3.

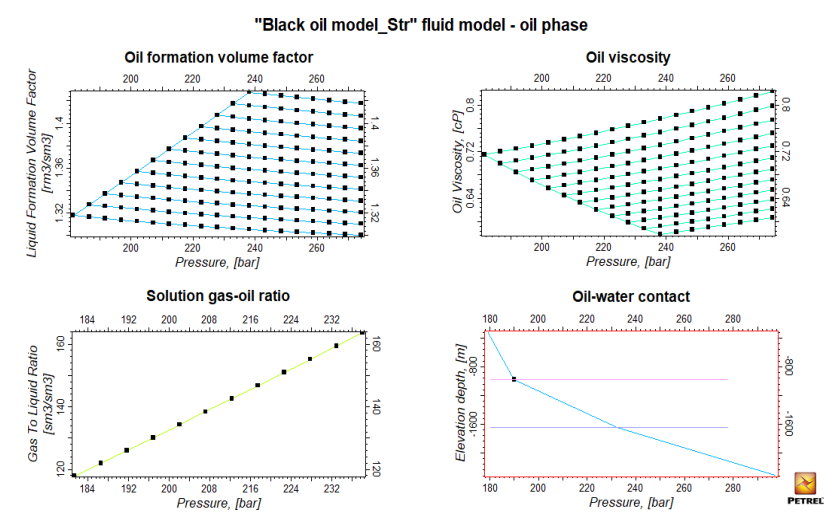

Малюнок 3 - Властивості PVT моделі флюїду для нижньоменілітового покладу Струтинського нафтового родовища

Після створення статичної і гідродинамічної моделі проведено ії адаптацію до історії розробки родовища. Після етапу калібрації побудованої моделі виконано прогнозування видобутку нафти з покладу із застосуванням вибраного методу підвищення нафтовилучення. В даному випадку таким методом $є$ запомповування розчину ASP. Запропоновано використати 4 існуючі нагнітальні свердловини, за допомогою яких запомповується в поклад вода 3 метою підтримування пластового тиску. Нагнітальні свердловини 8-Стр, 32-Стр, 86-Стр та 88-Стр. вибрано через значну приймальність при не дуже високих тисках, а 
також розташування по цілій площі даного блоку. Розташування нагнітальних свердловини показано на малюнку 4.

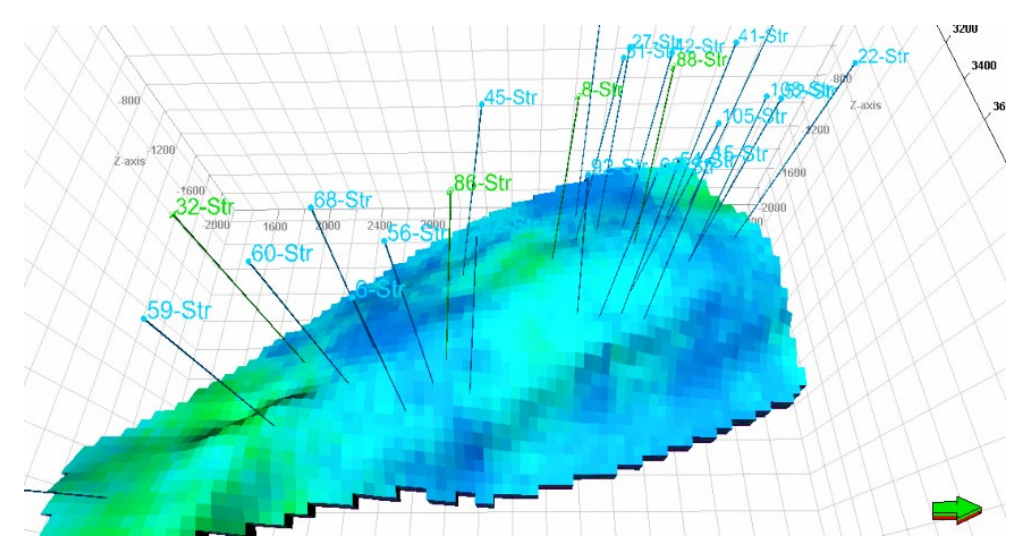

Малюнок 4- Розміщення нагнітальних свердловин для запомповування розчину ASP

В загальному, склад для ASP-заводнення включає три основних компоненти: лужний агент, поверхнево-активну речовину та полімер. На основі експериментальних даних [237] запропоновано найбільш ефективну концентрацію цих агентів, а саме: лужний агент концентрацією 0,7\% мас., полімеру типу НРАМ концентрацією 0,01850 \% мас і поверхнево-активної речовини концентрацією $0,2 \%$ мас. Полімер, який використовується для симуляції відноситься до гідролізованого поліакриламіду (НРАМ). Головною перевагою застосування такого типу полімеру є можливість отримання високої в'язкості розчину, його ціна, доступність, а також виробництво в промислових масштабах. B'язкість розчину полімеру для ASP-заводнення в даному випадку $\epsilon$ ключовим параметром, який покращує рухливість нафти по відношенню до води. Технологія запомповування розчину ASP полягає в залучення в розробку макрозащемленої нафти із пластів з початковою нафтонасиченістю, які вода обійшла в процесі заводнення нафтового родовища. Складні фізико-хімічні процеси такі як адсорбція, ретенція та утворення емульсії при закачуванні розчину ASP можуть спричиняти підвищення фільтраційних опорів та тиску. В 
результаті цього різниця тисків в пластах з високою проникністю стає більшою, ніж у пластах із середньою та низькою проникністю. На закачування розчину прореаговують зони із високою проникність, а слабкодреновані ділянки пласта не залучаться в розробку. Враховуючи вищенаведені особливості завершальної стадії розробки родовища пропонується проводити запомповування $30 \%$ розчину ASP від об'єму нафтонасичених пор пласта тривалістю 1 рік, потім 2 роки запомповування води в пласт (з метою поступового просування розчину ASP в зонах 3 меншою проникністю). Здійснювати метод підвищення нафтовилучення потрібно 10 років по обраному циклу. Для того, щоб змоделювати ASP - заводнення потрібно виконати прогнозування, змінивши модель флюїду згідно концентрації відповідних компонентів. Процес запомповування розчину ASP умовно планується проводити від 2019 до 2029 року, тобто тривалістю 10 років. Після обрахунків за допомогою симулятора Eclipse 100, отримано результати зміни вибійних тисків у свердловинах, які знаходяться на малюнку 5, а також прогнозований дебіт нафти із свердловин, представлений, відповідно, на малюнку 6.

Аналізуючи отримані результати можна побачити, що вибійний тиск у видобувних свердловинах збільшується. Це означає, що розчин ASP просувається крізь породу в напрямку від нагнітальних свердловин до видобувних, тим самим витісняє з неї нафту. На малюнку 6 наведено результати прогнозування видобутку нафти зі свердловин внаслідок ASP-заводнення. У свердловинах 63-Стр, 27-Стр, 85-Стр зростання дебіту не спостерігається. Такий результат можливий, внаслідок ускладненої геологічної структури покладу, тобто в зонах дренування цих свердловин знаходяться пласти 3 низькою проникністю, які не охоплені процесом запомповування розчину ASP. Через це ми не отримали додатковий видобуток нафти із цих свердловин, тобто їх дебіт зменшується. На рис. 9 бачимо, що додатковий видобуток нафти отримаємо із свердловин 15-Стр, 43-Стр, 54-Стр, 45-Стр, 56-Стр, 41-Стр, 51-Стр, 60-Стр, 92Стр, 42-Стр, 52-Стр, 62-Стр. Починаючи із 2019 року (на момент впровадження методу підвищення нафтовилучення) дебіти нафти зростають із 2-4 м³/д до 6-16 
м³/д (станом на 2030 рік). Додатковий видобуток нафти за рахунок фізикохімічного методу підвищення нафтовилучення із застосуванням розчину ASP отримаємо і після 2030 року, оскільки дебіти свердловин продовжують збільшуватись.

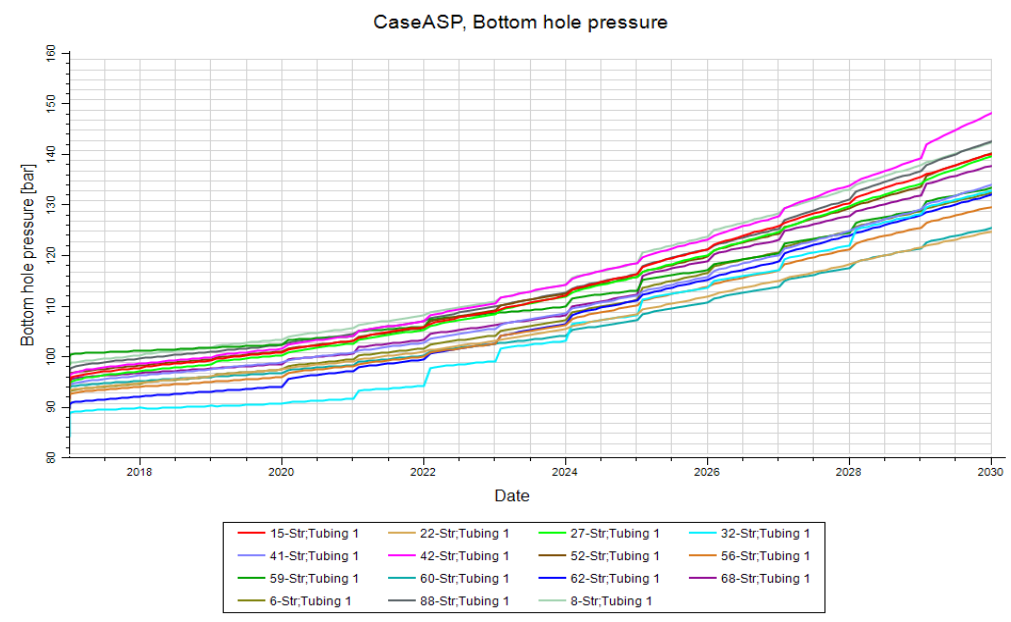

Малюнок 5 - Результати прогнозування зміни вибійного тиску у свердловинах, внаслідок ASP-заводнення

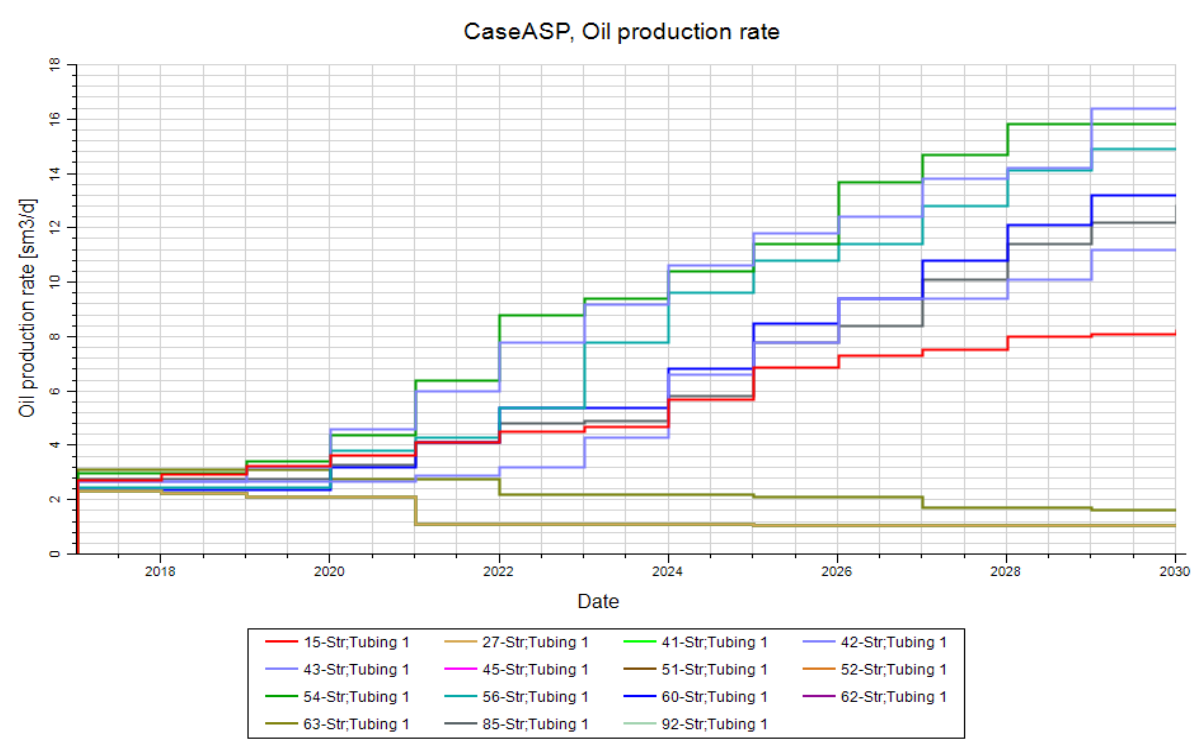

Малюнок 6 - Результати прогнозування видобутку нафти зі свердловин, внаслідок ASP-заводнення

Висновок. Струтинське нафтове родовище вступило в період спадного видобутку нафти і завершальну стадію розробки. Застосування технології витіснення нафти водою шляхом заводнення $є$ недостатньо ефективним i 


\section{THEORETICAL ASPECTS OF MODERN ENGINEERING}

залишає широке поле можливостей до його дорозробки з метою додаткового видобутку нафти.

Результати комп’ютерної симуляції свідчать про можливість і технологічну ефективність вилучення залишкової нафти за рахунок використання розчину ASP. Реалізація цього методу дозволяє істотно підвищити коефіцієнт кінцевого нафтовилучення від початкового $10,4 \%$ до прогнозованого $17,6 \%$ на нижньоменілітових відкладах Струтинського нафтового родовища. 


\subsection{Minimization of risks during the raises advance}

In the Kryvyi Rih basin, during the preparation of new horizons and cutting of blocks, about 25-27 thousand meters of raises for various purposes are annually passed. The vast majority of raises (over 95\%) are drilled and blasted [242].

Risks when driving raising workings can be divided into the following groups:

- geodynamic, associated with a high level of acting stresses in the rock mass and low strength properties of rocks;

- hydrogeological, associated with the high permeability of the massif and the possibility of mine water inflow into the mine workings;

- gas-dynamic, associated with impulse gas emissions into raises;

- technological, associated with complications in the development of raises, including press-in of wells, the formation of bells, crowns or narrowings, as well as deviation of the direction of the well.If the first three groups of risks are associated with natural conditions and it is difficult to influence them, then the last group can be minimized by changing the technology of driving raises.

Large-scale technologies using large-diameter wells began to be used in world practice, in the development of hard ores in underground conditions in the second half of the last century. At the same time, preference was given to the use of a block caving system. Experimental work on the development of blocks of ferruginous quartzites without any compensation space showed that, along with positive aspects, there is an increase in losses due to the uneven density of ore breaking [243]. The technology of deep-well blasting of magnetite quartzites into cut-off rising, traversed by sectional blasting of wells was tested in the system of staged forced collapse with ore breaking by bunches of deep wells into the vertical compensation space of the cut-off slot in Kryvbas [244]. Risks are shown in the above articles, when breaking ores from a mountain range. In [245], it is pointed out that there are serious drawbacks of drilling with deep wells and bundles of parallel wells. When driving horizontal and vertical workings, the creation of a cut-in (compensation) cavity is associated with pressing in the workings due to the small distance between the wells. 
The introduction of plasma processes of cavity formation and well expansion [246] into the technology of raising workings allows minimizing the above technological risks, significantly reducing drilling operations, accelerating the process of drilling and reducing the time required to prepare blocks for industrial drilling into the compensation space. This requires the development of cheap methods for producing plasma, the development of foundations for controlling its parameters in the process of cavity formation and well expansion, which could be competitive with mechanical methods.

Technologists need Plasma Well Expansion Units (PWEU), which allow creating low-temperature plasma flows with controlled parameters, directly responsible for the destruction of the borehole wall or the cavity. These parameters are the flow velocity of the plasma jet $V$, its average mass temperature $T$, and the useful power of the plasma torch. They substantially depend on the input and design parameters of the electric arc plasmatron, i.e. current, air flow rate, arc length, channel diameter and nozzle throat.

A mathematical model has been developed for determine the distribution of the temperature field in the near-wall region of the well. The movement of hightemperature air as a heat carrier in a cylindrical through well is considered in mathematical model. High-temperature gas $(T=1300-1800 \mathrm{~K})$ with constant velocity $(V<100 \mathrm{~m} / \mathrm{s}$ ) enters in cylindrical channel with a radius of $R=0.05 \mathrm{~m}$. Heat transfer from the coolant to the rock is carried out by convection. The intensity of heat exchange, the magnitude of heat fluxes which entering the rock depends on the mass velocity of the heat carrier $\rho \cdot V$ and its temperature.

The distribution of the temperature field $T(r, t)$ in the near-wall region of the well must be investigated for obtain rational parameters of heat transfer between the coolant and the rock. A physical model is considered: a heat source with an initial temperature $\theta_{0}$ acts inside a cylindrical cavity of an elastic half-space. Radiant and convective heat exchange occurs on the surface of the well $r=R$. It is necessary to determine the temperature field in the near-wall region of the well at $r>R$.

It is necessary to solve the heat conduction equation for determine the temperature field [247, 248]: 
THEORETICAL ASPECTS OF MODERN ENGINEERING

$$
\frac{\partial^{2} T(r, t)}{\partial r^{2}}+\frac{1}{r} \frac{\partial T(r, t)}{\partial r}=\frac{1}{a} \frac{\partial T(r, t)}{\partial r}
$$

Under the following boundary and initial conditions:

$$
\begin{gathered}
-\left.\lambda \frac{\partial T(r, t)}{\partial r}\right|_{r=R}=H_{1}\left(\theta_{0}-T(r, t)\right)+\sigma_{0} \varepsilon\left(\theta_{0}{ }^{4}-T^{4}(r, t)\right) \\
T(r, t=0)=0 ; \quad T(r=\infty, t)=0
\end{gathered}
$$

where $a, \lambda$-coefficients of thermal diffusivity and thermal conductivity of rock; $H_{1}$ - heat transfer coefficient from the plasma jet to the rock;

$\sigma_{0}-$ Stefan Boltzmann's constant;

$\varepsilon$ - rock surface emissivity.

Denoting for convenience $\sigma_{0} \varepsilon=\sigma$ and using the method of perturbation theory and the integral Laplace transform [247, 248], we obtain a solution to problem (1) - (2) in the following form:

$$
\begin{gathered}
T(r, t)=2 h \theta \sqrt{\frac{R}{r}}(a t)^{1 / 2}\left[\frac{1}{\sqrt{\pi}} \exp \left(-\frac{(r-R)^{2}}{4 a t}\right)-\frac{r-R}{2 \sqrt{a} t} \Phi^{*}\left(\frac{r-R}{2 \sqrt{a} t}\right)-\frac{\sqrt{a} t}{2} \frac{r(8 R h+3)+\mathrm{R}}{8 r R} .\right. \\
\cdot\left(\left(1+\frac{(r-R)^{2}}{2 a t}\right) \Phi^{*}\left(\frac{r-R}{2 \sqrt{a} t}\right)-\frac{r-R}{2 \sqrt{a} t} \frac{1}{\sqrt{\pi}} \exp \left(-\frac{(r-R)^{2}}{4 a t}\right)\right)+ \\
+a t \cdot \frac{r^{2}\left(128 R^{2} h^{2}+112 R h+33\right)+2 R h(8 R h+3)+9 R^{2}}{32 r^{2} R^{2}} \cdot i^{3} \Phi^{*}\left(\frac{r-R}{2 \sqrt{a} t}\right)
\end{gathered}
$$

where $\theta=\theta_{0}+\frac{\sigma}{h}\left(\theta_{0}{ }^{3} T_{0}(R, t)-T_{0}^{4}(R, t)\right)+\frac{\sigma}{h} T_{1}(R, t)\left(\theta_{0}{ }^{3}-4 T_{0}^{3}(R, t)\right)+$

$$
+\frac{\sigma}{h}\left(\theta_{0}^{3} T_{2}(R, t)-4 T_{0}^{3}(R, t) T_{2}(R, t)-6 T_{0}^{2}(R, t) T_{1}^{2}(R, t)\right) ;
$$

where $T_{0}(R, t)$ - the value of the function $T(r, t)$ at the point $r=R$ for $\theta=\theta_{0}$;

$T_{1}(R, t)$ - the value of the function $T(r, t)$ at the point $r=R$ for $\theta=\frac{\sigma}{h}\left(\theta_{0}{ }^{3} T_{0}(R, t)-\right.$ $\left.-T_{0}^{4}(R, t)\right)$

$T_{2}(R, t)$ calculated accordingly for $\theta=\frac{\sigma}{h} T_{1}(R, t)\left(\theta_{0}{ }^{3}-4 T_{0}^{3}(R, t)\right)$.

The temperature fields in the vicinity of a well with a diameter of $0.05 \mathrm{~m}$ were determined when its walls were heated by a high-temperature flow, based on equation 
(3). The calculations were made for magnetite quartzites of Kryvbas, the following rock constants were taken: $a=1.67 \cdot 10^{-6} \mathrm{~m}^{2} / \mathrm{s} ; \beta=3 \cdot 10^{-5} \mathrm{~K}^{-1} ; \lambda_{0}=0.3 ; E=7 \cdot 10^{10} \Pi \mathrm{a} ; \lambda_{0}$ $=4 \mathrm{BT} /(\mathrm{m} \cdot \mathrm{K}) ; \sigma_{\text {сж }}=2 \cdot 10^{8} \Pi \mathrm{a} ; \mu=0.22$. Since the thermophysical properties of rocks depend on the heating temperature, the values of $a, \lambda, \beta, E$ for a given rock are taken as averaged in the range of $300-1900 \mathrm{~K}$.

The calculations were performed for two values of the initial gas temperatures in the near-wall region of the well $\theta_{0}=1300$ and $1800 \mathrm{~K}$. Figure 1 shows the temperature distribution curves in the surface layer of the rock when the well walls are heated by a high-temperature gas flow. As can be seen from the graphs, with an increase in the coolant temperature and heating time, the temperature gradient in the rock increases. Calculations show that at the initial temperature of the coolant equal to $1300 \mathrm{~K}$, the contribution of the radiant component to the value of the calculated temperature of the rock is $12-24 \%$, and with an increase in the temperature of the coolant, this contribution increases. With an increase in the initial temperature to $1800 \mathrm{~K}$, the contribution of the radiant component does not change, but the steepness of the temperature drop increases with distance from the borehole walls into the massif.

The obtained dependences make it possible to select the operating parameters of the plasmatron when creating a cavity in various mining and geological conditions. Thus, it is possible to control the process of well expansion by changing the speed of the cyclic movement of the plasmatron along the length of the well.

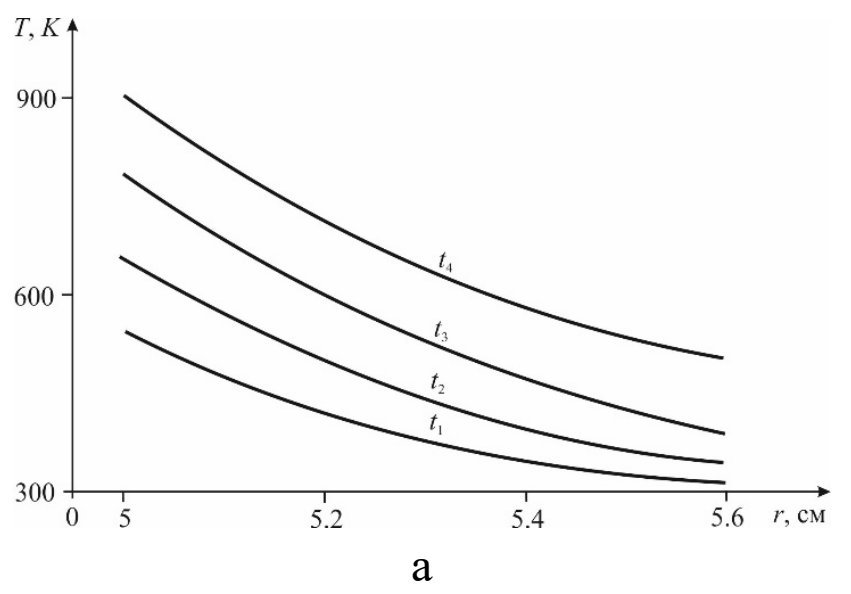




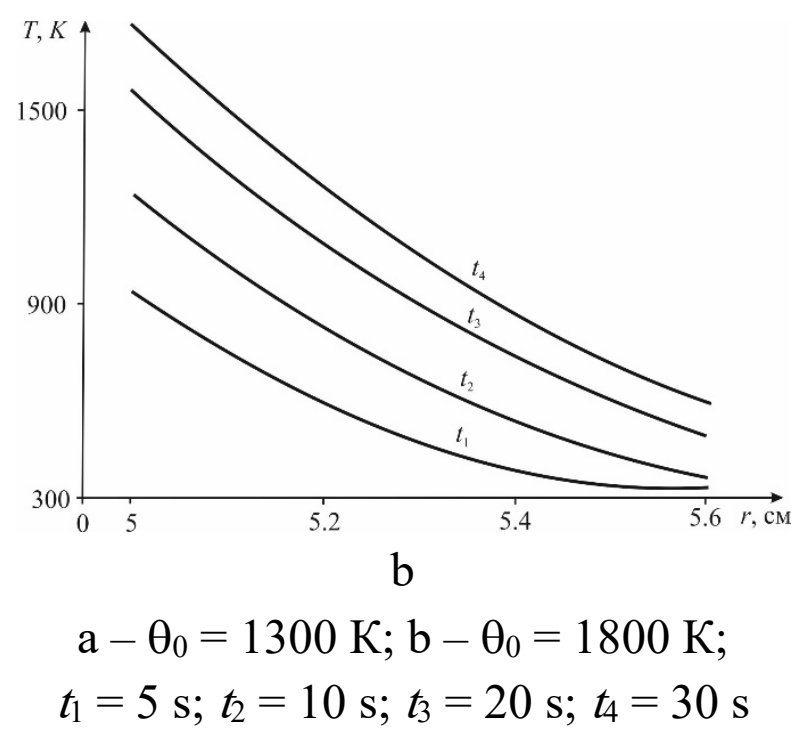

Figure 1. The nature of the temperature distribution in the surface layer of the rock

IGTM NAS of Ukraine together with the Institute NIGRI (Kryvyi Rih) and PA "Kryvbassruda" tested in the industrial conditions of the mines of Kryvbas several modifications of plasma well expansion units [242,249]. Studies carried out in various mining and geological conditions have shown good agreement between the obtained theoretical results and experimental $[250,251]$. The use of plasma technologies makes it possible to minimize technological risks arising from the development of raising workings in hard ores. 


\section{SECTION 12. RADIO ENGINEERING}

\subsection{Frequency meter based on microcontroller for biomedical measurement systems}

The described method of measurement allows to measure frequencies of biomedical signals with a small and constant error in a wide range. The measured signal enters the input of the device and is converted into a periodic sequence of pulses, the period of passage of which $T_{x}$ is equal to the period of the studied signal. Regardless of this sequence, the first time gates of duration $\Delta t_{1}$ are formed. They are filled with $\mathrm{n}$ pulses of the periodic sequence. Then the number $n$ is fixed. The ratio $\Delta t_{1} / n$ corresponds to the value $T_{x}^{\prime}$ of the measured frequency, and the value $n / \Delta t_{1}$ - the value $f_{x}^{\prime}$ frequency. Its deviation from the value of $f_{x}$ is determined by the error of discreteness, the reduction of which is the purpose of this method [252].

At the same time, the second time gate is formed, such that their front corresponds to the impulse of the sequence that appeared immediately after the beginning of the first gate, and the slice - the impulse that occurs immediately after the end of the first gate. Thus, the duration of the second time gate corresponds to an integer number of periods of the studied signal, namely $\Delta t_{2}=n t_{x}$.

The front and the cut of the formed gate are synchronized with the moments of appearance of the pulses of the periodic sequence formed from the studied signal, so the rounding error is excluded. The second time gate is filled with counting pulses, the number $N$ of which is fixed.

The formula for finding the value of the measured frequency is obtained as follows. The number of pulses entering the second time gate is determined by the ratio $N=n t_{x} / T_{c n t}=n F_{c n t} / f_{x}$

$$
f_{x}=\frac{n}{N} \cdot F_{c n t}
$$

where $F_{c n t}-$ is the frequency of the counting pulses, the value of which is known.

The accuracy of frequency measurement is determined by the error of discrete measurement of the time interval $n t_{x}$. 


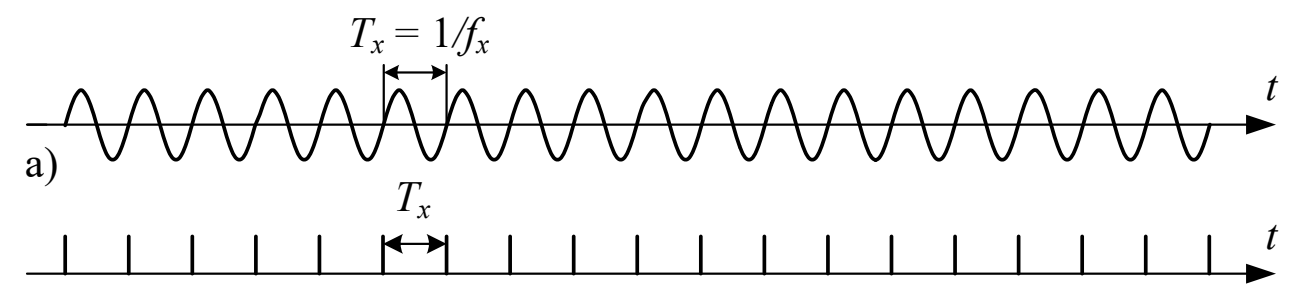

b)
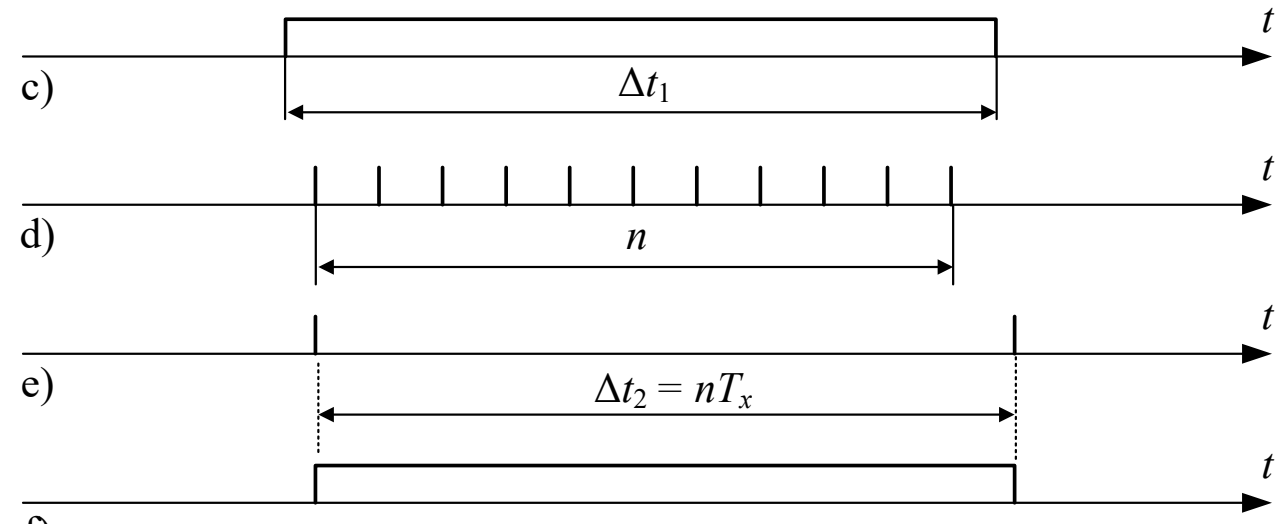

f)

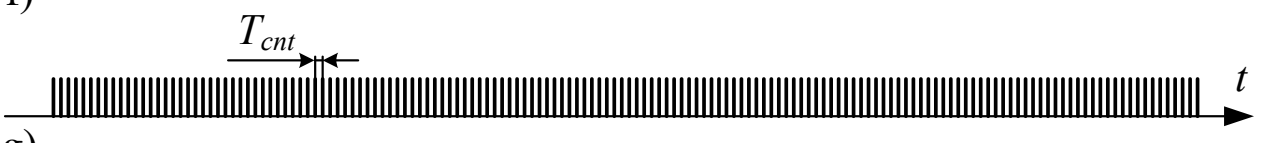

g)

h) $N$

Figure 1. Frequency meter operation diagrams

We can determine the value of the relative error of the discreteness of the frequency measurement $\delta_{f}$. The maximum value of the relative error of the discreteness of the measurement of the time interval $\Delta t_{2}=n t_{x}$ is determined by the absolute error. Because this interval is filled with counting pulses with a period of $T_{c n t}$, the maximum absolute error $\Delta_{2}= \pm T_{\text {cnt }}$ (see Fig. 1). Then the maximum relative error

$$
\delta_{2}= \pm T_{\text {cnt }} / \Delta t_{2}= \pm T_{\text {cnt }} / n t_{x} .
$$

The equality $\Delta t_{2}=n t_{x}$ can be represented as $f_{x}=n / \Delta t_{2}$. Then, according to the rules for calculating the errors of indirect measurements, the measurement error of the function $f_{x}$ is associated with the measurement error of the argument $\Delta t_{2}$ ratio (up to the second order)

$$
\delta_{f}=\delta_{2}
$$

After substituting $\delta_{2}$ with (1)

$$
\delta_{f}= \pm T_{\text {cnt }} / n t_{x}= \pm\left(f_{x} / n\right) T_{c n t} .
$$


When substituting in (3) instead of $f_{x} / n$ the ratio $f_{x}^{\prime} / n=1 / \Delta t_{1}$ is obtained

$$
\delta_{f}= \pm T_{c n t} / \Delta t_{1}= \pm 1 / F_{c n t} \Delta t_{1} .
$$

Formula (4) leads to the conclusion that the maximum value of the relative error of the discreteness of frequency measurement by the stated variant of the discrete number method does not depend on the value of the measured frequency and, therefore, is constant in the whole measuring range.

The sampling frequency is required

$$
F_{c n t}=1 /\left(\delta_{f} \Delta t_{1}\right),
$$

where $\delta_{f}-$ is the specified measurement discreteness error.

For example, at a pulse rate of $100 \mathrm{MHz}$ and a time gate duration of $1 \mathrm{~s}$ (as is the case in some frequency meters), the maximum value of the discrete error is $\pm 10^{-3}$.

Thus, the measurement method used in this project allows to measure the frequency from $1 \mathrm{~Hz}$ to $10 \mathrm{MHz}$ without changing the limits and measurement methods. Additional operations of control of value of the measured frequency are excluded [253].

The electrical functional diagram of the device consists of the following main components: a microcontroller, an input device, a generator of counting pulses, two counters, a unit for forming the second time gate and an output device [254].

The investigated signal with frequency $f_{x}$ (see Fig. 2, a) is transmitted through the input unit to the pulse shaper, where it is converted into a periodic pulse sequence (Fig. $2, \mathrm{~b})$. It is fed to the first input of the time selector 1, the input 2 of which is supplied with a gate pulse created inside the microcontroller, which is the first time gate with a duration of $\Delta t_{1}=1$ second (Fig. $2, \mathrm{c}$ ). The input pulses fill these time gates, their number $\mathrm{n}$ is counted by the counter 1 and fixed. The gating pulse, which plays the role of the first time gate, is fed from the microcontroller also to the input 2 of the logic element AND and to the input of the inverter. As a result, the pulses of the periodic sequence, fed from the output of the shaper to the inputs 1 of the logic elements $\mathrm{AND}_{1}, \mathrm{AND}_{2}$, can pass to the input 1 of the unit for forming the second time gate, when at the input of 2 elements $\mathrm{AND}_{1}$ there is a gating pulse. They pass to the input 2 of the forming unit when there is no gating pulse at the input of the inverter [255]. 


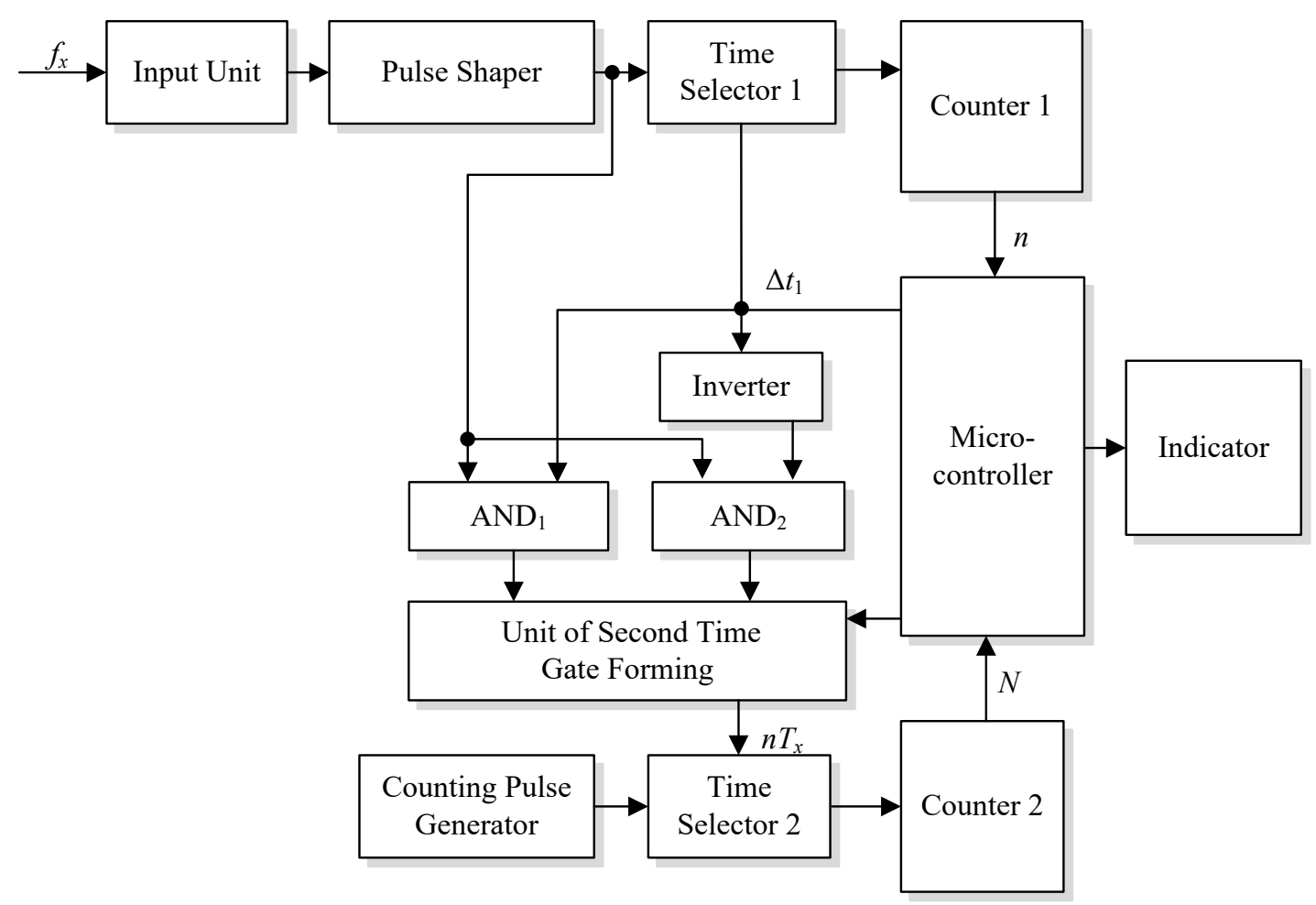

Figure 2. Electrical functional diagram

The scheme of formation of the second time gate is made on the RS-trigger. The first pulse supplied through the logic element $\mathrm{AND}_{1}$ to the S-input of the installation of the circuit throws the trigger into the state of logic "1", as a result, the output of the circuit forms the front of the second time gate. After that, the pulses supplied to the first input 1 of the forming circuit, its state does not change [256].

As long as there is a gating pulse at the inverter input, the pulses of the periodic sequence cannot pass through the logic element $\mathrm{AND}_{2}$. Immediately after the end of the action of the strobing pulse, the first pulse of the sequence enters through the logic element $\mathrm{AND}_{2}$ to the input of the reset R-trigger and returns it to its original state. At the output of the formation scheme, a slice of the second time gate is formed (Fig. 2, d, e). Thus, at the second input of the time selector 2 the second time gate with duration $\Delta t_{2}=n t_{x}$ is formed, through which the counting pulses pass (Fig. 2, g). the pulses that hit the gate are counted by counter 2 , it records their number $N$. The number of counted pulses $n$ and $N$ is transmitted to the microcontroller. In its memory, the value of the pulse frequency of the number is stored as a constant. Based on the obtained data, the 
microcontroller calculates the value of the frequency of the measured signal $f_{x}$ in accordance with formula (1).

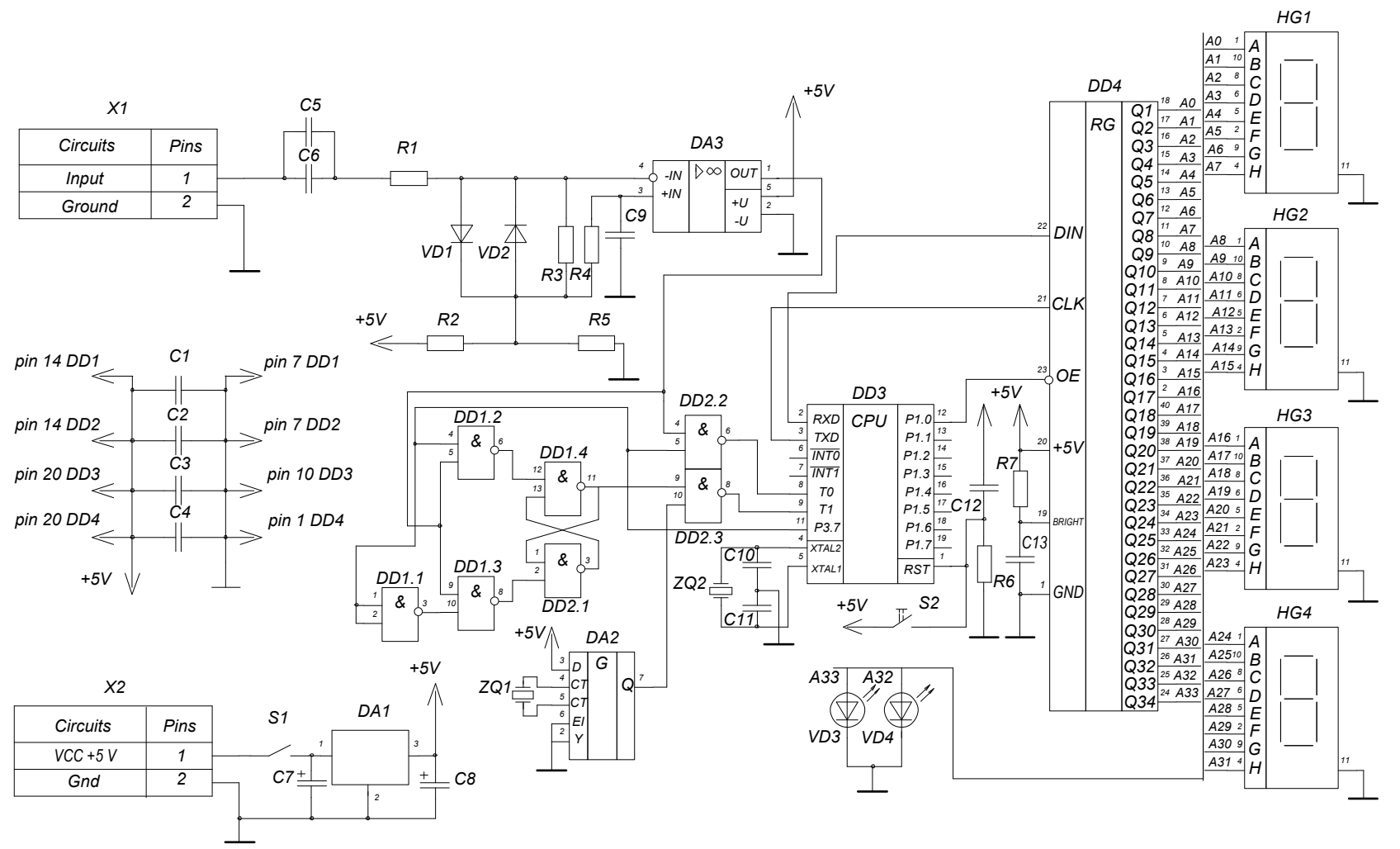

Figure 3. Schematic electrical principle

In the schematic diagram of the frequency meter (see Fig. 3) you can select the main nodes that carry a certain functional load. Separately, we can highlight the input logic of the device, compiled on integrated circuits DD1-DD2. The functions of the control and management device are taken over by the DD3 microcontroller. The source of the reference counting pulses is a quartz oscillator on the DA2 chip. The shift register DD4 is used to store the obtained result and communication of the microcontroller with the information display device on four seven-segment indicators HG1-HG4 [257]. 


\subsection{Compact waveguide polarizer with diaphragms for satellite telecommunication systems}

Тип поляризации электромагнитных волн оказывает сильное влияние на особенности процесса их распространения [258]. Применение сигналов с круговой поляризацией снижает эффект замирания и деструктивные помехи сигналов, вызванные многолучевым распространением волн. Поэтому разработка и оптимизация характеристик волноводных поляризаторов для облучателей спутниковых антенн является важной инженерной задачей.

Поляризатор выполняет преобразование электромагнитных волн с линейной поляризацией в круговую поляризацию или наоборот. Следовательно, волноводный поляризатор антенной системы определяет ее основные электромагнитные характеристики: дифференциальный фазовый сдвиг, коэффициент стоячей волны по напряжению (КСВН), коэффициент эллиптичности и кроссполяризационную развязку (КПР).

Часто применяют волноводные поляризаторы с перегородкой [259-261]. Основным преимуществом поляризатора этого вида является его компактная конструкция, которая объединяет ортомодовый преобразователь и поляризатор в единую структуру. Недостатком таких поляризаторов является узкая рабочая полоса частот, которая ограничивает его применение в некоторых современных системах спутниковой связи. В [259] показано, что относительная ширина рабочей полосы частот поляризатора с перегородкой может достигать $20 \%$, если одновременно требуются развязка портов выше 25 дБ и КПР выше 30 дБ.

Поляризатор с диафрагмами [262-267] представляет собой альтернативную конструкцию волноводного поляризатора, которая обеспечивает лучшие характеристики и более широкую относительную рабочую полосу частот. С одной стороны, в антенных системах с двойной поляризацией волноводный поляризатор с диафрагмами корректно функционирует только в сочетании с ортомодовым преобразователем [267-269], что усложняет структуру антенной системы. С другой стороны, при использовании волноводного поляризатора с диафрагмами можно получить гораздо лучшие характеристики в той же рабочей 
полосе частот по сравнению с поляризатором с перегородкой [259]. Таким образом, для разработки нового компактного поляризатора для облучателей спутниковых антенн была выбрана конструкция на основе квадратного волновода с диафрагмами [262-265].

В антенных системах с двумя ортогональными поляризациями применяется волноводный поляризатор с диафрагмами в сочетании с ортомодовым преобразователем, который определяет развязку всей антенной системы [267]. Bce остальные поляризационные параметры системы питания точно определяются применяемым волноводным поляризатором.

Обычно волноводный поляризатор обеспечивает хорошее согласование электромагнитных волн обеих поляризаций. Амплитуды компонент поля с ортогональными линейными поляризациями на входе и выходе поляризатора равны с высокой точностью. В этом случае равенство амплитуд компонент для обеих поляризаций на входе приводит к их равенству на выходе поляризатора. На практике это равенство выполняется лишь с определенной точностью. Таким образом, для расчета поляризационных характеристик волноводного поляризатора необходимо учитывать не только вносимый дифференциальный фазовый сдвиг, но и разность амплитуд компонент электрического поля с ортогональными линейными поляризациями на выходе.

Для моделирования и оптимизации характеристик поляризатора на основе квадратного волновода с тремя диафрагмами было выполнено численное моделирование с помощью метода конечных элементов в частотной области.

На рис. 1 показано внутреннюю структуру квадратного волноводного поляризатора с тремя диафрагмами. Обозначения всех размеров конструкции также приведены на рис. 1. Две внешние диафрагмы имеют равные высоты $h_{1}$. Они ниже центральной диафрагмы с высотой $h_{2}$ для улучшения согласования структуры. Толщина всех диафрагм равна $w$, а зазоры между ними равны $L_{1}$. 

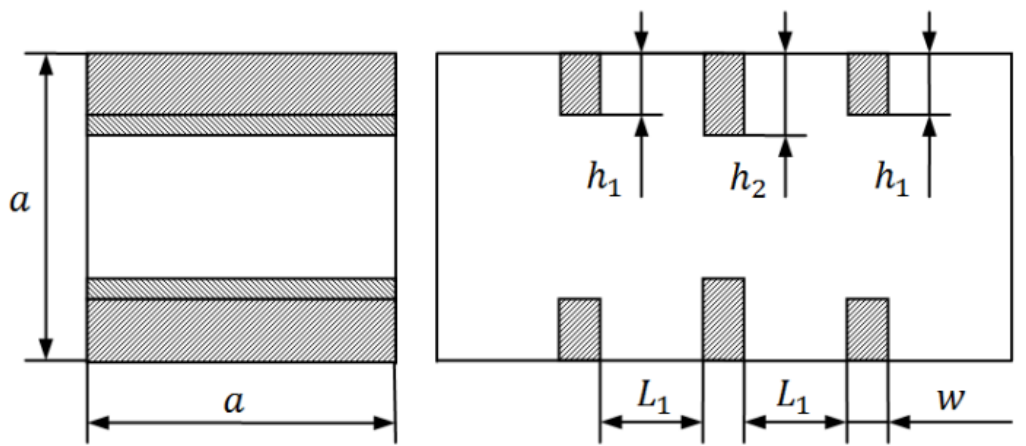

Рисунок 1. Структура волноводного поляризатора с тремя диафрагмами

На рис. 2 показаны характеристики оптимизированного волноводного поляризатора с тремя диафрагмами в рабочем диапазоне частот 10,7-12,8 ГГц. На рис. 2а показана зависимость КСВН от частоты. На рис. 2а видно, что максимальное значение КСВН для обеих поляризаций составляет 2,03 и достигается на самой низкой частоте рабочего Кu-диапазона 10,7 ГГц.

На рис. $2 б$ показана зависимость дифференциального фазового сдвига от частоты. Как видно на рис. 2б, дифференциальный фазовый сдвиг равен $90^{\circ}$ на частотах 10,76 ГГц и 12,63 ГГц. В рабочем диапазоне частот дифференциальный фазовый сдвиг изменяется от $86^{\circ}$ до $91,6^{\circ}$. Максимальное отклонение дифференциального фазового сдвига от $90^{\circ}$ составляет $4^{\circ}$ и наблюдается на частоте 11,7 ГГц. Частотные зависимости коэффициента эллиптичности и КПР показаны на рис. 2в и рис. 2г, соответственно.
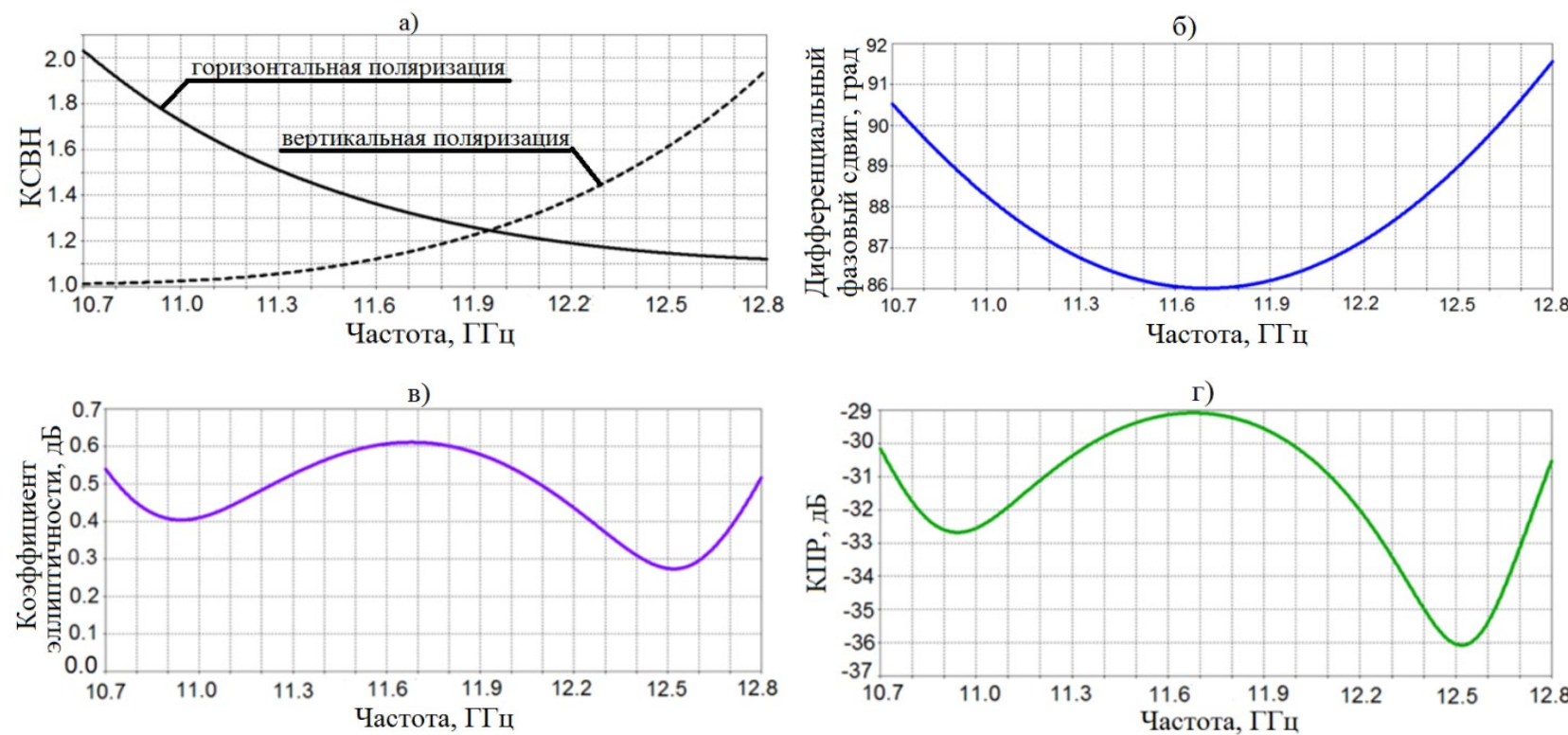

Рисунок 2. Электромагнитные характеристики волноводного поляризатора 
На рис. 2в видно, что в рабочей полосе частот коэффициент эллиптичности поляризатора меньше 0,61 дБ. Как видно на рис. 2г, соответствующая КПР поляризатора превышает 29 дБ. Максимум коэффициент эллиптичности (как и самая низкая КПР) наблюдается на частоте 11,7 ГГц, что с высокой точностью соответствует частоте максимального отклонения дифференциального фазового сдвига поляризатора от 90. Как видим, использования трех диафрагм в структуре достаточно для получения дифференциального фазового сдвига, который близок к $90^{\circ}$ в $18 \%$ относительной рабочей полосе частот.

Таким образом, в рабочем диапазоне частот 10,7-12,8 ГГц оптимизированный поляризатор на основе квадратного волновода с тремя диафрагмами обеспечивает КСВН для обеих поляризаций меньше 2,03. Его дифференциальный фазовый сдвиг находится в диапазоне $90^{\circ} \pm 4^{\circ}$. Коэффициент эллиптичности составляет менее 0,61 дБ, а КПР более 29 дБ.

В таблице 1 представлены все оптимальные внутренние размеры конструкции поляризатора на основе квадратного волновода с тремя диафрагмами, разработанного для рабочего диапазона частот 10,7-12,8 ГГц.

Таблица 1. Размеры оптимизированного волноводного поляризатора

\begin{tabular}{|c|c|c|c|c|}
\hline$a, \mathcal{M}$ & $w, M M$ & $l, \mathcal{M}$ & $h_{1}, \mathcal{M M}$ & $h_{2}, \mathcal{M M}$ \\
\hline 21,98 & 2,79 & 4,92 & 2,45 & 3,86 \\
\hline
\end{tabular}

В статье разработано и оптимизировано компактный волноводный поляризатор с тремя диафрагмами для спутниковых телекоммуникационных систем Кu-диапазона частот. Он обеспечивает эффективные фазовые и поляризационные характеристики, а также удовлетворяет требованиям к согласованию современных облучателей спутниковых антенных систем. 


\section{SECTION 13. TELECOMMUNICATIONS}

\subsection{Analysis of recursive estimation procedure}

In the capacity of evaluation procedure, it is reasonable to use Kalman-Bucy recursive algorithm for the local search optimization. Optimal evaluation according to the integral square error criterion is determined from the recursion equation solution also known as Kalman-Bucy method:

$$
\hat{x}(k+1)=F(k+1, k) \hat{x}(k)+K(k)[H(k) F(k+1, k) \hat{x}(k)-y(k)]
$$

where $K(k)=V(k) H^{T}(k) N_{v}^{-1}$ is a coefficient, which provides evaluation optimality and procedure convergence degree.

The template that includes observation, evaluation and processing models reflects distinct FKB deviations influence of the chosen model. Block diagram of the simulant is shown on Figure 1.

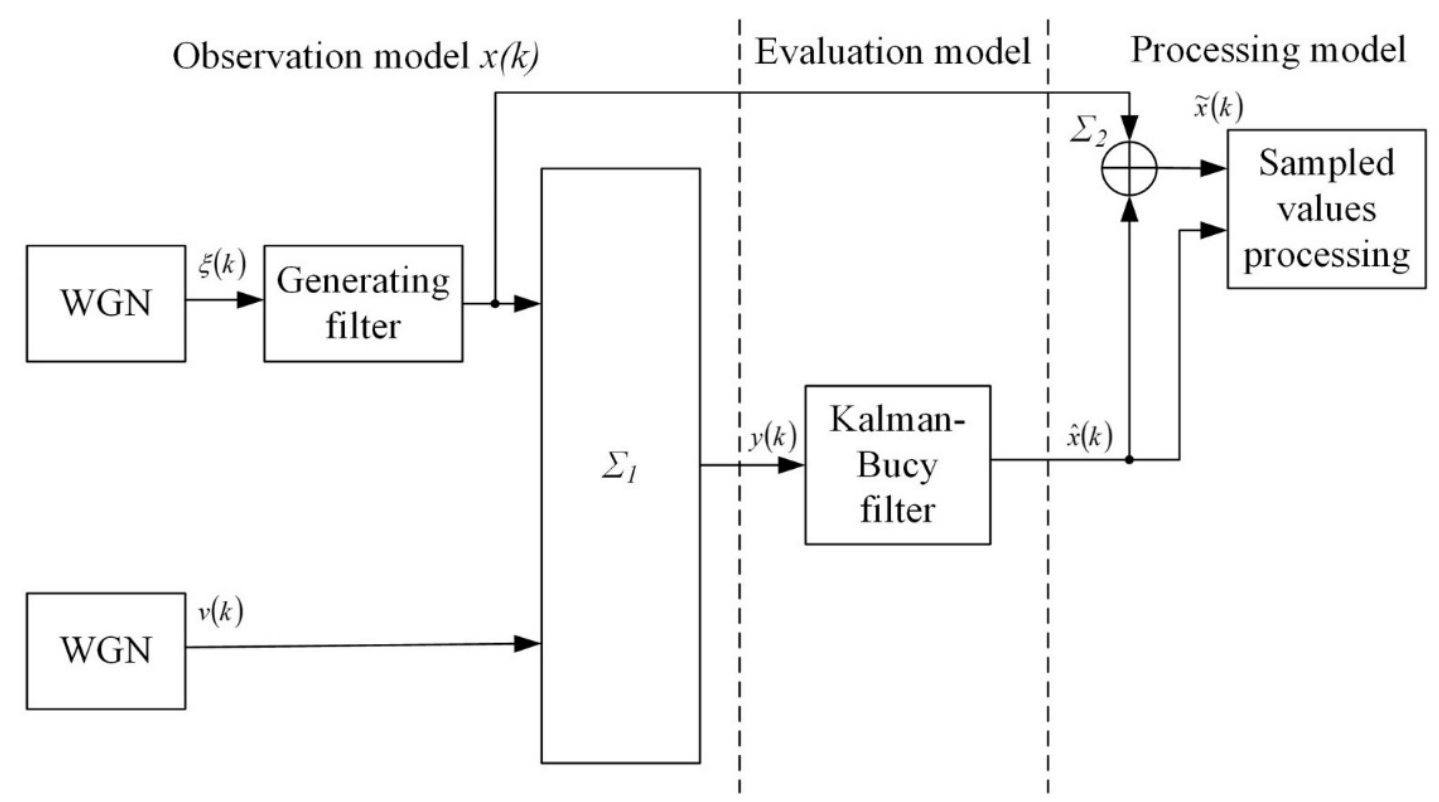

Figure 1: Block diagram model of the distinct FKB stimulant.

Proposed computer test model gives an opportunity to select options of the evaluated process model $\mathrm{x}(k)$ and inspection noise model $N_{v}(k)$ as to the stationary 
state and transient state. Individual noise $\xi(k)$ and $v(k)$ generators are to be standardized formation procedures with the choice of corresponding spectral power density $N_{v}(k)$ and $N_{\xi}(k)$ values. Models chosen parameters consistency is proved by receiving sample estimations of these parameters.

As it was mentioned above, the results of theoretical analysis of the filter responsivity under the effect of signal models, parameters of which differ from the filter parameters. It is shown that under deviation of filter parameters from the chosen model, the quality of estimation changes for the worth. A distinctive feature of nonstationary models is that the mentioned deviations of model parameters are not simply deviated, but these deviations are time variant. Therefore, the study of nonstationary effects is an assumption of the responsivity study under changing model parameters over time. At that, it is important to know how does FKB response on those or other nonstationary effects having different rates of these changes under various choice of filter parameters. We refer to the two standard for telecommunication situations when non- stationary changes are of gradual and stick-slip nature.

The effect of nonstationarities is evident from the moment of emitting useful signal to the filter input. Thus, different filters react on nonstationary signal differently. This response appears in the form of the transition process from the emitting until setting a stationary filter mode.

The analysis of filter efficiency at the nonstationary conditions has been held under the advanced observation model. Additive identity that reflects level and speed changes of the nonstationarity has been comprehended to the watch equation. Sinuous nonstationarity model has been chosen to be primary taking into the consideration the fact that traffic change is a result of multiple actions on the network load:

$$
y(k)=H(k) x(k)+C \sin \left(l k T / \tau_{c o r}\right)+v(k)
$$

where $l$ is a multiplication factor that changes nonstationary actions period, $C$ changes nonstationarity value, $T / \tau_{\text {cor }}$ changes intervals rate between sam-ple spacings $T$ and correlation intertissue $\tau_{c o r}$. 
In this work examine the situation for different cases of $\mathrm{T}_{s}$ periods, non-stationary changes. When provided changes become commensurable to the time of the process transition $T_{s}=5 \Delta t$ (Fig. 2) at low-speed nonstationary change $\mathrm{T} / \tau_{c o r}=25 \Delta t$ (Fig.3) and $\mathrm{T} / \tau_{\text {cor }}=500 \Delta t$ (Fig. 4).

The intent of the nonstationary entry influence is that evaluation stationary process has not approached yet but in the observation results there have already occurred the changes that the filter shall obtain as re-emerged information. Thus, the filter functions persistently as if in the transient mode.

Sampled values of posteriori variances are little different from functioning results of basic stationary process at the low-speed change. Thus, evaluation accuracy can be obtained at sample spacing shorthand in the condition of static entry changes.

In this work consider the influence of nonstationary processes of parameters abrupt change. Abrupt changes are typical at the traffic change. At this:

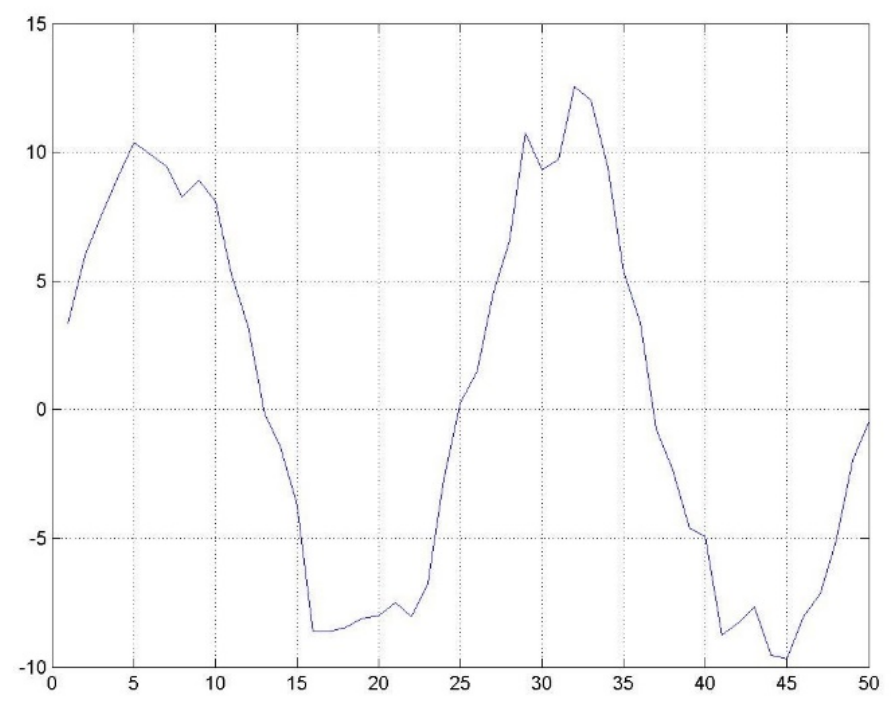

Figure 2: Realization segment of nonstationary signal at fast changes of nonstationary function 


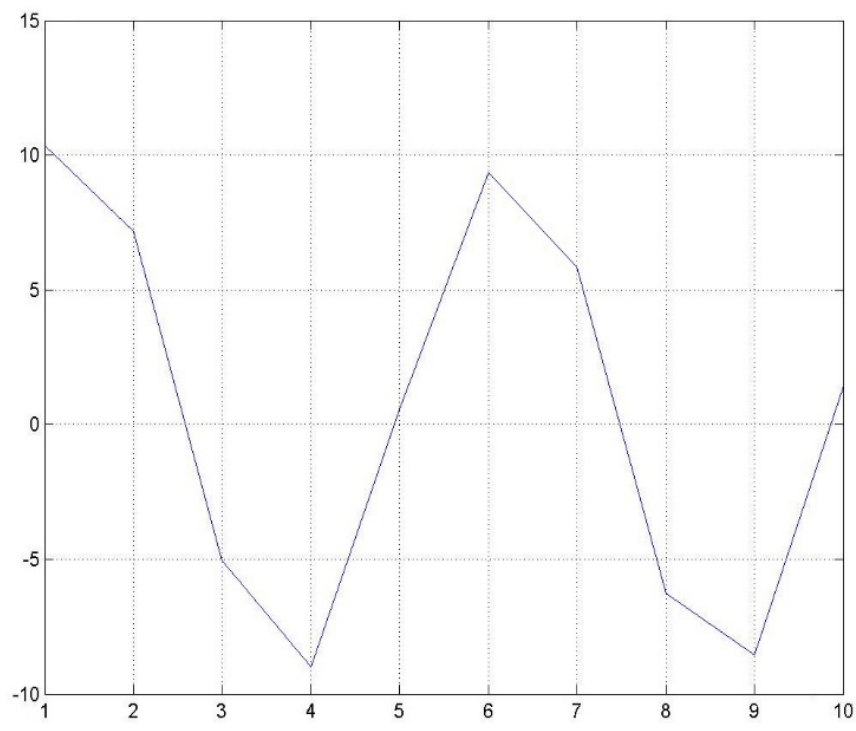

Figure 3: Realization segment of nonstationary signal at mean changes of nonstationary.

Function rate, on or off of acceptors with extensive datastream induces load abrupt changes. To perform abrupt changes modeling we avail an additive identity.

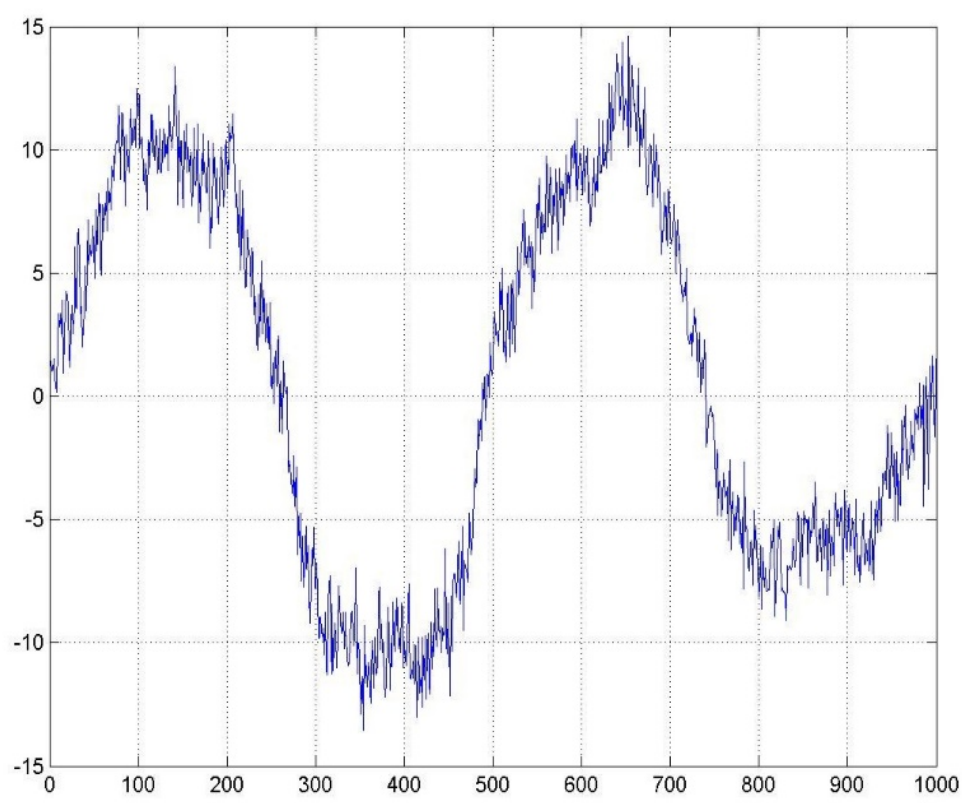

Figure 4: Realization segment of nonstationary signal at low-speed changes of nonstationary function (2) 
In this case $\sin \left(l k T / \tau_{c o r}\right)=1$ and value $C$ will build squarewave signal with the period of 100 sample spacings with various $l$ values.

The diagrams reflect that transiency in the form of discrete edge provides sharp increase of posteriori variance values. This value outweighs stationary condition by 50 and more times. Transient process is derived from the non-stationary impulse occurrence and endures for 100-150 steps. Such values increase of the posteriori variance results in control errors. It is typically that filter action is less tangible at nonstationary impulses dump than at its occurrence. Thus, sample spacing reduction gives an opportunity to control nonstationary changes that is an important factor that provides stable functioning of evaluation and control algorithms. 


\section{SECTION 14. TRANSPORT}

\subsection{Efficiency of the impact of speed limits on road traffic safety in Ukraine}

Особливу увагу проблемам обмеження швидкості руху у більшості розвинених країнах почали приділяти ще у 1980-90-ті роки. Головною метою введення таких обмежень було підвищення безпеки руху, як в цілому, так i найбільш вразливих категорій учасників руху.

Проте зрозуміло, що міські ліміти швидкості встановлюються у першу чергу, через турботу про пішоходів. I, як свідчить статистика, 80\% ДТП в містах відбувається саме 3 пішоходами. При цьому тільки чверть 3 них - на позначених переходах, а решта - у недозволених місцях, тобто там, де водій їх в принципі не чекає.

Таким чином, обмеження швидкості руху розраховано, як мінімум, на декілька позитивних ефектів.

По-перше, на те, що повільний автомобіль буде вчасно помічений пішоходом, а у водія буде більше часу завчасно помітити пішохода;

По-друге, при меншій швидкості гальмівний шлях коротше, а імовірність зіткнення менше. I, навіть у разі зіткнення, наслідки для людини можуть бути не такими жахливими, що підтверджується даними Всесвітньої організації охорони здоров’я щодо відсотку виживання пішоходів при зіткненні їх з автомобілем.

Згідно 3 офіційними даними, найпоширенішою причиною дорожньотранспортних пригод (ДТП) в Україні на протязі останніх років $є$ перевищення швидкості руху. Зокрема, у 2018 році перевищення безпечної та встановленої швидкості руху становило 48,2\% серед усіх причин виникнення ДТП на автомобільному транспорті (рис. 1) [270]. 


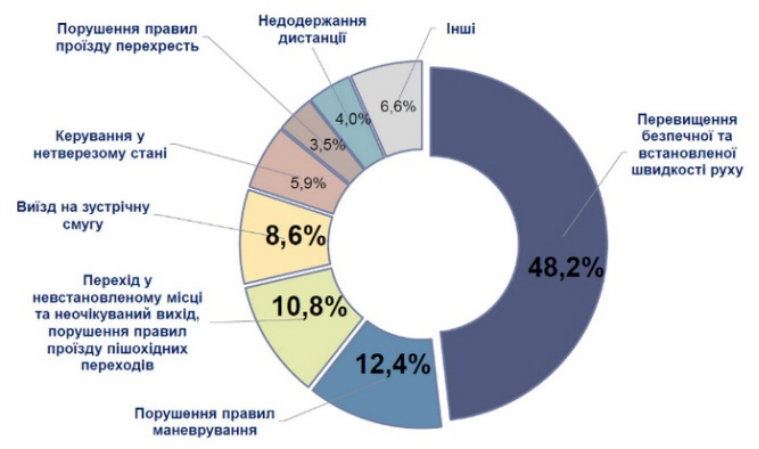

Рисунок 1. Основні причини виникнення ДТП на автомобільному транспорті

Не став виключенням 2019 і 2020 рік. За даними, які оприлюднив перший заступник начальника Департаменту патрульної поліції України Олексій Білошицький, у 2019 році 3 перевищенням безпечної швидкості руху зареєстровано 8761 автопригод, що відповідно склало 34\% від усіх ДТП із потерпілими [271]. А вже за перші ж 8 хвилин роботи 45 відеокамер, які увімкнули опівночі 1 червня 2020 р., тільки в Києві та області зафіксували 262 порушення швидкісного режиму [272].

Водночас, за даними Моторно (транспортного) страхового бюро України, які були наведені 11 листопада 2019 року на «Міжнародному конгресі з безпеки на транспорті» у м. Києві, перевищення швидкості займають 35\% у переліку основних причин ДТП [273].

Показово також, що статистика аварійності на автомобільному транспорті за даними Укртрансбезпеки дещо відрізняється від даних патрульної поліції, а саме:

44,2 \% - недотримання дистанції та інтервалу руху;

18,4 \% - порушення правил маневрування;

16,4 \% - перевищення швидкості руху;

15,5 \% - порушення правил проїзду перехресть;

$5,5 \%$ - інші (в т.ч. $1 \%$ - незадовільний техн.стан КТЗ, 0,7\% - сон за кермом). 
Така різниця в звітах пояснюється багатьма причинами, серед яких найбільш визначальними $€$ :

- об’єктивні розбіжності поміж джерелами надходження інформації;

- суб'єктивні фактори на стадії збору та обробки даних;

- відмінність відомчих методик у визначенні показників;

- неузгодженість єдиних приведених одиниць вимірювання та обліку;

- брак спеціальних обліково-метричних даних при оформленні ДТП;

- недосконалість нормативно-правової бази.

Через це оцінити поточний стан і справжню динаміку змін безпеки дорожнього руху в Україні не просто. А щодо визначення справжнього рейтингу швидкості серед інших причин виникнення ДТП, то вони фактично приречені на невдачу, оскільки це не простий і переважно довготривалий процес, уваги якому приділяється недостатньо.

Зважаючи на все це, у багатьох європейських країнах, у межах населених пунктів сьогодні дозволено рух зі швидкістю щонайбільше 50 км/год, а в деяких країнах (наприклад, Албанії та Андоррі) і 40 км/год.

Дана стаття $є$ результатом пошуку відповіді на проблемне питання - чи насправді обмеження швидкості руху в населених пунктах істотно поліпшить ситуацію на наших дорогах?

Відповідно до результатів аналізу можливих наслідків обмеження звернімо увагу на те, що [274]:

1. Обмеження до 50 км/год. швидкості руху в населених пунктах, які вступили в дію 31 січня 2018 року, не мають достатніх підстав.

2. Зниження швидкості зменшує інтенсивність дорожнього руху i пропускну спроможність міських магістральних вулиць і доріг. Діючі обмеження обумовлять загальне падіння пропускної спроможності орієнтовно на 17\%.

3. Зменшення пропускної спроможності розширить діапазони години пік i збільшить тривалість заторів у найбільш завантажених вузлах.

4. Зниження швидкості принесе додаткові витрати часу пасажирам,

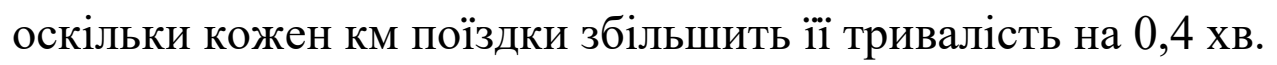


5. Збільшення загальної тривалості поїздки може призвести до порушення нормативних вимог щодо транспортного обслуговування віддалених районів міста.

6. Зі зменшенням швидкості витрати перевізників на один км поїздки зростуть не менше ніж на 1,5 грн.

7. Як доводить досвід найбільш резонансних ДТП, порушення швидкісного режиму є наслідком неадекватних дій окремих водіїв, всупереч дорожній ситуації і діючим обмеженням.

8. Для переважної більшості учасників дорожнього руху найбільш доцільним слід вважати не загальне, а вибіркове обмеження швидкості руху і посилений контроль на найбільш небезпечних ділянках, що по суті повністю відповідає діючим ПДР.

9. Значно більший ефект може принести активне застосування інформаційно-вказівних знаків, які рекомендують водіям транспортних засобів рухатись 3 певною швидкістю.

Відповідно до теоретичних розрахунків, втрати часу в наслідок зниження швидкості будуть становити близько 0,4 хв. на кожен км поїздки. В перерахунку на рівень середньомісячної заробітної плати в Україні, яка у 2018 році за даними [275] була на рівні 8865 грн. (3,69 грн./хв.), а це становить додаткові 1,5 грн. на один км поїздки. Розрахункові наслідки обмеження швидкості руху представлені в табл.1.

Зміни безумовно відіб'ються і на собівартості перевезень. Згодом варто очікувати підвищення вартості проїзду. Слід зазначити, що в окремих містах зростання цін вже почалось [276].

Невідповідність стану і розвитку міської вулично-дорожньої мережі, особливо поміж іï пропускною спроможністю i рівнем інтенсивності транспортного руху, вже зараз призвела до виникнення небачених заторів $\mathrm{i}$ рекордного зниження швидкості сполучення в столиці. 
Таблиця 1. Вплив швидкості руху на основні показники

\begin{tabular}{|c|c|c|c|}
\hline & Показник & $\begin{array}{c}\text { До зниження } \\
\text { швидкості }\end{array}$ & $\begin{array}{c}\text { Після зниження } \\
\text { швидкості }\end{array}$ \\
\hline \multirow[t]{4}{*}{11.} & $\begin{array}{c}\text { Орієнтовна } \\
\text { спропускна } \\
\text { прожність смуги, авт./год. }\end{array}$ & & \\
\hline & 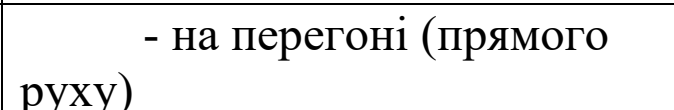 & 1500 & 1245 \\
\hline & ${ }_{\text {pyxy) }}^{\text {- на перехресті (прямого }}$ & 1000 & 830 \\
\hline & $\begin{array}{l}\text { - на перехресті } \\
\text { (поворотного руху) }\end{array}$ & 800 & 664 \\
\hline 22. & $\begin{array}{l}\text { Витрати часу, хв. на } 10 \text { км } \\
\text { поїздки }\end{array}$ & 20 & 24 \\
\hline
\end{tabular}

Показово, що 3 метою деякого покращання ситуації Департаментом транспортної інфраструктури КМДА спільно з Патрульною поліцією міста Києва розроблений проект організації дорожнього руху, а КП «Центр організації дорожнього руху» завершено установку дорожніх знаків «Обмеження максимальної швидкості 80 км/год» на деяких окремих вулицях. Зокрема, такі знаки встановлені на наступних маршрутах [277]:

- просп. Генерала Ватутіна (від Південного мосту до вул. О. Бальзака);

- вул. Набережно-Рибальська (від Гаванського мосту до вул. Електриків);

- Наддніпрянське шосе;

- Набережне шосе (від Поштової площі до Наддніпрянського шосе);

- Столичне шосе (до вул. Академіка Заболотного);

- вул. Саперно-Слобідська (від вул. Миколи Грінченка до Південного мосту);

- просп. Миколи Бажана (від Південного мостового переходу до Харківської площі).

Слід відзначити, що цей підвищений швидкісний режим триватиме лише до 1 листопада, а взимку буде діяти загальновстановлений ліміт швидкості 50 км/год. 
Очевидно, що подібні винятки не повинні розповсюджуватись виключно на м. Київ. 3 урахуванням вищенаведених аргументів потрібно також визнати, що зменшення швидкості повинне носити вибірковий характер і в інших містах нашої країни.

Окрім того, відповідно до доручення Президента України Кабінету міністрів і органам місцевого самоврядування необхідно взяти на контроль розслідування аварій і включити безпеку пасажирських перевезень до першочергових пріоритетів своєї роботи.

Висновки. Таким чином, у відповідності до результатів даних досліджень, загальне зниження швидкості дорожнього руху в містах України не є достатньо дієвим засобом підвищення безпеки дорожнього руху. При цьому найбільш ефективними заходами і відповідними пріоритетами слід вважати:

1. Розробку Схем організації дорожнього руху;

2. Організацію Центральних пунктів управління дорожнім рухом;

3. Широке впровадження світлодіодних табло;

4. Збільшення будівництва кільцевих розв'язок;

5. Вживання заходів по дотриманню правил дорожнього руху, зокрема широкого застосування автоматичної фіксації швидкості, як ефективного заходу по зменшенню дорожньої смертності;

6. Будівництво й облаштування достатньої кількості пішохідних переходів;

7. Впровадження сучасних систем вуличного освітлення та дорожніх знаків;

8. Комплексний ремонт вулиць і доріг. 


\subsection{Ensure reliability and safety of vessels during collision avoidance actions}

В настоящее время число аварий, возникающих по причине столкновения судов, остается на недопустимо высоком уровне. Снижение аварийности по указанной причине требует многоплановых научных исследований для разработки корректных практических рекомендаций судоводителям. Причем, как показано в работах [278-282], актуальной проблемой является усовершенствование Международных правил предупреждения столкновений судов (МППСС-72). Ограниченность и недостатки МППСС-72 могут повести иногда к столкновению судов [281].

Работы [283-286] посвящены принципам создания систем бинарной координации с оценкой их качества. Возможный вариант системы, содержащей два иерархических уровня, рассмотрен в работах $[283,284]$, причем описание первого уровня приведено в публикации [284], а формализация второго уровня рассмотрена в статье [285]. Вопросу определения угрозы ситуационного возмущения при опасном сближении судов посвящена работа [286]. Совершенствование МППСС-72 предусматривает согласованность взаимодействия судов в ситуации опасного сближения, чему посвящен настоящий доклад.

При опасном сближении требуется координация взаимодействия сближающихся судов для изменения относительного курса $K_{o t}$ с целью увеличения дистанции кратчайшего сближения $\min l$.

Знак выражения $q=\operatorname{sign}\left[\sin \left(K_{o t}-\alpha\right)\right]$, указывает в какую сторону необходимо изменять относительный курс $K_{o t}$ для увеличения дистанции кратчайшего сближения $\min l$. Очевидно, что в случае, если $q>0$, т. е $\sin \left(K_{o t}-\alpha\right)>0$ необходимо увеличивать относительный курс $K_{o t}$, в противном случае $(q<0)$ его следует уменьшать. 
Рассмотрим ситуацию опасного сближения двух судов $c_{1}$ и $c_{2}$, причем скорость $V_{1}$ судна $c_{1}$ превосходит скорость $V_{2}$ судна $c_{2}$. Рассмотрим возможность расхождения, когда судно $c_{1}$ изменяет курс $K_{1}$, а судно $c_{2}$ сохраняет неизменные параметры движения Эффективность этого маневра определяется возможностью увеличения дистанции кратчайшего сближения $\min l$, т.е. скоростью изменения относительного курса судов $K_{o t}$. Очевидно, что эффективность $E f$ такого маневра определяется скоростью изменения относительного курса при увеличении курса первого судна, т.е. $E f=\frac{\partial K_{o t}}{\partial K_{1}}$. В работе [287] получено выражение первой производной относительного курса $K_{o t}$ по истинному курсу $K_{1}$, которое имеет следующий вид:

$$
E f=\frac{\partial K_{o t}}{\partial K_{1}}=\frac{V_{1}\left(V_{1}-V_{2} \cos \Delta K\right)}{V_{1}^{2}+V_{2}^{2}-2 V_{1} V_{2} \cos \Delta K},
$$

где $\Delta K$ - разность курсов судов.

Анализ полученного выражения показывает, что максимальное и минимальные значения $\frac{\partial K_{o t}}{\partial K_{1}}$ достигаются соответственно при $\Delta K=0$ и $\Delta K=180$ , а зависимость эффективности $E f$ маневра от начальной разности курсов $\Delta K$ показана на рис 2.

Из рисунка следует, что рассмотренный маневр при угрозе столкновения может использоваться для всех ситуаций, т.е. при $\Delta K \in[0,2 \pi]$, причем сторона уклонения судна $c_{1}$ определяется знаком $q$.

После выбора курса уклонения необходимо рассчитать интервал времени $\Delta t_{1}$ удержания отклоненного пера руля на угол $\beta_{k}$ и интервал времени $\Delta t_{2}$, в течение которого производится одерживание судна. 


\section{THEORETICAL ASPECTS OF MODERN ENGINEERING}

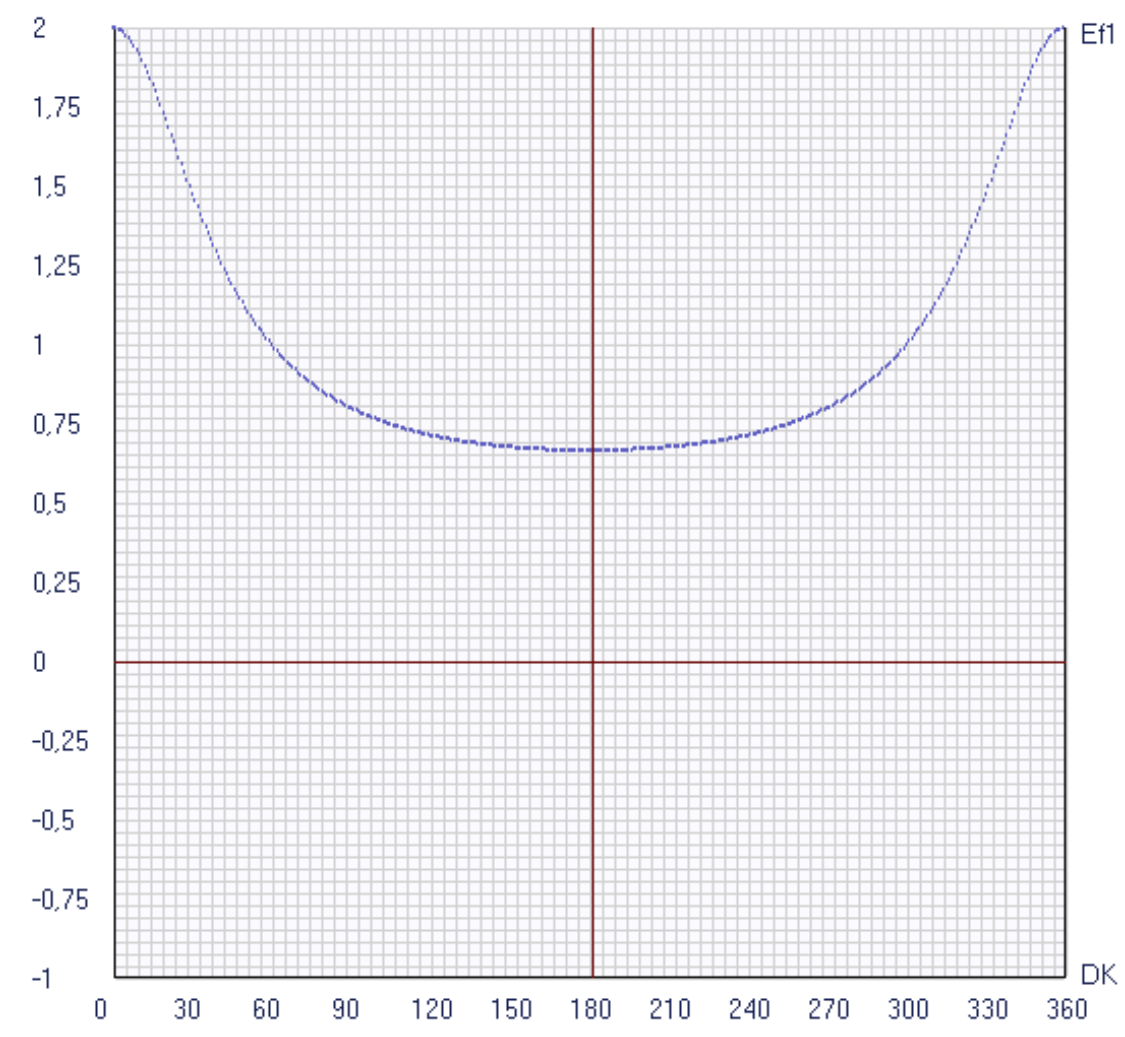

Рис. 1. Зависимость эффективности $E f$ от разности курсов $\Delta K$

Вращательное движение судна описывается неоднородным линейным дифференциальным уравнением третьего порядка с постоянными коэффициентами [288]:

$$
T_{1} T_{2} \dddot{K}+\left(T_{1}+T_{2}\right) \ddot{K}+\dot{K}=a_{\omega},
$$

где $T_{1}$ и $T_{2}$ - постоянные времени, характеризующие инерционные свойства судна;

$a_{\omega}=k_{p} \beta_{k}$, причем $k_{p}$ - коэффициент эффективности руля.

Данная модель, как показано в [289], позволяет записать систему уравнений относительно переменных $\Delta t_{1}$ и $\Delta t_{2}$ : 


$$
\left\{\begin{array}{c}
\Delta t_{1}=\Delta t_{2}+\left\{T_{1}^{2}\left[1-\exp \left(-\Delta t_{1} / T_{1}\right)\right]-T_{2}^{2}\left[1-\exp \left(-\Delta t_{1} / T_{2}\right)\right]\right\} /\left(T_{1}-T_{2}\right)- \\
-\left\{2-\left[T_{1} \exp \left(-\Delta t_{1} / T_{1}\right)-T_{2} \exp \left(-\Delta t_{1} / T_{2}\right)\right] /\left(T_{1}-T_{2}\right)\right\} \times \\
\left\{T_{1}^{2}\left[1-\exp \left(-\Delta t_{2} / T_{1}\right)\right]-T_{2}^{2}\left[1-\exp \left(-\Delta t_{2} / T_{2}\right)\right]\right\} /\left(T_{1}-T_{2}\right)+\Delta K / a_{\omega}, \\
\Delta t_{2}=-T_{1} \ln \left\{\left(T_{2} / T_{1}\right) \exp \left(-\Delta t_{2} / T_{2}\right)+\left[\left(T_{1}-T_{2}\right) / T_{1}\right] \times\right. \\
\left.\left\{2-\left[T_{1} \exp \left(-\Delta t_{1} / T_{1}\right)-T_{2} \exp \left(-\Delta t_{1} / T_{2}\right)\right] /\left(T_{1}-T_{2}\right)\right\}^{-1}\right\} .
\end{array}\right.
$$

Расчет величин $\Delta t_{1}$ и $\Delta t_{2}$ производится методом простых итераций.

Выводы. Предложена оценка эффективности маневра изменением курса, зависящая от скоростей судов и разности их курсов. Получена процедура расчета параметров поворота судна методом простых итераций. 


\subsection{Digital tools in practice TIR}

За останні роки в теорії та практиці транспортної індустрії з'явилося i зайняло міцне місце поняття «цифровізація», під яким розуміють використання цифрових технологій для підвищення доходів; іншими словами, це перехід до цифрового бізнесу. Незважаючи на те, що на транспорті і донині використовують паперові документи, з'явилася велика кількість цифрових платформ і послуг, що полегшують транспортним операторам планування і виконання перевезень на всіх ланках логістичного ланцюга. Наразі практично всі документи (книжка МДП, товарно-транспортна накладна CMR, митні декларації, дозвільні документи тощо) розглядаються під кутом подальшої цифровізації та впроваджуються в практику міжнародних перевезень [290].

Як відомо, глобальна система митного транзиту МДП, що опирається на Конвенцію МДП ООН (1975 р.) та є перевіреним, надійним, безпечним, простим способом переміщення товарів через кордони, перебуває нині у процесі глибоких змін, що стосуються переходу до електронних технологій. Це також питання конкурентоздатності митної системи у порівнянні з регіональними транзитними системами, що приваблюють перевізників простотою і вартістю.

Слід нагадати, що наприкінці 2000-х зроблено перші значні кроки на шляху комп'ютеризації МДП, а саме впровадження електронної системи контролю за завершенням операції МДП Safe TIR, яка представляє собою електронну базу даних, що місить інформацію про видачу книжки МДП Асоціацією та про завершення процедури МДП в митниці призначення. Передача даних відбувається за допомогою програм зв'язку CUTE або Black Box. В Україні система Safe TIR функціонує з 1997 р. [291].

Наступними розробками були додаток AskTIR та програма Real Time Safe TIR (RTS). AskTIR розроблено таким чином, щоб можна було враховувати будьякі майбутні поправки до Конвенції МДП і правил МСАТ. В додаток вбудовано процедури по контролю за рівнем запасів книжок МДП, по роботі з претензіями, інші корисні функції. AskTIR є обов'язковою системою контролю роботи 3 книжками МДП та підтримує двомовність. Асоціації міжнародних перевізників 
понад двох десятків країн використовують на даний час AskTIR: це AISO (Австрія), ABADA (Азербайджан), AEBTRI (Болгарія), RHA (Великобританія), OFAE (Греція), GIRCA (Грузія), ICCIM (Іран), NIWO (Нідерланди), BGL (Німеччина), TOBB (Туреччина), SKAL (Фінляндія) та ін.

MCAТ продовжує роботу по збільшенню числа країн, які передають дані в режимі реального часу. Технологія «Safe TIR в реальному часі», скорочено RTS, розроблена з метою автоматизації рутинних митних операцій МДП та надає митникам прямий доступ до контролю статусу книжки МДП в реальному часі на предмет електронної звірки даних. 3 послугою RTS процес звірки є швидким, надійним, простим, як звичайний обмін електронними повідомленнями. Технологію RTS впровадили в свої інформаційні системи митні служби більше 20 країн, в тому числі Азербайджан, Бельгія, Болгарія, Грузія, Казахстан, Латвія, Марокко, Росія, Туреччина, Фінляндія, Франція, а також Україна.

Для учасників міжнародних перевезень представляють інтерес і інші регіональні електронні транзитні системи, наприклад, система NCTS (New Computerized Transit System), яка об'єднує національні митні системи країн Європейського Союзу. За Постановою ЄК №1192/2008 всі перевезення МДП територіями країн СC відбуваються 3 використанням системи NCTS. Це загальноєвропейська комп'ютеризована система управління транзитними вантажами, розроблена на основі стандарту UN/EDIFACT для електронного документообігу. Вона подібна системі Safe TIR, однак децентралізована i складається з національних електронних систем.

MCAT розробив на базі Інтернет-технологій програму попереднього електронного деклалування TIR-EPD (Electronic Preliminary Declaration), за якою з 1 січня 2009 р. здійснюється пропуск транспортних засобів українських перевізників на/з митну територію ЄС. Нею безкоштовно може скористуватися будь-який підприємць, який виконує перевезення за системою MДП. TIR-EPD функціонує в митних органах більшості європейських країн. За Законом України «Про режим спільного транзиту та впровадження національної електронної транзитної системи» від17.06.2020 №720-IX, що імплементує положення 
Конвенції про спільну транзитну процедуру від 20.05.1987 p., програма TIR-EPD використовуватиметься для електронного обміну даними між митними органами України при режимі спільного транзиту.

У рамках системи NCTS розроблено і впроваджено і інші електронні системи для підвищення безпеки руху товарів та захищеності міжнародної торгівлі: це проект під назвою NCTS/MДП, що є містком між системами контролю NCTS та Safe TIR, система контролю імпорту ICS (Import Control System), система контролю експорту ECS (Export Control System).

Пандемія короновірусу внесла свої корективи в активізацію впровадження цифрових технологій для вирішення нагальних потреб транспортної галузі. За сумною статистикою, обсяги перевезень вантажів за час карантину скоротилися на 10-12\%, кількість укладених договорів на перевезення зменшилася на 60-90\%, прибуток вантажоперевізників знизився на 40\%. Закриття кордонів, обмеження на поїздки, посилення контролю по стримуванню короновірусу спричинили появу довгих черг і заторів на сухопутніх кордонах, в портах, аеропортах по всьму світі. Поширення COVID-19 завдало серйозного удару по автотранспортних підприємствах, що забезпечують рух вантажопотоків. Багато 3 них знаходяться сьогодні на межі краху та потребують допомоги. Одним із шляхів виходу з кризи є впровадження електронних документів, що сприятиме обмеженню фізичних контактів на кордонах, фізичних перевірок під час транзиту, захисту здоров'я працівників. Розглянемо деякі з них.

Міжнародні перевезення виконуються за правилами Конвенції про договір міжнародного перевезення вантажів автомобільним транспортом (КДПВ), відомої як Конвенція CMR, за якою відправник і вантажоперевізник оформляють міжнародну товаротранспортну накладну CMR як офіційний документ підтвердження передачі вантажу для перевезення, який знаходится у водія в кабіні автомобіля. Донедавна накладні CMR існували в паперовому вигляді, але зменшення можливості комунікації через карантинні обмеження вимагає переведення їх в електронний формат за допомогою планшету, мобільного телефону тощо. 
Які основні переваги е-CMR? Це підтвердження доставки в режимі реального часу, точність подання інформації, контроль відправлень, зменшення обсягу інформації, що вводиться, багатократне зниження витрат на обробку. Iснує консолідуючий аспект: e-CMR можна об'єднати 3 процедурами митного оформлення та фліт-менеджментом (послугами управління автопарком). Також важливий безпековий аспект: е-CMR можна прив'язати до системи екстреного реагування e-Call у випадку ДТП. Офіційний старт е-CMR у січні 2017 р. дало перше міжнародне перевезення між Францією та Іспанією з використанням електронної накладної. Правовим підгрунтям переходу на цифровий документообіг $є$ Протокол, що стосується електронної накладної, яким доповнена Конвенція КДПВ, чинний з 2011 р. На даний час до нього приєдналися 27 країн, в т.ч. Україна (ЗУ «Про приєднання України до Додаткового протоколу до Конвенції КДПВ про електронну накладну» від 03.06.2020 р. №660-IX). 3 ухваленням цього документу в Україні ініційовано пілотний проект використання е-CMR при здійсненні перевезень по міжнародному транспортному коридору Україна-Білорусь-Литва. Перевізники сподіваються на зменшення простоїв АТЗ при перетині кордонів і можливість детального аналізу операцій експорту/імпорту між трьома країнами.

Інший приклад: проект AEOLIX (Architecture for EurOpean Logistics Information eXchange) - інструмент для взаємодії цифрових інформаційних систем, розгорнутий у хмарній IT-платформі, яка оптимізує вантажопотоки і управління ланцюгами поставок, використовуючи дані e-CMR. Таким чином регулюється ефективна система транспортування товарів всією Європою, де нині функціонують 11 лабораторій AEOLIX. Проект демонструє, що цифрові транспортні документи - це вже інструмент сучасної реальності.

За умови успішного і повсюдного використання електронної накладної наступний логічний крок - впровадження електронного TIR-карнету. Це сприяє підвищенню конкурентоздатності системи МДП порівняно з іншими системами надання гарантій. Функціонуючи в режимі реального часу, електронна книжка МДП (e-TIR) дозволяє обмінюватися даними 3 митними органами та іншими 
зацікавленими сторонами, надавати попередню інформацію про вантаж, відстежувати питання гарантії та статусу позовів. Багато країн уже визнали переваги такого цифрового інструменту МДП. Метою пілотних проектів е-TIR $\epsilon$ подальша комп’ютеризація процедури МДП з використанням IT-інструментів на транспорті та в логістиці.

Ще у 2015 р. успішно проведено пілотний проект з використанням е-TIR між Туреччиною та Іраном, у стані підготовки до запуску - проекти Ірану та Азербайджану, а також у березні 2019 р. - застосування е-TIR у транспортному коридорі Україна-Грузія-Азербайджан-Казахстан. Країни, які нещодавно приєдналися до Конвенції МДП - Пакистан (2016), Саудівська Аравія (2018), Індія (2018), Китай (2019), Королівство Оман (2020) - також проводять активну роботу над створенням інтермодальних транспортних коридорів 3 використанням цифрових документів.

Переваги цифровізації МДП відчують усі зацікавлені сторони: національні асоціації, митні органи, експортери, імпортери. Наприклад, транспортні оператори отримають скорочення часу на обробку документів, скорочення часу очікування на кордоні, можливість відстежувати перевезення в режимі реального часу, отримати документи навіть в неробочий час.

Незважаючи на те, що на шляху впровадження цифрових технологій існує ряд перепон, наприклад, необхідність витрат та інвестицій, слабке розуміння різноманітності можливостей цифровізації, перехід до безпаперового документообігу має забезпечити доступність даних в режимі реального часу, онлайн-моніторинг митних процедур, безпеку транзитних операцій та конфіденціальність.

Враховуючи затребуваність комп’ютеризації процесів МДП, можна зробити висновок, наскільки зростає цінність переваг, які надає цифровізація. Слід визнати, що пандемія короновірусу привела до підвищення ролі цифрових технологій, які можуть забезпечити безперебійну роботу в будь-якій сфері та у будь-якому регіоні. Для повного використанні їх потенціалу треба подолати поточні перешкоди на шляху розвитку, як то відсутність загальнодоступних 
прозорих протоколів збереження i обробки інформації та інтерфейсів програмування, недостатність чи недоступність бази даних по вибору перевізників чи інших виконавців транспортних послуг тощо. Тому на європейському ринку з'явився проект GAIA-X, що може вирішити ці перешкоди [292].

Під час кризи, пов'язаної з COVID, компанії масово перейшли на віддалений режим роботи. Виникла нагальна потреба в безпечному сервісі для зберігання даних. GAIA-X розробляється як відкрита хмарна екосистема iз загальними стандартами зберігання та обробки інформації на серверах, розташованих в СС. У проекті беруть участь 7 європейських країн, 22 німецькі та французькі компанії (серед них Orange, Siemens, Bosch, Deutsce Telekom), понад 300 організацій по всьому світу. Хмарна платформа має стати конкурентом хмарним сервісам інших країн, в першу чергу американським - MS Azure, Google Cloud, AWS. Компанії з інших країн зможуть приєднатися до цієї ініціативи і працювати за європейськими правилами щодо сумісності та перенесення даних. Система може бути запущена з початку наступного року.

Впровадження цифрових технологій, інтелектуальних систем на транспорті вимагає саме життя як найкращі рішення, альтернативи яким немає. Перехід на повністю цифрову процедуру МДП впорядкує сумісність системи 3 іншими цифровими процедурами, що забезпечить ефективність і безпеку торгових потоків як у переіод пандемії, так і після кризи. 


\subsection{Analysis of technological and economical preconditions of intercity carriers business interaction}

Метою функціонування будь-якої транспортної компанії (ТК) є отримання максимального чистого прибутку. Прибуток залежить від обсягу виконаних замовлень, тарифів, а також собівартості виконання замовлень. Собівартість перевезення залежить від структури транспортного процесу. У сучасних умовах інтеграції виробничих процесів собівартість можна зменшити, якщо раціонально використовувати організаційно-технологічні зв'язки підприємств, які взаємодіють. Тариф для контрактної логістики в кожному технологічному випадку призначається індивідуально. Він залежить від географії транспортних пунктів, характеру вантажу, тривалості типового рейсу, загальної ваги i габаритів вантажу, необхідного графіка і часу гарантованої доставки. Перевезення вантажів по заданій території (населеному пункті, області, регіоні) може бути прив'язана до заданого часу, обмежена конкретним терміном. Може бути прописано кількість рейсів і обговорений точний маршрут руху.

Для визначення економічних передумов взаємодії перевізників проводились спостереження за вибіркою підприємств, які обслуговують задану географічну територію України. Величини, які підлягали спостереженню: 1) тарифи на перевезення вантажів; 2) вартість логістичних послуг (оформлення замовлення, експедиція, страхування вантажів); 3) експлуатаційні витрати при утриманні та використанні парку транспортних засобів; 4) орендні відносини на ринку транспортно-логістичних послуг; 5) інформаційне забезпечення транспортного процесу. При дослідженні вказаних величин була обгрунтована вибірка обсягом 34 з усіх автомобільних ТК, які виконують міжміські (внутріобласні і міжобласні) перевезення вантажів західного та центрального

регіону України. Усього таких підприємств, які містяться в бізнес-каталогах, налічується 781 по вказаних регіонах України $[0,0]$. Кількість і марочний склад парку транспортних засобів таких підприємств у бізнес-каталогах не вказано. Дані спостережень було розміщено у варіаційні ряди, проранговано. Побудовані 
ряди даних перевірено на стійкість. Відкинуто промахи спостережень. У табл. 1 представлено дані по вибірці зі спостережень - середні тарифи на міжміські перевезення по Україні транспортними засобами різної вантажності. Потрібно зауважити, що на сайтах окремих транспортних компаній, а також в прайслистах вказується гнучка система тарифів, яка залежить від відстані перевезень i обсягу вантажу, який перевозиться.

Таблиця 1.

Середні тарифи на перевезення вантажів автомобільним транспортом

\begin{tabular}{|l|c|c|c|c|}
\hline $\begin{array}{c}\text { Тип автотранспортного } \\
\text { засобу }\end{array}$ & $\begin{array}{c}\text { Повна } \\
\text { маса, т }\end{array}$ & $\begin{array}{c}\text { Довжина, } \\
\text { м }\end{array}$ & $\begin{array}{c}\text { Об’єм } \\
\text { вантажу, м³ }\end{array}$ & $\begin{array}{c}\text { Тариф за } 1 \\
\text { км, грн }\end{array}$ \\
\hline Автопоїд & до 40,0 & до 13,8 & до 120,0 & від 24 грн/км \\
\hline Автомобіль одиночний & до 20,0 & до 10,2 & до 90,0 & від 20 грн/км \\
\hline Автомобіль одиночний & до 10,0 & до 8,5 & до 60,0 & від 17 грн/км \\
\hline Автомобіль одиночний & до 5,0 & до 6,5 & до 35,0 & від 12 грн/км \\
\hline Автомобіль одиночний & до 2,0 & до 4,2 & до 20,0 & від 5 грн/км \\
\hline
\end{tabular}

Ціноутворення на транспорті $є$ складним процесом, що пов'язано 3 різноманітністю продукції, яка транспортується. Для перевезення вантажів і розрахунку за послуги транспортні підприємства встановлюють вантажні тарифи. Формування транспортних тарифів має певні особливості, пов'язані 3 особливостями транспорту як сфери діяльності. Розглянемо основні з них [0].

1. Тариф залежить також від умов транспортування, витрат на транспортування на різних ділянках шляхів, оптимальної пропускної здатності транспортної мережі.

2. Транспортний тариф залежить ще й від виду продукції, що транспортується, відстані, швидкості перевезення, виду відправлення. У розрахунку транспортного тарифу враховуються тип рухомого складу, ступінь завантаженості транспортного засобу тощо.

3. Транспортні підприємства використовують різні ресурси (залізо, вугілля, нафту, газ, електроенергію, будівельні матеріали та ін.), вартість яких входить у 
собівартість перевезень. Тому ціни на ці ресурси істотно впливають на витрати транспортних підприємств і вартість тарифу загалом.

Перелічені особливості зумовлюють складність процесу ціноутворення у сфері транспортних перевезень порівняно з процесами ціноутворення в інших галузях національної економіки. Принципи визначення тарифів автомобільного транспорту такі самі, що й для інших видів. Вони встановлюються на рівні, що забезпечує відшкодування собівартості перевезень і отримання прибутку, який можна буде використати для розвитку автотранспортного підприємства i стимулювання праці. На собівартість перевезення вантажів автомобільним транспортом впливає багато чинників: кліматичні умови; вид вантажу; характер вантажопотоку; тип рухомого складу; стан шляхів; ціни на пальне та мастила; норми витрат пального різними видами автомобілів; витрати на ремонт автомобілів та запасних частин; заробітна плата водіїв і обслуговуючого персоналу; розвантажувальні та експлуатаційні витрати.

Якщо транспортний тариф регулюється ще ринковими відносинами, то витрати ТК на перевезення 1 т вантажу, або на виконання 1 км пробігу 3 вантажем - випадкова величина, математичне сподівання якої $\mathrm{M}\left(\mathrm{C}_{\text {км})}\right)=5,45$ грн/год, а коефіцієнт варіації $v=0,86$ з врахуванням середньої експлуатаційної швидкості 22 км/год [0]. Такі дані $є$ досить варіативними і їх не доцільно використовувати як статистичні. Тому при плануванні інтегрованого транспортного процесу потрібно задаватись конкретним значенням собівартості для заданої ТК. На даний час на ринку вантажних автомобільних перевезень склалась така ситуація, при якій транспортні компанії можуть винаймати на визначений період транспортні засоби у партнерів, або здавати власні в оренду. Такі випадки трапляються досить часто, однак умови таких відносин залежать від конкретних контрактів. Інформаційне забезпечення транспортні компанії мають завдяки досить популярним і перевіреним он-лайн сервісам інтернет на сайтах, таких як Lardi-Trans.com, ua.transportica.com, della.com.ua, transatlas.com.ua та інші. На цих сайтах видається інформація про:

- маршрут руху; 
- часове вікно: актуальні часові межі виконання замовлення;

- вимоги до конструкції транспортного засобу;

- тип і характеристики вантажу, вимоги до вантажних робіт;

- тариф, умови оплати;

- інша комерційна інформація.

Потрібно відмітити, що рівень достовірності інформації, ï повнота $є$ не цілком задовільними. Крім того, можна виявити певні неузгодження інформації про одні і ті ж замовлення, які були подані різними сайтами. Тому перевізники, переважно, ведуть власні бази даних стосовно замовників і партнерів по вантажних перевезеннях.

Структурне моделювання інтегрованих процесів виконувалось на основі вхідних даних, які спостерігались на підприємстві ТК Львівської області, яке займається перевезеннями вантажів у міському і міжміському сполученні. Для даного підприємства станом на вересень 2020 року актуальними були такі параметри: середня собівартість пробігу з вантажем - 18,0 грн/км; середня собівартість простою автотранспорту - 5,2 грн/год; вартість купівлі інформації про існуючі замовлення у посередників - 280 грн; дохід від продажу інформації про наявні замовлення партнерам - 280 грн; кількість транспортних пунктів, які входять в одну зону обслуговування - 24; площа території, яка окреслена як одна зона обслуговування - 156,2 тис. га; кількість автомобільних транспортних засобів, які обслуговують задану зону - 10; горизонт планування (період, впродовж якого є відомі замовлення і планується транспортний процес) - 72 год; кількість транспортних засобів, які можна орендувати - необмежена; часові параметри замовлень $є$ досліджені і наперед відомі [0].

Ставилась задача виконати план горизонту прогнозування так, щоб отримати максимальний прибуток за формулою: 


$$
\begin{aligned}
& \Pi=\left(R-R_{z}\right) \cdot P_{r}-\left(R_{z}-R\right) \cdot C_{r}-\left(R_{z}-R\right) \cdot C_{z}+ \\
& +\sum_{i=1}^{N} \sum_{j=1}^{N} a_{i, j}^{m} \cdot\left(1-x_{i, j}\right) \cdot P_{z}+\sum_{i=1}^{N} \sum_{j=1}^{N} a_{i, j}^{m} \cdot x_{i, j} \cdot P_{m}-\sum_{i=1}^{N} \sum_{j=1}^{N} a_{i, j}^{m} \cdot x_{i, j} \cdot C_{m}-, \\
& -\sum_{i=1}^{N} \sum_{j=1}^{N} a_{i, j}^{s} \cdot x_{i, j} \cdot C_{s} \Rightarrow \max
\end{aligned}
$$

де $R_{z}$ - кількість фактично задіяних власних транспортних засобів;

$P_{r}-$ ринкова ціна здавання в оренду транспортного засобу, грн;

$C_{r}$ - витрати на оренду одиниці транспортного засобу, грн;

$C_{z}$ - вартість інформації про одне замовлення;

$C_{m}, C_{t}$ - витрати коштів АТП на 1 год, відповідно, руху і простою транспортних засобів;

$a_{i . j}^{m}-$ тривалість руху транспортного засобу при виконанні замовлення $j$, після виконання замовлення $i$;

$a_{i, j}^{s}-$ витрати часу на простій транспортних засобів у пунктах відправлення $\mathrm{i}$ призначення вантажу;

$x_{i, j}$ - двійкова змінна задачі.

Обмеження:

$$
\begin{aligned}
& \sum_{j=1}^{N} x_{i, j}-\sum_{i=1}^{N} x_{i, j}=0, \\
& \sum_{j=1}^{N+F} x_{i, j}-\sum_{j=0}^{N} x_{i . F}=-R_{z}, \\
& \sum_{j=1}^{N+F} x_{i, j}-\sum_{j=0}^{N} x_{j . F}=R_{z}, \\
& \sum_{j=1}^{N} x_{i, j} \leq 1, \\
& \sum_{i=1}^{N} x_{i, j} \leq 1, \\
& \sum_{i=1}^{N}\left(\left|x_{0 . i}-x_{i . F}\right|\right)=R_{z},
\end{aligned}
$$

де $x_{i . F}, x_{j . F}, x_{0 . i}, x_{0 . j}-$ формальні змінні, які означають, відповідно, завершення/ початок виконання замовлень $Z_{i}, Z_{j}$. 
При цьому ТК має використати власні транспортні засоби, орендувавши необхідні, а також здійснивши маніпуляції з наявною інформацією стосовно наявних, чи відсутніх замовлень. Допускається, що окремі замовлення не будуть виконуватись через їх невигідність. Якщо після розподілу транспортних засобів деякі 3 них є нерозподіленими, то вони здаються в оренду. Якщо внаслідок аналізу наявних замовлень виявляється брак транспортних засобів у перевізника, то перевізник орендує їх у наявних партнерів. Таким чином, в результаті оптимізації вибираються ті варіанти розподілу замовлень, які дають максимальний прибуток при заданих початкових даних.

При оптимізації наперед невідомо, при якій кількості необхідних транспортних засобів прибуток від виконання плану перевезень буде максимальним. Тому застосовано ітераційне моделювання при зміні кількості задіяних АТЗ. Так само, покроково, змінювались показники вхідного потоку замовлень: коефіцієнт нерівномірності тривалості виконання замовлень i коефіцієнт сумісності замовлень. На рис. 1 показано приклад результату одного кроку оптимізації інтегрованого транспортного процесу при кількості необхідних транспортних засобів $R=1$. Коефіцієнт сумісності замовлень $K_{c}=0,6$, коефіцієнт нерівномірності замовлень $\eta_{t}=1,8$. При $R=10$ розв'язок задачі $\epsilon$ тривіальним, оскільки усі 10 відомих замовлень виконуються усіма 10 наявними транспортними засобами. Як видно з рис. 1 оптимальним є варіант виконання лише двох замовлень №10 і №1 у названому порядку.

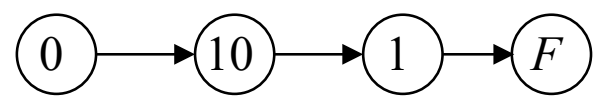

Рис. 1. Оптимальна схема виконання замовлень при кількості необхідних транспортних засобів $R=1$

Прибуток, який отримується при цьому - 10418 грн. Частина прибутку отримується: а) 71,7\% - виконання двох замовлень; б) 16,8\% - від продажу 
інформації про 8 інших відомих замовлень; в) 11,5\% - від здачі в оренду незадіяних транспортних засобів. В оренду здаються 4 транспортні засоби. Кількість власних транспортних засобів всього -5 .

На рис. 2 показано інший оптимальний варіант виконання замовлень, при кількості вільних транспортних засобів, які можна задіяти $-R=5$.

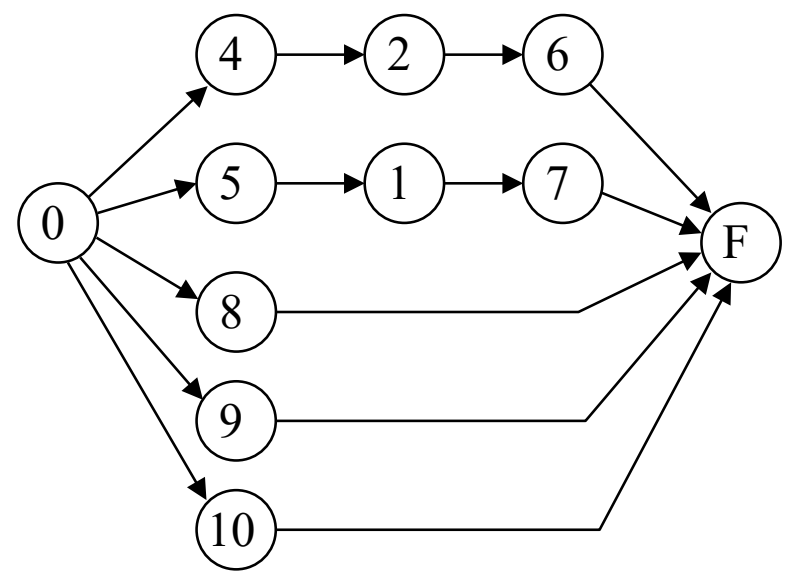

Рис. 2. Оптимальна схема виконання замовлень при кількості необхідних транспортних засобів $R=5$

Прибуток, який отримується при цьому - 20624 грн. Частина прибутку отримується: а) 98,5\% - виконанням дев'яти замовлень; б) 1,2\% - від продажу інформації про одне інше відоме замовлення; в) 0\% - від здачі в оренду зайвих транспортних засобів. При цьому в оренду не здається жоден транспортний засіб. Таким чином, отримані результати моделювання при сталих параметрах вхідного потоку замовлень і змінній кількості залучених автомобільних транспортних засобів можна відобразити на рис. 3 для конкретних значень коефіцієнту сумісності замовлень $\left(K_{c}\right)$ та коефіцієнту часової нерівномірності замовлень $\left(\eta_{\mathrm{t}}\right)$. Як видно з гістограми, найбільша частина доходів отримується підприємством від перевезення. Лише, коли підприємство має в наявності 5 власних транспортних засобів, а використовує для перевезень 1-2, то доходи від здачі в оренду автомобілів заледве перевищують $10 \%$ від сукупних. Доходи від продажу інформації для підприємства означають, що з 10 відомих замовлень 
$10-R$ буде продано партнерам, де $R$ - кількість задіяних автотранспортних засобів, разом з орендованими. Максимальні (100\%) доходи від перевезень отримано при залученні 6 АТЗ: 5 - власних +1 орендований і при 8 залучених АТЗ: 5 власних +3 орендованих.

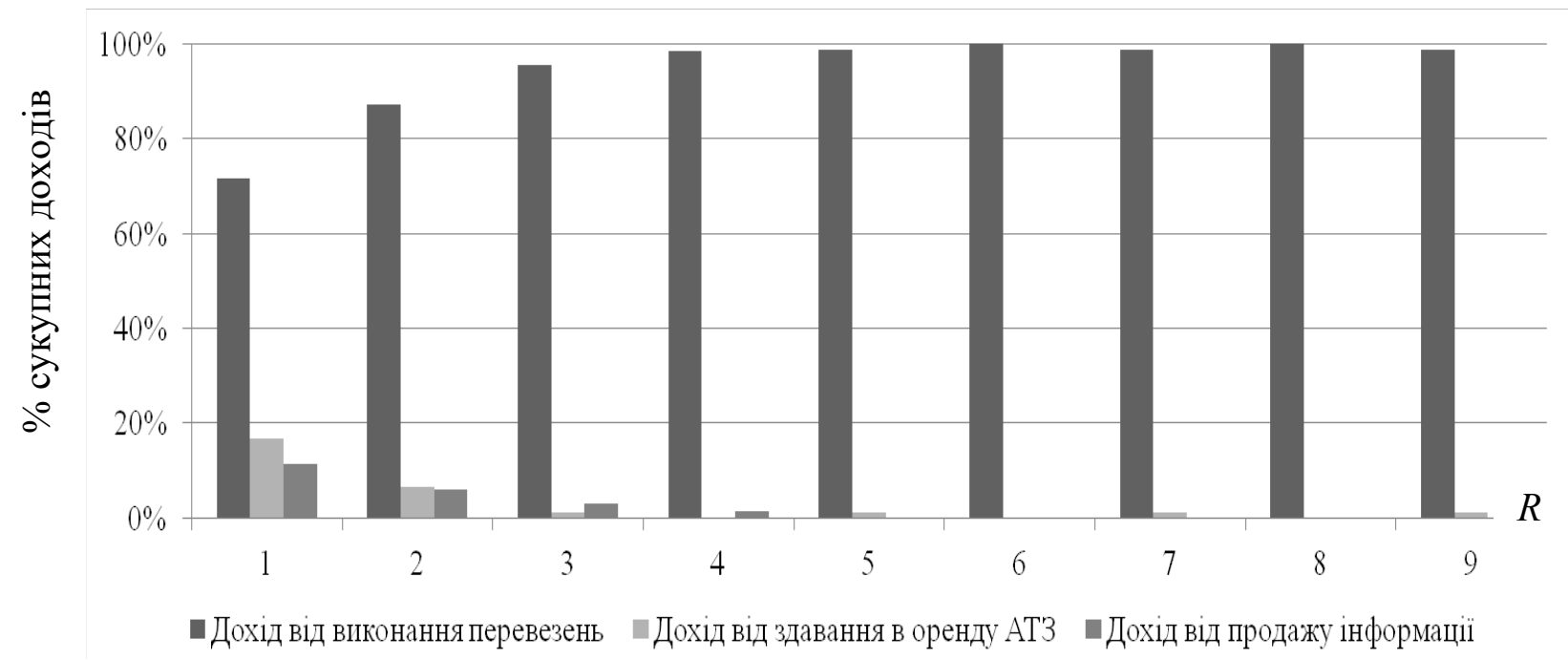

Рис. 3. Структура доходів транспортної компанії при різній кількості задіяних транспортних засобів, $K_{c}=0,6, \eta_{t}=1,8$

Як видно 3 результатів, доходи перевізника при залученні орендованих транспортних засобів зростають. Це пояснюється використанням більшої кількості замовлень. Однак, прибуток перевізника не збільшується. Це видно 3 рис. 4.

Так, якщо кількість орендованих АТЗ перевищує 3, або понад 60\% від задіяних власних, то прибуток перевізника зменшується, що пов'язано із зростанням орендної плати і неефективним використанням транспортних засобів, які є в розпорядженні. 


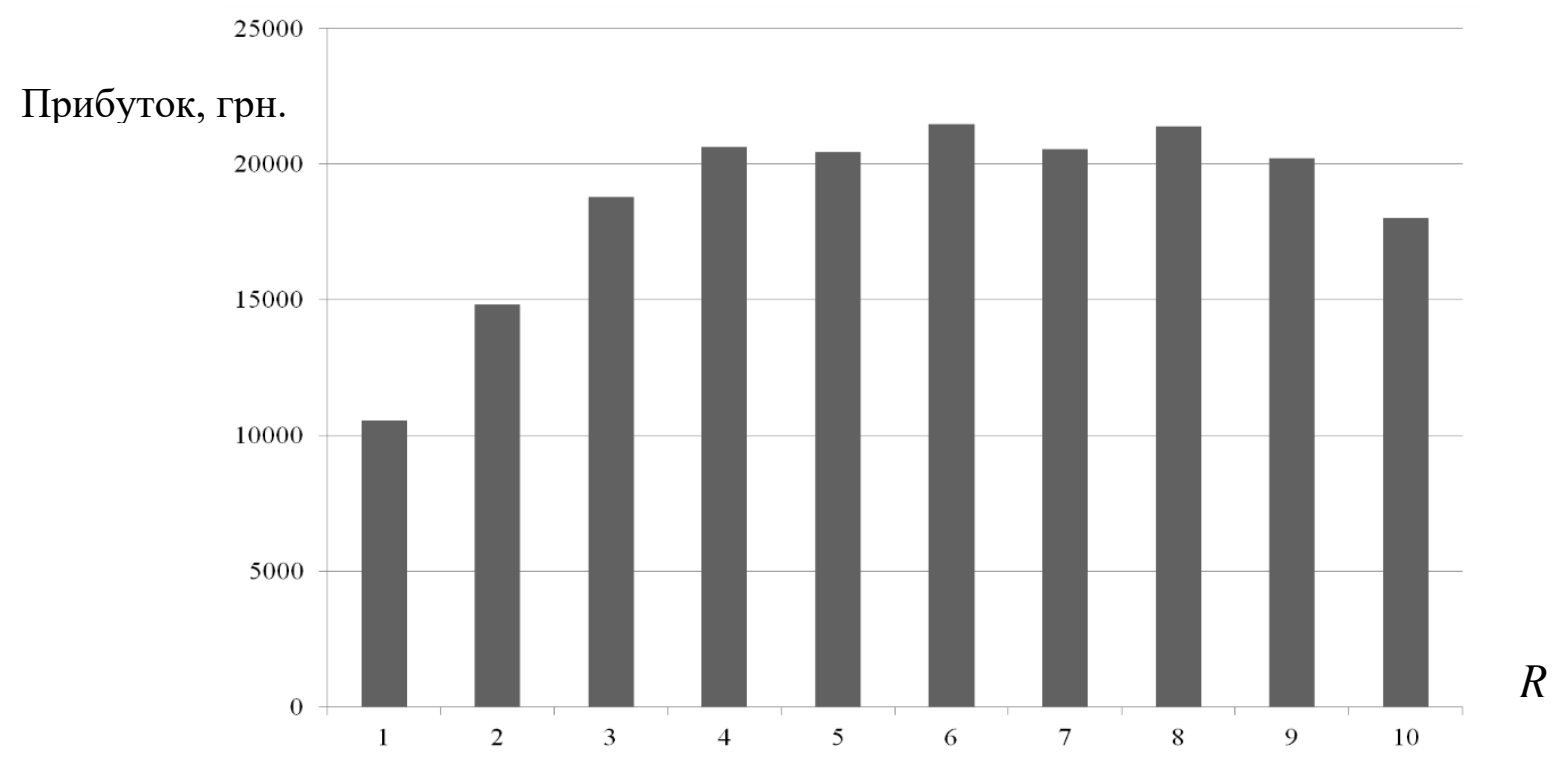

Рис.4. Залежність прибутку перевізника від кількості задіяних власних та орендованих транспортних засобів при 10 відомих замовленнях

Успішна діяльність перевізника із взаємодією 3 партнерами та конкурентами залежить від попиту на послуги перевезень [0]. Для того, щоб дослідити закономірності цієї залежності було виконано структурне моделювання $з$ оптимізацією за критерієм сукупного прибутку від діяльності перевізника для впорядкованих вхідних потоків замовлень.

Для того, щоб дослідити вплив коефіцієнтів сумісності і часової нерівномірності замовлень на можливість ТК досягнути максимальний прибуток П, було побудовано матрицю $\left|a_{i . j}\right|$ зв'язків, елементи якої обчислюються за виразом:

$$
a_{i, j}=a_{i, j-1}+a_{i, j-1} \cdot B,
$$

де $\quad i=1 . . N, j=0 \ldots N-$ номери замовлень;

$B$ - емпіричний коефіцієнт, числове значення якого підбиралось так, щоб середнє значення коефіцієнта сумісності $K_{c}$, обчислене за методикою [0], дорівнювало наперед заданому значенню $K_{c .3}$. 
Для того, щоб підібрати значення матриці $\left|a_{i . j}\right|$ за виразом (8), необхідно задатись початковими значеннями $a_{0 . j}$, які залежать від коефіцієнта часової нерівномірності замовлень $\eta_{t}$. Для того, щоб підібрати вектор початкових значень $a_{0 . j}$, де $j=1 . . N$, використано вираз:

$$
a_{0 . j}=a_{0 . j-1}+a_{0 . j-1} \cdot C,
$$

де $j=2 \ldots N$;

$C$ - емпіричний коефіцієнт, числове значення якого впливає на формування необхідного значення коефіцієнта нерівномірності $\eta_{t}$ серед величин $a_{0 . j}$ за формулою (9).

Для того, щоб підготувати вхідні дані для дослідження замовлень вибрано початкове значення $a_{0.1}=2$ год, що відповідає середній тривалості їздки 3 вантажем на ТК, де проводились спостереження, і яке здійснює вантажні автомобільні великогуртові перевезення. Для генерації ряду початкових даних $a_{0 . j}, j=1 . . . N$ застосовано пакет аналізу «What-if» 3 електронних таблиць Excel. Даний пакет дає змогу знайти таке значення змінної/константи, при якому задана формула набуває потрібного значення. Бажані значення коефіцієнта нерівномірності $\eta_{t}$ вибирались послідовно з множини $\{1,1,1,2,1,3,1,4,1,5,1,6$, $1,7,1,8,2,0,2,2\}$. Так, якщо потрібно, щоб $\eta_{t}=1,1$, то пакет аналізу «What-if» видав значення $C=0,02186$. При цьому ряд початкових значень для $N=10$ за формулою (9) набуває вигляду: $a_{0.1}=2,0 ; a_{0.2}=2,0 ; a_{0.3}=2,1 ; a_{0.4}=2,1 ; a_{0.5}=2,2 ; a_{0.6}=2,2 ; a_{0.7}$ $=2,3 ; a_{0.8}=2,3 ; a_{0.9}=2,4 ; a_{0.10}=2,4$. Усі інші елементи матриці $\left|a_{i . j}\right|$ встановлюються залежно від наперед заданого коефіцієнта сумісності $K_{c}$, який послідовно вибирався із множини ймовірних значень $K_{c} \in\{0,9,0,8,0,7,0,6,0,5,0,4,0,30,2\}$. Для обчислення матриці $\left|a_{i . j}\right|$ використано формулу (8), у якій коефіцієнт $B$ вибирався 3 допомогою пакету аналізу «What-if». Так, наприклад, при $\eta_{t}=1,8$ вектор даних $a_{0 . j}=\{2,0,2,3,2,7,3,1,3,7,4,3,5,0,5,8,6,7,7,8\}$. Задано було, що коефіцієнт сумісності має бути $K_{c}=0,6$. При застосуванні пакету аналізу для формули (8) знайдено $B=0,112418$ і побудовано відповідну матрицю. 
Для повнофакторного дослідження впливу коефіцієнтів $K_{c}$ i $\eta_{t}$ на структуру інтегрованого транспортного процесу та на прибуток від діяльності та кооперації перевізника потрібно побудувати $K_{c} \times \eta_{t}$ таких матриць, які охоплюють увесь вектор початкових значень як $K_{c}$ так і $\eta_{t}$.

Результати оптимізації подано на рис. 5.

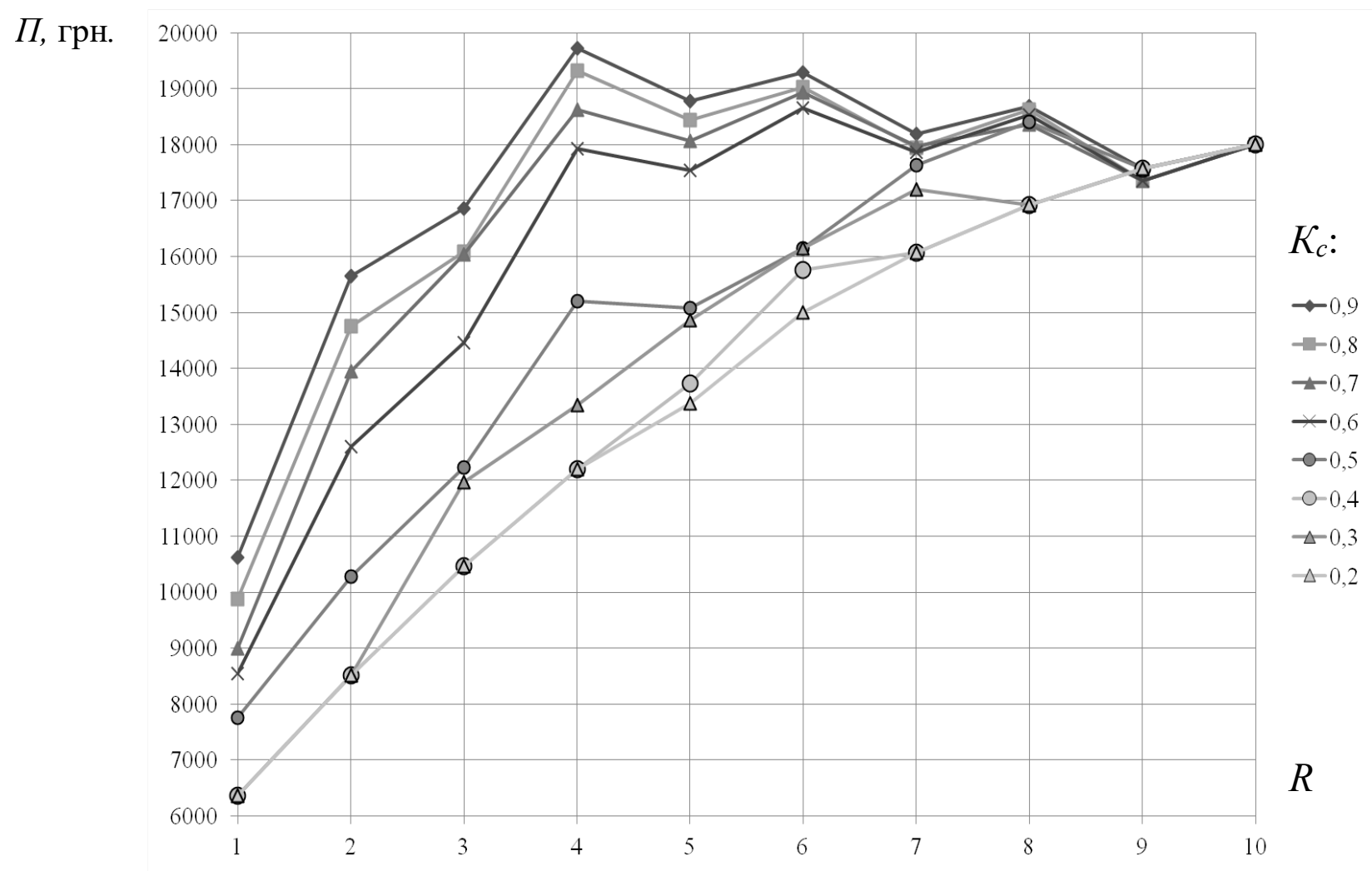

Рис. 5. Залежність сукупних прибутків перевезення вантажів від кількості задіяних транспортних засобів і коефіцієнта сумісності $\mathrm{K}_{\mathrm{c}}$

3 наведених результатів видно, що максимальний прибуток ТК залежить від коефіцієнта сумісності замовлень в єдиному потоці. Так, при $\mathrm{K}_{\mathrm{c}}=0,9$ максимальний прибуток становить 19,75 тис. грн. При цьому не усі замовлення приймаються до виконання. Частина замовлень продається партнерам. А вже при $\mathrm{K}_{\mathrm{c}}=0,2$ максимальний прибуток становить 18,1 тис. грн. При цьому усі замовлення 3 горизонту прогнозування виконуються власним і орендованим транспортом. Як можна помітити, максимальний прибуток, при зменшенні 
коефіцієнта сумісності замовлень зміщається в сторону збільшення задіяних власних + орендованих транспортних засобів.

В цілому, при збільшенні коефіцієнта сумісності замовлень максимальний прибуток починає зростати майже лінійно, але починаючи від числового значення $K_{c}=0,4$. Це пов'язано 3 тим, що при низьких значеннях коефіцієнта сумісності підприємство цілком перекладає функції виконання замовлень на орендовані транспортні засоби, тобто на партнерів. Низький коефіцієнт сумісності спричинює більші витрати на перевезення при тій самій ціні. А орендна плата - фіксована величина. Тому числове значення $K_{c}$ можна цілком пов'язати з рівнем спеціалізації та концентрації ТК.

Результати оптимізації структури транспортного процесу при лінійній апроксимації моделі (1) подано на рис.6.

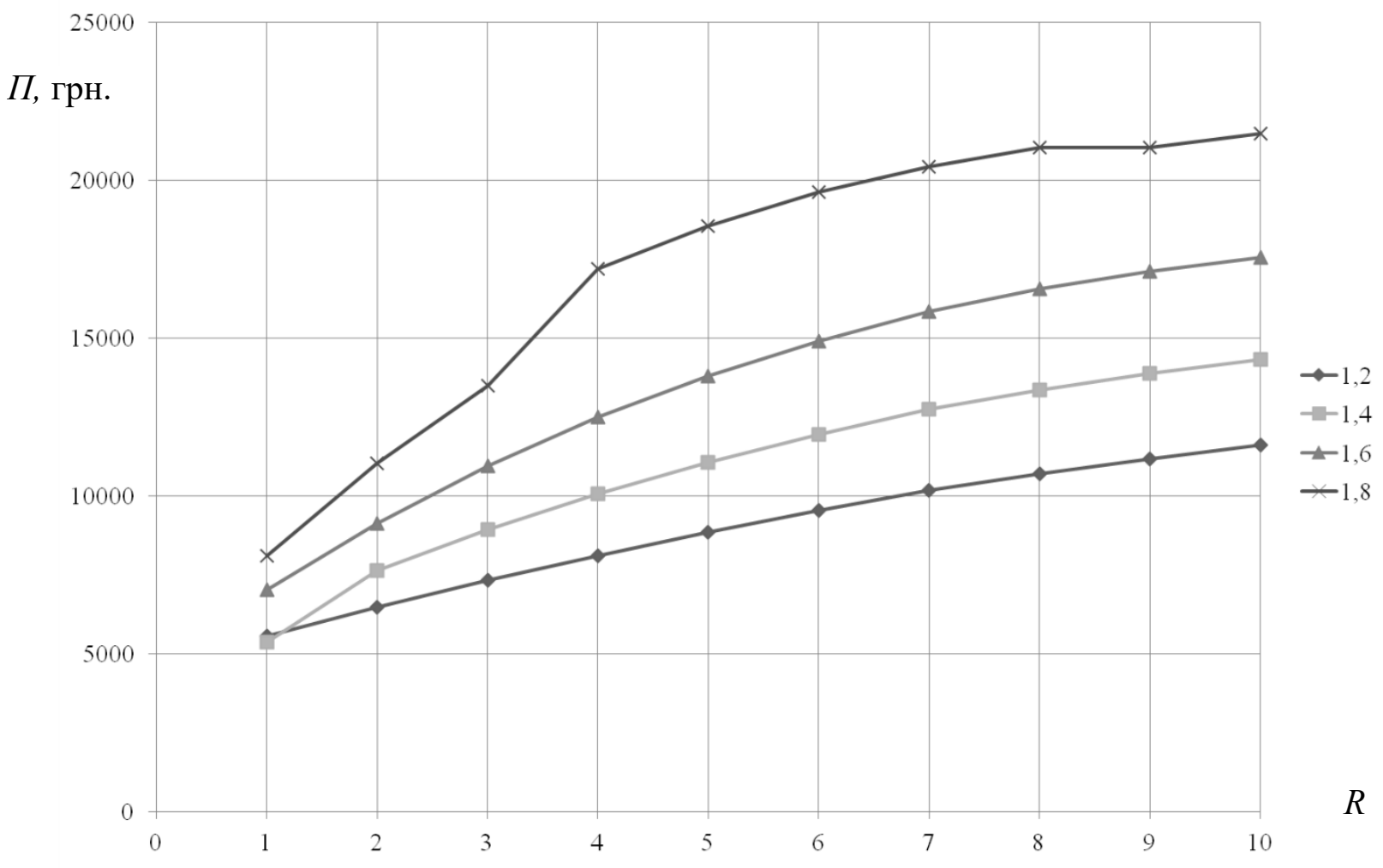

Рис. 6. Залежність сумарного прибутку від виконання замовлень на перевезення вантажів від кількості задіяних (власних і орендованих) транспортних засобів та коефіцієнта нерівномірності $\eta_{\mathrm{t}}$ при лінійній апроксимації моделі 
Розв'язки лінійної моделі отримуються без уведення крайових умов. Однак, якщо порівняти ці результати з нелінійною моделлю (див. рис. 5) з обмеженнями (2)-(7), то максимальний прибуток отримується понад двічі більший.

При лінійній апроксимації власні транспортні засоби підприємства виконують лише по одній завантаженій їздці за цикл, що пов'язано 3 недосконалістю моделі. Нелінійний варіант моделі дає складніші цикли для кожного транспортного засоби, коли вибираються сумісні замовлення, які включаються в єдиний маршрут. Також бачимо, що коефіцієнт часової нерівномірності замовлень позитивно впливає на можливість отримати більший максимальний сумарний прибуток. Це пояснюється наявністю в горизонті планування різних за тривалістю замовлень, які дають змогу побудувати більш досконалі цикли.

Отже, при спостереженні за вибіркою транспортних підприємств отримано стійкі статистичні дані про середні тарифи на перевезення, однак не вдалося такі дані сформувати стосовно собівартості послуг, структури парків, економіці орендних відносин. Структурне моделювання інтегрованого транспортного процесу доцільно проводити для конкретних умов заданого транспортного підприємства.

Коефіцієнт сумісності замовлень є прямою ознакою доцільності кооперації транспортних компаній, оскільки максимальні прибутки прямо-пропорційно залежать від його числового значення. Лінійна апроксимація моделі господарської діяльності ТК при відомій інформації про потік замовлень дає більш, як $100 \%$ похибку результатів. Побудована нелінійна модель дає вищі результати, однак для іiї розв'язку потрібно використовувати крайові умови. 


\subsection{The choosing of cargo delivery rational methods for international transportation customers}

Актуальність. При виконанні міжнародних перевезень, а також в багатьох випадках масових партіонних перевезень доцільно організовувати доставку вантажів 3 перевантаженням, що дозволяє використовувати для доставки партіонних вантажів ефективні транспортні засоби. Іншими словами при здійсненні міжнародних перевезень виникає питання вибору раціональних способів доставки вантажів кінцевим споживачам.

Тобто доставка вантажів замовникам міжнародних перевезень здійснюється тим же рухомим складом після здійснення митного контролю та митного оформлення, або може використовуватись інший рухомий склад, який відповідає партіонності збірних вантажів. Іншим варіантом $\epsilon$ перевезення вантажів в режимі експорт. В цьому випадку виникає необхідність визначення раціонального способу доставки вантажів в місце здійснення митного контролю та митного оформлення.

Одним 3 варіантів $є$ доставка збірних вантажів на митницю збірним маршрутом, тим же рухомим складом, що буде виконувати міжнародні перевезення. Другим варіантом $є$ доставка вантажів маятниковими маршрутами на митницю рухомим складом, який відповідає партіонності збірних вантажів. Раціональний варіант перевезення доставки вантажів обирають, співставляючи витрати на 1 тони при термінальному перевезенні та при доставці вантажів від “дверей до дверей”.

Розглянемо задачу на прикладі розвозу збірних вантажів після здійснення митного контролю та митного оформлення автопоїздом, який здійснював міжнародні перевезення або іншим рухомим складом, який відповідає середній партіонності збірного вантажу.

Перевантаження доцільно (доставка вантажу автомобілями, які відповідають середній партіонності збірних вантажів) при умові, що

$$
S_{m p_{1}}>\sum_{j=1}^{j=2} S_{n e p .}^{u-p}+S_{m p_{2}}+\left(K_{u-p .}-K_{p . c .}\right) \cdot E_{u}
$$


$\mathrm{S}_{m p 1}$ - собівартість доставки вантажу автопоїздом, який здійснював міжнародні перевезення, грн./т.;

$\mathrm{S}_{m p 2}$ - витрати на транспортування вантажів після перевантаження автомобілями, які відповідають партіонності перевезень, грн./т.;

$\sum_{j=1}^{j=2} S_{n e p .}^{\mu-p}$ - сумарні додаткові витрати на перевантаження та простої рухомого складу при здійсненні доставки партіонних вантажів замовникам міжнародних перевезень;

$K_{u-p .}, K_{p . c .}$ - капіталовкладення в навантажувально-розвантажувальні засоби та в рухомий склад із розрахунку на 1тону вантажу відповідно при доставці вантажів 3 перевантаженням і при доставці вантажів магістральним автопоїздом.

Собівартість доставки однієї тони на розвізному маршруті доставки вантажу кінцевим замовникам міжнародних перевезень складає:

$$
S_{m p_{1}}=\frac{l_{M_{1}}}{q_{1} \cdot \gamma_{c m_{1}}} \cdot C_{\kappa u}+C_{n o c_{1}}\left(t_{T_{1}}+\frac{t_{3}}{g_{p}}\right)
$$

Враховуючи, що $l_{м_{1}}=2 \bar{l}_{i_{1}}$, можна визначити витрати на 1тону доставки вантажів розрахунково-аналітичною залежністю:

$$
S_{m p_{1}}=\frac{2 \bar{l}_{i_{1}}}{q_{1} \cdot \gamma_{c m_{1}}} \cdot C_{\kappa m_{1}}+C_{n o c_{1}}\left(t_{T_{1}}+\frac{t_{3}}{g_{p}}\right)
$$

$\bar{l}_{i_{1}}$ - середня відстань доставки вантажу на розвізному маршруті;

$q_{1}$ - вантажність магістрального автопоїзда;

$t_{3}$ - середній час заїзду в пункт розвантаження на маршруті;

$t_{T_{1}}$ - середній час розвантаження 1 т на розвізному маршруті;

$g_{p}$ - середній розмір партії доставки вантажу;

$C_{\kappa u_{1}}$ - витрати на 1км пробігу;

$C_{\text {nос }}$ - витрати на 1 год роботи.

При доставці вантажів після перевантаження автомобілями вантажністю q2, які відповідають середній партії розвозу $\bar{g}_{p}$, загальний пробіг автомобіля складе : 
THEORETICAL ASPECTS OF MODERN ENGINEERING

$$
l_{M_{2}}=2 \bar{l}_{i_{2}}+2 \bar{l}_{o}
$$

де $\bar{l}_{i_{2}}$ - середня відстань доставки вантажу маятниковими маршрутами Тоді формулу можна записати так:

$$
S_{m p_{2}}=\frac{2 l_{M_{2}}}{q_{2} \cdot \gamma_{c m_{2}}} \cdot C_{\kappa u_{2}}+C_{n o c_{2}}\left(t_{T_{2}}+\frac{t_{3}}{\bar{g}_{p}}\right)
$$

або

$$
S_{m p_{2}}=\frac{2 l_{i_{2}}}{q_{2} \cdot \gamma_{c m_{2}}} \cdot C_{k k_{2}}+C_{n o c_{2}}\left(t_{T_{2}}+\frac{t_{3}}{\bar{g}_{p}}\right)+\frac{2 \bar{l}_{0}}{q_{2} \cdot \gamma_{c m_{2}}}
$$

де $q_{2}$ - вантажність автомобіля для доставки партіонних вантажів

Мінімальна рівноцінна відстань доставки вантажу може бути визначена 3 рівняння $S_{m p_{1}}=S_{m p_{2}}$ та буде складати $2 l_{\min }=2 l_{m p_{2}}=2 \bar{l}_{i_{1}}$.

Графічне визначення мінімальної рівноцінної відстані доставки вантажів $\operatorname{lmin}$ після перевантаження (рис.1).

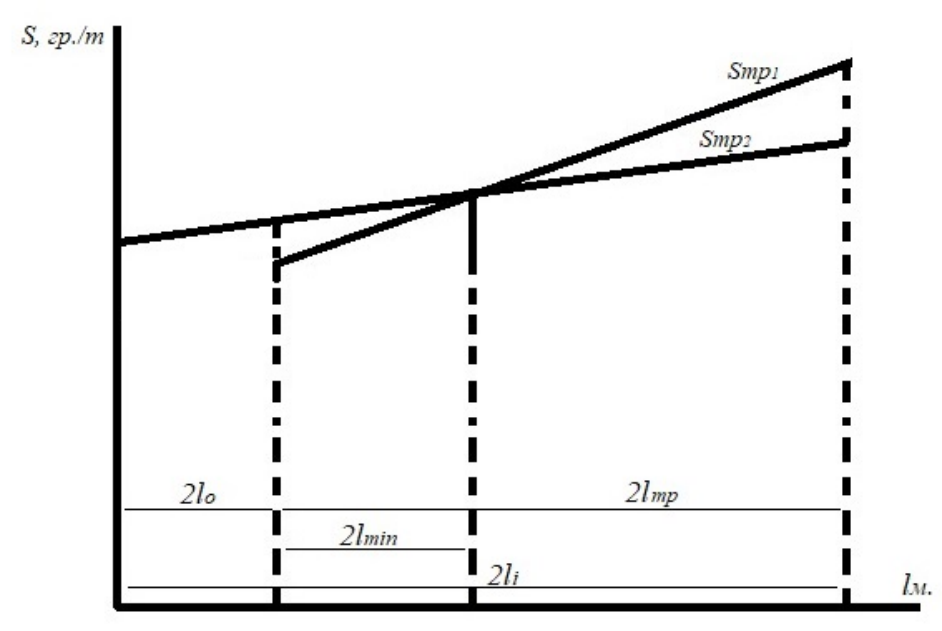

Рисунок 1. Графік залежності $l$ min від вантажності рухомого складу для визначення області ефективного його використання для доставки партіонних вантажів після митного оформлення та митного контролю

Після підстановки $\bar{l}_{i}$ в рівняння $\left(S_{m p_{1}}=S_{m p_{2}}\right)$ отримаємо:

$$
\begin{aligned}
& \frac{2 \cdot \bar{l}_{\text {min }_{1}}}{q_{1} \cdot \gamma_{c m_{1}}} \cdot C_{\kappa M_{1}}+C_{n o c_{1}}\left(t_{T_{1}}+\frac{t_{3}}{q_{p}}\right)=\frac{2 \bar{l}_{i o}}{q_{2} \cdot \gamma_{c m_{2}}} \cdot C_{\kappa u_{2}}+\frac{2 \cdot \bar{l}_{\text {min }_{1}}}{q_{2} \cdot \gamma_{c m_{2}}}\left(t_{T_{2}}+\frac{t_{3}}{\bar{g}_{p}}\right)+S_{n e p} \\
& \text { Якщу прийняти } C_{n о c_{1}}\left(t_{T_{1}}+\frac{t_{3}}{\bar{g}_{p}}\right)-C_{\text {nос } 2}\left(t_{T_{2}}+\frac{t_{3}}{\bar{g}_{p}}\right)+S_{\text {nep }}=\sum S_{n e p .}^{\mu-p}, \text { то }
\end{aligned}
$$




$$
\text { можна записати } \frac{2 \cdot \bar{l}_{\min }}{q_{1} \cdot \gamma_{c m_{1}}} \cdot C_{\kappa u_{1}}=\frac{2 \bar{l}_{i}}{q_{2} \cdot \gamma_{c m_{2}}} \cdot C_{\kappa u_{2}}+\frac{2 l_{\min }}{q_{2} \cdot \gamma_{c m_{2}}} \cdot C_{\kappa u_{2}}+\sum S_{n e p .}^{H-p}
$$

В результаті рішення цього рівняння мінімальна рівноцінна відстань доставки вантажу по собівартості 1тони складе:

$$
l_{\min }=\frac{\frac{2 \overline{l_{o}}}{q_{2} \cdot \gamma_{c m_{2}}} \cdot C_{\kappa u_{2}}+\sum S_{n e p .}^{\mu-p}}{\frac{2}{q_{1} \cdot \gamma_{c m_{1}}} \cdot C_{k u_{1}}-\frac{2}{q_{2} \cdot \gamma_{c m_{2}}} \cdot C_{\kappa u_{2}}}
$$

Таким чином область ефективного застосування рухомого складу при доставці вантажів кінцевим замовникам міжнародних перевезень буде залежати від витрат на 1кілометр пробігу магістрального автопоїзда та автомобілів, задіяних для доставки цих вантажів після здійснення митного контролю та митного оформлення (рис.2).

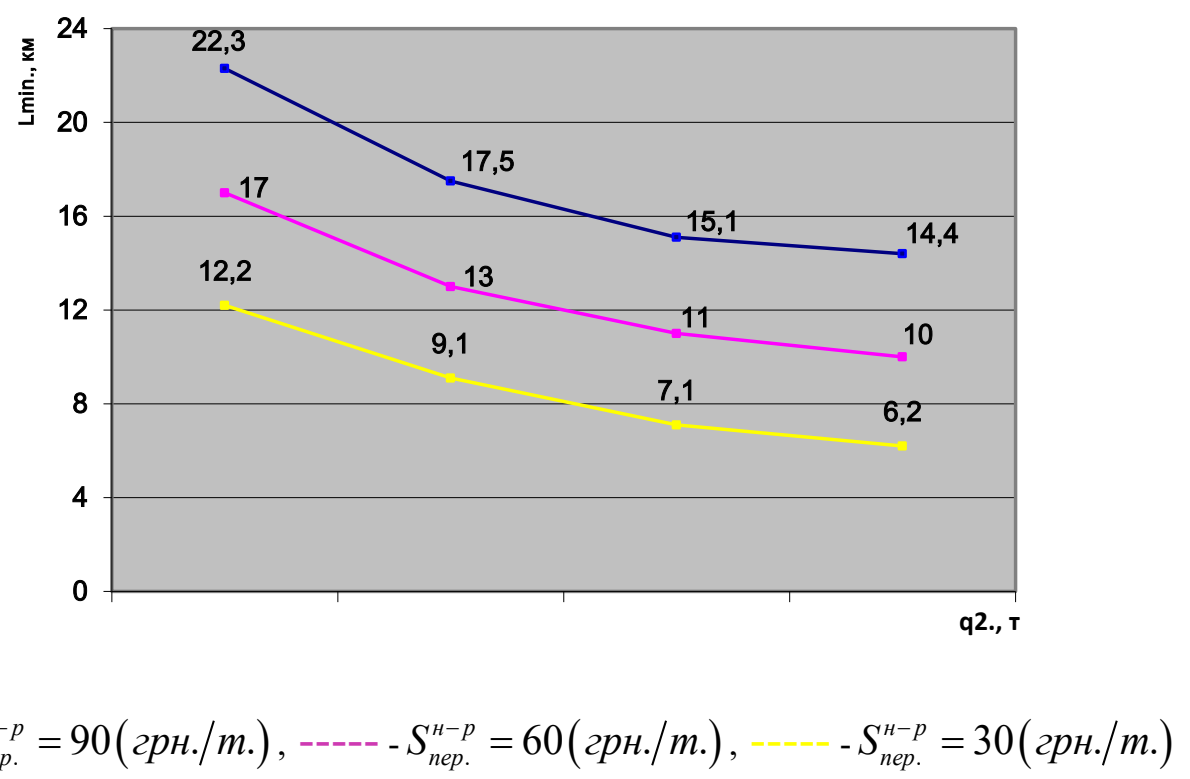

Рисунок 2. Графік залежності мінімальної відстані від вантажопідйомності рухомого складу для здійснення доставки вантажів замовникам міжнародних перевезень після перевантаження магістрального автопоїзда $\left(q_{1}=25 \mathrm{~T}\right.$, $\gamma_{c m 1}=\gamma_{c m 2}=0.8, l_{0}=5$ км, $V_{m 1}=V_{m 2}=20$ км/год, $t_{T}=0,1$ год, $t_{3}=0,05$ год).

Виходячи зі статистичних показників роботи підприємства середня вантажність магістрального автопоїзда складає 25,2 тони. Середня відстань доставки вантажу на розвізних маршрутах у 80\% випадків складає близько 20 км, середній розмір партії доставки збірного вантажу складає 3,2 тони.

При організації транспортного процесу в режимі експорт методика 
визначення раціонального варіанту доставки вантажу в міжнародному сполученні аналогічна режиму імпорт.

Слід визначити ефективний спосіб доставки збірного вантажу на митницю або маятниковими маршрутами, виходячи з партіонності відправлень, або збірним маршрутом магістрального автопоїзда.

\section{Висновки:}

- при збільшенні партіонності доставки вантажів мінімальна відстань ефективного використання доставки вантажів 3 перевантаження зменшується, а при зменшенні, навпаки збільшується;

- при зростанні витрат на перевантаження мінімальна ефективна відстань доставки партіонних вантажів маятниковими маршрутами збільшується.

Заміна розвізних маршрутів на маятникові, або навпаки, дозволить підвищити ефективність використання рухомого складу замовникам міжнародних автомобільних перевезень. 


\subsection{Modeling prerequisites for the route functioning of the passenger transport system taking into account quality criterias of passenger services and quarantine restrictions}

Urban, suburban and intercity passenger transport of various types - the backbone of the world economy. It contributes to the prosperity of many industries, including tourism, without it it is impossible to imagine either business or leisure travel [302]. However, due to measures to curb the spread of COVID-19, millions of people were forced to stay at home during severe quarantine restrictions, and passenger traffic was doomed to a partial cessation of operations. During these activities, only certain person categories were transported those who were supplied with special passes, in particular store staff, pharmacists, doctors, and police officers.

It is also important to note the sharp decline in demand for taxi operators' services on routes, observed around the world. Due to the suppression of mass events and shutdowns of catering services, as well as shops that do not sell basic necessities, consumer demands have almost completely disappeared. Some taxi operators are seeing an $80 \%$ reduction in revenue, and the good share of activity has been discontinued as a result of worldwide restrictions on transportation. Trying to adapt to new realities, many taxi operators are resourceful and take extreme measures. Some taxi companies reduce the prices of courier services, which allows in the current difficult conditions to use services for as many people as possible.

Although large passenger companies remain competitive, small and mediumsized enterprises (SMEs), which account for the majority of such companies, are on the verge of bankruptcy facing with a severe lack of revenue. Due to the suppression and restriction of the use of public transport and international transport in Europe, transport companies are experiencing revenue falls, which ranges from $50 \%$ to about $80 \%$. European passenger transport companies estimate that their losses in 2020 will reach 81 billion euros or $57 \%$ of annual revenue. Tourist (-82\%) and intercity (-70\%) suffered the most, followed by taxis (-60\%) and city buses (-42\%). Among European countries, Bulgaria (-92\%), Spain (-70\%), Sweden (-80\%) and Great Britain (-73\%) lost the most [303]. 
Recent research in Europe concerning risk of virus spreading while using public transport in compliance with the established requirements for the use of masks, gloves, special goggles and reducing unnecessary talk (silently) confirm its safety in contrast to gyms, pubs, concert halls. In particular, French scientists, having studied in Paris 150 clusters of crown viral infection, detected from May 9 to June 3, found that they were not related to public transport systems [304]. Similar conclusion was reached by researchers in such countries as Austria, Italy, Japan and others.

Therefore, in order to ensure the survival of passenger transport during the COVID-19 pandemic, it is necessary to immediately provide financial assistance. The state support program announced by the European Commission [305] is an important first step, but this example should be followed by non-EU countries, allocating funds at the national level and providing assistance to those small and medium-sized enterprises in the field of road transport, which need them the most.

Passenger transport continues to provide comprehensive support to national, regional and international measures to fight against COVID-19, but many are concerned about the risks associated with meeting the basic needs of the population in transport services. In this regard, agreed and harmonized approaches to the health of drivers and passengers must be adopted without delay.

The main announced priority is safety transportation for citizens' health. During the gradual resumption of transportations, the following measures are taken:

- encourage people to buy tickets and check in for an online flight to minimize crowds at airports;

- to reduce passengers number carried on one flight (buses, trains, steamers) to ensure safe distance if they are not members of the same family;

- mask mode and other additional safety measures in cases where it is difficult to ensure the distance; means of protection for transport staff;

- installation of protective barriers between the driver and the interior of the bus, boarding passengers through the rear door;

- ensure automatic opening of doors at transport stops so that people do not have to touch the handles / buttons; 
- antiseptics placement in transport salons and at stations;

- regular disinfection of passenger transport and improved ventilation;

- food and other goods sale prohibition during the trip to reduce contact with each other;

- to develop an algorithm for responding to the case if the passenger becomes ill during the trip or he has corona virus symptoms.

Significant factors that will affect the quality of passenger service (occupancy of the passenger compartment of vehicles and the waiting time for a passenger at a stop) will be:

1. Volumes of passenger traffic that will change under the influence of quarantine measures and after their abolition due to the fact that different focus groups will restore their transport mobility differently.

2. It is allowed to fill the interior of the vehicle in accordance with certain rules for transport services adopted by law in the country.

3. As a result of paragraphs 1, 2 the carrier will be forced to adjust the interval of vehicles on the routes, which will change the waiting time of passengers at the stop, or change such a normative indicator of the quality of passenger service as the average waiting time by passenger at the stop.

In Ukraine, during passenger transportation and the gradual easing of quarantine restrictions, it is necessary to follow the rules specified in the resolution of the Chief State Sanitary Doctor of Ukraine dated 21.05.2020 №23 "On approval of Interim recommendations for anti-epidemic measures due to the spread of coronavirus disease (COVID-19) "[306]. All passenger transportations by public urban, suburban, intercity transport (except metro) and on interregional and international routes should be carried out taking into account these recommendations, aimed to prevent the complication of the epidemic situation due to the spread of coronavirus disease (COVID-19).

It contains the following main points that directly affect the occupancy of the passenger compartment:

1. While passengers transportations, it should be maintained a distance between the driver and passengers of at least 1 meter or it should be represented by physical 
barriers (the driver's cab is isolated from the cabin, a transparent plastic partition between the driver and passengers, etc.). All crew members must be in respirators (without valve) or medical masks.

2. Passengers carriage is carried out within the number of seats provided by the technical characteristics of the passenger vehicle or specified in the vehicle registration documents, unless otherwise provided by the quarantine rules.

3 . In the case of transportation from / to a region where the mitigation of antiepidemic measures is not applied, it is allowed to transport within 50 percent of the seats number provided in technical characteristics of the vehicle or specified in the registration documents for this vehicle, providing passengers sitting with one free place next to, in front to and behind.

The main requirements for subway transportation - the presence of a protective mask or respirator, gloves and keeping of safe distance in $1.5 \mathrm{~m}(\approx 7 \mathrm{sq} . \mathrm{m}$.). To do this, on the floor of most stations applied auxiliary markings.

Simulation software approaches are used to determine the operating parameters of urban passenger transport system (UPTS). Typical stages of system research by simulation [307]:

1. Formulation of the problem, meaningful statement of the problem, research planning of the system.

2. Conceptual model development.

3. Creating a software implementation of the model.

4. Model adequacy checking.

5. Experiments and planning organization.

6 . Analysis of modeling results and decision making.

7. Registration of research results.

As a conceptual model for studying the operation of the UPTS route, it is proposed to use the mathematical apparatus of queuing systems (SMO) [308,309], in which passengers are described by transactions, stops - queues, passenger vehicles multichannel service devices with the number of channels equal to the passport capacity of mobile transport units (buses, trolleybuses, trams, river trams, metro or city 
trains). The level of detail of the description of the subject area can be taken on the following scale: one passenger - one transaction, one stop - one queue, one vehicle one multi-channel service device. In this case, the main parameters that we need to find that directly affect the quality of passenger service, in terms of QMS: the filling factor of the passenger compartment - the utilization of the multichannel device, the average waiting time of the passenger at the stop - the average time of the queue, the average number of passengers at stops - the average number of transactions in the queue [310].

An example of calculating the interval of passenger vehicles on a bus route in Kyiv (Ukraine) taking into account the quality of passenger service and man-made impact on the environment for normal (non-quarantine) conditions is given in [311].

To take into account the conditions of quarantine restrictions on the occupancy of the passenger compartment of the passenger vehicle, it is necessary in the above simulation model to take into account the restrictions on the maximum number of passengers. Performing a series of simulation runs of the model to determine the interval between flights on the route MPTS, which meets the quality of passenger services, and, accordingly, does not violate citizens' rights in receiving transport services. 


\section{7 Впровадження інтегрованого управління транскордонним співробітництвом в структуру транспортних систем}

Створення та впровадження у виробничі процеси інтегрованих митнологістичних систем останнім часом суттєво змінює структуру транспортного ринку у зв'язку з глобалізацією ланцюгів постачань, вагомим підвищенням рівня логістичних витрат та посиленням вимог щодо екологічних показників. Як наслідок, транспортування товарів призводить до зростання загальних виробничих витрат та збільшення терміну виконання замовлень на перевезення вантажів у міжнародному сполученні [312]. Тому цілком прогнозовано зростає необхідність у створенні і впровадженні окремих елементів інтегрованих митнологістичних систем у виробничі процеси транспортних організацій та користувачів комерційними і логістичними послугами.

3 такою метою була проведена диференційована оцінка готовності вітчизняного ринку транспортних послуг до гармонізації з єдиним цифровим ринком Європейського Союзу (СС). Комплексне дослідження визначило стан інфраструктури цифрового ринку, рівень існуючої регуляторної бази і якість розвитку електронних послуг для співробітництва із європейськими країнами в процедурах безпаперової торгівлі (eTrade) та в операціях електронної логістики (eLogistics). Проведена робота сприяє уніфікації національних систем міжнародного співробітництва, в тому числі для використання цифрових транспортних коридорів, відповідно до існуючих норм і практик в СС [313].

Впровадження цифрових технологій $\epsilon$ узагальнюючим результатом транскордонного співробітництва, який охоплює такі аспекти інтегрованих митно-логістичних систем, як електронна комерція, сервісні послуги митних органів та логістичне обслуговування вантажопотоків. Основною метою гармонізації в безпаперовій торгівлі є використання електронних процедур в ланцюзі постачань між Україною державами СС. А головним завданням гармонізації процедур електронної логістики в процесі обслуговування вантажопотоків міжнародного спрямування є надання точної інформації про 
місцезнаходження вантажів в будь-який момент часу на шляху від пункту відправлення до місця призначення через транзитні країни. Проведені дослідження оцінюють ступінь використання електронних документів та електронних процедур на всіх етапах ланцюга поставок між європейськими країнами. А результати виконаної роботи дозволяють провести оцінку можливості створення мультимодального транспортного коридору між Чорним i Балтійським морями 3 можливістю розширення цієї практики на інші країни [314].

Розроблена модель переміщення товарів та послуг описує основні процедури міжнародного співробітництва і включає наступні складові:

* важливість окремих елементів митно-логістичної системи для транспортної організації з точки зору іiї впливу на виробничий процес, критерії задоволення попиту споживачів, стратегію розвитку підприємства;

* можливість впливу окремих структур митно-логістичної системи щодо вільного вибору ділових партнерів, постачальників, споживачів, форм оплати тощо;

* важливість якості виконаної роботи та рівня економічних показників для окремих складових митно-логістичної системи;

* можливість інтегрованої системи задовольняти вимоги низки зацікавлених сторін.

Інтегроване управління митно-логістичними системами - це скоординована діяльність компетентних державних органів, спрямована на створення та підтримання балансу між забезпеченням належного рівня безпеки країни $\mathrm{i}$ збереженням відкритості iii економіки для законного транскордонного співробітництва. В рамках загальних вимог, що пред'являються до функціонування митно-логістичних систем, національне законодавство включає основні нормативно-правові положення щодо міжнародної торгівлі. Стратегію транскордонного співробітництва розроблено на виконання національних зобов’язань з імплементації Угоди про асоціацію між Україною, з однієї сторони, та Європейським Союзом, Європейським співтовариством з атомної енергії $\mathrm{i}$ 
їхніми державами-членами, 3 іншої сторони. Стратегія транскордонного співробітництва спрямована на реалізацію євроінтеграційного курсу розвитку України, що сприятиме збереженню стабільності у державному та міжнародному вимірах, і синхронізована із:

> Стратегією розвитку органів системи Міністерства внутрішніх справ на період до 2020 року, схваленою розпорядженням Кабінету Міністрів України від 15 листопада 2017 р. № 1023 (Офіційний вісник України, 2018 р., № 23, ст. 808).

$>$ Національною транспортною стратегією України на період до 2030 року, схваленою розпорядженням Кабінету Міністрів України від 30 травня 2018 р. № 430 (Офіційний вісник України, 2018 р., № 52, ст. 1848).

> Стратегією державної міграційної політики України на період до 2025 року, схваленою розпорядженням Кабінету Міністрів України від 12 липня 2017 p. № 482 (Офіційний вісник України, 2017 р., № 60, ст. 1837).

Стратегією інтегрованого управління кордонами на період до 2025 року, затвердженою розпорядженням Кабінету Міністрів України від 24 липня 2019 р. № 687-p.

Морською доктриною України на період до 2035 року, затвердженою постановою Кабінету Міністрів України від 7 жовтня 2009 р. № 1307 (Офіційний вісник України, 2009 р., № 94, ст. 3216; 2019 р., № 2, ст. 53).

Ситуація на державному кордоні України є контрольованою. Рівень загрози транскордонної злочинності оцінюється як помірний, проте має сталу тенденцію до зростання. Географічне розташування України робить ії привабливою для транзитного матеріальних та фінансових потоків. На кордоні регулярно здійснюються спроби незаконного переміщення товарів. Заходи, здійснені в рамках виконання Плану дій щодо лібералізації візового режиму між Україною та $€ C$, дали змогу посилити контроль в'їзду та виїзду на державному кордоні. Основними загрозами у сфері транскордонного співробітництва $є$ незаконне переміщення через кордон товарів та цінностей, ухилення від сплати установлених платежів. 
За останні п’ять років перелік зазначених загроз доповнився гібридними загрозами, які впливають на політичну та економічну обстановку в державі, безпеку і громадський порядок, а також на зростання рівня тероризму та кіберзлочинів. Зазначені загрози є транскордонними та існують на фоні складної внутрішньої ситуації: повільного розвитку прикордонної інфраструктури, високого рівня корупції, браку мотивованого та навченого персоналу, наявності проблем щодо координації та комунікації суб’єктів інтегрованого управління кордонами, обмеженого фінансування без можливості формування бюджету розвитку. Для забезпечення майбутньої оперативної та технічної взаємодії між системами інтегрованого управління митно-логістичними системами України та держав - членів СС важливо запроваджувати найкращі європейські практики та стандарти.

Модель інтегрованого управління митно-логістичними системами включає чотирирівневу систему контролю за рухом матеріальних потоків:

- у державах походження експортно-імпортних товарів та послуг;

- у державах, що межують або співробітничають з Україною;

- у пунктах пропуску через державний кордон і поза ним;

- на території власної держави.

Проведені дослідження дозволили сформулювати низку зауважень, на які необхідно звернути увагу при здійсненні митно-логістичних операцій між Україною і єдиним цифровим ринком СС [315]. За результатами досліджень основними проблемами управління митно-логістичними системами можна вважати наступні:

- невідповідність інфраструктури пунктів пропуску та під’їзних шляхів зростаючим потребам щодо пропускних спроможностей;

- періодичні ускладнення в роботі існуючих пунктів пропуску через кордон у зв'язку із сезонними та іншими змінами транскордонних транспортних потоків;

- застарілість технічних засобів контролю; 
- низька мотивація та недостатній рівень підготовки персоналу суб'єктів інтегрованого управління митно-логістичними системами, його неготовність протидіяти корупційним викликам;

- потреба у подальшому розвитку та вдосконаленні підходів до управління ризиками;

- недостатня швидкість обробки та передачі інформації, що не дає змоги вчасно реагувати на зміни в оперативній обстановці;

- необхідність продовження технічного переоснащення, нарощення процедур автоматизації процесів у сфері інтегрованого управління митнологістичними системи, запровадження європейських стандартів, забезпечення розвитку інформаційного обміну між усіма суб'єктами інтегрованого управління транскордонним співробітництвом.

Значну підтримку Україні у цьому надають:

- Представництво СС в Україні;

- Консультативна місія $\mathrm{CC}$;

- Місія ЄС з прикордонної допомоги Молдові та Україні.

Вони здійснюють моніторингову функцію, надають консультативну, дорадчу та технічну підтримку, спрямовану на розвиток інтегрованого управління кордонами, удосконалення взаємодії між суб'єктами інтегрованого управління кордонами в Україні та активізацію їх співпраці з іноземними партнерами. Співпраця з СС в цілому забезпечує контрольованість спільних кордонів та розвиток торговельних зв'язків.

Тому розвиток співробітництва 3 іншими державами та міжнародними організаціями насамперед спрямований на запобігання транскордонній злочинності. В рамках співпраці з ОБСЄ суб'єкти інтегрованого управління кордонами беруть активну участь в реалізації спільних проектів щодо підвищення спроможностей у протидії тероризму, виявленню зброї, боєприпасів, небезпечних хімічних речовин та розвитку аналізу ризиків. 
Проведений аналіз дає можливість сформулювати рекомендації у формі «дорожньої карти», яка містить комплекс заходів, необхідних для розвитку та удосконалення міжнародного співробітництва між Україною та єдиним цифровим ринком ЄС. За результатами всебічної оцінки поточного стану і практики інтегрованого управління митно-логістичними системи в Україні було запропоновано комплекс заходів, який адаптованний до політичної, економічної та соціальної ситуації в державі та враховує можливість появи нових загроз. 


\section{8 Аналіз напруженості роботи водіїв автобусів в містах}

Особливістю роботи водія міських автобусних перевезень $є$ висока напруженість праці, робота за змінними графіками, в тому числі в нічну зміну. У результаті проведених досліджень, встановлено, що кількість дорожньотранспортних пригод залежить від часу, в продовж якого водій керує транспортним засобом. Таке явище визначається динамікою працездатності водія, що залежить від виду перевезень. Планування робочого дня водія має велике значення для підвищення надійності їх роботи і передбачає розроблення раціональних режимів праці і відпочинку [316].

Раціональний режим праці і відпочинку - це послідовність роботи і перерв, що встановлюються на основі аналізу працездатності 3 метою забезпечення високої продуктивності праці і відпочинку працівників. 3 фізіологічних позицій режим праці та відпочинку являє собою процес управління функціональним станом працівника з метою оптимізації його діяльності. Крім того, до чинників напруженості праці операторів динамічних об'єктів можна віднести високу ступінь особистої відповідальності за життя людей і збереження транспортного засобу, постійне очікування аварійної ситуації, необхідність приймати рішення в умовах дефіциту часу, шум і вібрацію, значну фізичну та нервову напругу [317, 316].

Фізичні та психофізіологічні вимоги до водіїв міського пасажирського транспорту можуть бути визначені на основі аналізу діяльності водія міського автобусного маршруту. Водій міського автобусного маршруту повинен сприймати велику кількість інформації про характер і режимі руху всіх його учасників, про стан значної кількості параметрів дороги, навколишнього середовища, засобів регулювання, про стан вузлів і агрегатів автомобіля (за допомогою різних приладів), тощо. Водій на міських автобусних маршрутах повинен не тільки сприймати великий потік інформації, але і проводити іiі переробку (аналіз), в результаті чого приймати відповідне рішення і на його підставі виконувати дії для реагування на конкретну ситуацію. Весь цей процес 
від сприйняття до вчинення дії вимагає певної витрати часу. 3 огляду на швидкоплинність дорожньо-транспортної ситуації, що склалася, водій може зробити неправильні дії. До них призводять причини, наведені на малюнку 1.

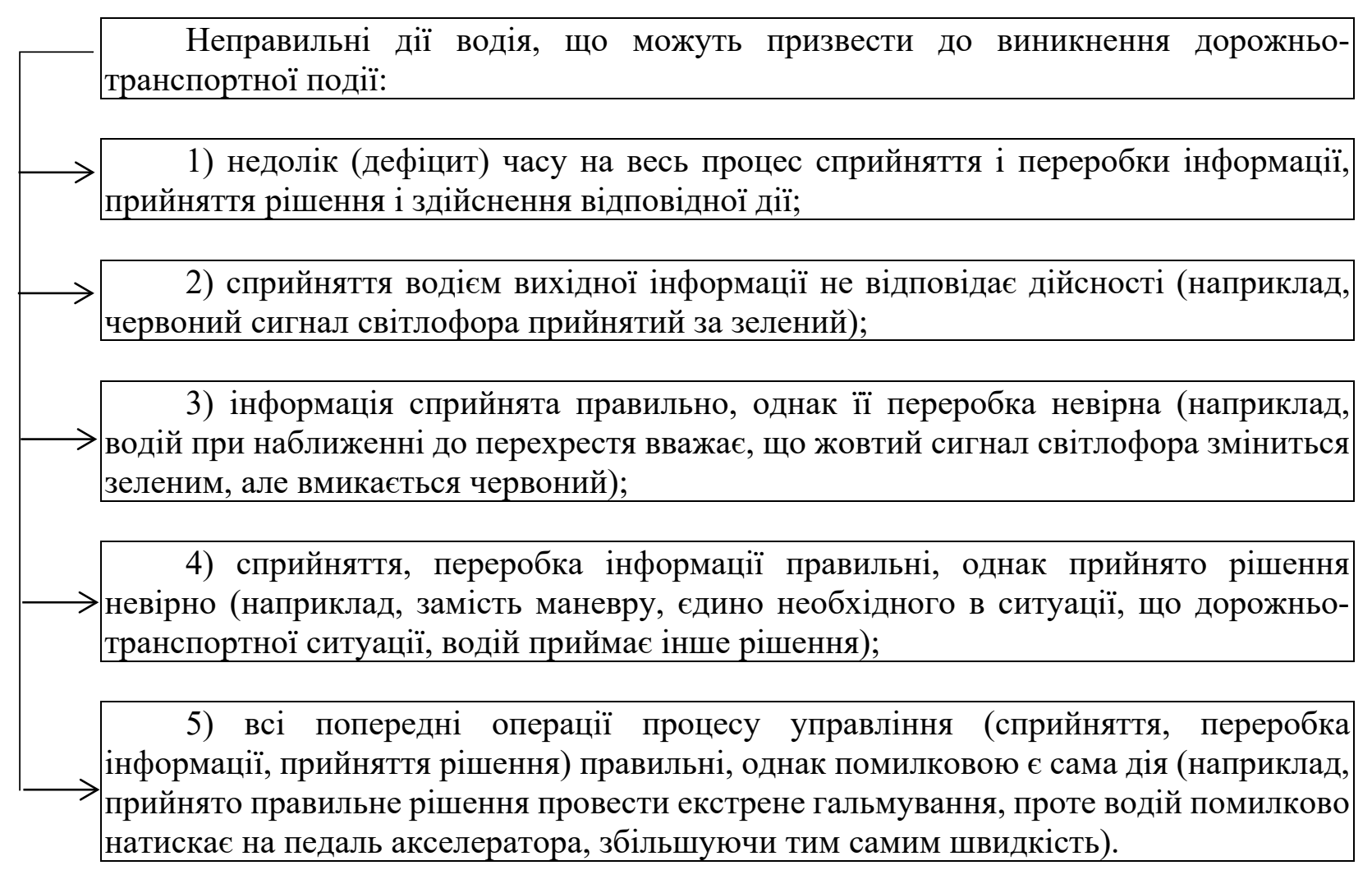

Малюнок 1. Неправильні дії водія, що можуть призвести до виникнення дорожньо-транспортної події

Необхідно відзначити, що перераховані причини можуть з'явитися, крім того, наслідком психічного стану водія в даний момент. Ось чому водієві при управлінні на міських автобусних маршрутах важливо зберігати тривалий час врівноважений психічний стан, при якому найбільш швидко і якісно протікає весь процес від сприйняття інформації до здійснення відповідних дій в постійно мінливих дорожньо-транспортних ситуаціях. Відхилення в той чи інший бік від врівноваженого психічного стану (збудження чи, навпаки, депресія) ускладнюють процес сприйняття і переробки інформації і тим самим збільшують 
ймовірність помилкових дій водія. Саме тому психічні особливості водія мають велике значення для продуктивної та безаварійної роботи.

Для правильного розуміння індивідуально-психологічних особливостей водія недостатньо тільки вивчення окремих психічних процесів, необхідне знання психічних властивостей, які характеризують людину як особистість. Адже особистість складається з великого різноманіття якостей, взаємопов'язаних між собою.

Це - здібності, інтереси, темперамент, характер, схильності, ставлення до своєї професії і іншим видам діяльності, до громадської роботи, тощо. Особистісні якості водія багато в чому визначають його професійні якості, що підтверджується виразом "Людина керує автомобілем так, як вона живе" [318].

Керування автомобілем вимагає від людини витримування такого безпечного режиму руху, який враховував би постійну зміну ситуації.

Мислення - це психічний процес відображення об'єктивної реальності, який є вищим ступенем людською пізнання [319]. Мислення нерозривно пов'язане 3 відчуттями, сприйняттями, пам'яттю, уявою. Найважливіша роль мислення i полягає в упорядкуванні, координації та синтезі цих процесів. У процесі мислення приймається ряд рішень, наслідком яких є виконання певних дій. Для водіїв важлива швидкість мислення, так як рішення і наступні за ними дії повинні проводитися тим швидше, чим вище швидкість руху автомобіля. Одночасно 3 цим у водія повинна бути розвинена широта мислення, тобто, здатність, що дозволяє одночасно врахувати різні сторони дорожньої обстановки і відповідно до неї оцінити наявні можливості. Ця здатність, що залежить від того, яка кількість вражень, органів почуттів і знань можливо використовувати в мисленні для обгрунтування висновків, особливо важлива, коли у водія $є$ можливість вибору між різними діями. У цих випадках особливого значення набувають пам'ять і навички водія. Набутий досвід, закарбований в пам'яті, дозволяє відтворити відомості, необхідні для вчинення дії в даному конкретному випадку, а навик дозволяє зробити ці дії без осмислення кожної складової руху, тобто, автоматично. Це дає можливість, особливо в умовах гострого дефіциту часу 
(критична чи аварійна ситуація), заощадити необхідні частки секунди. У людини, що автоматично виконує свою роботу, можуть виникнути психічні процеси, не пов'язані з роботою. У пам'яті можуть відбуватися одночасно два різних процеси: один пов'язаний з роботою, а другий, навпаки, відволікає від неї. Від свідомості водія, від його вміння керувати психічним станом залежить, наскільки він зможе використовувати цю властивість для полегшення своєї праці.

Разом 3 цим важливу роль відіграє здатність водія до прогнозування подальшого розвитку дорожньо-транспортної ситуації. I чим більшою здатністю до передбачення володіє водій, тим менше ймовірність його потрапляння в аварійну ситуацію.

Дуже велике значення в діяльності водія, що визначає в багатьох випадках правильність і точність його дій, має його емоційний стан.

Як показує аналіз дорожньо-транспортних подій, безпека руху залежить від надійності водія і в значній мірі визначається його оперативними якостями [320].

Найбільш важливими з них є наступні: висока емоційна стійкість, що забезпечує необхідний ступінь урівноваженості; швидка кмітливість в поєднанні 3 хорошою координацією, достатньою швидкістю і точністю рухових реакцій; велика швидкість перемикання і розподілу уваги; висока готовність пам'яті, від якої залежить швидше надання інформації, необхідної для виконання цілеспрямованих дій. Всі ці якості в реальній діяльності проявляються в тісній взаємодії і єдності, а їх фізіологічною основою є сила, врівноваженість i швидкість нервових процесів кори головного мозку людини.

Внаслідок цього, при організації праці водіїв необхідно неухильно дотримуватися встановленого нормованого режиму праці та відпочинку, правильного чергування ранкових, денних і вечірніх змін роботи, не допускати фізичної перевтоми водіїв через понаднормові роботи [317].

Особливістю роботи водіїв автобусів є наявність понаднормових робіт і велика питома вага часу безпосереднього керування автомобілем по відношенню до загальної тривалості робочої зміни - в середньому $9+1,4$ ч. 3 усіх водіїв, які 
працюють на транспорті, найбільше навантаження для нервової системи мають водії міського пасажирського транспорту [321].

Ефективне функціонування системи напівавтоматичного управління можливе лише за умови злагодженої роботи їі обох ланок - людини і машини. Під злагодженою роботою можна мати на увазі працездатність оператора, однак вона не є постійною величиною, а зміна функціонального стану людини може знизити його надійність і привести систему до повного розбалансування. У зв'язку з цим виникає необхідність постійного контролю над станом оператора [321].

Допустима тривалість робочої зміни визначається тим моментом часу, коли відбувається значне погіршення досліджуваних показників у порівнянні 3 тими, які були на початку фази стійкої працездатності операторів [322, 323]. За рекомендаціями фізіологів час роботи має визначатися іiі інтенсивністю. Одні пропонують визначати тривалість робочої зміни виходячи 3 нормального числа робочих годин водія в даному місяці, їх кількості в бригаді, загальної кількості робочих змін на закріплених транспортних засобах, інші - на основі місячного балансу робочого часу - не більше 178 годин або від 155-185 годин для семигодинного робочого дня, треті - на основі тривалості робочого часу водіїв за тиждень - 40 годин [326] або 41 годину [324, 325]. При понаднормових роботах тривалість робочого тижня не повинна перевищувати 48 годин [326]. Крім того, дослідниками наголошується, що час перебування водія за кермом не повинен перевищувати $7-8$ годин на добу, через кожні 2 години мають надаватися перерви в роботі тривалістю 15 хвилин. Це правило поширюється на водіїв автомобілів вантажопідйомністю більше 3,5 т та автобусів місткістю більше 9 осіб, включаючи водія.

Підтримка на необхідному рівні стан людино-машинної системи можливо за рахунок постійного контролю над їі ланками [321]. Контролювати стан людини можливо за допомогою оцінки функціонального стану його організму. Таким чином, раніше виконані дослідження визначили рекомендації 3 планування режимів праці та відпочинку водіїв. Однак вони не враховують 
THEORETICAL ASPECTS OF MODERN ENGINEERING

напруженість роботи водія на маршруті, яка істотним чином впливає на ефективність роботи водія та якість обслуговування пасажирів. 


\section{SECTION 15. METROLOGY, STANDARDIZATION AND CONFORMITY ASSESSMENT}

\subsection{International comparisons gas volume and volume flow rate standards}

Протягом 2019 - 2020 років в рамках діяльності Технічного комітету ТК 1.4 «Витратометрія» міжнародної організації з питань співробітництва державних метрологічних організацій КООМЕТ, ДП «ІваноФранківськстандартметрологія» як науковий метрологічний центр, який забезпечує збереження та застосування національних первинних та вторинних еталонів одиниць об'єму та об'ємної витрати газу, прийняв участь у міжнародних звіреннях еталонів за темою COOMET.M.FF-S9 680/RU/16 «Звірення національних еталонів в області витрати і об'єму газу в діапазоні від 20 до $6500 \mathrm{~m}^{3} /$ год» [327]. Звірення проводились 3 метою встановлення ступеня еквівалентності національних еталонів витрати газу та оцінки вимірювальних та калібрувальних можливостей лабораторій наукових метрологічних центрів в галузі витратометрії. Слід відзначити, що успішне проходження міжнародних звірень та підтвердження заявленого значення розширеної невизначеності $€$ обов'язковою умовою визнання еталонів, які забезпечують відтворення та передавання фізичних одиниць та, відповідно, внесення їхніх метрологічних характеристик до Бази даних (KCDB) вимірювальних та калібрувальних можливостей (CMC) Міжнародного бюро мір та ваг (BIPM). Крім того, для еталонів, які внесені в Базу даних КCDB та володіють СMC - рядками необхідно періодично приймати участь у міжнародних звіреннях для підтвердження своїх метрологічних характеристик.

ДП «Івано-Франківськстандартметрологія» після успішного проходження звірень за темою COOMET.M.FF-S1 219/SK-a/00 (Level A, Level B) занесено 3 СМС - рядки в діапазоні об'ємної витрати газу від $0,016 \mathrm{~m}^{3} /$ год до $1600 \mathrm{~m}^{3} /$ год (UA1 - UA3). Крім того, прийнято успішно участь та підтверджено занесені СМС 
- рядки в наступних звіреннях: COOMET.M.FF-S3 412/UA/07, CCM.FF.K6b.2011, COOMET 684/MD/16, COOMET.M.FF-S5 585/UA/12.

На етапі формування технічного протоколу між науковими метрологічними центрами за темою звірень COOMET.M.FF-S9 680/RU/16 встановлено наступних учасників: Фізико-технічний інститут (РТВ, м. Брауншвеіг, Німеччина), ДП «Івано-Франківськстандартметрологія» (Україна), Всеросійський інститут витратометрії (ВНИИР, м. Казань, Росія), Білоруський державний інститут метрології (БелГИМ, м. Мінськ, Білорусія), Литовський енергетичний інститут (LEI, м. Каунас, Литва), Метрологічна лабораторії «Сараєвогаз» (LABSAGAS, м. Сараєво, Боснія і Герцеговина). Тип звірень за вказаною темою - круговий, тобто еталонні лічильники транспортуються послідовно з однієї лабораторії в іншу для проведення вимірювань усіма учасниками звірень. Важливим етапом звірень $\epsilon$ визначення незалежних та залежних, тобто простежуваних лабораторій учасників. Умовою незалежності є наявність в лабораторії первинного еталона, який реалізує процедуру відтворення одиниць об'єму та об'ємної витрати газу шляхом забезпечення простежуваності до базових одиниць системи CI. Результати вимірювань, отримані під час звірень в незалежних лабораторіях використовуються для розрахунку опорного значення (reference value $-R V$ ). Незалежними лабораторіями - учасниками є: Німеччина (РТВ), Україна (ДП «Івано-Франківськстандартметрологія»), Росія (ВНИИР). Залежними учасниками є ті лабораторії, які отримують одиницю, тобто простежуються до первинних еталонів інших країн. Білорусія (БелГИМ) простежується до Німеччини (PTB), Литва (LEI) простежується до Німеччини (PTB), Боснія i Герцеговина (LABSAGAS) простежується до Чехії (CMI).

В якості еталонних лічильників для проведення міжнародних звірень було обрано два лічильника: еталонний лічильник роторного типу IRM-A-DUO G250 для досліджень в діапазоні об'ємної витрати газу від 20 м³/год до 400 м³/год та еталонний лічильник турбінного типу TRZ G4000 для досліджень в діапазоні об'ємної витрати газу від 320 м³/год до 6500 м³/год. Зовнішній вигляд еталонних лічильників представлений на рис. 1. 


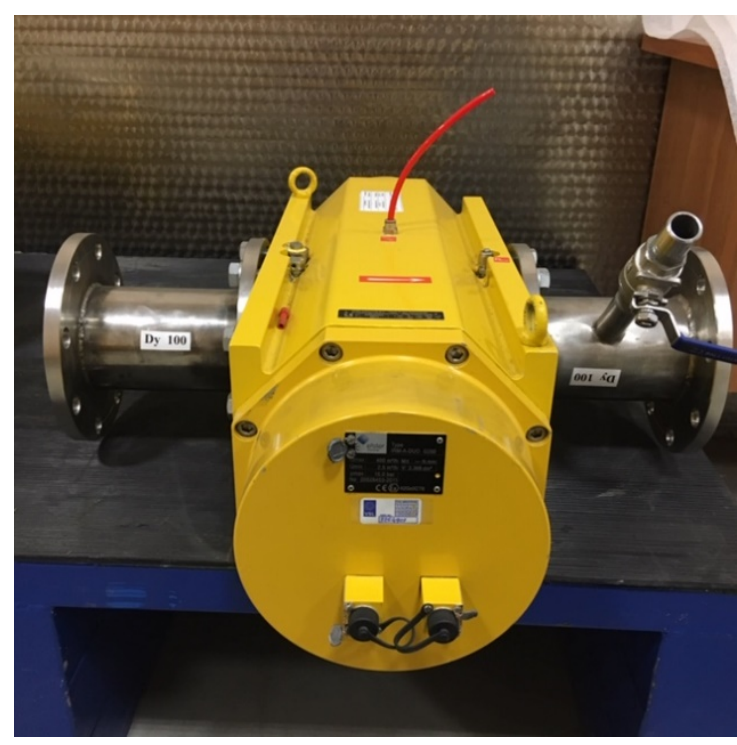

a)

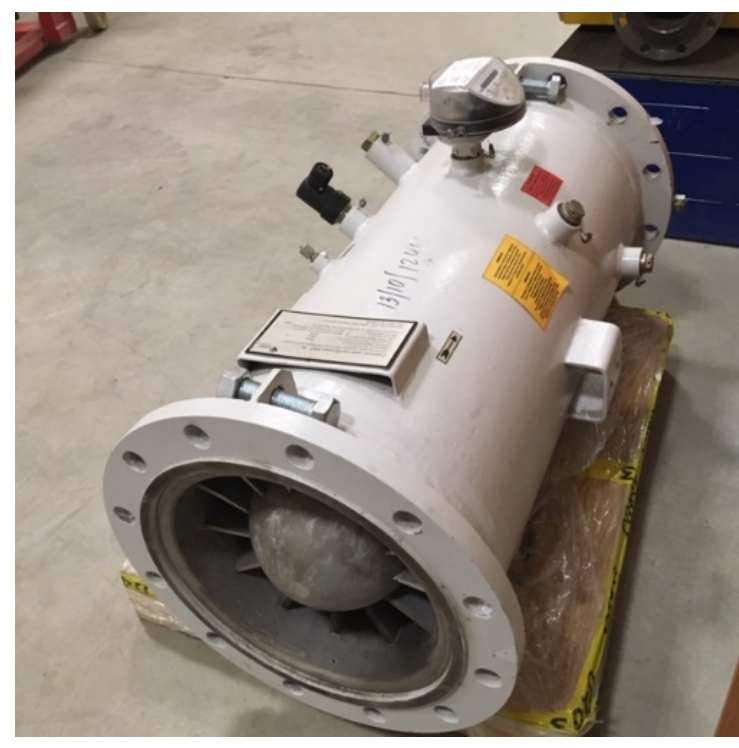

б)

Рис. 1 - Зовнішній вигляд еталонних лічильників для проведення міжнародних звірень за темою COOMET.M.FF-S9 680/RU/16 (a - роторний IRM-A-DUO G250, б - турбінний TRZ G4000)

Вимірювання, які проводились за даною темою міжнародних звірень, в ДП «Івано-Франківськстандартметрологія» проводились на: національному державному первинному еталоні одиниць об'єму та об'ємної витрати газу ДЕТУ 03-01-15 та на вторинних еталонах одиниць об'єму та об'ємної витрати газу BETУ 03-01-03-11 i BETУ 03-01-04-12.

Державний первинний еталон являє собою установку дзвонового типу [328], яка реалізує відтворення одиниць об'єму та об'ємної витрати газу шляхом витіснення $з$ дзвонового мірника порції повітря, приведеної до стандартних умов, об’єм якої чітко визначений шляхом забезпечення стабільності геометричних параметрів мірника: діаметра та висоти. Відтворення одиниці об'ємної витрати газу, в свою чергу, реалізується при умові стабільного вертикального переміщення дзвонового мірника з різним значенням заданої швидкості за певний часовий проміжок. В рамках проведення звірень, дослідження здійснювались із застосуванням лічильника IRM-A-DUO в діапазоні об'ємної витрати газу від 4 м³/год до 200 м³/год в межах підтвердження 
CMC - рядка UA1. На рис. 2 наведений зовнішній вигляд державного первинного еталона.

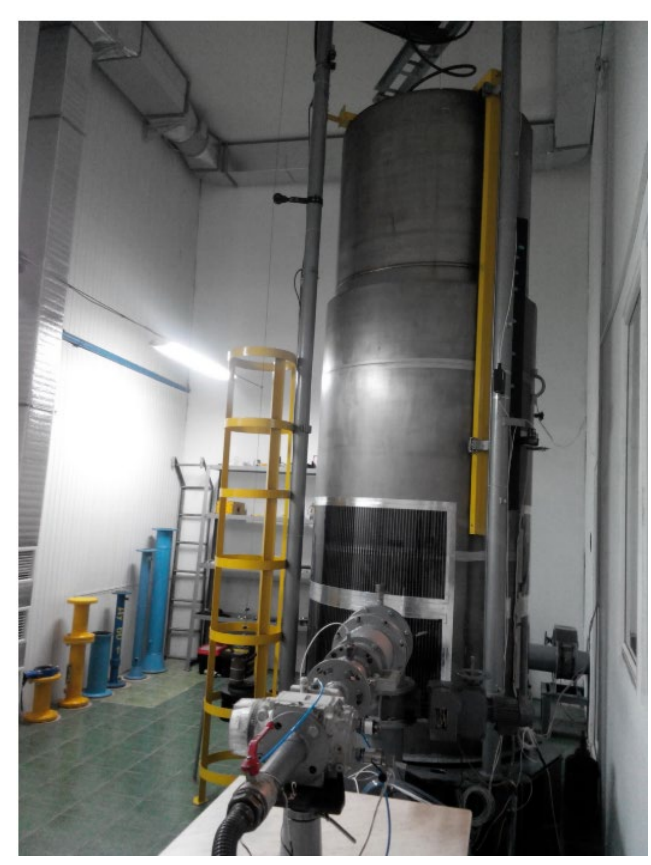

Рис. 2 - Загальний вигляд державного первинного еталона одиниць об'єму та об'ємної витрати газу ДЕТУ 03-01-15

Для проведення досліджень в діапазоні об'ємної витрати газу до максимального значення $6500 \mathrm{~m}^{3} /$ год застосовувалися вторинні еталони ВЕТУ 03-01-03-11 і ВЕТУ 03-01-04-12. Вторинні еталони функціонально об'єднані в одну еталонну установку [329]. Принцип робота установки побудований з використанням методу сумування або ж накопичення значення об’ємної витрати газу, шляхом застосування в складі установки наборів паралельно встановлених спеціалізованих еталонних лічильників, кожен з яких отримує одиницю об'єму та об'ємної витрати газу шляхом індивідуального калібрування безпосередньо на державному первинному еталоні ДЕТУ 03-01-15 або від набору аналогічних ідентичних еталонів порівняння, які в свою чергу також застосовуються паралельно для отримання необхідного значення об'ємної витрати газу. В склад установки входять дев'ять еталонних лічильників газу. На рис. 3 показаний зовнішній вигляд вторинних еталонів. 


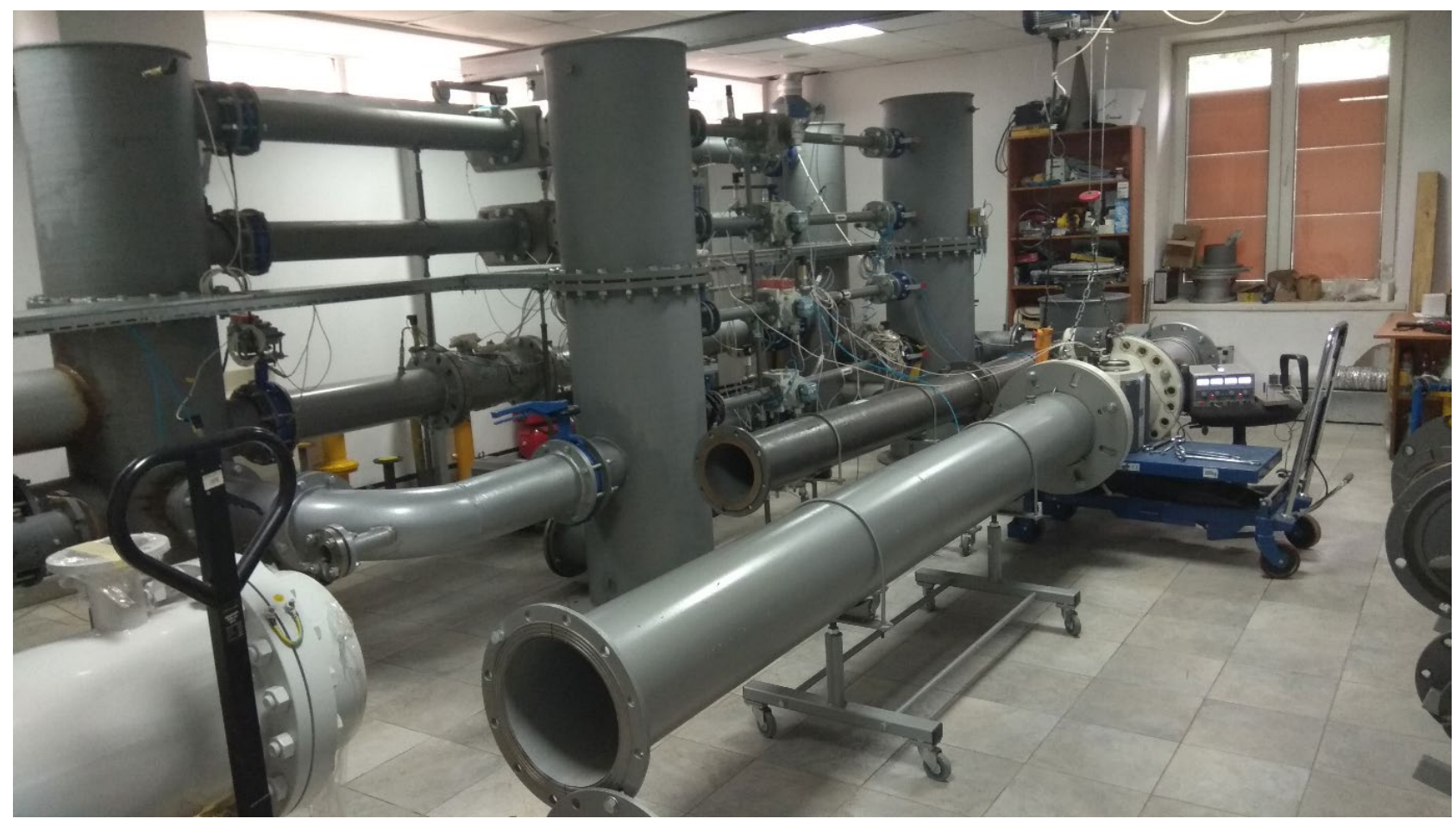

Рис. 3 - Вторинні еталони одиниць об’єму та об'ємної витрати газу в діапазоні об'ємної витрати газу від 1 м³/год до 7800 м³/год

Індивідуальна калібрувальна характеристика кожного еталонного лічильника, який входить в склад вторинних еталонів, апроксимується поліномом другого порядку виду:

$$
\delta_{N}(q)=A_{-2} q^{-2}+A_{-1} q^{-1}+A_{0}+A_{1} q^{1}+A_{2} q^{2}
$$

де $A_{i}$ - коефіцієнти апроксимаційного полінома, які визначаються за результатами калібрування;

$q$ - значення об'ємної витрати.

Сумарний об'єм еталонної установки, приведений до стандартних умов $V_{E}$, 3 врахуванням індивідуальної поліноміальної характеристики еталонних лічильників розраховується за формулою:

$$
V_{E}=\sum_{i}^{n}\left(\frac{V_{N, i}}{1+\frac{\delta_{N, i}}{100}} \cdot \frac{P_{N, i} \cdot 293,15 \mathrm{~K}}{T_{N, i} \cdot 101,325 \mathrm{~Pa}}\right),
$$

де $\quad V_{N}-$ об'єм виміряний $i$-им еталонним лічильником; 
$P_{N}$ - абсолютне значення тиску на і-му еталонному лічильнику;

$T_{N}$ - значення температури на і-му еталонному лічильнику.

Оброблення результатів вимірювань під час проведення міжнародних звірень здійснювалось наступних чином: відносне відхилення $x_{i}$ визначається як різниця між значенням об’єму, отриманого за результатами досліджень еталонного лічильника $V_{M}$ та об'єму еталона $V_{E}$, приведеного до значення об'єму, яке відтворює еталон, тобто:

$$
x_{i}=\frac{V_{M}-V_{E}}{V_{E}} \cdot 100
$$

Розширену невизначеність вимірювань для кожного значення об'ємної витрати газу $U_{M i}$ розраховують за наступною формулою:

$$
U_{M i}=\sqrt{U_{E}^{2}+2 \cdot\left(u_{A M}\right)^{2}},
$$

де $U_{E}$ - розширена невизначеність, з якою відтворюється значення об'ємної витрати газу,

$u_{A M}$ - невизначеність по типу А еталонного лічильника, дослідження якого проводиться на еталоні.

Після проведених відповідних розрахунків, визначається успішність проходження звірень лабораторіями - учасниками. Основним критерієм для оцінки є параметр ступеня еквівалентності (Degree of Equivalence) $E_{N}$, який розраховується наступним чином:

$$
E_{N i}=\left|\frac{d_{i}}{U\left(d_{i}\right)}\right|
$$

де $d_{i}$ - різниця значень між відхиленням $x_{i}$ та опорним значенням $y_{i}(R V)$, яке визначається як середньозважене значення результатів вимірювань незалежних лабораторій за методикою, описаною в [330];

$U\left(d_{i}\right)$ - значення розширеної невизначеності, яке визначається на основі розширеної невизначеності відтворення одиниць об’єму та об'ємної витрати газу національними еталонами незалежних лабораторій - учасників звірень. 
Отримані значення ступеня еквівалентності $E_{N}$ для кожного значення об'ємної витрати газу повинні знаходитися в межах $E_{N} \leq 1$, що свідчить про успішність проходження звірень. У разі перевищення значення $E_{N}>1,2$ можна стверджувати, що результати проходження звірень $є$ негативними і значення, які отримані при дослідженні на еталоні лабораторії - учасника звірень потребують негайного корегування. У разі знаходження результатів в інтервалі $l<E_{N} \leq 1,2$ вважається, що існують загальні некритичні недоліки, які потребують корегування.

На рис. 4 - 5 наведені результати міжнародних звірень лабораторій учасників відносно опорного значення $y(R V)$, розрахованого на основі досліджень незалежних лабораторій, первинні еталони яких забезпечують відтворення одиниць об'єму та об'ємної витрати газу.

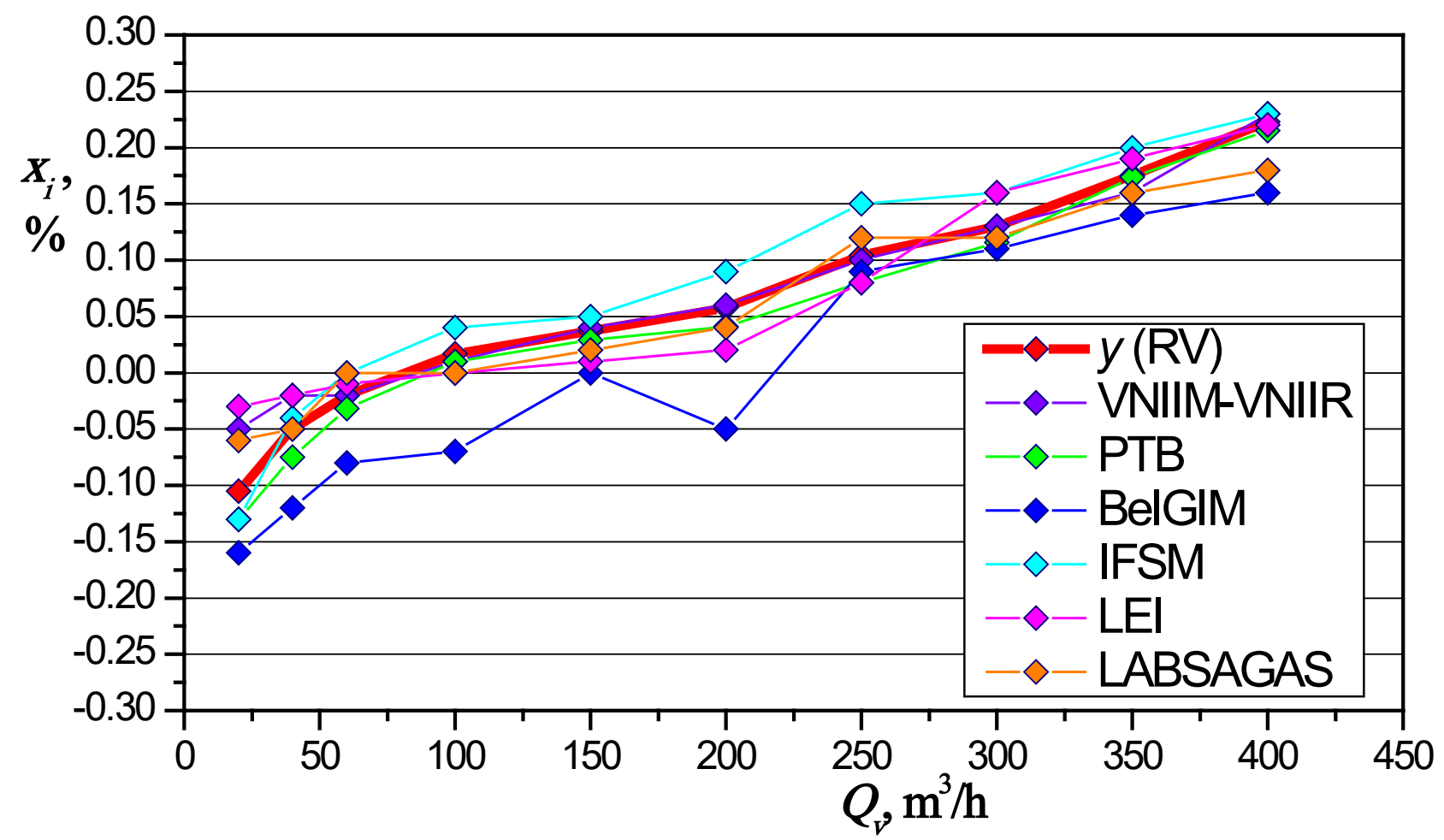

Рис. 4 - Зведені результати міжнародних звірень за темою COOMET.M.FFS9 680/RU/16 в діапазоні об'ємної витрати газу від 20 м³/год до 400 м³/год для еталонного лічильника IRM-A-DUO G250 


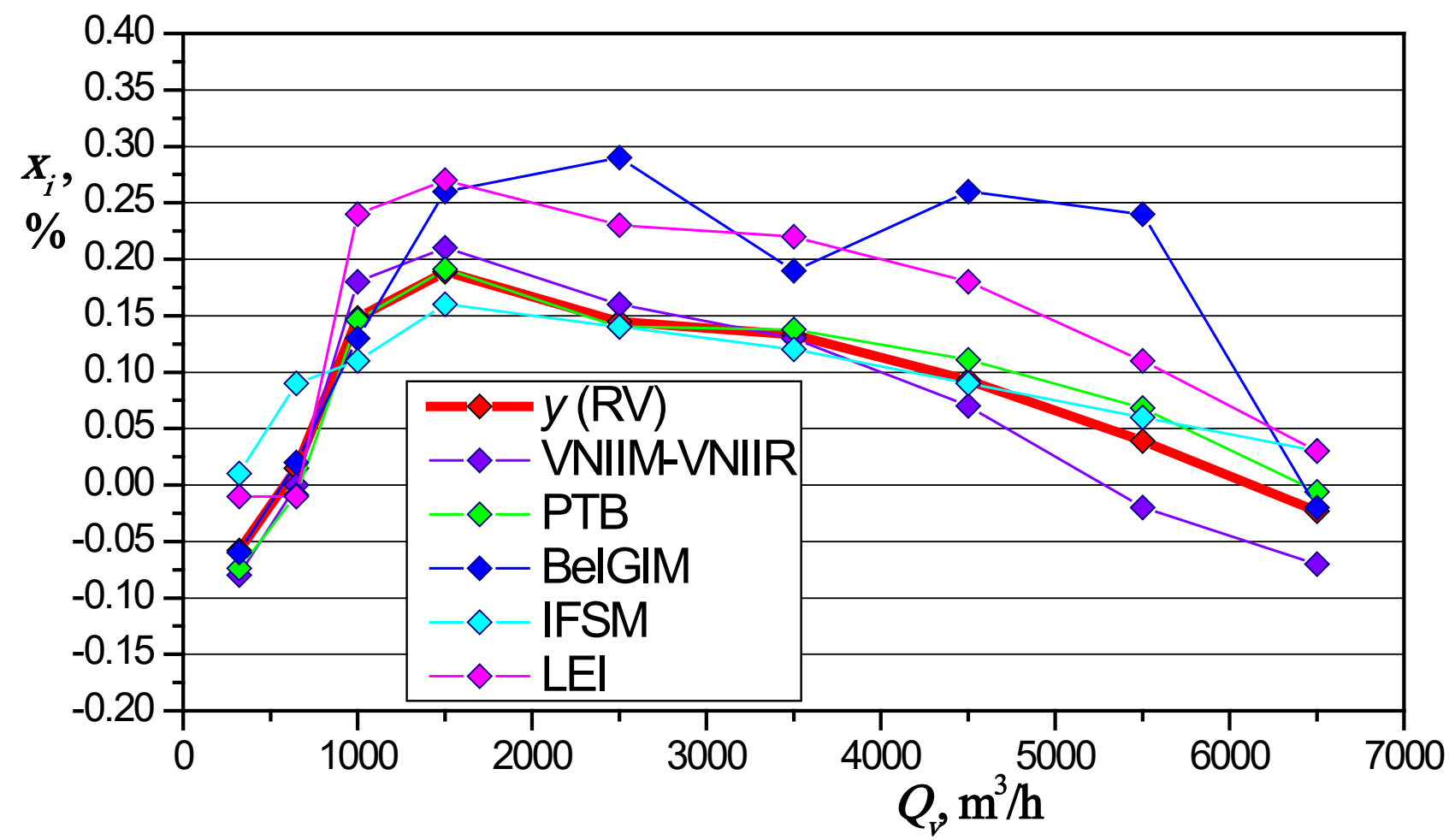

Рис. 5 - Зведені результати міжнародних звірень за темою COOMET.M.FFS9 680/RU/16 в діапазоні об'ємної витрати газу від 320 м³/год до 6500 м³/год для еталонного лічильника TRZ G4000

В таблицях 1 - 2 наведені результати розрахунку ступеню еквівалентності $E_{N}$ національного первинного еталона одиниць об'єму та об'ємної витрати газу ДЕТУ 03-01-15 та вторинних еталонів ВЕТУ 03-01-03-11 та ВЕТУ 03-01-04-12, які зберігаються в ДП «Івано-Франківськстандартметрологія».

Таблиця 1 - Результати звірень в діапазоні $20-400 \mathrm{~m}^{3} /$ год

\begin{tabular}{|c|c|l|}
\hline $\begin{array}{c}\text { Об’ємна } \\
\text { витрата, } \text { }^{3} / \text { год }\end{array}$ & $E_{N}$ & Результат \\
\hline 400 & 0.06 & Успішно \\
\hline 350 & 0.23 & Успішно \\
\hline 300 & 0.28 & Успішно \\
\hline 250 & 0.48 & Успішно \\
\hline
\end{tabular}

Таблиця 2 - Результати звірень в діапазоні $320-6500 \mathrm{~m}^{3} /$ год

\begin{tabular}{|c|c|l|}
\hline $\begin{array}{c}\text { Об'ємна } \\
\text { витрата, } \mathbf{m}^{3} / \text { год }\end{array}$ & $E_{N}$ & Результат \\
\hline 6500 & 0.51 & Успішно \\
\hline 5500 & 0.19 & Успішно \\
\hline 4500 & 0.03 & Успішно \\
\hline 3500 & 0.12 & Успішно \\
\hline
\end{tabular}




\begin{tabular}{|c|c|c|}
\hline 200 & 0.33 & Успішно \\
\hline 150 & 0.13 & Успішно \\
\hline 100 & 0.23 & Успішно \\
\hline 60 & 0.20 & Успішно \\
\hline 40 & 0.10 & Успішно \\
\hline 20 & 0.26 & Успішно \\
\hline Макс. зна & 0.48 & \\
\hline
\end{tabular}

\begin{tabular}{|c|c|c|}
\hline 2500 & 0.05 & Успішно \\
\hline 1500 & 0.27 & Успішно \\
\hline 1000 & 0.35 & Успішно \\
\hline 650 & 0.69 & Успішно \\
\hline 320 & 0.64 & Успішно \\
\hline Макс. знач. & 0.69 & \multicolumn{1}{|c}{} \\
\cline { 1 - 2 } & \multicolumn{2}{|l}{} \\
\cline { 1 - 2 } & \multicolumn{2}{|l}{} \\
\cline { 1 - 2 } & &
\end{tabular}

Висновок. За результатами участі в міжнародних звіреннях за темою COOMET.M.FF-S9 680/RU/16 «Звірення національних еталонів в області витрати і об'єму газу в діапазоні від 20 до 6500 м³/год» можна стверджувати, що національний первинний еталон одиниць об'єму та об'ємної витрати газу ДЕТУ 03-01-15 та вторинні еталони ВЕТУ 03-01-03-11 і ВЕТУ 03-01-04-12, які зберігаються та застосовуються в науковому метрологічному центрі ДП «ІваноФранківськстандартметрологія» еквівалентні національним еталонам інших лабораторій країн - учасників міжнародних звірень та $є$ підставою для розширення кількості СМС - рядків в діапазоні об'ємної витрати газу до $7800 \mathrm{M}^{3} /$ год. 


\section{REFERENCES}

1. Бусел ВТ (ред.) 2005- VIII, Великий тлумачний словник сучасної української мови, Ірпінь: Перун - Київ.

2. Вадимов В, 2003, Еколого-планувальна етика організації архітектурного середовища та ідеологічні установи, Вісник Національного університету «Львівська політехніка». Архітектура. № 486, с. 235-240.

3. Лоїк Г, Шульга Ю, 2003, Село та українська архітектурна традиція, Вісник Національного університету «Львівська політехніка».Архітектура.№ 486 , c. $348-359$.

4. Історія села Наварія [Електронний ресурс. - Режим доступу: http://pustomyty-miskarada.gov.ua/selo-navariya/istoriya-sela [17.09.2020]

5. Історія села Брахівка [Електронний ресурс]. - Режим доступу: https://uk.wikipedia.org/wiki/Брахівка. [20.09.2020].

6. Мигаль С, Дида I, Казанцева Т. 2013, Методологічні концепції ландшафтного дизайну та їх еволюція в сучасних умовах, Вісник Національного університету «Львівська політехніка». Архітектура. № 757, с.355-363.

7. Топилко C, 2003, Архітектурно-планувальна структура містечок Галичини, закладених у другій половині XVI XVII століттях. Автореферат дис. канд. арх. Національний університет у «Львівська політехніка», Львів.

8. State sanitary norms and rules. Hygienic requirements for drinking water,intended for human consumption: DSanPiN 2.2.4-171-10 - K. - 2010. (Normative directive legal documents).

9. Kolotilo VD Grain filters for drinking water preparation / V.D. Kolotilo, V.O. Orlov - Kharkiv: Factor, 2004. - 256 p.

10. Water defferrization in polystyrene foam filters with sediment layer / V. Orlov, S. Martynov, S. Kunitsky. - Saarbrucken, Deutschland: LAP LAMBERT Academic Publishing, 2016. - p.94.

11. Martynov S. A Simulation study of surface water purifying through a polystyrene foam filter/ S. Martynov, S. Kunitskiy, A. Orlova // Eastern European 
Journal of Enterprise Technologies. ECOLOGY - VOL 5, NO 10 (89) (2017). - P. 1926 (Scopus).

12. Енергозбереження у житловому фонді: проблеми, практика, перспективи: Довідник / "НДІпроектреконструкція", Deutsche Energie-Agentur GmbH (dena), Instituts Wohnen und Umwelt GmbH (IWU), 2006. - 144 c.

13. Дешко B.І., Білоус І.Ю. Математичні моделі будівель для оцінки енергоспоживання. Всеукраїнська науково-технічна конференція «Енергоефективність у будівництві. Сучасні конструктивні системи, ефективні матеріали та інженерне обладнання»(5 березня 2014 р., м.Київ). Київ: НДІБК, 2014. C. $68-72$.

14. Конспект лекцій 3 курсу “Енергозбереження будівель” для студентів спеціальності 7.000008 «Енергетичний менеджмент» денної форми навчання/ Укладачі С.С.Антоненко, А.А.Руденко. - Суми: Вид-во СумДУ, 2006. - 55 с.

15. Закон України від 22.06.2017p. № 2118-VIII «Про енергетичну ефективність будівель».

16. Норми та вказівки по нормуванню витрат витрат палива та теплової енергії на опалення житлових та громадських споруд, а також на господарськопобутові потреби в Україні. КТМ-204 Україна 244-94. Затверджені Держжитлокомунгоспом України 14 грудня 1993. К.: ЗАТ"ВІПОЛ", 2001. 376 с.

17. ДСТУ Б EN ISO 13790:2011. Енергоефективність будівель. Розрахунок енергоспоживання при опаленні та охолодженні (EN ISO 13790:2008, IDT). [На заміну ГОСТ 26629.85; чинний з 01.01.2013]. К. : НДІБК, 2011. 229 с.

18. ДСТУ Б А.2.2-12:2015. Енергетична ефективність будівель. Метод розрахунку енергоспоживання при опаленні, охолодженні, вентиляції, освітленні та гарячому водопостачанні [Уведений вперше; чинний від 2015.01.01]. К. Мінрегіонбуд України, 2016. 205 с.

19. Методичні вказівки до виконання розрахункових та практичних робіт на тему «Розрахунок теплового балансу будівель і споруд під час проведення енергетичного обстеження» 3 дисципліни «Системи виробництва та розподілу 
енергії» / укладачі: С.С. Антоненко, Е.В. Колісніченко. - Суми: Сумський державний університет, 2014. - 84 с.

20. ДСТУ-Н Б А.2.2.5:2007. Проектування. Настанова $з$ розроблення та складання енергетичного паспорта будинків при новому будівництві та реконструкції. [Уведено вперше ; чинний від 2008.07.01.]. К.: Мінрегіонбуд України, 2008. 44 с.

21. Еремкин А.И., Тепловой режим зданий: учебное пособие / А. И. Еремкин, Т. И Королева. - М. : Издательство АСВ, 2000. - 368 с.

22. Комп’ютерне моделювання систем та процесів. Методи обчислень. Частина 1 : навчальний посібник / Квєтний Р. Н., Богач I. В., Бойко О. Р., Софина О. Ю., Шушура О.М.; за заг. ред. Р.Н. Квєтного. - Вінниця: ВНТУ, 2012. $193 \mathrm{c}$.

23. Стеценко, I.В. Моделювання систем: навч. посіб. [Електронний ресурс, текст] / І.В. Стеценко ; М-во освіти і науки України, Черкас. держ. технол. ун-т. - Черкаси : ЧДТУ, 2010. - 399 с. та Єріна А. М. Статистичне моделювання та прогнозування: Навч. посібник. - К.: КНЕУ. — 2001.

24. Міжгалузеві норми споживання електричної та теплової енергії для установ і організацій бюджетної сфери України. Затверджені Держкомітетом України з енергозбереження 25.10.99. К.: ЗАТ"ВІПОЛ", 2000. 104 с.

25. Л.Ю. Федік. Особливості системи автоматизованого проектування SolidWorks. Науковий журнал «Комп’ютерно-інтегровані технології: освіта, наука, виробництво». Луцьк, 2014. Випуск № 15. С.127-130.

26. SolidWorks 2007/2008. Компьютерное моделирование в инженерной практике/ А.А. Алямовский, А.А. Собачкин, Е.В.Одинцов, А.И, Харитонович, Н.Б. Пономарев. - СПб.: БХВ-Петербург, 2008. - 1040с.

27. Хованський С.О., Колісніченко Е.В., Панченко В.О. Розрахункові дослідження теплового стану приміщення. Технологический аудит и резервы производства — № 6/3(26), 2015, с. 45-48. 
28. Аналіз ефективності використання енергоресурсів у розвинених зарубіжних країнах і залежність від їх імпорту - К.: НТЦЕ «НЕК «Укренерго» 2015. -89 c.

29. Дешко B.I., Суходуб I.O., Яценко О.I. Програмне середовище ENERGYPLUS для моделювання енергоспоживання будівель / Тези доп. XIV Міжнар. наук.-практ. конф. „Сучасні проблеми наукового забезпечення енергетики”. Том 1. - K.: 2016 - C. 199.

30. ДБН В.2.2-4:2018 Будинки і споруди. Заклади дошкільної освіти. Введ. 01.04.2019. - Київ : Мінрегіонбуд України, 2018. - 64 с.

31. ДБН В.2.2-40:2018 Інклюзивність будівель і споруд. Основні положення. Введ. 01.04.2019. - Київ : Мінрегіонбуд України, 2018. - 64 с.

32. Середовище, що належить дітям: порадник для педагогів закладів дошкільної освіти. За заг. ред. Засенка В.В. - Київ : ЮНІСЕФ, ВФ «Крок за кроком», 2019. - $66 \mathrm{c.}$

33. Шкляр С. П., Линник I. Е. Принципи формування ергономічного архітектурного середовища для дітей-інвалідів // Сучасні проблеми архітектури та містобудування: Наук.-техн. збірник - К.: КНУБА, 2017. - Вип. 49 - С.202-209

34. Шкляр С. П., Романенко І. І. Принципи формування і удосконалення архітектурного середовища для дітей // Містобудування та територіальне планування: Наук.-техн. збірник - К.: КНУБА, 2017. - Вип. 63 - С.499-508

35. Усачева Е.Ю. Аквапарки как перспективные рекреациационные комплексы для детей и молодежи в городской среде "Коммунальное хозяйство городов”. Научно-технический сборник. - К.: Из-во “Техника” Вып. №63, 2007 C457-462.

36. Крижановская Н.Я., Усачова Е.Ю. Инновационные тенденции в проектировании и строительстве аквапарков в Украине "Коммунальное хозяйство городов”. Научное-технический сборник. - К.: Из-во “Техника” Вып. №66, 2005- C108-112.

37. Усачева Е.Ю. Исследование особенностей формирования водних культурно-развлекательных комплексов (на примере аквапарка “Голубой залив" 
в п. Симеиз), “Коммунальное хозяйство городов”. Научно-технический сборник. - К.: Из-во “Техника” Вып. №76, 2005- С457-462.

38. Вабелина Е.В. Поиск новых форм в ландшафтной архитектуре. - М.: Архитектура, 2005. -157c.

39. Beuckels, A., Smolders, E., Muylaert, K. (2014) Nitrogen availability influences phosphorus removal in microalgae-based wastewater treatment. Water Research, 77, 98-106.

40. Guerra-Renteria, A. S., García-Ramírez, M. A., Gómez-Hermosillo, C., Gómez-Guzmán, A., González-García, Y., \& González-Reynoso, O. (2019) Metabolic Pathway Analysis of Nitrogen and Phosphorus Uptake by the Consortium between C. Vulgaris and P. aeruginosa. International journal of molecular sciences, 20(8).

41. Abdel-Raouf, N., Al-Homaidan, A.A., Ibraheem, I.B.M. (2012) Microalgae and wastewater treatment. Saudi J. Biol. Sci., 19(3), 257-275.

42. Molazadeh, M., Ahmadzadeh, H., Pourianfar, H. R., Lyon, S., Rampelotto, P. H. (2019). The Use of Microalgae for Coupling Wastewater Treatment With $\mathrm{CO}_{2}$ Biofixation. Frontiers in bioengineering and biotechnology, 7, 42

43. Mayhead, E., Silkina, A., Llewellyn, C. A., Fuentes-Grünewald, C. (2018) Comparing Nutrient Removal from Membrane Filtered and Unfiltered Domestic Wastewater Using Chlorella vulgaris. Biology, 7(1), 12.

44. Amenorfenyo, D. K., Huang, X., Zhang, Y., Zeng, Q., Zhang, N., Ren, J., Huang, Q. (2019) Microalgae Brewery Wastewater Treatment: Potentials, Benefits and the Challenges. International journal of environmental research and public health, $16(11), 1910$.

45. Szwarc, K., Szwarc, D., Zieliński, M. (2020) Removal of biogenic compounds from the post-fermentation effluent in a culture of Chlorella vulgaris. Environmental science and pollution research international, 27(1), 111-117.

46. Матлина С. Мобильное, реальное и виреальное: Социо-культурные аспекты модернизации библиотечного пространства / С. Матлина // Библ. дело. 2011. - № 21. - С. 9ᄀ 15. 
47. Архітектура будівель і споруд: Навчальний посібник / 3.І.Котеньова. Харків: ХНАМГ, 2007. - 170 c.

48. Бібліотека: культурний простір та інноваційний поступ : зб. вибр. ст. : 2012-2018 рр. : до 55-річчя наукової бібліотеки КНУКіМ / М-во культури України, Київ. нац. ун-т культури і мистецтв, наук. б-ка ; уклад. : Ю. І. Горбань, Л. А. Рибка, С. Г. Винокурова, В. В. Лук’яненко, О. О. Скаченко ; за заг. ред. Ю. І. Горбаня. - Київ : Видавництво Ліра-К, 2018 . - 544 с.

49. Jodidio Philip. Green architecture Now / Philip Jodidio. - Hong Kong, London, Paris, New York : Taschen, 2009. - 416 p. : il.

50. Смоляр И. М. Экологические основы архитектурного проектирования / И. М. Смоляр, Е. М. Микулина, Н. Г. Благовидова. - М. : Академия, 2010. - 157 c.

51. Gunshiro Matsumoto. Feature : Greenery landscape // SPA-DE. - Japan. Farest Design Editors Inc. 2007. - vol. 7. - P. 11-48.

52. Ковальський В. П. Використання золи виносу ТЕС у будівельних матеріалах / В. П. Ковальський, О. С. Сідлак // Сучасні технології, матеріали і конструкції у будівництві: науково-технічний збірник. - Вінниця : УНІВЕРСУМВінниця, 2014. - № 1 (16). - С. 35-40.

53. Лемешев М. С. Ресурсозберігаюча технологія виробництва будівельних матеріалів 3 використанням техногенних відходів / М. С. Лемешев, О. В. Христич, С. Ю. Зузяк // Сучасні технології, матеріали і конструкції у будівництві. - 2018. - № 1. - С. 18-23.

54. Ковальський В. П. Обгрунтування доцільності використання золошламового в'яжучого для приготування сухих будівельних сумішей / В. П. Ковальський, В. П. Очеретний, М. С. Лемешев, А. В. Бондар // Ресурсоекономні матеріали, конструкції, будівлі та споруди. - Рівне : Видавництво НУВГіП, 2013. - Випуск 26. - С. 186-193.

55. Лемешев М. С. В'яжучі з використанням промислових відходів Вінниччини / М. С. Лемешев // Тези доповідей XXIV міжнародної науково- 
практичної конференції "Інформаційні технології : наука, техніка, технологія, освіта, здоров'я", Харків, 18-20 травня 2016 р. - Харків : НТУ "ХПІ". - С. 381.

56. Сердюк В. Р. Комплексне в'яжуче з використанням мінеральних добавок та відходів виробництва / В. Р. Сердюк, М. С. Лемешев, О. В. Христич // Будівельні матеріали, вироби та санітарна техніка. Науково-технічний збірник. 2009. - Вип. 33. - С. 57-62.

57. Лемешев М. С. Электротехнические материалы для защиты от электромагнитного загрязнения окружающей среды / M. С. Лемешев, А. В. Христич // Инновационное развитие территорий : Матер. 4-й Междунар. науч.-практ. конф., 26 февраля 2016 г. - Череповец : ЧГУ, 2016. - С. 78-83.

58. Рижий В. К. Утилізація твердих побутових відходів на наявних комунальних ТЕЦ / В. К. Рижий, Т. І. Римар, І. Л. Тимофєєв // Вісник Національного університету «Львівська політехніка». - 2011. - № 712 : Теплоенергетика. Інженерія довкілля. Автоматизація. - С. 17-22.

59. Топливо RDF - опасная альтернатива «зелёным» источникам энергии [Електронний ресурс] : [Веб-сайт]. - Електронні дані. - Режим доступу : http://ecolog-ua.com/news/toplyvo-rdf-opasnaya-alternatyva-zelyonymystochnykam-energyy (дата звернення 28.02.19). - Назва з екрана.

60. Березюк О. В. Регресія площі полігону твердих побутових відходів для видобування звалищного газу / О. В. Березюк, М. С. Лемешев // Мир науки и инноваций. - Иваново : Научный мир, 2015. - Т. 5. - № 1 (1). - С. 48-51.

61. Березюк О. В. Виявлення параметрів впливу на питомий об’єм видобування звалищного газу / О. В. Березюк // Вісник Вінницького політехнічного інституту. - 2012. - № 3. - С. 20-23.

62. Ткаченко С. Й. Математичне моделювання робочих процесів в біогазовій установці / С. Й. Ткаченко, Н. В. Пішеніна // Вісник Вінницького політехнічного інституту. - 2011. - № 3. - С. 41-47.

63. Березюк О. В. Моделювання поширеності способів утилізації звалищного газу для розробки обладнання та стратегії поводження з твердими побутовими відходами / О. В. Березюк // Вісник Вінницького політехнічного 
інституту. - 2014. - № 5. - С. 65-68.

64. Березюк О. В. Розробка математичної моделі прогнозування питомого потенціалу звалищного газу / О. В. Березюк // Вісник Вінницького політехнічного інституту. - 2013. - № 2. - С. 39-42.

65. Березюк О. В. Моделювання ефективності видобування звалищного газу для розробки обладнання та стратегії поводження 3 твердими побутовими відходами / О. В. Березюк // Вісник Вінницького політехнічного інституту. 2013. - № 6. - C. 21-24.

66. Ратушняк Г. С. Тепловтрати в біогазових установках при різних температурних режимах анаеробного бродіння / Г. С. Ратушняк, К. В. Анохіна // Вісник Вінницького політехнічного інституту. - 2008. - № 5. - С. 20-24.

67. Березюк О. В. Моделирование состава биогаза при анаэробном разложении твердых бытовых отходов / О.В.Березюк // Автоматизированные технологии и производства. - 2015. - № 4 (10). - С. 44-47.

68. Крекотень Є. Г. Реалізація мікроконтролерного газоаналізатора для реєстрації вибухонебезпечних газів [Електронний ресурс] / С. Г. Крекотень, Д. Х. Штофель, С. В. Костішин // Матеріали XLVII наук.-технічн. конф. підрозділів ВНТУ, Вінниця, 14-23 березня 2018 p. - Режим доступу : https://conferences.vntu.edu.ua/index.php/all-frtzp/all-frtzp-2018/paper/view/4888.

69. Крекотень Є. Г. Вимірювач концентрації вибухонебезпечних газів у повітрі / Є. Г. Крекотень, О. В. Березюк // Пожежна та техногенна безпека : наука і практика : матеріали Всеукраїнської науково-практичної конференції курсантів і студентів, 15-16 травня 2018 р. - Черкаси, 2018. - С. 162-163.

70. Техніко-економічне обгрунтування "Програми утилізації звалищного метану в Луганській області за допомогою механізмів Кітського протоколу". Луганськ, 2008. - 124 с.

71. Рамкова конвенція Організації Об’єднаних Націй про зміну клімату [Електронний ресурс] : [Веб-сайт]. - Електронні дані. - Режим доступу : https://zakon.rada.gov.ua/laws/show/995_044 (дата звернення 28.02.19). - Назва 3 екрана. 
72. Березюк О. В. Визначення параметрів впливу на шляхи поведінки 3 твердими побутовими відходами / О.В.Березюк // Сучасні технології, матеріали i конструкції у будівництві : Науково-технічний збірник. - Вінниця : УНІВЕРСУМ-Вінниця, 2011. - № 2 (10). - С. 64-66.

73. Березюк О. В. Моделювання динаміки санітарно-бактеріологічного складу твердих побутових відходів під час літнього компостування / О. В. Березюк, С. М. Горбатюк, Л. Л. Березюк // Вісник Вінницького політехнічного інституту. - 2013. - № 4. - С. 17-20.

74. Березюк О. В. Моделювання динаміки санітарно-бактеріологічного складу твердих побутових відходів під час весняного компостування / О. В. Березюк, М. С. Лемешев, Л. Л. Березюк, І. В. Віштак // Вісник Вінницького політехнічного інституту. - 2015. - № 1. - С. 29-33.

75. Зомарев А. М. Санитарно-гигиенический мониторинг полигонов захоронения твердых бытовых отходов (ТБО) на этапах жизненного цикла : автореф. дисс. на соискание уч. степени докт. мед. наук / А. М. Зомарев. - Пермь : 2010. $-50 \mathrm{c}$.

76. Батракова Г. М. Моделирование переноса и рассеивания в атмосферном воздухе метана, эмитированного с территории захоронения твердых бытовых отходов / Г. М. Батракова, М. Г. Бояршинов, В. Д. Горемыкин // Вестник Воронежского государственного университета. Серия : Геология. - 2005. № 1. - C. 256-262.

77. Barsukov I.V. Novel materials for electrochemical power sources introduction of PUREBLACK ${ }^{\circledR}$ Carbons / Barsukov I. V., Gallego M. A., Doninger J. E. // J. Power Sources. - 2006. - № 2 - P. 288-299.

78. Shapiro D. Fundamentals of the theory of electromagnetic shielding / D. Shapiro // 1975. - P. 190.

79. Ivanovskyi S. The use of dispersed fillers for creating composite materials based on a polymer matrix / S. Ivanovskyi, M. Melnichenko // J. Young scientist. 2015. - №15. - P. 91-93.

80. T. Song, U. Paik, Journal of Materials Chemistry A, 4 (2016) 14-31. 
81. W. Wang, Y. Liu, X. Wu, J. Wang, L. Fu, Y. Zhu, Y. Wu, X. Liu, Advanced Materials Technologies, 3 (2018) 1800004.

82. H. Kim, M.Y. Cho, M.H. Kim, K.Y. Park, H. Gwon, Y. Lee, K.C. Roh, K. Kang, Advanced Energy Materials, 3 (2013) 1500-1506.

83. T. Du, W. Zhang, H. Peng, G. Jain, International Journal of Electrochemical Science, 13 (2018) 6229-6235.

84. W. Nachit, S. Touhtouh, Z. Ramzi, K. Benkhouja, R. Yazam, Lithium-Ion Batteries - Thin Film for Energy Materials and Devices, (2020).

85. X. Shi, Z. Zhang, K. Du, Y. Lai, J. Fang, J. Li, Journal of Power Sources, 330 (2016) 1-6.

86. L. Wu, D. Buchholz, D. Bresser, L.G. Chagas, S. Passerini, Journal of Power Sources 251 (2014) 379-385.

87. L. Wu, D. Bresser, D. Buchholz, G.A. Giffin, C.R. Castro, A. Ochel, S. Passerini, Advanced Energy Materials, 5 (2014) 1401142.

88. J.-Y. Liao, B.D.Luna, A. Manthiram, Journal of Materials Chemistry A, 4 (2015) 801-806.

89. K.-T. Kim, G. Ali, K.Y. Chung, C.S. Yoon, H. Yashiro, Y.-K. Sun, J. Lu, K. Amine, S.-T. Myung, Nano Letters, 14 (2014) 416-422.

90. L. Kavan, Journal of Solid State Electrochemistry, 18 (2014) 2297-2306.

91. W. Li, M. Fukunishi, B.J. Morgan, O.J. Borkiewicz, K.W. Chapman, W. Pralong, A. Maignan, O.L. Lebedev, J. Ma, H. Groult, S. Komaba, D. Dambournet, Chemistry of Materials, 29 (2017) 1836-1844.

92. J. Li, J. Liu, Q. Sun, M.N. Banis, X. Sun, T.-K. Sham, The Journal of Physical Chemistry C, 121 (2017) 11773-11782.

93. Z.-L. Xu, K. Lim, K.-Y. Park, G. Yoon, W.M. Seong, K. Kang, Advanced Functional Materials, 28 (2018) 1802099.

94. S.A. Kirillov, T.V. Lisnycha, S.I. Chernukhin, Journal of Power Sources, 196 (2011) 2221-2226.

95. N.I. Globa, T.V. Lisnycha, Yu.V. Shmatok, V.A. Sirosh, S.A. Kirillov, Ukrainian Chemistry Journal, 86 (2020) 14-27. 
96. A. Auer, E. Portenkirchner, T. Götsch, C. Valero-Vidal, S. Penner, J. KunzeLiebhäuser, ACS Applied Materials \& Interfaces, 9 (2017) 36828-36836.

97.https://www.techotopia.com/index.php/Creating_an_Android_User_Interface in_Java_Code

98. https://medium.com/@abduazizkayumov/android-ui-xml-inflation-vsdynamic-views-380ad5e 1 fae 5

99. Moscovich, T. (2007): Principles and Applications of Multi-touch Interaction, Ph.D. thesis, Brown University.

100. Hendriks, M., Kortenkamp, U., Kreis, Y., Marquès, D. (2009): D3.6: I2G Common File Format v2. Technical Report, Intergeo Project, http://i2geo.net/files/D3.6-Common-File-Format-v2.pdf

101. (2015), "The Standards and guidelines for quality assurance in the European Higher Education Area", available at: http:/www. enqa.eu/ ndirme/esg/ESG\%20in\%20Ukrainian_by\% 20the\%20 British\%20 Council.pdf (accessed July 28, 2016).

102. Chernyshenko, S.V. and Vorotnickogo, Yu.I. (2015), Metodologicheskie osnovy sozdanija, vnedrenija i razvitija integrirovannoj informacionnoj M54 sistemy upravlenija universitetom [The methodological basis for the creation, implementation and development of an integrated information management system of the University of M54], Sumskij gosudarstvennyj universitet, Sumy, Ukraine.

103. Liakhov, A.L., Demidenko, M.I. (2007), "Arhitektura avtomatizirovannoj informacionnoj sistemy upravlenija uchebnym processom v VUZe", Sb. trudov vtoroj nauchno-prakticheskoj konferencii s mezhdunarodnym uchastiem, Matematicheskoe i imitacionnoe modelirovanie sistem MODS 2007, Kiev, pp. 75-80.

104. Velychko, V.Yu., Kamyshyn, V.V., Stryzhak O.Ye. (2010) "Informatsiyni tekhnolohiyi formuvannya suchasnykh system znan yak osnova innovatsiynoho rozvytku osvity", Materialy mizhdystsyplinarnoyi naukovo-praktychnoyi konferentsiyi «Innovatsiyni tekhnolohiyi navchannya obdarovanoyi molodi», Kiev, pp. 168. 
105. Demyda, B., Sahaydak, S., Kopyl, I. (2011) "Systemy dystantsiynoho navchannya: ohlyad, analiz, vybir", Visnyk Natsionalnoho universytetu "Lvivska politekhnika". Kompyuterni nauky ta informatsiyni tekhnolohiyi, pp. 98-107.

106. Bogomolov, A.V. (2007) "Obzor besplatnyh sistem upravleniya obucheniem", Educational Technology \& Society, no. 10 (3).

107. Andon, F.I., Koval, G.I., Korotun, T.M., Suslov, V.YU (2002) "Osnovy inzhenerii kachestva programmnyh sistem", K: Akademperiodika, $502 \mathrm{~s}$.

108. De Bra, P. (2006) "Web-based educational hypermedia. Book chapter in: Data Mining in E-Learning" [edited by C. Romero and S. Ventura] Universidad de Cordoba, Spain, WIT Press, pp. 3-17.

109. Jie, C.Y., Benazir, Q., Nian-Shing, C., Qiang, M. (2016) "Effects of online presence on learning performance in a blog-based online course", Internet and Higher Education, vol. 30, pp. 11-20, available at: http://staff.csie.ncu.edu.tw/yangjc/ paper/2016_IntHighEdu_Yang.pdf (accessed October 28, 2016).

110. Dabbagh, N., Kitsantas, A. (2012) "Personal learning environments, social media, and self-regulated learning: A natural formula for connecting formal and informal learning", The Internet and Higher Education, vol. 15, no. 1, pp. 3 -8.

111. Ekwunife-Orakwue, K.C.V., Teng T.L. (2014) "The impact of transactional distance dialogic interactions on student learning outcomes in online and blended environments", Computers \& Education, vol. 78, pp. $414-427$.

112. Tsvetkov V. Ya., Lobanov A. A. Big Data as Information Barrier// European Researcher. 2014. Vol.(78). № 7-1. p. 1237-1242.

113. Bean J. COA and Web Services Interface Design. Principles, Techniques, and Standards. 2010-360 p.

114. Tanenbaum A., Van Steen M. Distributed systems. Pearson Prentice Hall, 2007.

115. Arne Koschel and Carsten Kleiner. Combining Grid, SOA and Web Services for Smaller Computing Environments / International Conference on Web Information Systems and Technologies/ WEBIST 2008: Web Information Systems and Technologies. - pp 93-106 
116. Yu, Liyang. Introduction to Semantic Web and Semantic Web services / Liyang Yu. - 2007. - 368 p.

117. Kulykovska, N., Skrupsky, S., Diachuk, T. A model of semantic web service in a distributed computer system / CMIS-2020 Computer Modeling and Intelligent Systems: Proceedings of the Third International Workshop on Computer Modeling and Intelligent Systems (CMIS-2020), Zaporizhzhia, Ukraine, April 27-May 1, 2020. CEUR-WS.org, online. P. 338-351

118. Kirichek G., System for detecting network anomalies using a hybrid of an uncontrolled and controlled neural network/ Kirichek G., Harkusha V., Timenko A., Kulykovska N.// CS\&SE@SW 2019: 2nd Student Workshop on Computer Science and Software Engineering, Kryvyi Rih, Ukraine, November 29, 2019 P. 138 - 148

119. Моделі, методи та інформаційна технологія діагностики технічного стану будівельних конструкцій і споруд: монографія / В.М. Міхайленко, О.О. Терентьєв, .С. Шабала, К.І. Київська, Є.В.Горбатюк. Київ: ЦП «Компринт», 2017. 161c.

120. Evaluation methods of the results of the scientists' research activities based on citation analysis of publications /A. Biloshchytskyi, A. Kuchansky, Yu. Andrashko, S. Biloshchytska, O. Kuzka, O. Terentyev. Eastern-European Journal of Enterprise Technologies ISSN 1729-3774 № 3/2 (87), March 2017. P.4-10.

121. Моделі та методи інформаційної системи діагностики технічного стану об’єктів будівництва: підручник / В.М. Міхайленко, I.В. Русан, П.Є. Григоровський, О.О. Терентьєв, А.Т. Свідерський, Є.В. Горбатюк. Київ: ЦП «Компринт», 2018. 325 с.

122. Аналіз сучасних інформаційних технологій системи діагностики технічного стану будівель і споруд / О.О. Терентьєв, К.І. Київська, О.В. Доля, Є.В. Горбатюк. Київ: Управління розвитком складних систем, збірник наукових праць, випуск 36/2018, КНУБА, 2018. С. 100-107. 
123. Інтелектуальні інформаційні системи i технології діагностики технічного стану будівель: навчальний посібник / О.О. Терентьєв, І.В. Русан, Є.В. Бородавка, Є.В. Горбатюк, К.І. Київська. Київ: ЦП «Компринт», 2019. 123 с.

124. Методи та моделі пошкодження автоматизованої системи діагностики технічного стану об’єктів будівництва / Терентьєв О.О., Горбатюк С.В., Доля О.В., Київська К.І., Азенко В.В., Бородиня В.В. Київ: Управління розвитком складних систем, збірник наукових праць, випуск 38/2019, КНУБА, 2019. C. 82-91.

125. Oleksandr Terentyev, Svitlana Tsiutsiura, Tetyana Honcharenko, Tamara Lyashchenko. Multidimensional Space Structure for Adaptable Data Model. International Journal of Recent Technology and Engineering (IJRTE) ISSN: $2277-$ 3878, Volume-8 Issue-3, September 2019. P. 7753-7758. DOI:10.35940/ijrte.C6318.098319.

126. Інтегровані моделі та методи автоматизованої системи діагностики технічного стану конструкцій будівель та споруд: підручник / О.О. Терентьєв, I.В. Русан, С.В. Горбатюк, І.С. Івахненко, О.В. Петроченко, О.П. Куліков. Київ: ФОП Ямчинський О.В., 2019. 240 с.

127. O.O. Terentyev, P.E. Grigorovskiy, A.A. Tugaj, O.V. Dubynka. Building a System of Diagnosis Technical Condition of Buildings on the Example of Floor Beams Using Methods of Fuzzy Sets. Proceedings of the 2nd International Conference on Building Innovations, June 14, 2020. P. 729-739.

128. Substantiation of adequacy of loading conditions at bench and field tests of construction machines / L. Pelevin, A. Fomin, Ie. Gorbatyuk, G. Machishin. EasternEuropean Journal of Enterprise Technologies. 2018. Vol. 3, № 7 (93): Applied mechanics. P. 41-52.

129. Ткаченко С.Й., Степанов Д.В., Степанова Н.Д. Аналіз соціальної та енерго - і природозбережної ефективності реалізації біогазової технології //Вісник ВПІ. - 2020. - №2. - С.34 - 41.

130. Гелетуха Г.Г. Перспективи біогазу в Україні. Електронний ресурс. Режим доступу: https://www.epravda.com.ua/rus/columns/2013/07/3/383399/ 
131. Аналітично-описова частина до Стратегії регіонального розвитку Вінницької області на період до 2027 року. Режим доступу: http://vin.gov.ua/images/doc/vin/ODA/strategy/CEanaliz_.pdf

132. Кількість сільськогосподарських тварин у 2020 році з сайту Головного управління статистики у Вінницькій області. Режим доступу: https://www.vn.ukrstat.gov.ua/index.php/statistical-information/6595-kilkist-sgtvaryn.html.

133. Баадер Б., Доне Е., Брендерфер М. Биогаз: Теория и практика:- М. : Колос, 1982. - 148 с.

134. Гелетуха Г.Г Перспективи виробництва та використання біогазу в Україні. Аналітична записка БАУ №4. /Г.Г. Гелетуха, П.П. Кучерук, Ю. Б. Матвеєв. Режим доступу: https://uabio.org/wp-content/uploads/2020/04/positionpaper-uabio-4-ua.pdf

135. Галицкая П.Ю. Совместная утилизация отходов различных производств с получением полезных продуктов и биогаза / П. Ю. Галицкая, П. А. Зверева, С. Ю. Селивановская. //Ученые записки Казанского университета. Том 153, кн. 1. - С. 152-160.

136. D. M. F. Lima. ANAEROBIC MODELING FOR IMPROVING SYNERGY AND ROBUSTNESS OF A MANURE CO-DIGESTION PROCESS // Brazilian Journal of Chemical Engineering. - 2016. - №4. - P.871-883.

137. Закон України “Про альтернативні джерела енергії” [Електронний pecypc]. - URL: http://zakon1.rada.gov.ua/laws/show/555-15.

138. Агровольтаїка: як це працює? Пропозиція - Головний журнал з питань агробізнесу: веб-сайт. URL: https://propozitsiya.com/ua/agrovoltayika-yak-cepracyuye

139. Стьопін Ю.О., Гулевський В.Б., Пєрова Н.П. Енергозбереження i використання поновлювальних джерел енергії: Методичні вказівки до практичних робіт для здобувачів ступеня вищої освіти «Магістр» зі спеціальності 141 -“Електроенергетика, електротехніка та електромеханіка” Мелітополь: ПП Белень Л.В., 2019. 60 с. - URL: 
http://elar.tsatu.edu.ua/bitstream/123456789/6789/1/\%d0\%9f\%d1\%80\%d0\%b0\%d0 \%ba\%d1\%82.-\%d0\%95\%d0\%92\%d0\%9f\%d0\%94\%d0\%95-15.19\%20-1.pdf

140. Стьопін Ю. О., Гулевський В. Б., Перова Н. П. Енергозбереження і використання поновлювальних джерел енергії: Методичні вказівки до лабораторних робіт для здобувачів ступеня вищої освіти «Магістр» зі спеціальності 141 - “Електроенергетика, електротехніка та електромеханіка" Мелітополь: ПП Белень Л.B, 2019. 40 с. - URL: http://elar.tsatu.edu.ua/bitstream/123456789/6784/1/\%d0\%09b\%d0\%b0\%d0\%b1\%d0 \%be \%d1\%80.\%d0\%95\%d0\%92\%d0\%9f\%d0\%94\%d0\%95-15.19\%20-1.pdf

141. Будівельна кліматологія ДСТУ - Н Б В.1.1-27 :2010 [Чинний від 01.11.2011]. Київ, Мінрегіонбуд України 2011. 123 с.

142. Сивков С.И. Методы расчета характеристик солнечной радиации. Л.: Гидрометеоиздат, 1968. 234 с.

143. Восход и закат Солнца в Мелитополе. Архив 2018. [Електронний peсурс]. - Режим доступу : https://ru.meteocast.net/sunrise-sunset/ua/melitopol/

144. Дінабурський В. С., Гулевський В. Б. Застосування інверторів напруги в автономних системах енергозабезпечення тепличних комплексів 3 використанням сонячних панелей [Електронний ресурс]. // Науковий вісник Таврійського державного агротехнологічного університету. 2018. Вип.8, Т.2. URL: http://oj.tsatu.edu.ua/index.php/visnik/article/view/40

145. Геліоконденсатор: пат. 116614 Україна: МПК51 F24J 2/02(2006.01), F24J 2/24(2006.01) Петров В.О. (UA), Федюшко Ю. М. (UA), Гулевський В. Б. (UA), Полуекто Д. О. (UA),Сагайдак А. В. u 2016 13093; заявл. 22.12.2016; опубл. 25.05.2017, Бюл. №10. 3 с.

146. Гулевський В.Б., Богатирьов Ю. О. За альтернативною енергетикоюнаше майбутнє! [Електронний ресурс]. Агро Таврія. ТДАТУ. 2014 №6. 9 с.- URL: http://elar.tsatu.edu.ua/bitstream/123456789/2040/1/209.pdf , вільний. - Загл. 3 екрану. (6.10.2020).

147. Сонячна енергія. Агровольтаїка. Ідеальна комбінація енергетики та фермерства?: веб-сайт. URL: https://sun-energy.com.ua/articles/agrovoltaic 
148. Стьопін Ю.О., Постол Ю.О., Гулевський В.Б. Вирішення інформаційних завдань при викладанні дисципліни "Енергозбереження i використання поновлювальних джерел енергії”. Зб. наук.-метод. пр. ТДАТУ «Удосконалення освітньо-виховного процесу в закладі вищої освіти». 2020. Вип. 23. C. 192-197. - URL: http://elar.tsatu.edu.ua/bitstream/123456789/10584/1/\%D0\%A1\%D0\%B1\%D0\%BE \%D1\%80\%D0\%BD\%D0\%B8\%D0\%BA\%20\%D1\%81\%D1\%82\%D0\%B0\%D1\%82 \%D0\%B5\%D0\%B9\%202020\%208.04-193-197.pdf

149. Volker Quaschning. «Understanding renewable energy systems»

150. Веников В.А. Расчеты и анализ режимов работы сетей

151. Корчагина Л. Н. Интерактивные формы и методы повышения познавательной и творческой активности обучаемых при обучении инженерной и компьютерной графике [Текст] // Инновационные педагогические технологии: материалы IV Междунар. науч. конф. (г. Казань, май 2016 г.). - Казань: Бук, 2016. - C. 148-150. — URL https://moluch.ru/conf/ped/archive/190/10390/

152. Москаленко В. О., Иванов Г. С., Муравьев К. А. Как обеспечить общегеометрическую подготовку студентов технических университетов // Наука и образование. МГТУ им. Н. Э. Баумана. Электрон. журн. - 2012. - № 8. - URL: http://technomag.bmstu.ru/doc/699795.html.

153. Князьков В. В., Фазлулин Э. М. Организация практических занятий по начертательной геометрии в условиях внедрения ФГОС ВПО // Инновационные технологии в образовательной деятельности: материалы Всерос. науч.-метод. конф., г. Н. Новгород, 7 февраля 2013 г. / Нижегород. гос. техн. ун-т им. Р. Е. Алексеева. - Н. Новгород, 2013. - 442 с.

154. Горшков Г. Ф., Бобов П. Г., Яшунский В. Б. Системная взаимосвязь традиционной и компьютерной технологии моделирования геометрических тел // Совершенствование подготовки учащихся и студентов в области графики, конструирования и стандартизации: межвуз. науч.-метод. сб. - Саратов: СГТУ, 2005. - C. $186-190$ 
155. Смченко I. В. Сенсорний аналіз: практикум : навчальний посібник / I. B. Ємченко, А. О. Троякова, А. П. Батутіна. - Львів : Афіша. - 2009. - 328 с.

156. Розробка м'ясомістких запечених виробів з м'яса птиці/ Н. В. Божко, В. І. Тищенко, В. М. Пасічний, М. М. Сацький // Продовольчі ресурси. - 2018. №11. - C.13-20.

157. Здобнов А. И. Сборник рецептур блюд и кулинарных изделий: для предприятий общественного питания : [сборник] / Київ : Арий, 2009. - 680 с.

158. Авдєєва Л. Ю., Шафранська І. С. Збагачення м'ясних напівфабрикатів біологічно активними речовинами рослинної сировини. Наукові праці Одеської національної академії харчових технологій. 2014. № 46(2). С. 174-176.

159. Strashynskiy I., Fursik O., Pasichniy V., Marynin A., Goncharov G. Influence of functional food composition on the properties of meat mince systems. Восточно-Европейский журнал передовых технологий. 2016. № 6(11). С. 53-58. DOI: $10.15587 / 1729-4061.2016 .86957$.

160. Evangelos S. Lazos. Certain functional properties of defatted pumpkin seed flour. Plant Foods for Human Nutrition. 1992. Vol. 42(3). P. 257-273. DOI: $10.1007 / \mathrm{bf02193934.}$

161. Sadia C. M. Health Benefits and Nutritional Value of Flaxseed-a Review. Indian journal of applied research. 2016. Vol. 6(1). P. 243-245. DOI: $10.15373 / 2249555 X$.

162. Kajla P., Sharma A., Sood D.R. Flaxseed - a potential functional food source. Journal of Food Science and Technology. 2015. Vol. 52(4). P. 57-71. DOI: 10.1007/s13197-014-1293-y.

163. Краєвська С. П., Стеценко Н. О. Аналіз хімічного складу насіння гарбуза, кунжуту та льону як перспективних джерел для виробництва біологічно активних добавок до їжі. Стратегия качества в промышленности и образовании : IX Міжнар. конф, 31 травня - 7 червня. м. Варна. 2013. С. 95-97.

164. Makni M., Fetoui H., Gargouri N. K. et al. Antidiabetic effect of flax and pumpkin seed mixture powder: effect on hyperlipidemia and antioxidant status in 
alloxan diabetic rats. Journal of Diabetes and its Complications. September - October 2011, Vol. 25, Issue 5, P. 339-345. DOI: 10.1016/j.jdiacomp.2010.09.001.

165. Kotlyar Y., Goncharenko T., Topchiy O. Development of formulation multicomponent protein-fat emulsion. Харчова наука і технологія. 2016. Vol. 10. № 4. C. 25-30. DOI: 10.15673/fst.v10i4.250.

166. Ковтун А. В., Коваль О. А., Галінська О. С. Удосконалення технології виробництва м'ясних виробів з ядром насіння соняшника. Вісник Харківського національного технічного університету сільського господарства імені Петра Василенка. 2014. Вип. 152. С. 334-340.

167. Гончаренко Т. Ю., Топчій О.А., Кишенько I.I. Дослідження ефективності різних способів підготовки рослинної сировини у рецептурі посічених напівфабрикатів. Наукові праџі Наџіонального університету харчових технологій. 2017. Т. 23. № 5. Ч.2. С. 142-148. DOI: 10.24263/2225-2924-2017-23$5-2-20$.

168. Кодекс комерційного обліку електричної енергії. - Режим доступу: https: //zakon.rada.gov.ua/laws/show/v0311874-18\#Text. Дата звернення 15.11.2020.

169. Автоматизована система комерційного обліку електроенергії (АСКОЕ). - Режим доступу: https://tke.com.ua/ua/askoe-2/. Дата звернення 15.11.2020.

170. Готович В.А. Математичне моделювання і статистичне оцінювання характеристик штатного режиму електроспоживання організацій: дис. канд. техн. наук: 01.05.02. / Готович Володимир Анатолійович. - Тернопільський національний технічний університет імені Івана Пулюя, Тернопіль, 2019. - 170 c. - Режим доступу: http://elartu.tntu.edu.ua/handle/lib/28925. Дата звернення 16.11.2020.

171. Якупова H.M., mailto:\%20Aleksey_Andreev_mail@mail.ruАндреев А.В. mailto:\%20Aleksey_Andreev_mail@mail.ruСовершенствование_ методов планирования потребления электроэнергии в бюджетних учреждениях // Фундаментальные исследования. - 2015. - № 10 (часть 1) - С. 214-218. - Режим 
доступу: https://www.fundamental-research.ru/ru/article/view?id=39153).Дата звернення 10.11.2020.

172. Каплун В. В. Математичне моделювання електроспоживання у будівлях закладів вищої освіти. Повідомлення 2 [Текст] / В. В. Каплун, С. М. Краснитський, В. М. Бобровник // Вісник Київського національного університету технологій та дизайну. Серія Технічні науки. - 2019. - № 2 (132). - С. 9-23. Режим доступу: https://er.knutd.edu.ua/bitstream/123456789/13259/1/V132_P009023.pdf). Дата звернення 10.11.2020.

173. María del Carmen Ruiz-Abellón, Antonio Gabaldon, Antonio Guillamón Load Forecasting for a Campus University Using Ensemble Methods Based on Regression Trees // Energies. - 2018. - 11(8) DOI: 10.3390/en11082038).

174. Експертний огляд програмного забезпечення для енергомоніторингу та енергоменеджменту /Асоціація «Енергоефективні міста України». - Львів. 2018. - 32 с. [Електронний ресурс]. - Режим доступу: https://enefcities.org.ua/upload/files/Експертний\%20огляд\%202018(2).pdf. Дата звернення 10.11.2020.

175. Power supply for educational institutions: efficiency and alternatives: Collective monograph /edited by M. Sotnyk, Doctor of Technical Sciences. Hamilton, Canada, Accent Graphics Communications \& Publishing, 2020. - 146 p.

176. ДСТУ 3215 «Метрологічна атестація засобів вимірювальної техніки. Організація i порядок проведення». - Режим доступу: http: //energy.volyn.ua/spozhyvacham/oblik-elektroenerhii/askoe/.Дата звернення $\underline{11.11 .2020 .}$

177. Технічні рекомендації щодо вибору розрахункових засобів обліку електричної енергії, до локального устаткування збору та обробки даних (ЛУЗОД) та автоматизованої системи комерційного обліку електроенергії (АСКОЕ) юридичних споживачів ПАТ «Волиньобленерго». - Режим доступу: http: //energy.volyn.ua/spozhyvacham/oblik-elektroenerhii/askoe/. Дата звернення 12.11.2020. 
178. Аль-Адеми Я. Т. А., Ахмед А. А. А., Пулко Т. А., Насонова Н. В., Лыньков Л. Н. Широкодиапазонные конструкции экранов электромагнитного излучения на основе влагосодержащей целлюлозы. Труды МАИ. 2014. № 77. С. $1-15$.

179. Jianjun Li, Liang Li, Min Wan, Haiping Yu, Lin Liu. Innovation applications of electromagnetic forming and its fundamental problems. Procedia Manufacturing. 2018. Vol. 15. PP. 14-30.

180. Glyva V., Lyashok J., Matvieieva I., Frolov V., Levchenko L., Tykhenko O., Panova O., Khodakovskyy O., Khalmuradov B., Nikolaiev K. Development and investigation of protective properties of the electromagnetic and soundproofing screen. Eastern-European Journal of Enterprise Technologies. 2018. Iss. 6/5 (96). P. 54-61. DOI: https://doi.org/10.15587/1729-4061.2018.150778.

181. Patil N., Velhal N.B., Pawar R., Puri V. Electric, magnetic and high frequency properties of screen printed ferrite-ferroelectric composite thick films on alumina substrate. Microelectronics International. 2015. Vol. 32. Iss. 1. PP. 25-31.

182. Han Qingyou. Ultrasonic Processing of Materials. Metallurgical and Materials Transactions. 2015. Vol. 46 B. PP. 1603-1614. DOI: https://doi.org/10.1007/s11663-014-0266-X.

183. The latest developments in fine and ultrafine grinding technologies (Plenary) / M. Gao, R. Holmes, J. Pease//XXIII International mineral processing congress. Tom 1. Istambul, Turkey $3-8$ September 2006.

184. Прядко Н.С. Акустические исследования струйного измельчения// LAP LAMBERT Academic Publishing.-OmniScriptum GmbH\&Co.Kg.-2013.Saarbrucken Germany.-172c.

185. Бовенко В. Н. О физических критериях разрушения и диспергирования / В. Н. Бовенко, Л. Ж. Горобец, Н. С. Прядко // Вестник НТУ «ХПИ». - Харь-ков. - 2007. - № 26. - С. $148-153$.

186. Acoustic monitoring of jet grinding / N.S. Pryadko, K.V. Ternova; NAS of Ukraine, Institute of Technical Mechanics of NAS of Ukraine and SSA of Ukraine. Kyiv : Akadem periodyka, 2020. - 192 p. 
187. Прядко Н. С. Анализ качества продукта струйного измельчения на основе акустического мониторинга / Н. С. Прядко // Техническая механика. 2010. - № 2. - C. 81 - 86 .

188. Pryadko N.S. Optimization of fine grinding on the acoustic monitoring basis // Power Engineering, Control \& Information Technologies in Geotechnical Systems 2015.- Taylor \& Francis Group, London, p. 99-108.

189. Pryadko N.S., Muzyka L.V., Strelnikov H.A., Grenev A.F. Control of mass flow in jet mill on base of acoustic monitoring// Scientific Bulletin of National Mining University. - 2019. - № 4. - p. 5-10.

190. Pryadko N.S., Muzyka L.V., Strelnikov H.A., Ternova K.V. Acoustic method of jet grinding study and control // E3S Web of Conferences 109, 00074 (2019) Essays of Mining Science and Practice 2019 p.1-11. https://doi.org/10.1051/e3sconf/201910900074

191. Виброзащитные системы с квазинулевой жесткостью. П.М. Алабужев, А.А. Гритчин, Л.И. Ким и др. Под ред. К.М. Рагульскиса. Л.: -Машиностроение, 1986. - 96 с. (Б-ка инженера, Вибрационная техника; Вып. 7).

192. А.с. СССР 1463985 МКИ F16 F 15/02. Виброзащитное устройство / А.Г. Архипов, В.Н. Полчанов, Н.И. Нагулин, Б.И. Генкин, В.Е. Петренко (СССР). №4235754/25-28; заяв. 27.04.87; опубл. 07.03.89, Бюл.№ 9.

193. Круглов Ю.Л. Ударовиброзащита машин, оборудования и аппаратуры. / Ю.Л. Круглов, Ю.А. Туманов. - Л.: Машиностроение, 1986. - 222 с.

194. Архипов А.Г. Синтез конструкцій віброзахисних систем з корекцією жорсткості і їх динаміки. Вибрации в технике и технологиях, Всеукраїнський науково-технічний журнал - №1 , 2001. -C. 97-99

195. Vernyhora V.D., Korobochka A.M., Mathematical modeling of the cleaning solution cleaning process on a continuous oil separator. Mathematical modeling: Science. Magazine. Kamyanske: DSTU. 2020. № 1 (42). P. 99-108.

196. Chaso D.P., Description of experimental studies of the effect of additional blades on the performance of the screw conveyor. Collection of scientific works of 
Dniprodzerzhynsk State Technical University (technical sciences) / Dniprodzerzhynsk: DSTU. 2016. Issue 2 (29). P. 61 - 64

197. Gustov Y.I. Biomekhanicheskie modelirovaniya v zemlerojnoj tekhnike / Y.I. Gustov, R.U. Shukurov, I.V. Voronina // Novye materialy i tekhnologii v mashinostroenii : sbornik nauchn. trudov po itogam mezhdunarodnoj nauchnotekhnicheskoj konferencii. - Bryansk : BGITA, 2007. - Iss. 7. - Pp. 16-18.

198. Mashini dlya zemlyanih robit : navch. posibnik / L.A. Hmara, S.V. Kravec, V.V. Nichke, L.V. Nazarov [ta in.] // Pid zagal'noyu redakciєyu prof. Hmari L.A. ta prof. Kravcya S.V. - Rivne-Dnipropetrovs'k-Harkiv, 2010. - 557 p.

199. Dyachenko S.S. Ionno-plazmova obrobka yak faktor pidvishchennya konstrukcijnoï micnosti stalevih virobiv / S.S. Dyachenko, I.V. Ponomarenko // Novi materiali i tekhnologiï v metalurgiï ta mashinobuduvanni. - 2009. - No.1. - Pp. 7177.

200. Vencel E.S. Povyshenie iznosostojkosti rabochih organov zemlerojnotransportnyh mashin : monografiya / E.S. Vencel, A.V. Shchukin. - Harkov, 2015. $106 \mathrm{p}$.

201. Pat. 68141 Ukraine, MPK S23S 14/48 (2006.1) Sposib pidvishchennya dovgovichnosti robochih organiv zemlerijno-transportnih mashin / Vencel E.S., Glushkova D.B., Shchukin O.V.; zayavniki ta patentovlasniki Vencel E.S., Glushkova D.B., Shchukin O.V. - No. 201112143 ; zayavl. 17.10.2011 ; opubl. 12.03.2012, Byul. No. 5.

202. Пат. 68115 А Україна, МПК В21К21/00. Спосіб виготовлення деталей 3 наскрізним отвором / Алієва Л. І., Савчинський І. Г., Лобанов О. І., Сивак К. І. № 2003109157; заявл. 10.10.2003; опубл. 15.07.2004, Бюл. № 7 .

203. Пат. 69057 U Україна, МПК В21К21/00. Спосіб виготовлення деталей 3 наскрізним отвором / Алієв І. С., Алієва Л. І., Бондарева О. М. - № u 2011 09298; заявл. 24.07.2011; опубл. 25.04.2012, Бюл. № 8.

204. Пат. 73920 Україна, МПК В21К21/00. Спосіб виготовлення деталей $з$ наскрізним отвором / Алієв І. С., Алієва Л. І., Бондарева О. М.; заявник і 
патентовласник Донбаська державна машинобудівна академія. № u 2012 04045; заявл. 02.04.2012; опубл. 10.10.2012, Бюл. № 19.

205. Алиев И. С. Поиск и классификация новых технологических способов выдавливания / И. С. Алиев // Удосконалення процесів та обладнання обробки тиском в машинобудуванні і металургії. Зб. наук. пр.: - Краматорськ Слов'янськ, 2000. - С. 207-213.

206. Farhoumand A. Analysis of forward-backward-radial extrusion process / A. Farhoumand, R. Ebrahimi // Materials and Design 30. - 2009. - p. 2152-2157.

207. Countis Industries 2670 Lockheed Way, Carson City, NV 89706, USA.

208. N.S. Bhattacharyya, G.P. Srivastava, On the instability threshold of cobalt substituted Ni-Al ferrite at high-microwave-power levels, J. Magn. Magn. Mater. 262 (2003) 212 - 217.

209. V.S. Bushkova, B.K. Ostafiychuk. Low temperature synthesis and characterization of spinel ferrite powders. Powder metallurgy and Metal Ceramics. 54 (2016) 509-516.

210. A.V. Kopayev, I.Y. Vylka, Patent of Ukraine No. 36451, Method of receipt of difficult oxides of different metals of stoichiometrical composition by the method of sol-gel autocombustion, Vasyl Stefanyk PreCarpathian National University. Nu. 200806839; Date: 19.05.2008; Publ. 27.10.2008, Bull. No. 11.

211. Ch.N. Barnakov, R.S. Iskhakov, The Co nanoparticles in the matrix of porous amorphous carbon, Book of Abstracts of the Conference NANO-2008, Minsk, 2008 (Belorus).

212. A. Corrias, G. Ennas, G. Mountjoy, G. Paschina, An X-ray absorption spectroscopy study of the $\mathrm{Fe} \mathrm{K}$ edge in nanosized maghemite and in $\mathrm{Fe}_{2} \mathrm{O}_{3}-\mathrm{SiO}_{2}$ nanocomposites, Phys. Chem. Chem. Phys. 2 (2000) 1045 - 1050.

213. O. Kopayev, Magnetic ordering in the structure of nickel ferrites, Physics and Chemistry of Solid State, 9 (No. 1) (2008) 58 - 63.

214. A.V. Kopayev, B.K. Ostafiychuk, I.P. Yaremiy, I.Y. Vylka, Structure and magnetic properties of Ni-Al ferrite nanopowders synthesized by the sol-gel auto- 
combustion method, Journal of Surface Investigations, X-ray, synchrotron and neutron techniques, 10 (2007) 79 - 83.

215. Тимощук О. I., Коваленко Т. П. Підвищення експлуатаційної надійності парогенератора ПГВ-1000 // Сучасні проблеми наукового забезпечення енергетики: у 2 т.: матеріали XVII Міжнародної науковопрактичної конференції молодих вчених та студентів, (Київ, 23-26 квітня 2019 року). - 2019. - С. 40.

216. Коваленко Т. П., Лукащук Д. І. Організація водно-хімічного режиму AEC 3 метою безпечної та надійної роботи парогенератора ПГВ-1000 // Перспективи майбутнього та реалії сьогодення в технологіях водопідготовки: матеріали III Міжнародної науково-практичної конференції (Київ, 14-15 листопада 2019 р.). - 2019. - С. 137-138.

217. Коваленко Т. П., Матіко Г. Ф. Особливості водно-хімічного режиму другого контуру атомних електричних станцій України // Ресурси природних вод Карпатського регіону. Проблеми охорони та раціонального використання: збірник наукових статей дев'ятнадцятої міжнародної науково-практичної конференції, (Львів, 8-9 жовтня 2020 р.). - 2020. - С. 216-218.

218. Лукащук Д. І., Коваленко Т. П. Дослідження корозійних пошкоджень теплообмінних труб парогенератора ПГВ-1000 АЕС // Всеукраїнський конкурс студентських наукових робіт з галузі "Енергетика": збірник тез доповідей, (Маріуполь, 25-26 березня 2020 р.). - 2020. - С. 4.

219. Kovalenko T., Lys S., Vostres V. Analysis of eddy-current testing and metallographic examinations for corrosion damages of heat exchanging tubes in NPP steam generators // Енергетика та системи керування. - 2020. - Vol. 6, №1 . - С. 7 15 .

220. Трунов Н. Б., Логвинов С. А., Драгунов Ю. Г. Гидродинамические и тепло-химические процессы в парогенераторах АЭС с ВВЭР. - М.: Энергоатомиздат, 2001. - 316 с.

221. Плачкова С.Г. Електроенергетика та охорона навколишнього середовища. Функціонування енергетики в сучасному світі [Електронний 
pecypc]. - Режим доступу: http://energetika.in.ua/ua/books/book-5/part-1/section$\underline{2 / 2-1 / 2-1-3}$. Дата звернення 1.11.2020.

222. Атлас енергетичного потенціалу відновлюваних i нетрадиційних джерел енергії України // НАН України, ін-т електродинаміки, Державний комітет з енергозбереження. - Київ - 2001 [Електронний ресурс]. - Режим доступу: $\quad$ http://www.intelcenter.com.ua/rus/library/atlas_alten_UA.htm. Дата звернення 1.11.2020.

223. Стан і перспективи розвитку відновлюваної енергетики в Ук раї ні: аналіт. доп. / О. М. Суходоля, А. Ю. Сменковський, А. І. Шевцов, М. Г. Земляний; за ред. О. М. Суходолі. - К.: НІСД, 2013. - 104 с. - (Сер. «Економіка», вип. 12). - Режим доступу: http://old2.niss.gov.ua/content/articles/files/Cyxodolya_Energ7463d.pdf. Дата звернення 2.11.2020.

224. Директива Свропейського парламениу та Ради 2009/28/СС від 23 квітня 2009 року «Про заохочення до використання енергії, виробленої з відновлюваних джерел та якою вносяться зміни до, а в подальшому скасовуються, Директиви 2001/77/СС та 2003/30/СС». [Електронний ресурс]. - Режим доступу: http://saee.gov.ua/documents/dyrektyva_2009_28.pdf. Дата звернення 2.11.2020.

225. Якупова H.M., mailto:\%20Aleksey_Andreev_mail@mail.ruАндреев А.В. mailto:\%20Aleksey_Andreev_mail@mail.ruСовершенствование методов планирования потребления электроэнергии в бюджетних учреждениях // Фундаментальные исследования. - 2015. - №10 (часть 1) - С. 214-218. - Режим доступу: https://www.fundamental-research.ru/ru/article/view?id=39153). Дата звернення 2.11.2020.

226. Каплун В. В. Математичне моделювання електроспоживання у будівлях закладів вищої освіти. Повідомлення 2 [Текст] / В. В. Каплун, С. М. Краснитський, В. М. Бобровник // Вісник Київського національного університету технологій та дизайну. Серія Технічні науки. - 2019. - № 2 (132). - С. 9-23. Режим доступу: https://er.knutd.edu.ua/bitstream/123456789/13259/1/V132_P009023.pdf. Дата звернення 2.11.2020. 
227. María del Carmen Ruiz-Abellón, Antonio Gabaldon, Antonio Guillamón Load Forecasting for a Campus University Using Ensemble Methods Based on Regression Trees // Energies. - 2018. - 11(8). DOI: 10.3390/en11082038.

228. Кожем'яко В. П. Оптимізація проектів будівництва сонячних електростанцій із врахуванням базових техніко-економічних показників / В. П. Кожем'яко, О. Г. Домбровський, В. І. Маліновський // Оптико-електронні інформаційно-енергетичні технології. - 2015. - № 2. - С. 66-81. - Режим доступу: http://nbuv.gov.ua/UJRN/oeiet 20152 11. Дата звернення 3.11.2020.

229. Бондарчук А.С. Методи і моделі визначення електричного навантаження цивільних обєктів 3 використанням графічного і макромоделювання та фрактальних властивостей. Автореферат дисертації на здобуття наукового ступеня доктора технічних наук. Національний університет «Львівська політехніка» Львів - 2020. 40 с. https://pnu.ua/research/disscoun/d3505202/bondarchuk-anatoliy-sergiyovych . Дата звернення 3.11.2020.

230. Мороз O.M., Мірошник О.О., Павлов А.О., Ганус О.І. Етапи та задачі техніко-економічного обгрунтування будівництва СЕС // «Енергетика і автоматика» №6, - 2019 - С. 43-54. - Режим доступу: http://journals.nubip.edu.ua/index.php/Energiya/article/view/13653. Дата звернення 4.11.2020.

231. Хацкевич Ю. В. Методика розрахунку техніко-економічних показників роботи системи електропостачання 3 фотоелектричними елементами / Ю. В. Хацкевич, I. М. Луценко, М. В. Александров // Строительство. Материаловедение. Машиностроение. Серия: Энергетика, экология, компьютерные технологии в строительстве. - 2016. - Вып. 92. - С. 163-172. Режим доступу: http://nbuv.gov.ua/UJRN/smmeect_2016_92_30. Дата звернення 4.11.2020.

232. Бондарчук А. С. Прогнозна енергетична, економічна та екологічна ефективність запровадження мережевих сонячних електростанцій в ринкових умовах / А. С. Бондарчук // Електротехнічні та комп’ютерні системи. - 2015. - № 
20. - С. 51-55. - Режим доступу: http://nbuv.gov.ua/UJRN/etks_2015_20_9. Дата звернення 4.11.2020.

233. Методичні підходи до оцінки соціо-еколого-економічної ефективності інвестиційних проектів з енергозбереження / О. М. Теліженко, І. А. Вакуленко, Ю. О. Мирошниченко // Энергосбережение. Энергетика. Энергоаудит. - 2014. № 11. - С. 40-51. - Режим доступу: http://nbuv.gov.ua/UJRN/ecee_2014_11_5. Дата звернення 4.11.2020.

234. Мороз Л. Б. Проблеми і перспективи застосування методів підвищення нафтовилучення на родовищах Передкарпаття / Л. Б. Мороз // Розвідка та розробка нафтових і газових родовищ, Івано-Франківськ. - 2014. - № 13. - С. $26-$ 32.

235. Кондрат Р. М. Дослідження процесу піноутворення з використанням водних розчинів пінотворних ПАР і стабілізаторів піни /Р. М. Кондрат, Н. С. Дремлюх, А. В. Угриновський// Науковий вісник Національного гірничого університету. - 2017. - №3. - С. 20-26.

236. Ayirala S. Surface and Subsurface Requirements for Successful Implementation of Offshore Chemical Enhanced Oil Recovery. /S. Ayirala, R. Chin, K. Raney, P. Verbeek P.// Offshore Technology Conference. - 2-5 May. - 2011. Houston, Texas, USA.

237. Sheng J. J. A Comprehensive Review of Alkaline-Surfactant-Polymer (ASP) Flooding / J. J. Sheng// SPE Western Regional \& AAPG Pacific Section Meetingю. Joint Technical Conference. - 19-25 April, 2013.- Monterey, California, USA.

238. Kosowski P. Metody zwiększenia efektywności wydobycia ropy naftowej./ P. Kosowski, S. Rychlicki, J. Stopa, P. Wojnarowski // Przemysł Naftowy w Polsce. AKNET. - Kraków - s. 22-36.

239. Мороз Л. Б. Огляд впроваджень технологій 3 інтенсифікації видобу0вання нафти і збільшення нафтовилучення на родовищах світу / Мороз Л. Б.// Нафтогазова енергетика, Івано-Франківськ. - 2014. - № 1. - С. 22-31.

240. EORgui Help. - 2010.- Petroleum Solutions Ltd. 
241. Podsobiński D. The use of computer simulations to assess the effectiveness of the revitalization of mature oil fields using the selected reservoir as an example. / D. Podsobiński, J. Stopa, P. Wojnarowski// AGH Drilling, Oil, Gas. - 2017. - p. 67-80.

242. Osinniy V.YA. Driving rising workings by blasting borehole charges into the compensation cavity formed by the plasma method. Ukrainian Union of Explosive Engineers: Information Bulletin. 2016. № 1(29). P.19-24.

243. Fursov E.G., Kirichenko V.M., Dyudin YU.K. et al. Improvement of elements of development systems with collapse. Mining magazine.2005. № 2. P.34-38.

244. Logachev E.I., Stupnak N.I., Morgun A.V. et al. Improvement of mining of magnetite quartzite by underground method using self-propelled loading and hauling equipment. Development of ore deposits. 2008. Issue. 92. P. 50-55.

245. Rimarchuk B.I. Choice of technology for drilling and blasting operations in underground mining of magnetite quartzites in Kryvbas. Ukrainian Union of Explosive Engineers: Information Bulletin. 2009. №2. P. 10-14.

246. Osinniy V.YA. Technique and technology for drilling magnetite quartzite blocks using plasmatrons in underground conditions of Kryvbas mines. Ukrainian Union of Explosive Engineers: Information Bulletin. 2014. № 2(23). C.14-20.

247. Kozdoba L.A. Solutions to nonlinear heat conduction problems. K.: Naukova Dumka, 1976. 136 p.

248. Karslow G., Eger D. Thermal conductivity of solids. M.: Nauka, 1964. 487 p.

249. Osinniy V.YA. On the effectiveness of the formation of a cutting gap in hard rocks. Ukrainian Union of Explosive Engineers: Information Bulletin. 2013. № 1. C.19-24.

250. Makeiev S.YU., Osinniy V.YA., Ryzhov G.A., Osinnja N.V. and Holyavik O.V. Theoretical consideration of the plasma energy transfer to the rock mass. GeoTechnical Mechanics: Journal of Collected Scientific Papers. Dnipro, 2016. Issue 128. P. 139-148.

251. Bulat A., Osennii V., Dreus A., Osennia N. Advanced technology of raise boring by non-sectional blasting to the full level interval. Advanced Drilling 
Technologies of Underground Resources: Int. conf. on the cooperation and integration industry, education, research and application. Changchun, China, 15-17 Sept. 2020.

252. D. Havrilov, S. Baraban, A. Volovyk, O. Zviahin, A. Semenov and A. Savytskyi, "Real-Time Video Processing System based on Field Programmable Gate Array," 2019 IEEE 14th International Conference on Computer Sciences and Information Technologies (CSIT), Lviv, Ukraine, 2019, pp. 192-196. doi: 10.1109/STC-CSIT.2019.8929758.

253. A. Semenov, D. Havrilov, A. Volovik, S. Baraban, A. Savytskyi, O. Zviahin, "Simulation of the Chaotic Dynamics of the Deterministic Chaos Transistor Oscillator based on the Hartley Circuit," 2020 IEEE 15th International Conference on Modern Problems of Radio Engineering, Telecommunications and Computer Science (TCSET), Lviv-Slavsko, Ukraine, 2020. doi: 10.1109/TCSET49122.2020.235384.

254. A. Volovik, D. Havrilov, A. Semenov, S. Baraban, A. Savytskyi and O. Zviahin, "Observation Trajectory Model for Radio-Frequency Aviation Landing Systems," 2019 International Conference on Information and Telecommunication Technologies and Radio Electronics (UkrMiCo), Odessa, Ukraine, 2019, pp. 1-5, doi: 10.1109/UkrMiCo47782.2019.9165505.

255. A. Volovyk, V. Kychak, D. Kudriavtsev, D. Havrilov, A. Yarovyi and L. Krylik, "Simultaneous Estimation in Linear Dynamic Systems with the Indeterminate Structure Disturbances," 2020 IEEE 40th International Conference on Electronics and Nanotechnology (ELNANO), Kyiv, Ukraine, 2020, pp. 651-655, doi: 10.1109/ELNANO50318.2020.9088884.

256. K. Selivanova, O. Ignashchuk, L. Koval, V. Kilivnik, A. Zlepko, D. Sawicki, A. Kalizhanova, A. Zhanpeisova, S. Smailova, "Computer-aided system for interactive psychomotor testing," Proc. SPIE 10445, 2017, 104453B, doi: 10.1117/12.2280815.

257. Y. Nosova, N. Shushliapina, S. Kostishyn, L. Koval, Z. Omiotek, W. Wójcik, A. Tuleshova, "The use of statistical characteristics of measured signals to increasing the reliability of the rhinomanometric diagnosis," Proc. SPIE 10031, 2016, 100312M, doi: 10.1117/12.2248364. 
258. Stutzman W.L. (2018). Polarization in Electromagnetic Systems. Artech House, Norwood, 352 p.

259. Dubrovka F.F., Piltyay S.I., Dubrovka R.R., Lytvyn M.M., Lytvyn S.M. (2020). Optimum septum polarizer design for various fractional bandwidths. Radioelectronics and Communications Systems, vol. 63, no. 1, pp. 15-23.

260. Dubrovka F., Piltyay S. et al. (2020). Compact X-band stepped-thickness septum polarizer, IEEE Ukrainian Microwave Week, Kharkiv, Ukraine, p.135-138.

261. Deutschmann B., Jacob A.F. (2020). Broadband septum polarizer with triangular common port, IEEE Trans. Microwave Theory Tech., vol. 68, no. 2, pp. 693700.

262. Piltyay S.I., Bulashenko A.V., Demchenko I.V. (2020). Compact polarizers for satellite information systems, IEEE Int. Conf. on Problems of Infocommunications. Science and Technology, Kharkiv, Ukraine, pp. 350-355.

263. Piltyay S.I., Bulashenko A.V., Demchenko I.V. (2020). Waveguide iris polarizers for Ku-band satellite antenna feeds, Journal of Nano- and Electronic Physics, vol. 12, no. 5, 05024-1-05024-5. http://doi.org/10.21272/jnep.12(5).05024.

264. Piltyay S.I., Bulashenko A.V., Demchenko I.V. (2020). Analytical synthesis of waveguide iris polarizers, Telecommunications and Radio Engineering, vol. 79, no. 18, pp. 1579-1597. http://doi.org/10.1615/TelecomRadEng.v79.i18.10.

265. Булашенко А.В., Пільтяй С.I., Демченко I.В. (2020). Оптимізація поляризатора на основі квадратного хвилеводу з діафрагмами, Наукоємні технології, Вип. 47, №. 3, С. 287-297.

266. Dubrovka F.F., Piltyay S.I. (2013). A novel wideband coaxial polarizer, $I X$ Int. Conf. on Antenna Theory and Techniques (ICATT), Odesa, Ukraine, pp. 473-474.

267. Piltyay S.I. (2017). High performance extended C-band 3.4-4.8 GHz dual circular polarization feed system, XI IEEE International Conference on Antenna Theory and Techniques (ICATT), Kyiv, Ukraine, pp. 284-287.

268. Piltyay S. I. (2014). Enhanced C-band coaxial orthomode transducer, Visnyk NTUU KPI Seriia - Radiotekhnika, Radioaparatobuduvannia, vol. 58, pp. 27-34. 
269. Dubrovka F.F., Piltyay S.I. (2017). Novel high performance coherent dualwideband orthomode transducer for coaxial horn feeds, XI IEEE Int. Conf. on Antenna Theory and Techniques (ICATT), Kyiv, Ukraine, pp. 277-280.

270. Редзюк А.М. Аварійність на транспорті [Електронний ресурс] - Режим доступу до ресурсу:_http://medtransvp.com.ua/redzyuk-m-avarijnist-na-transporti/

271. Білошицький Олексій Георгійович [Електронний ресурс] - Режим доступу до ресурсу: https://www.facebook.com/Bilosh/posts/10219504369992438

272. Оксана Поліщук: «Три дні автофіксації порушень ПДР: «шумахерів» реально поменшало» [Електронний ресурс]-Режим доступу до ресурсу: https://www.ukrinform.ua/rubric-society/3038988-tri-dni-avtofiksacii-porusen-pdrsumaheriv-realno-pomensalo.html

273. Шевченко В. МТСБУ [Електронний ресурс] - Режим доступу до pecypcy: http://medtransvp.com.ua/sheevchenko-v-mtsbu/

274. Гордієнко С.М. Можливі наслідки обмеження швидкості руху в містах і населених пунктах // Містобудування та територіальне планування: Наук.-техн. збірник / Головн. ред. М.М. Осєтрін.- К. КНУБА, 2019.-Вип. 69.- 443 с., с.77-83

275. Средняя зарплата в Украине: веб-сайт. URL: https://maanimo.com/indexes/142542-srednyaya-zarplata-v-ukraine (дата звернення: 14.02.2019).

276. Ціни в Україні 2019 веб-сайт. URL: http://hikersbay.com/prices/ukraine?lang=ua (дата звернення: 05.03.2019).

277. Микола Поворозник: «На 7 вулицях Києва можна розганятися до 80 км/год - встановлені відповідні дорожні знаки» [Електронний ресурс] - Режим доступу до ресурсу: https://kyivcity.gov.ua/news/mikola_povoroznik_na_7_vulitsyakh_kiyeva_mozhna_r ozganyatisya_do_80_kmgod_vstanovleni_vidpovidni_dorozhni_znaki.html

278. Cockroft A. N. E nige gezichtspunten t. a. v. de bepalingen ter voorkoming vananvazing op Zee/ Cockroft A. N. // Nautish en technicch tudscrift Zee, 1981, 10, № 10 , P. $238-241$. 
279. Corlet A. G. Automation of collision avoidance at sea with special reference to the international regulations for preventing collisions at sea. "Ship. Operat. Automat." Amsterdam-Oxford, 1975, P. 93 - 100.

280. Hinsch Werner. A new larboard he1m rule for powerdriven vessels/ Hinsch Werner. // The Journal of Navigation, I980, 33, № 3, P. 403 - 407.

281. Сафин И.В. Анализ результатов имитационного моделирования процесса расхождения судов/ Сафин И.В.// Судовождение. - 2003. - № 6. - С. $122-$ 129.

282. Cannell W. P. Collision avoidance as a game of coordination/ Cannell W. P.// The Journal of Navigation, 1981, 34, № 2, P. 220 - 239.

283. Заичко С.И. Управление взаимодействием судов в ситуации опасного сближения / Заичко С.И., Пятаков Э.Н. // Судовождение. - 2006. - № 11. - С. 56 -60 .

284. Заичко С.И. Возможности синтеза системы формирования стратегий расхождения группы судов/ Заичко С.И., Пятаков Э.Н. // Судовождение. - 2006. - № 12. - С. $63-66$.

285. Пятаков Э.Н. Требование к процедуре формирования второго уровня иерархической системы управления взаимодействием судов / Пятаков Э.Н. // Судовождение. - 2007. - № 13. - С. 145 - 148.

286. Пятаков Э.Н. Определение угрозы ситуационного возмущения при опасном сближении судов/ Пятаков Э.Н., Заичко С.И. // Судовождение: Сб. научн. трудов./ ОНМА, Вып. 19. - Одесса: Латстар, 2011 - С.

287. Пятаков Э.Н.. Оценка эффективности парных стратегий расходящихся судов / Пятаков Э.Н., Заичко С.И // Судовождение: Сб. научн. трудов. / ОНМА, - Вып.15. - Одесса: "ИздатИнформ", 2008. - С. 166 - 171.

288. Вагущенко Л.Л. Судно как объект автоматического управления. Одесса: ОГМА, 2000. - 140 с.

289. Цымбал Н.Н. Гибкие стратегии расхождения судов / Цымбал Н.Н., Бурмака И.А., Тюпиков Е.Е. - Одесса: КП ОГТ, 2007. - 424 с. 
290. Кунда Н.Т., Свинціцький О.І. Інформатизація на транспорті: проблеми та можливості. Матеріали II Міжнародної науково-практичної конференції «Наука, технології, інновації: світові тенденції та регіональний аспект» (м. Одеса, 27-28 вересня 2019 р.) - 192 с. С. 180-185 http://novaosvita.com/wpcontent/uploads/2019/10/ScTechInn-Odesa-Sept2019.pdf

291. Кунда Н.Т. "Організація міжнародних автомобільних перевезень". Навч. посібн. для студ. напряму «Транспортні технології» ВНЗ . - К.: Видавничий Дім «Слово», 2010. - 464 с. https://drive.google.com/open?id=11Y6NtWnahAmbKXK3GyCWYE4xe-0y68Pk

292. https://www.bmwi.de/Redaktion/EN/Publikationen/gaia-X-the-europeanproject-kicks-of-the-next-phase.pdf? blob=publicationFile \&v $=7$

293. Бізнес-каталог. Організація перевезення вантажів в Україні https://www.ua-region.com.ua/kved/Trt.63.40.0

294. Каталог підприємств України. https://www.poshuk.com/

295. Ціноутворення. https://sites.google.com/site/cinoutvorenna/

296. Бондар, Н. М. Об'єкти та моделі партнерських взаємодій держави i приватного сектору у сфері автомобільних пасажирських перевезень. Управління проектами, системний аналіз і логістика. Технічна серія, 2011, 8: 256-261.

297. Прокудін, Г. С.; Оліскевич, М. С. Вплив структури транспортної системи на показники якості доставки вантажів у міжміському сполученні. Вісник Національного транспортного університету, 2019, 1: 143-158.

298. Oliskevych, M. Dynamic scheduling of highway cargo transportation. Матеріали Міжнародної науково-технічної конферениії „Актуальні проблеми транспорту “, 2019, 141-151.

299. Хажанець В. В. Ефективність міжнародної транспортної логістики як складової логістичної системи / В. В. Хажанець, Л. М. Шульгіна // Молодий вчений. — 2018. — №4.

300. Дмитриченко М.Ф. Міжнародні перевезення: навч. посібник / М.Ф. Дмитриченко, І.А. Вікович, І.Л. Самсін, Р.В. Зінько. Львів: Видавництво Львівської політехніки, 2012. 308 с. 
301. Міжнародні автомобільні перевезення: /Л.М. Костюченко, Л.П. Докіль, Ю.Ф. Кучинський [ та ін.]; Асоц. міжннар.а втомоб. перевізників України. - К.: Бланк - Прес, 2010. 208 с.

302. Dolya VK Passenger transportation: a textbook / VK Dolya. - Kharkiv: Fort Publishing House, 2011. - 504 p.

303.COVID-19 Impacts on the Road Transport Industry- Executive summary. IRU. 29/06/2020.

304. https://www.leparisien.fr/societe/coronavirus-pourquoi-aucun-cluster-n-aete-detecte-dans-les-transports-05-06-2020-8330415.php

305. https://ec.europa.eu/

306. https://moz.gov.ua/

307. Tomaszewski, VM Modeling systems: textbook. for students. higher textbook zakl., which taught. in the areas of "Computer Science", "Computerized Systems, Automation and Control", "Computer Engineering", "Applied Mathematics" / V.M. Tomaszewski. - K .: Edition group BHV, 2007. - 349 c.

308.Kleinrock L.Queueing Systems - Vol. 1: Theory. WILEY INDIA; (2013). ISBN-10: 8126546034. ISBN-13: 978-8126546039.

309. Kleinrock L. Queueing Systems - Vol. 2: Computer Applications. WILEY INDIA; (2014). ISBN-10: 9788126546381. ISBN-13: 978-8126546381.

310. Oleg E. Sokulskiy, EkaterinaYu. Hilevska, Natalya N. Vasiltzova, Dmitriy L. Panchenko. Simulation Technology of the Route of the City Passenger Transport System with Considering Service Quality and Technogenous Impact on Environment // Journal of Automation and Information Sciences, Volume 49, 2017 Issue 7, pp. 77 81, DOI: 10.1615/JAutomat Inf Scien.v49.i7.60.

311. Oleg E. Sokulskiy, EkaterinaYu. Hilevska, Natalya N. Vasiltzova, Dmitriy L. Panchenko. Solving the Problem of the Route Modeling of the Urban Passenger Transport System with Considering Quality of Passenger Service and Technological Impact on Environment // Journal of Automation and Information Sciences, Volume 49, 2017 Issue 12, pp. 45-56, DOI: 10.1615/JAutomatInfScien.v49.i12.50. 
312. Величко К.Ю., Козуб В.О., Носач Л.Л., Чернишова Л.О., Печенка О.І. Митне регулювання зовнішньоекономічної діяльності: навч. посіб. Харків: Видавництво «Форт», 2017. $221 \mathrm{c}$.

313. Нагорний Є.В. Аналіз сучасних підходів до підвищення ефективності логістичних систем доставки вантажів в міжнародному сполученні / Є.В. Нагорний, В.С. Наумов, А.В. Іванченко // Транспортні системи та технології перевезень : зб. наук. пр. Дніпропетр. нац. ун-ту залізн. трансп. ім. акад. В. Лазаряна. - Дніпропетровськ, 2012. - Вип. 3. - С. 68-72.

314. Мережко Н.В., Пашко П.В., Рождественський О.В. Митна справа: підручник. Київ: Київ. нац. торг.-екон. ун-т, 2016. 572 с.

315. Кузьмін О.Є. Митне обслуговування міжнародної економічної діяльності в умовах євроінтеграції: теоретичні положення і методичні підходи до практичних і лабораторних занять: навч. посіб., Нац. Ун-т «Львів. Політехніка», 2015. $161 \mathrm{c}$.

316. Давідіч Ю.О. Розробка розкладу руху транспортних засобів при організації пасажирських перевезень. Харків: ХНАМГ, 2010. 345 с.

317. Ищенко В.И., Поберезкин Г.А., Штанов В.Ф. Организация перевозок пассажиров автомобильным транспортом. Киев: Техника, 1988. 94 с.

318. Коноплянко В. И. Основы безопасности дорожного движения. Москва: Издательство ДОСААФ, 1978. 128 с.

319. Павелків Р.В. Загальна психологія. Київ: Кондор. 2002. 506 с.

320. Дмитриченко М.Ф., Лановий О.Т., Поліщук В.П. Системологія на транспорті. Ергономіка (Книга V). Київ: Знання України, 2008. 267 с.

321. Давідіч Ю.О. Розробка розкладу руху транспортних засобів при організації пасажирських перевезень. Харків: ХНАМГ, 2010. 345 с.

322. Вайнштюк М.А., Лигум Ю.С., Рева В.М., Сотников В.Е. Управление пассажирским автотранспортом: Справочное пособие. Киев: Техника, 1985. 167 c.

323. Гаврилов Э.В. Эргономика на автомобильном транспорте. К.: Техника, 1976. $152 \mathrm{c}$. 
324. Афанасьев Л.Л., Воркут А.И., Дьяков А.Б. Пасажирські автомобільні перевезення. Москва: Транспорт, 1986. 220 с.

325. Рыженко Л. И. Оценка качества обслуживания пассажиров городским транспортом. Совершенствование организации и управления перевозочным процессом на пассажирском автомобильном транспорте. Москва: НИИАТ, 1988. C. $65-75$.

326. Зинченко В.П. Введение в эргономику. Москва: Советское радио, 1974. $352 \mathrm{c}$.

327. A. Mingaleev, A. Yakovlev, B. Mickan, A. Bardonov, D. Serediuk, A. Stankevicius and I. Busuladžić Comparisons of national standards in the field of gas flow rate and volume, gas flow rates from 20 to $6500 \mathrm{~m} 3 / \mathrm{h} / /$ Metrologia, Volume 57, Number 1A, 2020.

328. Петришин I.С., Вощинський В.С., Джочко П.Я. та ін. Удосконалення державного первинного еталона одиниць об'єму та об’ємної витрати газу // Методи та прилади контролю якості, 2016. - № 36, С. 38 - 47.

329. Саєвич І.Б., Джочко П.Я., Середюк Д.О., Пелікан Ю.Т., Бас О.А. Калібрувальна установка в діапазоні об'ємної витрати газу до 7000 м3/год // XVIII Міжнародна науково-технічна конференція "ПРИЛАДОБУДУВАННЯ: стан і перспективи”, 15-1 6 травня 2018 року, КПІ ім. Ігоря Сікорського, Київ. С. 215.

330. M. Cox The evaluation of key comparison data // Metrologia, 2002, No. 39, P. $589-595$. 